
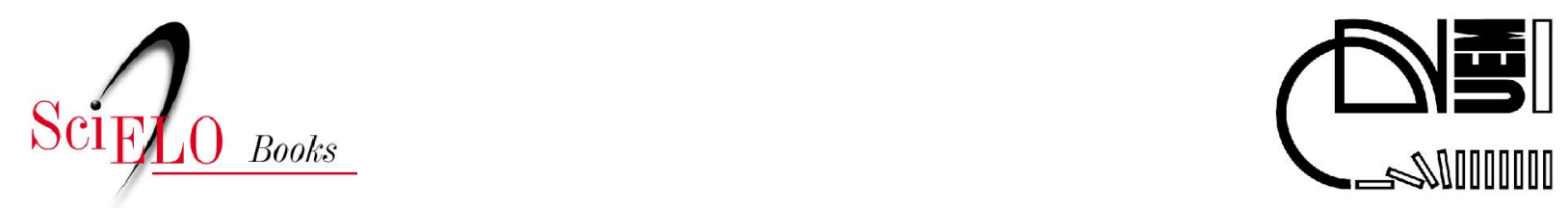

\title{
Colonização agrária no norte do Paraná
}

processos geoeconômicos e sociogeográficos de desenvolvimento de uma zona pioneira subtropical do Brasil sob a influência da plantação de café

\author{
Paulo Astor Soethe (org.) \\ Daniel Martineschen (coord.) \\ Caio Heleno da Costa Pereira \\ Dionei Mathias \\ Elisete Antoniuk \\ Fernanda Boarin Boechat \\ Frederico Füllgraf \\ Natasha Pereira da Silva \\ Sibele Paulino \\ Sirlene Nair Neubauer \\ (transl.)
}

\section{SciELO Books / SciELO Livros / SciELO Libros}

SOETHE, PA., org. MARTINESCHEN, D., et al., transl. KOHLHEPP, G. Colonização agrária no Norte do Paraná: processos geoeconômicos e sociogeográficos de desenvolvimento de uma zona subtropical do Brasil sob a influência da plantação de café [online]. Maringá: Eduem, 2014, 310 p.

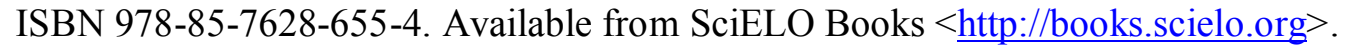

\section{@)(1)(9)}

All the contents of this chapter, except where otherwise noted, is licensed under a Creative Commons Attribution-Non Commercial-ShareAlike 3.0 Unported.

Todo o conteúdo deste capítulo, exceto quando houver ressalva, é publicado sob a licença Creative Commons Atribuição Uso Não Comercial - Partilha nos Mesmos Termos 3.0 Não adaptada.

Todo el contenido de este capítulo, excepto donde se indique lo contrario, está bajo licencia de la licencia Creative Commons Reconocimento-NoComercial-CompartirIgual 3.0 Unported. 


\section{COLONIZAÇÃO AGRÁRIA NO Norte do Paraná}

Processos geoeconômicos e sociogeográficos de desenvolvimento de uma zona pioneira subtropical do Brasil sob a influência da plantação de café 


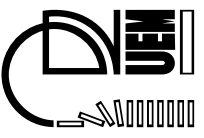

EDITORA DA UNIVERSIDADE ESTADUAL DE MARINGÁ

Reitor: Prof. Dr. Júlio Santiago Prates Filho. Vice-Reitora: Profa. Dra. Neusa Altoé. Diretor da Eduem: Prof. Dr. Alessandro Lucca Braccini. Editora-Chefe da Eduem: Profa. Dra. Terezinha Oliveira

\section{CONSELHO EDITORIAL}

Presidente: Prof. Dr. Alessandro Lucca Braccini. Editores Científicos: Profa. Dra. Ana Lúci Rodrigues, Profa. Dra. Angela Mara de Barros Lara, Profa. Dra. Analete Regina Schelbauer, Prof. Dr. Antonio Ozai da Silva, Profa. Dra. Cecília Edna Mareze da Costa, Prof. Dr. Eduardo Augusto Tomanik, Profa. Dra. Elaine Rodrigues, Profa. Dra. Larissa Michelle Lara, Prof Dr. Luiz Roberto Evangelista, Profa. Dra. Luzia Marta Bellini, Prof. Me. Marcelo Soncin Rodrigues, Prof. Dr. Márcio Roberto do Prado, Profa. Dra. Maria Cristina Gomes Machado, Prof. Dr. Oswaldo Curty da Motta Lima, Prof. Dr. Raymundo de Lima, Profa. Dra. Regina Lúcia Mesti, Prof. Dr. Reginaldo Benedito Dias, Profa. Dra. Rozilda das Neves Alves, Prof. Dr. Sezinando Luis Menezes, Profa. Dra. Terezinha Oliveira, Profa. Dra. Valéria Soares de Assis.

\section{EQUIPE TÉCNICA}

Projeto Gráfico e Design: Marcos Kazuyoshi Sassaka. Fluxo Editorial: Cicilia Conceição de Maria, Edneire Franciscon Jacob, Mônica Tanamati Hundzinski, Vania Cristina Scomparin. Artes Gráficas: Luciano Wilian da Silva, Marcos Roberto Andreussi. Marketing: Marcos Cipriano da Silva. Comercialização: Norberto Pereira da Silva, Paulo Bento da Silva, Solange Marly Oshima. 
Gerd Kohlhepp

\section{COLONIZAÇÃO AGRÁRIA NO Norte do Paraná}

Processos geoeconômicos e sociogeográficos de desenvolvimento de uma zona pioneira subtropical do Brasil sob a influência da plantação de café

Organização

Paulo Astor Soethe

Daniel Martineschen (Coordenação)

Tradução

Caio Heleno da Costa Pereira

Dionei Mathias

Elisete Antoniuk

Fernanda Boarin Boechat

Frederico Füllgraf

Natasha Pereira da Silva

Sibele Paulino

Sirlene Nair Neubauer

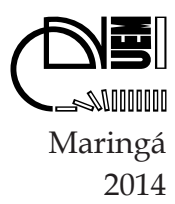


Copyright (C) 2014 para o autor (Língua Portuguesa)

1a. Edição

Título original: Agrarkolonisation in Nord-Paraná. Wirtschafts- und sozialgeographische Entwicklungsprozesse einer randtropischen Pionierzone Brasiliens unter dem Einfluß des Kaffeeanbaus (1975)

Versão em Língua Portuguesa autorizada pelo Autor e pela Editora Franz Steiner Verlag GmbH

Todos os direitos reservados. Proibida a reprodução, mesmo parcial, por qualquer processo mecânico, eletrônico, reprográfico etc., sem a autorização, por escrito, dos autores.

Todos os direitos reservados desta edição 2014 para Eduem.

Revisão textual e gramatical: Daniel Martineschen e Paulo Astor Soethe

Revisão técnica: Daniel Martineschen e Paulo Astor Soethe

Normalização textual e de referência: Daniel Martineschen

Projeto gráfico/diagramação: Marcos Kazuyoshi Sassaka

Capa - imagem: fotos de Sergio Matulevicius (publicadas na reportagem "Norte do Paraná: 'Eldorado' do Brasil”, revista Panorama, Curitiba, n. 90, 1959, p. 41-42)

Capa - arte final: Luciano Wilian da Silva

Ficha catalográfica: Cicilia Conceição de Maria (CRB 9-1066)

Fonte: Book Antiqua

Tiragem - versão impressa: 2.000 exemplares

Dados Internacionais de Catalogação-na-Publicação (CIP)

(Eduem - UEM, Maringá - PR., Brasil)
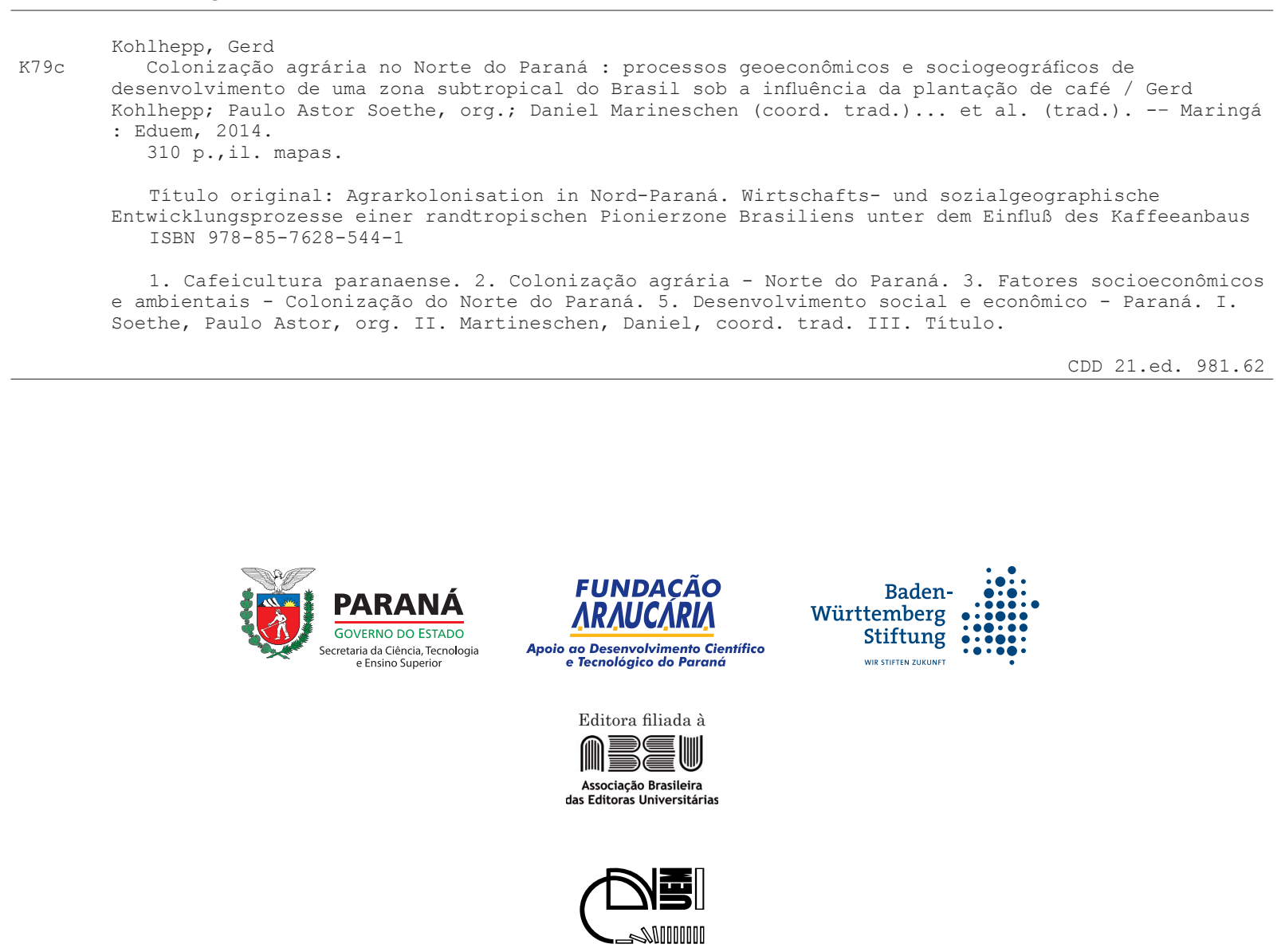

Eduem - Editora da Universidade Estadual de Maringá

Av. Colombo, 5790 - Bloco 40 - Campus Universitário

87020-900 - Maringá-Paraná - Fone: (0xx44) 3011-4103 - Fax: (0xx44) 3011-1392

www.eduem.uem.br - eduem@uem.br 
A presente tradução do livro de Gerd Kolhepp pôde tornarse realidade com o apoio da Fundação Baden-Württemberg.

A Fundação empenha-se por um estado de BadenWürttemberg que seja cheio de vida e no qual valha a pena viver. Ela torna mais fáceis os caminhos para a pesquisa de ponta, para diversas atividades educacionais e para o convívio responsável com as pessoas que convivem com sua gente. A Fundação BadenWürttemberg está entre as grandes fundações da Alemanha. É a única que investe de maneira exclusiva e suprapartidária no estado federado de Baden-Württemberg e, com isso, no futuro de seus cidadãos e cidadãs.

Com seu programa de intercâmbio internacional BOLSA Baden-Württemberg para Estudantes Universitários (BadenWürttemberg-STIPENDIUM für Studierende), destinado a jovens durante seus estudos em nível superior, a Fundação Baden-Württemberg mantém desde o ano de 2001 uma relação estreita com o Brasil - e em especial com o estado do Paraná.

No âmbito da viagem do Sr. Governador Winfried Kretschmann em novembro de 2011 ao Brasil, também a Fundação Baden-Württemberg foi convidada a integrar a delegação de visitantes.

Ao participarmos do financiamento da tradução da presente obra para a língua portuguesa é grande nossa alegria por continuar fortalecendo, com este apoio, as relações entre os estados do Paraná e de Baden-Württemberg. 
Figura 1: Diagrama de clima e armazenamento de água em estações selecionadas do Norte do Paraná.

Figura 2: Fundação dos principais centros municipais atuais

Figura 3: Número de cafeeiros e produção de café de regiões de cultivo selecionadas do Brasil..

Figura 3a: Esquema da estrutura social agrária na área de cultivo de café no Norte do Paraná

Figura 4: Mobilidade social e espacial específica segundo grupos e classes no cultivo de café no Norte do Paraná

Figura 5: Desenvolvimento de preços de determinados tipos de café

Figura 6: Área de cultivo, produção, exportação e estoques de café do Brasil entre 1960 e 1972.

Figura 7: Relações de temperatura com a entrada da frente fria no Norte do Paraná

Figura 8: Regiões alvo dos trabalhadores pendulantes boias-frias vindos de Londrina, segundo a distância e a distribuição quantitativa

Figura 9: Mudanças na estrutura de uso do solo entre 1960 e 1970 (parcela da área cultivada): Norte Novo de Londrina e Maringá

Figura 10: Mudanças na estrutura de uso do solo entre 1960 e 1970 (parcela da área cultivada): Norte Novíssimo.

Figura 11: Mudanças na estrutura de uso do solo entre 1960 e 1970 (parcela da área cultivada): Norte do Paraná e Norte Novo de Apucarana.

Figura 12: Rotação das pastagens na Fazenda Paranapanema (município de Inajá)

Figura 13: Rendimentos das plantações de café G. Schlieper/Rolândia

Figura 14: Altitude e extensão das novas plantações de café de janeiro a junho de 1970.

Figura 15: Sedes dos depósitos de café do IBC no Norte do Paraná 
Foto 1: Altônia. Jovem colônia no frontier do Norte Novíssimo do Paraná................................. 227

Foto 2: Avanço da frente pioneira próximo a Tapira (Norte Novíssimo de Umuarama) (foto

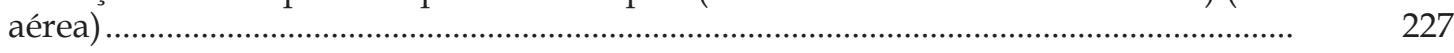

Foto 3: Paisagem de cultivo no final da fase pioneira entre Umuarama e Iporã......................... 228

Foto 4: Plantação de café em minifúndio no município de Marialva (Norte Novo de Maringá) 228

Foto 5: Plantações de café em pequenas propriedades agrícolas perto de Apucarana (foto aérea) (......................................................................................................................... 229

Foto 6: Plantação de café com um ano e culturas nos canteiros intermediários.......................... 229

Foto 7: Terreiro de um sítio no Norte Novo próximo a Apucarana ................................................. 230

Foto 8: Paisagem agrícola próxima à cidade de Maringá.................................................................... 230

Foto 9: Empreendimento de café e trigo na região de Campo Mourão .......................................... 231

Foto 10: Fazenda de café próximo a Paiquerê (Norte Novo de Londrina) (foto aérea)............... 231

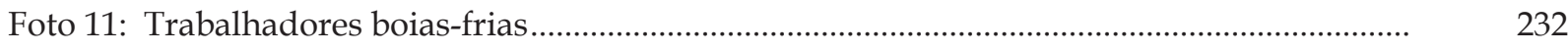

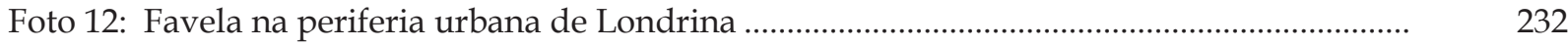

Foto 13: Plantações de café depois de estragos causados pela geada no município de Rolândia. 233

Foto 14: Transição da monocultura do café à policultura no Norte Novo ..................................... 233

Foto 15: Estragos causados pela geada no cafezal e adaptação à atividade pecuária.................. 234

Foto 16: Pecuária extensiva em campos desmatados no Norte Novíssimo do Paraná................ $\quad 234$ 
Mapa 1: Localização da região estudada e divisão regional do Paraná ....................................... 237

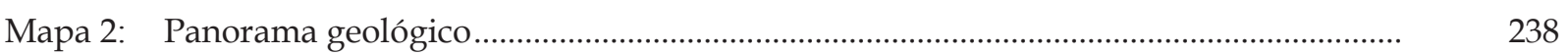

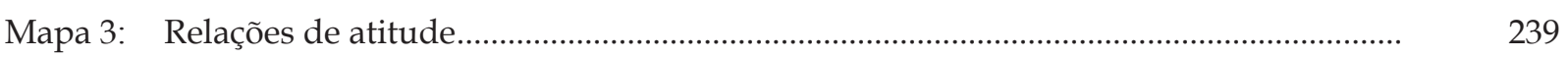

Mapa 4: Temperaturas médias anuais no Sul do Brasil................................................................ 240

Mapa 5: Número médio de dias de geada por ano no Sul do Brasil ......................................... 241

Mapa 6: Precipitações anuais médias e número de meses áridos no Sul do Brasil .................... 242

Mapa 7: Vegetação natural. Mapa panorâmico .............................................................................. 243

Mapa 8: Fundação de colônias espanholas e reduções guaranis jesuíticas na província Guayrá 1554-1632 ............................................................................................................. 245

Mapa 9: Grilos no Norte do Paraná ………................................................................................ 246

Mapa 10: Colonização privada e estatal no Norte do Paraná ........................................................ 247

Mapa 10a: Lotes em linhas latitudinais na área de colonização particular controlada da CTNP, Gleba Cianorte

Mapa 11: Fases de ocupação, deslocamento da fronteira, limites das plantações de café e origem dos colonizadores no Norte Novo e Novíssimo no Paraná.....

Mapa 12: Rede viária da Cia. Terras Norte do Paraná por volta de 1950 ...................................... 250

Mapa 13: Formas de terrenos e assentamentos urbanos no eixo de ocupação LondrinaArapongas

Mapa 14: Fundações de assentamentos da Cia. Terras Norte do Paraná e fundações particulares em terras da CTNP.

Mapa 15: Desenvolvimento da divisão administrativa do Norte Novo e Novíssimo do Paraná 1940-1950

Mapa 15a: Desenvolvimento da divisão administrativa do Norte Novo e Novíssimo do Paraná 1960-1970

Mapa 16: População urbana e rural em São Paulo e no Norte do Paraná em 1950.

Mapa 17: Provimento de infraestrutura de transporte no Norte Novo e Norte Novíssimo em 1948.

Mapa 18: Desflorestamentos no Norte do Paraná até 1950

Mapa 19: Deslocamento das áreas de produção do café em São Paulo e no Paraná em 1920, 1940 e 1950.

Mapa 20: Situação da ocupação da região em torno de Cianorte, em 1953 ...................................

Mapa 21: Situação da ocupação da região em torno de Cianorte, em 1963 ................................... 260

Mapa 22: Topônimos no Norte Novo e Norte Novíssimo do Paraná.............................................. 261

Mapa 23: Origem étnica e regional dos proprietários de terras da gleba Jacaratiá/Município de Umuarama (Norte Novíssimo)

Mapa 24: Aumento populacional absoluto e relativo no Sul, Sudeste e Centro-Oeste do Brasil, $1950 / 1960$ 
Mapa 25: Densidade populacional no Paraná em 1960

Mapa 26: Distribuição regional da produção de café em São Paulo e no Paraná de 1962 a 1964

Mapa 27: Uso do solo em 1960 (com base nos municípios)

Mapa 28: Porção territorial das classes de magnitude dos empreendimentos agrícolas em 1960

Mapa 29: Empreendimentos agrícolas segundo o estatuto jurídico de quem os explora economicamente

Mapa 30: Erradicação e uso do solo nas áreas livres de café 1966/67

Mapa 31: Erradicação e uso do solo nas áreas livres de café 1967/68

Mapa 32: Danos por geadas em plantações de café da Fazenda Ubatuba/ Apucarana em 1955 e 1962 (com e sem corredor para escoamento de ar frio)

Mapa 33: Intensidade das geadas, danos e perdas de colheita nas plantações de café no Norte do Paraná em 1969

Mapa 34: Uso do solo 1969/1970

Mapa 35: Parcela do terreno dedicada ao plantio de café, trigo e produtos agrícolas anuais em $1969 / 1970$

Mapa 36: Área de plantio, forma e importância do cultivo alternado - milho

Mapa 37: Área de plantio, forma e importância do cultivo alternado - arroz

Mapa 38: Área de plantio, forma e importância do cultivo alternado - feijão

Mapa 39: Distribuição espacial da produção de alguns produtos agrícolas no Paraná: café, algodão, milho, feijão

Mapa 40: Distribuição espacial da produção de alguns produtos agrícolas no Paraná: arroz, amendoim, mandioca, soja

Mapa 41: Área de plantio de trigo e número de plantadores de trigo em 1969/70

Mapa 42: Aumento da pecuária entre 1960 e 1967 e rebanho atual em 1975.

Mapa 43: Fazenda Guanabara. Uso do solo

Mapa 44: Variação absoluta e relativa da população urbana e rual 1960/70

Mapa 45: Variação populacional rural em relação com o crescimento natural 1960-70

Mapa 46: Inajá. Sede municipal na região do arenito Caiuá do Norte Novíssimo......

Mapa 47: População municipal, densidade populacional urbana e parcela urbana da população em 1970 ...

Mapa 48: Densidade populacional no Paraná em 1970

Mapa 49: Parcela dos empreendimentos com cafezais e parcela da área de plantações de café na área total dos municípios.

Mapa 50: Principais sedes do plantio e produção de café no Norte Novo e Norte Novíssimo do Paraná

Mapa 51: Novas plantações de café de janeiro a julho de 1970

Mapa 52: Estrutura espacial agrária em minifúndios na região cafeeira do Norte do Paraná (Jussara) 
Mapa 54: Uso do solo - Fazenda Balu e Sítio Pindorama (Rolândia)...

Mapa 55: Mapa de uso do solo. Município de Marialva

Mapa 56: Área de fixação das cooperativas de plantadores de café, 1970

Mapa 57: Abertura de vias de transporte, 1971

Mapa 58: Exportação de café por Paranaguá e Santos em 1969 (meios de transporte até o porto, destino da exportação, diferenciação de qualidade)

Mapa 59: Restos de florestas no Norte do Paraná (situação em 1970)..... 


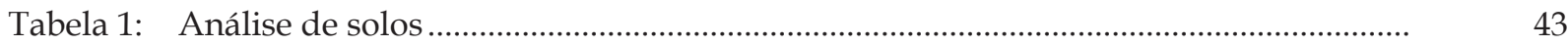

Tabela 2: Os maiores grilos do Norte do Paraná em extensão de terra ......................................... 55

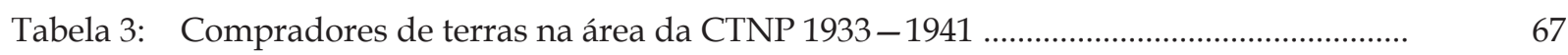

Tabela 4: Venda de Terras e Construção de Estradas na área da CTNP........................................ 72

Tabela 5: Fundações de colônias da Companhia de Terras ou Melhoramentos Norte do Paraná (conforme áreas reservadas acima de 50 ha)

Tabela 6: População rural e urbana do Norte do Paraná entre 1940 e 1970 (Norte Novo e Norte Novíssimo; população em 1000).

Tabela 7: Densidade populacional das regiões do Norte Novo e Norte Novíssimo do Paraná entre 1940 e $1970\left(\mathrm{~h} / \mathrm{km}^{2}\right)$.

304

Tabela 8: Dimensões da estrutura dos estabelecimentos agrícolas no Norte Novo em $1950 \ldots \quad 78$

Tabela 9: Número de pés de café e produção cafeeira no Norte Novo de 1942 a 1950 .............. $\quad 78$

Tabela 10: Participação do Paraná na exportação brasileira e participação do café na exportação paranaense entre 1942 e 1951.

Tabela 11: Formas de contrato entre proprietários de terras e empreiteiros no cultivo de café no Norte do Paraná

Tabela 12: Mudanças populacionais no Norte do Paraná entre 1940 e 1970.

Tabela 13: Procedência dos proprietários de terra em Mandaguari e Umuarama (segundo local de nascimento; parcela em \%)

Tabela 14: Procedência dos colonos (segundo cidade natal/estado) de duas fazendas em Rolândia e Apucarana (parcela em \%).

Tabela 15: Procedência de trabalhadores migrantes, trabalhadores rurais, trabalhadores de fábricas e funcionários da Usina Central Porecatu (parcela em \%) ......

Tabela 16: Uso da terra no Norte Novo e Norte Novíssimo do Paraná em 1960 (em \% da área dos empreendimentos).

Tabela 17: Extensão das propriedades de empreendimentos agrícolas em 1960 (ordens de grandeza em ha).....

Tabela 18: Ordens de grandeza dos empreendimentos rurais com plantio de café em 1961 .....

Tabela 19: Parcela de cultivo de café em área de empreendimento e área de cultivo dentro de cada ordem de grandeza dos empreendimentos

Tabela 20: Idade das plantações de café nas regiões de cultivo do Norte do Paraná em 1961 (Parcelas em \%)...

Tabela 21: Formas dominantes de gestão de cultivo no cultivo de café segundo a posição do gestor e ordens de grandeza dos empreendimentos

Tabela 22: A importância econômica da exportação do café em países selecionados (1963) .....

Tabela 23: A relação de dependência entre o Brasil e os EUA na economia do café ao tempo do acordo do ICA 
Tabela 24: Produção de café mundial do tipo exportação. Situação antes e no início do ICA (em 1.000 sacas de $60 \mathrm{~kg}$ )

Tabela 25: Pagamentos pela erradicação de cafeeiros no Brasil. Agosto de 1966 - Abril de 1967.

Tabela 26: Redução do número de cafeeiros no Brasil, em 1962-1967 .

Tabela 27: Extensão da erradicação no Norte do Paraná de acordo com o tamanho das plantações de café

Tabela 28: Erradicação no Paraná no contexto do programa Gerca (junho 1962 - final de 1965) (Número de cafeeiros erradicados em 1000)

Tabela 29: Erradicação no Norte Novo e Novíssimo do Paraná em 1966 e $1967 .$.

Tabela 30: Quantidade de cafeeiros no Norte do Paraná entre 1961 e 1963, estimativa (em 1000)

Tabela 31: Utilização da terra da antiga área de cultivo de café no Paraná que se tornou livre por meio da erradicação de 1962 a 1966, em comparação com todo o Brasil

Tabela 32: Uso da terra das antigas lavouras de café (1966/67 e 1967/68)

Tabela 33: Prejuízos da geada no cultivo de café

Tabela 34: Quantidade de dias com temperatura mínima abaixo de $5^{\circ} \mathrm{C}$ por ano $(\varnothing 1966$ 1970)

Tabela 35: Intensidade e extensão de danos causados pela geada em plantações de café no Norte do Paraná

Tabela 36: Danos causados pela geada no plantio de café no Paraná em 10 de julho de 1969 (em 1000 cafeeiros)

Tabela 37: Danos causados pela geada em 1969 nas plantações de café, no Norte do Paraná, de acordo com a idade e a situação de produção dos cafeeiros

Tabela 38: Retrocesso de produção no plantio de café no Paraná, após a ocorrência de geadas

Tabela 39: Mudanças estruturais no uso da terra no Norte do Paraná entre 1960 e 1970...........

Tabela 40: Cultivos paralelos nos cafezais do Norte do Paraná em 1970 (parcela dos cultivos paralelos em relação à área total, em \%)

Tabela 41: Diferenças regionais das formas de cultivo de lavouras selecionadas em 1968 (parcela em \%)

Tabela 42: Cultivo de trigo no Norte Novo e Norte Novíssimo do Paraná

Tabela 43: Comercialização de produtos agrícolas dos membros da Cotia em 1969 (em \% do valor total)

Tabela 44: Desenvolvimento da pecuária no Norte Novo e Norte Novíssimo do Paraná entre 1960 e 1967

Tabela 45: Quantidade de empreendimentos com plantações de café e área de cultivo de café no Norte Novo e Novíssimo do Paraná em 1968 
Instituições, organizações e companhias estatais, mistas e privadas

$\mathrm{ABCAR}=$ Associação Brasileira de Crédito e Assistência Rural

ACARPA = Associação de Crédito e Assistência Rural do Paraná

BADEP = Banco de Desenvolvimento do Paraná (antiga CODEPAR)

$\mathrm{CAC}=$ Cooperativa Agrícola de Cotia

CAFE do Paraná = Companhia Agropecuária de Fomento Econômico do Paraná

CCLEF = Comissão Central de Levantamento e Fiscalização das Safras Tritícolas

CEPRES = Comissão de Estudos de Previsão de Safras do Paraná

CERENA = Comissão de Estudos dos Recursos Naturais Renováveis do Estado do Paraná

CIBPU = Comissão Interestadual da Bacia Paraná - Uruguai

CODEM = Comissão do Desenvolvimento Municipal

CODEPAR = Companhia de Desenvolvimento Econômico do Paraná

CONTAG = Confederação Nacional dos Trabalhadores na Agricultura

COPEL = Companhia Paranaense de Energia Elétrica

$\mathrm{CMNP}=$ Companhia Melhoramentos Norte do Paraná

$\mathrm{CTNP}=$ Companhia de Terras Norte do Paraná

$\mathrm{DAC}=$ Departamento de Assistência à Cafeicultura

DEE $=$ Departamento Estadual de Estatística

DER $=$ Departamento de Estradas e Rodagem

DGTC $=$ Departamento de Geografia, Terras e Colonização (Curitiba)

DNER $=$ Departamento Nacional de Estradas e Rodagem

FAEP = Federação de Agricultura do Estado do Paraná

FETAEP = Federação dos Trabalhadores na Agricultura do Estado do Paraná

GERCA = Grupo Executivo de Racionalização da Cafeicultura

IBC = Instituto Brasileiro do Café

$\mathrm{IBDF}=$ Instituto Brasileiro de Desenvolvimento Florestal

IBG = Instituto Brasileiro de Geografia

IBGE $=$ Instituto Brasileiro de Geografia e Estatística

IBPT = Instituto de Biologia e Pesquisas Tecnológicas (Curitiba)

IBRA = Instituto Brasileiro de Reforma Agrária 
ILO = International Labour Office (Genebra)

INCRA = Instituto Nacional de Colonização e Reforma Agrária

INDA = Instituto Nacional de Desenvolvimento Agrário

OEA = Organização dos Estados Americanos 
PREFÁCIO À EDIÇÃO ORIGINAL

APRESENTAÇÃO

I. INTRODUÇÃO AO FENÔMENO DA COLONIZAÇÃO AGRÁRIA ...

II. FUNDAMENTOS AMBIENTAIS DA COLONIZAÇÃO AGRÁRIA NO NORTE DO PARANÁ.

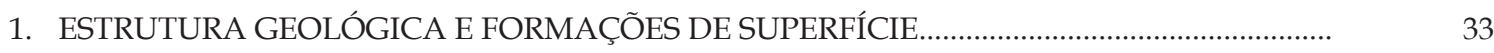

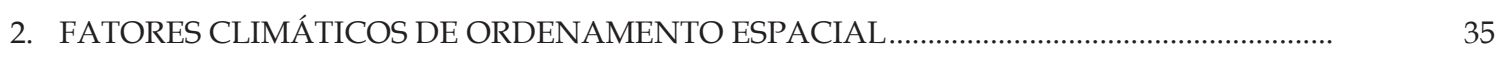

3. INVENTÁRIO VEGETACIONAL ...................................................................................................

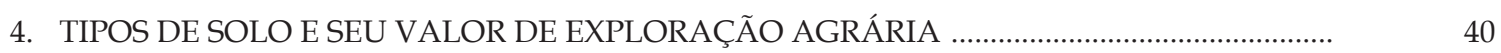

III. PROBLEMAS DA CONQUISTA DE TERRAS E ANÁLISE DOS PROCESSOS DA COLONIZAÇÃO AGRÁRIA EM SUA DIFERENCIAÇÃO ESPAÇO-TEMPORAL

1. OS PRIMÓRDIOS DA COLONIZAÇÃO NA PROVÍNCIA GUAYRÁ NOS SÉCULOS XVI E XVII

2. BASES DA DIVISÃO ECONÔMICA E SOCIOESPACIAL DO PARANÁ NOS SÉCULOS XVIII E XIX.

3. RELAÇÕES DE POSSE DE TERRA NA ZONA PIONEIRA A OESTE DO RIO TIBAGI NO INÍCIO DA EXPLORAÇÃO MODERNA DO NORTE DO PARANÁ

4. O SIGNIFICADO DA COLONIZAÇÃO DIRIGIDA PRIVADA PARA O DESENVOLVIMENTO DO NORTE DO PARANÁ DESDE 1930

5. COLONIZAÇÃO ESTATAL E POLÍTICA DE VENDA DE TERRAS

6. DESENVOLVIMENTO DA PAISAGEM AGRÁRIA DO NORTE NOVO DO PARANÁ

IV. A EXPANSÃO DO CULTIVO DE CAFÉ COMO FATOR DE CONFORMAÇÃO DA PAISAGEM E DA ESTRUTURA SOCIAL AGRÁRIAS DO NORTE DO PARANÁ..

1. DESLOCAMENTOS DAS ÁREAS CENTRAIS DO CULTIVO DO CAFÉ BRASILEIRO 
2. ESTRUTURA DA ORGANIZAÇÃO SOCIAL RURAL E DA ORGANIZAÇÃO DE TRABALHO NO CULTIVO DE CAFÉ DO NORTE DO PARANÁ..

3. MOBILIDADE SOCIAL E ESPACIAL ESPECÍFICA DE GRUPOS E CLASSES NO ÂMBITO DA ECONOMIA CAFEEIRA PARANAENSE

4. POSIÇÃO E ANÁLISE DA ESTRUTURA DO CULTIVO DO CAFÉ NO NORTE DO PARANÁ NO INÍCIO DOS ANOS 1960.

V. O DESENVOLVIMENTO DA SITUAÇÃO DO MERCADO CAFEEIRO MUNDIAL E O SIGNIFICADO DO INTERNATIONAL COFFEE-AGREEMENT.

1. PROBLEMAS DE ESTABILIZAÇÃO DO MERCADO CAFEEIRO MUNDIAL ............................... 119

2. TENTATIVAS INTERNACIONAIS DE COORDENAÇÃO E FUNDAMENTOS DO ICA........

VI. MEDIDAS ECONÔMICO-POLÍTICAS DE RESTRIÇÃO NO CULTIVO DO CAFÉ E MUDANÇAS ESTRUTURAIS DA GEOGRAFIA AGRÁRIA NO NORTE DO PARANÁ.

1. PROGRAMA DE REDUÇÃO DA QUANTIDADE DE CAFEEIROS (1962-1967)

2. O DESENVOLVIMENTO DA ERRADICAÇÃO NO NORTE DO PARANÁ. AVALIAÇÃO DA IMPORTÂNCIA E DAS CONSEQUÊNCIAS

3. APROVEITAMENTO DA TERRA DAS ANTIGAS ÁREAS DE PLANTIO DE CAFÉ E PROBLEMAS DA DIVERSIFICAÇÃO DOS PRODUTOS A SEREM PLANTADOS

4. PROBLEMAS SOCIAIS E CONSEQUÊNCIAS DA ERRADICAÇÃO

VII. AS CONSEQUÊNCIAS ECONÔMICAS E SOCIOGEOGRÁFICAS DOS DANOS CAUSADOS PELA GEADA NA ECONOMIA CAFEEIRA DO NORTE DO PARANÁ

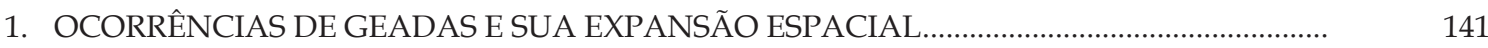

2. MÉTODOS PARA IMPEDIR DANOS CAUSADOS PELA GEADA NO PLANTIO DE CAFÉ. 145

3. ANÁLISE QUANTITATIVA DOS DANOS CAUSADOS PELA GEADA EM 1969........................ 147

4. CONSEQUÊNCIAS SOCIOGEOGRÁFICAS DIRETAS E INDIRETAS DA GEADA DE $1969 .$.

\section{A SITUAÇÃO AGRÁRIA DO NORTE NOVO E NORTE} NOVÍSSIMO DO PARANÁ NO INÍCIO DOS ANOS 1970 ..................... 159

1. DIFERENCIAÇÃO ESPACIAL DAS MUDANÇAS NA ESTRUTURA AGRÁRIA ..................... 159

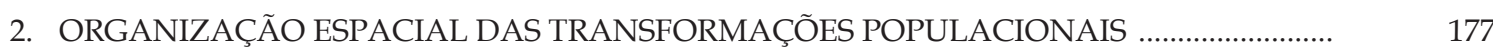

3. IMPORTÂNCIA DO PLANTIO DE CAFÉ NO NORTE DO PARANÁ AO CONCLUIR-SE A PESQUISA

4. CONSEQUÊNCIAS DO DESMATAMENTO EXCESSIVO NO CURSO DA COLONIZAÇÃO CAFEICULTORA PARANAENSE

5. A AMEAÇA DO CULTIVO DE CAFÉ PELO SURGIMENTO DA HEMILEIA VASTATRIX .... 
IX. CONSIDERAÇÕES FINAIS ............................................................................. 199

X. REFEREANCIAS ............................................................................................... 203

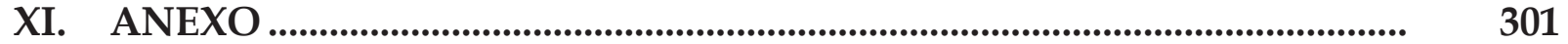


O desenvolvimento dos espaços econômico e social no Norte do Paraná me fascinou desde minha primeira visita a essa região no ano de 1963. Naquela época, empreendi com alguns conhecidos uma viagem aventuresca desde a região à qual dedicava meu trabalho como doutorando, o Nordesde de Santa Catarina, até o Norte do Paraná. Naquele tempo, passamos por estradas quase que na maioria ainda não asfaltadas. E entre as minhas experiências mais impressionantes até hoje está a viagem no trecho de Foz do Iguaçu às Sete Quedas, que ainda existiam na época, na região de Guaíra. Interrompida por longas paradas por causa das fortes chuvas, a viagem nos levou por um caminho estreito próximo ao rio Paraná, entre florestas tropicais ainda intactas, com sua flora e fauna exuberantes.

Junto às quedas arrebatadoras, eram sobretudo a vegetação variada da floresta e o esplendor das incontáveis e magníficas borboletas que animavam os visitantes. Ao mesmo tempo, era possível ver a rápida expansão das regiões do oeste do Paraná, com assentamentos em que os primeiros pioneiros se fixavam em meio à floresta e tentavam começar ali uma nova vida. Com isso, ficou claro também que a colonização, com sua dinâmica e criação de novas paisagens culturais, rapidamente passaria por cima da paisagem natural com seus desmatamentos extensivos.

Consegui travar contatos institucionais e pessoais no Norte do Paraná por conta de visitas posteriores entre 1965 e 1968. Depois de uma preparação intensiva, que me havia sido aconselhada sobretudo por Reinhard Maack, professor na UFPR, em Curitiba, eu comecei então em 1970 um projeto de pesquisa financiado por uma agência alemã de fomento à pesquisa sobre a expansão espacial e desenvolvimento socioeconômico do Norte do Paraná, que se tornou no começo dos anos de 1960 uma das mais significativas áreas de cultivo de café de toda a Terra.

O começo de minhas pesquisas em 1970 se deu em uma fase difícil de mudanças estruturais no meio agrícola, mas extremamente dinâmica para o Norte do Paraná. A forte geada de 9 e 10 de julho de 1969 havia destruído novamente as plantações de café, mas dessa vez de maneira especialmente intensa. Desse modo, no ano seguinte, presenciou-se a transformação da agricultura regional, da monocultura do café para o agronegócio diversificado e para a pecuária, sobretudo nos solos arenosos do Noroeste. A isso se somavam grandes reviravoltas sociais nessa região: depois de anos de forte imigração de Minas Gerais, São Paulo e Nordeste nos anos de 1950 e 1960, ocorria agora uma emigração por causa de demissões de mão de obra agrícola efetiva, depois da erradicação do café. A mudança para uma agricultura mecanizada ou para pecuária extensiva levou a região a uma rápida diminuição da população rural, bem como ao desemprego, ou a relações de trabalho socialmente inseguras como as de boia-fria.

A área de trabalho expandida ficava a oeste do rio Tibagi e se estruturou naquela época nos Nortes Novo e Novíssimo centrais, as áreas de assentamento mais jovens no Noroeste, que se estendiam para o sul até o rio Piquiri. O Norte Novo se estabelecia com base em uma colonização privada para propriedades pequenas e médias, muito bem organizada e dirigida pela Cia. Melhoramentos Norte do Paraná, o que no Brasil daquela época constituía uma inovação para o cultivo do café. No Norte Novíssimo, predominava a colonização conduzida pelo Estado, bem como atividades de sociedades privadas e ocupação espontânea, com algumas disputas de direito de posse. A fronteira sul da área de pesquisa era a fronteira da geada, que separava, de um lado, as áreas tropicais periféricas [randtropisch] com sua monocultura cafeeira destinada à exportação e expandida até a extrema fronteira sul, e, de outro, as regiões subtropicais. Lá ocorria a expansão por meio de migrantes internos vindos do Rio Grande do Sul e Santa Catarina, e predominava o cultivo de alimentos essenciais, naquela época em fase inicial e ainda frequentemente no sistema de rotação de terras melhorada.

Nesse ínterim, passaram-se mais de 40 anos desde o meu estudo sobre a colonização agrária no Norte do Paraná, e a atual paisagem agrária no estado revela as mudanças radicais ocorridas desde então. Hoje, o cultivo de café, outrora dominante no Norte do Paraná, quase não tem importância, com seus cerca de $5 \%$ da área de cultivo de antes. Na contramão está o cultivo de soja, que começou no Paraná nos anos 1960 e que, seguida do milho, é de longe a cultura mais importante. Também o cultivo 
de cana-de-açúcar assistiu no norte do estado a uma forte expansão por conta do boom do bioetanol, assim como a pecuária.

Por causa dos meus contatos acadêmicos já desde 1961 com o Centro de Pesquisas de Geografia do Brasil, no Rio de Janeiro (UFRJ), e segundo as leis vigentes em 1970 para a pesquisa científica, eu estava ligado à base institucional local como cientista estrangeiro, e do mesmo modo ao Departamento de Geografia do IBGE.

Infelizmente, em 1970 a Universidade de Londrina, no Norte do Paraná, ainda se encontrava em construção, e em Maringá ainda não havia universidade alguma, de modo que, exceto na capital paranaense, os contatos acadêmicos na região eram bastante limitados. Por outro lado, houve a possibilidade única de consultar diretamente os atores socias de todos os níveis, especialmente os pioneiros dos processos de desenvolvimento que se realizavam. A amabilidade e a boa vontade da população da região facilitaram muito os meus trabalhos.

O trabalho se baseia em incursões estendidas a todas as áreas acadêmicas com observações estruturadas; em entrevistas amplas com representantes de todas as camadas sociais na área rural, junto a instituições privadas ou estatais; em inúmeros mapeamentos, para os quais também a minha esposa Brigitte me apoiou durante algumas semanas; e na utilização de fontes acadêmicas privadas e de arquivo. Infelizmente a análise de fotos aéreas mais recentes não era possível para cientistas estrangeiros, naquela época.

Juntamente com a análise da sucessão de processos de desenvolvimento, o objetivo das pesquisas era contribuir com a investigação do desenvolvimento regional em zonas pioneiras voltadas para o mercado internacional, marcadas pela dinâmica interna e pela mobilidade social e espacial, fatores exógenos e endógenos de instabilidade, conflitos de interesse e dependências. Com isso, devem-se revelar as mudanças agrárias estruturais e as tendências de diversificação que são importantes para a diminuição de riscos naturais, econômicos e ecológicos em regiões de monoculturas tropicais e para a melhoria das relações socioeconômicas.

Já no prefácio da primeira edição de língua alemã, no ano de 1975, eu tinha agradecido às inúmeras instituições e pessoas no Norte do Paraná, bem como no restante do estado, e no Brasil. Para mim, sempre foi de fundamental importância a apresentação de uma versão em língua portuguesa deste estudo. Infelizmente, não chegou a se concretizar a destinação de recursos financeiros brasileiros para uma tradução, que fora aprovada em 1973. Lamentei que por tantos anos isso tenha limitado o conhecimento deste estudo a leitores com domínio da língua alemã.

Desse modo, foi uma enorme alegria para mim, quando Paulo Astor Soethe, professor de Letras Alemão da UFPR, ofereceu-me a possibilidade de uma tradução, e em colaboração com a Editora da UEM, da publicação desse estudo histórico. Para mim é uma oportunidade especial de agradecer imensamente a Paulo Soethe e seus colaboradores, à editora da UEM e a sua editora-chefe Terezinha Oliveira, e à editora Franz Steiner, em Stuttgart (Alemanha), pela cessão sem custo da licença para a tradução. Pelo apoio financeiro, agradeço à Fundação Baden-Württemberg e à Fundação Araucária.

Para o autor desse estudo, trata-se de uma possibilidade há tempos almejada de poder oferecer esse trabalho ao povo do estado do Paraná e aos colegas no Brasil em sua língua materna. O trabalho foi admitido em 1972, como tese de livre docência, na tradicional universidade alemã de Heidelberg e é uma

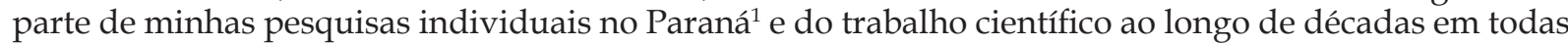

1 Entre outros, foram publicados os seguintes estudos sobre o Paraná:

- 1969: Types of agricultural colonization of subtropical Brazilian Campos limpos. - In: Revista Geográfica 70, pp. 131-155. Rio de Janeiro.

- 1976: Gelenkte Agrarkolonisation im Rahmen der Expansion des Kaffeeanbaus im Norden Paranás [Colonização agrária dirigida no contexto da expansão do cultivo do café no Norte do Paraná]. - In: Nitz, H.-J. (ed.): Landerschließung und Kulturlandschaftswandel an den Siedlungsgrenzen der Erde. Göttinger Geogr. Abhandlungen 66, pp. 71-90. Göttingen.

- 1982: Rolândia (Norte do Paraná) 1932-1982. Início e desenvolvimento econômico da colônia alemã no Brasil. - In: Revista Brasileira de História 4, pp. 221-229.

- 1986: A emigração brasileira para o leste do Paraguai. Uma análise das causas, evolução e consequências. - In: Benecke, D.W. et al. (eds.): Desarrollo demográfico, migraciones y urbanización en América Latina. Eichstätter Beiträge 17 (América Latina 1), pp. 207-224. Regensburg.

- 1987: Itaipu. Basic geopolitical and energy situation - socio-economic and ecological consequences of the Itaipu dam and reservoir on the Rio Paraná (Brazil/ Paraguay). - In: GTZ Division 21, Ecology and Environmental Protection, 100 pp. Braunschweig, Wiesbaden: Vieweg \& Sohn.

- 1987: Itaipu. Raumwirksame sozioökonomische Probleme hydroelektrischer Inwertsetzung des Rio Paraná im brasilianischparaguayischen Grenzraum [Itaipu. Problemas socioeconômicos espacialmente relevantes da valorização hidroelétrica do Rio Paraná na fronteira Brasil-Paraguai]. - In: Kohlhepp, G. (ed.): Brasilien. Beiträge zur regionalen Struktur- und 
as regiões do Brasil, assim como cooperações científicas com colegas brasileiros e relações amigáveis com esse país.

Gerd Kohlhepp

Tübingen, Alemanha

fevereiro, 2013

Professor Emérito da cátedra de Geografia Econômica e Social e ex-diretor do Centro de Pesquisas

Geográficas sobre a América Latina na Universidade de Tübingen, Alemanha

Membro da Academia Brasileira de Ciências.

e-mail: gerd.kohlhepp@t-online.de

Entwicklungsforschung. Tübinger Beiträge zur Geographischen Lateinamerikaforschung 1, pp. 71-116. Tübingen (coautor: B. Karp).

- 1991: Espaço e etnia. [O exemplo dos Suábios do Danúbio de Entre Rios no Paraná]. - In: Estudos Avançados 5 (11), pp. 109-142. São Paulo.

- 1991: Mudanças estruturais na agropecuária e mobilidade da população rural no Norte do Paraná. - In: Revista Brasileira de Geografia 53 (2), pp. 79-94. Rio de Janeiro.

- 1999: Grandes projetos de barragem no Brasil: problemas ecológicos e sócio-econômicos. - In: Revista de Estudos Ambientais 1 (1), pp. 50-61. Blumenau/SC. 
Este livro é o resultado de uma viagem de pesquisas realizada entre maio e novembro de 1970 ao Estado do Paraná, Brasil. A viagem tornou-se possível graças ao generoso patrocínio da DFG Fundação Alemã para a Pesquisa Científica, à qual devo especial agradecimento pela bolsa de estudos para minha habilitação acadêmica, como também à oportuna ajuda de custo para a impressão do meu trabalho.

Contudo, a escolha do Paraná como território de pesquisa de campo deve-se a uma viagem anterior, focada nos problemas específicos do desenvolvimento regional, que, já com o apoio da DFG, pude empreender em 1965 em companhia do meu respeitado Professor, Dr. G. Pfeifer, às regiões Sul, Sudeste e Central do Brasil: a ele aqui expresso meu agradecimento por seu múltiplo apoio, as muitas discussões e o extraordinário interesse pessoal e científico, com que acompanhava e incentivava o curso dos trabalhos.

As breves visitações subsequentes do terreno, realizadas no período que vai de 1965 a 1968, e que contemplavam a investigação comparativa de outro repertório de questões, auspiciaram-me a oportunidade de acompanhar a trajetória do processo de desenvolvimento geo-cultural do Paraná. Essas viagens não apenas proporcionaram a assimilação de importantes conhecimentos sobre o país em si, como também facilitaram o primeiro acesso às fontes da pesquisa, em particular, os acervos estatístico e aerofotogramétrico, estabelecendo também grande número de contatos humanos e profissionais, que muito me auxiliaram durante a interpretação do material, em 1970.

Agradecido, evoco os muitos incentivos e referências do Prof. Dr. Reinhard Maack, de Curitiba, que durante minhas viagens anteriores e na preparação da minha estada enquanto pesquisador introduziume às suas experiências acumuladas durante décadas no Paraná, mas que infelizmente não mais vivenciou o início propriamente dito das atividades ${ }^{3}$.

É oportuno lembrar que a realização das pesquisas foi facilitada pelo interesse, o espírito cooperador e a assessoria de grande número de pessoas físicas, funcionários de autarquias públicas e instituições e organismos privados, na prospecção de informações e materiais em todos os âmbitos da investigação, em particular em Curitiba, São Paulo, no porto de Paranaguá, exportador de café, mas também em Santos, no Rio de Janeiro e Brasília.

A receptividade e postura generosa de agentes de todas as camadas sociais, em grande número de encontros e sindicâncias - fossem proprietários de terra, administradores, arrendatários parciais, trabalhadores rurais e sazonais ambulantes; fosse durante a interpretação de contratos de trabalho e levantamento estatístico em fazendas de todos os portes; fosse ainda em Prefeituras, filiais da Cia. Melhoramentos Norte do Paraná, sedes regionais da Acarpa, da empresa Cotia, ou no convívio com agrônomos e escritórios regionais do Instituto Brasileiro do Café e do Gerca, como também durante o mapeamento do material - todos esses contatos foram, enfim, de enorme valia para a realização da minha pesquisa, motivo pelo qual registro aqui meu reconhecimento do tradicional espírito de colaboração e meu sincero agradecimento à cordial hospitalidade brasileira.

Meu agradecimento especial vai para as famílias H. M. Bresslau e A. von Treuenfels, de Rolândia, que me acolheram em suas residências, onde por algum tempo me foi permitido instalar minha "base operacional".

Infelizmente, o espaço exíguo não permite recordar nominalmente todas as pessoas e repartições que o mereceriam, advirto, porém, que os nomes de meus informantes mais importantes estão registrados ao longo de todos os capítulos do presente trabalho.

Contudo, em nome de tantos aqui não citados, desejo lembrar, agradecido, o Sr. A. W. Nieffeler, o Dr. W. Babkov (CMNP), o Dr. H. Maier e o Eng. Agr. G. Neves Calefti (IBC/Gerca), em Maringá. Em Londrina tive o apoio do srs. V. Frech e K. Schnitzius, além do Dr. I. Meirelles (Faep), e P. C. Rohrbach (DGTC). Em Curitiba auxiliaram-me a sra. Dr. G. Maack e a família Dr. G. Kurowski.

2 Tradução de Frederico Füllgraf.

3 O Prof. Maack faleceu em 26 de agosto de 1969 [N.T.] 
Meu profundo agradecimento é extensivo a todos os colegas e amigos brasileiros, lotados em diversas faculdades de Curitiba e do Rio de Janeiro, em especial aos professores Lysia M. C. Bernardes, Nilo Bernardes, Maria do Carmo Corrêa Galvão, Orlando Valverde, e aos professores e colegas da Fundação Instituto Brasileiro de Geografia, pelo grande número de sugestões e sua valiosa colaboração.

O caráter temporário de minha permanência e o decreto-lei que controla a pesquisa científica de estrangeiros no Brasil, a impossibilidade do acesso às imagens aerofotogramétricas mais recentes, assim como a atitude reservada, ditada pela conjuntura político-econômica, de órgãos governamentais face ao meu pedido de informações detalhadas; os grandes obstáculos, enfim, interpostos à minha tentativa de acesso aos dados estatísticos não foram capazes de refrear decisivamente o curso das pesquisas.

Muito agradecido sinto-me, finalmente, ao Prof. Dr. H. Graul, por ter-me liberado de minhas funções no Instituto Geográfico de Heidelberg, durante minha viagem de pesquisas e a vigência da bolsa de habilitação ao Professorado, como também devo agradecer ao Prof. Fricke pelo interesse e o apoio proporcionado à pesquisa, que no outono de 1972 foi aceita pela Faculdade de Geociências da Universidade de Heidelberg, como Tese de Habilitação.

Aos editores das 'Heidelberger Geographische Arbeiten' [Obras Geográficas de Heidelberg] agradeço pela seleção da minha pesquisa para essa série editorial; agradecimento extensivo aos funcionários da Editora Franz Steiner, por sua assistência durante a edição do texto.

Agradeço também à sra. Maria Solymossy, cartógrafa da unidade de Geografia Cultural do Instituto Geográfico da Universidade de Frankfurt, por seu valioso trabalho de ilustração cartográfica, em especial, a produção dos mapas coloridos.

Dedico a presente publicação à minha esposa, a cujo incansável apoio com digitação, revisão, além da produção cartográfica, deve-se em grande parte a concretização da presente publicação.

Devido à minha mudança de Heidelberg para Frankfurt, infelizmente a produção gráfica sofreu algum atraso. Originalmente concluída no verão de 1972, a pesquisa sofreu atualizações cabíveis, dois anos mais tarde.

Frankfurt, em dezembro de 1974.

Gerd Kohlhepp 
O estudo do Prof. Gerd Kohlhepp, mesmo após 40 anos desde a primeira publicação do original alemão, constitui referência imprescindível para a descrição e compreensão do processo de colonização agrária do Norte paranaense e oferece um excelente fundamento para a reflexão sobre seus desdobramentos até hoje.

A presente edição, portanto, não tem apenas o sentido histórico, que por si mesmo já a justificaria, de registrar um produto de altíssimo nível científico da Geografia de tradição alemã em meados da década de 1970; mais que isso, a publicação ainda torna acessível a paranaenses, brasileiros e toda a comunidade lusófona um desses textos de fundação do Brasil sob perspectiva e colaboração estrangeira, que hoje, ao se tornarem visíveis, ajudam a refletir sobre as características contemporâneas da sociedade local e sobre os caminhos futuros que ela pode tomar - ou não - nas próximas décadas.

O livro do Prof. Kohlhepp, agora em português, revela com o próprio atraso de sua publicação - e com a evidenciação da pouca visibilidade, no espaço público, dos processos geográficos, históricos e materiais que conformaram a sociedade paranaense de hoje - o quanto é urgente apropriarmo-nos de categorias e informações consistentes para discutirmos com maior propriedade, justamente "no espaço público', questões que perfazem a ordem do dia em nosso país. A abertura de novas fronteiras agrícolas no centro-norte do Brasil, por exemplo, a opção por monoculturas e pela obtenção de resultados econômicos rápidos às custas da devastação de florestas, o regime desordenado de mobilizações populacionais sem a devida infraestrutura para fixação dos trabalhadores e suas famílias - eis aí aspectos que podem ver-se iluminados hoje pela descrição e reflexão minuciosa de Gerd Kohlhepp sobre os processos ocorridos do Norte paranaense nas décadas de 1940 a 1970. E isso vale tanto mais quando se trata do valor da obra para a discussão sobre a realidade de hoje no estado, a partir da compreensão crítica de seus fundamentos.

Assim, e de outra parte, talvez a publicação chegue justamente na hora certa: quando a sociedade brasileira (e paranaense, em particular) se encontra ávida por compreender-se, por delinear com profundidade aspectos identitários e particularidades de suas conformações regionais e em nível nacional, quando ela se encontra ávida por consolidar estruturas que proporcionem justiça social e por inserir-se e destacar-se na comunidade internacional.

Esta publicação, a propósito, deve-se em grande medida ao último fator mencionado, o da internacionalização, já que nasce apoiada por fomento bilateral proporcionado pelos estados do Paraná e de Baden-Württemberg, por ocasião da visita de delegação governamental alemã a Curitiba, em novembro de 2011. Da parte brasileira, o projeto editorial recebeu recursos da Fundação Araucária, para financiamento da produção editorial e gráfica; da parte alemã, a Baden-Württemberg Stiftung financiou o trabalho de tradução e revisão técnica. A Universidade Federal do Paraná colaborou com a digitalização do original da obra, que será disponibilizado oportunamente. Na ocasião da visita dos dirigentes alemães ao Paraná, o estudo do Prof. Kohlhepp foi reconhecido pelos respectivos representantes governamentais da área científica como obra de referência que deveria marcar o início da cooperacão entre os dois estados, no que se refere à difusão de estudos de interesse para essa parceria promissora.

No momento em que o Brasil e o Paraná ganham um vulto científico que lhes confere grande visibilidade na comunidade internacional, a contribuição científica de um dos maiores brasilianistas europeus de sua geração vem novamente evidenciar, com grande sensibilidade histórica, social e humana, que o desenvolvimento econômico implica e exige um lastro cultural de igual envergadura. A leitura e recepção desta obra científica no Brasil, na comunidade acadêmica e para além dela, certamente colaborará com o adensamento cultural dos debates sociais em curso, neste espaço público nem sempre livre de sofrer as consequências da compartimentalização excessiva de ações e de conhecimentos. $\mathrm{O}$ livro de Gerd Kohlhepp, por sua abrangência, profundidade e sensibilidade, é em si mesmo um libelo contra a dissociação dos diversos campos do saber e um grato exemplo da incorporação sensata e sólida de referências culturais à reflexão sobre a dimensão material e econômica da constituição dos espaços humanos e suas transformações.

Paulo Astor Soethe 


\section{INTRODUÇÃO AO FENÔMENO DA COLONIZAÇÃO AGRÁRIA ${ }^{4}$}

Entre o início e meados do séc. XX, a colonização agrária em territórios tropicais, subtropicais e extratropicais da América Latina suscitou efeitos de desenvolvimento com intensidades regionais diversas.

Enquanto que, até o início do séc. XIX, os assentamentos coloniais restringiam-se apenas às bordas continentais e aos territórios da Alta Cultura indígena no Planalto Andino, após a independência de países como a Argentina e o Brasil, principalmente a partir de meados do séc. XIX, com a chegada das primeiras levas de imigrantes europeus, observamos uma expansão da ocupação territorial de direcionamento limitado. As incursões isoladas, em sentido centro-periferia, alcançaram êxito apenas parcial.

Até meados da década de 1950, predominaram em territórios florestais da América Latina, a ocupação e colonização espontânea, isto é, não dirigida. Apesar do efeito psicológico do ato da posse da terra, para a maioria dos colonos no papel de posseiros, seu peso econômico frequentemente limitou-se às culturas de subsistência, sob condições assaz primitivas, além de isoladas, sem quaisquer vínculos com mercados.

Somente em épocas mais recentes e devido ao aumento da pressão demográfica e das tensões sociais, começa a surtir efeito o planejamento regional de corte estatal, que no contexto da Reforma Agrária alavanca projetos de colonização de variada extensão.

A pesquisa geográfica da colonização agrária e de suas especificidades regionais, seja de caráter espontâneo, seja dirigida por agentes privados ou da esfera pública, desde a publicação dos trabalhos de Bowman, na década de 1930 (BOWMAN, 1931, 1932 e 1937) $)^{5}$, que ilustravam comparativamente o patamar de desenvolvimento no continente latino-americano em escala global, adquiriu notável importância.

Desde então, foi investigada a colonização pioneira em territórios de floresta pluvial do istmo centroamericano, do noroeste colombiano, das florestas do Planalto Andino, entre a Colômbia e a Bolívia, do leste paraguaio, da Patagônia oriental ${ }^{6}$, do extremo nordeste argentino, assim como do Sudeste e Sul brasileiros $^{7}$

No início da década de 1960, encerravam-se no Brasil tanto o ciclo da ocupação e colonização dos últimos espaços extra-amazônicos de floresta tropical pluvial, como também o assentamento expansivo em territórios de floresta subtropical da região Sul do país. No decurso espontâneo desses processos de desenvolvimento de grandes extensões territoriais, marcados por motivações econômicas diferenciadas e protagonizados pelos mais diferentes agentes de colonização, foram finalmente ocupados e colonizados o oeste do estado de São Paulo, a foz do Rio Doce e o sul da Bahia, o 'Mato Grosso' de Goiás, o território do Alto Uruguai, no norte do Rio Grande do Sul, o oeste de Santa Catarina, além do norte e do oeste do Paraná.

As pré-condições naturais destes processos, nas zonas climáticas sempre-úmidas e tropicais de umidade alternada, muito diferentes umas das outras, ocorreram sobre solos com graus de fertilidade muito diferenciados. Também a velocidade e intensidade das ocupações decorreram da pressão demográfica nas regiões de origem e segundo diferentes objetivos da colonização, dos quais eram portadoras camadas sociais com interesses diferenciados, sem falar de sua inserção em ciclos

4 Tradução de Frederico Füllgraf.

5 A título de comparação, veja-se também os estudos regionais detalhados de numerosos especialistas internacionais, em Joerg (1932).

6 Argentina [N.T.]

7 Entre outros, Sandner (1961, 1964) e Sandner/Nuhn (1971); Parsons (1968); Brücher (1968); Sick (1963); Maas (1969); Monheim (1965 e 1968); Schoop (1970); Dozier (1969); Wilhelmy (1940, 1941, 1949a); Lauer (1961), Golte (1973); Eriksen (1970); Eidt (1971); Waibel (1949, 1955a e 1955b), Monßeig (1952), Pfeifer (1966a e 1966c, 1967), Kohlhepp (1966a e 1966b). - Sobre o tema, de modo geral, ver Schauff (1959) e Caviedes (1971). Pesquisas sobre a recente ocupação da região amazônica brasileira entre outras, as do próprio Autor - não foram levadas em consideração. 
econômicos marcados por fortes oscilações dos mercados agroexportadores. Dentro das limitações apontadas, brotam zonas de colonização pioneira, cuja dinâmica, marcada pela especulação imobiliária e disputas pela posse da terra, e como consequência do modo de produção extrativo, em pouco tempo foi suplantada pelas manifestações da hollow frontier ${ }^{8}$, isto é: exaustão dos solos, quebra das colheitas e, com isso, deslocamento das prioridades produtivas, transformação das áreas de cultivo em pastos para a criação extensiva de gado e, finalmente, o abandono da região pelos próprios assentados.

Em oposição à dinâmica conhecida de processos geoculturais de ocupação uniforme de grandes extensões, está o desenvolvimento muito mais diferenciado do Norte do Paraná, objeto da presente pesquisa, que se expande sobre uma área de $57.000 \mathrm{~km}^{2}$ ao sul do Rio Paranapanema - divisa natural dos Estados do Paraná e de São Paulo - , delimitado a oeste pelo Rio Paraná, que a partir de Guaíra estabelece a fronteira natural com o Paraguai.

Aqui, a fronteira climática da cafeicultura estabelece certo critério de delimitação em direção ao sul, que se confunde com a ocorrência anual de geadas. Em bases naturais de clima e vegetação, esta delimitação será acentuada pela convergência de duas formas de organização agrícola, marcadas por elementos populacionais, formas econômicas e metas de produção distintas:

1. A 'Cafeicultura', com sua estrutura social particular no Norte do Paraná, constituída por contingentes populacionais luso-brasileiros, originários de São Paulo, Minas Gerais e do Nordeste, bem como pelos descendentes de trabalhadores italianos nos cafezais paulistas. Tratase de uma formação econômica de corte tropical, voltada para o mercado mundial, e que a partir do Norte do Paraná se expande em sentido sudoeste;

2. 'Forma de produção agrícola subtropical' estabelecida nos territórios ao sul da região cafeeira e protagonizada pelos descendentes de imigrantes alemães e italianos, originários do Rio Grande do Sul e Santa Catarina, que se afirmou como organização autônoma de melhoramento do sistema de cultivos alternados e da produção de alimentos.

De acordo com o fluxo migratório dos colonos originários no estado de São Paulo, com sucessivas levas que se deslocaram no tempo e no espaço em sentido leste-oeste, é possível interpretar a geografia do Norte do Paraná da seguinte forma (Mapa 1):

a) O Norte Velho, cuja ocupação se iniciou de forma aleatória desde a segunda metade do séc. XIX, e que se estende da divisa com São Paulo, a leste, até o Rio Tibagi, a oeste;

b) O Norte Novo, colonizado sistematicamente apenas desde 1930 com poucas exceções, e que em sentido oeste toca uma linha geográfica que vai do Rio Pirapó até o joelho do Ivaí;

c) O Norte Novíssimo, ocupado a partir da década de 1940, embora efetivamente colonizado apenas a partir da década de 1950, consta como o território de colonização mais jovem do estado. Essa região situa-se a oeste do Norte Novo e ao norte do rio Ivaí, assim como ao sul do rio Paranapanema, bordejando o rio Piquiri. Devido ao seu desenvolvimento no setor norte, a microrregião de Campo Mourão costuma ser agregada ao Norte Novíssimo.

A presente pesquisa, contudo, centra seu foco sobre o território situado a oeste do rio Tibagi. Em oposição ao Norte Velho, que fora ocupado espontaneamente segundo o tradicional sistema da cafeicultura paulistana, o desenvolvimento do Norte Novo funda-se sobre a colonização privada, organizada em torno da pequena e média propriedades. Ocorre que a crise da economia mundial e a crise do setor cafeeiro haviam forçado uma reestruturação da estrutura de propriedade rural no frontier brasileiro", pois no Norte Novíssimo, além das atividades de algumas empresas privadas e da posse espontânea da terra, prevaleceu sobretudo a colonização dirigida pelo Estado.

Durante a crise do café - momento que coincidiu com o início do processo de colonização não especulativo, marcado por excelente planejamento regional - o território situado nos limites da zona climática tropical, ao sul da zona hegemônica de economia de plantações apontada por Pfeifer (1966a), devido à sua importância para a conformação de territórios de cultivo no Novo Mundo, ofereceu uma excelente oportunidade no Norte Novo para uma empresa britânica de colonização.

8 Fronteira oca ou última fronteira, como, p. ex. A ocupação de Rondônia, segundo James (1938, [N.T.]).

9 Aqui subentendido como fronteira agrícola [N.T.] 
Hoje $^{10}$, quando todos os esforços de ocupação territorial no Brasil estão concentrados na Amazônia inexplorada e são instaladas pequenas e médias empresas ao longo de estradas interestaduais e eixos de inclusão territorial, as diretrizes para a colonização, os processos de desenvolvimento e as experiências colhidas no Norte do Paraná voltam a ganhar importância.

Exceção feita a alguns projetos isolados do governo revolucionário do México, a colonização agrária dirigida, em uma área com mais de $12.500 \mathrm{~km}^{2}$, a oeste do rio Tibagi, foi um dos primeiros e raros grandes projetos de desenvolvimento regional na América Latina até a década de 1950, e constituiu-se em coluna vertebral do desenvolvimento no Norte Novo e Novíssimo do Paraná, capaz de transformá-lo, com o boom cafeeiro do pós-guerra que se iniciara 25 anos antes, numa das zonas de colonização pioneira mais dinâmicas e brilhantes da América Latina (DOZIER, 1969, p. 9; JAMES, 1969, p. 494). No curso de apenas 20 anos, mais de 2 milhões de pessoas emigraram para essa região onde, apesar das quebras de suas colheitas devido às geadas, desenvolveu-se não apenas o mais importante polo cafeeiro do Brasil, mas de todo o mundo ${ }^{11}$, pois suas safras recordes chegaram a colher até 25 por cento de toda a safra mundial de café.

O cerne da presente pesquisa é, portanto, a análise do fluxo temporal e espacial de processos em suas variadas estratificações da colonização agrária, e dos fatores econômicos, políticos e socioeconômicos e ambientais que influíram em seus efeitos regionais. A ênfase está nos processos de desenvolvimento econômicos e sociogeográficos ocorridos no contexto da expansão da cafeicultura e dos problemas a ela relacionados. A dependência do café do mercado mundial, como também a tentativa de dirigir a produção em escala nacional e internacional acabaram por influenciar as fases desse desenvolvimento e a intensidade das respectivas reações à configuração das áreas de cultivo.

Mobilidade espacial e social de distintas camadas sociais e grupos etno-sociais deverão ser analisados de acordo com seus impactos sobre a engrenagem social das zonas pioneiras e suas transformações até os dias atuais. Devido a que essas zonas se caracterizam por poucos centros comerciais que se encontram ainda no início do processo de industrialização, a questão do desenvolvimento urbano no Norte do Paraná será abordada apenas tangencialmente nos quesitos que têm relevância para os processos de desenvolvimento rural.

A integração tardia dos territórios da fronteira histórica entre os domínios espanhol e português ao espaço geoeconômico do Brasil durante a crise do café, o predomínio monocultural da cafeicultura na fase seguinte, como também a geração dos atuais problemas estruturais de caráter socioeconômico - cuja causa é uma agricultura marcada por fatores econômicos e tendências de diversificação, e também pela busca por novos territórios apropriados - são elementos que ordenam o encadeamento da pesquisa.

Devido ao estágio de desenvolvimento muito recente da região, a pesquisa científica sobre o Norte do Paraná, nestes meados dos anos 1970, dá apenas seus primeiros passos. Para situá-la, são de suma importância as pesquisas fundacionais, com estudos da geografia física e da geologia da região, escritos por Maack. Devido à estrutura econômica e social diversa, Waibel (1949) não incluiu o Norte do Paraná em sua investigação da colonização europeia na Região Sul do Brasil. Já Monbeig (1952), nos seus trabalhos, concentrou-se em São Paulo, tecendo algumas referências (1935) ao estágio de desenvolvimento do norte paranaense de então, mas apenas de passagem e para efeito comparativo. Exceção feita a alguns ensaios valorosos do início da década de 1950, de estudantes de Waibel, e de algumas abordagens gerais ${ }^{12}$, os estudos geográficos brasileiros tampouco deram muita importância a essa região negligenciada pelas pesquisas, que à época tinham outras prioridades.

Neste sentido, o presente trabalho também é o resultado de extensos deslocamentos pelo território, grande número de entrevistas pessoais e levantamento estatístico em alguns municípios, como também de observações e mapeamentos, triagem de imagens aéreas e emprego de material de arquivos e fontes diversas.

Seu objetivo não é apenas analisar a sucessão de processos de desenvolvimento de geografia agrária, além de suas causas e efeitos na zona de influência da cafeicultura. Mais do que isso, ela também pretende

10 O autor escreve durante a década de 1970. O leitor deve considerar que os prognóstocos e afirmações do autor foram feitos nessa época, e devem ser comparados com o que realmente aconteceu desde então. [N.T.]

11 Na média anual dos doze anos entre 1961 e 1972: 50\% da produção brasileira de café.

12 Bernardes (1952); C. Bernardes (1950, 1953); Valverde (1956); Müller (1956); França (1956). Do lado americano: Dozier (1956), Dambaugh (1959); a partir de um ponto de vista sociológico e econômico: Margolis (1970, 1972), bem como Nicholls e Paiva (1969) e Nicholls (1970). 
contribuir ao debate sobre a problemática do planejamento regional em novas áreas de assentamento voltadas para o mercado mundial, e à questão das zonas pioneiras de colonização, cujo estágio de desenvolvimento, de um lado, é marcado por dinâmica e mobilidade social e, de outro, por fatores de instabilidade exógenos e endógenos, conflitos de interesse e estruturas de dependência. Além disso, seu objetivo é contribuir ao estudo das mudanças estruturais e tendências de diversificação geoagrárias, tanto espontâneas como dirigidas, no campo das monoculturas tropicais, que são de fundamental importância para a minimização de riscos de ordem natural e econômica, e a melhoria das condições socioeconômicas nos países em desenvolvimento. 


\section{FUNDAMENTOS AMBIENTAIS DA COLONIZAÇÃO AGRÁRIA NO NORTE DO PARANÁ ${ }^{13}$}

\section{ESTRUTURA GEOLÓGICA E FORMAÇÕES DE SUPERFÍCIE}

A estruturação geológica do sul do Brasil revela, principalmente no Paraná, uma ordenação muito clara (Mapa 2): a leste, sob forma de degrau com $2.000 \mathrm{~m}$ de altitude, as dobras montanhosas cristalinas precipitam-se abruptamente no Atlântico. A oeste, outro degrau íngreme parte da Serra do Mar e desfralda-se em um planalto cristalino, com 900 a $1.000 \mathrm{~m}$ de altitude.

Em sentido oeste, sobre esse Planalto cristalino acumularam-se poderosas camadas paleozoicas e mesozoicas, que esculpiram notáveis degraus na paisagem, cujas faces estão direcionadas tanto para o leste, como o oeste (ALMEIDA, 1949). Em sentido noroeste, as camadas decaem suavemente em direção ao Rio Paraná, que pode ser compreendido como eixo sinclinal de uma enorme bacia sedimentar (LEHMANN, 1958, p. 54).

O segundo plateau interior - o planalto paleozoico - é constituído por arenitos, xistos argilosos e outros depósitos de origem devônica, carbônica e pérmica, formando um 'teto' a partir de $1.100 \mathrm{~m}$ na beirada do escalão de sedimentação, que a leste sobrepuja o planalto cristalino com $200 \mathrm{~m}$, e a oeste com $600 \mathrm{~m}^{14}$.

A partir dele prolonga-se um terceiro escalão de superfície com várias centenas de metros de elevação, constituído por arenitos mesozoicos, e que na jazida encontra-se erguida por poderosos bancos de rochas básicas eruptivas. Na aresta desses degraus (no Paraná, a Serra da Boa Esperança), os relevos alcançam $1.200 \mathrm{~m}$, enquanto que em sentido noroeste o planalto decai até 200-300 m em direção aos rios Paraná e Paranapanema.

As gigantescas fendas distendidas, que ocorrem em sentido noroeste-sudeste, sob forma de camadas de lava em derramamentos sucessivos, com seus 1,2 milhões de $\mathrm{km}^{2}$ no planalto mesozoico ${ }^{15}$ do sul e sudeste brasileiros, pertencem às maiores expressões vulcânicas da Terra (BAKER, 1923; BEURLEN, 1970).

As camadas de meláfiras ${ }^{16}$, diábases e basaltos do triássico superior, respectivamente do jurássico inferior ${ }^{17}$, formadoras das camadas de lava, alcançam extensões que vão de 50 a $600 \mathrm{~m}$. Elas se sobrepõem aos arenitos triássicos de Botucatu da série São Bento (ver nota 14), que em parte também apresentam finas incrustações de lava.

A disseminação de extrusões vulcânicas é de particular importância para o norte do Paraná, uma vez que seus produtos expostos aos agentes atmosféricos deteriorantes, como p.ex. os solos extremamente férteis de argila vermelha (terra roxa), tornaram a região um dos mais importantes centros de cultivo cafeeiro.

Em sentido noroeste, é possível reconhecer rochas básicas eruptivas sob formações de arenitos jurássicos e cretáceos, que em São Paulo (Arenito de Bauru) estão disseminados por extensas áreas, de modo que as camadas de lava estão expostas apenas de forma marginal (FRANÇA, 1956, p. 29ss.; ver Mapa 2).

Já no Paraná, numa extensão de aprox. 14.000 km², que vai até o rio Piquiri (Norte Novíssimo), apenas no noroeste do Estado encontramos arenitos eólicos do Cretáceo Superior, que em oposição aos

13 Tradução de Frederico Füllgraf.

Ver Maack (1953): Mapa geológico do Estado do Paraná 1:750 000.

15 No Paraná, visto de leste em sentido oeste, em geral chamado de Terceiro Planalto.

16 Pórfira ígnea escura contendo cristais de feldspato [N.T.]

17 Conforme as mais recentes pesquisas geo-cronológicas, a datação correta da série São Bento não seria triássico-jurássica e, sim, jurássico-cretácea (EL-KHATIB, 1969, v. 2, p. 100). 
Arenitos de Botucatu, toscos, apresentam uma granulação de fina até média; em geral, são chamados de Arenitos de Caiuá (MAACK, 1940 e 1947).

Com o depósito dos Arenitos de Caiuá, chegava ao fim nesta região o grande ciclo de sedimentação. Já na fase erosiva que se seguiu, as jazidas de basalto foram parcialmente liberadas. Sobre sua fronteira oriental de disseminação, o Arenito Caiuá, solto e avermelhado, apresenta volumes de 10 a $20 \mathrm{~m}$, que, porém, aumentam de 200 a $250 \mathrm{~m}$ em sentido oeste (EL-KHATIB, 1969, v. 2, p. 106). Enquanto no Norte Novo do Paraná é possível encontrar apenas algumas ilhas isoladas do Arenito Caiuá, situadas ao norte do principal divisor de águas entre os rios Tibagi e Pirapó, e desatadas pela ação da erosão, com volumes que vão de 20 a $70 \mathrm{~m}$, os rios tributários do Paraná no Norte Novíssimo provocaram incisões apenas parciais nas bases basálticas. Somente nos vales do Paranapanema e do Ivaí a superposição do Caiuá encontra-se estrugida em sentido oeste-noroeste, e a fronteira geológica entre Caiuá e camadas de lava [Trapp] apresenta-se descontinuada.

No Paraná, o escalão do planalto mesozoico estende-se desde Santa Catarina em sentido sul/ sudeste-norte/noroeste, e somente descreve uma curva quando o rio Alonzo desemboca no rio Ivaí. Os tributários respectivamente dos rios Paraná e Paranapanema, interrompidos por grande número de corredeiras e cascatas, como o Ivaí, Tibagi, Laranjinha e Cinzas, cortam esse escalão em vales de ruptura antecedentais (MAACK, 1968, p. 272).

O território objeto da presente pesquisa compreende um recorte do planalto mesozoico, entre o rio Tibagi, a leste, e o Piquiri, a sudoeste, como também uma pequena parcela desse mesmo planalto na perna do Ivaí (Mapa 2). Os rios Piquiri, Ivaí e Tibagi produziram cortes incisivos nas camadas mesozoicas, de modo a desmembrar o campo da observação em dois blocos: o do planalto de Campo Mourão (entre o Piquiri e o Ivaí) e o de Apucarana (entre Ivaí e Tibagi), por sua vez desmembrado pelo rio Pirapó, apresentando em seu setor norte um relevo apenas levemente ondulado (Mapa 3).

Enquanto nas bordas do escalão do Terceiro Planalto ainda predominam altitudes de $1.000 \mathrm{~m}$ ou mais, o bloco do planalto no setor norte decai para $300 \mathrm{~m}$ acima do nível do mar, na foz do Tibagi, e para $250 \mathrm{~m}$ acima do nível do mar na foz do Paranapanema, ao precipitar-se no rio Paraná.

O rio Paraná, que pouco antes de atingir Guaíra, a $15 \mathrm{~km}$ da foz do Piquiri, ainda possui uma largura de $4 \mathrm{~km}$, derrama-se nas Sete Quedas, por sua vez consideradas um dos maiores conjuntos de quedas d'água do mundo ${ }^{18}$, com um canhão de $50 \mathrm{~km}$ de comprimento, cujos paredões verticais de meláfiras distam apenas entre 60 a $80 \mathrm{~m}$ uns dos outros. Com nível médio de volume, o espelho d'água do rio situa-se a $120 \mathrm{~m}$ de altitude, aos pés das cachoeiras ${ }^{19}$.

A inclinação das camadas em sentido noroeste e a alternância de variados sedimentos resistentes e de intrusões intermediárias criam a oeste do Tibagi um relevo fortemente diferenciado. Rios consequentes e rios subsequentes menores recortam a superfície do planalto.

As divisoras d'água estendem-se sob forma de encostas rasas, fracamente arredondadas e estiradas entre os vales e ribeiras, e em parte apresentam - principalmente na área dos arenitos, ao norte do Ivaí e na região de Umuarama - expansões à semelhança de planaltos (Mapa 3).

Os territórios das divisoras d'água são fragmentados por grande número de pequenos rios afluentes do Piquiri, Ivaí, Pirapó e Tibagi em chapadas, morros e encostas de terreno estreitas, estendidas e planas. As encostas localizadas entre $400 \mathrm{~m}$ e $850 \mathrm{~m}$ de altitude apresentam condições de relevo e altitude ideais para a cafeicultura no Paraná. Contudo, os vales pequenos são evitados como calhas de absorção de ar frio.

Em casos de inclinação mais acentuada das encostas, manifesta-se rápida erosão dos arenitos, que nos sedimentos soltos do Caiuá em pouco tempo é capaz de sulcar precipícios com mais de 10m de profundidade, chamados voçorocas, provocando o arrasto do solo arenoso (KUROVSKI, 1962).

Tendo em vista a qualidade dos solos para o desenvolvimento do terreno agricultável, a diferenciação geológica do Norte do Paraná entre zona de rochas vulcânicas eruptivas, a leste, e arenitos eólicos, soltos, a oeste, é de suma importância. Uma vez encerrado o ciclo agrário pioneiro, e

18 O potencial hidráulico em nível médio de águas do rio Paraná foi estimado ali em 13,5 milhões de kW (MAACK 1968, p. 253) representando a mais importante fonte energética até agora conhecida e, do ponto de vista técnico, explorável com relativa facilidade. Em 1975, 150 km rio abaixo, iniciar-se-ão as obras da Hidrelétrica Itaipu, de grande porte, como projeto bilateral, brasileiro-paraguaio, cujo potencial instalado deverá alcançar 10,7 milhões de kW.

19 Como é sabido, com o fechamento das eclusas da Hidrelétrica de Itaipu, o conjunto das Sete Quedas foi submergido definitivamente em 1983. Como documento memorial, recomenda-se o filme Quarup Sete Quedas (1983). [N.T.] 
muito particularmente para estes meados da década de 1970, esta configuração pode ser confirmada como pré-requisito do planejamento regional da ocupação do território rural e das eventuais medidas de investimento de parte do próprio Estado.

\section{FATORES CLIMÁTICOS DE ORDENAMENTO ESPACIAL}

O clima da região pesquisada, como de resto o da Região Sul do Brasil, encontra-se sob a influência de três categorias de massas de ar, que determinam seu caráter de zona climática de transição. Nesta zona convergem massas de ar atlântico-tropicais e equatorial-continentais. Devido à influência constante, durante o ano todo, do vento Passat-sudeste ${ }^{20}$, as massas de ar atlânticas adquirem grande importância. Contudo, principalmente no período que vai de outubro a março, ar tropical quente-úmido desprendese da Bacia Amazônica e dirige-se ao sul, provocando fortes precipitações convectivas e determinando o curso da intempérie durante esse período.

Entre abril e setembro, devido à infiltração de massas de ar frio durante o avanço dos anticlones no Atlântico sul, arrefece a influência das massas atlânticas tropicais, que se manifestam na área pesquisada em sentido nordeste-leste, aqui devido ao encurvamento das correntes "passatistas" durante seu choque com as bordas orientais do continente. A intensidade alternada das correntes de ar frio, que costumam trazer consigo chuvas frontais e geadas, além da oscilação do curso tomado pelas frentes frias, são de particular importância para o Norte do Paraná (IBG, 1968; ver tb. Cap. VII, l).

As condições de temperatura, em particular a ocorrência de geadas, são de fundamental importância para a expansão e/ou retração da cafeicultura no Norte do Paraná. "A fronteira vegetal e agroclimática do trópico quente segue [...] em segmentos continentais da borda exterior dos trópicos, a fronteira de ocorrência de geadas" (WISSMANN, 1948, p. 87). Em oposição às zonas oceânicas, nesse setor, a fronteira das geadas encontra-se mais próxima da Linha do Equador, ou abaixo da fronteira de baixo calor da cafeicultura lucrativa, cuja temperatura média anual segundo Wissmann $\left(1948\right.$, p. 86) é de $18,3^{\circ} \mathrm{C}$. Em suas bordas a zona tropical de transição é caracterizada por algumas áreas com evasão desimpedida de massas de ar frio e, portanto, livre de geadas; já as bacias, vales e baixios, estão, sim, sujeitos ao efeito das geadas.

$\mathrm{Na}$ área pesquisada, a temperatura média anual oscila entre $19,5^{\circ} \mathrm{C}$ e $22^{\circ} \mathrm{C}$, isto é, para o cultivo do café, que ali ultrapassa o trópico, estas são temperaturas ideais (Mapa 4, estações 1 e 2). Com muita ênfase, na tabulação da temperatura média anual, transparece a transitoriedade em sentido norte-sul ${ }^{21}$. No extremo noroeste do Paraná, a isoterma anual de $22^{\circ} \mathrm{C}$ corta os vales do Paraná e Paranapanema. Enquanto que no Vale do Ivaí e na Bacia do Paraná a média anual de $20^{\circ} \mathrm{C}$ ainda se manifesta em profundidade, ao sul, a média nos pontos mais elevados do Planalto cai rapidamente abaixo de $18^{\circ} \mathrm{C}$.

A média mensal mais alta é atingida no Norte do Paraná no mês de janeiro e, dependendo da altitude, situa-se entre $23^{\circ} \mathrm{C}$ e aprox. $26^{\circ} \mathrm{C}$. As médias mensais mais baixas manifestam-se em junho e na zona da cafeicultura situam-se entre $16^{\circ} \mathrm{C}$ e $18^{\circ} \mathrm{C}$. Em zonas tropicais de fronteira, o andamento anual das temperaturas alcança valores característicos, entre $7^{\circ} \mathrm{C}$ e $10^{\circ} \mathrm{C}$, cuja amplitude diária nos meses de verão pode atingir em média $10^{\circ} \mathrm{C}$, mas que na estação invernal pode alcançar mais do que $20^{\circ} \mathrm{C}$.

Enquanto as mínimas absolutas em elevações favorecidas (p. ex. Londrina, com $610 \mathrm{~m}$ de altitude, cf. Figura 1,1) raras vezes caem abaixo do ponto de congelamento, em Apucarana $(870 \mathrm{~m})$ já foram medidos $-7^{\circ} \mathrm{C}$ e, devido à formação de um lago de massa de ar frio no Vale do Paraná, em Guaíra (265 m) foram registrados $-5^{\circ} \mathrm{C}$. As mínimas invernais médias situam-se entre $11^{\circ} \mathrm{C}$ e $13^{\circ} \mathrm{C}$.

20 O Passat (de passar, em português, ou passata, em italiano) é um vento forte e constante, que irrompe nos trópicos na longitude aproximada de $23,5^{\circ}$ e sopra ao redor de todo o globo terrestre [N.T.].

21 Indicadores climáticos em: Simões (1954 e 1956); CIBPU (1955 e 1958) e Maack (1968). 
As temperaturas máximas absolutas oscilam entre $37^{\circ} \mathrm{C}$ e $40^{\circ} \mathrm{C}$, sendo que em todos os meses as temperaturas do meio-dia poderão alcançar mais de $30^{\circ} \mathrm{C}$, e as máximas médias do mês mais frio (junhojulho) podem mesmo atingir de $22^{\circ} \mathrm{C}$ a $24^{\circ} \mathrm{C}$.

Apesar de que em todo o território dos Nortes Novo e Novíssimo do Paraná a média anual de temperatura situe-se acima do limite crítico de $18,3^{\circ} \mathrm{C}$, a ocorrência de geadas avança para zonas mais ao norte, e sua manifestação anual acaba impedindo a expansão de culturas tropicais suscetíveis às geadas, como o café, em direção ao sul.

Devido ao número reduzido de estações meteorológicas, a representação cartográfica da ocorrência de geadas apresenta dificuldades. O Mapa $5^{22}$ ilustra o número médio de dias com geada/ano, que podem ocorrer no Paraná Central entre os meses de abril e setembro. Nos meses de junho a agosto, o quadrante da cafeicultura do Norte do Paraná está ameaçado por geadas (ver Cap. VII, 1). Para Londrina, p. ex., registra-se o valor 0,3, isto é, em média, 3 dias de geada por década. Como os terrenos de encostas com exposição em sentido norte estão protegidos do impacto de massas de ar frio, do sul, onde também se pode observar grande irregularidade na ocorrência de geadas noturnas, com o incentivo de solos férteis de terra roxa, a cafeicultura expande-se no Norte do Paraná até uma zona que no Mapa 5 se situa próximo da isolinha de 5 dias de geada/ano.

No Norte do Paraná devemos diferenciar dois tipos de geada:

a) A 'geada negra': que ocorre após o impacto de massas de ar frio, abrangendo grandes áreas. A água acumulada na galhada e na folhagem dos arbustos de café congela sob o efeito de ar seco e ventos fortes, e sua folhagem tinge-se de negro intenso, caindo do arbusto ${ }^{23}$.

b) A 'geada branca': tipo de geada ocorrida apenas em vales e depressões, como resultado de forte irradiação noturna e inversão térmica, que congelam o sereno acumulado na galhada e folhagem da vegetação.

Para a cafeicultura, as ameaças envolvendo o tipo 'a' são bem maiores, e todas as perdas ocorridas no Norte do Paraná e em São Paulo foram causadas por esse tipo de geada. Devido ao acúmulo estacionário de massas de ar frio, evita-se a cafeicultura em terrenos baixos e vales (Figuras 5 e 9). Já as plantações de café que se expandem sobre as cristas de encostas estão pouco ou nada expostas a geadas de irradiação.

Ainda não se pode responder satisfatoriamente se nas zonas-limite da cafeicultura as árvores de sombra poderiam servir de proteção contra geadas (SCHRÖDER, 1956b, p. 135). Enquanto o cultivo do café protegido por árvores de sombra em zonas com pronunciada estiagem sazonal não é possível em virtude da competição recíproca pela água, a cafeicultura concentrada na zona úmida do Norte do Paraná, sem a proteção de árvores de sombra, tem por objetivo maximizar as colheitas. Tendo como principal objetivo o predomínio do lucro, na fase pioneira deste modo de cultivo a rápida exaustão das plantas daí decorrente não foi detectada a tempo, ou foi simplesmente ignorada.

Na área estudada, as chuvas aumentam em sentido norte-sul de aprox. $1200 \mathrm{~mm}$ para 1650 $\mathrm{mm}$ arredondados (Mapa 6). Contudo, mais importante que o volume anual de precipitações é sua distribuição em volume e espaço ao longo do ano. Ocorre que o Norte do Paraná, assim, como São Paulo, caracteriza-se por períodos invernais secos e mais frios, como também por verões quentes e ricos em chuvas. Em oposição ao estado vizinho, ao norte, no Paraná, quanto mais meridional, tanto mais acentuado é um breve período secundário de chuvas, que ocorre antes da estiagem anual $^{24}$, de fundamental importância para o balanço hídrico das plantas (Figura 1) ${ }^{25}$.

22 Com base em CIBPU (1958, II) e nas indicações complementares de Maack (1968) para o Paraná.

23 Também chamada de 'geada preta' (ver Cap. VII, 1).

24 Schröder (1956b, p. 131) - ver também Figura 1.

25 Na Figura 1 puderam ser empregadas apenas 5 aferições de precipitação para a estação Cianorte (apud MAACK, 1968, p. 161), de modo que os valores médios apresentam ainda caráter descompensado, onde o período secundário de chuva, de abrilmaio, se manifesta estranhamente forte. 
Figura 1: Diagrama de clima e armazenamento de água em estações selecionadas do Norte do Paraná

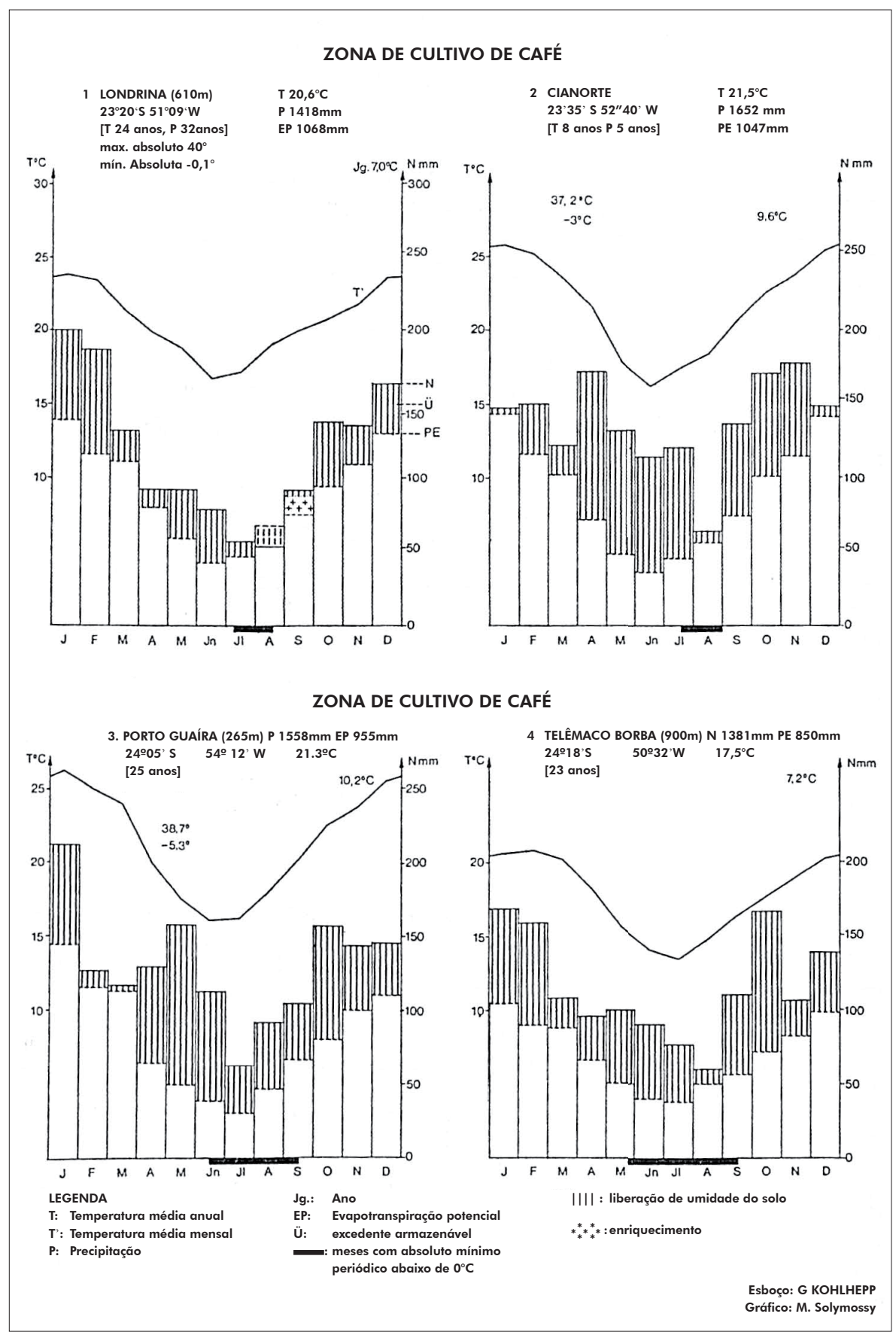


Em toda a extensão do degrau territorial do Planalto mesozoico, são alcançados níveis de precipitação anual de $1750 \mathrm{~mm}$, que soem expandir-se rapidamente em sentido nordeste ao território invernal, seco, de São Paulo (Mapa 6). Os meses mais quentes são julho e agosto, que, apesar da estiagem na região pesquisada, não deixam de apresentar precipitações levemente acima de $50 \mathrm{~mm}$. A distribuição das chuvas no Norte do Paraná por sua vez apresenta um andamento anual muito mais equilibrado do que no território de São Paulo, logo ao norte.

Este fenômeno tem efeito notável sobre o balanço hídrico das plantas da região, porque nesse balanço entre precipitação e evaporação aparecem meses completamente úmidos e também notáveis excedentes de umidade acumulada ${ }^{26}$. Após demorada observação, pode-se afirmar que na região cafeeira do Norte do Paraná, Londrina apresenta apenas o mês de agosto, subúmido, ao longo de 11 meses completamente úmidos ao ano (Figura 1). Segundo a classificação decimal hígrica estabelecida por Jätzold (1970), a Londrina corresponderia a zona $\mathrm{h}_{5,3}$ (isto é, úmida virtualmente o ano todo, compreendendo um breve interregno semiúmido) um clima agrário que apesar de sua alta umidade, e que é a característica das principais zonas cafeicultoras no Brasil da atualidade, parece ainda tolerável para o cultivo de Coffea arabica $^{27}$.

Segundo o ATLAS NACIONAL DO BRASIL (1966), o Norte do Paraná não apresenta um único mês genuinamente árido ao longo do ano, como ilustra o Mapa 6. Conforme as tabulações climatológicas para Porecatu ${ }^{28}$, na divisa com São Paulo, deve-se presumir, contudo, que uma faixa estreita, entre 30 e $40 \mathrm{~km}$, no norte extremo do Paraná, ao longo do Paranapanema, ainda apresente de 1 a 2 meses semiáridos, que não se manifestam nas grandes zonas cafeeiras, localizadas mais ao sul do Norte do Paraná.

Apesar de que um breve período de estiagem, como nas zonas de Araraquarense, Paulista e Mogiana em São Paulo, seja favorável à colheita e secagem do café, períodos de estiagem prolongada (abril/maio até setembro) foram muito frequentes em São Paulo na última década ${ }^{29}$, impactando negativamente as colheitas de café.

Em anos considerados normais, entretanto, no Norte do Paraná não há motivos para temer qualquer agravamento da falta de água. Entretanto, a evolução climática em anos mais recentes registra maior instabilidade, isto é: por um lado, há períodos de estiagem invernal, por outro, fortes chuvas invernais, cujas causas devem estar associadas ao excessivo desmatamento nas últimas décadas ${ }^{30}$.

Outro é o problema que afeta as regiões sem o referido déficit hígrico: a qualidade do sabor do café (tipos 'rio', 'riado'). Além disso, e baseado em experiências, nas regiões com déficit hígrico anual inferior a $70 \mathrm{~mm}$ se fez necessário o emprego de equipamento a ar quente para secagem, como é o caso no Norte do Paraná e de algumas zonas do sul do estado de São Paulo (CAMARGO, 1966, p. $12-13)^{31}$.

O início da colheita do café orienta-se pelas condições pluviométricas e, no Norte do Paraná, pelo menos em parte, somente pode ser iniciada no mês de junho.

Arbustos de café reagem muito suscetíveis à influência de ventos frios. No setor fronteiriço da cafeicultura do extremo meridiano do Norte do Paraná, que se encontra na zona de influência das frentes frias que avançam para o norte, o café evita as encostas expostas em direção ao sul.

26 O cálculo da evapotranspiração na Figura 1 foi realizado segundo o Método de Thornthwaite e Mather (1955), em base a documentos consultados na Secção de Climatologia Agrícola do Instituto Agronômico de Campinas (armazenamento de água $125 \mathrm{~mm})$.

27 O tipo $h_{3,4}$ (8-9 meses primordial e integralmente úmidos e 3-4 meses principalmente semiáridos) apresentado por Jätzold (1970, p. 66), baseado na descrição das condições climáticas de São Paulo por James (1932) , não se aplica para a cafeicultura brasileira em geral e, sim, apenas a um setor determinado de São Paulo. Desde 1932, o centro de gravidade da cafeicultura deslocou-se à grande distância da região central de São Paulo para o oeste e sudoeste, mais úmidos. Por sua vez, a experiência no Norte do Paraná demonstra que a Coffea arabica também se desenvolve de modo excelente sob condições do tipo climático $\mathrm{h}_{5,3}$ e até mesmo do $\mathrm{h}_{5,4}$ (ex.: Cianorte, Figura 1: 12 meses completamente úmidos - ver IBC $1970 \mathrm{~b}$ ).

28 Triagem própria do autor, de medições de temperatura e precipitações da fábrica de açúcar em Porecatu, completada por dados sobre o balanço hídrico de Porecatu, apud Holzmann (1967, p. 29).

29 Manifestação de períodos de estiagem extraordinariamente prolongados em São Paulo (Alta Araraquarense, em parte também Marília Mogiana): 1961, 1963, 1967, 1968, 1969.

30 Problema ao qual nos referimos pormenorizadamente no Cap. VIII, 4, ele foi objeto de pesquisa particularmente em variados trabalhos de Maack (entre outros 1953b, 1956, 1960, 1968). Sobre o Alto-Paraná, nos vizinhos Argentina e Paraguai, Wilhelmy (1950, p. 138-139) também apontou fortes desmatamentos como causa das alterações climáticas.

31 Para um déficit de $150 \mathrm{~mm}$ / ano, um cultivo longevo e economicamente rentável corre sérios riscos. 


\section{INVENTÁRIO VEGETACIONAL}

O caráter climático transitório nas zonas limítrofes do trópico no Brasil também se reflete na distribuição zonal da vegetação.

As florestas tropicais decíduas, que avançam Brasil adentro, até a latitude $24^{\circ}$, vinculando-se às florestas tropicais sempre verdes da Serra do Mar, confundem-se em sentido $\mathrm{N}$ e O com as florestas secas semidecíduas (Mapa 7).

No Paraná Central, além da depressão de alagamento, aprox. 25 a $30 \mathrm{~km}$ sobre território do Mato Grosso, a fronteira vegetacional corre entre as formações florestais e os campos cerrados do Brasil Central, apenas interrompidos por florestas de galeria, e que se caracterizam por, pelo menos, quatro meses áridos ao ano (PAFFEN, 1957, p. 221; LAUER, 1952; HUECK, 1966).

Aproximadamente à altura do rio Piquiri, no Paraná $\left(24^{\circ} \mathrm{S}\right)$, as florestas tropicais submergem nas florestas sempre verdes subtropicais dos grandes vales e zonas limítrofes, até altitudes de $500 \mathrm{~m}$. Exceção feita às calhas mais profundas de ar esfriado, esta altitude é o limite inferior da distribuição espacial da Araucaria angustifolia, que ocupa níveis elevados do Planalto Meridional.

Originalmente, os Nortes Novo e Novíssimo do Paraná eram cobertos por florestas tropicais pluviais. Apenas as zonas limítrofes meridionais do território aqui analisado eram povoadas respectivamente por floresta subtropical ou de araucárias (MAACK, 1950) 32.

A floresta tropical do Terceiro Planalto do Norte do Paraná caracterizava-se por solos vulcânicos residuais, ricos em palmáceas (Euterpe edulis), plantas epífitas, bromeliáceas e orquídeas. Exemplares notáveis, com mais de $30 \mathrm{~m}$ de altura, da figueira branca (Urostigma Ficus sp.) - a árvore mais alta da Floresta Pluvial Paranaense, com suas gigantescas raízes tabulares - e do pau d'alho (Gallesia gorarema), constituem a 'cobertura' do edifício florestal (MAACK, 1968, p. 214 ss.). Nele, a cabriúva (Myrocarpus fastigiatus), caviúna (Dalbergia niger), jacarandá (Machaerium sp.) e o pau marfim (Balfourodendron riedelianum) também eram espécies bem distribuídas. Contudo, a expansão da cafeicultura em grande medida devastou e extinguiu essas florestas pluviais. Várias espécies de peroba (Aspidosperma sp.), do cedro (Cedrela fissilis) e da canela (Ocotea pretiosa e Nectandra sp.) foram exploradas industrialmente.

Na região do Arenito Caiuá, a floresta tropical pluvial é menos pujante e suas árvores de menor tamanho. A virtual extinção da Euterpe edulis e a ocorrência de Arecastrum romanzoffianum torna-se visível na paisagem. Fazem falta a Gallesia gorarema, estimada por compradores de terras como sinal de solos férteis, e o Ficus. Ao longo do rio Paraná ocorre a palmeira macaúba (Acrocomia sclerocarpa). A floresta tropical sobre o Arenito Caiuá revela aspectos do cerradão, periodicamente seco (MAACK, 1949 e 1968; STELLFELD, 1949).

Ao sul da divisora de águas Ivaí-Piquiri, a floresta decidual é gradativamente substituída pela floresta subtropical pluvial, rica em ciateáceas, epífetas e cipós, na qual ainda persistem a Euterpe editlis e a Arecastrum romanzoffianum, mais resistente ao frio. Esta também se desenvolve na floresta tropical pluvial, em leitos de vales ameaçados por geadas, devido à acumulação de ar frio.

Na zona da divisora deáguas, a araucária avança notavelmente em sentido N, podendo ser observadas ainda algumas aglomerações a leste de Arapongas. Originalmente, as florestas de araucárias estavam amplamente distribuídas em toda área ao sul de Campo Mourão. Já na floresta mista de planalto, além da Araucaria angustifolia, com suas coroas planas à semelhança de guarda-chuvas, ocorrem ainda a imbuia (Phoebe porosa), Dicksonia sellowiana, Dalbergia brasiliensis, Machaerium sp., Balfourodendron riedelianum e a Ilex paraguariensis.

As araucárias, que em parte ocorrem sob forma de densas colônias, em grande medida caíram vitimadas pela depredação madeireira e só aparecem ainda nos pontos mais elevados e inacessíveis das bordas do Planalto.

Na zona a sudoeste de Campo Mourão, ocorrem grandes concentrações de erva-mate, que passaram a ser exploradas de forma planificada.

Os campos ocorrem em apenas duas 'ilhas', nos Nortes Novo e Novíssimo do Paraná, próximas de Campo Mourão $\left(100 \mathrm{~km}^{2}\right)$ e também entre Sabaudia e Astorga $\left(40 \mathrm{~km}^{2}\right)$ (Mapa 18). Os Campos Cerrados

32 Mapa fitogeográfico do Estado do Paraná 1:750 000. 
são relíquias de vegetação velho-quaternária (MAACK, 1968, p. 224), cujos representantes típicos são o Stryphnodendron adstringens (barbatimão) e a espécie palmácea Diplothemium campestre.

Originalmente, $47 \%$ da superfície total do estado do Paraná $\left(200.000 \mathrm{~km}^{2}\right)$ tinham cobertura de florestas pluviais tropicais e subtropicais, e $37 \%$ eram cobertos por florestas de araucárias ${ }^{33}$. As grandes migrações econômicas internas, a expansão de cultivos tropicais de longa duração (café), a partir de São Paulo, além da penetração, pelo sul, do sistema agrário de cultivos sobre alternação de solos, trazido pelos colonos de origem europeia, disseminaram as práticas das queimadas extensivas $^{34}$ (Fotos 2; 3); tais práticas foram agravadas pela exploração das florestas pela indústria e o comércio madeireiros. Essas tendências foram aguçadas com os grandes incêndios territoriais do ano de 1963, que devastaram principalmente o que restava das florestas de araucárias do Paraná Central ao Norte Novíssimo (LOWDEN, 1965; STERNBERG, 1968).

De acordo com Maack (1968, p. 199), em meados da década de 1960, aprox. 28\% da superfície do Paraná ainda possuíam cobertura de florestas pluviais, principalmente no Caiuá do noroeste do Estado (aprox. $10.500 \mathrm{~km}^{2}$ ). Neste ínterim, porém, a devastação florestal avançou, mesmo com o arrefecimento do boom da cafeicultura. Em seu lugar, surgiu a pecuária extensiva, que começou a cultivar pastos em gigantescas áreas florestais (Foto 16).

Com exceção do território da foz do Ivaí, as florestas tropicais pluviais que até há poucos anos avançavam vale adentro, desapareceram por completo. Atualmente (em 1970 [N.T.]), as poucas florestas subtropicais residuais da região do Piquiri, encontram-se desbastadas ao norte do rio, como também na zona de influência da migração interna gaúcha, ao sul do Piquiri, onde o desmatamento as reduziu a sobras insignificantes (Mapa 59).

Com minhas viagens realizadas ao Norte do Paraná em 1963, 1965, 1968 e 1970, pude constatar o processo de desmatamento irreversível que avançara ao longo daqueles anos. Se compararmos o estágio do desmatamento de 1963 com o de 1970, observamos uma alteração dramática na paisagem do Norte Novíssimo, a oeste de Umuarama: até 1963, nas florestas pluviais da região fora desmatada apenas uma trilha com 10 m de largura; a colonização apenas começara, com pequenas derrubadas localizadas. Em meados da década de 1960, porém, ocorreu o encontro das duas grandes frentes, nordeste e sul, de desmatamento por queimadas, que deixou para trás apenas restos de florestas carbonizadas. Com a devastação das florestas originárias e a alteração das condições do meio-ambiente, cinco a sete anos depois a fauna local estava quase que completamente aniquilada.

Enquanto a cafeicultura exigiu o desmatamento total nas atuais áreas de cultivo, instaladas em meio aos tocos das árvores, a criação de pastos para a pecuária na área do Caiuá apoiou-se exclusivamente nas queimadas, sem derrubadas prévias.

Hoje, em uma extensão de muitos quilômetros, o viajante se depara com ghost-forests, as florestasfantasmas, feitas de árvores solitárias, que remanescem como esqueletos carbonizados em meio aos pastos recém semeados.

Os amplos efeitos dessas interferências na paisagem natural já se traduzem, entre outros, em alterações do microclima, do balanço hidrológico, na forma de erosão, e deverão criar entraves para o desenvolvimento agrícola do Noroeste do Paraná.

\section{TIPOS DE SOLO E SEU VALOR DE EXPLORAÇÃO AGRÁRIA}

Enquanto a ocorrência de geadas determina a fronteira da zona agrícola tropical, delimitando o quadrante da cafeicultura paranaense em direção ao sul, a condição dos solos, conforme sua estratificação geológica na região pesquisada, permite uma classificação em sentido leste-oeste.

Grande parte do Norte Novo e um segmento do Norte Novíssimo erguem-se sobre solos profundamente depurados, com coloração de vermelho intenso, como aluviões de rochas eruptivas básicas (diábases, meláfiras, basaltos), também disseminados pelo oeste do Paraná. Esta assim chamada

33 Segundo cálculos de Maack (1968, p. 196 ss.).

34 Mapa 18 (Desmatamentos 1950) e Mapa 59 sobre o estágio da devastação florestal no final dos anos 1960. 
'terra' roxa pertence à categoria dos solos mais férteis do planeta e, por conseguinte, o solo ideal para a cafeicultura em ambiente livre de geadas. A terra roxa possui boa permeabilidade, como também boa capacidade de retenção da água, além de ser rica em minerais e matéria orgânica, apresentando índice baixo até neutro de reação, com $\mathrm{pH}$ de 6 a 7 .

Os latossolos de coloração vermelha até rubro-marrom apresentam diferenças graduais, conforme suas características físicas e químicas. Há diferenças estabelecidas, por exemplo, entre a chamada terra roxa legítima, que ocorre principalmente na região de Ribeirão Preto, São Paulo, e a terra roxa estruturada, do Paraná, que apresenta diferenças de coloração mais intensas entre os horizontes A e B, como também maior acumulação de materiais cerâmicos (SOUZA, 1965, p. 18) ${ }^{35}$.

Há ainda a 'terra roxa misturada', que em comparação com a terra roxa estruturada apresenta maior volume de material arenoso.

Em forma pura, a terra roxa ocorre principalmente em faixas superiores de solos, enquanto na área de contato com o arenito Caiuá, em solos de fundos de vale e de encostas, seja mais frequente o tipo misturado.

No Noroeste do Paraná, no Norte Novíssimo, as camadas vulcânicas encontram-se sobrepostas pelo Arenito Caiuá, que do Norte Novo também cobre parte das divisoras de água. Na zona principal de disseminação dos arenitos eólico-mesozoicos, predominam os solos arenosos de coloração vermelha clara a escura, que apresentam conteúdo nutricional inferior ao da terra roxa. Estes solos arenosos são extraordinariamente soltos, sua capacidade de retenção da água é baixa, têm reação ácida ( $\mathrm{pH} 4,3-5,8)$, e após breve período de exploração, perdem sua fertilidade. O desmatamento em grande escala no Norte do Paraná teve efeitos catastróficos exatamente nessa região, tais como a forte erosão de solos e a formação de 'sumidouros', que em parte forçaram até mesmo a mudança de núcleos de colonização. E isso não foi tudo, pois a erosão causada por ventos acarretou fortes danos por acumulação de areia em suspensão $0^{36}$.

Nas zonas de ocorrência da araucária e da erva-mate, os solos são significativamente mais ácidos.

Quando as camadas inferiores de lava são expostas nos vales dos arenitos, em parte sói ocorrer uma 'inversão do uso da terra': em oposição à habitual expansão da cafeicultura na região de encostas da terra roxa, as terras férteis de origem vulcânica da região do Caiuá estão situadas nos vales, enquanto as cumeeiras do relevo estão tomadas por solos arenosos de baixa fertilidade. Neste caso, e apesar do alto risco de geadas como resultado do congestionamento de massas de ar frio, o café é plantado nos vales.

A seguinte tabela de análises de solo em dois perfis, com cobertura florestal natural, ilustra as grandes diferenças na estrutura mecânica e química apresentada pelos dois principais tipos de solo do Norte do Paraná (Tabela 1).

Particularmente ilustrativa é a distribuição diferenciada de matéria orgânica (gradação de húmus), que no caso da terra roxa chega a quadruplicar o valor do solo arenoso da camada superior. No caso estudado, a discrepância entre os componentes minerais chega a oscilar entre 3 e 20 vezes a favor da terra roxa. O mais elevado índice nutricional da terra roxa no cotejo com os solos arenosos não se manifesta apenas através de colheitas maiores, mas principalmente em relação ao tempo de uso dos solos, que durante décadas não sofreram adubação e somente agora davam sinais de exaustão. Em comparação, em dez, no máximo doze anos, as colheitas extraídas dos solos arenosos despencam de modo tão vertiginoso, que a continuidade de exploração desses solos é virtualmente impossível sem adubação.

O quadro de comparação da distribuição regional dos cafezais, de acordo com o tipo de solo, no início da década de 1960, revelava as seguintes diferenças entre os Nortes Novo e Novíssimo do Paraná (IBC-OEA, 1964, p. 49-50).

35 Para abordagens gerais sobre o quesito qualidade dos solos de cultivo de café (VAGELER, 1939; COOLHAAS, FLUITER, KOENIG, 1960; FINCK, 1963).

36 Sobre os efeitos climáticos, pedológicos e econômicos da devastação florestal como resultado da colonização agrária no Norte do Paraná (ver Cap. VIII, 4). 
Do total de cafeeiros, havia as seguintes proporções de distribuição:

$\begin{array}{lcc} & \text { Norte Novo } & \text { Norte Novíssimo } \\ \text { em terra roxa estruturada } & 24 \% & 1 \% \\ \text { em terra roxa misturada } & 49 \% & 25 \% \\ \text { em solos arenosos } & 21 \% & 67 \% \\ \text { em outros solos } & 6 \% & 7 \%\end{array}$

O fato de que dois terços dos cafezais do Norte Novíssimo tenham sido plantados em solos arenosos, enquanto $73 \%$ dos pés de café do Norte Novo se encontram plantados em terra roxa, explica as diferentes tendências de desenvolvimento que ambas as regiões apresentam após a etapa pioneira da cafeicultura. Particularmente para a cafeicultura, a disseminação de solos arenosos no quadrante livre de geadas do Noroeste paranaense revela-se desvantajosa, dado que as zonas de terra roxa expandidas, que lhes fazem divisa ao sul, já se situam na região anualmente afetada por geadas, por isso consideradas impróprias para o cultivo de espécies tropicais.

Deste modo, em virtude de suas atribuições de clima e solo, o Norte Novo torna-se a região mais importante para a agricultura na região fronteiriça do trópico do Norte do Paraná. Na fase especulativa e conjuntural da expansão cafeeira, foi atribuída pouca importância às condições ambientais durante a ocupação dos solos e, ao que tudo indica, somente na década em curso é que parece ocorrer o que James (1932, p. 244) pôde observar em relação à cafeicultura de São Paulo: "Quanto mais intensiva se torna a economia, mais os padrões de distribuição se ajustam às qualidades subjacentes de ambiente físico"37.

37 No original: The more intensive the economy becomes, the more the patterns of distribution become adjusted to the underlying qualities of the physical milieu. 
Tabela 1: Análise de solos

\section{A. Terra roxa estruturada}

Perfil: Apucarana (Fazenda Ubatuba $750 \mathrm{~m}$ )

Vegetação: Floresta; Relevo: ligeiramente ondulado; Geologia: Diábases

Análise Mecânica (em \%)

\begin{tabular}{|c|c|c|c|c|c|}
\hline Horizonte & $\mathrm{cm}$ & Areia grossa & Areia fina & Lodo & Barro \\
\hline A1 & $0-25$ & 2,0 & 13,0 & 20,5 & 64,5 \\
\hline B1 & $25-53$ & 0,9 & 6,5 & 18,0 & 74,6 \\
\hline B21 & $53-103$ & 0,3 & 5,2 & 16,2 & 80,3 \\
\hline B22 & $103-163$ & 0,3 & 3,1 & 12,6 & 84,0 \\
\hline B3 & $163-203$ & 0,3 & 8,2 & 28,8 & 62,7 \\
\hline $\mathrm{C}$ & $203-253$ & 1,2 & 12,8 & 27,4 & 58,6 \\
\hline
\end{tabular}

Fonte: Perfil n. 1, (SOUZA, 1965, p. 28-31).

Análise química (em g/100 g)

\begin{tabular}{|c|c|c|c|c|c|c|c|c|}
\hline Horizonte & $\mathrm{pH}$ & Mat. Orgânico & C & $\mathrm{N}$ & $\mathrm{P}_{2} \mathrm{O}_{5}$ & $\mathrm{SiO}_{2}$ & $\mathrm{Al}_{2} \mathrm{O}_{3}$ & $\mathrm{Fe}_{2} \mathrm{O}_{3}$ \\
\hline A1 & 6,4 & 5,92 & 3,44 & 0,35 & 0,21 & 15,7 & 11,2 & 31,5 \\
\hline B1 & 5,6 & 1,93 & 1,12 & 0,13 & 0,15 & 19,1 & 17,2 & 34,3 \\
\hline B21 & 5,1 & 1,22 & 0,71 & 0,08 & 0,13 & 21,6 & 19,7 & 27,3 \\
\hline B22 & 5,3 & 0,77 & 0,45 & 0,06 & 0,12 & 20,3 & 15,0 & 23,2 \\
\hline B3 & 5,6 & 0,46 & 0,27 & 0,04 & 0,12 & 22,3 & 17,4 & 27,0 \\
\hline C & 5,0 & 0,45 & 0,26 & 0,04 & 0,19 & 22,3 & 14,5 & 23,5 \\
\hline
\end{tabular}

B. Latossolo arenoso, vermelho-escuro

Perfil: Nova Esperança (480 m) (6 km em direção a Alto Paraná)

Vegetação: Floresta; Relevo: ligeiramente ondulado; Geologia: Arenito Caiuá

Análise Mecânica (em \%)

\begin{tabular}{|c|c|c|c|c|c|}
\hline Horizonte & $\mathrm{cm}$ & Areia grossa & Areia fina & Lodo & Barro \\
\hline A1 & $0-18$ & 35,2 & 52,2 & 4,2 & 8,4 \\
\hline A3 & $18-39$ & 32,1 & 58,1 & 1,3 & 8,5 \\
\hline B1 & $39-67$ & 44,8 & 44,1 & 2,3 & 8,8 \\
\hline B21 & $67-162$ & 45,6 & 41,3 & 1,2 & 11,9 \\
\hline B22 & $162-212$ & 32,4 & 48,3 & 1,1 & 18,2 \\
\hline
\end{tabular}

Análise Química (em g/100 g)

\begin{tabular}{|c|c|c|c|c|c|c|c|c|}
\hline Horizonte & $\mathrm{pH}$ & Mat. Orgânico & C & $\mathrm{N}$ & $\mathrm{P}_{2} \mathrm{O}_{5}$ & $\mathrm{SiO}_{2}$ & $\mathrm{Al}_{2} \mathrm{O}_{3}$ & $\mathrm{Fe}_{2} \mathrm{O}_{3}$ \\
\hline A1 & 5,8 & 1,51 & 0,88 & 0,11 & 0,02 & 1,71 & 1,27 & 1,68 \\
\hline A3 & 5,5 & 0,27 & 0,16 & 0,02 & 0,01 & 1,87 & 1,15 & 2,32 \\
\hline B1 & 5,3 & 0,14 & 0,08 & 0,02 & 0,01 & 1,96 & 1,13 & 2,40 \\
\hline B21 & 5,2 & 0,10 & 0,06 & 0,01 & 0,01 & 2,71 & 1,84 & 2,48 \\
\hline B22 & 4,7 & 0,04 & 0,01 & 0,01 & 0,01 & 4,37 & 3,77 & 3,35 \\
\hline
\end{tabular}

Fonte: Perfil n. 6 (SOUZA, 1965, p. 43-45). 


\section{PROBLEMAS DA CONQUISTA DE TERRAS E ANÁLISE DOS PROCESSOS DA COLONIZAÇÃO AGRÁRIA EM SUA DIFERENCIAÇÃO ESPAÇO-TEMPORAL ${ }^{38}$}

\section{OS PRIMÓRDIOS DA COLONIZAÇÃO NA PROVÍNCIA GUAYRÁ NOS SÉCULOS XVI E XVII}

Foi apenas em meados do século XVI que a região montanhosa coberta de florestas localizada a leste do rio Paraná e ao sul do rio Paranapanema e pertencente ao império colonial espanhol despertou de fato o interesse de seus senhores. Um sistema de trilhas indígenas existente desde tempos précolombianos permitiu que os espanhóis saíssem da costa leste do continente e chegassem a Asunción por via terrestre. A famosa expedição de Alvar Núñez Cabeza de Vaca partiu em 1541/42 da foz do rio Itapocu, na fronteira entre as zonas portuguesa e espanhola - atualmente no estado brasileiro de Santa Catarina -, para o noroeste e encontrou, na região dos Campos do planalto do Paraná, o antigo caminho transcontinental chamado pelos índios de 'Peabiru' (Mapa 8). Essa trilha, que passava pelas florestas de araucárias e florestas subtropicais e conduzia em direção oeste às Sete Quedas do rio Paraná, foi utilizada pelos espanhóis somente até o rio Piquiri. a partir dali, eles mudaram seu curso para o sul, em direção a Asunción ${ }^{39}$.

\section{a) Assentamentos espanhóis}

Quando o impulso de expansão espanhol, que partia da cidade de Asunción, fundada em 1537, foi direcionado para leste devido à ameaça indígena na região da foz do Rio da Prata, surgiu em 1554 o primeiro assentamento na margem oeste do rio Paraná, poucos quilômetros acima de suas quedas: Ontiveros $^{40}$. Com isso, os espanhóis puderam começar a utilizar e proteger o caminho de Peabiru em sentido leste. Contudo, Ontiveros foi novamente abandonada três anos mais tarde, depois que a Ciudad Real del Guayrá foi fundada em 1556 na margem oposta, na confluência dos rios Piquiri e Paraná, e elevada a capital da província.

O avanço espanhol para o leste chegou ao seu posto avançado mais extremo em 1576, com a fundação de Villa Rica del Espírito Santo em uma região isolada no meio da floresta tropical às margens do rio Ivaí. A atividade espanhola de assentamento encontrou aqui a resistência fervorosa dos índios Guarani, que seriam forçados pelos donos de terras a trabalhar sob o sistema das encomiendas.

A influência espanhola no atual estado do Paraná - pertencente à Espanha segundo o Tratado de Tordesilhas - limitou-se, devido à densidade das florestas, às regiões ao longo dos rios principais e em pontos especialmente importantes do ponto de vista estratégico. Em Ciudad Real havia, por volta de 1565, entre 200 e 300 espanhóis, e a população total da cidade compreendia, contando com as esposas indígenas e os filhos desses espanhóis, cerca de 4000 habitantes (WILHELMY; ROHMEDER 1963, p. 407). A região de fronteira entre as áreas de influência espanhola e portuguesa permaneceu predominantemente de posse dos indígenas. Em relatos da época, a quantidade de índios Guarani na

Tradução de Daniel Martineschen e Sirlene Nair Neubauer.

39 O lansquenê alemão Ulrich Schmidel também chegou ao caminho de Peabiru em sua travessia de Oeste a Leste do continente americano partindo de Asunción em 1552/53; esse caminho deveria levá-lo pela costa até São Vicente, partindo do Sul e passando pelos rios Monday e Iguaçu (sobre isso, cf. MAACK, 1959, p. 35ss.).

40 A data de fundação de Ontiveros é controversa. Com base em várias fontes, Wilhelmy e Rohmeder (1963, p. 406) indicam o ano de 1543 (no rio Piquiri), Samhaber (1939, p. 228) o ano de 1549 e Maack (1959, p. 37) o ano de 1554. Contudo, Ontiveros e, por conseguinte, o acesso direto ao Alto Paraná e ao caminho de Peabiru não poderiam ter sido conhecidos antes da viagem de Schmidel, uma vez que este alcançou o Peabiru no início de 1553 somente na bacia do Piquiri, depois de muitos desvios a partir do sul. Segundo Maack, relatos do fundador Irala à coroa espanhola e ao Consejo de las Indias indicam que, depois de ter encontrado as quedas do rio Paraná algumas semanas após Schmidel partir de Asunción em 1553, Irala estabeleceu ali em 1554 uma base fortificada. 
região de Guayrá, que ficava a leste do rio Paraná e limitada pelo rio Paranapanema ao norte e pelo Iguaçu ao sul, era estimada em cerca de 200 mil (SAMHABER, 1939, p. 240).

A fronteira, isto é, a zona neutra sem assentamentos entre os impérios coloniais da Espanha e de Portugal na região que atualmente corresponde ao Paraná, manteve-se assim também durante o período da união pessoal sob Filipe II, após 1580. Os problemas administrativos da gigantesca região de La Plata fizeram com que somente em 1617, após intervenção do governador Hernandarias de Saavedra, viesse a ser separada administrativamente a região de Guayrá: Villa Rica e Ciudad Real, bem como Santiago de Xerez no alto rio Paraguai e a capital Asunción, tornaram-se parte da província do Paraguai ou Guayrá. As comunidades-filhas fundadas no último quarto do século XVI seguindo o curso do rio a partir de Asunción - Santa Fé, Buenos Aires (fundação secundária), Corrientes e Concepción del Bermejo foram integradas à província de La Plata. Contudo, o isolamento dos postos avançados espanhóis em cidades na região de Guayrá manteve-se mesmo depois do reordenamento político-administrativo (MÖRNER, 1953, p. 53-54) . $^{4}$

\section{b) Reduções jesuíticas guaranis}

Quando a economia de encomiendas começou a se desenvolver de maneira aparentemente indesejada também no Paraguai, o governador Hernandarias chamou para o país, em 1588, missionários jesuítas vindos do Brasil, onde já estavam ativos desde a metade do século XVI"2. Um decreto real de 1601 ordenara a pacificação dos índios sem repressão violenta nem escravização ${ }^{43}$. Recaiu sobre os jesuítas - tanto segundo as ordenanzas de poblaciones do governo espanhol de $1573^{44}$, quanto segundo a determinação do Superior Geral da Companhia de Jesus, Aquaviva - a difícil tarefa de assentar os índios Guarani de Guayrá em colônias fixas separadas, protegê-los da exploração por parte de encomenderos espanhóis, cristianizá-los e também educá-los tanto para a agricultura quanto para o artesanato.

No âmbito dessa atividade, acreditava-se obter uma valorização das regiões no extremo leste do império colonial espanhol e poder avançar para o sudeste até a costa atlântica de Santa Catarina.

Em 1604 foi fundado o estado missionário jesuíta do Paraguai. OSuperior Provincial Diego de Torres, que já tivera experiências com essas atividades no Peru, foi encarregado de organizar a construção de colônias missionárias, as chamadas reduções.

Com a construção das reduções Guarani em Guayrá iniciou-se uma profícua atividade por parte dos missionários jesuítas na bacia do Paraná-Paraguai que durou mais de $150 \operatorname{anos}^{45}$ e, com isso, uma nova fase da colonização na região oriental de fronteira na bacia do Rio da Prata.

Os rios Paranapanema e Ivaí, afluentes do Paraná, bem como seus subafluentes Tibagi e Corumbataí (Mapa 8), serviram de ponto de partida para as atividades jesuíticas e de localização para as reduções. Não obstante as condições geográficas favoráveis ao transporte proporcionadas por rios navegáveis, as reduções eram ameaçadas por enchentes e pelo perigo da malária nos vales dos rios. Em 1610 ocorreu a fundação de Loreto, na confluência do rio Pirapó no rio Paranapanema, e pouco a Leste dali foi fundada San Ignacio. Até 1628, sobretudo a partir do início da década de 1620 e sob o comando do Superior Montoya, surgiram mais 11 reduções, na maioria comunidades-filhas: San José, San Francisco Xavier, Encarnación e, mais para sudeste na região de fronteira das florestas de Campos, San Miguel, todas às margens do rio Tibagi. No curso médio do rio Ivaí foram fundadas San Pablo e San Antonio, e no curso superior, Jesus María e nas proximidades San Pedro; surgiram às margens do Corumbataí as reduções de San Tomás, Arcángeles e Concepción ${ }^{46}$. Algumas aldeias indígenas foram convertidas em reduções, enquanto algumas colônias missionárias foram reinstaladas. Os índios das 13 reduções, cuja população

41 Os esforços de Hernandarias em estabelecer relações comerciais entre Ciudad Real e Villa Rica, por um lado, e São Paulo, por outro, não foram sancionados pela coroa.

42 A atividade missionária jesuítica no Peru começara em 1568.

43 Cédula Real de 21/11/1601, cf. Hernandez (1913, II, p. 97).

44 Sobre isso cf. Garsch (1934, p. 54 e 60): "Sob a influência dos missionários deveria ser criado um espaço vital para os nativos que compreendesse áreas habitacionais, comerciais e de transporte e que estivesse em constante transformação para se adaptar a novas e mais elevadas exigências culturais."

45 Sobre isso, cf., entre outros, Fassbinder (1926), Garsch (1934), Mörner (1953), Aigner (1959) e Otruba (1962).

46 Os dados sobre os nomes, a localização exata e, em certos casos, até sobre a existência dessas e de outras reduções são muito variados. Sobre essa questão foram consultados sobretudo Hernandez (1913, I, p. 50ss.); Dorfmund (1963, mapa à p. 95); ElKhatib (Org.). História do Paraná, 1969, I, p. 50ss.; Chmyz (1963, p. 104) e o Mapa do Estado do Paraná, 1969. 
beirava os 40.000 (SAMHABER, 1939, p. 240), eram na sua maioria guaranis, mas havia também carijós e tupis das regiões vizinhas nas fronteiras oeste e leste, respectivamente.

A atividade bem-sucedida missionária e de colonização realizada pelos jesuítas se baseava no reconhecimento da posição privilegiada dos caciques na ordem social indígena, no acordo fechado com estes na fundação das reduções e no pagamento dos trabalhos realizados pelos indígenas. Além disso, a falta de uma tradição cultural e religiosa bem como de consciência política facilitou o trabalho com os Guaranis - ao contrário do que ocorreu com os povos andinos (MÖRNER, 1953, p. 66 e 201).

O florescimento rápido das reduções e a grande quantidade de indígenas que foram assentados ali privaram a aristocracia espanhola do acesso a eles, o que fez com que logo surgisse uma forte oposição aos jesuítas por parte dessa aristocracia. O impacto das ordenanzas do visitador Alfaro e a proibição geral da escravização violenta de índios abalaram o sistema econômico e, consequentemente, a existência dos assentamentos espanhóis ${ }^{47}$. A emigração e a fuga da força de trabalho guarani para as reduções encontrou violenta resistência por parte da população espanhola em Ciudad Real, e especialmente em Villa Rica.

A construção das reduções seguia um planejamento preciso. A planta ortogonal, com ruas perpendiculares, fora determinada pelo vice-rei espanhol Francisco de Toledo para pueblos indígenas. Em torno da praça quadrangular no centro da colônia havia, de um lado, a igreja, a casa dos missionários com salas de aula, oficinas e depósito, a casa das viúvas e o cemitério. Os outros lados da praça eram ocupados pelas casas dos indígenas ordenadas em grupos de quatro a seis, todas cobertas com palha e com paredes de pau-a-pique, conforme a tradição de construção guarani.

O fato de os índios Guarani já conhecerem uma agricultura primitiva antes da chegada dos espanhóis contribuiu substancialmente para o sucesso econômico das reduções. A empatia dos missionários jesuítas, em sua maioria espanhóis, fez o resto durante o lento processo de habituação de seus protegidos aos trabalhos coordenados. Os trabalhos de agricultura no sistema de roça em terra comum eram decididos diariamente e conduzidos sob uma rígida divisão de trabalho. A organização cooperativa das reduções deixava livre uma área de cultivo particular (amambaê) semelhante a um pequeno quintal para cada uma das várias famílias, que tinham de trabalhar somente dois dias por semana na terra comum (tupambaé). No sistema de rotação de terras praticada com pau-cavador, um período de cultivo de dois a três anos era seguido por um período de pousio de 6 a 12 anos.

A gestão de plantações maiores e de hortas coexistiam segundo a diferenciação de direito de posse já mencionada. Além do cultivo de milho, mandioca, batata-doce, painço, cevada, algodão e cana-deaçúcar, bem como da manutenção de pomares, praticava-se a pecuária, que compreendia tanto gado bovino quanto ovino. ${ }^{48}$ Contudo, os jesuítas atingiram o melhor resultado com as plantações de Yerba Mate (erva-mate, Ilex paraguaiensis). Apesar de o mate ser nativo da floresta mista das áreas altas do Paraná, os jesuítas procuraram organizar a colheita de modo mais racional em plantações próprias, e eliminar tanto os problemas de transporte quanto o risco de captura dos índios por encomenderos ou bandeirantes, ocorrência comum na economia de colheita do mate em regiões afastadas.

Depois do chá-mate se tornar, na primeira metade do século XVII, um produto de mercado do império colonial espanhol, estabeleceu-se uma situação de concorrência na exportação de mate entre as reduções jesuíticas e os donos de terra - que sofriam com a falta de mão de obra -, principalmente de Villa Rica. Posteriormente, surgiram as suntuosas igrejas das missões, financiadas principalmente com as receitas da venda do mate. Além disso, realizou-se com sucesso a formação profissional dos índios

A redução de Arcángeles também é mencionada como Los Angeles e Siete Arcanjos de Taioba. - A localização de Jesus María no Mapa do Estado do Paraná de 1969 (curso inferior do rio Ivaí, hoje município de Amaporã) difere muito das outras fontes. Duvida-se de que as reduções de Copacabana (no curso inferior do rio Piquiri?) e de Santa Maria (perto de Foz do Iguaçu?) tenham chegado a ser fundadas.

47 As ordenanzas emitidas em 1611 por Francisco de Alfaro em Asunción se baseavam em relatos de jesuítas. O servicio personal dos indígenas estava proibido; espanhóis, mestiços e negros não podiam entrar nas reduções, e os indígenas das reduções não podiam ser mantidos no sistema de encomiendas e estavam livres de pagar tributos por 10 anos. No entanto, depois de passado esse período, os indígenas de Loreto e de San Ignacio, isto é, homens entre 18 e 50 anos de idade, tinham de prestar servicio personal aos encomenderos dois meses por ano (MÖRNER, 1953, p. 67Sss. e 73; GARSCH, 1934, p. 86; EL-KHATIB (Org.). 1969, I, p. 52, cf. também p. 9).

48 Cf. a esse respeito Hernandez (1913); Garsch (1934) e Aigner (1959). Apesar da proibição da coroa portuguesa, chegaram a Asunción em 1555 as primeiras cabeças de gado na famosa expedição das 'sete vacas e um touro', que se tornou o ponto de partida do processo inovativo da criação de gado na região cisplatina (cf. PFEIFER, 1967, p. 172). 
para a tecelagem, a marcenaria e a ferraria, bem como para a produção de artigos têxteis de lã e algodão, na atual região do Paraná no início do século XVII, provavelmente em um estágio inicial primitivo. ${ }^{49}$

Não há relatos sobre a extensão do arroteamento e sobre a utilização da rotação de culturas para a região do Guayrá. Além do mais, viviam em Loreto - a redução mais importante dessa província - cerca de 2.000 famílias em 1628, num total de 12 mil pessoas que tinham de ser providas dentro do sistema econômico autossuficiente da colônia. ${ }^{50}$

Além das disputas internas na província da missão, que se acenderam entre os colonos e os missionários espanhóis por conta do trabalho escravo e do tributo obrigatório dos índios Guarani, chegou ao Guayrá uma ameaça externa muito mais forte.

A localização geográfica das colônias missionárias do Guayrá na região de fronteira luso-espanhola gerou, já em 1611, um choque com os caçadores de escravos que avançavam a partir de São Paulo em direção oeste e sudoeste..$^{51}$

A grave falta de mão de obra nas plantações de cana-de-açúcar no litoral brasileiro diminuíra perceptivelmente desde que se começou a introduzir escravos negros africanos em 1574, porém quando a Holanda obteve na década de 1620 o controle absoluto sobre o tráfego marinho na costa leste sulamericana, não havia mais como se garantir um suprimento regular de escravos. Por esse motivo, os paulistanos organizavam as chamadas 'malocas', caçadas aos índios Tupi e Guarani dispersos, para cobrir sua demanda por força de trabalho. ${ }^{52}$ Depois das reviravoltas geográficas decorrentes da colonização na província missionária do Guayrá, que levaram os índios antes dispersos a se estabelecerem nas recém-fundadas colônias missionárias fechadas, criou-se aqui um alvo lucrativo para os 'mamelucos'. ${ }^{53}$ Em vez das difíceis caçadas a índios na densa floresta tropical, a partir de então podia-se capturar em grande quantidade os índios concentrados nas reduções, convertidos ao cristianismo e já acostumados ao trabalho no campo. Os participantes das bem planejadas e equipadas 'bandeiras', os 'bandeirantes', viajavam pelos rios Tietê e Paraná em direção sudoeste, ou avançavam para o centro da província missionária passando pelo antigo caminho indígena, apesar da paz entre Espanha e Portugal. Suas ações, partindo com frequência de Piratininga, eram chanceladas extraoficialmente pelas autoridades em São Paulo. A esperança dos jesuítas de que muitas forças fossem deslocadas de São Paulo por causa da ameaça de invasão holandesa em Pernambuco falhou.

Em 1628 apareceram, às margens do Tibagi, quatro 'bandeiras'54 sob o comando do famoso Antônio Raposo Tavares e do proprietário de plantações de cana-de-açúcar Manuel Prêto. As reduções Encarnación e San Miguel, bem como Jesus Maria e San Antonio no alto Ivaí foram destruídas de janeiro a março de 1629, e milhares de índios foram capturados se não tinham conseguido escapar antes como ocorreu em San Miguel, Arcángeles, San Tomás e San Pablo. ${ }^{55}$

Os índios que escaparam do ataque foram reunidos novamente pelos jesuítas e distribuídos nas reduções restantes. Contudo, em 1630 somente as duas colônias missionárias mais antigas e isoladas às margens do rio Paranapanema ainda tinham permanecido intocadas.

Em face da ameaça permanente dos paulistanos, ocorreu no final de 1631 a evacuação de Loreto e San Ignácio, bem como o deslocamento das reduções em direção à região do alto Paraná, em ambas as

49 Tanto o artesanato e o comércio quanto a agricultura das reduções tiveram seu real desenvolvimento somente depois de 1680 , sobretudo após o ano de 1700 sob a influência de jesuítas vindo de várias províncias alemãs da ordem, que, ao contrário dos missionários espanhóis, também tinham formação para o artesanato, a agricultura, a medicina, tinham educação escolar e musical (QUELLE, 1934/35, p. 280-81). Não há dados estatísticos da época sobre a região do Guayrá.

50 Em comparação com os 40 mil índios cristianizados que viviam nas reduções de Guayrá, a quantidade de habitantes espanhóis de Ciudad Real, Villa Rica e Xerez era infimamente pequena, totalizando pouco mais de 1000 pessoas (SAMHABER, 1939, p. 240-41).

51 Em 1612 o governador de Buenos Aires recebeu uma queixa do cabildo de Ciudad Real contra portugueses de São Paulo que teriam perambulado pela região para capturar índios, tendo capturado mais de 3.600 deles (TAUNAY, 1919 , p. 451 e HOLLANDA, 1949 no seu todo).

52 Cf. a esse respeito, entre outros, Franco (1940) e Taunay (1946).

53 Descrição dos jesuítas para a população mestiça de São Paulo originária da mistura de imigrantes portugueses e mulheres indígenas. A origem do nome vem ou do termo Tupi mamã-ruca para 'mestiço', ou do árabe mamaluk, possivelmente uma alusão aos temidos mamelucos no Egito.

54 Essas ‘bandeiras' saíram da cidade de São Paulo com 69 paulistanos, 900 ‘mamelucos' e cerca de 3000 índios Tupi como tropas auxiliares em setembro de 1628 (EL-KHATIB, 1969, 1, p. 54).

55 Em San Antonio: 2000 capturados; Jesus Maria: 1500 (SAMHABER, 1939, 2, p. 241-242). 
margens do rio. Mais de 12 mil índios viajaram com os jesuítas sob o comando de Montoya em mais de 700 jangadas até Ciudad Real. Aqui as Sete Quedas do Paraná tiveram de ser contornadas, deixando-se as jangadas e canoas pelo caminho, e o resto do caminho teve de ser feito a pé. Isso se deu com muitas dificuldades e perdas, sob ameaça constante dos guaireños espanhóis em Ciudad Real que esperavam obter mais mão de obra com os índios fugidos. Somente cerca de um terço dos moradores indígenas das reduções conseguiu chegar às novas áreas das missões.

Entre 1629 e 1632 os 'bandeirantes' tinham escravizado dezenas de milhares de Guaranis retirados de reduções e os levado para Santos e para o Rio de Janeiro, onde o mercado escravista prosperava apesar de uma grande parte dos capturados terem morrido na viagem (MÖRNER, 1953, p. 91). ${ }^{56}$

Depois do deslocamento das reduções Guarani, os paulistanos direcionaram seus ataques a partir de então diretamente às cidades espanholas, cujos moradores não tinham percebido a posição estratégica das colônias missionárias como muralha de proteção contra os ataques portugueses em direção oeste. Em 1632 Ciudad Real e Villa Rica tiveram de ser abandonadas. ${ }^{57}$

O impulso colonizatório pontual dos jesuítas na região que atualmente corresponde ao Paraná deve ser analisado sob o aspecto da atividade missionária que durou pouco menos de duas décadas. As invasões dos 'bandeirantes' destruíram os sucessos colonizatórios e econômicos das reduções da província Guayrá já na sua fase de construção. Desenvolvimento e florescimento completos só foram vivenciados pelas reduções missionárias indígenas na primeira metade do século XVIII, depois do deslocamento para a região missionária de Tape (atualmente no noroeste do Rio Grande do Sul) e para a região interfluvial dos rios Uruguai e Paraná (atualmente a argentina Misiones), onde surgiu o novo centro da atividade missionária (EIDT, 1971, p. 36ss.), bem como para o vizinho Paraguai.

A situação político-geográfica dos estados missionários sul-americanos localizados nas planícies da região de fronteira luso-espanhola ${ }^{58}$ era a mesma das missões espanholas no México e na Califórnia. Na sua função destaca-se, contudo, um contraste marcante: no México e na Califórnia o mecenato real permitia que os missionários tivessem uma dupla função ao servir o Estado e a Igreja. Por parte do Estado, as reduções de fronteira recebiam uma pequena guarnição para segurança militar contra ataques de tribos indígenas inimigas e para o controle dos índios das reduções.

Por outro lado, as reduções Guarani dos jesuítas no Guayrá tiveram de estabelecer uma força armada própria que tinha de estar sempre à disposição das autoridades espanholas, que por sua vez nada faziam por iniciativa própria para proteger as reduções no Guayrá contra os 'bandeirantes' paulistanos. ${ }^{59} \mathrm{O}$ fato de o governador do Paraguai, Céspedes, possuir uma plantação de cana-de-açúcar no Brasil sendo genro do governador no Brasil, Martim de Sá, alimentava a suspeita de cumplicidade, ou, mais precisamente, de tolerância com relação à captura de escravos por interesses egoístas. ${ }^{60}$

Mesmo depois da mudança para a região missionária de Tape (atualmente no noroeste do Rio Grande do Sul), os paulistanos continuavam a ameaçar as reduções que foram deslocadas para norte e noroeste, mas que a partir de então já conseguiam se organizar militarmente e munir parcialmente os índios com armas de fogo. Em 1639 e 1641, os ‘mamelucos’ opressores foram combatidos em Caazapaguazú,

56 A caminhada da redução Jesus Maria até São Paulo durou 47 dias. Segundo Schmieder (1962, p. 417), o total de índios capturados das missões compreendia, entre 1628 e 1630, de mais de 60 mil.

57 Villa Rica foi finalmente estabelecida no interior do Paraguai depois de seis transferências de local (WILHELMY; ROHMEDER, 1963, p. 407).

58 Além do estado missionário do Paraguai, havia ainda os seguintes estados missionários jesuíticos na América do Sul: Maynas (1638) no rio Marañón no Leste do Equador; Mojos (1684) na bacia do Mamoré no nordeste da atual Bolívia; e Chiquitos no alto Paraguai, fundada em 1691. Entre as outras ordens que fundaram estados missionários, deve-se mencionar sobretudo os capuchinhos catalães e a sua região missionária no baixo Orinoco existente desde a metade do século XVII (QUELLE, 1934/35, p. 274ss.).

59 Essas diferenças nas missões da América hispânica foram especialmente enfatizadas por Bolton (1917 apud MÖRNER, 1963, p. 200) - cf. a esse respeito as considerações feitas em Pfeifer (1970) sobre a política de missões e de frontera na Frontera del Norte da Califórnia durante a primeira metade do século XIX.

60 Céspedes foi testemunha, em uma parada intermediária em São Paulo durante sua viagem da Espanha ao Paraguai, da mobilização de algumas bandeiras; protocolou um protesto oficial e alertou os jesuítas no Guayrá, com quem ele, apesar disso, acabou entrando em conflito pouco tempo depois. Com base nas alegações dos jesuítas, ele foi deposto em 1631 por omissão de auxílio para as reduções no Guayrá contra os paulistanos (MÖRNER, 1953, p. 89 e 91). Segundo a opinião de Quelle (1934/35, p. 279), os espanhóis consideravam os estados missionários como sendo estruturas autossuficientes, uma vez que lhes era proibido entrar nelas. Por esse motivo, a proteção das regiões das missões também era incumbência dos jesuítas que lá exerciam domínio e administração. 
ou, mais especificamente, em Mbororé, enquanto as colônias missionárias permaneceram intocadas por décadas. ${ }^{61}$

Depois que isso solucionou o problema dos deslocamentos constantes das reduções - causados pelas ameaças dos paulistanos - , a construção das colônias pôde ser realizada pela primeira vez de maneira sistemática, especialmente sob a influência de jesuítas alemães e holandeses. ${ }^{62}$

Inteligência, formação ampla, disciplina rígida, senso de missão, grande coragem e vontade de ferro, grande capacidade de comunicação, habilidade e um bom senso de organização eram traços distintivos dos missionários jesuítas, cujos sucessos e, principalmente, métodos de condução das reduções não estão livres de controvérsia. ${ }^{63}$

Com a extinção das reduções indígenas jesuítas e das colônias urbanas espanholas, a área do atual estado do Paraná passou da soberania espanhola para a área de influência portuguesa sob a pressão dos 'bandeirantes' paulistanos. ${ }^{64}$ Contudo, isso significou (por causa da disposição espacial da economia e da colonização brasileira) uma posição periférica em um local isolado sem o atrativo de recursos minerais. As regiões despovoadas do norte e do centro do Paraná, em cujas florestas ainda se mantinham alguns poucos grupos indígenas esparsos, caíram em total esquecimento. As ruínas soterradas de Villa Rica só foram redescobertas perto do final do século XVIII por uma patrulha militar brasileira (MAACK, 1937, p. 212).

Contudo, a colonização extensiva do Norte do Paraná começou somente cerca de três séculos após o fim do estado jesuíta no Guayrá, quando a pressão da população de São Paulo e a expansão cafeeira determinada pelo progresso econômico iniciaram a exploração moderna dessa região.

\section{BASES DA DIVISÃO ECONÔMICA E SOCIOESPACIAL DO PARANÁ NOS SÉCULOS XVIII E XIX}

Com o restabelecimento do abastecimento de escravos africanos para as plantações de cana-deaçúcar próximas da costa, e com o começo da fase de desenvolvimento da mineração em Minas Gerais, modificou-se a motivação das relações estabelecidas pelos paulistanos com as partes que faziam fronteira ao sul da área colonial portuguesa.

Se no século XVII ainda dominavam objetivos puramente estratégicos com a fundação de fortificações militares na costa sul do Brasil,$^{65}$ o interesse de São Paulo direcinava agora para a exploração econômica do gado semisselvagem dos 'Campos limpos' ao sul.

Os jesuítas que retornavam para o Rio Grande do Sul pelo Rio Uruguai a partir de 1682 haviam fundado as Sete Missões na região fronteiriça da floresta e dos 'Campos' ${ }^{66} \mathrm{Na}$ área de floresta próxima à colônia no planalto de trapp escarpado a oeste, praticou-se a coivara e explorou-se as Yerbales, plantações de Ilex espalhadas pelas áreas altas. Nas regiões de estepe ao sul do Ibicuí e do Jacuí se localizavam as pastagens naturais da Campanha - que já tinham sido utilizadas durante o período de colonização dos jesuítas a oeste do Uruguai como área de recuo dos rebanhos bovinos nos casos de ataques de

61 Cf. a esse respeito Hernández (1913, I, p. 16ss.). O retorno para a região do Rio Grande do Sul e a fundação dos famosos 'Sete Povos da Banda Oriental do Uruguai' ocorreu, contudo, somente a partir de 1687 (HANSEL, 1958, p. 8ss.). Os jesuítas foram definitivamente expulsos do império colonial espanhol em 1767/68.

62 No âmbito da construção civil, desenvolveu-se a 'casa de adobe' coberta com telhas e com uma varanda na parte frontal. As suntuosas igrejas surgiram perto do final do século XVII. Na agricultura firmou-se uma lavoura primitiva com arado, e além disso instalaram-se grandes fazendas de criação de gado nos 'Campos' das Sete Missões. Inovações como o arado, utilização do ancinho (SCHMIEDER, 1962, p. 396), pecuária e o cultivo de hortaliças se estabeleceram sobretudo graças aos missionários jesuítas alemães (FASSBINDER, 1926, p. 89).

63 Cf. a esse respeito, entre outros: Métraux (1949, p. 645) e Mörner (1953, p. 206).

64 Foi só com o Tratado de Madrid em 1750, e definitivamente com a troca de regiões (Colônia Sacramento - Missões Orientais) no Tratado de Ildefonso, em 1777, que o avanço português em direção Oeste foi legalizado, e as fronteiras brasileiras atuais se estabeleceram nessa região.

65 Além disso, a ocorrência de ouro aluvial entre 1630 e 1640 atraiu moradores de Iguape para a região da atual Paranaguá e para Assungui, e os levou a fundar colônias primitivas (BERNARDES, 1952, p. 431/33).

66 Cf. a esse respeito também Porto (1943). 
espanhóis vindos de Santa Fé. As cabeças de gado da chamada 'Vacaria do Mar' tinham se multiplicado amplamente até a metade do século XVIII. ${ }^{67}$

Os jesuítas conheciam dois sistemas de pecuária, cuja disposição espacial dá uma visão importante sobre o processo de desenvolvimento da configuração cultural do sul: 'vacaria' e 'estancia'.

A pecuária das 'vacarias', a forma extensiva da economia meio selvagem de pecuária nos limites do ecúmeno, corresponde à forma econômica do anel mais externo dos Anéis de Thünen. Os produtos dessa zona eram couro e carne-seca ('charque'), e em menor escala sebo e gordura.

Ao contrário da abordagem econômica puramente extrativista do gado das 'vacarias', as 'estancias' ficavam mais próximas das reduções jesuíticas e eram vigiadas por índios. Obstáculos naturais como cachoeiras e florestas constituíam as fronteiras das estancias, que funcionavam no sistema open-range. Somente vacas leiteiras e bezerros eram mantidos em currais nas colônias. A principal fonte de renda das 'estancias' era a venda de cabeças de gado (VALVERDE, 1956, p. 88-89).

A pecuária das estâncias das reduções não era ameaçada somente pelos ladrões de gado espanhóis vindos da bacia do Prata, mas também pelos índios nômades Minuanos e Charruas das pradarias, resistentes à cristianização, e ainda pelos portugueses que avançavam a partir da fortificação de Laguna para a Campanha. Se primeiramente predominaram o roubo de gado e o comércio de couro, a partir de 1733 luso-brasileiros se estabeleceram na região dos Campos de Viamão, localizada próximo ao litoral, e fundaram fazendas de gado próprias.

Já na primeira metade do século XVIII, paulistanos tinham saído à procura de novas áreas de pastagem saindo dos 'Campos cerrados' perto de Sorocaba e Itapetininga em São Paulo em direção sudoeste. Lá chegaram aos 'Campos limpos', localizados próximo a Itapeva, os quais tinham forma de arco e se seguiam ao segundo planalto no leste do Paraná, cuja extensão propiciava as linhas mestras para a continuidade da expansão em direção ao Sul.

A 'corrida do ouro' nas Minas Gerais trouxe por volta de 1700 um intenso fluxo migratório para o até então despovoado interior da antiga Capitania de São Paulo e Minas de Ouro, que foi dividida em 1720 em duas partes autônomas. Problemas de abastecimento que acometiam as regiões de Minas Gerais distantes do litoral, bem como os graves problemas de transporte para o litoral de São Paulo e do Rio de Janeiro, levaram a uma valorização econômica dos 'Campos' das regiões elevadas do Paraná e ao desenvolvimento de relações de troca econômica com o sul.

Os rebanhos das vastas 'estancias' de 'Vacaria do Mar' bem como da 'Vacaria dos Pinhais' surgida no início do século XVIII nas regiões altas no leste do Rio Grande do Sul, isolada como uma ilha e por isso segura contra exploração na região de fronteira (PFEIFER, 1967, p. 173) ${ }^{68}$ - possibilitavam o fornecimento de carne dos grandes centros em São Paulo e Minas Gerais. Mais importante, contudo, era a necessidade de animais de carga para o transporte de mercadorias pela Serra do Mar e pela Serra da Mantiqueira, partindo de Santos ou do Rio para Minas e retornando com a valiosa carga de ouro. As únicas regiões de criação de mulas no século XVIII eram, devido a uma proibição de criação aplicada a todas as capitanias (MACHADO; BALHANA, 1963, p. 17), o oeste e o sudoeste do Rio Grande do Sul, que podiam fornecer os animais de carga tão necessitados.

Assim, o principal problema que se configurou foi o estabelecimento de uma via de transporte primitiva, um caminho de condução de gado a partir dos 'Campos' do Sul até as regiões mercantes em São Paulo. O capitão-mor de São Paulo determinou em 1730 que se construísse uma via atravessando as áreas de floresta (MACHADO; BALHANA, 1963, p. 17).

Esse caminho de gado passava pelas florestas de araucárias do planalto, aproveitando habilmente as ilhas naturais dos 'Campos' muito bem distribuídas desde a 'Vacaria dos Pinhais' até Curitiba e

67 Além das 'estancias' das sete colônias missionárias a leste do Rio Uruguai (a norte do Jacuí: Estancia San Luis; ao sul do Jacuí e de leste a oeste do Ibicuí: Estancia S. Lorenzo, S. Juan, S. Miguel, S. Nicolás, S. Borja e S. Angel), permaneceram também na Campanha riograndense as 'estancias' das reduções restantes na margem oeste do Uruguai, La Cruz e Santo Tomás (ao norte do Ibicuí), bem como as de Concepción e Yapeyú (ao sul do Ibicuí). Ao mesmo tempo, Yapeyú, a maior 'estancia', incorporou mais uma parte do atual norte do Uruguai. A pecuária das reduções localizadas a leste do rio Uruguai compreendia em 1768, ano da expulsão dos jesuítas, 178.000 cabeças de gado, 5800 mulas, 7800 jumentos, 22.700 cavalos e mais de 110.000 ovelhas e cabras (segundo números em HERNÁNDEZ, 1913, I, p. 544ss. bem como em mapa nessa publicação; reimpressão em GARSCH, 1934, n. 3).

68 'Vacaria dos Pinhais' ficava fora do alcance dos ataques espanhóis. 
depois até Sorocaba, o maior mercado de jumentos e mulas do Brasil. ${ }^{69}$ A ligação das áreas de pastagem natural de terras altas do Rio Grande do Sul com a planície era feita primeiramente por um caminho de mulas que levava até Araranguá, localizada no litoral catarinense. Dali se chegava ao centro comercial mais importante do Rio Grande: Viamão, fundada em 1725 e localizada na região da atual Porto Alegre. ${ }^{70}$ Algumas décadas mais tarde surgiu uma ligação direta entre Viamão e Vacaria - um ponto intermediário surgido em 1760 no planalto - passando pela floresta subtropical da encosta (WAIBEL, 1955a, p. 38).

Ao longo do caminho de gado, pelo qual, além de jumentos e mulas, também eram conduzidos para o Norte grandes rebanhos de gado, surgiram outras pequenas colônias intermediárias nos locais de parada do rebanho, como a importante Lages e Curitibanos (nos 'campos' elevados catarinenses), Lapa, Palmeira, Ponta Grossa, Castro e Jaguariaíva (na região do Segundo Planalto) e também Curitiba (na região do planalto cristalino).

Entre 1750 e 1800, criadores de gado paulistanos tomaram posse das estepes da região Leste do Planalto Meridional. A economia de pecuária extensiva dos 'Campos Gerais' do atual Paraná estava nas mãos de alguns poucos latifundiários cujos tocadores de gado nas áreas de campo aberto tinham registrado - para seus patrões residentes em São Paulo, São Vicente ou Paranaguá - direitos de propriedade relativos a 'sesmarias' com áreas entre 4.000 e 8.000 alqueires. ${ }^{71}$

Em 1772 havia 29 grandes fazendas de gado na porção Norte dos 'Campos' paranaenses, 12 na porção central e 9 na porção Sul perto da Lapa. Em oposição a essas 50 'sesmarias' que dominavam a criação de gado e o fornecimento para os mercados de São Paulo, Minas Gerais e Rio de Janeiro, havia 125 propriedades menores ao longo do caminho de condução de gado entre Curitiba e Sorocaba (WESTPHALEN; MACHADO; BALHANA, 1968, p. 8-9).

Se a princípio menos de um quinto dos grandes fazendeiros moravam em suas propriedades, no início do século XIX a maioria dos latifundiários tinham residência em suas fazendas, e iam para os locais de acampamento mais próximos somente nos meses de inverno.

A condução de gado iniciada no Rio Grande do Sul em setembro/outubro se valia das boas pastagens durante a época de chuva no seu caminho até São Paulo. Os rebanhos, que em parte vinham também do Uruguai e da Argentina, descansavam nos abundantes pastos do Planalto do Paraná, e alcançavam os mercados de Sorocaba entre janeiro e março, dependendo das condições do tempo. A tomada espontânea de terras nos 'Campos' pelos paulistanos trouxe uma boa fonte de renda por meio do arrendamento das pastagens naturais para as 'tropas' do Rio Grande. Logo as 'invernadas' arrendadas sobrepujaram as pastagens para a pecuária própria. Com a apropriação dos 'Campos' do Terceiro Planalto perto de Guarapuava e de Palmas, realizada a partir de São Paulo, foi aberto um segundo caminho de gado importante até as pastagens do Norte e do Noroeste do Rio Grande, onde especialmente a região das Missões tornou-se famosa pela criação de gado e de mulas. Os dois caminhos convergiam nos 'Campos Gerais' do Paraná. ${ }^{72}$

Os fazendeiros de gado do Paraná, em grande parte a primeira ou a segunda geração de descendentes de imigrantes portugueses, criaram uma estrutura de poder feudal com seus latifúndios geridos extensivamente que, mais tarde, fundamentou a posição social mais elevada de seu grupo social. ${ }^{73} \mathrm{~A}$ prestação de serviços era feita por escravos, em sua maioria negros, mas também índios Botocudos e Coroados capturados. Os primeiros sinais de uma classe média viam-se nos chamados 'camaradas' que, apesar de serem cidadãos livres, agiam como supervisores ou atuavam na milícia privada do fazendeiro de maneira completamente dependente deste. Depois da independência do Brasil e da constituição da

69 Como centro do mercado de animais de carga, Sorocaba desempenhava, na região colonial portuguesa, a mesma função que Salta (atualmente na Argentina) desempenhava para o império colonial espanhol na América do Sul.

70 São conhecidos vários trechos parciais e ligações cruzadas desses caminhos de condução de gado: Viamão - Laguna - Lages - Sorocaba; a Estrada do "Convento" de Araranguá em aclive acentuado em direção a Lages (VALVERDE, 1956, p. 99) e uma ligação entre Lages e Desterro, hoje Florianópolis (cf. a esse respeito KOHLHEPP, 1966a, p. 220-221).

711 alqueire paulista $=2,42$ ha.

72 Na década de 1850 chegou-se ao ponto alto do comércio de mulas em Sorocaba. Entre 1855 e 1860, pastavam anualmente 100.000 mulas e jumentos nas fazendas do Paraná ao passarem pelo caminho até Sorocaba (cf. a esse respeito MACHADO e BALHANA, 1963, p. 18).

73 Saint-Hilaire (1851) menciona mesmo assim o baixo grau de instrução da maior parte dos fazendeiros iletrados que notou em sua viagem de 1820, bem como as suas relações com os 'peões', que praticamente correspondiam às de uma sociedade sem classes e patriarcal. 
província do Paraná em 1853, os grandes fazendeiros dos ‘Campos Gerais’ exerceram influência decisiva em posições de liderança no decorrer dos desenvolvimentos políticos do estado.

A percepção de interesses políticos e comerciais nas cidades e a crescente ausência dos fazendeiros de gado de suas propriedades daí decorrente levou a uma decadência da pecuária extensiva nos 'Campos' paranaenses a partir da segunda metade do século XIX. Se o arrendamento de pastagens de engorda para os rebanhos que estavam de passagem fez com que a iniciativa própria dos donos de terra diminuísse devido a oportunidades de ganho mais fácil, a pecuária declinou ainda mais depois do final do boom de mineração em Minas Gerais e depois da criação de possibilidades de suprimento próprias e próximas aos mercados de São Paulo e do Rio. O mercado de mulas chegou quase totalmente ao fim no final do século XIX, e os escravos libertos se mudaram para as cidades.

Enquanto a vida econômica nos 'Campos Gerais' do Paraná estagnava, dois novos ciclos econômicos - a extração do chá mate ${ }^{74}$ e a exploração madeireira intensificada a partir de $1880^{75}$ - se tornaram muito significativos, o que deslocou o centro econômico para a região das florestas de araucárias do Paraná. Contudo, a expansão partindo do leste para o oeste sobre o Terceiro Planalto só se deu aos poucos. ${ }^{76}$

Em oposição à apropriação total dos 'Campos' do leste por latifundiários luso-brasileiros individuais, havia a exploração primitiva das florestas de araucárias e das florestas subtropicais próximas ao rio Paraná a sudoeste, conduzida por grandes grupos internacionais, bem como posteriormente também por companhias estrangeiras, sobretudo inglesas e argentinas, como a Compañía Maderas del Alto Paraná ou a Companhia Matte Laranjeiras. As concessões de terra que foram fornecidas a essas empresas estavam geralmente condicionadas à colonização e à ocupação da área concedida. Contudo, essas condições não foram satisfeitas, pois, entre outras coisas, a revolução de 1924 e a marcha da Coluna Prestes também trouxeram muita destruição para a região entre Guaíra e Foz do Iguaçu. As companhias se dedicaram principalmente à extração mais lucrativa possível dos produtos dedicados ao mercado, erva-mate e madeira, no menor tempo possível. A estrutura social do Paraná era marcada pelo sistema feudal da economia pecuarista, na qual geralmente os 'peões' viviam em condições tão miseráveis quanto os lenhadores e coletores de erva-mate brasileiros e paraguaios que trabalhavam nas empresas comerciais financeiramente sólidas.

Na primeira metade do século XIX iniciou-se a colonização planejada com imigrantes europeus, e com os 'colonos' introduziu-se uma nova fase de desenvolvimento no Paraná com relação à estrutura econômica e social.

Se as primeiras colônias (por exemplo, Rio Negro, fundada em 1829$)^{77}$ ainda eram fundadas na orla das matas com o intuito estratégico de garantir a segurança das vias de ligação contra ataques de índios, a partir da década de 1870 iniciou-se a exploração controlada das florestas mistas do Primeiro e Segundo Planaltos, bem como o assentamento na região de fronteira entre a mata e os 'Campos' (BIGG-WITHER, 1878).

Apesar de a província do Paraná - separada de São Paulo em 1853 - ter sido a primeira província brasileira a emitir, em 1854, uma lei estadual de sublocação de propriedades para fins de colonização, ${ }^{78}$ a colonização agrária dirigida começou a funcionar muito lentamente, e se restringiu primeiramente à região de Curitiba no planalto cristalino coberto de florestas, onde colonos alemães e poloneses passaram a garantir o fornecimento de alimentos básicos à cidade depois de 1860.

Os alemães do Volga, que chegaram ao Paraná no final dos anos 1870, tiveram logo de abandonar sua meta econômica de cultivar trigo nos solos arenosos e pobres de nutrientes das estepes do Segundo Planalto, formado a partir de sedimentos paleozoicos. Enquanto a maior parte dos colonos voltou a migrar, aqueles que permaneceram mudaram para a prática da coivara na floresta próxima

74 Como o suprimento de mate dos mercados de Buenos Aires e de Montevidéu se tornou impraticável devido à Guerra do Paraguai, a extração de mate do Paraná tomou o lugar dos antigos fornecedores paraguaios.

75 Com o término da construção da Estrada da Graciosa entre Curitiba e Antonina em 1873 e com a ligação ferroviária CuritibaParanaguá, possibilitou-se a exportação de madeira de araucária.

76 Sobre a história do Paraná, cf. entre outros: Fugmann (1929); Figueiredo (1937); Oliveira Vianna (1938); Martins (1939); Machado (1952); Centenário Paraná (1953); Balhana (1955); Valverde (1956); IBGE (1959); Prado (1962); Vianna (1963); ElKhatib (1969); e IBGE (1968, II).

77 O lugar recebeu o nome de Capella da Estrada da Matta e surgiu no local onde o caminho de gado Sul-Norte entrava para a 'Mata do Sertão' (MARTINS, 1941, p. 59).

78 A primeira colônia, Assungui, na região do curso superior do profundo Vale do Ribeira, foi um fracasso devido a uma escolha infeliz de localização, altos preços de terras e péssima organização (WAIBEL, 1955a, p. 85-86). 
a Ponta Grossa, Palmeira e Imbituva. A ocupação, que no Paraná ainda tinha ficado restrita quase que exclusivamente aos 'Campos Limpos' em meados do século XIX, deslocou seu foco de atenção, a partir de então, definitivamente para as amplas regiões de florestas, no que somente as florestas inteiramente de araucárias eram evitadas, devido ao seu solo infértil. A construção da ferrovia que avançava a sudoeste deu, no início do século XX, um impulso para a colonização da floresta por colonos.

Tanto os latifundiários luso-brasileiros com muito capital e pecuária extensiva sobre os 'Campos', quanto os imigrantes do Centro e do Leste europeu - que praticavam a agricultura de coivara em pequenas propriedades nas regiões de florestas - , constituíam dois grupos sociais contrários, cada um com seus objetivos e espírito comerciais diferentes, cujos confrontos levantam problemas até hoje (KOHLHEPP, 1969, p. 151-152). Com isso, os colonizadores da floresta, isolados, iletrados e desorganizados, jamais poderiam concorrer com os clãs de criadores de gado que dominavam a política, cuja hegemonia só foi abalada por volta da virada do século por exportadores de mate e por madeireiros enriquecidos.

A oposição dos latifundiários no Paraná contra a imigração de europeus - numericamente superior aos grupos tradicionais da população - e a ausência dos imigrantes alemães após 1859 como consequência do édito de Heydt, foram as causas para o baixo contingente de imigrantes entre 1853 e 1889: somente 19.000 pessoas. Em um momento em que - depois da proclamação da república - a quantidade de imigrantes sobretudo italianos e espanhóis em São Paulo superava a marca de 100.000 pessoas por ano (1891), no Paraná a população total era de 149.000 pessoas!

Enquanto o cultivo de café atingia seu primeiro ápice no estado de São Paulo, iniciaram-se, com o estabelecimento de alguns fazendeiros vindos de Minas Gerais e São Paulo no Norte Velho do Paraná, os primórdios de uma exploração das florestas tropicais, que se mostraria extensiva 50 anos mais tarde, e que se realizou desde o Norte Velho do Paraná até o rio Tibagi, ainda seguindo o modelo tradicional de plantações.

A expansão dos cafeicultores paulistas trouxe a quinta fase de exploração do Paraná, no âmbito da expansão para o sul vinda de São Paulo, depois das expedições dos bandeirantes no séc. XVII, da ocupação de posições costeiras estrategicamente importantes na mesma época, da apropriação dos 'Campos limpos' do Planalto por parte de criadores de gado no séc. XVIII e da colonização das florestas por pequenos camponeses no leste do estado, iniciada no século XIX.

\section{RELAÇÕES DE POSSE DE TERRA NA ZONA PIONEIRA A OESTE DO RIO TIBAGI NO INÍCIO DA EXPLORAÇÃO MODERNA DO NORTE DO PARANÁ}

As relações de posse nas áreas de floresta tropical e subtropical não-ocupadas no Norte do Paraná se igualavam, em sua opacidade no início da colonização agrária na década de 1920, à situação relativa ao direito de propriedade confusa e já conhecida de outras partes do Brasil.

Com a declaração da independência do Brasil em 1822, tornara-se impossível a nova aquisição de sesmarias, contudo o que dominava era a simples ocupação de propriedades que só veio a ser proibida em 1851. Na mesma época ocorreu a cobrança de todas as concessões de terra que não tinham sido valorizadas pelo cultivo de produtos agrícolas e pela residência fixa dos donos nas propriedades. Uma nova lei de posse de terras definiu a compra como sendo o único método válido para aquisição de terras. Somente o governo imperial poderia dar concessões de terra para a fundação de colônias.

Em 1889, pouco tempo depois da proclamação da república, foi cedida uma concessão de terras de vários milhares de $\mathrm{km}^{2}$ à companhia Estrada de Ferro São Paulo-Rio Grande, sob a condição de que se realizasse a colonização em ambos os lados da ferrovia a ser construída no noroeste e no oeste do Paraná. A partir de 1891, as terras desocupadas passavam a ser da competência de cada estado da federação (WESTPHALEN; Machado; BALHANA, 1968, p. 12). Depois disso, iniciou-se um novo período de concessão de terras, concedidas frequentemente a aliados políticos dos partidos que estavam no poder.

A Revolução de 1930 trouxe a revogação de várias concessões de terras que não tinham preenchido as condições legais dentro do prazo de 5 anos. As terras concedidas à Estrada de Ferro São PauloRio Grande - uma filial da Brazilian Railway Co. - foram devolvidas ao estado do Paraná, já que a 
construção da ferrovia tinha se realizado nesse ínterim para o extremo leste do estado e a colonização das regiões ocidentais não tinha sido realizada pela companhia ferroviária.

Contudo, foi extremamente difícil a luta da colonização dirigida privada e pública contra os chamados 'grileiros'. Esses especuladores de terras, em geral residentes nas cidades e politicamente influentes, tinham tomado posse de enormes áreas de terra ('grilos') por meio de concessões de terra duvidosas, transferências falsificadas e títulos de propriedade em geral falsos. Dessa maneira, já no início da real colonização no norte do estado foram reivindicados por grileiros cerca de $55.000 \mathrm{~km}^{2}$ de área florestal não-ocupada, ou seja, mais de um quarto de toda a área do estado. Os 'grilos' compreendiam, em geral, várias dezenas de hectares, e as reivindicações de propriedade totalizavam áreas de mais de 1 milhão de hectares, como se pode depreender do Mapa 9 e da Tabela 2 abaixo:

Tabela 2: Os maiores grilos do Norte do Paraná em extensão de terra ${ }^{79}$

\begin{tabular}{l|c|}
\hline 1. Reconquista & 1.080 .000 \\
\hline 2. Bandeirantes & 977.100 \\
\hline 3. Pirapó & 894.400 \\
\hline 4. Boa Esperança & 619.500 \\
\hline 5. Corumbataí & 523.400 \\
\hline 6. Guavirova & 413.800 \\
\hline 7. Barra do Tibagi & 358.900 \\
\hline 8. Ubá & 242.000 \\
\hline 9. São Manuel & 171.800 \\
\hline 10. Ribeirão Vermelho & 108.900 \\
\hline 11. Tigre & 42.700 \\
\hline 12. Barra Bonita & 39.400 \\
& 5.471 .900 ha
\end{tabular}

Área em ha

.471 .900 ha

As práticas dos grileiros estiveram quase sempre ligadas a tomadas de posse controladas por eles frequentemente violentas e ilegais - e que eram levadas a cabo pelos chamados 'intrusos', introduzidos para assegurar as reivindicações de direito de propriedade. Tanto para se opor às legítimas pretensões de posse de terra das companhias colonizadoras particulares - que tinham comprado a terra do governo do estado de maneira correta -, quanto para se opor aos representantes dos órgãos do poder executivo, os grileiros fizeram uso frequente de milícias privadas próprias ${ }^{80}$, tanto no Paraná quanto em outras áreas do Sudeste e do Nordeste brasileiro. Confrontos violentos marcam tanto o avanço para oeste da fronteira no norte do Paraná quanto o movimento migratório interno sul-norte vindo do Rio Grande para o sudoeste do Paraná. ${ }^{81}$

A colonização agrária que se iniciava foi dificultada, além do movimento controlado dos 'intrusos', também pela tomada de posse espontânea de terras devolutas ou que já tinham sido vendidas mas ainda não exploradas pelos proprietários, por parte de 'intrusos' individuais ou de grupos de tais ocupantes [squatter].

79 Segundo o Relatório da Interventoria Federal do Paraná ao Presidente da República, relativamente ao período de 1932 a 1944 (p. $24-26$ e Mapa 1). Recálculo das extensões de terra realizado segundo Westphalen et al. (1968, p. 24-25).

80 Chamados de jagunços, capangas ou também pistoleiros.

81 Cf. sobre isso El-Khatib (1969); Martins (1939) e notícias em jornais diários paranaenses. 
Para se avaliar as relações de direito de posse nas regiões pioneiras do Paraná, deve-se diferenciar a atividade e a motivação de dois grupos de ocupantes:

a) Os 'intrusos' não estão interessados na legalização de suas 'posses', mas sim em uma exploração delas a curto prazo. Eles se aproveitam do objetivo do proprietário legal que quer cultivar sua terra, porém só saem por vontade própria das terras ocupadas por eles quando há uma compensação financeira, e imediatamente depois disso voltam a exercer essa prática em outro lugar (WESTPHALEN; MACHADO; BALHANA, 1968, p. 22-23).

b) Em oposição à mobilidade dos 'intrusos', os 'posseiros' anseiam por estabilidade e não têm interesses especulativos. São famílias sem terra ou grupos de famílias que se estabelecem em terras não-ocupadas ou que não foram cultivadas pelo proprietário. Elas estabelecem sua morada fixa e praticam primeiramente agricultura de subsistência, mas objetivam com frequência passarem a um produto de mercado com o progresso da colonização e o desenvolvimento da infraestrutura. Os 'posseiros' desejam obter o título de posse da terra cultivada por eles.

A especulaçãofundiária feita pelos grileiros, quecom frequência apresentavam suas reivindicações de posse somente depois de iniciada a exploração e depois da consequente valorização da terra, adiantou-se ao avanço da frente pioneira. Suas atividades criminosas se dirigiam principalmente contra os posseiros, cuja força de trabalho prometia muitos ganhos principalmente antes da realização da colheita. Tanto o confronto dos grileiros, posseiros e intrusos entre si, bem como entre eles e a colonização dirigida privada e estatal, por motivos jurídicos e morais, são característicos da região de fronteira no Brasil.

Porém, uma vez que a colonização do Norte Novo do Paraná começou no início da década de 1930 - uma época em que a crise cafeeira e a crise econômica mundial alcançavam seus ápices e em que a economia cafeeira não podia contar com uma área grande de cultivo no norte do Paraná por causa da forte geada de 1918 nas regiões sul e oeste de São Paulo - , a primeira fase dessa colonização se diferencia da que se deu no oeste de São Paulo.

Nessas regiões, clãs familiares poderosos controlavam, com auxílio de seus 'capangas', a concessão de terras durante a expansão do cultivo do café. No Norte do Paraná, as disputas de posses só tomaram formas mais sérias com a revalorização das terras ocorrida no boom cafeeiro que se iniciou na década de 1950, principalmente nas regiões em que se realizava a venda de terras pelo estado. ${ }^{82}$

As formas da colonização dirigida privada e da colonização controlada estatal no norte do Paraná apresentam grandes diferenças em sua concepção, plano de desenvolvimento e na realização de projetos de assentamento individuais, cujos impactos sobre a exploração agrária como um todo serão analisados a seguir.

\section{O SIGNIFICADO DA COLONIZAÇÃO DIRIGIDA PRIVADA PARA O DESENVOLVIMENTO DO NORTE DO PARANÁ DESDE 1930}

\section{a) A Companhia de Terras Norte do Paraná: Modelo de planejamento regional na fronteira do assentamento}

A contribuição mais significativa para a exploração e para o desenvolvimento econômico do Norte do Paraná foi feita por uma companhia colonizadora inglesa de iniciativa privada ${ }^{83} \mathrm{O}$ fundador dessa companhia foi Lord Lovat, ${ }^{84}$ um escocês especialista em agricultura, reflorestamento e problemas de colonização. Em 1924, ele estudou, juntamente com a Comissão Montagu a convite do governo brasileiro, possibilidades para o desenvolvimento econômico em diferentes regiões do

82 Sobre as condições subjacentes a esse problema, ver Cap. III, 5.

83 Sou grato de maneira especial às seguintes pessoas (entre muitas outras) por diversas discussões sobre a atividade colonizatória da CTNP, bem como por comunicações pessoais e pela ajuda na exploração do material de arquivo e de demais fontes: Dr. C. Vidigal, G. Fox Rule, B. Kiiswerk (São Paulo), A. de Souza Melo (Londrina), A. W. Nieffeler, Dr. W. Babkov e A. Bianchini da Rocha (Maringá).

84 Simon Joseph Fraser; cf. sobre isso Lindley (1935). 
país - principalmente tendo em vista o cultivo do algodão e o fornecimento de matéria-prima à indústria têxtil inglesa - , e também visitou o nordeste do Paraná no ponto final da Ferrovia Sorocabana, na região de Cambará.

A intenção original da Brazil Plantations Syndicate Ltd. - fundada por um grupo inglês financeiramente sólido ainda no ano de 1924 em Londres por iniciativa de Lovat - de investir em extensas plantações de algodão com base nas experiências adquiridas no Egito e no Sudão anglo-egípcio (o 'Projeto Gezira') falhou devido a maus resultados de experimentos. Após estimativas corretas do potencial natural das áreas de 'terra roxa' do norte do Paraná, foram fundadas em 1925 duas novas companhias pelo mesmo grupo, que tinham como objetivo um grande projeto de colonização com base em pequenas e médias propriedades:

a) A Paraná Plantations Ltd., com sede em Londres, que assumiu todo o finaciamento. ${ }^{85}$

b) A 'Companhia de Terras Norte do Paraná' (CTNP), com sede em São Paulo e com a tarefa de operar a compra de terras, conduzir a exploração da terra e recrutar colonos.

Ao contrário do que fazia a maioria das companhias colonizadoras privadas em atividade no Brasil, os preparativos para esse projeto - que se estenderam por 5 anos - foram conduzidos com os maiores cuidados, e a venda das terras se iniciou somente em 1930. A coordenação foi assumida por um especialista em colonização escocês que atuou anteriormente no Sudão e que combinava experiência em agricultura tropical e subtropical com talento organizacional e dom de negociação.

Contudo, a companhia colonizadora auferiu seu maior mérito por meio de sua sólida política de aquisição e posterior venda de terras. Até o ano de 1928, a CTNP já tinha obtido cerca de $12.500 \mathrm{~km}^{2}$ de área de florestas na região ao sul do rio Paranapanema e a oeste do rio Tibagi, ${ }^{86}$ uma região que se estendia para além do rio Ivaí (Mapa 10) e era composta na sua maior parte por uma área livre de malária com altitudes entre 500 e $875 \mathrm{~m}$. A resolução das questões de propriedade e a obtenção dos títulos de propriedade das terras compradas se configurava uma tarefa especialmente difícil em uma região com forte especulação fundiária e permanentes disputas pela posse das terras. Dentro de um prazo especificado e com apoio do então governador Munhoz da Rocha, foram adquiridas todas as reivindicações de direito de posse - seja de antigas concessões de terra ou de compras de terras - , tanto de grileiros, intrusos e posseiros quanto do estado do Paraná. Assim, tanto reivindicações legais quanto títulos falsificados de posse foram comprados, compensações foram dadas a intrusos e a posseiros, e por alguns terrenos chegou-se a pagar cinco vezes seguidas. Esse método era o único que podia ser utilizado na frente pioneira do Brasil, e com isso todos os direitos de propriedade foram passados à CTNP antes do início da valorização das terras. O baixo preço das terras - cerca de US\$ 2 por alqueire paulista (= 2,42 ha) - permitiu que a Companhia comprasse todos os direitos de propriedade com um encargo financeiro total quase dobrado.

Em 1944, durante a II Guerra Mundial, a britânica Cia. de Terras Norte do Paraná foi vendida, no âmbito do financiamento de guerra, a um grupo brasileiro de empreendedores ${ }^{87}$, que comprou no mesmo ano a gleba Cruzeiro (com $725 \mathrm{~km}^{2}$ ) no Norte Novíssimo, que já tinha sido agrimensada e devolvida ao estado do Paraná devido a conflitos pela posse. ${ }^{88}$ A companhia colonizadora brasileira obteve em 1951 o nome de 'Companhia Melhoramentos Norte do Paraná' (CMNP). Durante a operação imobiliária, o governo brasileiro insistiu na transferência da linha férrea construída pela companhia, que teve que ser vendida para a União. A péssima condição financeira do estado e a organização insuficiente fizeram com que se postergasse o seguimento da construção da ferrovia. Por outro lado, os trabalhos de exploração

85 O capital inicial de $£ 750.000$ foi posteriormente aumentado para $£ 1.85$ milhões (SCHAUFF, 1957b, p. 35).

86 Em 1925 foi realizada a compra de uma gleba de 350.000 alqueires juntamente com a concessão da construção da ferrovia pela Cia. Marcondes de Colon., Ind. e Com., bem como de uma área de 100.000 alqueires da propriedade de Dr. Coelho de Almeida. Entre 1926 e 1928 foram obtidos os títulos de posse de 3 áreas de terra, com 30.000 (Concessão de Alves de Almeida), 20.000 (Francisco Beltrão) e 15.000 alqueires (Cia. Tibagi Ltda.) respectivamente, totalizando 515.000 alqueires $=12.463 \mathrm{~km}^{2}$ (VIDIGAL, 1970, p. 123-24).

87 As negociações se estenderam por 5 anos. O grupo foi liderado por brasileiros que tinham cargos chave na CTNP (engenheiros, consultores jurídicos) e que se ligaram a banqueiros de São Paulo e Rio de Janeiro. Cf. sobre isso Thomas (1949); Barrros (1953); e Vidigal (1970).

88 Por razões políticas, a gleba Cruzeiro estava separada das demais terras da CTNP. Nesse espaço se localizava a colônia estatal de Cruzeiro do Oeste, cuja localização de fronteira oferecia vantagens de proximidade. A medição realizada pelo governo foi totalmente assistemática, e as propriedades eram blocos de, em média, mais de 200 ha. A CTNP teve que realizar novas medições sob condições adversas, e optou aqui também pelo sistema de lotes da divisora de águas ('espigão') para o curso da água. 
da nova companhia foram continuados sob o comando do antigo chefe de projeto inglês segundo o mesmo sistema.

Além da agrimensura exemplar e da garantia também exemplar dos títulos de posse dos compradores posteriores, o desenvolvimento do transporte recebeu atenção especial na região de colonização. Primeiramente, tratava-se da acessibilidade das terras a Oeste do rio Tibagi, que - apesar de estarem no estado do Paraná - recebiam impulsos de exploração e ocupação quase que exclusivamente de São Paulo.

O plano de uma ligação ferroviária de Presidente Prudente à ferrovia Sorocabana em direção sul até o rio Paranapanema - para onde já havia sido traçado um caminho vindo do sul até a região do rio Pirapó - foi novamente descartado, já que o arenito Caiuá se sobrepunha às capas vulcânicas nas divisoras de águas dispostas em forma de platô e localizadas entre os afluentes do Paranapanema, o que ocasionava a ausência do tão esperado solo fértil de 'terra roxa' (MAACK, 1937, p. 232).

Assim, tomou-se a decisão de avançar a linha férrea para oeste, em rota direta de impacto com a expansão paulistana sobre o terceiro planalto do Paraná, na região dos solos de decomposição vulcânica. Um ramal ferroviário já existente, que fora instalado por proprietários de cafezais vindos de São Paulo no extremo nordeste do Norte Velho e que se estendia de Ourinhos até Cambará $(29 \mathrm{~km})$, serviu de ponto de partida. Em 1928, a CTNP obteve a maioria das ações dessa linha férrea; em 1929 retomou a construção dela, e dentro de 3 anos criou uma ligação ferroviária até o rio Tibagi que foi ampliada em 1935 até Londrina.

A colonização interna dos $12.500 \mathrm{~km}^{2}$ da área de assentamento foi levada a cabo segundo um plano previamente concebido. A construção das estradas de acesso pelas divisoras de águas antecedeu a venda das terras. Estradas de 4 a $5 \mathrm{~m}$ de largura rodáveis o ano todo, providas tanto de caminhos laterais quanto de pistas de vistoria foram construídas de maneira sistemática, de forma que todo terreno vendido tivesse ligação com a malha viária.

A venda das terras começou no ano de 1930 em Londrina, a primeira base principal da companhia e o ponto de partida para a exploração. A área total foi dividida em 6 zonas, e estas por sua vez desmembradas nas chamadas 'glebas'. A venda de terras, comprometida claramente com as melhores condições possíveis, ${ }^{89}$ foi feita na forma de pequenas e médias propriedades, em que a área dos terrenos vendidos nos primeiros 10 anos era de, em média, 40 hectares.

A motivação para a agrimensura dos lotes era o desejo da companhia colonizadora de garantir a todos os compradores de terra tanto uma ligação viária para as estradas de rodagem, que passavam pelas cumeeiras das divisoras de águas, quanto o acesso à água. A distribuição em forma de faixas dos lotes retangulares, desde a divisora de águas até o fundo do vale, facilitava - dum ponto de vista organizacional - a agrimensura e a avaliação dos terrenos, e deu a todos os colonos partes iguais às unidades com grandes diferenças naturais entre si, devidas a fatores microclimáticos e pedológicos. A forma de divisão de terras que se firmou - lotes em faixas largas no sistema Waldhufen (Mapa 10a) - é uma adaptação às condições naturais do terreno (que permitiam uma divisão sistemática ${ }^{90}$ ) e não resulta de normas de agrimensura ditadas pelo governo ${ }^{91}$ (Fotos 2 e 5). Contudo, não se pode esquecer que alguns dos agrimensores ativos no norte do Paraná vinham da Alemanha, já tinham feito algumas medições de terra no sul do Brasil e por isso estavam familiarizados com as formas de divisão de terras no sistema Waldhufen.

89 O preço de compra por hectare corria inicialmente entre US\$ 7 e US\$ 8 por hectare, em Rolândia chegava a US\$ 16. Condições de pagamento diferenciadas de acordo com a distância centro-periferia e com o tamanho das áreas tinham por objetivo permitir a exploração simultânea mesmo dos lotes mais distantes dos assentamentos, mediante um adiantamento de $30 \%$ do preço do lote e pagamento do restante parcelado em 4 anos. Para pequenos lotes próximos da cidade, o adiantamento era de $40 \%$ e 2 anos para para pagar o restante. Terrenos nos assentamentos urbanos planejados eram concedidos mediante adiantamento de $50 \%$ e um prazo de 1 ano para pagamento do restante do valor. A taxa de juros era de $8 \%$ a.a., um valor extremamente baixo para o Brasil. No caso de inadimplência devido a erros iniciais de gestão, era adiado o pagamento do montante devido por colonos dispostos a trabalhar.

90 Para o Rio Grande do Sul e para Santa Catarina, Waibel (1955a, p. 9) e Smith (1963) admitem o mesmo, apesar de a encosta do Planalto Meridional apresentar diferentes condições morfológicas.

91 Na argentina Misiones, a divisão dos campos segundo o sistema Waldhufen, adaptada ao terreno e à bacia hidrográfica, só se firmou muito lentamente nas regiões montanhosas em contraponto ao sistema ortogonal de dameros, definido pelo governo (WILHELMY, 1949a, p. 25ss.). A nova divisão de terrenos com acesso a água em Misiones teve como resultado o início da atividade pecuária e uma venda mais rápida dos terrenos assim agrimensados (EIDT, 1971, p. 99). 
Contudo, no norte do Paraná não se firmou a forma de assentamentos correspondente à do sistema de aldeias alinhadas, uma vez que as casas e os prédios comerciais, instalados durante o primeiro estágio da colonização à beira dos riachos no fundo dos vales, ${ }^{92}$ foram instaladas na fase seguinte, de expansão interna, colina acima e a cerca de um terço da altitude com relação à fronteira inferior das plantações de café.

As casas dos vilarejos em sistema de Waldhufen - por exemplo, na área de colonização medieval do leste - se alinham por quilômetros em linhas ao longo de estradas e frequentemente dispostas ao longo do curso de um rio. Um "assentamento disperso linear" (WAIBEL, 1955a, p. 92) predomina também em áreas de assentamento de alemães nos estados do Rio Grande do Sul e de Santa Catarina, no sul do Brasil, onde as casas se alinham no fundo do vale, à 'picada', à 'linha colonial' ou à 'raia' dos colonizadores vindos do Hunsrück. Ao contrário, a forma de assentamento que consiste em séries de casas individuais em uma divisão em largas faixas no sistema de Waldhufen ${ }^{93}$ não previu, no norte do Paraná, a ligação dos quintais das casas à estrada; os quintais das casas se dispunham lado a lado na encosta, sem ligação por estrada, mas com ligações transversais até as estradas principais. ${ }^{94}$ As razões para as casas dos colonos e os prédios comerciais se localizarem no terço inferior da encosta são, por um lado, o gradiente do valor do solo desde a cumeeira - reservada exclusivamente para a valiosa lavoura de café - até o fundo do vale, sujeito a geadas e por isso não apropriado para o cultivo do café; por outro, a dificuldade no fornecimento de água ao espigão. Importância secundária tem a ação da poeira, que faz com que uma faixa de 30 a $40 \mathrm{~m}$ para ambos os lados das rodovias não pavimentadas sejam quase inabitáveis. ${ }^{95}$

As dimensões dos terrenos se orientavam pelo tamanho planejado de aprox. 40 ha, de acordo com a profundidade no vale e a distância entre a divisora de águas e o curso do rio.

As faixas tinham originalmente uma largura que variava de 150 a $300 \mathrm{~m}$, e um comprimento entre 1 e $2,5 \mathrm{~km}$ (muito raramente mais do que isso), de forma que a proporção entre largura e comprimento fosse, em geral, entre 1:5 e 1:15. Propriedades maiores - que se encontravam no final do vale ou às margens de rios maiores - eram agrimensadas só muito raramente.

As distâncias entre os lotes individuais são mantidas de tal forma que surge um sentimento de vizinhança, e se torna possível haver ajuda mútua entre os vizinhos em casos de emergência. Em muitos casos duas casas ficam próximas aos limites das propriedades de frente uma à outra, justamente devido à estrada de acesso à estrada principal que ambas compartilhavam. A distância entre as casas individuais fazem, contudo, com que sempre surja o sentimento de propriedade isolada - um fator psicológico extremamente importante para a grande quantidade de antigos trabalhadores rurais e arrendatários que foram a primeira geração a obter terras próprias no norte do Paraná. A disposição espacial das propriedades mostra uma clara estruturação partindo do centro do assentamento em direção à periferia:

1. Na área mais estreita em torno dos assentamentos até aprox. $1 \mathrm{~km}$ de distância eram instaladas 'chácaras', pequenas propriedades de até 1ha que eram vendidas a moradores da cidade e eram previstas para o plantio de árvores frutíferas, hortaliças e pecuária de leite intensiva para cobrir a demanda local. As chácaras constituem o mais interno dos Anéis de Thünen (Mapa 10a).

Em torno de assentamentos urbanos maiores também era planejado um "cinturão verde" que devia ser composto de restos de floresta tropical e de reflorestamentos.

2. Depois destes seguiam os 'sítios', com área de 25 a 50 ha, que compreendiam $90 \%$ dos lotes agrimensados e que eram previstos para o cultivo comercial do café (Fotos 4 e 5).

3. Na área mais retirada, geralmente distante mais de $15 \mathrm{~km}$ e topograficamente mal localizada, eram agrimensadas também 'fazendas' (mais de 200 ha) - frequentemente com grandes reservas de mata - que deveriam se dedicar, entre outras coisas, à pecuária.

92 A localização à margem do curso d'água foi escolhida menos para o suprimento de água do que para os animais domésticos (MONBEIG, 1935, apud MONBEIG, 1945, p. 12).

93 Cf. sobre isso Nitz (1962, p. 79); cf. Nitz (1974) e Kohlhepp (1975), bem como o Mapa 52.

94 Em Misiones também foi feito o desmatamento do curso do rio subindo a encosta até a estrada, no que a casa do colono ficava primeiramente à margem do rio, porém depois era transferida para próximo da estrada. Eidt (1971, p. 101) diferencia como formas de assentamento, além de 3 tipos de 'Waldhufen-like settlements' ('assentamentos no estilo Waldhufen'), vilarejos Waldhufen com funções urbanas centrais de 'Waldhufenweiler' (German-style forest long-lot farm settlements, 'assentamentos em fazendas de longos lotes no estilo alemão') com poucas e parcas funções centrais, ou mesmo nenhuma.

95 Problemas semelhantes são descritos por Eidt (1971, p. 140) para a aldeia Waldhufen de Monte Carlo, em Misiones. 
Na divisão planejada da área, com base em núcleos funcionais, foram criados grandes centros urbanos ao longo dos $100 \mathrm{~km}$ do eixo leste-oeste formado pela ferrovia e pela estrada e que passava pela divisora de águas. Foi o caso de Londrina, Maringá, Cianorte e mais tarde, na recém-obtida gleba Cruzeiro, Umuarama (cf. Mapa 10). Nesse espaço surgiram - também sobre os espigões - pequenos centros urbanos como pontos intermediários das glebas, localizados a cada 12 ou $17 \mathrm{~km}$ ao longo das estradas rodáveis o ano todo (Mapa 10a: Jussara, Terra Boa). Fora das vias de transporte principais e entre os pequenos centros foram criados os chamados 'patrimônios' no sistema de planta ortogonal, locais centrais da classe mais baixa para o suprimento mais básico da população rural (Mapa 10a: Malu; Vidigal) ${ }^{96}$.

O objetivo da CTNP era a criação de uma zona mista de assentamento com elementos colonizadores brasileiros, mas também europeus e japoneses. Os grupos deveriam ser assentados juntos segundo sua nacionalidade, por razões psicológicas. ${ }^{97} \mathrm{~A}$ importância desse fator foi frequentemente subestimada pelos órgãos oficiais brasileiros.

Faziam parte dos serviços prestados pela CTNP o transporte gratuito dos compradores de terras até as suas propriedades, o fornecimento de meios de transporte, e o estabelecimento de esquadrões de derrubada que realizavam o trabalho de desmatamento, algo a que muitos dos novos colonos não estavam habituados. Essa prestação de serviços era compensada parcialmente com a compra de lenha pela Companhia. Os cuidados médicos para os colonos, bem como a construção e a manutenção de escolas, foram realizados de maneira exemplar.

O trabalho da CTNP - o maior e mais bem sucedido projeto de colonização da América do Sul mostra que os maiores sucessos no desenvolvimento regional brasileiro se baseiam nas (infelizmente muito poucas) companhias colonizadoras privadas e financeiramente sólidas, ${ }^{98}$ que tiveram como objetivo o desenvolvimento com garantias de direito de posse de médias e pequenas propriedades e, com isso, a colonização mais intensiva com a construção da infraestrutura necessária e a fundação de pontos urbanos intermediários. Foi somente o trabalho conjunto de companhias colonizadoras e empresas de transporte (linha férrea), uma novidade para o Brasil, que possibilitou um planejamento regional integrado no norte do Paraná.

\section{b) Atividades de pequenas companhias colonizadoras privadas}

A colonização a oeste do rio Tibagi fora iniciada por duas companhias menores ${ }^{99}$ que em 1919 já tinham obtido cada uma 50.000 ha (Mapa 10, n 1 e 2). Desde 1923, as colônias Primeiro de Maio e Sertanópolis foram desenvolvidas com colonizadores de São Paulo que avançavam pelo rio Paranapanema em direção sul.

O objetivo da colonização era a utilização dos férteis solos de 'terra roxa' nas cumeeiras das divisoras de águas. Além das chácaras menores próximas aos centros dos assentamentos, foram agrimensados sítios em faixas largas na direção das encostas, um sistema que foi utilizado mais tarde pela CTNP em larga escala. Fazendas menores, com 300 a 400 ha, foram concedidas especialmente para o cultivo de café em lugares mais altos.

Além disso, os compradores dos lotes da colônia Sertanópolis eram obrigados a erguer, dentro de 2 anos, um prédio no centro do assentamento em um terreno destinado a eles sem custo, o que levou a um rápido desenvolvimento de Sertanópolis - que em 1927 foi elevada a sede do distrito e, em

96 Sobre isso ver Cap. III, 6.

97 Depois de 1938, isso foi proibido com base na nova legislação sobre o assentamento de estrangeiros. Contudo, em oposição a isso, principalmente Waibel (1955a, p. 134-35) ressaltou a importância de uma comunidade linguística, religiosa e cultural para a psique dos imigrantes em um ambiente estranho a eles. A criação de assentamentos com colonos brasileiros e imigrantes de diferentes nacionalidades em vizinhança direta evita temores do surgimento de 'enclaves estrangeiros' de grande extensão. Assentamentos mistos no Paraná - assim como em outras partes do Sul do Brasil - tiveram normalmente um péssimo desenvolvimento, devido à decadência do padrão cultural e econômico dos imigrantes, como p. ex. Cruz Machado e Cândido Abreu (MAACK, 1937, p. 232).

98 No oeste de São Paulo ganhou em importância a Cia. Paulista de Estradas de Ferro, que surgiu como empresa de transportes para aprimoramento do transporte das plantações de café de alguns latifundiários paulistanos, e a partir da qual se desenvolveu - só secundariamente - uma companhia de colonização, a Cia. Agrícola de Imigração e Colonização. A Soc. Colonizadora do Brasil surgiu na propriedade japonesa e era a organização tutelar pra o assentamento de imigrantes japoneses em São Paulo e no nordeste do Paraná. Sua organização tomava conta das áreas econômica, social e cultural dos colonos japoneses (MONBEIG, 1952, p. 217-218).

99 Corain e Co. e, adjacente ao sul, Cia. Paula Vieira. 
1929, à categoria de cidade. ${ }^{100}$ Devido ao relevo acidentado do local nas proximidades dos rios Tibagi e Paranapanema, somente os espigões eram apropriados para o cultivo do café, e já desde cedo a pecuária extensiva se estabeleceu nos fundos de vale.

Algumas outras tentativas colonizatórias privadas que se estenderam do sul do Paranapanema até o Pirapó falharam por razões financeiras e devido ao seu isolamento, e foram devolvidas ao estado do Paraná. ${ }^{101}$ Somente a colônia Zacarias de Góis permaneceu, porém se desenvolveu só muito lentamente (Mapa 10: $\mathrm{n}^{\circ}$ 6).

Grandes fazendeiros paulistas também tinham obtido propriedades na fronteira das terras da CTNP, porém eram somente áreas pequenas; entre estes estava Barbosa Ferraz de Ribeirão Preto, que, para além de sua atividade colonizatória no Norte Velho, mandou colonizar também a Fazenda Ubá entre os rios Ivaí e Corumbataí. ${ }^{102}$

As localidades de Ibiporã e Engenheiro Beltrão são criações privadas do engenheiro Beltrão, que obteve em 1935 concessões de terras do governo na região periférica da CTNP.

Empresas colonizatórias privadas menores vindas do Rio Grande do Sul - sobretudo no noroeste do Paraná - tinham como objetivo o assentamento controlado de colonizadores teuto- e ítalo-brasileiros. Contudo, frequentemente as atividades dessas companhias foram limitadas devido a dificuldades financeiras. ${ }^{103}$ Resultados permanentes com importância regional não puderam ser obtidos por nenhuma dessas empresas menores no norte do Paraná.

\section{COLONIZAÇÃO ESTATAL E POLÍTICA DE VENDA DE TERRAS}

Fora dos limites das terras ocupadas por sociedades privadas de colonização, a ocupação territorial desregrada efetuada por intrusos e posseiros havia tomado grandes proporções já na década de 30, sobretudo na região entre os Rios Piquiri e Ivaí. Caboclos vindos das regiões central e sul do Paraná, bem como os descendentes de imigrantes italianos e poloneses haviam se apossado de vastos territórios em um movimento espontâneo, nos quais utilizavam a agricultura itinerante irregular e, mais raramente, o sistema de rotação de terras (coivara) no cultivo do milho para a engorda de porcos. Extensas regiões florestais foram desmatadas devido a essa prática, antes que a colonização oficial entrasse em vigor.

Em face desse desenvolvimento e no intento de realizar uma exploração controlada nas regiões florestais paranaenses restantes por meio de colonos brasileiros, o governo do Paraná decidiu, em 1939, implantar um programa oficial de colonização.

Surgiram então as colônias Mourão, Goio-Erê, Goio-Bang, Cantú, Piquiri, Muquilão e Manoel Ribas (Mapa 10). Cada uma das glebas das colônias foi subdividida em terrenos de 10-200 ha, em parte na forma de faixas, mas em parte também em blocos irregulares, medindo em média, em sua maioria, mais de 50 ha, e em algumas regiões até mesmo mais de 100 ha.

Contudo, o objetivo dessas medidas - levar os caboclos a assentar-se permanentemente por meio da entrega de títulos de propriedade - foi apenas parcialmente alcançado. Em algumas colônias (Piquiri, Cantú), o número de intrusos excedia o de lotes (BERNARDES, 1953, p. 351ss.) previstos, de modo que uma vigorosa subdivisão teve de ser relizada, o que, no entanto, não foi capaz de evitar que frequentemente mais de uma família intrusa se alojasse em uma mesma propriedade.

100 A partir das fontes não resulta evidente se aqui se havia pensado no estabelecimento dos colonizadores num povoado ou na possibilidade de se disponibilizar ou alugar moradias no local para os recém-chegados ativos no comércio (cf. sobre isso BERNARDES, 1953, p. 362-363).

101 Glebas Nova Bahia e Pirapó em 1934.

102 Obtida em 1929, Companhia colonizadora Soc. Territorial Ubá Ltda. (sócios, entre outros, também G. Lunardelli), porém a venda de terras só se iniciou em 1951 com pequenas propriedades ( 20 ha).

103 Por outro lado, uma companhia fundada em Porto Alegre - Maripá - teve sucessos significativos ao sul do rio Piquiri (fora da região consderada aqui), entre cujas realizações conta a colonização da região em torno de Toledo e General Rondon (cf. sobre isso OISERG e JABINE, 1960, bem como MULLER, 1974). 
Das colônias mencionadas, as que se encontravam ao sul situavam-se em meio à floresta de araucárias e à floresta mista do terceiro planalto, cuja altitude varia entre $650 \mathrm{~m}$ e $1000 \mathrm{~m}$ acima do nível do mar. A ocupação controlada foi severamente dificultada pelas lentas obras de viabialização realizadas por instituições estatais financeiramente debilitadas.

Uma malha viária deficitária, a grande distância dos centros de comércio e a incerteza com relação às condições de posse adiavam o avanço da frente pioneira em direção ao noroeste e ao oeste do estado. Em algumas colônias, a agrimensura definitiva dos terrenos que já haviam sido apossados somente pôde ser efetuada após 1950 (Mapa 10).

Já a colônia Mourão, localizada mais ao Norte, encontrava-se em situação relativamente mais favorável. Ali, a uma altitude entre $400 \mathrm{~m}$ e $650 \mathrm{~m}$, as condições naturais ainda permitiam o cultivo de café ao longo da ligeira inclinação do relevo em direção ao rio Ivaí.

Aqui, bem como nas regiões de colonização estatal situadas ao sul e na região de Faxinal de São Sebastião - localizada na orla do Terceiro Planalto - , como também na região a leste do rio Pirapó e - no extremo noroeste do estado - na colônia Paranavaí, houve inúmeras disputas pela posse da terra, duradouras e em parte violentas.

Muitos dos caboclos abandonavam suas terras após a agrimensura e a obtenção do título de propriedade, deixando de pagar o devido preço de compra e vendendo ou arrendando a terra que ainda não lhes pertencia integralmente para posseiros que os coagiam a isso.

Alguns dos governos subsequentes ao exercício do interventor Ribas complicaram o quadro geral da questão da posse de terra devido a uma política de venda de terras pouco confiável. Colônias de localização privilegiada e com solo de terra roxa foram concedidas a membros do partido e a mediadores fiéis ao governo.

Tiveram grande repercussão a exploração e devastação total das reservas florestais que já haviam sido demarcadas a leste do rio Piquiri, às margens do Corumbataí, bem como no noroeste às margens do Paranapanema (Mapa 10), assim como o desmatamento de extensas faixas de florestas de araucária localizadas nas regiões central e sul do Paraná - ações realizadas especialmente sob o governo de Moisés Lupion.

O papel desempenhado pelo então governador Lupion se esclarece pela sua participação na indústra madeireira (serrarias), no comércio e na exportação de madeira ${ }^{104}$. O Departamento de Geografia, Terras e Colonização, órgão do estado responsável pela colonização estatal, também foi criticado publicamente de maneira muito dura.

Nos anos de 1946 e 1947, os conflitos pela posse de terras na região de Jaguapitã e Porecatu chegaram ao seu apíce em um confronto armado entre cerca de 1500 famílias intrusas e de posseiros e o governo, que se posicionou a favor dos latifundiários daquela região.

Em caso de as famílias se retirarem por livre e espontânea vontade, o governador prometeu a cada uma delas 24 ha de terra e uma casa de madeira, bem como o transporte para os novos assentamentos às margens do rio Paranapanema. Os posseiros e intrusos recolheram suas colheitas, prepararam-se para a transferência e abandonaram suas plantações.

Contudo, o governo estadual não cumpriu sua promessa e os caboclos passaram por dificuldades para se alimentarem durante os meses de inverno. Os posseiros resistiram obstinadamente à polícia militar, posta em ação por causa das decorrentes inquietações (WESTPHALEN; MACHADO; BALHANA, 1968, p. 33).

Inúmeros outros casos semelhantes sublinham a desorganização e especulação, a concessão ilegal de terras a partidários do governo e a falta de boa vontade para com os posseiros. Títulos de propriedade emitidos por governos anteriores eram invalidados pelos seus sucessores.

A morosidade na emissão desses títulos e a falta de planejamento por parte do governo possibilitavam a expulsão de posseiros e de pequenos proprietários ('sitiantes') por pistoleiros a serviço dos latifundiários das imediações, como o que aconteceu, por exemplo, na região de Campo Mourão em 1948.

104 Por volta de 1950, o grupo Lupion detinha, entre outros negócios, 10 empresas de exportação, comércio e indústria no ramo madeireiro (KRETZEN, 1951, p. 143-145). A população 'elogiava' as diversas medidas controversas do governador pelo uso de uma nova forma verbal: lupionar = roubar, enganar. 
Além disso, a convergência descontrolada de pessoas em busca de terras nas colônias de ex-concessões que haviam retornado para o domínio do governo estadual dificultava uma divisão planejada das terras à disposição, provocando, consequentemente, reações violentas por parte dos posseiros desiludidos ${ }^{105}$.

Para além dos posseiros, das quadrilhas organizadas pelos latifundiários, dos grileiros, aventureiros, representantes do governo, políticos em busca de votos, pequenas empresas imobiliárias, do cultivo extensivo de milho para a engorda de porcos praticado pelos chamados 'safristas' e dos pequenos proprietários com direito de posse controverso, também as terras estaduais de fronteira se encontravam ameaçadas pela ação de criminosos ${ }^{106}$.

Em 1961, as disputas pela posse legal fora da região administrada pela CMNP diminuíram por meio da reordenação do Departamento de Terras e Colonização ${ }^{107}$, contudo continuaram a irromper de tempos em tempos em algumas regiões ${ }^{108}$.

As últimas grandes propriedades a se encontrarem em posse do estado situadas no Norte Novíssimo entre os rios Ivaí e Piquiri foram recolonizadas após 1955 - processo que perdurou, sob o impulso da cultura cafeeira, até o início da década de 1960, ao passo que a migração interna a partir do Rio Grande do Sul predominava ao sul do Piquiri.

A incerteza com relação às questões de posse em partes da área de colonização do estado conduziu a uma intensa exploração dessas propriedades, sobretudo em decorrência dos arrendamentos de curto prazo e da falta de medidas para a conservação da fertilidade do solo e para a diminuição da erosão na região do arenito Caiuá.

\section{DESENVOLVIMENTO DA PAISAGEM AGRÁRIA DO NORTE NOVO DO PARANÁ}

\section{a) Curso colonizatório e elementos povoadores}

Já na década de 1860 a cultura cafeeira paulistana, em sua expansão rumo ao oeste, havia ultrapassado o curso médio e o superior do rio Itararé e a fronteira da recém fundada província do Paraná.

Em um avanço territorial espontâneo, fazendeiros de Minas Gerais e de São Paulo cultivavam grandes plantações de café sobre o solo de sedimentos permocarboníferos do Segundo Planalto, constituído de numerosas intrusões diabásicas.

Com o surgimento da primeira colônia ${ }^{109}$, a frente pioneira avançou até o rio das Cinzas. A bissecção norte-sul do Planalto pelos afluentes do rio Paranapanema impediu o avanço da colonização para o oeste. Apenas no início do século XX é que se tomou posse da região nordeste do Terceiro Planalto paranaense.

A estação final da ferrovia sorocabana existente na época, Ourinhos (desde 1908), serviu como ponto de partida para a exploração dos solos vulcânicos de terra roxa. As plantações de café avançaram

105 Durante a revolta na região de Porecatu, ocorrida em 1950, membros do proibido Partido Comunista do Brasil atuaram pela primeira vez na zona rural, formando as assim denominadas Ligas Camponesas (WESTPHALEN et al., 1968, p. 36). Sucederam-se ações de transferência dos posseiros para as colônias Campo Mourão e Goio-Erê.

106 Especialmente a região de Faxinal de São Sebastião e a Serra da Pitanga foram alvo não somente das ações de bandos de caboclos insatisfeitos, mas também de fugitivos da lei (MARTINS, 1955, p. 100).

107 No ano de 1962 ainda havia pelo menos cerca de 1,5 milhões de hectares de terra em disputa fundiária em todo o Paraná.

108 Cf. no jornal Folha de Londrina, de 16 de junho de 1970 (p. 14), a declaração pública sobre direitos de propriedade dos legítimos proprietários dirigida ao estado do Paraná, no caso assim chamado 'Grilo dos Apertados': uma fazenda de 194.000 ha, situada na região do rio Paranavaí, havia sido dividida, sob a administração corrupta de Lupion, entre companheiros de partido, conhecidos senadores, cabos eleitorais etc.

Casos semelhantes a esse aparecem com frequência na imprensa diária paranaense, o que remonta a décadas, sendo que nenhuma das partes pleiteantes detém a efetiva posse da terra, visto que esta se encontra arrendada e subarrendada. Ademais, há também registros oficiais de casos de grileiros que, para obter crédito agrícola do Banco do Brasil, falsificaram títulos de propriedade.

109 Colônia Mineira, hoje Siqueira Campos (1862), Sto. Antônia da Platina (1866), Wenceslau Braz e Sao José da Boa Vista (1867) entre outras (FRANÇA, 1956, p. 188). 
com relativa lentidão até a região hoje denominada Cambará, que ganhou uma conexão privada com a estação de Ourinhos em 1925 (BERNARDES, 1952, p. 448) ${ }^{110}$.

Na década de 1920, as florestas tropicais das regiões de bacias hidrográficas em torno de Bandeirantes (1921) e Cornélio Procópio foram desmatadas, e em seu lugar foram cultivadas, segundo a tradição agrícola paulista, grandes plantações de café, antes mesmo da existência de uma malha ferroviária para o leste.

A necessidade de se estabelecer vias de acesso para as terras da Companhia de Terras Norte do Paraná localizadas a oeste do rio Tibagi levou à aquisição da companhia ferroviária existente pela CTNP. Partindo de Cambará (km 29), a construção da via férrea deu-se com uma rapidez incomum a partir de 1929, o que pode ser percebido pelos dados das estações de trem abaixo (MONBEIG, 1935, p. 16):

$\begin{array}{lrrr}\text { Ingá } & \mathrm{km} 57 & \text { abril } & 1930 \\ \text { Bandeirantes } & \mathrm{km} 82 & \text { julho } & 1930 \\ \text { C. Procópio } & \mathrm{km} 124 & \text { dezembro } & 1930 \\ \text { Jataí } & \mathrm{km} \mathrm{184} & \text { maio } & 1932\end{array}$

Contudo, a construção da ponte sobre o rio Tibagi fez com que a obra de construção da linha férrea sofresse um atraso de dois anos, sendo que o km 236 (que em 1934 se tornou Londrina, então elevada à categoria de cidade) somente foi alcançado em dezembro de 1935.

A colonização do Terceiro Planalto a oeste do rio Tibagi teve início por volta de 1920 com o avanço de colonos e caboclos rumo à região que hoje corresponde a Faxinal, os quais vinham do sudeste do estado, bem como do vale do Ribeira e da então decadente colônia Assungui.

A superação da cuesta triássica com altitude de até $1100 \mathrm{~m}$ recompensou os colonos com terras férteis e cobertas por florestas de araucárias situadas na orla sul da região do trapp basáltico, que foram espontaneamente ocupadas e agrimensadas pelo governo somente em 1925, sendo divididas em blocos irregulares de 50-200 ha (BERNARDES, 1953, p. 362).

No sistema de coivara, as plantações de milho, mandioca e abóbora cultivadas nas áreas desmatadas serviam para a engorda de porcos. Os animais eram conduzidos para Ponta Grossa, a estação de trem mais próxima localizada a uma distância de mais de $200 \mathrm{~km}$, onde anualmente eram vendidas até 30000 cabeças. ${ }^{111}$

Quase simultaneamente ocorreu um avanço controlado de colonização privada vindo do norte e passando pelo rio Paranapanema, que teve início com a ocupação nos anos 1922 e 1923 e com a fundação de Sertanópolis em 1925; esta, já em 1929, foi a primeira localidade a ser elevada ao status de município no Norte Novo (Mapa 15). Já a fundação privada da cidade de Primeiro de Maio demonstrou ser um equívoco, uma vez que os colonos foram afugentados pela malária e outras doenças tropicais decorrentes da baixa altitude da cidade ${ }^{112}$.

Na região pertencente à CTNP, os primeiros arroteamentos começaram em 1929 na cidade de Londrina, o ponto de partida da colonização, que deve seu nome a Londres, cidade sede da Paraná Plantations. A uma altitude de $610 \mathrm{~m}$ e cerca de $25 \mathrm{~km}$ a oeste do rio Tibagi foi construída uma casa para recepção dos novos colonos e um escritório.

A crise do café e a crise econômica mundial impediram a especulação de terras e a compra de terrenos agrimensados com, em média, 40 ha e pertencentes a pequenos e médios proprietários rurais por latifundiários. Como o estado do Paraná ainda não estava sujeito ao sistema de quotas

110 O impulso principal para o desenvolvimento do Norte Velho foi dado pelo cafeicultor Barbosa Ferraz Jr., de Ribeirão Preto, SP.

111 O desenvolvimento de Faxinal esteve intimamente ligado aos avanços colonizatórios da CTNP. Para lá foram vendidos, mais tarde, porcos jovens e porcos magros para engorda. A partir de 1935, Londrina assumiu, como estação de trem, cerca de um terço das exportações de suínos (MAACK, 1937, p. 238).

112 O fundador, Correia Pôrto de Abreu, regressou apenas em 1937 para o norte do Paraná, depois de 10 anos em São Paulo, e deu o impulso para a escolha de uma nova localização em terras altas, climaticamente mais favoráveis e situadas a uma distância maior dos vales de rios contaminados pela malária (KRETZEN, 1949; IBGE, 1959). 
de produção brasileiro devido a baixa produção de café, os terrenos agrimensados em forma de faixas (localizados em terras mais elevadas posteriormente arroteadas) também foram previstos para o cultivo do café.

Das seis grandes zonas de colonização, as zonas Tibagi e Pirapó, localizadas ao norte da bacia hidrográfica principal, foram as primeiras a serem exploradas com o avanço da frente pioneira do leste para o oeste, seguidas logo depois por Rio Bom, localizada ao sul (Mapa 14).

As primeiras propriedades foram adquiridas em 1930 na região de Londrina por colonos japoneses que, passando pelo Norte Velho, vieram do estado de São Paulo para a área de colonização da CTNP ${ }^{113}$. Terrenos localizados em torno da recém fundada cidade de Londrina foram adquiridos por um bom número de alemães e teuto-brasileiros que, em parte, já residiam há várias gerações no Brasil ${ }^{114}$.

$\mathrm{Na}$ mesma época, havia surgido ao norte de Londrina uma pequena colônia de alemães chamada Heimtal. Esses alemães haviam ganhado seu dinheiro para a compra de terras trabalhando na construção de estradas na região da ferrovia Sorocabana, contaminada pela malária e pela ancilostomose.

Quinze quilômetros a oeste de Londrina, colonos alemães vindos da cidade de Dantzig implantaram, em 1930, a colônia Nova Dantzig (hoje Cambé). Posteriormente, ambos os grupos não tiveram influência decisiva no desenvolvimento como um todo das respectivas colônias, sobretudo os trabalhadores de Dantzig, que não se ajustaram ao trabalho no campo.

Em face da situação econômica mundial por volta de 1930, da crise brasileira do café e da grande distância dos mercados, a venda de terras teve, a princípio, um início hesitante. Somaram-se a isso os temores com relação à infectação por malária e ao perigo das geadas e, em decorrência disso, da eventual pouca adequação das terras para a lavoura de café.

No início da colonização no norte do Paraná, a malária era endêmica em todas as áreas com altitude inferior a aproximadamente $450 \mathrm{~m}$, ocorrendo sobretudo entre os meses de outubro e março.

Os vales do grandes rios Ivaí e Piquiri ainda se encontravam totalmente despovoados, e os colonos também evitavam o vale do Tibagi. Dessa forma, a área de colonização da CTNP começava somente a partir de cerca de $20 \mathrm{~km}$ a oeste desse rio.

A ocorrência de casos de malária em Londrina estava diretamente ligada à construção da ferrovia, uma vez que muitos dos trabalhadores das equipes de arroteamento e seus familiares já estavam infectados e traziam a doença para o Norte do Paraná, a partir da área de construção da ferrovia da linha noroeste em São Paulo e do Mato Grosso do Sul ou da região costeira.

Uma vez que Jataí, localizada no vale do Tibagi, foi estação final da linha de trem entre 1932 e 1935, e os colonos, que geralmente chegavam ali no final da tarde, tinham de transpor o rio levados por balsas antes de continuarem a viagem para o oeste, o risco de contaminação tornou-se alto naquele lugar, que somente diminuiu com o término da construção da ponte e da conexão ferroviária sem interrupções ${ }^{115}$.

Antes da existência da conexão ferroviária para Londrina, os novos colonos eram transportados para a sua terra com família e bagagem às custas da CTNP, para o que se utilizavam as chamadas jardineiras - caminhões com carrocerias abertas providos de bancos -, que partiam da estação final da ferrovia, localizada no leste.

No ato de compra de terras, a qualidade do solo e o risco de geadas eram identificados por agrimensores experientes por meio da ocorrência de determinadas espécies de árvores ou de formações vegetativas. Na área pertencente à CTNP, até 1935 somente as encostas ao sul apresentavam ocorrência de geadas.

113 As terras da ex-fazenda Três Barras (45000 ha) situadas a leste do Tibagi foram vendidas quase simultaneamente pela empresa japonesa Soc. Colonizadora do Brasil Ltda. em forma de pequenas propriedades a colonos japoneses que trabalhavam ali sobretudo com o cultivo do algodão. A colônia japonesa Assaí acolheu até 1941 muitos dos japoneses vindos de São Paulo (de 1932 a 1941: 1384 famílias).

114 O primeiro terreno ('data') vendido na atual Londrina foi adquirido por A. Koch no dia 28 de novembro de 1930 (arquivo da CTNP). As 'datas' localizadas em torno de Londrina, medindo $13 \mathrm{~m}$ de frente por $40 \mathrm{~m}$ de comprimento, foram vendidas por um total que variava entre US\$13,00 e US\$ 15,00. Para evitar especulações concedia-se $50 \%$ de desconto àqueles que começassem a construção da casa dentro de um período de 6 meses (Little London in the forest, 1948, p. 5).

115 Maack (1937, p. 227-229). Em períodos relativamente secos, quando a falta de correnteza das águas favorecia o desenvolvimento do mosquito do gênero Anopheles em poças d'água, regiões localizadas até $600 \mathrm{~m}$ de altitude também eram assoladas pela malária. 
Aqui, as correntes descendentes de ar frio - morfologicamente determinadas e decorrentes da inversão térmica noturna - eram caracterizadas como limite de distribuição climática devido à ocorrência de araucárias nas encostas de vales profundamente entalhados, o que acontecia também abaixo da linha dos $500 \mathrm{~m}$ de altitude. ${ }^{116}$

Os primeiros terrenos foram concedidos nas proximidades dos assentamentos planejados, o que contribuiu para a diminuição do isolamento dos colonos. Vendas de terra posteriores foram efetuadas sistematicamente do centro para a periferia, sendo que as poucas terras cultiváveis maiores ficavam localizadas mais longe do centro a que correspondiam.

Depois da fundação de Rolândia em 1932 e do assentamento de imigrantes alemães, assim como da fundação da localidade de Arapongas em 1935, um fluxo maior de imigrantes se estabeleceu com o término da ferrovia que ia até Londrina (km 236: dez. de 1935).

Também contribuíram para isso as primeiras colheitas de café, que não tinham sido prejudicadas pela geada e que foram incomumente produtivas. Mas o verdadeiro boom do café somente começaria depois da Segunda Guerra Mundial, com o aumento do preço internacional devido ao repentino aumento do consumo.

Seguindo em sentido sul da bacia hidrográfica principal localizada entre Paranapanema e Ivaí, iniciou-se em 1938 o arroteamento para a construção do assentamento de Apucarana, que já em 1941 foi alcançada pela ferrovia, rapidamente construída até ali (Mapa 11) considerando-se que a altitude passava de $610 \mathrm{~m}$ em Londrina a $765 \mathrm{~m}$ em Rolândia, e chegava a $810 \mathrm{~m}$ em Apucarana.

A migração a partir do estado de São Paulo tornou-se cada vez intensa, sendo que aumentou a quantidade de descendentes de trabalhadores rurais italianos, que eram os principais arrendatários no Norte do Paraná ou formadores de cafezais. Eles adquiriam seus próprios terrenos.

A mistura bastante heterogênea dos elementos colonizadores se reflete já em suas nacionalidades (Tabela 3).

Imigrantes procedentes de mais de 20 países encontraram uma nova pátria no Norte do Paraná. Os compradores de terras registrados como 'brasileiros' na Tabela 3 eram oriundos de várias regiões do país, como São Paulo, Minas Gerais, sul do Paraná ou eram teuto-brasileiros vindos do Rio Grande do Sul.

Entre 1933 e 1941, metade dos compradores de terras da CTNP eram brasileiros e, em parte, também ítalo-brasileiros. O segundo maior grupo era formado por italianos, com pouco mais de $10 \%$, seguido pelos japoneses, alemães, espanhóis e portugueses.

Em decorrência do desenvolvimento político na Europa e no Leste Asiático e da participação dos países envolvidos na Segunda Guerra, a imigração de alemães, italianos e demais europeus, assim como de japoneses, parou totalmente perto do fim da década de 1930. Os compradores de terras dessas nacionalidades, registrados na tabela 3 nos três anos seguintes à guerra, são oriundos da migração interna brasileira.

As equipes de desmatamento eram formadas em sua maioria por baianos, os quais haviam se especializado largamente nesse tipo de trabalho. Junto a estes, lenhadores dos países bálticos também realizavam o desmatamento.

Trabalhadores itinerantes se juntavam a esse grupo vindos das áreas atingidas pela seca no Nordeste, encontrando trabalho durante a época de colheita do café no norte do Paraná. Espanhóis vindos de São Paulo, que como comerciantes de grãos se interessavam pela comercialização dos produtos da entressafra - a saber, milho e arroz - , ofereciam seus serviços como empreiteiros. ${ }^{117}$

Com relação à origem social dos imigrantes e às suas diferentes motivações para assentar-se na zona pioneira no Norte do Paraná, a colônia alemã de Rolândia representa um caso especial dentro das terras da CTNP.

116 A vantagem das áreas não sujeitas a geadas foi evidenciada em Londrina (altitude de $610 \mathrm{~m}$ ) em 1933, quando prejuízos decorrentes da geada afetaram as lavouras de café de São Paulo, sendo que em Londrina foi medida a temperatura mínima de + 0,1 ${ }^{\circ} \mathrm{C}$ (MAACK, 1937, p. 223).

117 O ‘empreiteiro’ é uma forma especial de arrendatário que se especializa na lavoura nova de café e, de acordo com o contrato, ganha como pagamento os produtos da entressafra do $1^{\circ}$ e do $4^{\circ}$ anos (cf. sobre isso p. 84ss. e Tabela 11, p. 85). 
茫

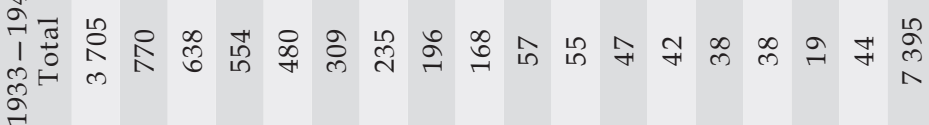

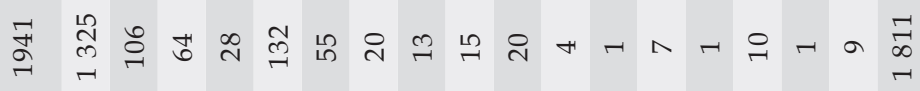

章辛

孚

色

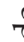

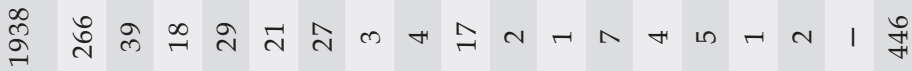

๙ิ

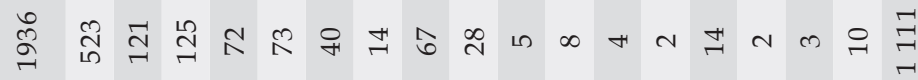

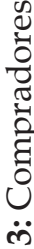

$\frac{\sqrt{-1}}{\frac{\pi}{0}}$

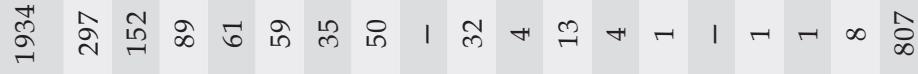

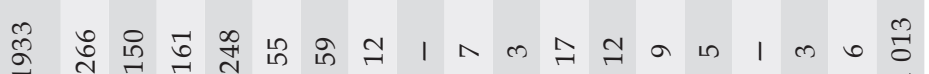

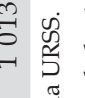

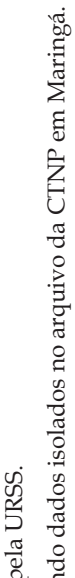

๙

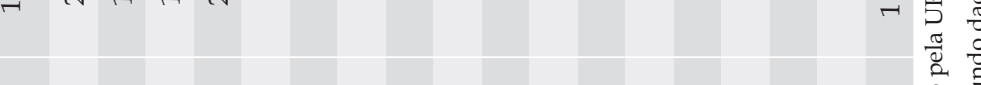

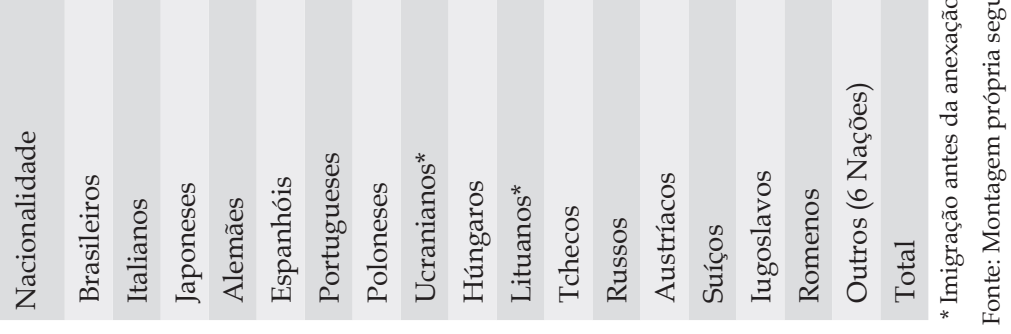




\section{b) Rolândia - Sucesso colonizatório de um assentamento de refugiados alemães ${ }^{118}$}

O surgimento e o desenvolvimento da colônia alemã Rolândia têm de ser analisados no contexto da imigração alemã e das tentativas de colonização no sul do Brasil e de seus países vizinhos no período entre guerras, levando-se em conta também o desenvolvimento político na Alemanha.

Em 1919/20, teve início no Rio Grande do Sul um movimento de emigração a partir das antigas áreas de colonização alemã para a colônia argentina de Misiones (Puerto Rico, San Alberto), bem como também para a colônia de Hohenau, localizada na margem paraguaia do rio Paraná.

Possibilidades de assentamento foram oferecidas aos novos imigrantes no nordeste de Santa Catarina pela Sociedade Colonizadora Hanseática [Hanseatische Kolonisationsgesellschaft], bem como às margens do rio Uruguai no Oeste do mesmo estado pela Companhia Colonizadora Chapecó-Peperí (diretor Faulhaber) (KOHLHEPP, 1966a).

A emigração espontânea de numerosos pequenos grupos bem como de um grande número de famílias alemãs que vieram para morar com parentes na América teve como consequência - durante o período da inflação - uma grande fragmentação e dispersão desses colonos também no sul do Brasil.

Negociações entre a Secretaria do Reich Alemão para Assuntos de Imigração [Reichsstelle für Auswanderungswesen], com sede em Berlim, e a Sociedade Paulista de Imigração e Colonização - uma associação de proprietários de plantações de café para a mediação da imigração de trabalhadores alemães para as fazendas de café de São Paulo - haviam falhado devido à revogação da travessia livre por parte do governo brasileiro.

Na década de 1920 foi realizada também no Brasil uma ação de ajuda caritativa bastante abrangente com o assentamento de colonos alemães da região da Volínea (Ucrânia), bem como de refugiados menonitas alemães-russos. Contudo, as precárias condições financeiras bem como a falta de planejamento e má escolha das terras levou a casos malsucedidos e à emigração de muitos colonos.

No ano de 1927, o ex-chanceler da Alemanha, Luther, fundou a Sociedade para Estudos Econômicos no Ultramar[Gesellschaft für wirtschaftliche Studien in Übersee], que era mantida por instituições financeiras, por companhias de navegação que lideravam o tráfego marítimo na América do Sul e por outras personalidades conhecidas.

O objetivo dessa sociedade, cuja presidência logo foi assumida pelo ex-ministro das Relações Internas de Alemanha E. Koch-Weser, era o de fomentar a colonização alemã planejada na América do Sul. ${ }^{119}$

$\mathrm{Na}$ Alemanha, a grande taxa de desemprego decorrente da crise econômica mundial acarretou a necessidade urgente da expansão dos projetos de colonização para o leste do país e da criação da possibilidade de assentamento no Ultramar. ${ }^{120}$ Por meio da iniciativa do Ministério das Relações Exteriores surgiu, em 1931, a Sociedade de Colonização no Exterior [Gesellschaft für Siedlung im Ausland (G. S. A.)]. ${ }^{121}$

No início de 1932, a Paraná Plantations Ltd. em Londres pediu à Sociedade para Estudos Econômicos no Ultramar para entrar em contato com alemães que desejassem imigrar. Nas negociações, uma área

118 Agradeço aos senhores cônsul honorário M. H. Bresslau, Dr. M. H. Maier, Dr. R. Loeb-Caldenhof, O. Nixdorf, G. Schlieper, Von Treuenfels, Kaphan e Rosenthal de Rolândia, entre outros moradores da colônia não citados, por numerosas informações pessoais gentilmente cedidas.

119 Viagens de estudos ao Brasil, Argentina, Chile e Uruguai realizadas pelo estudioso da área de pedologia, Prof. Vageler, e pelo especialista em colonização von Freeden (do serviço nacional de emigração [Reichsstelle $f$. Auswanderungswesen], Depto. América do Sul) contribuíram para pesquisas preparatórias (cf. sobre isso, entre outros, SCHAUFF, 1957a e 1959; KOCHWESER, 1957 e informações gentilmente cedidas por vários cidadãos de Rolândia).

120 O Serviço Nacional de Consultoria Migratória, com sede em Berlim, cujo diretor - o parlamentar Schauff, do Partido de Centro - e alguns outros colegas viriam a imigrar mais tarde para Rolândia, e a Companhia de Colonização Bauernland, sob a direção de F. W. Lübke (temporariamente também em Rolândia; após a Segunda Guerra Mundial, governador do estado de Schleswig-Holstein) e do ex-presidente alemão H. Lübke, trabalharam em conjunto sob o governo de Brüning na abertura de novos sítios para colonos depois da reforma agrária no leste da Alemanha após o fim da Segunda Guerra Mundial (cf. sobre isso: ROLAND, 1957, n. 5, p. 3).

121 A única colônia fundada pela G.S.A, entidade incorporada em 1933 pelo governo nazista, foi a de Terra Nova, formada por campos e floresta e localizada próxima de Castro, no leste do Paraná, o que ocorreu nesse mesmo ano (WAIBEL 1955a, p. 111ss.). Os colonos que vieram após 1935 para Terra Nova, assim como também, em parte, para Rolândia por intermédio da G. S. A. tinham de ser de origem "alemã, mais especificamente, ariana, conforme as Leis de Nuremberg". O preço da terra estipulado para 24,2 ha em Rolândia era de RM 1500 a 2000 [Reichsmark] e como capital de giro, RM 3000 (GESELLSCHAFT, 1937) 
maior de terras contíguas localizada a cerca de $25-30 \mathrm{~km}$ a oeste de Londrina havia sido reservada para os colonos, e um agricultor com experiência de trabalho em regiões tropicais foi imediatamente enviado como responsável pela colonização, conforme acordado. ${ }^{122}$

A área escolhida, denominada Roland, teve grandes dificuldades para se desenvolver, uma vez que, após a agrimensura e o preparo dos terrenos com a ajuda dos colonos vindos de Heimtal, os esperados colonos não chegaram devido à revolução em São Paulo em julho de 1932.

Somente a convocação de colonos teuto-brasileiros do sul do país é que possibilitou dar-se continuidade à colônia, cuja praça municipal, 'Rolândia', somente foi construída em 1934 com a abertura de uma conexão ferroviária para Londrina. Logo, vários imigrantes alemães se estabeleceram no leste da colônia (Schwabental).

Depois que o partido nazista tomou o poder na Alemanha, a composição dos elementos colonizatórios modificou-se rapidamente. Alemães perseguidos por motivos políticos, religiosos e étnicos procuraram refúgio em Rolândia.

Já em 1933 chegaram à colônia os ex-ministros Koch-Weser e Schlange-Schöningen, depois de terem analisado diferentes possibilidades de assentamento no Sul do Brasil em conjunto com outros líderes do movimento alemão pela reforma agrária e colonização, perseguidos pelo regime nazista. ${ }^{123}$

Além de opositores políticos do regime nazista, membros ativos de organizações juvenis confessionais imigraram para Rolândia, assim como também católicos do Partido de Centro [Zentrumspartei] e de associações dos trabalhadores. ${ }^{124}$

A restrição ao fluxo de saída de moeda estrangeira na Alemanha ${ }^{125}$ e as dificuldades da CTNP em transferir mil-réis brasileiros para a Inglaterra levaram ao desenvolvimento de um negócio de intercâmbios: a compra de material ferroviário da companhia ferroviária inglesa passou a ser efetuada - em vez de na Inglaterra - na Alemanha, onde o pagamento era feito com os bens dos imigrantes. Os valores foram transformados em crédito agrícola em Rolândia. Dessa forma, mais de 150 famílias, em sua maioria judias, puderam escapar das ameaças de perseguição na Alemanha depois da adoção da Leis de Nuremberg em 1935, assentando-se às margens do rio Pitangueiras em Rolândia. ${ }^{126}$ Um grupo ligado a E. Stinnes e ao conde Henckel von Donnersmarck teve participação importante no sucesso do intercâmbio ${ }^{127}$ e adquiriu, no decurso das transações, depois que a colonização havia transcorrido rapidamente para o oeste, grandes áreas de terras próximas a Apucarana, uma exceção na área administrada pela CTNP.

Entre as várias centenas de famílias alemãs que imigraram para Rolândia encontravam-se numerosos profissionais com titulação acadêmica. Ao lado de uma série de juristas que exerciam cargos no governo ou eram profissionais liberais, entre eles políticos e advogados renomados, havia médicos, economistas, engenheiros, professores universitários e não universitários, bancários, comerciantes e artesãos que vieram para Rolândia como refugiados por motivos políticos e religiosos, bem como em decorrência das leis raciais nacional-socialistas (MALER, 1957a, 1957b; ROLAND, 1957, n. 5; ISAY, 1960). Ao lado destes também haviam imigrado agricultores - de latifundiários a

122 O. Nixdorf foi incumbido dessa tarefa por ter acumulado experiência sobre os trópicos nos vários anos em que esteve em Sumatra, tendo escolhido assim a terra para os colonos. A área recebeu o nome de Roland, escolhido pelos fundadores (KochWeser, von Freeden, Nixdorf), todos de Bremen, o que foi aceito pela Companhia de Colonização inglesa (PRÜSER, 1957, p. 48 ss.).

123 Como, entre outras, a "Colônia de Associação Juvenil Heimat" [Jugendgemeinschaftssiedlung Heimat], fundada próxima a Timbó, Santa Catarina, pelo capelão berlinense Beil, onde cerca de 350 jovens católicos foram assentados no planalto em uma localização desfavorável, assim como a colônia Treze Tílias, fundada na região do Rio do Peixe, oeste de Santa Catarina, pelo ministro da agricultura austríaco Thaler com jovens colonos procedentes do Tirol do Sul.

124 A organização dessa emigração foi conduzida pelo já mencionado político de centro J. Schauff, que também propiciou a transferência de uma parte dos membros do malsucedido experimento de uma colônia de sociedade juvenil próxima a Timbó (ROLAND, 1957, n. 5, p. 4).

125 Até meados de 1934 era permitido a cada colono levar consigo um valor de até RM 10.000 em divisas (PRÜSER, 1957, p. 57).

126 Entre essas famílias estavam grupos de emigrantes procedentes de Duisburg e Düsseldorf.

127 O conde Henckel von Donnersmarck colocou à disposição sua influência, e o professor E. Stinnes, hoje residente nos EUA, seus contatos internacionais. Somente o bom trabalho em conjunto juntamente a representantes da CTNP, da Ferrostaal, de diversas instituições financeiras etc., sob a orientação de Koch-Weser em contato com organizações beneficentes judaicas e cristãs, é que possibilitou, sobretudo depois de novembro de 1938, a aquisição extremamente difícil de vistos e certificados de transferência. O presidente Getúlio Vargas permitiu, a pedido do Papa Pio XII, uma cota de vistos para colonos não arianos (ROLAND, 1957, n. 5, p. 5; SCHAUFF, 1957a). 
pequenos produtores - , bem como pessoas atuantes no sistema de colonização e de assentamento ${ }^{128}$, para os quais a experiência de colonização em uma área tropical foi proveitosa.

Apesar das extremas dificuldades de adaptação física e psicológica que esses imigrantes - em sua maioria vindos de centros urbanos - tinham de superar no arroteamento primitivo na frente pioneira, não demorou muito para que predominasse o espírito pioneiro e a ajuda mútua nas atividades agrícolas e de economia doméstica a que não estavam acostumados, e logo no início estabeleceu-se um sistema educacional e uma intensa vida cultural ${ }^{129}$. Em decorrência das compensações, alguns imigrantes adquiriram grandes propriedades em Rolândia, as quais chegavam a ter mais de 500 ha, mas ao chegarem tinham pouco capital de giro devido a rigorosas leis de câmbio, o que causou o atraso do desenvolvimento e, em alguns casos, uma crise e em parte venda de terra. O aumento do preço da terra, que em quatro anos chegou até a quadruplicar devido à grande procura, bem como os salários relativamente altos, também se mostraram bastante desfavoráveis (MAACK, 1937, p. 237).

Como, no entanto, alguns novos imigrantes já haviam transferido previamente grandes fortunas, colocou-se à disposição de colonos com poucos recursos a possibilidade de adquirir dinheiro em espécie por meio de serviços prestados nas propriedades maiores - sobretudo no oeste do distrito - o que foi especialmente vantajoso para os pequenos produtores no início da cultura de subsistência (AULICH, 1953, p. 215).

A chegada dos primeiros imigrantes a Rolândia em 1932/33 se deu em uma época em que a queima de grandes estoques de café excedentes em São Paulo fez com que o plantio desse produto não parecesse ser recomendável ${ }^{130}$. Depois dos arroteamentos iniciais e da construção de um rancho primitivo feito das metades dos troncos de palmeiras e coberto com telhas de madeira, ou mesmo de uma pequena casa de madeira feita de troncos, plantaram-se primeiramente alimentos básicos como milho, arroz, feijão e mandioca; mais tarde abriram-se pastos, criaram-se algumas cabeças de gado e praticou-se a engorda de porcos. Tentativas de se obter óleo de rícino e de tungue, bem como o cultivo de cana-de-açúcar e soja não foram comercialmente bem sucedidos ${ }^{131}$, pois em parte ainda faltava aos imigrantes alemães a experiência no cultivo desses produtos. Contudo, logo uma cooperativa agrícola assumiu tarefas organizacionais e consultivas. Com relação aos empreendimentos industriais em Rolândia, em 1937 já havia numerosas serrarias e fábricas de madeira compensada (MAACK, 1937, p. 238).

Contudo, a partir de 1963 - não menos por recomendação da CTNP - passou-se a cultivar café em um contingente cada vez maior. O plantio das lavouras de café foi deixado aos cuidados de empreiteiros de São Paulo com larga experiência e que - dependendo das condições financeiras do dono da terra - eram contratados com base em contratos de 4 a 6 anos de duração, e cujo pagamento consistia nas entressafras e na primeira colheita de café ${ }^{132}$. Eles costumavam se mudar para as casas pioneiras dos donos da terra, que nesse interim já tinham construído, em sua maioria, uma casa nova e maior.

Por meio do assentamento de alguns imigrantes suíços em Rolândia pretendeu-se diminuir as tentativas de instituições nacional-socialistas internacionais de exercer influência na região. A propaganda nacional-socialista teve como consequência a remigração de alguns dos primeiros colonos e acabou causando dissonância entre os refugiados, que vieram para cá por diferentes motivos. No entanto, com esforço conjunto os problemas foram logo superados.

Mas o cultivo do café mal havia sido introduzido em escala maior no final da década de 1930, quando a geada de 1942 ocasionou grandes perdas às plantações de café que se encontravam no seu estágio inicial. Para a continuidade do desenvolvimeto da colônia, foi de suma importância o fato de o governo brasileiro ter colocado crédito agrícola à disposição dos colonos, sem levar em conta a nacionalidade destes apesar do estado de guerra com a Alemanha.

A área de reserva prevista para colonos alemães em Rolândia foi vendida a outros colonos durante a guerra, uma vez que a imigração tinha ficado totalmente interrompida em decorrência

128 Entre outros, alunos de Sering e Aereboe.

129 Maier (1957a, p. 26-27). A assim chamada associação colonial assumiu a responsabilidade de cuidar das instituições culturais e a autoadminitração da colônia.

130 Koch-Weser (1957, p. 56-57). Contudo, conforme decreto federal de 19/12/1932, o cultivo de pés de café era permitido nas terras pertencentes à CTNP.

131 Dessa forma, a construção de uma fábrica de açúcar não foi efetuada como havia sido prometido pelo governo federal (relato oral do Sr. G. Schlieper, Rolândia).

132 Cf. sobre isso em geral p. 84/86 e Tabela 11, p. 85. - cap. IV - Expansão do cultivo de café. 
das ações de guerra. Com a exceção de certas restrições de viagem e a proibição do uso da língua, bem como da venda de terras, os colonos alemães de Rolândia, da mesma forma que seus vizinhos italianos e japoneses, não foram impedidos por quaisquer medidas econômicas coercivas por parte do governo brasileiro ${ }^{133}$.

Com o início da exportação livre de café em fins da década de 1940 e o consequente boom do café, iniciou-se a fase principal de desenvolvimento econômico em Rolândia, cuja localização em uma região de solos ricos de terra-roxa e altitude apropriada deram condições ideais para o cultivo do café, um desenvolvimento que não podia ser previsto de início.

\section{c) Tendências de exploração e fundações de colônias}

O assentamento de imigrantes e seus descendentes em áreas de colonização fechada teve seu fim com os esforços de nacionalização no Brasil. Depois de 1938, o governo brasileiro empenhouse em assentar grupos estrangeiros da maneira mais espalhada possível entre colonos nativos. Até aquele momento, a região em torno de Nova Dantzig (Cambé) era caracterizada sobretudo pela colonização italiana, Rolândia pela alemã, Arapongas e Mandaguari, por sua vez, pela espanhola e sua descendência.

Com tal movimento populacional de luso-brasileiros e também de brasileiros descendentes de italianos, japoneses e espanhóis que avançava, sobretudo, de São Paulo em direção ao oeste, deparou-se um contingente imigratório de poloneses, bielorrussos, bem como de teuto-brasileiros vindos das antigas regiões de colonização no sul do Paraná, em parte também da área de colonização estatal malsucedida em torno de Faxinal. Apucarana desenvolveu-se sobretudo como estação ferroviária terminal de 1941 a 1948 , tornando-se o grande melting-pot dos diferentes elementos populacionais ${ }^{134}$.

Outro avanço populacional vindo do sul que, no entanto, não pôde estabelecer nenhum contato com a real zona de café até a década de 1950 deu-se primeiramente de modo espontâneo entre Piquri e Ivaí e, a partir de 1939, no âmbito da colonização estatal oficial, na qual por volta de 1940 a ramificação mais ao norte correspondia à região em torno de Campo Mourão (Mapa 11).

Nesse lugar já se encontravam estabelecidas algumas famílias de caboclos desde o início do século XX como os postos avançados mais distantes na pequena ilha de 'campo cerrado', na despovoada área de transição da mata subtropical para a Mata de Araucária. Campo Mourão era a entreestação na criação de gado do Mato Grosso do Sul, passando por Porto Camargo, às margens do rio Paraná, em direção aos ‘campos limpos' de Guarapuava. Em 1934, viviam aproximadamente 250 famílias em Campo Mourão. A região a oeste até o rio Piquiri ainda estava totalmente despovoada ${ }^{135}$.

Nas vastas áreas de floresta às margens do Piquiri, que se estendiam até a divisora de águas em direção ao Ivaí, em 1936 havia se configurado a possibilidade de uma colonização com imigrantes suíços desempregados, para os quais foram reservadas terras oficiais de no máximo 500.000 ha pelo período de um ano. O projeto, que previa investir os pagamentos de benefícios de desemprego por parte do governo suíço na administração da colônia e que oferecia a oportunidade de saldar o preço total de compra (3,15 francos suíços por hectare) por meio da construção de mais de $225 \mathrm{~km}$ de estradas (MOESCHLIN, 1936, p. 22 ss.), ${ }^{136}$ fracassou, uma vez que uma quota anual específica de imigração da Suíça não podia ser garantida.

A partir do ano de 1939, no âmbito da colonização estatal, ocorreu nessa região uma colonização de uma área de 130.000 ha nas colônias Mourão, Goio-Bang, Cantú e Piquiri. Na região do Piquiri, houve tanto a participação de 'caboclos' como também de descendentes de poloneses e de ucranianos, que trabalhavam como 'safristas' no movimento de expansão espontâneo baseado na criação de porcos. Por sua vez, a região em torno de Campo Mourão recebeu, depois da abertura de uma picada primitiva em 1945 em direção à planejada Maringá, o afluxo de colonos vindos do Rio Grande do Sul e de Santa Catarina, primeiramente sobretudo de origem italiana, mas mais tarde também de origem alemã. Vindo

133 Prüser (1957, p. 60-61) e informações pessoais obtidas em Rolândia.

134 Pelos nomes dos primeiros colonos de Apucarana é possível perceber as migrações internas diferenciadas etnicamente de diferentes origens: entre outros, Vieira dos Santos, Almeida, Oliveira Rosa; Massaretto, Bonetto, Carlini; Gomez, Gonzales; Kinoshito; Kaniowski; Glück, Schmidt etc. (EL-KHATIB, 1969, v. 4, p. 24).

135 Cf. sobre isso o relatório da expedição de Maack de 1934 (MAACK, 1936 e 1937, p. 212).

136 Moeschlin (1936, p. 22 ss.) - Pensava-se aqui em uma conexão rodoviária com um porto no rio Paraná, planejado para ser construído, entre Porto Mendes e Foz do Iguaçu. 
do norte em direção ao sul avançavam paulistanos, mineiros e baianos, penetrando até os limites das áreas com condições climáticas para o cultivo do café $e^{137}$.

A exploração do norte do Paraná foi significativamente determinada pelo afluxo de compradores de terras na área da CTNP, onde os ricos solos de 'terra-roxa', o clima tropical ameno e a segurança por meio da emissão dos títulos de propriedade logo ficaram conhecidos em todo o Brasil. O problema da localização do norte do Paraná, longe dos portos de exportação e dos centros populacionais da região costeira foi amenizado após conclusão de uma conexão ferroviária e da expansão da malha rodoviária.

O fácil acesso às propriedades tinha um valor especial, o que se deve à bem planejada e executada construção de ruas e estradas por parte da CTNP. As ruas dentro da área de colonização foram construídas com uma largura de $5 \mathrm{~m}$, sendo que mais $5 \mathrm{~m}$ foram desmatados para ambos os lados da rua para facilitar o secamento das ruas depois de chuvas. Após 4 anos, a CTNP já havia construído mais de $400 \mathrm{~km}$ de ruas, cuja constante manutenção e melhoria era realizada com incomum cuidado. Em 1950, havia uma malha rodoviária de $3.000 \mathrm{~km}$ de extensão! (Mapa 12). Uma vez que as conexões de ruas e estradas foram todas construídas em condições de superfície levemente ondulada sobre as cristas que se estendiam por longas distâncias, e as ruas secundárias terminavam na parte baixa do declive, os custos com obras de engenharia nas principais vias de acesso foram bastante baixos. A expansão da malha rodoviária e da venda de terra se deu no mesmo ritmo, contudo sempre crescente.

Como desde 1940 já havia se dado um forte aumento na venda de terras, o preço da venda de sítios aumentou significativamente a partir de 1945, devido à expansão da produção de café atrelada ao aumento dos preços do mercado mundial. Somente no período entre 1945 e 1950, a CTNP vendeu 482.000 ha de terra, ou seja, quase dois quintos do total da área original da concessão.

Contudo, mais impressionante do que isso foi o aumento do número de propriedades vendidas nos pequenos centros urbanos e 'patrimônios'.

Tabela 4: Venda de Terras e Construção de Estradas na área da CTNP

\begin{tabular}{|c|c|c|c|c|}
\hline & $\begin{array}{c}\text { Venda de terras } \\
\text { em ha }\end{array}$ & $\begin{array}{c}\text { Proporção de } \\
\text { concessão original }^{*} \\
\text { em \% }\end{array}$ & $\begin{array}{c}\text { Venda de propriedades } \\
\text { urbanas }\end{array}$ & Estradas em km \\
\hline 1930-1934 & 57.000 & 4,6 & 1.088 & 421 \\
\hline 1935-1939 & 82.000 & 6,5 & 1.705 & 480 \\
\hline 1940-1944 & 290.000 & 23,3 & 3.329 & 592 \\
\hline $1945-1950$ & 482.000 & 38,7 & 12.071 & 1.507 \\
\hline $1930-1950$ & 911.000 & 73,1 & 18.193 & 3.000 \\
\hline
\end{tabular}

* $12.463 \mathrm{~km}^{2}$

Fonte: Dados da CTNP.

Ao contrário do frontier paulistano, a construção das cidades no Norte do Paraná foi em grande parte planejada. Além disso, os centros urbanos construídos de acordo com conceitos de planejamento urbano modernos e os pequenos assentamentos urbanos dentro da área da Companhia de Terras Norte do Paraná diferiam dos assentamentos espontâneos ou em parte mal planejados encontrados no restante do norte do Paraná.

As localizações dos centros urbanos foram estabelecidas, sem exceção, por razões medicinais e de tráfego pelo departamento de agrimensão da Companhia de Colonização nas partes mais altas do relevo. Na fundação da primeira colônia, Londrina, a planta foi esquematicamente criada em sistema ortogonal (Mapa 13), sendo que a praça ocupou a parte mais alta da área a ser construída. Contudo, esse padrão rígido, com suas ruas cruzando-se perpendicularmente, revelou-se desfavorável devido ao

137 Martins (1955, p. 108); C. Bernardes (1950, p. 579/80; 1953, p. 350ss.), bem como Bernardes (1952, p. 447). Cf. sobre isso também os Mapas 10 e 11. 
desnível apresentado pela cidade. Com o aumento da população urbana, a área de 325 ha reservada para o estabelecimento da colônia também logo se mostrou insuficiente.

Com base nessa experiência, o segundo maior centro urbano, Maringá, localizado a aproximadamente $125 \mathrm{~km}$ a oeste de Londrina, foi estabelecido com dimensões muito mais generosas em uma área mais que quatro vezes maior (Mapa 14 e Tabela 5).

A fundação de Maringá se iniciou com a construção de uma grande área para pouso de aviões. A cidade foi planejada para comportar, futuramente, uma população de 100.000 habitantes, e apresentava em uma boa adaptação às condições morfológicas uma planta regular mas modificada pela aplicação de padrões radiais e semicirculares. Largas avenidas com até $48 \mathrm{~m}$ de largura (mas geralmente com 30 $\mathrm{m}$ ), com duas faixas separadas por canteiros, suavizavam a ampla e vasta área, que desde o princípio foi dividida em sete zonas funcionalmente diferenciadas e que era atravessada, em trajeto semicircular, pela já planejada ferrovia. Em ambos os lados da ferrovia criou-se um amplo corredor para oficinas de reparação, armazéns e pátios de estocagem, empresas comerciais e industriais. A estação de trem localizava-se no centro, muito próxima ao centro comercial da cidade. Os bairros, classificados com rigidez hierárquica, foram estruturados em três categorias (padrão alto, médio e baixo), e se interligavam a sul, sudoeste, sudeste e norte.

A rua principal corria em geral perpendicularmente à linha férrea, em direção à estação. Esse padrão não foi aplicado apenas em Maringá, mas já anteriormente no planejamento das localidades de Arapongas, Apucarana (estação fora da cidade), Pirapó, Jandaia, Mandaguari, Marialva e Sarandi. Por razões topográficas, esse padrão foi modificado em Londrina, Cambé e Rolândia. As plantas de pequenos assentamentos também foram adaptadas às condições topográficas.

Com base nas experiências obtidas em Londrina, as plantas regulares das cidades que foram fundadas mais tarde não foram mais divididas em forma de quadrados, mas em retângulos. Desse modo, deveria evitar-se a divisão mais complicada dos quadrados da planta em locais de construção retangulares, e, associado a isso, a consequente desvantagem higiênica dos lotes centrais em decorrência da instalação de fossas nos fundos das propriedades adjacentes.

Os pequenos centros, que primeiramente tinham apenas uma função de abastecimento e de mercado para as "chácaras' e "sítios" localizados em suas proximidades, cresceram rapidamente (MAACK, 1937, p. 234):
Londrina
1930-1936:
1.200 casas
Rolândia
1934-1936:
500 casas
Arapongas
1935-1936:
100 casas

Por outro lado, uma área de assentamento japonês dispersa, localizada ao sul de Nova Dantzig (Nova Tokio, atual Caramuru), não possuía sequer um centro próprio.

O grande número de pequenos proprietários dentro da área da CTNP contribuiu significativamente para o crescimento das colônias que haviam sido fundadas, cuja importância central em nível comercial e cultural crescia continuamente.

Os 'patrimônios' fundados pela CTNP (p. 52 e Mapa 14) desenvolveram rapidamente uma vida empresarial ativa, e ao rápido aumento da população seguiu-se logo também a reorganização da estrutura de gestão e da elevação à categoria de 'vila', ou seja, a sede distrital ou até mesmo municipal.

O Mapa $14^{138}$ analisa a ascensão das colônias fundadas pela CTNP, as quais atualmente se tornaram quase todas municípios e que se estendem ao longo da linha divisora de águas em uma impressionante sequência.

Além disso, foi fundado também um número significativo de 'patrimônios' privados nas propriedades da CTNP. Estes eram criados em grande parte longe dos principais eixos com a aprovação da Companhia, cujas terras continuaram a ser valorizadas pela fundação de novas colônias. Assim, um comprador de terras interessado em negociar demarcava em sua terra um assim chamado "patrimônio"139,

138 O processo de desenvolvimento da colonização será descrito em maiores detalhes posteriormente, por meio do Mapa 14 em conjunto com a Figura 3.

139 Em termos da gênese das colônias, o 'patrimônio' era uma forma ampliada da capella, o local de encontro religioso e ponto central das fazendas do séc. XVIII. O patrimônio também era, enquanto presente para a Igreja Católica, dedicado a um santo. As dimensões do patrimônio demonstravam a posição econômica do fazendeiro. A quantia recebida pela venda das 
centro de uma futura colônia, e vendia os lotes 'urbanos' (500-800 $\left.\mathrm{m}^{2}\right)$ a interessados. Os gastos com agrimensão e planejamento eram em muito superados pelas receitas provenientes da venda dos lotes e pela valorização da sua própria terra, adjacente a nova colônia.

Particularmente importante foi o estabelecimento de instituições cruciais como escola, farmácia, médico, dentista, notário, loja de artigos têxteis, bem como armazém, hotel, pousada, bares, oficina, posto de gasolina, mas também de máquinas de beneficiamento, como as de café e de arroz, bem como uma serraria.

Alguns desses patrimônios privados experimentaram, em decorrência da economia cafeeira e em parte também por razões políticas, uma rápida ascensão ao status de sede do distrito e, em lugares um pouco mais isolados, a sede do município, principalmente na vertente em direção ao Ivaí (Mapa 14).

Devido a um número grande demais de localidades fundadas, as zonas de influência se sobrepuseram de modo desfavorável, inibindo o desenvolvimento. Embora as localidades fundadas pela CTNP tivessem um papel dominante no Norte Novo, em alguns casos elas foram suplantadas por localidades fundadas por iniciativa privada. Assim, por exemplo, a localidade de Maristella, fundada pela CTNP às margens da estrada de Maringá para o Noroeste, que até hoje permanece apenas como sede distrital (Mapa 14 e Tabela 5, número 27), enquanto a vizinha imediata, Alto Paraná, ascendeu à sede do município. O mesmo vale para Guadiana (número 20), que foi superada em muito em importância pela localidade de Mandaguaçu.

Em áreas com um avanço da população pioneira ligado à construção da ferrovia, a estação ferroviária terminal exercia uma particular influência sobre o desenvolvimento regional. Com o fim da linha férrea, o desenvolvimento das vias de acesso terminava e a colônia que se desenvolvia na estação terminal e as células de arroteamento que dela partiam eram portas de entrada para as áreas de florestais tropicais ainda não povoadas em torno delas. No Brasil, esses lugares são chamados de 'boca de sertão'.

No Estado de São Paulo, Ribeirão Preto, Barretos, Rio Preto, Bauru, Ourinhos e, mais recentemente, Marília foram estações terminais desse tipo ${ }^{140}$. Atrasos na continuação da construção da linha férrea favoreciam o povoamento da cidade. A construção da ferrovia era também frequentemente interrompida propositalmente, dando à planejada colônia uma boa posição inicial com a absorção do fluxo de pessoas que para ali afluíam.

Ao contrário do oeste de São Paulo, onde a distância de $20 \mathrm{~km}$ entre as estações ferroviárias comprovou ser geralmente muito pequena, tendo em vista a predominância do latifúndio, e as estações demonstraram não ser viáveis enquanto células de colônias, no Norte do Paraná, a distância de 15 km foi totalmente aceitável diante de um povoamento muito mais denso.

propriedades com patrimônios era aplicada na construção da igreja, no pagamento do religioso e para o uso das instalações religiosas. Além do puro ato de piedade, o fazendeiro tinha em vista a expansão do patrimônio, a venda de suas próprias terras adjacentes e a valorização geral de suas posses, um procedimento que estava ligado frequentemente aos interesses do padre.

Desde o início do séc. XX predominava, contudo, o patrimônio secular, o qual o proprietário das terras planejava em planta ortogonal, agrimensava e cujos locais de construção eram vendidos ou arrendados. O fazendeiro se tornava o povoador, ou seja, o fundador da colônia. Os patrimônios não levavam mais nomes de santos, mas frequentemente o nome do fundador. Propriedades precisavam ser edificadas dentro de um prazo (de até um ano) e construções especiais demarcavam as frontes das ruas em torno da praça (DEFFONTAINES, 1938, p. 390 ss. e MONBEIG, 1952, p. 310 ss.). Em áreas com latifúndios foram estabelecidos, em parte, patrimônios para se ter à disposição, em uma localização imediata, um bom número de trabalhadores para a época da colheita. Como chamariz para o assentamento, concedeu-se pequenas chácaras de graça para os imigrantes para o cultivo de alimentos básicos (LEHMANN, 1958, S. 90/91).

140 No Estado de São Paulo, Marília é um exemplo impressionante de cidades ‘boca de sertão': Marília foi fundada em 1925 às margens da linha férrea Alta Paulista e já contava, em meados dos anos 1930, com uma população de 20.000 habitantes (sobre isso, entre outros, DEFFONTAINES, 1938, p. 388; e em geral MONBEIG, 1935 e 1952; bem como GUTERSOHN, 1940) 
Tabela 5: Fundações de colônias da Companhia de Terras ou Melhoramentos Norte do Paraná (conforme áreas reservadas acima de 50 ha)

1. Cianorte

2. Maringá

3. Umuarama

4. Londrina

5. Nova Esperança

6. Mandaguari

7. Terra Boa

8. Arapongas

9. Apucarana

10. Rolândia

11. Jandaia do Sul

12. Marialva

13. Cambé

14. Jussara

15. São João do Caiuá

16. Paiçandu

17. Florida

18. Cruzeiro do Sul

19. Indianópolis

20. Guadiana

21. Inajá

22. São Tomé

23. Sabaudia

24. Sarandi

25. Perobal

26. Dr. Camargo

27. Maristella

28. Santo Antonio do Caiuá

29. Água Boa

\begin{tabular}{|c|c|}
\hline & Fundaçãc \\
\hline 1865 ha & 1953 \\
\hline 1463 ha & 1947 \\
\hline 802 ha & 1955 \\
\hline 325 ha & 1930 \\
\hline 272 ha & 1948 \\
\hline 252 ha & 1937 \\
\hline 235 ha & $1955^{*}$ \\
\hline 228 ha & 1935 \\
\hline 211 ha & 1938 \\
\hline 200 ha & 1932 \\
\hline 184 ha & 1951 \\
\hline 148 ha & 1940 \\
\hline 146 ha & 1930 \\
\hline 136 ha & $1955^{*}$ \\
\hline 130 ha & 1951 \\
\hline 99 ha & $1960^{*}$ \\
\hline 80 ha & 1955 \\
\hline 74 ha & 1952 \\
\hline 74 ha & $1967^{*}$ \\
\hline 71 ha & $\mathrm{D}$ \\
\hline 69 ha & 1955 \\
\hline 63 ha & $1960^{*}$ \\
\hline 59 ha & 1945 \\
\hline 58 ha & D \\
\hline 58 ha & $\mathrm{D}$ \\
\hline 57 ha & $1964^{*}$ \\
\hline 54 ha & $\mathrm{D}$ \\
\hline 52 ha & 1961 \\
\hline 50 ha & $\mathrm{D}$ \\
\hline
\end{tabular}

* A data indicada designa aqui a elevação à sede do município

D atualmente: sede distrital

(Fonte: arquivo da CMNP) situação em 19.01.1970 (Mapa 14).

No norte do Paraná, Apucarana tirou proveito de sua posição enquanto 'boca do sertão' durante quase 10 anos. A linha férrea tinha chegado à cidade em 1941 e continuou a ser construída em direção a Maringá apenas no início dos anos 1950, onde chegou apenas em 1954. Esse atraso foi motivado pela aquisição da companhia ferroviária inglesa pelo Estado, cuja permanente escassez de recursos financeiros não permitiu dar continuidade à planejada linha férrea, que passaria originalmente por Guaíra, chegando até Asunción.

Enquanto Apucarana vivenciou um avanço significativo como estação ferroviária terminal até fins da década de $1940^{141}$, Maringá havia atingido em 1954 - embora existisse há apenas 7 anos - um estágio mais elevado de desenvolvimento devido ao tráfego de caminhões e ônibus em forte expansão.

O desenvolvimento das áreas de floresta tropical situadas mais ao oeste, para além do rio Ivaí, deu-se com a rápida construção de estradas na era do automóvel. Até a data da publicação da primeira edição deste livro a conexão férrea entre Maringá e o centro urbano mais próximo, Cianorte, ainda não havia sido concluída. A partir de meados dos anos 1950, a construção da ferrovia não exerceu mais influência alguma sobre o desenvolvimento regional. A função das localidades 'boca de sertão' passou a ser exercida pelas colônias situadas nos pontos finais das ruas pavimentadas, nas quais o tráfego de

141 Waibel (1948, p. 628) descreve a grande quantidade de lojas de todo tipo 'repletas de produtos'. Numerosos hotéis, pousadas, mas também bares, salões de beleza, grandes depósitos de madeira definiam a atmosfera da estação ferroviária terminal de uma importante ferrovia. 
caminhões e veículos de passageiros se intensificava depois de fortes chuvas, pelo fato de as pistas de terra roxa ou de areia ficarem intransitáveis até que estivessem secas.

O progresso econômico do norte do Paraná, sobretudo o boom do café que se delineava lentamente, levou a um rápido aumento do preço das terras. Se em Londrina o $\mathrm{m}^{2}$ do terreno era vendido a três centavos em 1931/32, em 1948 teve-se de pagar por ele US\$ 50. Desde sua fundação em maio de 1947, o preço de terrenos em Maringá centuplicou no período de um ano! Um sítio nos arredores de Londrina, que podia ser adquirido por 200 dólares em 1932, era vendido em 1948 com 9.000 pés de café já produzindo por US\$ $15.000 .{ }^{142}$

Com os primeiros lucros financeiros significativos em decorrência de boas safras de café, os pequenos proprietários do Norte Novo em torno de Londrina podiam adquirir para os seus filhos novas terras na região de Maringá e, mais tarde, também além do rio Ivaí.

A recém fundada cidade de Maringá oferece um exemplo do rápido estabelecimento do processo de desenvolvimento na região de terra-roxa no Norte do Paraná. Após 3 anos de existência, já haviam sido construídas, em 1950, mais de 1.200 casas, 320 lojas, 75 fábricas e pequenas indústrias, 8 igrejas, 3 hospitais, 4 filiais bancárias, 4 clubes esportivos e duas escolas com 1.200 alunos. O campo de pouso, com uma pista de 1.600 m, contava com várias conexões semanais para São Paulo e demais colônias urbanas no Norte Novo do Paraná.

O desenvolvimento e colonização da região em torno de Maringá trouxe um avanço significativo da colonização rumo ao oeste em direção ao rio Paraná, e inaugurou, com o início do boom do café, o avanço das frentes de arroteamento na região do arenito Caiuá. As condições ecológicas em modificação e a passagem para uma nova fase colonizatória, com um alvo econômico com base na produção exclusiva de café, ou seja, critérios naturais e espaço-temporais, econômicos e de geografia social caracterizam a passagem para o assim chamado Norte Novíssimo, as zonas pioneiras dos anos 1950.

Antes disso, contudo, deve-se elucidar o desenvolvimento populacional que ocorreu até 1950 e procurar estabelecer-se a situação da colonização por volta de 1950.

\section{d) Desenvolvimento populacional e situação da colonização por volta de 1950}

Nas duas décadas entre 1930 e 1950 houve uma imigração de mais de meio milhão de pessoas para a região ao norte do rio Piquiri e a oeste do Tibagi. No ano de 1950, 60\% da população dessa região vivia na área de colonização da CTNP.

Se em 1932/33 a população total dessa parte do terceiro planalto era apenas de cerca de 27.000 habitantes (MAACK, 1937, p. 211) em uma área de $75.000 \mathrm{~km}^{2}$, esse número aumentou, até 1940, para 117.000 habitantes (Tabela 6, p.303, Anexo). Conforme demonstra o Mapa 11 referente ao desenvolvimento do norte do Paraná, a colonização se concentrava em uma faixa de até $25 \mathrm{~km}$ de largura a oeste do rio Tibagi, assim como em um corredor de 10 a $30 \mathrm{~km}$ de largura ao longo da ferrovia que se expandia no sentido oeste-sudoeste até as proximidades de Apucarana. Ao mesmo tempo, as regiões periféricas do planalto entre Tibagi e Ivaí estavam ocupadas por uma população pouco estabelecida.

O censo populacional de 1940 desmonstrou haver uma população de 23.000 habitantes $^{143}$ para toda a região ainda não desenvolvida do atual Norte Novíssimo, que corresponde à região a oeste do rio Pirapó e a sul do Paranapanema até o Piquiri, no sul, e o Paraná, no oeste, a qual se estabeleceu em algumas passagens dos rios Paraná e Paranapanema, assim como em torno de Campo Mourão e na região da antiga Fazenda Brasileira ${ }^{144}$, ou espalhada nas florestas como uma população de lenhadores ou colhedores de mate.

142 Little London [Pequena Londres], 1948, p. 17.

143 A distribuição regional da população em 1940 - ao norte do Ivaí existiam apenas os municípios de Sertanópolis e Londrina e ao sul, apenas Guarapuava (Mapa 15) - foi calculada pelo autor segundo informações fornecidas na CIBPU em 1958, com base em áreas regionais como se encontram atualmente.

144 A enorme fazenda que se encontrava na região onde atualmente é a cidade de Paranavaí, em cujas terras havia sido plantado café já na década de 1920, passou a pertencer, em 1930, ao Estado do Paraná. Desde 1915/16 havia sido estabelecido um caminho de gado que saía de Porto São José às margens do rio Paraná (o ponto de conexão para o Mato Grosso) em direção à sede da Fazenda Brasileira (atual Paranavaí) e avançava para Campo Mourão e Guarapuava. Depois de 1930, plantações e instalações entraram em declínio, e somente em 1944 começou a definitiva colonização urbana da Colônia Paranavaí, com a agrimensão de 400 lotes entre 100 e 130 ha. 
Nos 10 anos entre 1940 e 1950, a população da área estudada quintuplicou, o que se deveu principalmente ao crescimento populacional no Norte Novo de Londrina entre os rios Tibagi e Pirapó ${ }^{145}$. Lá o número de habitantes subiu de 69.000 (1940) para 327.000 (1950). Enquanto o Norte Novo se encontrava em fase de estabelecimento nos arredores de Apucarana e na primeira fase de ocupação nos arredores de Maringá, o Norte Novíssimo, uma área de quase $36.000 \mathrm{~km}^{2}$, somente foi alcançado pelo avanço da população no início da década seguinte (1960). De 1940 a 1950, o total do crescimento populacional foi de apenas 50.000 habitantes.

Ao aumento da população seguiu-se a divisão administrativa entre os rios Tibagi e Pirapó, afluentes do Paranapanema. Do município de Sertanópolis foram separadas Ibiporã, Bela Vista do Paraíso, Jaguapitã e Porecatu; de Londrina, os novos municípios de Cambé, Rolândia, Arapongas, Apucarana e Mandaguari. Este último compreendia, por volta de 1950, o Norte Novo de Maringá e a área total entre os rios Paranapanema, Paraná e Ivaí (Mapa 15, 1940, 1950).

A maior colônia do Norte do Paraná, Londrina, cresceu de 10.500 (1940) para quase 34.000 habitantes (1950) e obteve, como único município, apesar do grande território, uma maior imigração urbana do que rural.

A densidade populacional no nordeste da área estudada ficou entre 15 (Jaguapitã) e $87 \mathrm{hab} / \mathrm{km}^{2}$ (Cambé). A média da densidade populacional rural no Norte Novo de Londrina atingia cerca de $25 \mathrm{hab} / \mathrm{km}^{2}$, em torno de Maringá $12 \mathrm{hab} / \mathrm{km}^{2}$ e na região de Apucarana, $10 \mathrm{hab} / \mathrm{km}^{2}$ (Tabela 7, p. 304, Anexo). Ao sul do Ivaí, os números da densidade populacional de pouco mais de $1 \mathrm{hab} / \mathrm{km}^{2}$ indicam o estado em que se encontrava a colonização por volta de 1950.

A situação geral da distribuição populacional em 1950 é elucidada no Mapa 16. Em São Paulo, a 'fronteira' havia chegado ao rio Paraná na segunda metade da década de 1940. A expansão da cafeicultura paulistana, que se deu nos sentidos noroeste e oeste sobre as linhas divisoras de águas entre os afluentes do Paraná, se reflete no enfileiramento de colônias urbanas e na distribuição da população rural ao longo dessas linhas mestras.

A principal direção da colonização também pode ser reconhecida claramente no norte do Paraná, e o modelo de expansão da população urbana e rural se parece com o exemplo paulistano. Contudo, a expansão no norte do Paraná até o rio Tibagi foi dificultada pela necessidade de se transpassar numerosos afluentes do rio Paranapanema que afluíam do sul. Somente a oeste do rio Tibagi se deu a continuidade da expansão em direção à principal linha divisora de águas.

O desenvolvimento das vias de acesso no fim da década de 1940 (Mapa 17) apresentava a orientação unilateral do Norte Novo e Novíssimo para o leste, ou seja, na direção de São Paulo. Havia falta de conexões transitáveis o ano todo para o sul. Com exceção da estrada principal de cascalho de Maringá a Londrina, todas as demais vias eram pistas naturais sem cobertura firme ou macadame. Após fortes chuvas, a maioria das estradas de terra roxa estavam interditadas devido à lama ou à pista escorregadia ${ }^{146}$.

Maringá era ligada a Campo Mourão, assim como a Paranavaí, por meio de vias naturais primitivas; rios tinham de ser atravessados por meio de balsas. Longe das linhas de conexão mais importantes havia somente caminhos simples e picadas.

A conexão ferroviária do Norte Novo com Curitiba, capital do Paraná, e com o porto de Paranaguá passava apenas por Ourinhos e Ponta Grossa, ou seja, cerca de 2 vezes e meia a distância que uma conexão direta entre Apucarana e Ponta Grossa compreenderia.

Em contraste com isso, surgiram numerosos voos regulares para São Paulo, mais raramente para Curitiba, que partiam, com exceção de Londrina, também das pequenas localidades pioneiras Mandaguari, Maringá e Campo Mourão.

O desenvolvimento do Norte Novo trouxe consigo o arroteamento de grandes áreas de floresta tropical semi-decídua na região da terra roxa (Mapa 18). As áreas mais afetadas foram as de maior altitude, devido à excelente adequação para o cultivo do café. Uma vez que a distribuição de terra nessa região do norte do Paraná foi feita em grande porcentagem em pequenas e médias propriedades de 30 a

145 Ver também a Tabela 12 sobre a mudança populacional no Norte do Paraná (p. 305, Anexo).

146 Waibel (1948, p. 628) fez uma descrição - que, à exceção da estrada principal, ainda é válida na época de publicação da primeira edição deste livro - da situação das vias de acesso nos arredores de Apucarana: Depois das chuvas “ [...] as ruas ficam cheias de caminhões que não conseguem prosseguir; comboios de ajuda saem em todas as direções e mesmo na cidade o trânsito inteiro se limita ao necessário“. 
50 ha, a parcela da área desmatada na área cultivável era de qualquer forma elevada. Na área da CTNP, a recomendação da Companhia para que se deixasse no mínimo $10 \%$ da área cultivável como floresta remanescente foi, na maioria da vezes, respeitada até o ano de 1950.

Na área estudada surgiram, em 1950, pouco mais de 20.000 fazendas com área cultivável de 1,3 milhões de hectares, das quais $57 \%$ somente no Norte Novo de Londrina, assim como suas respectivas áreas. A parcela da área utilizada para o plantio de produtos agrícolas na área cultivável total oscilava, na região mencionada, entre $70 \%$ no município de Cambé e 17\% no município de Londrina, cuja área, em sua maior parte, estava localizada fora da área da CTNP e era ainda pouco utilizada.

O contraste das dimensões da estrutura da dos estabelecimentos agrícolas pode ser visualizado pela comparação entre os municípios de Cambé (CTNP) e Porecatu:

Tabela 8: Dimensões da estrutura dos estabelecimentos agrícolas no Norte Novo em 1950

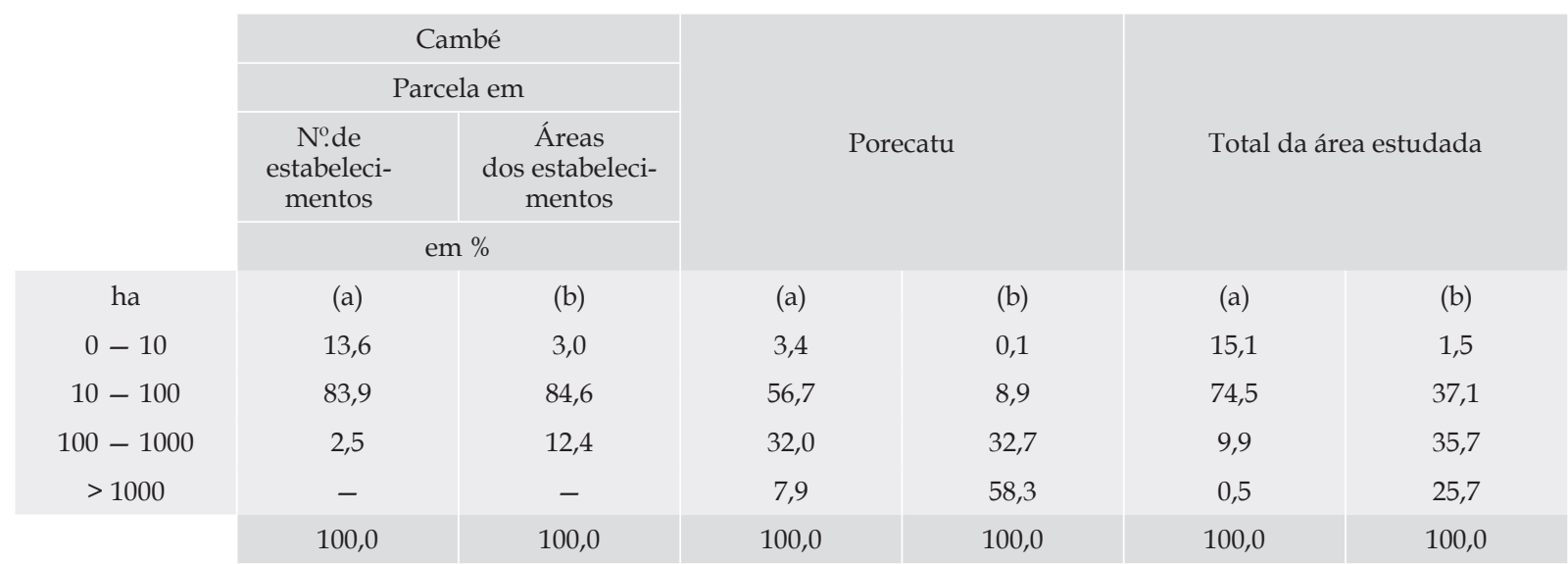

Fonte: CIBPU (1958).

Enquanto Cambé representava o modelo das dimensões das propriedades agrimensadas pela CTNP, surgiam, na região de Porecatu e Bela Vista do Paraíso, grandes plantações de cana-de-açúcar e café do grupo paulistano Lunardelli ${ }^{147}$.

A rápida expansão do cultivo do café por volta do fim da década de 1940 pode ser vista resumidamente com o auxílio da tabela a seguir:

Tabela 9: Número de pés de café e produção cafeeira no Norte Novo de 1942 a 1950

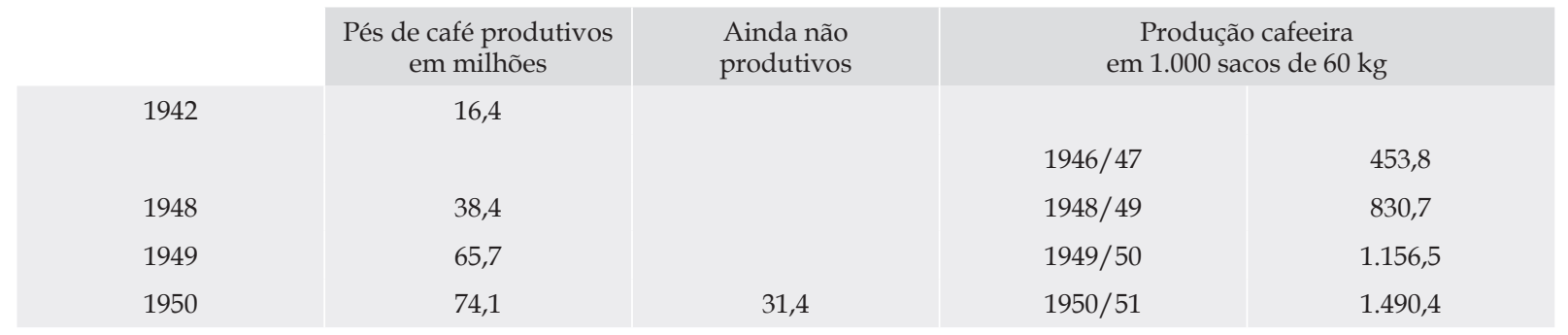

Fonte: Kretzen (1951, p. XXXVIII/XXXIX).

147 Por volta de 1950, G. Lunardelli era reconhecido, com 12 milhões de pés de café em São Paulo, Paraná, Mato Grosso e Goiás, como rei do café do Brasil (KRETZEN, 1951, S. 437). 
De 1948 a 1950 o número de pés de café produtivos duplicou, como consequência das novas plantações cultivadas desde 1945/46.

O extraordinário aumento expressivo da produção cafeeira no Paraná trouxe, com a elevação dos preços do café, grandes ganhos financeiros para o Norte Novo. Em 1950, dois terços dos bancos do Paraná já se encontravam no norte do estado, destes, 63 no Norte Novo. Entre os 10 municípios paranaenses com os maiores depósitos bancários, 8 estavam localizados na região de plantação de café, entre eles Londrina, Mandaguari, Arapongas, Cambé, Rolândia e Apucarana. Os créditos bancários de Londrina somavam mais de 50\% dos depósitos na capital Curitiba, tendo ainda que se levar em consideração o significativo afluxo financeiro do Norte do Paraná para São Paulo. A agência do Banco do Brasil em Londrina ficava, depois do Rio de Janeiro, São Paulo e Santos, em quarto lugar no Brasil em volume de negócios!

Na segunda metade da década de 1940, o café se tornou o produto de exportação mais importante do Paraná. A participação do Paraná na exportação brasileira aumentou em 7 vezes de 1946 ao início de 1951 e o Paraná havia passado da $7^{\mathrm{a}}$ a $2^{\mathrm{a}}$ colocação no ranking dos estados brasileiros na exportação, atrás de São Paulo.

Tabela 10: Participação do Paraná na exportação brasileira e participação do café na exportação paranaense entre 1942 e 1951

\begin{tabular}{|c|c|c|c|c|}
\hline & & $\begin{array}{c}\text { Participação do Paraná na expor- } \\
\text { tação brasileira, em \% }\end{array}$ & Colocação & $\begin{array}{c}\text { Participação do café na exporta- } \\
\text { ção do Paraná, em \% }\end{array}$ \\
\hline 1942 & & - & - & 9,3 \\
\hline 1946 & & 2,3 & $7^{\circ}$ & 20,6 \\
\hline 1948 & & 4,5 & $6^{\circ}$ & 32,3 \\
\hline 1949 & & 7,1 & $4^{\circ}$ & 43,1 \\
\hline 1950 & & 9,5 & $3^{\circ}$ & 55,4 \\
\hline 1951 & (janeiro-abril) & 16,3 & $2^{\circ}$ & . \\
\hline
\end{tabular}

Não há dados sobre o aumento da área plantada para os demais produtos agrícolas por município relativos ao período anterior a 1950. O aumento da área para o cultivo do café corresponde, contudo, no sistema de cultivo dominante no Paraná, a um aumento significativo da área de cultivo para as entressafras de milho, feijão e arroz montês, os quais são plantados entre os pés de café jovens nos 4 primeiros anos para suprir a demanda de alimentos básicos.

No aumento da aréa cultivável brasileira de 3,2 milhões de hectares entre 1939 e 1949, o Paraná teve uma participação individual de $28 \%$ !

Nos grandes vales dos rios, no entanto, a vegetação natural foi mantida, como, por exemplo, no vale do Tibagi (com exceção do 'corredor' da travessia leste-oeste em direção a Londrina), no vale do Pirapó e outros afluentes menores do Paranapanema. O vale do Ivaí ainda se encontrava tomado, em seu médio e baixo cursos, por florestas tropicais (Mapa 18). Os motivos para o desenvolvimento mais lento dos profundos vales dos grandes cursos d'água já foram mencionados, sendo eles a baixa adequação para o cultivo do café em decorrência da retenção de ar frio e o risco de malária nos meses quentes.

A frente de desmatamento avançou em um largo arco entre o Pirapó e o Ivaí na direção noroeste, sendo que o flanco sudoeste se dirigia, em sua extenção total entre Maringá e Apucarana, em direção ao Ivaí. Na área do arroteamento surgia, de forma bastante nítida, a conexão entre Maringá e Paranavaí. Ao longo da linha de separação de águas e em direção ao antigo caminho de gado é possível reconhecer um corredor quase contínio até o rio Paraná (Mapa 18). Enquanto as aréas de desmatamento que partiam de Maringá na direção sudoeste se achavam a apenas $10 \mathrm{~km}$ do rio Ivaí, partindo de Campo Mourão para o nordeste havia somente células de desmatamento isoladas na floresta tropical da bacia do Ivaí, onde, contudo, existia uma conexão de caminhos contínua.

Em um grau maior que as florestas tropicais do norte, as reservas valiosas de araucárias das regiões elevadas do Terceiro Planalto já haviam sido largamente exploradas. Nas regiões de floresta subtropical 
do sudoeste localizadas ao sul do Piquiri, o movimento de colonização do Rio Grande do Sul estava a todo vapor. Todavia, o impulso colonizatório do sul não deixou uma frente pioneira uniforme avançar para o norte, ocasionou, antes disso, uma fragmentação do frontier, como pode ser observado no Mapa 11.

Áreas isoladas do Norte Novo e toda a zona tropical do Norte Novíssimo que ainda não havia sido explorada proporcionaram amplo espaço para o avanço da 'colonização cafeeira' depois de 1950. 


\section{A EXPANSÃO DO CULTIVO DE CAFÉ COMO FATOR DE CONFORMAÇÃO DA PAISAGEM E DA ESTRUTURA SOCIAL AGRÁRIAS DO NORTE DO PARANÁ ${ }^{148}$}

\section{DESLOCAMENTOS DAS ÁREAS CENTRAIS DO CULTIVO DO CAFÉ BRASILEIRO}

Rühl (1929) já apontou a livre mobilidade das áreas centrais de cultivo de produtos agrários em países jovens no estágio inicial do desenvolvimento econômico. Esse caso excepcional era o que ocorria no Brasil com relação ao cultivo de café, cujo processo de expansão foi determinado espacialmente pela existência de solos florestais férteis e das vias de transporte que marcavam a distância da costa. O componente cronológico da migração das localizações foi determinado pela velocidade com que se exauria o solo das antigas regiões de cultivo e pelas flutuações do mercado mundial.

No século XX, o ciclo extrativista do cultivo do café assumiu, de maneira cada vez mais intensa, a forma de um permanente movimento evasivo, como escapatória da inevitável intensificação transformadora da gestão do cultivo. Com a colonização das últimas áreas de floresta úmida do sudeste do Brasil, apropriadas para o cultivo de café, esse deslocamento das áreas de cultivo do café no norte do Paraná alcançou sua fase final. Fatores climáticos (geada) e diversos fatores humanos (origem étnica, espírito econômico, sistema agrícola e escolha das plantas cultivadas pela população do sul do Brasil) limitaram de maneira irredutível o alcance da mobilidade espacial das culturas tropicais permanentes em direção ao sul.

A forma tipicamente brasileira de cultivo de café, que geria o sistema de colonato - organizado economicamente pela monocultura de café e em grande medida um sistema empresarial de plantio de autarquia com casa senhorial e numerosas colônias de empregados - , desenvolveu-se no Rio de Janeiro e em São Paulo com base nas experiências do plantio de cana-de açúcar do Nordeste, ${ }^{149}$ moldando-se decididamente pela estrutura social e econômica paulista, sobretudo.

As formas regionais específicas da economia cafeeira do Paraná assumiram com efeito traços essenciais de São Paulo, quanto à disposição e forma de cultivo das plantações e quanto à sua organização de gestão interna de trabalho. No Norte Novo e no Norte Novíssimo, entretanto, elas se diferenciaram significativamente do tipo paulista de 'civilização do café' quanto à relação socioeconômica ${ }^{150}$. Enquanto o Norte Velho do nordeste do Paraná é um 'clássico' desdobramento da economia cafeeira tradicional paulista, as inovações vindas da fronteira oeste do café em São Paulo sob a influência da crise econômica mundial, passaram ao largo dessa região paranaense e prosseguiram com seu processo de expansão mais adiante, na fronteira oeste do rio Tibagi ${ }^{151}$. Quanto a essas inovações, deve-se incluir a implantação - revolucionária para o Brasil - de pequenas e médias propriedades no cultivo de café, o melhor cultivo das sementes e a escolha de variedades, a maior densidade da lavoura (GUIMARÃES, 1953, p. 46) e a tendência mais forte à diversificação da área de plantio, assim como o desenvolvimento de culturas intermediárias e a mobilidade social junto à fronteira.

148 Tradução de Sibele Paulino e Fernanda Boarin Boechat.

149 As primeiras plantações de café no Vale do Paraíba foram estabelecidas pelos baianos que traziam seus escravos das regiões de plantação de cana-de acúcar para o Rio e São Paulo e lá adquiriam terras.

150 Conceito segundo Araujo (1956, p. 115).

151 Sobre o problema da difusão de processos de inovação, cf. Hägerstrand (1967, tradução de 1953) e Borcherdt (1961). 


\section{a) Modelos temporais e espaciais de propagação do cultivo de café em São Paulo}

Para compreender os deslocamentos do cultivo brasileiro de café e o seu significado para o Paraná, primeiramente devem ser elucidadas as fases decisivas do processo de expansão em São Paulo.

Na região nordeste em torno de Ribeirão Preto, uma das poucas áreas de terra roxa do estado de São Paulo, desenvolveram-se, no último terço do século XIX, as enormes plantações de café, que caracterizaram o estado durante muito tempo. Começando pelo estado do Rio de Janeiro, duas fases do 'roteiro do café' (MILLIET, 1941) no Vale do Paraíba (1830-1885) e na região em torno de Campinas (1850-1900) haviam precedido a abertura daquela região e deixaram para trás solos exauridos e prejuízos da erosão, depois de um tempo relativamente curto de prosperidade (MONBEIG, 1952); CAMARGO; TELLES, 1953; FRANÇA, 1956; ARAÚJO FILHO, 1956; PRADO JR. 1962; TAUNAY, 1961; FURTADO, 1968). A abertura de vias de transporte seguiu-se à migração do cultivo de café dos arredores dos centros populacionais próximos à costa - Rio de Janeiro e São Paulo - para o sertão inexplorado do planalto, no interior. Em 1883, a linha férrea de Mogiana chegou a Ribeirão Preto e possibilitou o transporte da colheita de café e a entrada de mão de obra, o que sempre faltava na região pioneira. Depois da abolição da escravatura em 1888, imigrantes europeus tornaram-se a força de trabalho, sobretudo os italianos.

Latifundiários como Almeida Prado, Silva Prado, Toledo Piza, Queiroz Telles ou Alves de Lima tinham domínio sobre extensas plantações de café. Eles e parte considerável dos membros de seus clãs conquistaram influência política e econômica significativa ao atuarem como políticos (secretários de Estado de Economia, prefeitos de São Paulo, entre outros), banqueiros, diretores de companhias de estrada de ferro e de empresas comerciais. Além disso, controlavam a política estatal com a economia cafeeira. Diversos proprietários rurais de muitas posses vindos de Minas Gerais, que em parte tinham emigrado de São Paulo para lá durante a febre do ouro, retornaram a São Paulo, e faziam parte do grupo dos primeiros grandes proprietários de plantações de café no nordeste do estado, constituindo a nova elite do Brasil (MONBEIG, 1952, p. 121ss.; DAMBAUGH, 1959, p. 5).

Mas não eram somente os tradicionais paulistanos fazendeiros do café - cujos filhos em parte já deixavam a direção dos negócios nas mãos de administradores e se dedicavam a operações financeiras em São Paulo - que tiveram a possibilidade de constituir fortuna com o cultivo desse grão. O primeiro grande boom do café possibilitou também a imigrantes europeus uma ascensão econômica inesperada na região pioneira, a exemplo de um Franz Schmitt ou Geremia Lunardelli, que foram elevados a 'reis do café' na virada do século e possuíam cada um mais de 10 milhões de árvores!

Depois da proibição oficial da escravatura em 1888 e da emigração dos ex-escravos para as cidades grandes, o suprimento das plantações de café com mão de obra representou um dos maiores problemas de São Paulo. Com a imigração em massa de europeus, iniciou-se uma nova fase do desenvolvimento econômico e populacional do estado.

Se entre 1875 e 1886 chegaram a São Paulo algo mais de 42 mil imigrantes, entre 1887 e 1900 uma onda de imigração inundou o estado com 910 mil pessoas, que em 1886 já contava com 1,22 milhões de habitantes (PETRONE, 1956, p. 41) ${ }^{152}$. Cerca da metade desses imigrantes veio da Itália e um terço da Espanha. Os imigrantes sul-europeus foram levados em sua maior parte diretamente às plantações, onde eram empregados como 'colonos' e, mais tarde, também como 'parceiros'. Nas primeiras duas décadas do século XX, outros 890 mil imigrantes seguiram para São Paulo ${ }^{153}$.

Em São Paulo, a classe trabalhadora das plantações de café compunha-se em sua maioria de imigrantes europeus, sobretudo italianos. Os colonos italianos destacavam-se por meio da rápida adaptação e aprendizado no tratamento de problemas com relação aos cuidados do café, e percebiam, com isso, a chance de se tornarem parceiros ou arrendatários onde quer que fosse. Muitos dos descendentes desses trabalhadores rurais foram recrutados para o Paraná numa consequente migração interna da metade do século XX, o que trouxe consigo, além da mobilidade espacial, uma mobilidade social significativa (ver Cap. IV, 3).

152 No ano de 1900, 23,2\% da população paulistana eram estrangeiros; em comparação ao mesmo período e à mesma situação, nos Estados Unidos a parcela de estrangeiros era de 13,4\%.

153 No Paraná, no período de 1889 a 1934, houve uma imigração oficial de apenas 82 mil pessoas, se comparado aos 1,8 milhões de imigrantes em São Paulo entre os anos 1887 e 1920 ! 
O deslocamento do cultivo de café dentro de São Paulo realizou-se no interior das famílias de fazendeiros como sucessão de gerações na região, sob o espírito bandeirante inalterado de seus membros. Se o avô tivesse uma plantação na área de Campinas, os filhos se radicariam na região da Alta Mogiana próximo a Ribeirão Preto e, por sua vez, investiriam para os filhos em plantações de café na região da Alta Paulista (MONBEIG, 1952, p. 110). Até 1920 o cultivo de café se expandira, em São Paulo, para o centro do estado na zona de arenito cretáceo do Grupo Bauru e para os espigões entre os afluentes do Rio Paraná154 (Mapa 19). Até a grande crise do café atrelada à crise econômica mundial, a década seguinte levou o avanço mais distante rumo a oeste ao longo da linha divisora de águas.

A construção da grande linha férrea seguiu-se imediatamente à colonização do café. Por trás disso, a colonização se sucedeu em um típico modelo de frontier (JAMES, 1938, p. 356) que, em São Paulo, não foi conduzido na forma de integração entre transporte e colonização (MONBEIG, 1937, p. 349). O cultivo de café na região dos espigões pôde conformar-se com os solos do arenito Bauru, que eram de qualidade inferior e além disso apresentavam os preços de terra mais altos ao longo da linha férrea. Por outro lado, com frequência havia rochas vulcânicas expostas nos vales e, com isso, confirmava-se a existência de solos de terra roxa ('misturada'). No entanto, os solos dos vales, sobretudo no sudoeste por causa de sua altitude, não eram propícios ao cultivo de café e à colonização, porque normalmente havia o perigo da geada no inverno e, no verão, eclodiam constantemente epidemias de malária. O gráfico de distribuição da população urbana e rual caracteriza esse movimento de expansão (Mapa 16).

As regiões de divisoras de águas e com elas as zonas de cultivo de café de São Paulo ficaram conhecidas pelos nomes das companhias da estrada de ferro: de norte a sul, a 'Alta Araraquarense' (entre o rio Turvo e o rio São José dos Dourados); a 'Douradense' (entre o rio São José dos Dourados e o Tietê); 'Noroeste' (Tietê-Aguapeí); 'Alta Paulista' (Aguapeí-Peixe) e 'Alta Sorocabana' (Peixe-Paranapanema) (GUTERSOHN, 1940; MILLIET, 1941; FRANÇA, 1956; Mapa 19). À exceção da linha 'Noroeste', que fazia conexão com o Mato Grosso do Sul, as linhas restantes terminavam no rio Paraná.

Desde 1928 a crise do café não pôde impedir a expansão de novas plantações no sentido oeste. Ela causou, no entanto, uma tranformação no caráter do frontier: não mais os grandes fazendeiros eram a força motriz da expansão do café, mas sim os sitiantes, um número considerável de pequenos proprietários de terra e invasores [squatter]. Juntamente com os imigrantes europeus e japoneses ${ }^{155} \mathrm{e}$ colonos de plantações de café, também inúmeros nordestinos (sobretudo da Bahia e de Pernambuco) migraram para São Paulo, depois do forte aumento da migração interna desde 1919, e passaram a almejar a aquisição de propriedades (JAMES, 1938; KELLER, 1954).

Além disso, a ampliação do frontier para novas regiões de floresta foi acompanhada - em esquema tradicional - pela diminuição de produção em antigas regiões de cultivo, pelo abandono de plantações improdutivas, pela mudança para criação de gado e pelo despovoamento (JAMES, 1932, p. 244).

James (1932) supunha, em vista das relações de solo e de clima das zonas de cultivo jovens, "uma diminuição da margem do café", consolidação do cultivo do café e uma concentração para trás das faixas de terra roxa da região central de São Paulo. Também Platt (1935, (p. 239) acreditava no fim da expansão do cultivo do café: "Tendo em vista a depressão mundial de maneira geral e o fracasso da política do café no Brasil em particular, a região do café pode preservar a sua forma atual por muitos anos, suas lacunas podem permanecer não preenchidas e seu frontier inalterado. Marília pode envelhecer e ainda se manter como uma cidade de frontier"156.

Enquanto grandes capitais de proprietários de plantações de café eram aplicados na indústria depois da distribuição e da venda das terras, e proporcionavam a São Paulo um impulso industrial significativo, o algodão se transformou no novo produto agrícola comercial [cash-crop] das zonas pioneiras. Um fluxo intenso de japoneses se iniciou. ${ }^{157} \mathrm{Na}$ verdade, apenas 1,8\% dos japoneses possuíam suas próprias terras,

154 O Mapa 19 mostra a média de produção de café por ha em diferentes fases. Para poder avaliar o avanço do cultivo de café apropriadamente, deve-se considerar que os cafeeiros ainda não produtivos com menos de 4 ou 5 anos da zona pioneira não foram computados aqui cartograficamente. Essas plantações jovens estendiam-se por toda região entre o nível de produção mais baixo (cafeeiros entre 4 e 6 anos antes da produtividade máxima) até a frente pioneira.

155 Entre os 584.000 imigrantes estrangeiros que vieram com destino a São Paulo, no período entre 1921-1934, os japoneses predominavam com $23 \%$ sobre os portugueses (20\%) e os italianos (13\%) (PETRONE, 1956, p. 43).

156 No original, em inglês: "In view of world-wide depression in general and the failure of Brazilian coffee policy in particular, the coffee region may retain its present form for many years to come, its gaps unfilled, its frontier unchanged. Marilia may grow old and still remain a frontier town".

157 No ano de 1934, os japoneses perfaziam 18\% da população do estado de São Paulo. 
entretanto eles cultivavam $46 \%$ do algodão em São Paulo e produziam quase 30\% da produção agrária do estado. De 1932 até 1935, o crescimento excepcional do cultivo do algodão - de 72.000 ha para 653.000 ha - junto ao crescimento de trabalhadores rurais - de 30.000 para 250.000 - , resultou, em 1935 e 1936, numa forte emigração populacional da região do café, de modo que $20 \%$ das plantações não puderam ser cultivadas por conta da escassez de trabalhadores ${ }^{158}$. No fim dos anos 30 , porém, houve novamente uma recuperação da situação na economia do café.

Por volta de 1940, o ponto forte da produção brasileira de café encontrava-se na região de Bauru e Marília e, já com uma participação relativamente significativa, no Norte Velho do Paraná. Enquanto em São Paulo a expansão do cultivo de café em 1950 revelava um afastamento significativo do modelo de ampliação indiscriminada de área em direção ao de seleção regional mais intensa de áreas de cultivo ecologicamente favoráveis, ${ }^{159}$ o frontier do café no Norte do Paraná avançava de modo ininterrupto para oeste e sudoeste, ainda em um fronte amplo (Mapa 19).

\section{b) O avanço do frontier do café no Norte do Paraná}

Ao contrário de muitas outras regiões do interior do Brasil e da região do planalto mesozóico central e sul do Paraná, onde ocorreu o processo de colonização não em fronte fechado mas de modo pontual e linear em avanços isolados uns dos outros, surgiu no norte do Paraná, a oeste do rio Tibagi, uma autêntica 'frente pioneira', ${ }^{160}$ que se assemelha à "unidade de movimento do frontier" [unity of frontier movement] de Turner $(1920)^{161}$. Os pioneiros não se infiltravam em interstícios despovoados às costas de 'frontiers vazios' [hollow frontier], ${ }^{162}$ mas se apoderavam efetivamente de terras florestais e de modo permanente.

Na América Latina, há poucos exemplos desse movimento de expansão de atividades de pequenos agricultores com tendências à intensificação do uso da terra. Seriam eles o planalto de Costa Rica, Antioquia, na Colômbia, a região norte do Chile central e o sul do Brasil ${ }^{163}$. Enquanto no cultivo de café da Costa Rica e da Colômbia a pequena propriedade se converteu em um elemento característico, o Norte do Paraná constitui um caso especial tanto para o movimento de frontier brasileiro de maneira geral quanto para o avanço do frontier do café de modo específico. "Essa é a nova frente, uma frente

158 Segundo Immigration and settlement in Brazil, Argentina and Uruguay, 1937, p. 235; e James (1938, p. 357-359); sobre isso também Matos (1954).

159 Apenas quase 15\% das plantações de café em São Paulo estavam em áreas de terra roxa, enquanto 64\% dos cafeeiros tinham o seu lugar nos solos arenosos da região de Bauru (United Nations, 1960, p. 22).

160 Cf. sobre isso as explicações de C. Bernardes (1953, p. 374), que, no entanto, baseiam-se apenas na expansão até cerca de 1950 e ainda não consideram a investida principal sobre o rio Ivaí para o oeste. Do mesmo modo, Lehmann (1958, p. 71).

161 A teoria de frontier de Turner, do ano de 1893, desenvolvida para os EUA, desperta até hoje uma discussão de suas ideias na literatura histórica, geográfica e sociológica. Entre os trabalhos mais recentes, deve-se mencionar Beck (1955), Wyman e Kroeber (ed., 1957), Gulley (1959), Hofstadter e Lipset (ed., 1968), entre outros. Sobre o problema do frontier na América hispânica, ver Zavala (1957).

O uso do conceito de frontier de Turner compreende quatro significados complementares: 1) 'linha de expansão' [frontier line] como linha de densidade populacional entre áreas com menos ou mais que 2 pessoas por milha quadrada; 2) 'zona de população esparsa' [zone of sparse population]; 3) 'margem inóspita' [wilderness margin] e 4) 'fronteira com uma organização econômica específica, vida pioneira' [border with a specific economic organization, pioneer life] (GULLEY, 1959, p. 65 e BECK, 1955, p. 59ss.).

Cf. em contrapartida Bowman (1931, p. 53): "Nenhuma área pioneira é um cinturão amplo e ininterrupto. Pelo contrário, ela é uma série de fragmentos esparsos e faixas dispostas de maneira vaga na forma de um cinturão, para além da franja do assentamento atual." [No pioneer area is a broad unbroken belt. It is, rather, a series of scattered patches and strips loosely disposed in beltlike form beyond the fringe of present settlement].

O significado do avanço do frontier para os EUA (PFEIFER, 1935) se dá, para Turner, a partir de um afastamento permanente da influência europeia e de um aumento consequente da independência americana. No frontier móvel do café no Brasil, permanecia, no entanto, uma duradoura dependência, no sentido quantitativo e qualitativo, da atitude consumista do alémmar devido à orientação do mercado mundial dos produtos agrícolas de mercado [cash crops].

162 Sobre o problema do 'frontier vazio' [hollow frontier] como exploração especulativa do interior, em grande medida típico para o Brasil, sob a forma de uma fase de transição do uso agrícola com degradação imediata por causa da devastação total da floresta, esgotamento do solo e mobilidade elevada da população do campo, ver James (1938, p. 361-62).

163 James (1941, p. 183) divide essas áreas em "quatro frontiers que não são vazias" [four frontiers which are not hollow]. (Para Costa Rica, cf. SANDNER, 1961; para Antioquia, PARSONS, 1968). O desenvolvimento no planalto de Antioquia é o que mais de aproxima da concepção de Turner sobre o frontier (HOFSTADTER e LIPSET, 1968, p. 155). - James entende como sendo sul do Brasil os três estados do sul de maneira geral, e não faz qualquer referência direta ao Norte do Paraná, que naquela época estava no começo do seu desenvolvimento. 
diferente e a última frente" [This is the new frontier, a different frontier and the last frontier] (DAMBAUGH, 1959, p. 22). ${ }^{164}$

A colonização do Norte Novo e Novíssimo do Paraná, que se deu no âmbito da colonização privada dirigida, não era dependente nem da autoridade de proprietários de plantações influentes, nem de coronéis ${ }^{165}$. A mudança da estrutura de propriedade tinha sido anunciada em São Paulo com a crise econômica mundial e impôs-se com o surgimento de novos produtos agrícolas de mercado, como o algodão, e de uma nova camada social de pequenos proprietários rurais. Pequenos e médios estabelecimentos agrícolas tornaram-se os tipos dominantes de atividades da zona pioneira paranaense, depois da economia cafeeira se revigorar.

Esse tipo de zonas pioneiras surgem "[...] quando de repente a expansão da agricultura se acelera por algum motivo, quando uma espécie de febre atinge a população do entorno mais próximo e mais distante, e se inicia o influxo de uma corrente humana intensa. Em outras palavras: quando a agricultura e a colonização provocam o que os americanos [...] chamam de boom ou rush. Então o preço das terras vai às alturas, as florestas são derrubadas, casas e ruas são construídas, povoados e cidades surgem da noite para o dia e um espírito arrojado e otimista acomete toda a população" (WAIBEL, 1955b, p. 393, trad. do autor).

O norte do Paraná se tornou o novo Eldorado do Brasil, e a produção cafeeira orientada pelo mercado mundial fez surgir uma das poucas zonas pioneiras clássicas do país, o que se compara ao desenvolvimento norteamericano no Centro-Oeste ${ }^{166}$. Se somente a venda de terras da CTNP entre 1945 e 1950 havia superado em quase 500.000 ha a venda total de terras dessa sociedade desde 1930, as compras de terra se multiplicaram sobretudo por causa do avanço de área da colonização do café na região do Norte Novíssimo, para norte e para sul do rio Ivaí.

A colonização agrária resultou de uma forte migração interna, que avançou de São Paulo ou a usou como estação intermediária para o Norte do Paraná. Antes de cada período de arroteamento (maio-agosto) e de plantio (setembro-outubro), filas extensas de caminhões carregados esperavam nos cruzamentos com rios em São Paulo para realizar a travessia com ferryboats, o que interrompia a viagem para o oeste. Embora a imigração também se desse por meio do trem, o avanço do frontier para o oeste de Maringá foi caracterizado somente pelo transporte de caminhão, cujo emprego causou a nova orientação geográfica e de tráfego da zona pioneira. Postos de gasolina e oficinas mecânicas foram criados e linhas de ônibus circulavam até as novas colônias na fronteira de área desmatada.

O movimento de massa de pioneiros, imprescindível para o frontier nos EUA por causa do perigo da presença indígena, explica-se no Norte do Paraná tanto a partir do tipo de produção agrícola de mercado do café - que, enquanto arboricultura, necessita de quatro anos até a primeira colheita e somente a partir do sétimo ano produz colheitas ideais - quanto também a partir das áreas limitadas da região. Os colonos tentavam adquirir o mais rápido possível terras baratas ${ }^{167}$

164 O avanço em direção ao Rio Paraná representava o fim dos deslocamentos do cultivo do café.

$165 \mathrm{O}$ coronel, em geral um comerciante rico com grande influência local e regional, exercia uma autoridade política peculiar no Brasil rural. "Pequeno tirano local, que invalidava qualquer sistema político democrático, o coronel ainda era capaz de realizar obras úteis" [Petit tyran local, viciant tout système politique démocratique, ce coronel était donc pourtant capable de faire oeuvre utile] (MONBEIG, 1952, p. 125). Baseado na estrutura social tradicional do campo no Brasil, o coronelismo significa uma coexistência de resquícios de poder privado do proprietário e a representação local do regime político. O aparecimento do coronelismo foi favorecido pela grande distância dos centros urbanos e o isolamento das localidades rurais, e alcançou o seu ápice em São Paulo, entre 1890 e 1920/30 (sobre isso, ver TORRES, 1965).

166 Waibel (1955b) evidenciou as diferenças das zonas pioneiras americanas e da maioria das brasileiras nos pressupostos naturais, quanto ao andamento da apropriação de terra e da colonização, assim como quanto às relações de mercado e de tráfego, mas também ressaltou a igualdade incipiente do sistema agrícola e do espírito especulativo dos colonos. Ao contrário do desenvolvimento nos EUA, o cultivo pelo sistema de coivara e da rotação de terras constituíram, em várias partes do Brasil, não um fenômeno passageiro, mas sim um estado permanente. - O mercado interno ausente e a carência de conexões de transporte eficazes impediam uma colonização em massa no interior do Brasil. São Paulo e o Norte do Paraná, com sua orientação de exportação baseada no comércio mundial de café, representavam as grandes exceções entre as zonas pioneiras do Brasil.

167 Bowman $(1931$, p. 6) descreve essa situação em suas observações gerais sobre "a margem pioneira": "Boa parte da vantagem do pioneirismo reside em chegar lá antes, pois a essência da coisa consiste em conseguir terra boa por baixo preço" [A large part of the advantage of pioneering lies in getting there first, because the essence of the thing is to get good land cheap]. Na área fora da colonização dirigida do Norte do Paraná, o slogan dos invasores "não basta estar no encalço do agrimensor; deixe que ele esteja no seu encalço" [it is not enough to be on the heels of the surveyor; let him be on your heels] (BOWMAN, 1931, p. 6) tinha o mesmo significado do dos colonos fronteiriços do frontier americano (PFEIFER, 1935, p. 155). 
e começar imediatamente o cultivo de café, antes que se iniciasse a extensa produção massiva e com isso novamente a queda dos preços. O fato de estar adiantado em uma colheita em relação ao vizinho significava, com frequência, a base para a construção de um patrimônio. Uma outra vantagem sucedia quando no ano seguinte, depois de estragos de geada, a colheita anterior podia ser mais valorizada, graças à especulação.

Enquanto o frontier ao norte do Ivaí já tinha alcançado o Paraná na primeira metade dos anos 1950, a frente pioneira avançou ao sul do Ivaí somente em 1960 até a fronteira oeste do país (Foto 1). Permaneceram inabitadas apenas a foz do Ivaí e do Piquiri, assim como a região de floresta situada na parte baixa da Bacia do Paraná, ente as regiões de confluência de ambos os rios (Mapa 11) ${ }^{168}$.

A velocidade e intensidade do avanço da frente pioneira se reflete claramente na fundação ou no surgimento dos municípios atuais do Norte do Paraná (Figura 2). A crescente recolonização das áreas de floresta tropical a oeste do Tibagi, na primeira fase até o fim da Segunda Guerra Mundial, corresponde ao número relativamente pequeno de fundações de colônias até 1944. Na segunda metade dos anos 1940, observa-se um forte aumento de atividade fundadora estatal e privada. O boom do café, que imperava desde 1950, manifestava-se em um único acúmulo de fundação de colônias. Na área da Cia. Melhoramentos Norte do Paraná, surgiram 22 novos lugares num período de 5 anos que se tornaram definitivamente sedes de municípios autônomos (Mapa 14 e Figura 2). Enquanto na antiga área da CMNP ainda foram fundados, depois de 1955, apenas alguns 'patrimônios' tanto por parte da sociedade de colonização quanto por iniciativa privada ${ }^{169}$ - os quais são, em parte, 20 anos mais tarde, sedes distritais - , a fundação de novos núcleos reginais só teve fim em 1960, e mesmo fora da região da CMNP, alcançando o rio Paraná.

No período entre 1947 e 1955, as fundações das cidades da CMNP foram projetadas em maior extensão, levando em conta o crescimento econômico do Norte do Paraná de maneira geral. Desse modo, Maringá, Cianorte e Umuarama excederam de longe a já existente Londrina, em vista da área reservada para a cidade (Tabela 5). O tipo de colônia planejada de frontier, predominante no Norte Novo e Novíssimo, era uma forma absolutamente nova de colonização na zona pioneira que havia se imposto em São Paulo pela primeira vez nos anos $1930^{170}$.

O espírito pioneiro do Norte do Paraná no momento da fundação dos pontos centrais de colônias encontra expressão também nas denominações dos lugares privados e estatais que foram fundados (Mapa 22). Ao lado de inúmeros nomes tupi-guarani, ${ }^{171}$ criações modernas de grupos de visão nacionalista ${ }^{172}$, nomes de santos difundidos em todo Brasil ${ }^{173}$ e nomes de fundadores de colônias ou políticos, ${ }^{174}$ predominam as designações de otimismo e espírito pioneiro ${ }^{175}$.

168 Após o fim da guerra, suspenderam-se novamente a desvinculação das regiões fronteiriças do oeste de Santa Catarina e Paraná, ocorrida em 1943 por razões estratégicas, e a formação do território de Iguaçu, com quase 66.000 km², estendendo-se do rio Ivaí, ao norte, até o rio Uruguai, ao sul.

169 Até o o começo de 1970, havia sido fundado um total de 62 localidades pela CMNP, das quais 35 eram sedes de municípios e 27 localidades distritais. As 50 fundações privadas nas terras da CMNP dividem-se em 14 localidades municipais, 24 localidades distritais e 12 'patrimônios'.

170 Cf. Monbeig (1937) e Gutersohn (1940). Com frequência a planta ortogonal do mapa da cidade foi acrescida de ruas diagonais por razões técnicas ligadas ao trânsito. Por razões psicológicas, deu-se valor especial ao crescimento orgânico que ia do centro para a periferia, à construção de casas de pedra (agraciadas com prêmios) e à conformação da praça, pois a cota de atratividade migratória dependia da aparência externa.

171 Iguaraçu, Apucarana, Ivaiporã, Icaraima, Mandaguari etc.

172 Por razões nacionalistas, alguns nomes foram modificados: Nova Dantzig para Cambé; Lovat (fundador da Paraná Plantations) para Mandaguari; Roland para Caviúna, que, depois da guerra, voltou no entanto a se chamar Rolândia.

173 São Jorge, Santa Inês, São João do Ivai, Santo Antonio etc.

174 Presidente Castelo Branco, Engenheiro Beltrão, Doutor Camargo, Janiópolis.

175 Grandeza, beleza, alegria, esperança, sucessos: p. ex. Bela Vista do Paraíso do Norte, Terra Rica, Pérola, Bom Sucesso, Alvorada, Diamante do Norte, Nova Esperança, Jardim Alegre, Fênix, Florestópolis entre outros. 
Figura 2: Fundação dos principais centros municipais atuais

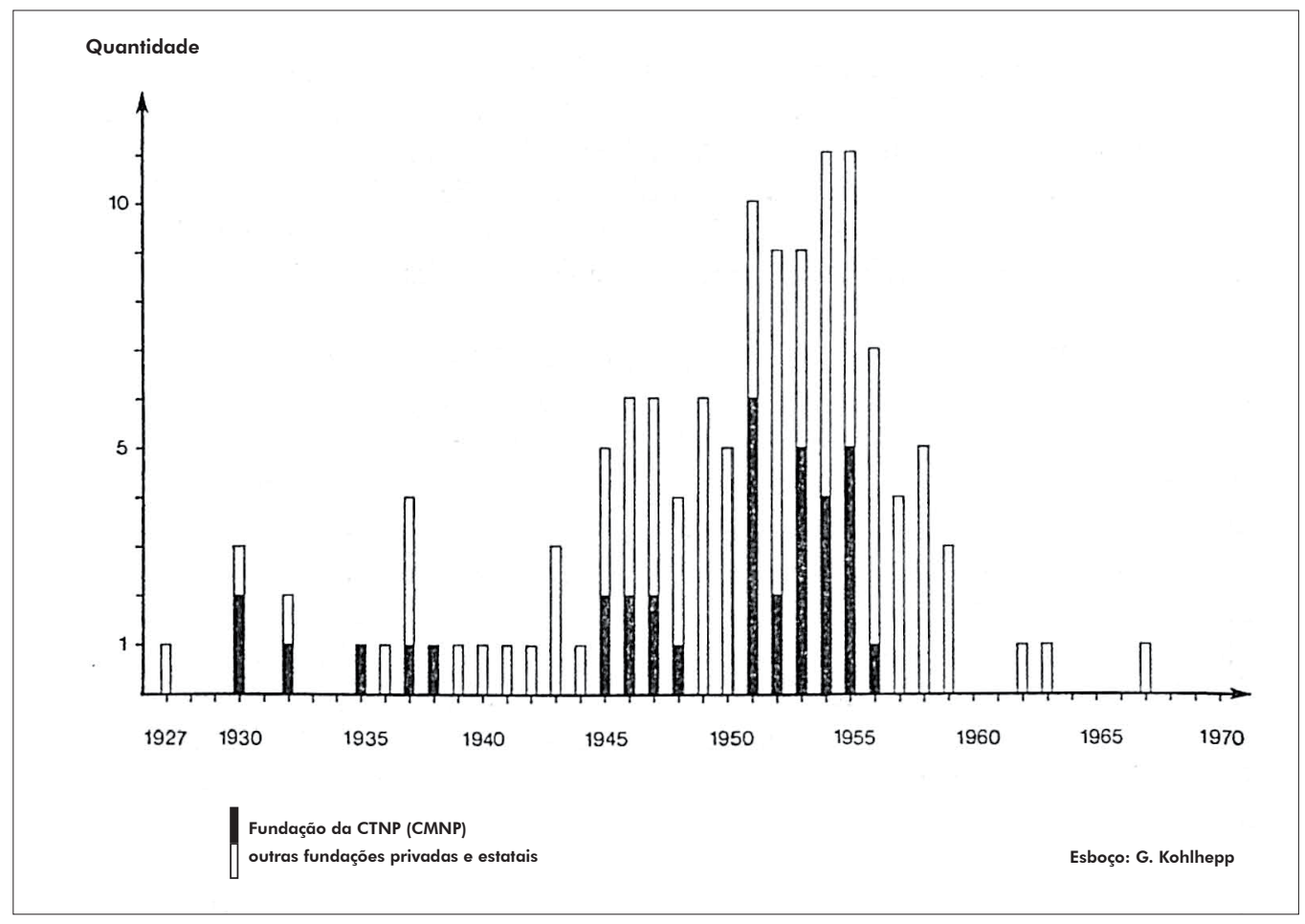

Fontes: Arquivos da CTNP, documentos do DGTC; IBGE, 1959, vol. 31, Paraná.

O processo de derrubada transformou grande parte do Norte Novíssimo ao longo de poucos anos. Como mostra o exemplo da região em torno de Cianorte, lá ocorria também o desmatamento em geral ao longo de clareiras nas divisoras de águas (Mapa 20), onde já havia sido planejado um extenso caminho principal para a futura construção da estrada de ferro. No período de uma década, a floresta tropical praticamente desapareceu, à exceção de poucos vestígios nos vales do rio e de um cinturão verde em torno do centro urbano de Cianorte (Mapa 21). Uma densa rede de ruas e de caminhos percorre a jovem paisagem cultivada, cujas áreas preenchidas e desmatadas - porém ainda com tocos de árvore apodrecendo - são tomadas de cafeeiros - à exceção do sopé do vale e das encostas mais baixas.

O cultivo de café estabeleceu novas medidas econômicas no Norte do Paraná, depois que as consequências da crise do café e a situação de transição durante a Segunda Guerra Mundial foram superadas. O aumento abrupto dos preços do café (ver Cap. V), no fim dos anos 1940 e no começo dos 1950, fez surgir um boom do cultivo do café no Norte do Paraná, que, fundado na pequena e média propriedade, superava todos os recordes de São Paulo até então.

A reserva de cafeeiros, que havia aumentado para 233 milhões até 1950 (1942: 61 milhões), sendo $55 \%$ no Norte Velho, alcançou no Norte do Paraná:

$\begin{array}{rr}\text { em } 1953 & 695 \text { milhões } \\ \text { em 1958 } & 1.141 \text { milhões } \\ \text { em 1961 } & 1.281 \text { milhões }\end{array}$

(ver Figura 3)

Destes números, $85 \%$ ficavam no Norte Novo e Novíssimo. A área de cultivo compreendia mais de 1,5 milhões de hectares em 1958.

Em 1950/51, o Paraná já tinha superado em número de cafeeiros o estado do Espírito Santo, que até então estava em $3^{\circ}$ lugar no Brasil; em 1952/53, superou também Minas Gerais; em 1961, alcançou e 
ultrapassou o desde então dominante estado no cultivo de café, São Paulo, cujas reservas mais velhas e menos produtivas tinham sido radicalmente reduzidas desde $1960^{176}$.

O aumento da produção do café no Paraná ocorreu não apenas com a usual fase de retardamento de 4 anos até o amadurecimento da produção das árvores, mas por causa de duas geadas de intensidade moderada, em 1953 e 1955, com um adiamento adicional de 2 a até 3 anos. Depois das colheitas fracas por causa da geada nos anos de 1954 e 1956 - que fizeram com que o Paraná fosse mais uma vez superado e alcançado pela produção em Minas Gerais e Espírito Santo - , a primeira grande colheita de 1958 rendeu 8,6 milhões de sacas de $60 \mathrm{~kg}$ e foi excedida, já em 1959, por um recorde de 20,7 milhões de sacas de $60 \mathrm{~kg}$ (Figura 3). Com isso, o Norte do Paraná também ultrapassou São Paulo e tornou-se uma região de cultivo de liderança no Brasil, sendo que a participação na produção total de café no Brasil cresceu 50\% até 1961.

Depois que as plantações de café das zonas pioneiras do Norte do Paraná entraram em plena produção, a situação da economia cafeeira brasileira mudou totalmente dentro de uma década. O Norte Novo e Novíssimo do Paraná ocuparam uma posição dominante (Figura 2). Os férteis solos de terra roxa das florestas tropicais representavam os principais atrativos. O fluxo da população pioneira que procurava por terras desembocou, no entanto, mais adiante para o noroeste, na região dos solos arenosos, cuja fertilidade era no início também relativamente alta, e também lá fez elevar os rendimentos da colheita, para além da medida usual de São Paulo. Essa fertilidade iludiu o colono sobre o real valor útil agrário. As consequências apareceram de modo intenso nos anos sessenta (ver Cap. VI).

O frontier do norte do Paraná, que avançou do oeste do rio Tibagi para o rio Paraná de 1930 até o fim dos anos 40 de modo relativamente lento, mas depois disso com grande velocidade até 1960 por causa do boom do café, não demonstra a sucessão de 'estágios de frontier' [frontier-stages] no sentido de Turner, no entanto proporcionou na composição de sua população "uma secção transversal da sociedade" [ $a$ cross section of society] (BOWMAN, 1931, p. 1).

A motivação da colonização na frente pioneira foi, na verdade, o desejo de ganho rápido. No entanto, as possibilidades sociais do pioneiro ascender para 'sitiante' 177 fazem surgir, no Norte Novo e Novíssimo, sob a nova camada social de pequenos proprietários, "um ar de permanência e um desejo de construir um futuro seguro" [an air of permanency and a desire to build a secure future] (DAMBAUGH, 1959, p. 22). A partir da observação subsequente da organização social do Norte do Paraná, conclui-se que esse desenvolvimento positivo não pôde influenciar e melhorar a situação precária e a contínua e alta mobilidade espacial dos trabalhadores rurais.

176 Em 1958, 31\% dos cafeeiros em São Paulo tinham mais de 30 anos de idade; em 141.000 ha de áreas cultivadas $7 \%$ com até mais de 50 anos (UNITED NATIONS, 1960, p. 26).

177 Proprietário de um sítio (pequena e média propriedade). 
Figura 3: Número de cafeeiros e produção de café de regiões de cultivo selecionadas do Brasil
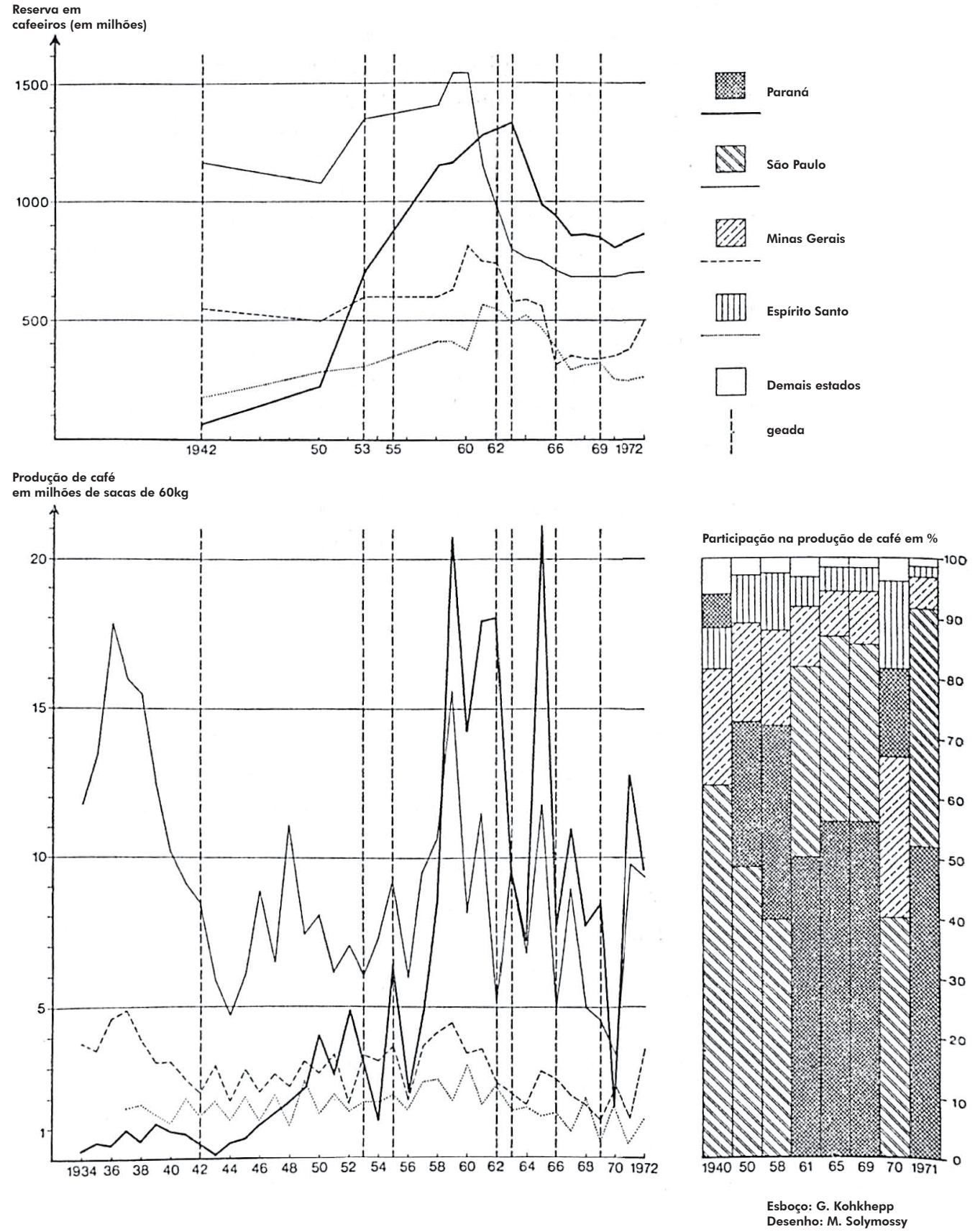

Fontes: IBC, Anuários Estatísticos do Café, 1965-1972. 


\section{ESTRUTURA DA ORGANIZAÇÃO SOCIAL RURAL E DA ORGANIZAÇÃO DE TRABALHO NO CULTIVO DE CAFÉ DO NORTE DO PARANÁ}

A estratificação da estrutura social rural mostra, na verdade, claras graduações entre os grupos principais. Claramente existem entre trabalhadores rurais e arrendatários inúmeras diferenças graduais, que resultam em relações de dependência diferenciadas, compromissos de trabalho distintos ou variantes diversas de pagamento (dinheiro, produtos, remuneração parcial).

Na observação das relações em todo o Brasil, chamam a atenção as incontáveis variantes regionais não só quanto às designações, mas também quanto às formas mesmas de dependência da população rural não autônoma. Os nomes atribuídos aos trabalhadores rurais mudam, em parte, conforme o produto de cultivo correspondente.

Também a estrutura social rural no Norte do Paraná é caracterizada dentro de grupos isolados por transições correntes e formas especiais. Na sequência, procura-se apresentar a organização social rural, sobretudo com o exemplo da economia cafeeira característica do Norte do Paraná.

\section{a) 'Volante' ou 'camarada'}

Na hierarquia da estrutura social agrária, o trabalhador migrante, conhecido como 'volante' ou 'camarada', encontra-se na camada social mais baixa. A designação 'volante' (do adjetivo 'instável', 'móvel'), circunscreve a alta mobilidade dessa camada social, cujos membros migram de plantação em plantação, tanto de São Paulo até o Paraná como dentro de áreas regionais isoladas no Paraná, à procura de trabalho.

O trabalhador migrante não tem uma colocação fixa e é contratado apenas temporariamente, tanto na colheita do café (junho - setembro no Paraná) quanto na colheita de algodão (março - maio), o que provoca migrações pendulares prolongadas entre o Paraná e São Paulo. São quase sempre pessoas jovens que encontram emprego a curto prazo em plantações e nas relativamente poucas lavouras grandes de café no Norte do Paraná, enquanto trabalhadores migrantes mais velhos e aqueles que vêm com a família são empregados apenas de mau grado.

Nos anos de colheitas fortes, períodos de trabalho intenso (cavas e mondas) ou estruturação de pastos e cercas, toda mão de obra torna-se necessária e a solicitação de 'braços' ou 'enxadas'178 é perceptível. Após os anos de geada, no entanto, o que se vê são trabalhadores migrantes procurando por trabalho nas ruas. As correntes espontâneas de trabalhadores migrantes trazem consigo problemas quase insolúveis para o Paraná, especialmente depois dos estragos de geadas e da colheita de café suspensa ou depois de colheitas ruins em São Paulo, já que há poucas possibilidades de trabalho.

Apesar de toda perseverança, os trabalhadores migrantes, fatalistas, esgotados e subnutridos, com frequência quase não têm condições físicas de executar com regularidade um trabalho pesado no campo. A isso se acrescenta o clima do inverno, com o qual não estão acostumados, sobretudo os nordestinos, e que provoca resfriados graves nos 'volantes' e suas famílias que moram em 'ranchos' ou casas coletivas sem aquecimento. Quase sem exceção infestados por doenças amébicas e verminosas, por ancilostomíase (parasitas nematóides) e frequentemente por esquistossomose ( $S$. mansoni), os trabalhadores migrantes são, como transmissores de doenças infecciosas tropicais, um problema grave para o Norte do Paraná. Uma grande parte deles está infectada pela malária, e também comprovou-se a ocorrência da Doença de Chagas ${ }^{179}$, incurável, em uma parcela relativamente alta. A preocupação com a subsistência e a possibilidade de guardar economias para os membros da família que ficaram para trás faz com que os trabalhadores migrantes trabalhem frequentemente sob condições indignas. A isso se acrescenta um sentimento peculiar acentuado de saudade ${ }^{180}$ diante do 'ambiente' do Norte do Paraná.

Para plantações maiores ou fazendas de café são preferíveis, com frequência, as chamadas 'turmas', grupos de 10 a 15 jovens trabalhadores, que se unem sob a coordenação de um líder

178 Frequentemente, o trabalhador rural simples é chamado, informalmente, de enxada.

179 Doença infecciosa provocada pelo Trypanosoma cruzi.

180 Três quartos dos 125 entrevistados responderam que estar 'longe da família e da nossa terra' era um dos principais motivos de insatisfação. 
de equipe de trabalho e realizam trabalhos sobre a terra somente em grupo. Essas equipes já desenvolveram uma consciência de grupo e não serão exploradas tão facilmente pelos proprietários de terras.

O pagamento dos trabalhadores migrantes se dá segundo acordo em dinheiro, no entanto, em uma colheita no máximo de 5 a 6 sacas de café ${ }^{181}$ por dia, rende para os trabalhadores apenas o mínimo para sobreviver. Um trabalhador temporário mal consegue um salário mínimo estipulado pelas novas leis trabalhistas. Mesmo que os salários de colheita sejam menores no Paraná do que em São Paulo, o rendimento maior das lavouras jovens de café do Paraná em melhor idade de produção resultam em um desempenho diário maior e, com isso, em possibilidade de ganho maior.

Uma grande parte das lavouras de café do Norte do Paraná está em pequenas e médias propriedades e pouco necessita de mão de obra adicional, já que a família do proprietário do 'sítio' e as famílias de colonos contratadas e ali domiciliadas cumprem uma grande parte do esforço de trabalho ${ }^{182}$. Em algumas das grandes fazendas, ao contrário, são necessárias várias centenas de trabalhadores temporários.

Segundo estimativas da Fetaep, o número de trabalhadores migrantes chega a atingir, em anos de boa colheita de café e algodão, mais de 300 mil pessoas que, sem seguro social durante a temporada de trabalho, vivem muitas vezes sob condições de higiene extremamente precárias e sobre cujos índices e variações não há quaisquer informações estatísticas exatas. ${ }^{183}$ Na grande maioria, são recrutados como trabalhadores migrantes nordestinos e mineiros, estes últimos provenientes do leste de Minas Gerais.

Como resultado da nova formulação da lei social agrária, o número de diaristas também aumentou nas lavouras de café. Eles moram, em geral, nos pequenos 'patrimônios' ou em áreas metropolitanas dos centros regionais e vão trabalhar por oito horas diárias em diversos trabalhos agrários ${ }^{184}$.

\section{b) Trabalhadores rurais}

O trabalhador rural com moradia fixa no 'sítio' ou na 'fazenda', o 'colono', tem em geral um contrato de trabalho fixo anual. A economia de 'colonato' é a forma tradicional da organização de trabalho no cultivo de café. O 'colono' cuida de 4 a 6 mil cafeeiros, que ele administra com sua família, sendo que recebe para isso um salário fixo em espécie para cada mil árvores ${ }^{185}$. A colheita do café é paga segundo a tarifa por saca, e as horas extras devem ser remuneradas, ao menos segundo a lei. Uma casa simples de madeira com cobertura de telhas, um lugar para o fogão e um poço são disponibilizados para o trabalhador. Para isso, 20\% do salário ${ }^{186}$ devem ser descontados para o aluguel da moradia.

A principal causa da atratividade das zonas pioneiras para os 'colonos' está na possibilidade de poder plantar culturas intermediárias para o próprio sustento, entre os carreadores de café novos, que ainda não estão em produção. Em áreas com lavouras de café em grande produção ou com lavouras mais antigas e com rendimentos mais fracos, por conta da absorção competitiva de nutrientes e - na região central do estado de São Paulo - da retenção da água pelas plantas, essas culturas de subsistência não podem ser empregadas sem que haja uma diminuição de produção no cultivo do café.

Muitos proprietários de terras no Norte do Paraná concedem aos 'colonos' - segundo acordo sobre o tipo de produto de cultivo e o número de carreadores no plantio de milho, feijão e arroz uma parte determinada da 'fazenda' ou do 'sítio' para cultivo paralelo durante os quatro primeiros

1811 saca de café na casca (em côco) = 40 quilos; 3 sacas não limpas = 1 saca de café limpo (beneficiado) com 60 quilos.

182 No município de Maringá, o percentual de trabalhadores temporários necessários como força de trabalho nos empreendimentos cafeeiros variou, de 1961 a 1963, entre 14 e 43\%, segundo o volume da colheita (NICHOLLS e PAIVA, 1969, p. 138).

183 Sobre isso, ver as análises de amostragem e os levantamentos estatísticos realizados pelo autor (ver Cap. IV, 3).

184 Quanto ao problema do sistema boia-fria no cultivo do café (ver Cap. VII, 4b).

185 1970: em média 200 cruzeiros (cerca de 170 marcos alemães) por 1.000 cafeeiros ao ano.

186 O salário total por mês, segundo o salário mínimo estipulado pela lei de 1970, deve alcançar para cada colono 170 cruzeiros, ou seja, algo como 140 marcos alemães. 
anos da lavoura de café, ou seja, até a primeira colheita ${ }^{187}$. Dos rendimentos das culturas, vão para o proprietário da terra de 20 a 50\% como arrendamento da terra, dependendo de cada contrato. O restante vai para a alimentação dos 'colonos', assim como para venda, sendo que o proprietário da terra tem preferência de compra. Através da venda dos produtos das culturas intermediárias, o 'colono' pode melhorar parcialmente os seus rendimentos até o dobro do valor de seu salário ${ }^{188}$.

Quando os cafeeiros entram na idade de produção, é então destinado aos 'colonos' um pequeno pedaço de terra, desfavorável para o plantio de café (fundo de vale), para utilização agrária ou também para manter alguns porcos ou uma vaca. Como esse pedaço terra muitas vezes se localiza distante da moradia, o 'colono' prefere as plantações paralelas no café, que são mais próximas. A suspensão de plantações paralelas no cultivo de café, antes da primeira colheita, frequentemente era motivo para que os trabalhadores rurais seguissem para uma nova plantação no frontier. Outros proprietários de terra - especialmente se tinham se comprometido com 'empreiteiros' consignavam aos 'colonos', desde o começo, um pequeno pedaço de terra fora da plantação de café para o uso próprio.

A fronteira climática do Norte do Paraná e o permanente risco de geadas originaram uma generalizada expansão temporal das plantações paralelas também depois do quarto ano. Depois dos anos de geada, desenvolveu-se um plantio intensivo de alimentos básicos que deve ter ajudado a superar a crise financeira de todo o negócio.

A nova ordem de salário na segunda metade dos anos 1960, baseada no salário mínimo mensal, trouxe uma reestruturação na utilização de culturas intermediárias no plantio de café. É proibido abater do salário do colono a parte do arrendamento das rendas da plantação paralela. Por outro lado, caso o proprietário da terra não tenha plantado mudas de café de modo algum, ele mantém para si a renda da colheita das respectivas plantações paralelas.

Com isso, no futuro, o 'colono' provavelmente tem a importante segurança do salário mínimo garantido por lei, mas não pode mais, como até então, melhorar muito sua situação financeira por meio da renda das plantações paralelas para poder comprar sua própria terra. A mobilidade social (ver p. 90ss.), com isso, existe para o trabalhador rural somente em dimensões insignificantes (ver Cap. VII, 4b).

Por outro lado, mantém-se a dependência total do proprietário da terra, que, nos pequenos e médios negócios, é atenuada frequentemente através da presença do proprietário e do estabelecimento de uma comunidade. Em estabelecimentos médios e grandes de maior magnitude, os administradores, que pensam em obter a maior comissão possível, dominam os 'colonos' de maneira mais rígida e, sem dúvida, se servem de um importante controle do aproveitamento do trabalho do 'fiscal', um tipo de vigia com posição privilegiada diante dos trabalhadores.

\section{c) Parceiros}

São inúmeras as formas de arrendamento no Brasil, fixadas por contatos orais ou escritos entre os proprietários de terra e os 'arrendatários'189. Em geral predominam os 'parceiros', que normalmente trabalham em associações familiares sem mão de obra desconhecida, com base no meeiro, terceiro, quartista etc. Segundo a relação de interesse do 'parceiro', ele é chamado de 'meeiro', 'terceiro' ou 'quartista'. No plantio de café, o meeiro é o mais comum (Foto 7). A forma de arrendamento ocorre em propriedades pequenas, médias e grandes. Como tempo mínimo de contrato de arrendamento foram fixados três anos, legalmente, a partir de $1966 .{ }^{190}$ Com isso teve-se uma melhora significativa, já que até então predominava apenas o curto período de um ano ou no máximo dois para contratos de arrendamento, e a rápida exploração dos solos aumentava com a redução do tempo de execução. Compreensivelmente, o arrendatário tentava obter a melhor colheita possível com o mínimo de investimento em fertilizantes e pulverizantes, pois um ano depois podia ser que o seu contrato com o proprietário da terra não fosse prorrogado.

187 Já no começo do século, fazendeiros paulistanos, temendo a diminuição da produção, fizeram ressalvas contra plantações paralelas na lavoura do café e proibiram seus colonos de plantar culturas intermediárias entre os cafezais.

188 Com relação à expansão mais recente, ver cap. VII, 4b.

189 As denominações para as formas de arrendatário são usadas diferentemente de acordo com a região: entre outras, arrendatário, rendeiro, parceiro, foreiro, quotista, locatário, vazanteiro (DIÉGUES, 1959, p. 95).

190 Fetaep (1967): Manual de legislação rural, art. 13, item IIa. 
Em geral o 'parceiro' não possui recursos financeiros. O proprietário da terra lhe empresta dinheiro e mercadorias, e com isso ele permanece em dívida, de acordo com a cota de arrendamento. No plantio de café, o 'parceiro' é obrigado a cuidar da plantação e a realizar a colheita. Utensílios e sementes são disponibilizados para o cultivo de alimentos básicos. Proporcionalmente, o proprietário da terra pode exigir do arrendatário o desembolso pelos fertilizantes e pulverizantes, de acordo com o preço de custo.

Além do cultivo de café, a parte do proprietário da terra junto ao rendimento da colheita compreende:
$10 \%$ no emprego da terra não trabalhada
$20 \%$ na arada e na instalação de uma moradia
$30 \%$ nas instalações adicionais (coberturas, cercas de pasto, bebedouros etc.)
$50 \%$ nos empregos adicionais de sementes, animais de tração, instalações e máquinas agrícolas

Arrendatários e parceiros - também no curso de colheita favorável - têm um padrão de vida consideravelmente melhor que os diversos grupos de trabalhadores rurais. Eles podem trabalhar de maneira autônoma, na sua maioria, com base nas diretrizes gerais estabelecidas. No Norte do Paraná, muitos antigos arrendatários aproveitaram a oportunidade para adquirir sua própria terra no frontier.

\section{d) Empreiteiro}

Uma forma especial na estrutura social agrária é o chamado 'empreiteiro', um fenômeno específico da zona pioneira, onde ele realiza como subempregador, por exemplo, o arroteamento para o proprietário da terra. No frontier cafeeiro, ele é especializado no primeiro estágio da plantação do café. Ele cuida da plantação de café até a idade de produção e, por esse motivo, é chamado também de 'formador'.

Sob sua orientação, são dispostas covas na distância de aproximadamente 3,7 x 3,7 metros, com $40 \mathrm{~cm}$ de diâmetro e com 20 a $30 \mathrm{~cm}$ de profundidade, nas quais são colocadas de 6 a 4, em parte até 15 (!) sementes, e então levemente cobertas de terra ${ }^{191}$. Cobre-se as cavidades com talhas de madeira para fazer sombra e para proteção contra chuvas fortes. No crescimento das plantas, as madeiras são dispostas como grades para que o processo de crescimento subsequente não seja prejudicado e, pouco depois, totalmente removidas. Depois de um ano, todas as mudas, de 4 a 6, serão retiradas. O cafeeiro, segundo o esquema de plantio brasileiro, consiste portanto de diversas plantas. ${ }^{192}$ Essa atividade de extrema responsabilidade é executada pelo 'empreiteiro' com grande dedicação, também por interesse próprio, no que diz respeito ao que lhe cabe segundo as condições contratuais.

Nos contratos entre os proprietários das terras e os 'empreiteiros', há o formato de 4, 5 e 6 anos, de modo que, com a duração mais longa do contrato, diminui o rendimento do proprietário da terra, e a do 'empreiteiro' aumenta. Algo parecido acontece com as possibilidades de ganho (Tabela 11).

O contrato de 4 anos requer altos investimentos do proprietário da terra. Esse formato de contrato é o mais difundido em negócios médios e grandes; visto em conjunto, porém, é relativamente raro, já que o proprietário capitalizado prefere implementar a plantação de café com trabalhadores pagos - e por isso mais controláveis - e também ele mesmo comercializar o primeiro rendimento da colheita (KOCH-WESER, 1957, p. 63). Para o 'empreiteiro' a vantagem consiste no fato de ele poder começar com o trabalho mesmo sem nenhum capital.

191 Sobre viveiros modernos, ver Cap. VIII, 3.

192 Depois de se ter considerado por longo tempo a folhagem abundante daí decorrente como vantagem para o sombreamento da própria planta ou proteção contra geada, em novas plantações financiadas pela IBC só podem ser colocadas três sementes em cada cova, para o melhor desenvolvimento do cafeeiro. 
Tabela 11: Formas de contrato entre proprietários de terras e empreiteiros no cultivo de café no Norte do Paraná

\begin{tabular}{|c|c|c|c|c|c|}
\hline $\begin{array}{l}\text { Duração do } \\
\text { contrato em } \\
\text { anos }\end{array}$ & $\begin{array}{l}\text { Investimentos do } \\
\text { proprietário da terra }\end{array}$ & $\begin{array}{l}\text { Investimentos do } \\
\text { empreiteiro }\end{array}$ & Ganho do empreiteiro & $\begin{array}{l}\text { Ganho do proprietário } \\
\text { da terra }\end{array}$ & \\
\hline 4 & $\begin{array}{l}\text { Derrubada da mata } \\
\text { Casa de madeira } \\
\text { Estradas } \\
\text { Poços } \\
\text { Sementes de café } \\
\text { Instrumentos de tra- } \\
\text { balho } \\
\text { Animais de tração e } \\
\text { de montaria } \\
\text { Veículos }\end{array}$ & $\begin{array}{l}\text { Remover a madeira, plan- } \\
\text { tar o café, cuidar dos ca- } \\
\text { feeiros, cortar, carpir, lim- } \\
\text { par por } 4 \text { anos }\end{array}$ & $\begin{array}{l}\text { Determinação soma/ } \\
\text { cova; } \\
\text { produto da venda da } \\
\text { colheita de café do } 1^{\circ} \text { ao } \\
4^{\circ} \text { ano. }\end{array}$ & $\begin{array}{l}\text { Mantém a plantação } \\
\text { produtiva de café de- } \\
\text { pois de } 4 \text { anos, ou seja, } \\
\text { antes da primeira co- } \\
\text { lheita. }\end{array}$ & 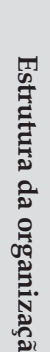 \\
\hline 5 & $\begin{array}{l}\text { Derrubada da mata } \\
\text { Casa de madeira } \\
\text { Sementes de café }\end{array}$ & $\begin{array}{l}\text { Vide acima. } \\
\text { Adicionalmente, constru- } \\
\text { ção da estrada e do poço, } \\
\text { instrumentos de trabalho } \\
\text { por custo próprio }\end{array}$ & $\begin{array}{l}\text { Colheita do café do } 4^{\circ} \text { e } \\
\text { do } 5^{\circ} \text { anos e plantações } \\
\text { paralelas do } 1^{\circ} \text { ao } 4^{\circ} \\
\text { anos. }\end{array}$ & $\begin{array}{l}\text { Plantações produtivas } \\
\text { de café depois do } 5^{\circ} \\
\text { ano. }\end{array}$ & 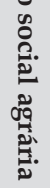 \\
\hline 6 & Nenhum & $\begin{array}{l}\text { Trabalho completo por } \\
\text { custo próprio; em parte } \\
\text { delegação de trabalhos a } \\
\text { terceiros }\end{array}$ & $\begin{array}{l}\text { Colheita de café do } 4^{\circ} \text { ao } \\
6^{\circ} \text { anos e plantações pa- } \\
\text { ralelas do } 1^{\circ} \text { ao } 4^{\circ} \text { anos. }\end{array}$ & $\begin{array}{l}\text { Plantações produtivas } \\
\text { de café depois do } 6^{\circ} \text { ano }\end{array}$ & \\
\hline
\end{tabular}

Fonte: Pesquisas próprias do Autor em 1970.

Em contratos de 5 anos, o empreiteiro deve ter algumas reservas para poder construir estradas e poços às próprias custas. Além dos rendimentos nas plantações paralelas, seu ganho é a primeira colheita do café (no quarto ano, bastante limitada) e a segunda (no quinto ano, bem maior). Essa forma de contrato se expandiu, em geral, nas propriedades de porte médio.

A forma de contrato de 6 anos exige meios financeiros maiores do empreiteiro, que se torna empresário por um tempo e recebe do proprietário da terra apenas "o mato em pé e a água no córrego", segundo a formulação tradicional do contrato. O empreiteiro passa os trabalhos menores para terceiros, como, por exemplo, a derrubada de floresta para grupos de lenhadores e fazer as picadas e limpeza do solo para colonos, cujo pagamento o próprio empreiteiro deve assumir. Em condições climáticas favoráveis, o ponto de partida para o empreiteiro, nessa forma de contrato, é naturalmente o melhor, pois como ganho principal ele recebe a colheita do quarto e do sexto anos (Tabela 11), além dos rendimentos das plantações paralelas ${ }^{193}$. Com o benefício alcançado a partir disso, os empreiteiros adquirem com frequência a própria terra, ascendem na escala social e se tornam plantadores de café autônomos na fronteira pioneira avançada. Mas existem também empreiteiros que, enquanto comerciantes, interessamse principalmente pelos produtos das plantações paralelas.

No Norte do Paraná, para os empreiteiros com seis anos de contrato o perigo de uma geada dentro de um período tão longo de tempo é sem dúvida maior. Depois do quarto ano, o risco de geada recai totalmente sobre o empreiteiro. Para ele, geadas no terceiro e quinto anos são especialmente severas, porque eventualmente ele pode não alcançar uma colheita de café plena e não lucrar sobre seus investimentos financeiros.

Para o pequeno emédio proprietário de terra sem capital ou sem disposição para riscos deinvestimento, o contrato de seis anos era a forma ideal da economia cafeeira: sem qualquer investimento, ele adquiria depois de seis anos uma plantação de café com produção plena. Sob o ponto de vista econômico, embora com as três primeiras colheitas de café, destinadas aos empreiteiros, ele perdesse mais do que havia

193 No que diz respeito às plantações paralelas, certas prescrições são feitas aos empreiteiros em geral pelos proprietários. É permitido o cultivo de milho, feijão, arroz montês e batata. São proibidas as plantações de abóbora, mandioca, batata-doce e todas as plantas de raízes profundas, que podem prejudicar os cafeeiros jovens. A partir do terceiro ano, podem ser plantadas apenas duas fileiras de milho ou três de feijão, arroz ou - apenas recentemente - trigo. No quarto ano, uma fileira a menos, para não prejudicar o crescimento dos cafeeiros. 
custado o investimento na plantação, evitava assim, por outro lado, nas regiões periféricas meridionais do Norte do Paraná, perdas diretas de capital próprio por meio de danos causados pela geada nas plantações de café jovens, particularmente sensíveis.

Além disso, há ainda inúmeras variantes de contrato para o empreiteiro, entre outras a transferência de uma parte (em geral 20\%) da terra cafeeira lavrada e cultivada por ele, depois de transcorridos 6 anos. Para muitos empreiteiros sem recursos, essa é a forma direta de ascensão a proprietário de terra.

A classe social dos empreiteiros revela uma diferenciação interna bastante evidente, que vai do subempreiteiro autônomo com reserva de capital, que trabalha com subgrupos e formas diferentes de arrendamento e subarrendamento, até o arrendatário sem recursos, que organiza e toma conta da plantação de café graças a sua experiência, com o objetivo de adquirir propriedade privada por meio do rendimento da venda das duas primeiras colheitas de café.

A forma original do empreiteiro passa então por um processo de transformação e se aproxima mais da forma de arrendatário meeiro: o frontier alcança o rio Paraná e assim não existem mais terras virgens próprias para o cultivo de café no estado do Paraná, tampouco no sul do Mato Grosso do Sul.

No norte do Paraná, cabe incluir os arrendatários com contratos de arrendamento favoráveis e empreiteiros com 4 anos de contrato em uma classe média rural mais baixa, em si bastante diferenciada. Empreiteiros com contratos de longo prazo e pequenos proprietários (algo como 10 a 25 ha) ${ }^{194}$ ocupam, no cultivo de café, uma classe média elevada para os padrões brasileiros.

\section{e) Proprietários de terra}

Dentro da camada social autônoma dos proprietários de terra há também grandes diferenças. Excetua-se aqui o grupo dos 'ocupantes'195, intrusos e posseiros (ver Cap. III, 3), que já nos anos 1970 está pouco presente no Norte do Paraná. Esse grupo, embora sem legitimação jurídica, caracteriza-se administrar com a mesma liberdade dos demais proprietários de terra, no entanto são-lhe recusados os créditos.

$54 \%$ de todos os empreendimentos agrários no Norte Novo e Norte Novíssimo do Paraná têm uma área entre 10 e 40 ha. No cultivo do café, $58 \%$ de todos os empreendimentos possuem entre 4.000 e 16.000 cafeeiros (IBC-OEA, 1964). Aí se incluem os sítios, atividades de pequeno porte, que em grande parte são geridas por proprietários de terra também com a ajuda de algumas famílias de colono (Fotos 4, 5).

Nos empreendimentos de médio porte (até aprox. 65.000 cafeeiros, 22\% deles) predominam três formas de gestão do cultivo agrícola. Os empreendimentos de médio porte menores são realizados pelos proprietários e trabalhadores rurais em conjunto. Em parte, o proprietário rural mora no município mais próximo e se desloca quase que diariamente para a propriedade, onde atuam alguns parceiros, trabalhadores rurais ou um administrador (Foto 3), dos quais o último recebe casa, salário e uma parte do rendimento da colheita.

O absentismo aparece, em geral, nos empreendimentos de médio porte maiores, que garantem ao proprietário um rendimento muito bom nos anos normais de colheita. O proprietário, que vive geralmente na capital Curitiba ou em grandes cidades do estado de São Paulo, emprega um administrador, que organiza o negócio de maneira geral, paga a mão de obra e recebe entre 40 e $50 \%$ da colheita. 50\% do total líquido da colheita pertence ao proprietário, que aparece 3 a 4 vezes no ano sobretudo em tempo de colheita e para o controle geral. A designação dos empreendimentos de médio porte maiores variam entre 'sítio' e 'fazenda'.

O último tipo de atividades de médio porte começa no cultivo de café de aprox. 60 a 70.000 árvores. No entanto, suas fronteiras também são fluidas e os critérios para demarcação de uma fazenda (ver Cap. IV , 4), sobretudo as próprias instalações de preparo e organização da comercialização, aparecem com frequência somente nos empreendimentos com mais de 100.000 árvores (Foto 10), levando em consideração as diferenças regionais. Entretanto, essas dimensões aparecem no Norte

194 Os proprietários de terra com menos de 10 ha (ou seja, $\varnothing$ de aprox. 3 a 4 ha de café) devem eles mesmos agregar arrendamentos para alcançar a melhoria de suas condições de existência no cultivo do café. Para os proprietários de chácara, pequenos vendedores ou comerciantes, pequenas propriedades ou minifúndios significam apenas uma subaquisição na periferia da cidades.

195 Gestores de cultivo de terras alheias, sem necessidade de recolhimento de impostos, com ou sem consentimento dos proprietários ausentes. 
do Paraná em menos de $2 \%$ dos empreendimentos de cultivo do café. ${ }^{196}$ Mais administradores à base de ordenado dirigem os negócios da fazenda, em geral com um bônus nos ganhos da colheita, e possuem um padrão e estilo de vida frequentemente ainda mais altos que os dos pequenos proprietários autônomos.

A classe dos latifundiários investe grande parte do seu capital em imóveis, especulações financeiras, nas indústrias de construção locais (p. ex. Londrina) e em participações em empreendimentos industriais dos grandes centros urbanos. O escoamento de capital para São Paulo é considerável.

A influência dos chamados 'maquinistas' na zona rural é até hoje significativa, já que o sistema cooperativo no cultivo de café do Norte do Paraná se desenvolveu somente no começo dos anos 1960. Esses maquinistas possuem os equipamentos para o processamento e classificação do café e têm sua sede nos pequenos patrimônios ou nas principais localidades municipais. Os proprietários de atividades de pequeno porte e de médio porte menores enviam suas colheitas para os maquinistas e são totalmente dependentes deles, porque estes pré-financiam as colheitas aos cafeicultores com o abatimento de uma determinada porcentagem do café limpo. Os proprietários das instalações para beneficiamento do café tomam créditos dos bancos locais e, com frequência, são dependentes de firmas nacionais ou estrangeiras de exportação de café no âmbito regional ou suprarregional. Essas firmas compram as colheitas por atacado na área de cultivo de café, em parte sob concorrência acirrada.

As 'cooperativas' do café procuram reduzir a pressão de comercialização sobre os pequenos proprietários, tentando conseguir elas mesmas as possibilidades diretas de exportação para os seus membros, o que é possível contudo apenas para as grandes cooperativas.

As fazendas de café possuem suas próprias instalações de beneficiamento e, com frequência, também relações diretas com firmas de exportação nos portos de escoamento de Paranágua ou Santos.

O pagamento exigido para o trabalhador rural, com base no salário mínimo mensal prescrito pela lei, é absolutamente insuficiente. Apesar disso, uma parte dos plantadores de café procura ainda no contexto do início dos anos 1970 evitar esse pagamento. O governo militar se esforça por garantir a instituição do salário mínimo no meio rural, no entanto, até então consegue controlar apenas o cumprimento das prescrições legais para os trabalhadores da indústria.

Se esse desenvolvimento significa uma tentativa concebida para o Brasil rural de modo geral com o intuito de regulamentar a situação financeira das classes sociais mais inferiores, então a sua prescrição rígida causa uma situação estruturada do cultivo de café totalmente diferente e também um 'congelamento' das chances de ascensão social dos trabalhadores rurais para meeiro. Atualmente, deixa-se de considerar os rendimentos das plantações paralelas antes incluídos no cálculo econômico dos trabalhadores rurais e pequenos arrendatários ativos e, por causa do salário mínimo muito baixo, impede-se a permeabilidade atual das classes sociais, que via de regra está associada à dinâmica das zonas pioneiras produtivas.

A estrutura social agrária atual na zona de cultivo cafeeiro do Norte Novo e Norte Novíssimo do Paraná é apresentada na Figura 3 mais uma vez de modo esquemático e resumido. Isso proporciona uma visão geral sobre a estrutura das classes sociais rurais e suas relações, funções e situação jurídica.

Para o desenvolvimento da estrutura social na zona de cultivo de café no Norte do Paraná, a mobilidade social ligada à espacial tem um significado peculiar, que se manifesta diferentemente nos grupos e classes específicos.

196 No entanto, os proprietários de terra realizavam com frequência mais atividades de médio e pequeno porte por meio de aquisição adicional. Essas atividades aparecem de tal modo nas estatísticas que, em parte, senão totalmente, acabam designando seus proprietários como fazendeiros. 
Figura 3a: Esquema da estrutura social agrária na área de cultivo de café no Norte do Paraná

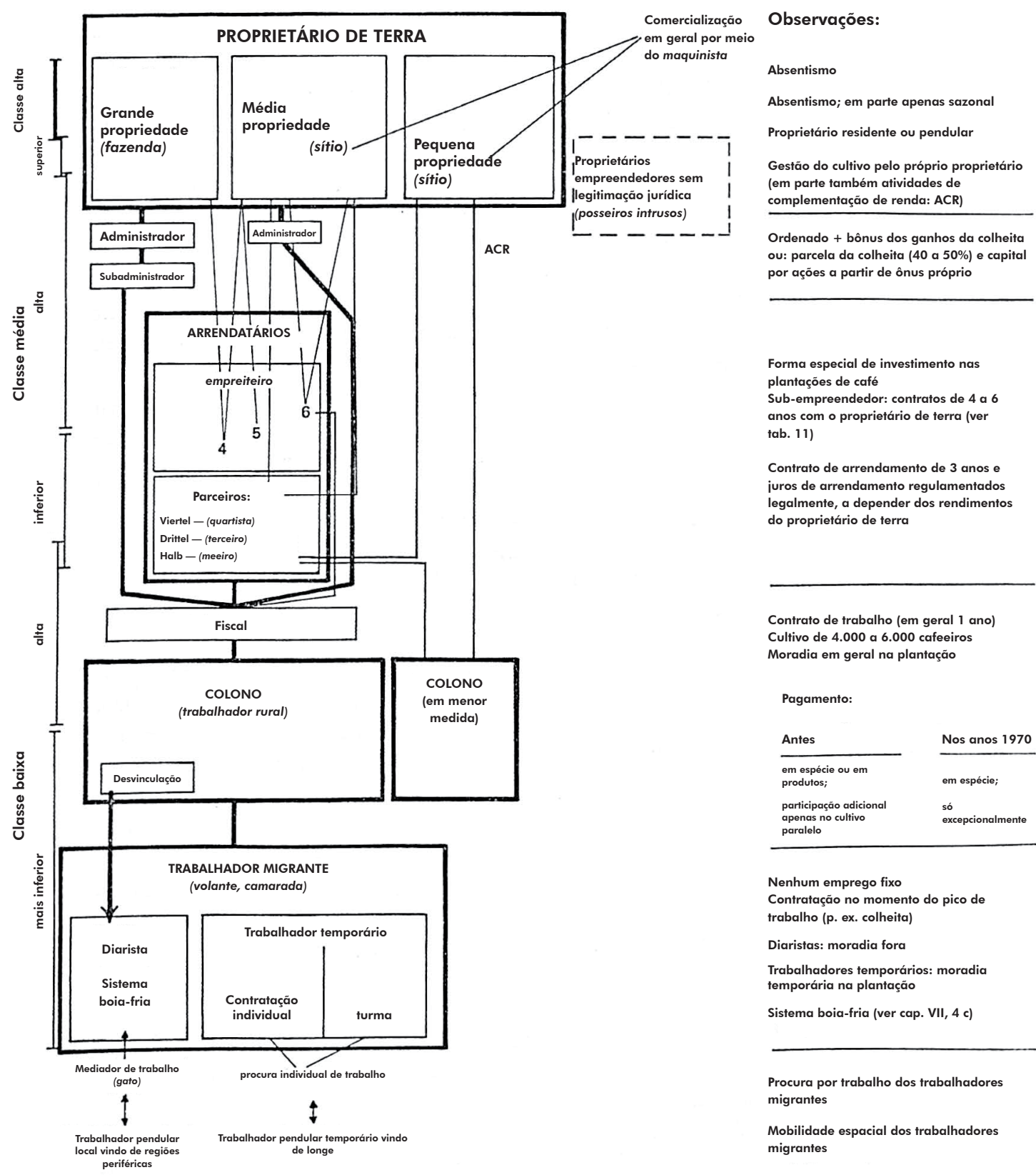




\section{MOBILIDADE SOCIAL E ESPACIAL ESPECÍFICA DE GRUPOS E CLASSES NO ÂMBITO DA ECONOMIA CAFEEIRA PARANAENSE}

\section{a) Sobre o conceito de mobilidade}

Nas Ciências Sociais, compreende-se 'mobilidade' como "[...] o movimento de pessoas de uma posição para uma outra" (BOLTE, 1969, p. 1). Sorokin (1927) designa mobilidade 'vertical' e 'horizontal' como as formas principais da mobilidade social, sendo que 'vertical' significa a ascensão ou queda de indivíduos ou de grupos dentro de um sistema social, enquanto mobilidade 'horizontal' significa '[...] uma mudança na posição social que não encerra em si uma mudança de classe" (HORSTMANN, 1969, p. 43).

No entanto, o verdadeiro componente horizontal da mobilidade é dado por pessoas ou grupos em deslocamento, o que é chamado de mobilidade 'regional' ou 'espacial' (HORSTMANN, 1969, p. 43), de "migração" no sentido de um movimento no espaço ou também pelo termo 'mobilidade geográfica' (ALBRECHT, 1972, S. 23).

Frequentemente, a motivação para a mobilidade espacial é o desejo de se tornar socialmente móvel, isto é, de buscar uma chance de ascensão na hierarquia de classes sociais em uma nova posição.

A mobilidade espacial pode ser analisada segundo o seu curso e seu alcance geográficos; a peridiocidade e tempo de permanência em um lugar particular; seu transcurso organizador; motivos socioeconômicos e segundo o tamanho e composição dos grupos migrantes (HORSTMANN, 1969, p. 48; ALBRECHT, 1972, p. 33 ss.).

Em seguida, serão investigadas a mobilidade social e a espacial de diferentes classes sociais agrárias, assim como de grupos étnico-sociais selecionados dentro dessas classes, no caso da economia cafeeira no Norte do Paraná.

Antes disso, no entanto, cabe apresentar ainda uma breve visão de conjunto sobre o a evolução populacional.

\section{b) Evolução populacional}

O avanço do frontier do café no Norte do Paraná, de leste a oeste, trouxe consigo migrações internas prolongadas, que atingiram o seu apogeu entre 1950 e 1960 com a ocupação de terras em áreas do norte do Paraná ainda desocupadas ${ }^{197}$.

Nas décadas de 1950 e 1960, a população total da área estudada cresceu de 552.000 para 1,89 milhões, ou seja, em 242\% (Tabela 6, p. 303, Anexo; Tabela 12, p. 305, Anexo). No transcurso temporal da frente pioneira que avançava, a comparação da evolução populacional do Norte Novo e do Norte Novíssimo mostra que há, frente ao Norte Novo, um adiamento de fases do fluxo principal para as novas regiões colonizadas do Noroeste do Paraná:

\section{População em 1000}

$\begin{array}{llll} & \text { Norte Novo } & \text { Norte Novíssimo } & \text { Total } \\ 1940 & 94 & 23 & 117 \\ 1950 & 479 & 73 & 552 \\ 1960 & 1110 & 778 & 1889 \\ 1970 & 1479 & 1529 & 3008\end{array}$

Dentro dessa evolução peculiar do Norte do Paraná, a porcentagem da população rural abrange, até 1960, um total de $74 \%$ no Norte Novo e $86 \%$ no Norte Novíssimo. A evolução populacional mais recente na última década não foi aqui considerada, pois a apropriação das terras ocorreu na maior parte até 1960 (ver Cap. VIII, 2).

197 A média anual da taxa de crescimento da população paranaense compreende 7,2\% nesta década. 
Enquanto a população rural na região de Londrina apresentou o menor crescimento - 66\% de 1950 a 1960 - , as regiões de Apucarana (colonização das regiões periféricas do nordeste) e Maringá (avanço na direção de Ivaí) presenciaram um aumento da sua população rural em três ou quatro vezes. No Norte Novíssimo foram registrados crescimentos de sete a doze vezes, a depender da região (Tabela 6, p. 303, Anexo; Tabela 12, p. 305, Anexo).

No ano de 1940, 17\% da população paranaense não era nascida nesse estado. Em 1950, isso já correspondia a $31 \%$ da população total do estado ${ }^{198}$, sendo que essa evolução se atribui quase que exclusivamente à migração interna de São Paulo para o frontier do café no Norte do Paraná. 53\% da população que imigrou vêm de São Paulo, $24 \%$ de Minas Gerais e cerca de $8 \%$ do Nordeste. Apenas uma parcela de $15 \%$ provinda de Santa Catarina e do Rio Grande do Sul se opôs à migração interna dos estados do norte para a região cafeeira do Norte Novo e Norte Novíssimo. Aquela pertence sobretudo ao movimento de expansão dos colonos teuto e ítalo-brasileiros para as florestas subtropicais do Sudoeste e Oeste do Paraná (CIBPU, 1958, I, p. 3637; TORRES, 1957, p. 166). ${ }^{199}$

Na próxima seção são investigadas a procedência geográfica (segundo local de nascimento ou estado) e a mobilidade espacial e social da população que imigrou para o Paraná em duas áreas regionais determinadas, a partir de diferentes fases de evolução. Também faz-se necessário empreender uma tentativa de diferenciação dos dados para grupos étnico-sociais individuais.

\section{c) Mobilidade espacial e social das classes sociais agrárias, assim como de grupos étnico-sociais selecionados}

A procedência dos proprietários de terra atuais é analisada por meio de dois exemplos. ${ }^{200}$ Um deles é Mandaguari (Norte Novo), pesquisada na primeira fase da metade da década de 1930, e outro Umuarama (Norte Novíssimo), na segunda metade dos anos 1950.

Tabela 13: Procedência dos proprietários de terra em Mandaguari e Umuarama (segundo local de nascimento; parcela em \%)

\begin{tabular}{|c|c|c|}
\hline & \multirow[b]{2}{*}{ Mandaguari } & \multirow[b]{2}{*}{ Umuarama } \\
\hline & & \\
\hline São Paulo & 61 & 53 \\
\hline Minas Gerais & 20 & 17 \\
\hline Nordeste & 1,5 & 11 \\
\hline Rio de Janeiro & 1 & 3 \\
\hline Paraná & 6 & 3 \\
\hline Santa Catarina & 1 & 2,5 \\
\hline Rio Grande do Sul & 0,5 & 2,5 \\
\hline \multirow[t]{2}{*}{ Exterior } & 9 & 8 \\
\hline & 100,0 & 100,0 \\
\hline
\end{tabular}

Fonte: Entrevistas próprias do Autor, 1970.

Ambos os estudos de caso mostram que a absoluta maioria dos proprietários de terra nos anos 1970, no Norte Novo e Novíssmo, vem de São Paulo. Minas Gerais segue com uma diferença enorme. A quantidade de estrangeiros imigrados sem recurso, que hoje dispõem de terra, é considerável ${ }^{201}$.

198 Com isso, o Paraná foi ultrapassado apenas pelo Distrito Federal (43\%).

199 Não há dados estatísticos correspondentes para o ano de 1960.

200 As entrevistas e investigações foram realizadas pelo autor em 1970: a) em Mandaguari, com 311 membros da Cooperativa dos Cafeicultores; b) em Umuarama (Gleba Jacaratiá), com 288 proprietários com título de propriedade (cadastro de terras da CMNP e entrevistas próprias). Cf. também Mapa 11.

201 Em todo o Norte Novo e Novíssimo, existem casos de ascensão social rápida por causa da situação peculiar das zonas pioneiras. É mencionado aqui apenas o exemplo de um galiciano, hoje assentado em Londrina, mas que imigrou em 1928 sem recursos, veio para o Norte do Paraná via São Paulo, atuou primeiramente como garçom, depois no ramo de transporte 
No caso dos membros da cooperativa de cafeicultores em Mandaguari, ${ }^{202}$ pôde-se determinar um padrão da procedência geográfica dentro do estado de São Paulo:

$28 \%$ provêm da região de Mogiana, no nordeste de São Paulo; 10\% do norte, na região da Alta Araraquarense e $6 \%$ da região de fronteira com Minas Gerais; $12 \%$ do noroeste e $16 \%$ da zona paulista. Do sul e sudoeste, da alta e da baixa Sorocabana, imigraram 7 e $9 \%$, respectivamente, e, das regiões restantes do estado, $12 \%$. Em meados dos anos 30, a ampla dispersão das regiões de procedência dentro do estado de São Paulo aponta para uma tendência bastante vasta de emigração para o Paraná, sendo que os pontos principais ficavam nas antigas zonas de plantação de São Paulo (NE, E, centro).

A partir de uma amostra aleatória da entrevista sobre a posição social antes da aquisição de terra no Norte do Paraná, ${ }^{203}$ depreende-se que $22 \%$ já tinham propriedade (com plantação de café) em São Paulo $^{204}$ (das quais $90 \%<25$ alq. paul. $=65$ ha), enquanto que anteriormente $30 \%$ atuavam no cultivo de café como arrendatários (meeiro) e 25\% como empreiteiros (em São Paulo, em parte também já no Norte Velho do Paraná). Dos 23\% restantes, estão os estrangeiros imigrados recentemente; membros de profissões livres e comerciantes que antes não haviam se dedicado ao cultivo do café; e também uma quantidade extremamente baixa de antigos trabalhadores rurais. ${ }^{205}$ Dos que vieram de São Paulo, $45 \%$ eram de ascendência italiana, que, quase sem exceção, atuavam como arrendatários ou empreiteiros no cultivo do café antes da sua migração interna.

Dos proprietários de plantações de café, na maioria pequenos proprietários de terra, apenas 32\% moram em sua propriedade, enquanto $2 \%$ vivem parte na propriedade, parte na cidade (Mandaguari). $36 \%$ declararam Mandaguari como principal moradia, 30\% outras localidades do município. Apenas $66 \%$ se denominaram cafeicultores sem outra ocupação secundária ou principal. 8\% dos restantes são comerciantes, $7 \%$ médicos ou dentistas, $4 \%$ advogados e notários. Esses são, na maior parte, pertencentes à geração de filhos de imigrantes e, em menor número, imigrantes tardios que adquiriram plantações de café como investimento de capital, por causa de suas boas rendas.

O exemplo de Umuarama (Gleba Jacaratiá/CMNP) compreende a migração interna ocorrida 20 anos mais tarde. A porcentagem de proprietários rurais provenientes de São Paulo também predomina com 53\%. Com base em consulta detalhada e na avaliação das informações no registro da CMNP, foi averiguado que $55 \%$ dos imigrantes paulistas são de ascendência italiana, $38 \%$ luso-brasileira, $4 \%$ japonesa e 3\% de outra ascendência. Em Umuarama, do número total de compradores de terra imigrantes, 53\% são luso-brasileiros, 35\% ítalo-brasileiros, $4 \%$ de ascendência japonesa e $8 \%$ estrangeiros (4\% japoneses, italianos, portugueses, espanhóis e outros europeus). ${ }^{206}$

Os proprietários de terra de ascendência italiana são quase exclusivamente descendentes dos trabalhadores rurais italianos que, desde 1888, já migravam para São Paulo. ${ }^{207}$ Quanto aos estágios de

(construção de ferrovias, transporte de imigrantes), vendeu terras, começou em 1941 com a criação de gado paralela ao cultivo de café e, em 1959, importou zebu, raça de gado indiana, apesar de ser proibido. À época desta pesquisa ele possui a criação de zebu mais significativa do sul do Brasil, além da maior empresa de ônibus do país (350 ônibus), e deve ser um dos homens mais ricos do Norte do Paraná.

202 Dos 311 membros, apenas 42\% têm sua propriedade no município de Mandaguari. A ampla zona de alcance da cooperativa (Mapa 56) permite considerar os resultados das entrevistas, feitas em 1970, aplicáveis também a amplas regiões do Norte Novo e Novíssimo.

203 Dos 45 entrevistados provindos de São Paulo ou Minas Gerais (relação 3:1), sendo 30 com propriedade em Mandaguari, 41 puderam responder às perguntas por si mesmos ou por seus pais.

204 Cerca de um terço dessas pessoas mantiveram sua residência principal no estado de São Paulo ou regressaram para lá após alguns anos de gestão de suas atividades paranaenses e da nomeação subsequente de um arrendatário ou administrador.

205 Apenas um entrevistado declarou ser essa sua atividade mais antiga.

206 Um exame comparativo de 304 proprietários de terrenos registrados, na cidade de Umuarama, mostra os seguintes dados de origem regional e étnica: 47\% são de São Paulo (dos quais 55\% são de ascendência luso-brasileira, 32\% de italiana e $8 \%$ de japonesa), $14 \%$ estrangeiros (japoneses, portugueses, sírios, italianos e outros europeus), $12 \%$ do Paraná, $11 \%$ do Nordeste, $9 \%$ de Minas Gerais, 3\% de Santa Catarina, 2\% do Rio Grande do Sul, 2\% do restante do Brasil.

Do número total de proprietários de datas (terrenos urbanos): $59 \%$ são de ascendência luso-brasileira, 23\% de italiana e 5\% de japonesa, $5 \%$ são japoneses, $4 \%$ portugueses, $3 \%$ sírios e $1 \%$ de outras nacionalidades. - A comparação com proprietários de lotes rurais mostra, na cidade de Umuarama, um forte retrocesso dos proprietários de terrenos de ascendência italiana, em contraposição ao aumento dos de ascendência luso-brasileira e japonesa e à porcentagem da entrada de portugueses e sírios, que no Brasil se ocupam tradicionalmente do comércio.

207 As principais regiões de emigração na Itália foram Vêneto, Piemonte, Abruzos, Ligúria, Campânia, Sicília, Lombardia, Emilia e Calábria. Quase 90\% dos trabalhadores rurais italianos, no Paraná, vieram de Vêneto (BALHANA, 1956, p. 481; ROCCHETTI, 1958). 
trabalhadores rurais, pequenos arrendatários e empreiteiro, eles progrediram profissionalmente para proprietários rurais autônomos, no Norte Novo (por exemplo em Mandaguari) e no Norte Novíssimo (por exemplo em Umuarama). Apenas pouco mais de 5\% deste grupo já havia alcançado esse estágio em São Paulo.

Os resultados das entrevistas do Autor sobre a proveniência geográfica e étnica dos trabalhadores rurais da gleba Jacaratiá, no Município de Umuarama, se reflete no Mapa 23208: forte predominância de paulistas e de ascendência italiana, entre estes 'sitiantes'. A parcela relativamente alta (11\%) de proprietários de terra provindos do Nordeste do Brasil (sobretudo da Bahia), na maioria antigos trabalhadores rurais e pequenos arrendatários (ver Tabela 13, p. 99), demonstra que, no Norte Novíssimo, a estratificação social aponta de modo satisfatório para uma permeabilidade vertical. Ademais, nas zonas pioneiras do Oeste na segunda fase de expansão consideravelmente mais nordestinos tiveram chances de ascensão social do que nos dois decênios anteriores, por exemplo, na região de Mandaguari (1,5\%).

Com relação à migração ligada à expansão cafeeira, provinda do estado de São Paulo, Minas Gerais e do Nordeste, em contraposição aos valores de Mandaguari (22\%), o exame da posição social antes da aquisição de terra no Norte Novíssimo do Paraná mostra que apenas $5 \%$ possui propriedade rural em São Paulo, no Norte Velho e, em parte, também no Norte Novo. Este grupo permaneceu domiciliado nas cidades ou, na sua maioria, na antiga propriedade. Por outro lado, mais do que três quartos dos atuais proprietários rurais, no exemplo de Umuarama, são antigos empreiteiros, meeiros, pequenos arrendatários, ou também trabalhadores rurais.

O Mapa 23 mostra que, na compra de terra nas proximidades de Umuarama por novos colonos provenientes de São Paulo (e em número inferior, também de Minas Gerais), esses colonos se estabeleceram em associações de turmas próximas uma das outras. Isso acontecia seja por causa do espírito de comunidade tradicional proveniente da região de emigração, seja por causa da mesma origem étnica (sobretudo italiana). A associação de vizinhança ganhou um significado bastante especial na fronteira de colonização.

Apesar de a gleba Jacaratiá (localizada nos atuais distritos Cedro e Perobal, do Município de Umuarama) estar localizada adiante em direção sudoeste da região de cultivo de café, a influência da migração provinda dos estados do Sul - Santa Catarina e Rio Grande do Sul - é extremamente pequena, com apenas $5 \%$ de proprietários rurais.

Entre os arrendatários domina uma alta mobilidade. Enquanto os empreiteiros trabalham diretamente na frente pioneira e seguem no frontier avançado - depois do decorrer de 4 a 6 anos, a depender do contrato - para que lá iniciem novamente a plantação de café, os arrendatários parceiros, ou também os colonos sucessores de empreiteiros estão em serviço, porém sob outra base contratual e função. A mobilidade espacial dos arrendatários é também direcionada para regiões recém colonizadas cujo solo ainda apresenta alta fertilidade. A duração das relações de arrendamento chegam, em geral, a 1 ou até 2 anos. Empreiteiros e meeiros são uma 'classe especialista' no plantio de café.

É certo que também muitos dos atuais trabalhadores rurais (colonos) se ocupam permanentemente no plantio de café, mas eles também mudam para outras ocupações facilmente. ${ }^{209}$ As regiões principais de procedência dos trabalhadores rurais - segundo a cidade natal ou a procedência dos pais - são os estados do Nordeste do Brasil e Minas Gerais. Em São Paulo, primeiramente tratou-se de familiarizar sobretudo os nordestinos com o plantio de café. O Paraná teve a grande vantagem de receber uma classe de trabalhadores rurais 'instruídos'. Em grande medida, nordestinos e mineiros são, como trabalhadores rurais, os sucessores dos descendentes de trabalhadores rurais italianos em São Paulo, os quais, na estrutura social rural do Norte do Paraná, ascenderam a arrendatários, empreiteiros ou pequenos proprietários rurais.

Primeiramente duas entrevistas apresentam as principais tendências no Município de Rolândia e de Apucarana, respectivamente:

208 No Mapa 23, os lotes de terra designados como ‘sem título' (41\%) estão na posse de sitiantes, que, até então, em confiança da segurança jurídica das propriedades do CMNP, ainda não buscaram a certidão de registro lavrada em cartório elaborada por uma taxa baixa.

209 A procura pelas melhores possibilidades de ganho leva frequentemente os trababalhadores à troca de um trabalho rural por outras ocupações urbanas. O alto grau de mobilidade profissional não é de forma alguma um sinal de insatisfação constante ou troca profissional forçada, mas muitas vezes o desejo de ascensão social. Nas marchas profissionais se reflete a situação instável da economia cafeeira, que leva a demissões temporárias. 
Tabela 14: Procedência dos colonos (segundo cidade natal/estado) de duas fazendas em Rolândia e Apucarana ${ }^{210}$

(parcela em \%)

\begin{tabular}{|c|c|c|}
\hline & \multirow[b]{2}{*}{ Rolândia } & \multirow[b]{2}{*}{ Apucarana } \\
\hline & & \\
\hline São Paulo & 23 & 28 \\
\hline Minas Gerais & 27 & 35 \\
\hline Nordeste & $\underline{44}$ & $\underline{19}$ \\
\hline Bahia & 16 & 8 \\
\hline Pernambuco & 11 & 2 \\
\hline Alagoas & 9 & 3 \\
\hline Sergipe & 3 & 2 \\
\hline Ceará & 4 & 2 \\
\hline Outros estados do NE & 1 & 2 \\
\hline Paraná & 2 & 16 \\
\hline Rio de Janeiro & 1 & 2 \\
\hline Outros estados & 2 & - \\
\hline \multirow[t]{2}{*}{ Estrangeiros } & 1 & - \\
\hline & 100 & 100 \\
\hline
\end{tabular}

Fonte: Entrevistas próprias do Autor (1970).

A alta porcentagem de trabalhadores rurais procedentes do Nordeste, no exemplo de Rolândia (44\%), corresponde à média geral do final dos anos 1950. ${ }^{211}$ Para evitar a alta flutuação desses colonos, muitos empreendimentos de médio e grande porte dão preferência, no processo de aumento de áreas de pastagem, aos trabalhadores de Minas Gerais, sobretudo porque eles em geral têm mais experiência também com os trabalhos que têm a ver com criação de bovinos. A porcentagem relativamente alta dos trabalhadores paranaenses no exemplo de Apucarana indica a contratação crescente de diaristas jovens que se estabeleceram, na maioria das vezes, em áreas periféricas dos centros urbanos do município.

Dos colonos naturais de São Paulo (23 a 28\%) em ambos os casos pesquisados, apenas $4 \%$ eram de ascendência italiana, um exemplo de que esse grupo étnico, pertence agora a outra classe social.

Para uma grande parcela de colonos provindos do Nordeste e de Minas Gerais, a colocação com contrato significa uma melhora significativa (plantações paralelas, moradia) em contraposição às ocupações que lhes eram dadas como trabalhadores migrantes.

É especialmente difícil fornecer indicações seguras sobre os trabalhadores migrantes. Quanto ao exemplo dos trabalhadores da usina de açúcar em Porecatu, deve-se fazer uma análise comparativa da procedência dos trabalhadores migrantes com trabalhadores rurais e de fábricas e funcionários da empresa.

Com relação aos trabalhadores migrantes, a parcela de nordestinos, com $46 \%$, é especialmente alta e o número dos que provêm de Minas Gerais, sobretudo os da parte norte e leste do Estado, é igualmente considerável. Uma vez que o conglomerado pertencente ao grupo de Lunardelli em Porecatu opera, para além do cultivo de cana-de-açúcar, plantações extensas de cultivo de café, há, entre junho e setembro, certos problemas de organização devido à sobreposição de períodos de colheita. Quanto às colheitas de cana-de-açúcar, prefere-se os nordestinos, que já trabalharam nas colheitas de cana-de-açúcar na região costeira de suas terras natais. O mesmo vale para os trabalhadores na usina de açúcar. A procedência dos trabalhadores rurais no cultivo de café oferece o já conhecido quadro da alta parcela dos paulistanos e mineiros.

210 Fazenda Conquista/Município de Rolândia: 167 fichas de trabalho entre os anos 1958 e 1961; Fazenda Ubatuba, Sta. Veronica, Sta. Helena/Município de Apucarana: 227 fichas de trabalho entre os anos 1968 e 1970. - Ver também o Mapa 11.

211 Duração média do contrato: 1,4 anos; número de pessoas por família de trabalhadores rurais: 5,7; idade do chefe de família: média de 37 anos. 
Tabela 15: Procedência de trabalhadores migrantes, trabalhadores rurais, trabalhadores de fábricas e funcionários da Usina Central Porecatu ${ }^{212}$ (parcela em \%)

\begin{tabular}{|c|c|c|c|c|c|}
\hline & \multirow[b]{2}{*}{$\begin{array}{l}\text { Trabalhadores } \\
\text { migrantes (sobre- } \\
\text { tudo no plantio de } \\
\text { cana-de-açúcar) }\end{array}$} & \\
\hline & & $\begin{array}{l}\text { Trabalhadores } \\
\text { rurais (café) }\end{array}$ & $\begin{array}{l}\text { Trabalhadores (da } \\
\text { usina de açúcar) }\end{array}$ & $\begin{array}{l}\text { Funcionários de } \\
\text { escritórios, oficinas } \\
\text { e armazéns }{ }^{213}\end{array}$ & Total \\
\hline São Paulo & 14 & 34 & 18 & 40 & 25 \\
\hline Minas Gerais & 35 & 32 & 17 & 12 & 26 \\
\hline Nordeste & $\underline{46}$ & $\underline{25}$ & $\underline{56}$ & $\underline{31}$ & $\underline{40}$ \\
\hline Bahia & 13 & 12 & 17 & 8 & 12 \\
\hline Pernambuco & 12 & 5 & 17 & 11 & 11 \\
\hline Alagoas & 9 & 3 & 6 & 4 & 6 \\
\hline Sergipe & 7 & 2 & 7 & 5 & 5 \\
\hline Ceará & 3 & 2 & 3 & 1 & 3 \\
\hline Outros estados do NE & 2 & 1 & 6 & 2 & 3 \\
\hline Paraná & 4 & 6 & 7 & 14 & 7 \\
\hline \multirow[t]{2}{*}{ Estados restantes } & 1 & 3 & 2 & 3 & 2 \\
\hline & $\begin{array}{c}100 \\
(1011)\end{array}$ & $\begin{array}{c}100 \\
(504)\end{array}$ & $\begin{array}{c}100 \\
(322)\end{array}$ & $\begin{array}{c}100 \\
(612)\end{array}$ & $\begin{array}{c}100 \\
(2449)\end{array}$ \\
\hline
\end{tabular}

Fonte: Entrevistas próprias do Autor (1970).

A mobilidade social e espacial específica segundo grupos e classes no Norte do Paraná será demonstrada de maneira resumida na Figura 4, a partir de grupos étnico-sociais petencentes a três classes sociais diferentes:

a) O primeiro grupo compreende os proprietários de plantação de café em São Paulo, em grande medida luso-brasileiros. Sua amplitude de reação ${ }^{214}$ no âmbito da expansão de café no Norte do Paraná decresce fortemente de leste para oeste. Enquanto o desenvolvimento da região de terra roxa do Norte Velho ainda é atribuído quase que totalmente a esse grupo, ele possui também algum significado no Norte Novo, sob parâmetros modificados de propriedade numa fase tardia, depois de 1930. Nas zonas pioneiras do Oeste, porém, sua influência direta se deu de modo reduzido.

b) Quanto ao segundo grupo, trata-se dos trabalhadores descendentes de italianos que, na segunda fase do século passado, formaram, como sucessores dos escravos em São Paulo, uma nova classe de trabalhadores de plantação. Seus filhos e netos, que em São Paulo eram ainda quase que exclusivamente trabalhadores rurais e arrendatários, demonstraram uma mobilidade social surpreendente, ao lado da mobilidade espacial, passando pelas zonas pioneiras do oeste paulista e do Norte Velho desde 1930 e, sobretudo desde o fim da Segunda Guerra, em todo Norte Novo e Norte Novíssimo. Passando pelas fases intermediárias de arrendatário ou empreiteiro, eles ascenderam, no Norte Novíssimo, a uma classe ativa de proprietários rurais autonômos.

c) Em contrapartida a esse forte componente de mobilidade social, a classe de trabalhadores migrantes mostra uma mobilidade predominantemente espacial. Esse grupo compõe-se de uma alta porcentagem de migrantes provindos dos Estados do Nordeste e de Minas Gerais. Também os trabalhadores rurais dessa procedência, empregados com contrato, mostram somente pouca mobilidade social.

212 Avaliação de fichas empresariais de 2.449 empregados, feita pelo autor. Trabalhadores migrantes em Porecatu: colheita de cana-de-açúcar em meados de maio a novembro e colheita de café de junho a setembro. Em São Paulo: colheita de algodão entre março e maio.

213 Para isso, comparar estrutura de procedência semelhante quanto à entrevista a trabalhadores industriais em Londrina (círculo interno) apresentada no Mapa 11, que, em 1970, foi realizada pelo autor, em Londrina com fins comparativos. Aqui também agradecemos o apoio amigável de V. Frech (Londrina).

214 Comparar com a concepção de amplitude de reação [Reaktionsweite] típica de grupo no estudo de Ruppert (1968). 
Figura 4: Mobilidade social e espacial específica segundo grupos e classes no cultivo de café no Norte do Paraná

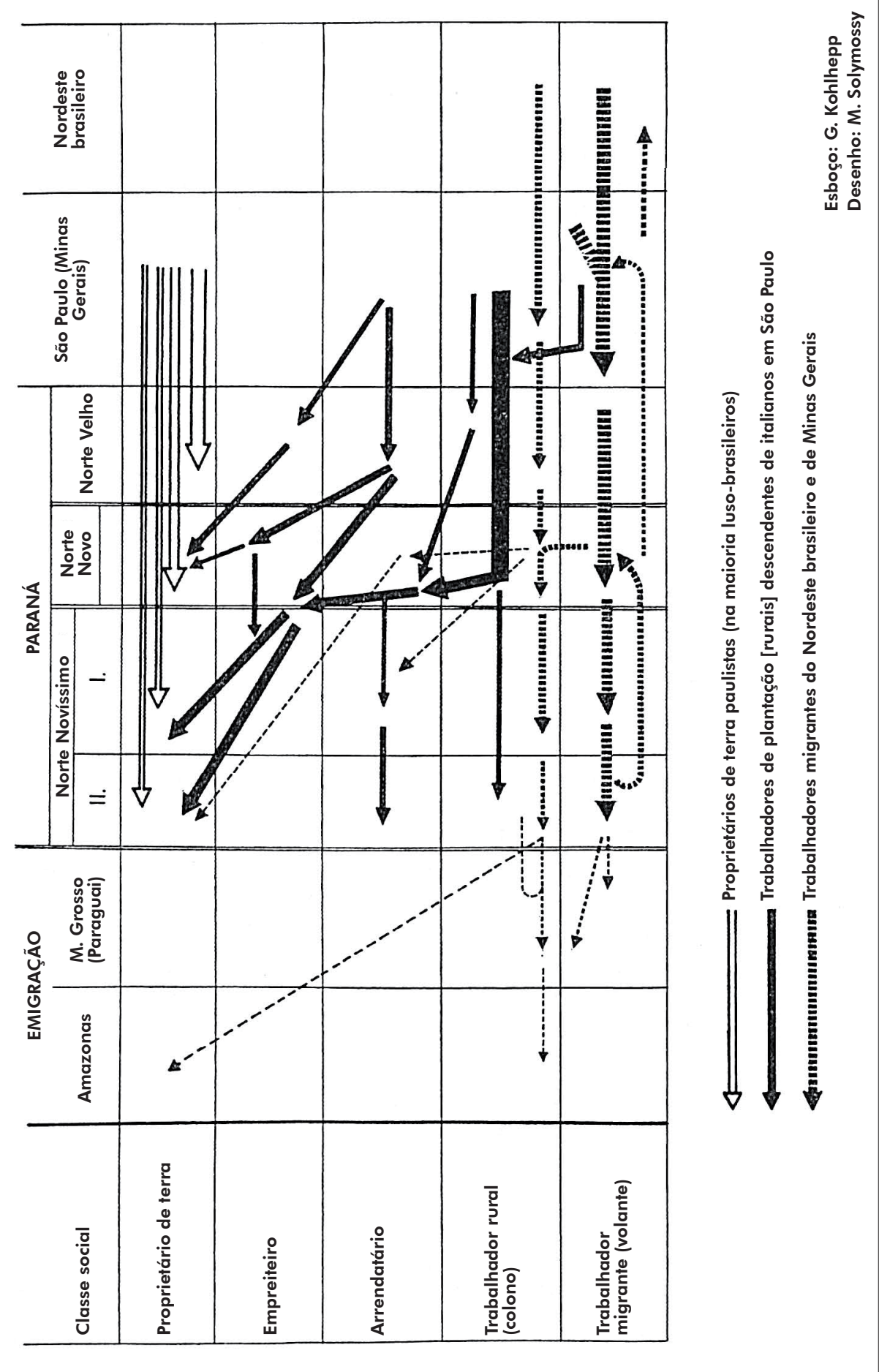

Fonte: Entrevistas e levantamentos do Autor, 1970. 
Cada uma das regiões são estações de passagem dos trabalhadores migrantes na sua busca constante por trabalho nos períodos de colheita. Parcialmente também se formou, como foi mencionado acima, uma migração pendular recíproca entre Paraná e São Paulo. Com as recentes crises do café sucedeuse, em parte, uma migração contínua para o Mato Grosso e a região amazônica, com a construção da Rodovia Transamazônica.

Até o momento desta pesquisa, no início dos anos 1970, apenas um pequeno grupo de nordestinos conseguiu dar o salto para aquisição de uma propriedade rural nas zonas pioneiras do noroeste (ver Figura 4). Na região de Porto Rico às margens do rio Paraná - explorada no começo dos anos 1950 —, $60 \%$ dos compradores de pequenas porções de terras, entre 2,5 e 35 ha, eram, no entanto, nordestinos que vieram, em grande medida, da região entre Mandaguari e Paranavaí, onde haviam trabalhado como colonos (PETRONE, 1957, p. 85).

As migrações internas provenientes do Nordeste trouxeram anualmente, nos anos 1950, mais de 500 mil pessoas para o sul. Secas catastróficas no sertão fizeram com que centenas de milhares de pessoas migrassem do Ceará, do interior do Rio Grande do Norte, Paraíba, Pernambuco, Alagoas, Sergipe e Bahia, passando pelos centros regionais urbanos, em direção às grandes cidades na região costeira, onde, porém, também não havia possibilidade alguma de trabalho (PFEIFER, 1956; TORRES, 1957). A principal onda migratória veio para o sul ou através da rodovia Salvador-Rio de Janeiro ou através da Ferrovia Central Monte Azul-São Paulo. Caminhões eram carregados frequentemente com mais de 70 pessoas, amontoadas em bancos de madeira, e eram designados de modo macabro como 'pau de arara'. Depois de muitos dias de viagem, chegavam às metrópoles do Rio ou de São Paulo ou em parte também direto para as regiões de plantio de café, onde, por conta da escassez de mão de obra, se pagava ao motorista do caminhão uma quantia para cada cabeça de trabalhador rural.

Por conta da crescente saturação de necessidade de mão de obra por volta do final do boom do café, a migração desordenada de nordestinos ocasionou grandes problemas no Norte do Paraná. Sobretudo o costume de autoridades da polícia local de entregar passagens de trem gratuitas 'até a última estação' à grande quantidade de pessoas desempregadas e esfomeadas no Nordeste, levou essas 'últimas estações' - os pontos finais da linha de trem no Norte do Paraná - a situações caóticas. Em Doutor Camargo, estação final a oeste de Maringá, centenas e milhares de pessoas chegavam em uma região que ficava muito atrás do frontier de meados dos anos 1950 e em cujas imediações predominavam, em sua maioria, pequenas e médias propriedades sem grandes necessidades de mão de obra. Junto ao problema de alimentação e sustento dos membros da família ${ }^{215}$ dos agora inúmeros nordestinos recém-chegados, o problema da obtenção de trabalho permaneceu sem solução.

Enquanto os baianos, em geral, mostravam um alto grau de estabilidade e se estabeleciam no Paraná, cerca de apenas $20 \%$ dos migrantes pernambucanos permaneceram. Depois do final do período de seca no Nordeste, a maioria retornou para lá.

\section{d) A mobilidade social dirigida dos colonos japoneses}

A observação do decurso dos processos de mobilidade espacial e social no Norte do Paraná leva a uma forma especial da mobilidade social dos imigrantes japoneses e de seus descendentes que se revela de modo "dirigido".

Para esclarecer o pano de fundo socioeconômico das atividades japonesas no Brasil, cabe fazer um breve relato.

A emigração do Japão, depois das restrições imigratórias dos Estados Unidos, dirigiu-se para a América do Sul, onde o Brasil, desde 1908 e, em maior medida, desde 1912, dirigiu a acolhida aos imigrantes japoneses. O objetivo brasileiro de ganhar trabalhadores assalariados para as plantações de café de São Paulo determinou o destino da primeira fase de imigração japonesa. Os imigrantes foram trazidos principalmente para a região de Mogiana.

O desconforto dos japoneses a respeito da função que foi prevista para eles e uma alta mobilidade espacial desse grupo - devido às más condições de vida nas fazendas de café - levaram à suspensão do subsídio dos custos de viagem pelo governo paulista, o que quase acabou com a imigração japonesa no começo dos anos 1920. A segunda fase da imigração japonesa para o Brasil começou com a intervenção do governo japonês, que assumiu os custos de passagem. O governo contribuiu não apenas para a fundação

215 Em meados dos anos 50, a zona pioneira apresenta ainda o típico excedente humano: 63\% dos migrantes eram homens, $21 \%$ mulheres e 16\% crianças (DIÉGUES, 1959, p. 118). 
de organizações de imigração, mas também providenciou a criação da fundação Brazil Takushoku Kumiai (Sociedade de desenvolvimento brasileiro) no Brasil. Devido à restrição da emigração italiana em 1927, a imigração japonesa articulada para o Brasil vivenciou o seu auge entre os anos de 1926 e 1935 com 133 mil pessoas.

Nesta fase, os emigrantes alistados no Japão foram cuidadosamente escolhidos e preparados para sua futura ocupação agrícola no Brasil. A maioria dos emigrantes foi para o Sudeste brasileiro, onde sobretudo a comunidade Kaigai Kogyo Kaisha era ativa (PELZER, 1937, p. 176ss.). O desenvolvimento florescente da imigração e da atividade colonizadora japonesa foi interrompida em 1934 pela nova constituição brasileira, que, como etapa preliminar da nacionalização, fixou a cota de imigração para cada país em $2 \%$ do número de imigrantes dos últimos 50 anos. Para o Japão, isso significou 3.480 imigrantes por ano. Nessa época, $40 \%$ dos imigrantes japoneses eram colonos nas plantações de café, $30 \%$ pequenos arrendatários e 30\% atuavam como colonos autônomos. (BOWMAN, 1937, p. 339)

Uma grande parte dos trabalhadores rurais japoneses emigrou e, depois do cumprimento de 1, 4 ou 6 anos de contrato nas plantações de café, começou como arrendatários ou, com reservas de dinheiro correspondentes, como proprietários de terra independentes em terras de comunidades japonesas de colonização (sobretudo na região costeira paulista, em torno de Iguape e no Vale do Ribeira, próximo a Registro) ou nas zonas pioneiras do noroeste de São Paulo. A colonização dessa zona era baseada especialmente no rendimento dos japoneses, que se estabeleceram como pequenos proprietários rurais e, nos anos anteriores à crise econômica mundial, trabalharam sobretudo no cultivo de café (MONBEIG, 1937 e 1952). A crise do café também ocasionou, entre os colonos japoneses, uma forte mobilidade espacial, concentrando-se, em parte, na região em torno da grande São Paulo, onde os japoneses obtiveram grande sucesso com o cultivo de legumes.

Na região da Alta Paulista e da Alta Sorocabana, sobretudo depois da crise econômica mundial, instaurou-se um boom do plantio de algodão, que, levado quase sempre por arrendatários e parceiros japoneses, trouxe uma nova orientação econômica para as zonas de expansão do oeste de São Paulo. O recuo do plantio de algodão, devido à exaustão dos solos arenosos, foi compensado pelos japoneses através da reestruturação para a criação de aves. A produção de ovos tornou-se a nova concentração econômica (AUGELLI, 1958a, segundo exemplo da colônia japonesa de Bastos, na região da Alta Paulista), mas não pôde evitar a emigração.

Além do forte fluxo de japoneses para a grande São Paulo - que foi uma consequência da rápida expansão industrial, exercendo influências significativas na mobilidade social e consequentemente profissional dos emigrantes japoneses - , a mobilidade geográfica teve como objetivo as novas zonas pioneiras do norte e noroeste do Paraná. Lá, a leste do Rio Tibagi, no começo dos anos 1930 já havia surgido uma colonização japonesa significativa em torno de Assaí, que se tornou o centro do cultivo de algodão paranaense..$^{216}$

Enquanto a mobilidade vertical dos membros de grupos examinados até aqui se dava seletivamente e sob a peculiar situação socioeconômica das zonas pioneiras, oferecia-se agora aos colonos da segunda fase de imigração japonesa, já escolhidos no Japão, o apoio da organização japonesa de colonização.

$\mathrm{O}$ alto rendimento característico de trabalho dos pequenos agricultores japoneses foi valorizado através do trabalho da Cooperativa Agrícola Cotia, a maior cooperativa da América do Sul, fundada pelos japoneses em 1927. Consultoria agrícola, planejamento de plantio, concessão de crédito e comercialização bem organizada dos produtos agrários estão entre as realizações dessa sociedade, cujos membros são até hoje $90 \%$ japoneses ou brasileiros de ascendência japonesa (ANDO, 1961). A ascensão social para proprietário da própria terra, aspirada com vontade férrea depois dos anos de aprendizagem como trabalhadores assalariados ou pequenos arrendatários, deu-se praticamente segundo os planos da Cooperativa Central Cotia com a ajuda dos bons rendimentos advindos da venda de bens agrícolas, em razão do afastamento de intermediários (Foto 8).

A migração japonesa de São Paulo para o Norte Novo do Paraná começou em 1930, quando se instaurou a venda organizada de terras pela Cia. Terras Norte Paraná. Entre 1933 e 1941, os japoneses eram o terceiro grupo mais forte entre os compradores de terra da CTNP, depois dos brasileiros e dos italianos (Tabela 3). Em 1950, dos 65 mil estrangeiros domiciliados no Paraná, os japoneses eram o grupo

216 Sobre isso, de modo geral, entre outros, Câmara e Neiva (1941); Willems (1951); Monbeig (1952); Sasaki (1958); Dorneich (1960); Saito (1961); Smith (1953); e uma visão geral da bibliografia de Harms - Baltzer (1968a e 1968b). 
mais expressivo, com $23 \%$, cuja porcentagem na população total do estado, porém, correspondia apenas a $0,7 \%$.

Em 1958, dos quase 400 mil japoneses e brasileiros descendentes de japoneses que eram domiciliados no Brasil, 75\% viviam no estado de São Paulo e 18\% no Paraná (SAITO, 1961, p. 159) - os últimos, quase sem exceção, na parte norte do estado.

Apesar de os japoneses terem um papel relativamente pequeno no plantio de café do Norte Novo e do Norte Novíssimo do Paraná, eles deram um impulso decisivo para o caráter cooperativo na região, com a construção da filial regional da 'Cotia'.

No cultivo de café ameaçado pela geada no norte do Paraná, os colonos de ascendência japonesa deram inúmeros estímulos para vantajosas culturas sucessoras.

A consciência de grupo deles - mais no sentido de união do que na forma de separação nacionalista -, sua capacidade para trabalhar duro e de maneira concentrada, e um vivo senso para desenvolvimento econômico e mercantil vantajoso produziram uma mobilidade social exemplar, cuja realização, através de diligências flanqueadas das sociedades japonesas de colonização e da infraestrutura comercial organizada cooperativamente, foi promovida e guiada conforme previsto.

\section{e) Mobilidade espacial: o exemplo dos cafeicultores alemães de Rolândia}

Para discorrer sobre os cafeicultores alemães ou de ascendência alemã em Rolândia (Norte Novo), é preciso antes atentar brevemente para a mobilidade espacial desses proprietários de empreendimentos de médio porte, no contexto de aquisição de terras para o cultivo de café. ${ }^{217}$

Para tanto, pode-se distinguir quatro grupos, cujas atividades, com diferentes motivações, concentram-se em duas fases de desenvolvimento e quatro áreas bastante distantes espacialmente:

1. No começo dos anos 1950, o objetivo do primeiro grupo era a expansão das plantações de café por meio da compra de terras no Oeste do Paraná. Sobretudo as condições extremamente favoráveis de crédito fundiário do Banco do Brasil, em Foz do Iguaçu, deram o impulso para isso.

Na região de Toledo (Vila Maripá), ao sul do rio Piquiri (a $360 \mathrm{~km}$ de Rolândia), havia ainda nessa época terras virgens, que foram loteadas por uma sociedade de colonização rio-grandense em porções de até 25 ha e compradas pelo grupo na forma de inúmeros lotes pequenos, com uma área total de muitos milhares de hectares. A fertilidade do solo era boa e a altitude de $550 \mathrm{~m}$ era propícia. Embora houvesse a consciência do perigo de geada, esperava-se poder reduzir esse fator de risco pelo aspecto da exposição das plantações no declive para norte ou pelo cultivo no espigão.

Após o começo do cultivo de café, os compradores de terra se transferiam mês a mês para a administração e para a supervisão das terras. As conexões de transporte e a aquisição de mão de obra foram extremamente difíceis. Por motivos de precaução, não se realizou nenhuma instalação fixa nos primeiros anos.

Depois de duas geadas leves e de uma boa colheita, com rápida recuperação dos cafeeiros, foram construídos terreiros e instalada uma máquina de descascar café. Depois, no entanto, as colheitas não puderam mais ser realizadas, em parte por causa das precipitações muito intensas e das geadas anuais, ocorridas extraordinariamente cedo. Assim, o experimento foi suspenso depois de quase uma década.

$2-3$. A partir dessas experiências, os outros grupos buscavam terras, que fossem baratas, livres de geada e propícias ao cultivo do café. O objetivo era, sobretudo, uma distribuição dos riscos no cultivo do café, por causa do perigo permanente de geada no Norte do Paraná.

Enquanto o grupo 2 migrava para o Espírito Santo, para as florestas tropicais inexploradas na fronteira sul do cultivo de cacau (1300 km de Rolândia em linha reta), o grupo 3, junto com um grande empresário industrial alemão, investia em plantações de café na região do Alto Jaurú, no noroeste do Mato Grosso, a uma distância de $1200 \mathrm{~km}$ de Rolândia ${ }^{218}$. Por causa das pragas na região próxima à costa, bem como dos problemas no controle do ciclo do trabalho, os proprietários residentes em Rolândia renunciaram às plantações de café no Espírito Santo. No Mato Grosso, as plantações dirigidas por paranaenses e por administradores alemães ainda existem neste início dos anos 1970, apesar das longas distâncias e péssimas conexões de transporte.

217 Informações gentilmente cedidas por diversos cidadãos de Rolândia, especialmente Sr. H. M. Bresslau.

218 Sobre o desenvolvimento na área de Alto Jaurú, cf. Pfeifer (1966a, p. 326ss.). 
4. O desenvolvimento mais recente mostra o desvio de um quarto grupo para o nordeste do Paraguai (região de Pedro Juan Caballero). Apesar de essa região distar algo como $500 \mathrm{~km}$ em linha reta, só se consegue chegar a ela percorrendo-se aprox. $900 \mathrm{~km}$ por estrada. O investimento em plantações de café em uma faixa de terra roxa do platô de Amambay, no Paraguai, tem motivos econômicos. O Paraguai não cobra impostos sobre o café, o que chega a render mais que o dobro para os plantadores de café na exportação, embora a condição de transporte seja bastante desfavorável. Por outro lado, o risco de geada é considerável. Apenas poucas plantações com localização favorável conseguiram escapar da geada em 1969.

A partir de uma visão geral ecológica e econômica, o empenho dos diferentes grupos de proprietários de plantações de café de Rolândia mostra que o cultivo de café já ocupa uma posição ideal e que a variedade de áreas de cultivo favoráveis já está esgotada. ${ }^{219}$

\section{f) Norte do Paraná: região-alvo da migração interna}

A caracterização do norte do Paraná como região-alvo para migração interna regional e suprarregional trouxe a essa região um benefício migratório significativo nas década de 1950 e 1960. Especialmente em comparação com as regiões mais importantes de cultivo de café do estado de São Paulo até o momento, a posição de exceção na evolução populacional absoluta e relativa é nítida (Mapa 24) ${ }^{220}$.

No Norte do Paraná, a distribuição da densidade populacional em 1960 (Mapa 25) mostra, de maneira impressionante, um direcionamento de oeste para sudoeste, o que se reflete na expansão do frontier do café. Na zona central, na região da divisora de águas entre Londrina e Maringá, os valores chegaram a mais de 75 habitantes por $\mathrm{km}^{2}$. Em alguns lugares na região de concentração urbana de colônias, os números sobem para mais de 100 por $\mathrm{km}^{2}$. Em direção ao sul, na zona periférica do cultivo de café com forte perigo de geada, ocorre uma queda rápida da densidade populacional na área de contato com a economia primitiva de sistema de rotação de terras na região de florestas de Araucária do Paraná central, em grande parte destruídas.

A propagação extensiva da densidade relativamente alta da população no Norte do estado se dá em clara oposição a ambas as zonas restantes de concentração relativa. No Sudoeste, os valores uniformes de densidade são um sinal do desenvolvimento da pequena propriedade rural pelos descendentes de colonos europeus do Rio Grande do Sul e Santa Catarina, na base da distribuição igualitária de propriedade. O Sudeste do Paraná, zona do primeiro e segundo planalto colonizada há tempos, aponta, ao contrário, para fortes fenômenos de densificação em torno de Curitiba e do centro urbano regional de Ponta Grossa. As regiões de pecuária extensiva dos Campos Gerais apresentam uma densidade populacional bastante pequena.

Entre 1950 e 1960, a intensidade dos processos de mobilidade da população rural, no Norte do Paraná, foi marcada pela fase final da expansão do cultivo de café brasileiro, que ocorre já há mais de um século. Essa década trouxe não apenas uma ampliação extraordinária das áreas de cultivo e um crescimento da produção de café, como também apresentou o apogeu de um fluxo de processo que se acelerou desde o fim da guerra, na velocidade da expansão do frontier do café (Mapa 19, 1950; Mapa 26, 1962-1964).

O Mapa 26 fornece uma impressão da propagação espacial de rendimentos relativamente altos 221 do cultivo de café no Norte do Paraná, sobretudo na comparação entre Paraná e São Paulo. A análise subsequente da economia agrária do Norte do Paraná posiciona-se sobretudo quanto à questão da predominância do cultivo de café e de sua estrutura interna.

219 Sobre a questão das áreas potenciais de cultivo de café, ver também Jonasson (1958).

220 O Norte Novíssimo, partes do Norte Novo (Maringá), o oeste e sudoeste do estado aparecem na estatística de 1950 e 1960 ainda como 'zona oeste' e são apresentados de maneira correspondente no Mapa 24.

221 Os valores de produção no Mapa 26 se relacionam a uma 'cálculo de densidade’ por hectare de área municipal e, por isso, aparecem desproporcionalmente baixos. No Paraná, o rendimento médio, em 1961, foi de 784kg por hectaare de área de cultivo de café. O rendimento trienal de 1962 a 1964 foi menor que a média correspondente de colheitas normais, por causa das geadas de 1962 e 1963. 


\section{POSIÇÃO E ANÁliSE DA ESTRUTURA DO CULTIVO DO CAFÉ NO NORTE DO PARANÁ NO INÍCIO DOS ANOS 1960}

O momento escolhido de 1960 e 1961 é caracterizado pelo fim do amplo ciclo migratório do cultivo de café. O frontier do café alcançou o rio Paraná; o cultivo de café ocupou espaços de apropriação qualitativamente graduados de acordo com fatores climáticos e pedológicos. Em seu desenvolvimento espacial e predominância econômica, o boom do café atingiu o seu apogeu no Norte do Paraná.

No ano de 1961, mais de 65\% das atividades agrícolas do Norte do Paraná implementou o cultivo de café a oeste do rio Tibagi. Com isso, negligenciam-se as áreas periféricas do Norte Novo e Novíssimo mais ao sul, nas quais se renunciou incisivamente à plantação de café por causa do perigo mais elevado de geada; assim, a porcentagem na área restante aumenta em $74 \%$.

O cultivo de café ocupa $71 \%$ da área total cultivada da zona analisada e $82 \%$ da terra cultivada dos empreendimentos para cultivo de café222. A área de cultivo de café no Norte Novo perfazia 685.000 ha e, no Norte Novíssimo, 718.000 ha. Somente essas regiões do Paraná possuem $24 \%$ da totalidade de cafeeiros no Brasil ${ }^{223}$ e quase $40 \%$ da produção de café do país.

Como então classificar o cultivo de café dentro da área total do empreendimento?

\section{a) O uso da terra no Norte Novo e no Norte Novíssimo}

Em termos de diferenciação regional, o estudo do uso da terra no Norte Novo e Novíssimo (Tabela 16, p. 106) evidencia uma predominância muito forte, até mesmo absoluta, da cultura permanente nas regiões de Londrina e sobretudo Maringá. A parte da cultura permanente na área das propriedades, ou seja, do cultivo de café, atinge o seu máximo com $61,4 \%$, na região em torno de Maringá, e diminui claramente nas áreas periféricas do sul (região de Apucarana e Campo Mourão). Lá, a parte da área para cultura temporária, sobretudo de alimentos de primeira necessidade, cresce nitidamente e supera a área para cultivo de café na região de Campo Mourão. Os pastos de desmatamento se desenvolveram, contudo a criação de gado encontra-se num estágio ainda inicial de desenvolvimento. Em todo o Norte Novíssimo (40\%), assim como ao sul do Norte Novo (Apucarana: 30\%), a porção de floresta na área dos estabelecimentos agrícolas era, em 1960, ainda considerável (ver Tabela 16).

Os estágios de desenvolvimento podem ser percebidos na porção da área das propriedades agrícolas dentro da área municipal, que perfaz quase $88 \%$, na região em torno de Londrina e mais de $75 \%$ no Norte Novo como um todo. Por volta de 1960, também o norte do Norte Novíssimo (Paranavaí) já havia sido apropriado em sua maior parte (área de atividade: $77 \%$ da área total), enquanto que na região de Umuarama a área dos estabelecimentos agrícolas ocupava somente algo mais que um terço da área total que, em sua maior parte, ainda era de florestas. No entanto, essa apropriação de terra tinha se realizado no decorrer de poucos anos.

A observação da porção da área de cultivo de café na terra cultivada em âmbito municipal (Mapa 27) acaba por mostrar a predominância, em grande medida absoluta, do cultivo de café, que compreende, por exemplo, na região de Maringá, em média $72 \%$ da área cultivada, e, em casos isolados, atinge mais de $80 \%$. Apenas nas áreas de cultivo mais ao sul, com grande risco de geadas, o café fica atrás de outros produtos agrícolas. De maneira geral, as áreas de pastagem, quase sem exceção artificiais, ocupam a segunda posição depois do café.

Em 1960, durante o auge do boom do café, esse modelo de cultivo não era de modo algum limitado à região dos solos férteis de terra roxa, mas se estendia também até a região dos solos arenosos do Oeste e Noroeste, como mostra o Mapa 27.

222 Dados numéricos segundo IBC-OEA (1964), recalculados para nível regional.

223 O total de cafeeiros na área em estudo perfazia 1,035 bilhões em 1961. 


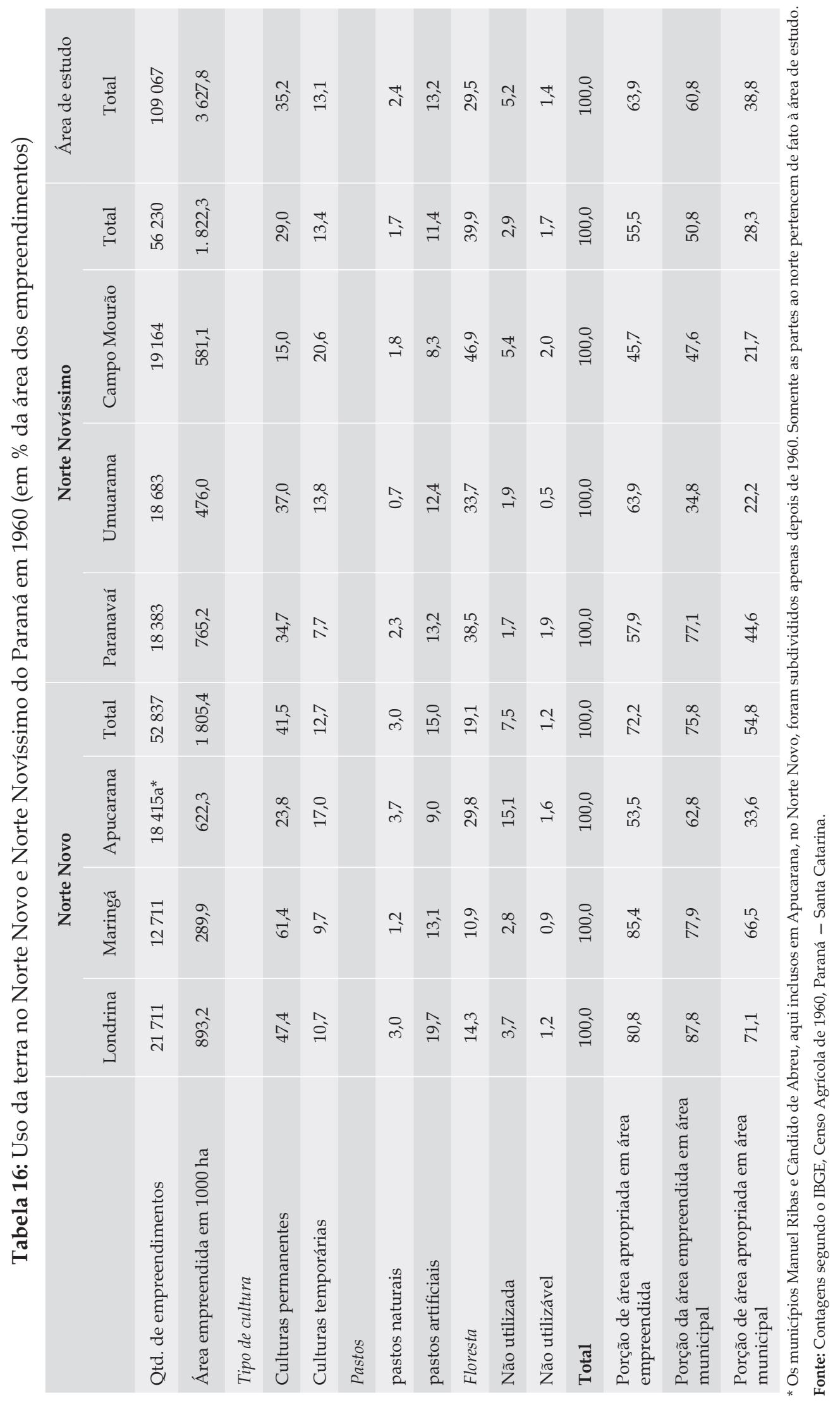




\section{b) Tamanho do empreendimento}

A diferenciação do tamanho dos empreendimentos agrícolas da área em estudo é apresentada na Tabela 17 para as regiões específicas do Norte Novo e Novíssimo.

A concentração das escalas de frequência de empreendimentos e de suas áreas mostra uma proeminência inequívoca dos empreendimentos entre 10 e 50 ha, que, na região de Maringá, são, por exemplo, $55 \%$ do número e $53 \%$ da área dos empreendimentos. A grande importância dos empreendimentos de pequeno e médio porte remonta sobretudo à distribuição de terra no contexto da colonização privada induzida no Norte do Paraná.

As porções correspondentes da área dos empreendimentos das classes de tamanho específicas na área de empreendimento total (Mapa 28) mostram um modelo de distribuição característico e relativamente uniforme para partes vastas do Norte do Paraná, a oeste do Tibagi. A antiga área de colonização da CTNP se distingue claramente com uma porção de área predominante da pequena e média propriedade (até 50 ha). Em municípios como Terra Boa ou Jussara, as atividades de pequeno porte de até 20 ha ocupam, em parte, mais de $60 \%$ da área empreendida. Existem poucos empreendimentos com mais de 100 ha.

Apenas no norte e no sudeste da região de Londrina, no sul da região de Apucarana, assim como no Norte Novíssimo ao norte do rio Ivaí, os empreendimentos de grande porte ocupam uma posição significativa. As porções de área dos empreendimentos com mais de 500 ha ficam em Porecatu e Florestópolis (plantações de cana-de-açúcar e café do grupo Lunardelli), com $84 \%$ e $58 \%$ da área total, respectivamente, e, em Querência do Norte e Loanda, no rio Paraná, (pecuária) com $80 \%$ e $51 \% .{ }^{224} \mathrm{Na}$ região de Paranavaí, empreendimentos desse porte exigem mais de um terço da área do empreendimento (Tabela 17).

\section{c) Análise da estrutura dos empreendimentos de cultivo de café}

Uma clara diferença vem à tona ao se comparar as dimensões de empreendimentos de plantio de café das regiões pesquisadas com outras regiões agrícolas do Brasil:

Em média, a área de empreendimento no Norte Novo comporta 49,7 ha, no Norte Novíssimo 69,5 ha, em Minas Gerais 76 ha e em São Paulo 115 ha. Porém, quando se compara cada área de plantio de café por empreendimento, então, as regiões paranaenses, com áreas entre 21,8 e 26,7 ha, são muito maiores que as áreas médias de plantação de café por empreendimento em Minas Gerais $(8,4$ ha) e São Paulo (16,2 ha), mesmo que as dimensões totais de área das últimas sejam maiores. ${ }^{225}$

No Norte do Paraná, segundo o número de cafeeiros, o conjunto de ordens de grandeza de empreendimentos de plantio de café mostra o claro domínio dos pequenos e médios empreendimentos. Como critério de delimitação para empreendimentos pequenos, médios e de grande porte no plantio de café, entre outros, tem-se a existência de instalações para secagem, preparação, classificação etc., e, quanto ao funcionamento, começa-se vagarosamente a partir de 16.000 árvores, aumenta-se significativamente a partir de $64.000^{226}$ e torna-se regra de instalação a partir de 100.000 a 120.000 árvores.

224 Cálculos segundo IBGE, Censo Agrícola de 1960. Paraná - Santa Catarina.

225 Segundo informações no IBC-OEA (1964) e UNITED NATIONS - ECLA/FAO (1960). (Para São Paulo 1958, Paraná e Minas Gerais 1961).

226 Segundo o esquema classificatório do Instituto Brasileiro do Café no IBC-OEA (1964). 


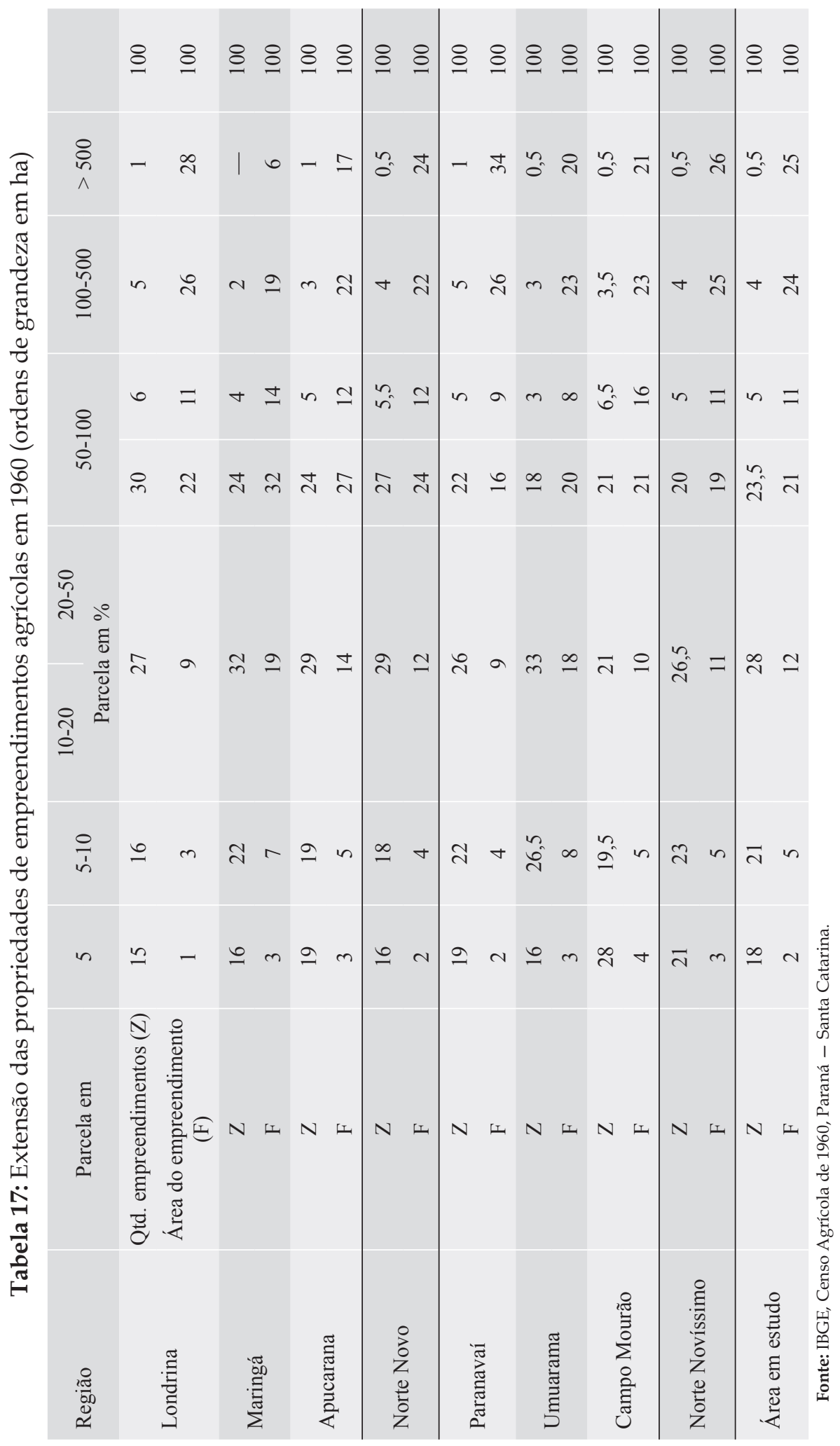


Tabela 18: Ordens de grandeza dos empreendimentos rurais com plantio de café em 1961

\begin{tabular}{|c|c|c|c|}
\hline \multirow{2}{*}{ (em 1000 cafeeiros) } & & Qtd. empreendimentos & Qtd. cafeeiros \\
\hline & & \multicolumn{2}{|c|}{ Parcela em \% } \\
\hline$<1$ & $\begin{array}{l}\text { Menor empreend. } \\
\text { (chácara) }\end{array}$ & 4,4 & 0,2 \\
\hline $\begin{array}{c}1-4 \\
4-8 \\
8-16\end{array}$ & $\begin{array}{l}\text { Pequeno empreend. } \\
\text { (sítio) }\end{array}$ & $\begin{array}{l}11,1 \\
31,3 \\
26,5\end{array}$ & $\begin{array}{c}1,5 \\
10,3 \\
16,6\end{array}$ \\
\hline $\begin{array}{l}16-32 \\
36-64\end{array}$ & $\begin{array}{l}\text { Empreend. médio } \\
\text { (sítio) }\end{array}$ & $\begin{array}{c}14,8 \\
7,6\end{array}$ & $\begin{array}{l}17,8 \\
19,2\end{array}$ \\
\hline \multirow[t]{2}{*}{$\begin{array}{c}64-128 \\
128-256 \\
256-1.024 \\
>1.024\end{array}$} & $\begin{array}{l}\text { Grande empreend. } \\
\text { (fazenda) }\end{array}$ & $\begin{array}{l}2,8 \\
1,1 \\
0,4\end{array}$ & $\begin{array}{c}13,5 \\
10,5 \\
8,4 \\
2,0\end{array}$ \\
\hline & & 100,0 & 100,0 \\
\hline
\end{tabular}

Fonte: IBC-OEA (1964).

Enquanto $73 \%$ dos empreendimentos com parcos $29 \%$ de cafeeiros têm menos que 16.000 cafeeiros, $22 \%$ pertencem, com $37 \%$ do estoque, ao grupo das propriedades de médio porte, que ainda são chamadas igualmente de sítio; com relação às maiores, em parte, já são chamadas de 'fazenda'.

Em 1961, apenas 4,3\% dos empreendimentos com 34\% do número total de cafeeiros ${ }^{227}$ podiam ser considerados empreendimentos de grande porte ('fazendas').

Isso levanta a questão quanto a tratar-se realmente de plantations nesses empreendimentos de grande porte. O conceito de plantation na forma clássica de Waibel (1933) e na tipologia de Gerling (1954) deve ser ampliado ao aspecto social e econômico e compreendido "somente como conceito geral abrangentes". 228

Precisamente com relação às plantações de café no Brasil, não se trata de uma forma tradicional de serviço 'colonial', mas sim de procedência 'nacional', no que diz respeito aos proprietários de terra, empreendedores ou administradores, e, em parte, também à organização da comercialização e da exportação. Na estrutura social daqueles que se ocupam das plantações de café, desenvolvem-se formas especiais (por exemplo, empreiteiro) (ver Cap. IV, 2) que certamente mostram traços bastante distintivos na fase inicial. Da mesma forma, o trabalho rural reestruturado através da legislação agrária não pode ser visto como um grupo social uniforme, como se tentou apresentar nas ponderações do capítulo anterior.

Os critérios das dimensões dos empreendimentos e a expansão territorial de culturas específicas de plantio seguiram orientados para a monocultura, bem como a grande necessidade de mão de obra e a orientação do mercado mundial, 229 e também altos investimentos capitalizados para instalações, necessários para o processo de preparação e comercialização (terreiro, instalações de secagem; máquina de beneficiamento, máquina descascadora; separadora; ensacamento de grãos, meios de transporte etc.)

Partindo-se da dimensão do empreendimento, o valor limite mais baixo citado para empreendimentos de grande porte (64 mil cafeeiros) corresponde, então, a uma área de plantio de 88 ha. ${ }^{230}$ Segundo a tabela 19 abaixo, a parcela de área de plantio de café, na área de empreendimento de grande porte de 64 a 128 mil, compreende $33,8 \%$, de modo que o valor limite da área do empreendimento compreende, quanto à ordem de grande porte de 64.000 árvores, em torno de 260 ha.

Essa área de empreendimento e o tamanho da área de plantio do cash crop - cuja parcela na área do empreendimento é relativamente baixa, conforme relevo e expansão da área nos vales com perigo

227 Esses valores concernem a todo o Norte do Paraná, também o Norte Velho, e não puderam ser classificados por meio das estatísticas existentes. O número dos empreendimentos de grande porte e a parcela correspondente de cafeeiros devem ser consideravelmente menores no Norte Novo e Novíssimo.

228 Manshard (1968, p. 140); sobre isso, ver Courtenay (1969) e em Kostrowicki e Tyskiewicz (1970, p. 91ss.).

229 O cultivo de café de empreendimentos agrícolas no Norte do Paraná sustentados por uma ampla classe média também é orientado pelo mercado mundial.

230 Em uma densidade de plantação de 730 cafeeiros/ha, ou seja, 13,7 $\mathrm{m}^{2}$ para cada árvore, o que no Paraná corresponde, em média, a empreendimentos com mais de 64.000 cafeeiros (IBC - OEA, 1964, p. 123). 
de geadas no caso especial do Paraná - formam, juntamente com a acumulação já mencionada de instalações técnicas e os investimentos capitalizados necessários para isso, um limite mais baixo para a designação de plantations ${ }^{231}$.

A sensibilidade conjuntural do café como produto e a situação especial do risco de geada no Paraná refletem-se em uma tendência crescente de diversificação de plantações, assim como a criação de bovinos ${ }^{232}$ que, no entanto, se difere ainda fortemente dos empreendimentos paulistas de café e bovinos ou café e lavouras ${ }^{233}$.

Tabela 19: Parcela de cultivo de café em área de empreendimento e área de cultivo dentro de cada ordem de grandeza dos empreendimentos

\begin{tabular}{|c|c|c|c|}
\hline Em 1000 cafeeiros & $\begin{array}{c}\text { Área de empreendimento } \\
\text { em } 1.000 \text { ha }\end{array}$ & $\begin{array}{c}\text { Parcela da área de cultivo de café } \\
\text { na área de empreendimento }(\%)\end{array}$ & $\begin{array}{c}\text { Parcela da } \\
\text { área de cultivo de café } \\
\text { em terreno agrícola }(\%)\end{array}$ \\
\hline$<1$ & 26,6 & 22,2 & 69,4 \\
\hline $1-4$ & 234,6 & 15,8 & 43,9 \\
\hline $4-16$ & 194,0 & 39,4 & 76,2 \\
\hline $16-32$ & 301,2 & 41,5 & 82,3 \\
\hline $12-64$ & 310,4 & 50,0 & 83,6 \\
\hline $256-128$ & 347,7 & 46,0 & 88,6 \\
\hline 1.024 & 231,1 & 33,8 & 83,7 \\
\hline
\end{tabular}

Fonte: IBC - OEA (1964).

Nos empreendimentos de médio porte (com entre 16 e 32 mil cafeeiros), a parcela de área de cultivo de café na área de empreendimento está com 50\% no máximo. Mesmo que dos altos valores da parcela de plantações de café no terreno agrícola se possa deduzir o domínio da monocultura do plantio de café, deve-se aqui enfatizar a importância das plantações paralelas. Essa plantações paralelas, no entanto, não se limitam no Paraná de modo algum apenas às partes próximas das casas, mas formam, em grande medida, uma verdadeira cultura mista, ${ }^{234}$ que não se limita somente aos primeiros quatro anos até o começo da primeira colheita das plantações de café, diferentemente das regiões de plantio de café restantes no Brasil. No total, mais de $60 \%$ das áreas de cultivo de café apresentam plantações paralelas de milho ( $44 \%)$, feijão $(27 \%)$, arroz ( $26 \%$ ) etc., de modo que os valores em pequenos empreendimentos e de médio e grande porte têm diferenças irrelevantes $(54-65 \%){ }^{235}$

231 Já apontou-se anteriormente que uma autonomia total no beneficiamento e na comercialização no Norte do Paraná frequentemente só se alcança em empreendimentos com mais de 100.000 cafeeiros, que, em média, possuem por volta de 400 ha de área empreendida.

232 Em média, no ano de 1961, com relação aos empreendimentos que cultivam café do Norte do Paraná, 40\% da área empreendida estava com café plantado e $9 \%$ com plantio de frutas. $18 \%$ foram ocupados por pastagem, $3 \%$ por estradas, construções etc., $7 \%$ por capoeira, $19 \%$ por mata virgem. A parcela de reflorestamentos consiste em $0,3 \%$, e 3,4\% não foram utilizados (segundo IBC - OEA, 1964, p. 44).

233 Lá, são comuns valores menores ou pouco maiores que 20\% para áreas de plantio de café e o restante de 40 - 65\% para áreas de pastagem ou $40-50 \%$ para área de cultivo. Cf. United Nations (ECLA/FAO), 1960, 11 e exemplos utilizados em Blankenburg e Cremer (1967, 1 p. 191-192).

234 As declarações contrastivas de Manshard (1968, p. 144) não se aplicam no Paraná e, em São Paulo, somente em parte.

235 Apenas em pequenos empreendimentos de menos de mil árvores, são cultivados somente $27 \%$ da área de plantio com plantações paralelas (IBC - OEA, 1964, p. 118). 
As plantações paralelas ${ }^{236}$ são cash crop apenas para os empreiteiros, caso contrário elas servem quase que exclusivamente como abastecimento de alimentos básicos para trabalhadores rurais, parceiros etc.

De uma visão econômica, o café como cash crop tem uma posição monopolizadora. No começo dos anos 1960, 90\% dos rendimentos de pequenos e médios empreendimentos foi o café, e em empreendimentos de grande porte significou em média $70 \%$.

Tabela 20: Idade das plantações de café nas regiões de cultivo do Norte do Paraná em 1961

(Parcelas em \%)

\begin{tabular}{|c|c|c|c|c|c|}
\hline Idade em anos & Época de plantio & $\begin{array}{c}\text { Norte } \\
\text { Novíssimo }\end{array}$ & $\begin{array}{l}\text { Norte } \\
\text { Novo }\end{array}$ & $\begin{array}{l}\text { Norte } \\
\text { Velho }\end{array}$ & Total \\
\hline até 3 & $1959-61$ & 11,6 & 5,6 & 3,6 & 7,9 \\
\hline $4-6$ & $1956-58$ & 13,8 & 6,4 & 7,0 & 9,7 \\
\hline $7-12$ & $1950-55$ & 71,3 & 57,8 & 38,0 & 60,0 \\
\hline $13-20$ & $1942-49$ & $\begin{array}{l}\text { Sobretudo a partir de } \\
\text { 1947: } 3,3\end{array}$ & 26,4 & 26,2 & 16,1 \\
\hline $21-30$ & $1932-41$ & - & 3,5 & 17,2 & 4,6 \\
\hline$>30$ & antes de 1932 & - & 0,3 & 8,0 & 1,7 \\
\hline & & 100,0 & 100,0 & 100,0 & 100,0 \\
\hline \multicolumn{2}{|c|}{ cafeeiros em milhões } & 564,8 & 470,3 & 245,9 & $1.281,0$ \\
\hline \multicolumn{2}{|c|}{ Idade média em anos } & 8,1 & 11,3 & 15,7 & \\
\hline \multicolumn{6}{|c|}{ Estoque total segundo grupos de idade } \\
\hline até 3 & $1959-61$ & 64,7 & 26,4 & 8,9 & 100,0 \\
\hline $4-12$ & $1950-58$ & 53,7 & 33,9 & 12,4 & 100,0 \\
\hline $13-20$ & $1942-49$ & 9,0 & 59,9 & 31,1 & 100,0 \\
\hline$>20$ & antes de 1942 & -- & 22,5 & 77,5 & 100,0 \\
\hline
\end{tabular}

Fonte: IBC - OEA (1964).

Em 1961, no Norte Velho, nordeste do estado, mais do que 25\% dos cafeeiros existentes tinham acima de 20 anos (plantio anterior a 1942); no Norte Novo, por outro lado, menos de 4\%. Enquanto mais do que um quarto dos cafeeiros no Norte Velho e no Norte Novo foram plantados entre 1942 e 1949 (sobretudo depois de 1946), somente neste momento começou o plantio no recém-constituído Norte Novíssimo. A primeira metade dos anos 1950 trouxe o grande boom do café. Nas regiões jovens de colonização foi implementada muito mais do que a metade das plantações de café existentes; no Norte Novíssimo mais do que 70\% neste período de tempo de 5-6 anos (1950 até 1955), e se encontravam, no começo dos anos 1960, na melhor idade de produção (7-12 anos).

Em 1961, aproximadamente 12\% dos cafeeiros do Norte Novíssimo ainda não tinham chegado à idade de produção, outros $14 \%$ ainda se encontravam em estágio inicial. Esse fato fez com que a zona pioneira do noroeste esperasse por um próximo aumento considerável da produção.

O grave problema da produção excedente de café ocorreu não somente por conta da quantidade de cafeeiros em plena produção, mas sobretudo pelos altos rendimentos consequentes, que foram obtidos graças aos solos virgens do Norte do Paraná.

Em 1961, o rendimento médio no Norte Novo ascendeu a 1.309 kg para cada mil árvores, ou seja, 904 kg/ ha de área cultivada. São valores excepcionalmente altos, que mostram a fertilidade da terra roxa. ${ }^{237}$

236 Veja também Cap. VIII, 1a, Tabela 41 (p. 310, Anexo) e Mapas 36-38.

237 Ademais, cabe observar que as declarações do Instituto Brasileiro do Café consideram o número total de cafeeiros, ou seja, incluem também os que ainda não estão produzindo. Considerando apenas os cafeeiros com mais de 3 anos, os números de rendimento são aproximadamente 8-9\% mais altos. 
Apesar de os números de rendimento nos solos arenosos do Norte Novíssimo consistirem em $770 \mathrm{~kg} / 1.000$ árvores ou $609 \mathrm{~kg} / \mathrm{ha}$ - quase $50 \%$ mais baixos do que na região da terra roxa - , eles ainda superam amplamente - no estágio inicial de produção - os rendimentos das outras regiões brasileiras de cultivo: São Paulo (1958: 446 kg/ha), Minas Gerais (347 kg/ha) e Espírito Santo (307 kg/ha). Os números de rendimentos comparáveis com a Colômbia compreendem $523 \mathrm{~kg} / \mathrm{ha}$ em 1955/56 e, em 1954/55 em El Salvador, 659 kg/ha, e são também consideravelmente mais baixos do que os valores médios do Norte Novo e também abaixo da média de todo o Paraná (784 kg/ha). No Norte Novo, apenas $27 \%$ dos cafeeiros foram adubados ( $8 \%$ de adubo químico, $19 \%$ orgânico), no Norte Novíssimo até mesmo apenas $21 \%$ deles. ${ }^{238}$

\section{d) Formas de gestão de cultivo}

A análise da forma de gestão de cultivo das plantações de café mostra que $35 \%$ dos empreendimentos com plantio de café ( $27 \%$ dos cafeeiros) são geridos por parceiros (sobretudo meeiros), 33\% (13\%) pela família do proprietário, $11 \%$ (23\%) por colonos, $7 \%(10 \%)$ por diaristas, $6 \%$ por meeiros e proprietários, $1,5 \%$ por colonos e proprietários, $1,4 \%$ por empreiteiros ( $5 \%$ dos cafeeiros); o restante foi gerido por outras combinações (IBC-OEA, 1964, p. 66).

Com isso, a média do tamanho do empreendimento aumenta - dependendo da forma de gestão de cultivo - de 7.000 cafeeiros, com relação a empreendimentos geridos somente pelo proprietário, para mais de 13.000 quando geridos pelos parceiros; 38.000 quando geridos por colonos; e para 65.000 quando geridos pelos empreiteiros.

Segundo uma pesquisa por amostragem do IBC em 1961, as formas de gestão de cultivo e as classes de dimensões de empreendimentos com plantio de café estão correlacionadas da maneira como demonstrada na Tabela 21.

Tabela 21: Formas dominantes de gestão de cultivo no cultivo de café segundo a posição do gestor e ordens de grandeza dos empreendimentos

\begin{tabular}{|c|c|c|c|c|c|c|c|}
\hline \multirow[t]{2}{*}{ em 1000 cafeeiros } & proprietário & colono & parceiro & empreiteiro & diarista & outros & Total \\
\hline & \multicolumn{7}{|c|}{ Parcela em \% } \\
\hline$<1$ & 51 & 5 & 49 & & & & 100 \\
\hline $1-4$ & 63 & 5 & 32 & & & & 100 \\
\hline $4-8$ & 49 & 6 & 39 & 1 & 5 & & 100 \\
\hline $8-16$ & 31 & 11 & 44 & 2 & 11 & 1 & 100 \\
\hline $16-32$ & 19 & 16 & 50 & 6 & 9 & & 100 \\
\hline $32-64$ & 8 & 36 & 31 & 7 & 14 & 4 & 100 \\
\hline $64-128$ & 2 & 41 & 26 & 8 & 13 & 10 & 100 \\
\hline $128-256$ & 1 & 34 & 12 & 23 & 23 & 7 & 100 \\
\hline$>256$ & - & 56 & 5 & 7 & 31 & 1 & 100 \\
\hline
\end{tabular}

Fonte: IBC-OEA (1964); resumo generalizante.

A parcela de proprietários rurais entre os gestores se reduz rapidamente com o crescimento da dimensão do empreendimento. Empreendimentos de grande porte quase não são geridos pelo próprio proprietário, prevalece o absentismo [absentee-ownership]. Os parceiros também retrocedem com o aumento da dimensão do empreendimento. A tendência contrária observa-se com relação aos colonos e diaristas, cuja parcela aumenta com a dimensão do empreendimento. A forma de gestão de cultivo mostra, através dos empreiteiros, um aumento médio da propriedade de grande porte; apenas com relação a grandes plantações fortemente capitalizadas o empreiteiro tem uma importância menor, pois o

238 Adubos químicos são utilizados apenas em empreendimentos de grande porte. Com relação ao adubo orgânico predomina a palha de milho $(80 \%)$. 
administrador sediado trabalha preferencialmente com colonos contratados ou diaristas que não podem exigir parcela alguma da colheita de café. Dentro de cada ordem de grandeza dos empreendimentos, o proprietário é responsável pela gestão de até 8.000 cafeeiros, nos empreendimentos pequenos e médios (de 8 a 16 mil e de 16 a 32 mil, respectivamente) cabe ao parceiro essa responsabilidade, e, a partir dos empreendimentos de médio porte maiores, prevalece o colono na gestão do cultivo.

A alta parcela de parceiros (meeiros) evita, devido aos breves contratos de parceria - como já foi mencionado - uma gestão de cultivo conservadora e contínua no plantio de café. A economia de parceria é um dos principais motivos para a escassa difusão da adubação.

No que concerne ao estatuto jurídico de gestão de cultivo, há no nível do município dados do ano de 1960 somente para todos os empreendimentos agrícolas (Mapa 29). ${ }^{239}$

No total, predomina o número de empreendimentos geridos pelos proprietários no Norte Novo (62\%); na área central da antiga região de colonização da CTNP, predomina também sua parcela de área que alcança, em alguns municípios, valores entre 70 e $77 \%$. Aqui, representam exceção apenas terrenos de grande porte no norte, junto ao Rio Paranapanema, e no sul do Município de Londrina. Em 1960, $28 \%$ dos empreendimentos do Norte Novo foram geridos por arrendatários, dos quais $85 \%$ realizam os pagamentos com produtos.

Também no Norte Novíssimo prevalecem os empreendimentos dirigidos pelo proprietário rural e sua família (55\%). Contudo, sobretudo no Noroeste (região de Paranavaí), a parcela de área dos empreendimentos geridos pelo proprietário retrocede fortemente - como se pode depreender do Mapa 29. Lá, $50 \%$ da área do empreendimento - ou seja, grandes empreendimentos de médio e grande porte - é gerida pelo administrador. No Norte Novíssimo em 1960, a relação entre o pagamento em produtos e o pagamento em dinheiro em contratos de arredamento chega a 3:1.

A pouca influência dos ocupantes ativos sem título de propriedade é de especial importância para a estabilidade das relações legais de possse. Os ocupantes, em toda a região estudada, gerenciam apenas quase $2 \%$ dos 110 mil empreendimentos totais em cerca de 1,5\% da área. Essa porcentagem, para a zona pioneira brasileira, é extraordinariamente baixa e mostra o valor da colonização conduzida com atribuição impecável de título de propriedade. Isso vale para o Norte Novo desde o começo da colonização privada através da CTNP. Para o Norte Novíssimo, somente desde a regularização dos problemas legais de posse originados no âmbito da colonização estatal.

No final dos anos 1940 até o começo dos anos 1960, a análise global do desenvolvimento do plantio de café no Norte do Paraná mostra a construção de uma formação econômica ${ }^{240}$ que é determinada principalmente pelo plantio de café em sistemas empreendedores do campo. 284 mil famílias com 576 mil trabalhadores, ao todo 1,46 milhões de pessoas, foram domiciliadas em plantações de café ou se ocuparam das mesmas (IBC-OEA, 1964, p. 72-73).

O boom do café no Norte do Paraná, com a expansão extraordinariamente rápida das áreas de plantio e com os altos rendimentos em solos virgens, confrontou o Brasil em 1960 novamente com o problema da produção excessiva de café, que, três décadas antes, já tinha estremecido a economia do país.

A análise que se segue sobre a situação do mercado cafeeiro mostra as repercussões diretas das oscilações de preços sobre a atividade de plantio de café. Diante do pano de fundo da situação econômica e política do café de países produtores em desenvolvimento na América Latina, a nova crise cafeeira que se delineia trouxe o impulso decisivo para o começo dos anos 1960 segundo um empenho vagaroso em relação ao acordo internacional para o ajuste da produção e consumo de café.

239 Segundo IBGE, Censo Agrícola de 1960. Santa Catarina - Paraná.

240 O conceito de formação econômica foi cunhado pela primeira vez por Waibel em 1927, no exemplo de Sierra Madre de Chiapas. Pfeifer (1936) o introduziu posteriormente como formação agrícola. Para apresentação sistemática das observações de formação agrícola, cf. Nitz (1970, p. 82), assim como declarações na ocasião do simpósio sobre Waibel em Pfeifer (1972). 


\section{O DESENVOLVIMENTO DA SITUAÇÃO DO MERCADO CAFEEIRO MUNDIAL E O SIGNIFICADO DO INTERNATIONAL COFFEE-AGREEMENT ${ }^{241}$}

\section{PROBLEMAS DE ESTABILIZAÇÃO DO MERCADO CAFEEIRO MUNDIAL}

A situação do mercado cafeeiro mundial ao final da Segunda Guerra Mundial foi o resultado de um processo de desenvolvimento complicado, em cujo transcurso a política cafeeira brasileira fez uma tentativa desesperada de manter os preços do mercado mundial através de restrições de plantio e destruindo grandes quantidades de café não-industrializado.

A destruição ${ }^{242}$ de cerca de 70 milhões de sacas de café $(60 \mathrm{~kg})$ no Brasil, entre os anos de 1931 e 1943 , em grande parte provenientes de aquisições de estoques de depósito mas também de novas colheitas de café, levou, no entanto, somente a uma desaceleração da queda de preços. O preço de venda do tipo Santos 4 em Nova York caiu de 9-11 centavos/lb. entre 1931 e 1937 para 7 centavos até o final de 1940, e foi então tabelado oficialmente em 13,4 centavos pelos Estados Unidos até 1945, de modo a reduzir os problemas de orçamento de produtores latino-americanos decorrentes das dificuldades de exportação ocasionadas pela guerra. ${ }^{243}$

Enquanto a safra média brasileira de café caiu de 24,5 milhões de sacas no começo dos anos 1930 para 14,4 milhões de sacas por volta do final da Segunda Guerra Mundial, as colheitas de café na Colômbia cresceram nesse período com um aumento contínuo de $50 \%$, enquanto a produção de café na América Central permaneceu quase a mesma. A Indonésia sumiu totalmente do mercado mundial em consequência da invasão japonesa; em comparação com isso, a produção de café na África triplicou!

No total, o balanço do mercado mundial mostrou, na média quinquenal, entre 1928/29 até 1933/34 e entre 1940/41 até 1945/46, uma redução da produção exportável de café por volta de 7-8 milhões de sacas.

A uma breve fase mundial de esgotamento após o término das negociações bélicas seguiu-se um forte aumento do consumo de café, sobretudo nos EUA. O produção de café refreada por décadas logo já não pôde mais suprir o crescimento surpreendentemente rápido do consumo de café, especialmente porque o potencial de consumo europeu começava a se recuperar. O déficit, no entanto, pôde ser suprido no primeiro momento por meio dos 6 milhões de sacas ainda existentes ao final da Guerra nos estoques de depósito brasileiros até seu esgotamento, em 1949 (ROWE, 1963, p. 13-14).

No Brasil, sobretudo em São Paulo, a mais importante área de produção de então, o plantio de café depois da Segunda Guerra Mundial a princípio só voltou a crescer relativamente devagar, especialmente porque os plantadores reagiram - após 15 anos de preços baixos, interdição de novos plantios (salvo Paraná) e destruição de colheitas - de maneira hesitante à situação do mercado mundial e à valorização do café.

A repentina escassez de café, que surgia pela primeira vez depois de duas décadas e depois de consumir totalmente os estoques que encobriam a verdadeira situação, causou uma subida de preço de 50\% no tipo Santos 4 de 1949 a 1950: de 33 centavos a 50,5 centavos/lb. ${ }^{244}$ Após alguns anos de estabilização dos preços de café, os preços explodiram em decorrência de notícias sobre os vastos

241 Tradução de Dionei Mathias e Natasha Pereira da Silva.

242 A maior parte foi queimada nas áreas de produção, afundada no mar ou também usada como combustível nas locomotivas. Quantidades menores serviram para a produção de adubo e produtos sucedâneos (DAMBAUGH, 1959, p. 42).

243 A estabilização do comércio de café no Ocidente durante a Segunda Guerra Mundial foi garantida pelo Inter-American Coffee Agreement (1940-1948), inspirado pelo desejo dos EUA de consolidar o apoio às forças aliadas por parte dos 14 países exportadores de café das América Latina (FREDERICK, 1970, p. 25).

244 Preços para Santos 4 na Bolsa de café de Nova York na média anual/em centavos/lb.: 1946: 18,7; 1947/48: 26 - 27; 1949: 33; (ROWE, 1963, p. 14). 
prejuízos decorrentes de geadas na segunda metade do ano de 1953 nas regiões brasileiras de plantio de café; Santos 4 alcançou em 1954 sua mais alta média mensal de 88 centavos! ${ }^{245}$

As oscilações de preço na Bolsa de café de Nova York mostram claramente uma dependência direta das condições brasileiras que influenciavam decisivamente a situação geral:

Se o aumento de preço do café em 1950 no Brasil já havia levado a uma expansão dos cafezais, agora, em 1954, o boom do preço do grão teve como efeito uma expansão das plantações cafeeiras até então desconhecida, ${ }^{246}$ sobretudo nas regiões pioneiras do Paraná (ver Cap. IV, 1b), e isso apesar do risco de geadas.

Como a perda da colheita por causa da geada de 1953 acabou sendo menor do que se temia ${ }^{247}$ e o ano de 1955 - por meio da regeneração dos cafeeiros atingidos pela geada como também através das plantações amanhadas no início dos anos 1950 que começavam a produzir - trouxe uma colheita especialmente grande (Figura 2), os preços do café voltaram a cair rapidamente (Figura 5).

A forte geada de 1955 nos estado do Paraná e São Paulo surtiu um aumento dos preços do mercado mundial das 'arábicas' colombianas, enquanto as variedades brasileiras mesmas aumentaram pouco. Apesar da subsequente queda abrupta dos preços do café por causa da oferta elevada, as plantações de café no Brasil, sobretudo no âmbito da exploração do Noroeste paranaense, mas também na África e em outros países da América do Sul e Central, continuaram a ser expandidas até o final dos anos 50 ( Figura 2).

Figura 5: Desenvolvimento de preços de determinados tipos de café

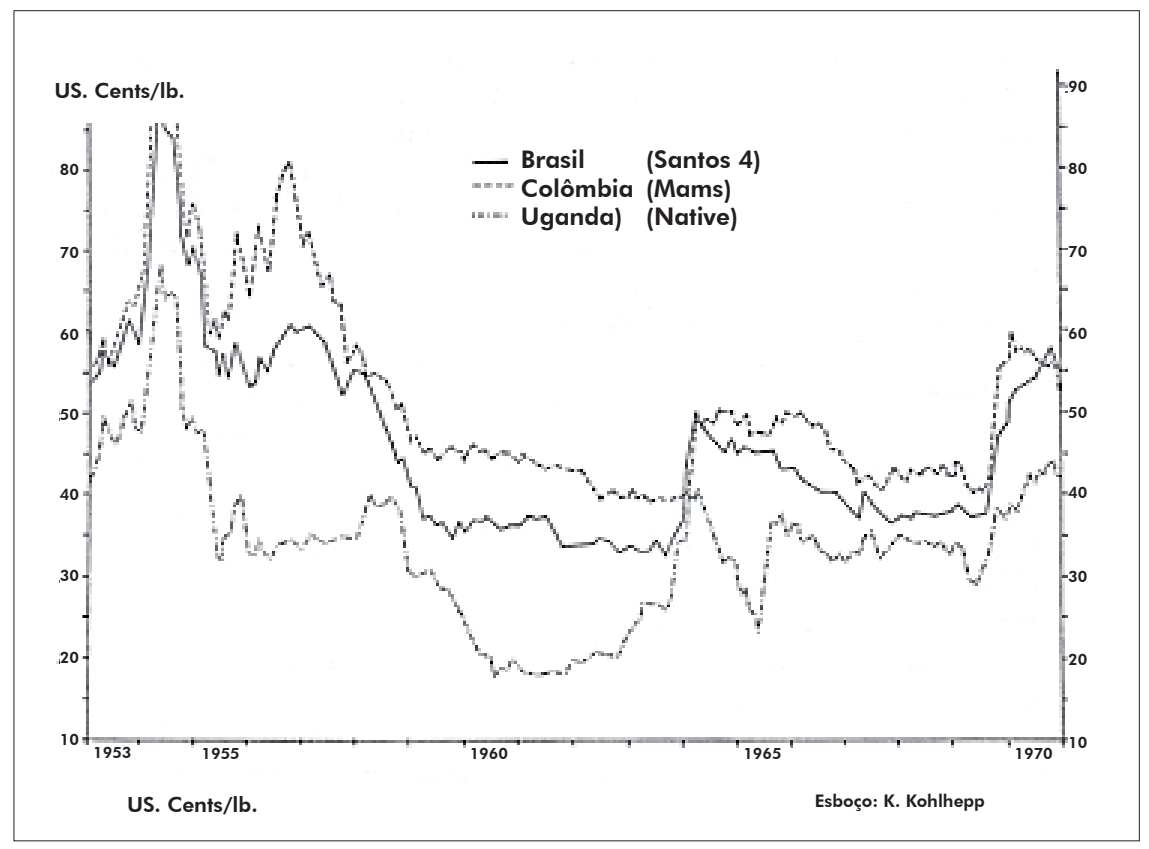

245 Ver Figura 5 de acordo com dados em: IBC, Anuário Estatístico do Café, 1968/70.

246 A quantidade de pés de café no Brasil cresceu de 2.337 milhões de árvores em 1950 para 3.865 milhões (1958/59), e só no Paraná cresceu, no mesmo período, de 233 a 1.141 milhões (Figura 2).

247 No Brasil, muitas vezes prejuízos relativamente pequenos ocasionados por geadas nas regiões de plantio de café foram dramatizados por parte dos plantadores e dos órgãos de controle regionais para conseguir empréstimos e subvenções.

No comércio internacional de café, notícias de geadas oriundas do Brasil aumentavam a exportação através de compras preventivas por parte dos países consumidores mais importantes. 
Quando em 1957 novamente sérios problemas de excedente por parte dos principais países produtores voltavam a acossar o comércio internacional de café, fortaleceu-se a tendência geral de um acordo multilateral no mercado cafeeiro mundial.

\section{TENTATIVAS INTERNACIONAIS DE COORDENAÇÃO E FUNDAMENTOS DO ICA}

Os esforços unilaterais de décadas por parte do Brasil para tabelar os preços de café não haviam surtido efeito. Tampouco as Conferências Cafeeiras em Sevilha (1929), São Paulo (1931), Bogotá (1936), Havana (1937), Nova York (1940) e Washington (1940) levaram a acordos internacionais, com exceção do Interamerican Coffee Agreement ocasionado pela guerra. ${ }^{248}$ Foi somente o Pacto da Cidade do México de 1957 que originou um acordo suprarregional diante da delicada situação cafeeira mundial: Brasil, Colômbia, Costa Rica, El Salvador, Guatemala, México acordaram a fixação de cotas de exportação.

Em 1958 essa convenção se estendeu para um Latin-American Coffee Agreement [Acordo Latinoamericano do Café], com a adesão de 15 nações. A partir disso, desenvolveu-se em 1959 uma convenção internacional, na qual o Brasil, dentre outros países, aceitou um controle da exportação e do transporte do café para os portos de exportação, e, como todo país produtor de café, deveria reter futuramente como reserva $20 \%$ da média do café exportado entre 1957 e 1958. A França e Portugal tornaram-se membros por causa das colônias africanas, a Inglaterra e a Bélgica garantiram uma restrição da exportação de suas colônias africanas com base na convenção. Quando o Reino Unido tornou-se efetivamente membro em 1960, na convenção, que foi prorrogada em 1960 e 1961 por um ano, estava associada cerca de $90 \%$ da produção mundial de café para a exportação.

Desde 1958, um grupo de pesquisa sobre o café estava encarregado da análise da situação mundial do café, com o objetivo de redigir uma convenção internacional a longo prazo. A Coffee Federation of the Americas (FEDECAME) ${ }^{249}$ - que representava os tipos de café ameno das regiões elevadas e o Brasils - e a Inter-African Coffee Organisation (I.A.C.O.) - fundada no final de 1960 e porta-voz das 'robustas' - funcionavam como representações regionais de interesse no círculo inflexível em torno da solução do problema dos excedentes da produção de café.

O desenvolvimento da constelação política no hemisfério ocidental por meio da presença comunista em Cuba deu um impulso decisivo para a conclusão da convenção internacional do café.

Depois do presidente Kennedy ter anunciado a 'Aliança para o Progresso' em março de 1961, os EUA acentuaram, na Conferência dos Estados Americanos em Punta Del Este realizada em agosto desse mesmo ano, seu interesse por uma convenção mundial e por uma consolidação dos preços do café, que deveriam reverter sobretudo para a estabilidade econômica e consequentemente para a política da América Latina. O Inter-American Economic and Social Council [Conselho Econômico e Social Interamericano] da Organização dos Estados Americanos resolveram por unanimidade pela proteção de uma convenção de longo prazo sobre o café entre países produtores e consumidores.

248 Com relação ao problema de desenvolvimento dos acordos internacionais sobre o comércio de café, v. entre outros: Pan American Coffee Bureau (1959); Silveira (1963); Dambaugh (1959); King (1962); Rowe (1963); Faraco e Borio (1964); Lazzarini (1967); Krug e Poerck (1968); Frederick (1970); The song is ended - but what of the International Coffee Agreement? (1970); IBC, Anuário Estatístico do Café (1968-1970).

249 Paralelamente a isso, o chamado Mexican Club - que compreendia os sete estados-membros do acordo de 1957 da Cidade do México - também realizou alguns encontros (ROWE, 1963, p. 17). 
Tabela 22: A importância econômica da exportação do café em países selecionados (1963)

\begin{tabular}{|l|c|c|}
\hline Ranking segundo grau de dependência & $\begin{array}{c}\text { Receita da exportação de café } \\
\text { (em US\$ 1.000) }\end{array}$ & \begin{tabular}{c} 
Parcela no PIB do país (\%) \\
\hline 1. Colômbia
\end{tabular} 303.006 \\
\hline 2. Brasil & 756.951 & 53,9 \\
\hline 3. Uganda & 76.200 & 52,8 \\
\hline 4. Guatemala & 77.075 & 51,2 \\
\hline 5. Etiópia & 44.360 & 49,6 \\
\hline 6. Costa Rica & 45.328 & 47,7 \\
\hline 7. El Salvador & 71.400 & 46,4 \\
\hline 8. Portugal & 68.660 & 41,9 \\
\hline 9. Burundi (inclusive Ruanda) & 5.534 & 40,9 \\
\hline 10. Costa do Marfim & 99.000 & 38,8 \\
\hline Para comparar: México & 52.259 & 5,6
\end{tabular}

Fonte: IBC, Anuário Estatístico do Café (1968-1970, p. 79) e ICA - Doc. ED (418/69).

De modo análogo ao que ocorreu com o Inter-American Agreement de 1940 (determinado pela guerra), o engajamento americano para a realização do International Coffee Agreement [Acordo Internacional do Café - ICA] em 1962 tinha uma relevância geopolítica devido à crescente crise cubana e à infiltração comunista acentuada na América Latina - temida pelos EUA - no caso de uma eventual crise na economia do café.

A Tabela 22 oferece um panorama do grau da dependência econômica de alguns países da América Latina e da África pela exportação do café.

A dependência do comércio de café dos estados latino-americanos em relação ao potencial de consumo dos EUA tornou-se especialmente significativa no exemplo brasileiro:

Tabela 23: A relação de dependência entre o Brasil e os EUA na economia do café ao tempo do acordo do ICA

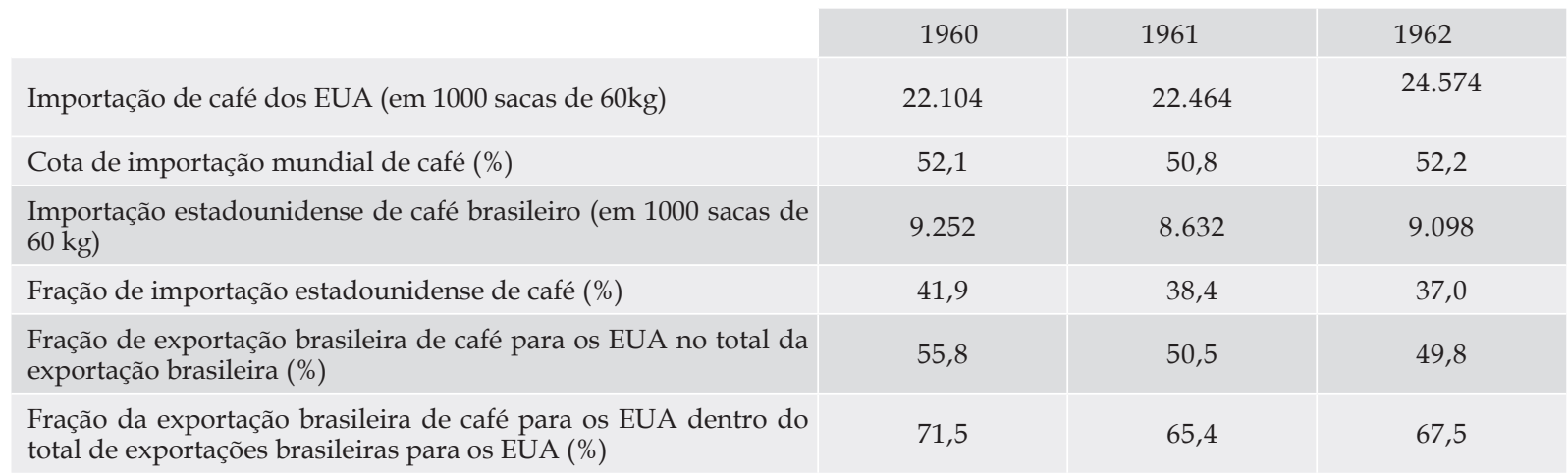

Fonte: IBC, Anuário Estatístico do Café (1968-1970).

A metade da exportação de café do Brasil era destinada aos EUA, cuja fração correspondia a mais de $50 \%$ ao total de importação mundial de café. A fração brasileira de café importado pelos EUA diminuiu um pouco entre os anos de 1960 e 1962. Em 1962, o café ainda ocupava cerca de 2/3 do valor de exportação do comércio brasileiro aos EUA. 
O projeto da ICA, modificado depois da recusa do Brasil e de outros países a uma internacionalização de estoques de café, foi aprovado em 1962 pela United Nations Coffee Conference [Conferência das Nações Unidas para o Café] em Nova Iorque. O acordo, válido por 5 anos, entrou em vigência em 1963, e no mesmo ano a Organização Mundial do Café, à qual pertencem os 34 países de exportação e os 22 de importação, estabeleceu suas atividades em Londres.

Resumidamente, as bases do International Coffee Agreement são as seguintes:

1. Acordo multilateral para ajuste de produção e consumo durante a ocorrência do convênio a longo prazo.

2. Estabilidade do preço com base no preço do café no ano de 1962 no mínimo.

3. Controle centralizado de exportação e regulação de importação.

4. Aumento contínuo do consumo de café e eliminação dos entraves de tributos de importação.

5. Redução dos excedentes de café dos principais países produtores por responsabilidade própria pela medida encontrada.

6. Proteção dos países produtores de café através de segurança das vagas de trabalho, melhores salários e uma melhor qualidade de vida.

A estipulação de cotas específicas de exportação para todos os países, que venderam mais de 100.000 sacas de café nos mercados principais nos EUA e na Europa foi a principal medida do ICA. A 30 dias do começo de cada ano do café, são estimadas a exportação de café e a importação do ano que se inicia. Depois disso, são determinadas as cotas por uma complicada fórmula de distribuição.

O enorme crescimento da produção mundial de café desde 1957 foi resultado sobretudo da expansão dos cafeeiros na região pioneira do Norte do Paraná desde o começo dos anos 50. Para evitar a queda do preço do café a um patamar muito baixo, o Brasil recorreu ao método de estocar a quantidade excedente. Com isso, por um lado o rendimento da exportação de café foi mantido, por outro, a decadência financeira de muitos produtores de café em São Paulo, sul de Minas Gerais, Espírito Santo - estados que trabalhavam com custos elevados - foi reduzida com a existência de cafeeiros antigos e menos produtivos.

No âmbito internacional, uma queda de preço pôde ser evitada. Por meio de acordos internacionais, o preço se manteve em média em 35 cts/lb., entre a metade de 1959 até 1962 (Figura 5).

Do outro lado, os estoques de café no Brasil até 1962 cresciam em torno de 55 milhões de sacas (Figura 6), isto é, o triplo de um ano de exportação médio do Brasil ou, ainda, mais que o consumo anual de café (1961: 44 milhões de sacas). No Brasil, as cotas de crescimento anuais previstas dos estoques de café verde foram estimadas em cerca de 10 milhões de sacas.

Nessa situação de excedente, a forte geada de 1962 no Paraná só poderia ter trazido uma redução temporária da pressão.

Para o cumprimento dos acordos firmados, a destruição ao menos dos cafeeiros antigos e menos produtivos revelou-se como solução do problema do café, tanto interno quanto em nível internacional ${ }^{250}$.

O boom do café no Paraná - cuja fração alcançou 30\% da produção mundial em 1962 e 1963 indicava a necessidade de se fechar um acordo internacional do café (Tabela 24).

O papel dominante do Brasil na economia mundial de café como produtor (1962/1963: 47\% _Tabela 24) e a dependência das relações de preço da produção do país exigiram do Brasil, tanto nas regiões de cultivo antigas quanto nas regiões mais jovens e inadequadas ecologicamente, medidas de restrição decisivas, que foram realizadas em dois programas de grande alcance para destruir as árvores de café e que assim provocaram mudanças decisivas na paisagem agrária, bem como transformações na estrutura agrária.em sua infraestrutura.

250 Além disso, exigiu-se a destruição dos estoques brasileiros e colombianos, bem como recomendou-se uma redução extrema do preço, de modo a cessar o boom do cultivo de café e promover espontaneamente a destruição dos cafeeiros não rentáveis. A perda do rendimento que surgiu através da baixa quantidade de exportação deveria substituir o café de países produtores (ROWE, 1963, p. 198 e 199). 
Figura 6: Área de cultivo, produção, exportação e estoques de café do Brasil entre 1960 e 1972

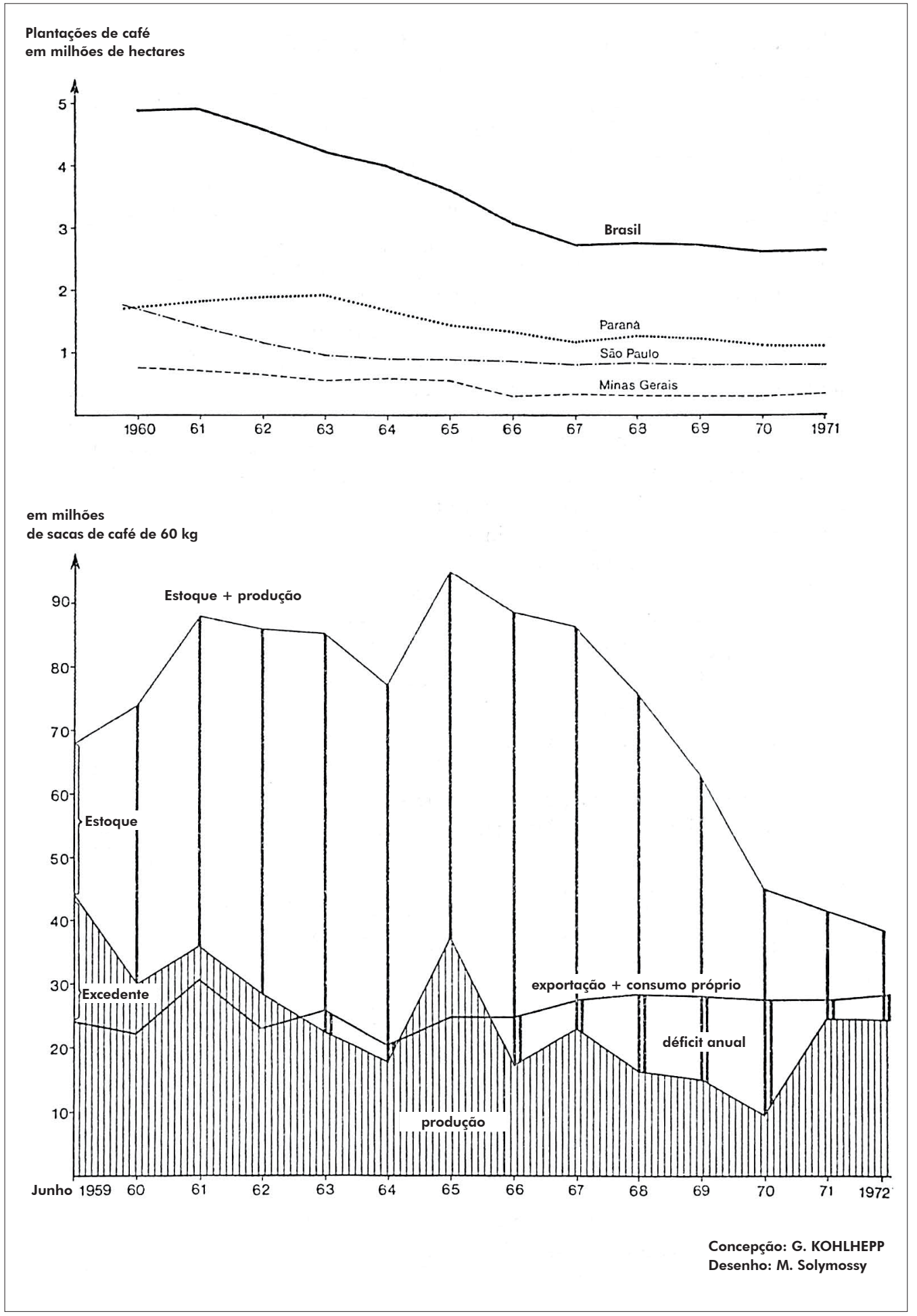

Fonte: IBC, Anuários Estatísticos do Café, 1965-1972 
Tabela 24: Produção de café mundial do tipo exportação.

Situação antes e no início do ICA (em 1.000 sacas de 60kg)

\begin{tabular}{|c|c|c|c|c|c|}
\hline Ranking & & $1960-61$ & $1961-62$ & $1962-63$ & $1962-63$ \\
\hline Total mundial & & 60.407 & 68.748 & 61.577 & 100,0 \\
\hline Membros do ICA & & 60.227 & 68.468 & 61.455 & 99,8 \\
\hline 1. Brasil & $(\mathrm{C})$ & 29.800 & 39.600 & 28.900 & 47,0 \\
\hline 2. Colômbia & $(\mathrm{A})$ & 7.000 & 6.800 & 6.500 & 10,6 \\
\hline 3. Costa do Marfim & (D) & 3.150 & 1.600 & 3.300 & 5,4 \\
\hline 4. Angola & (D) & 2.700 & 2.750 & 3.050 & 5,0 \\
\hline 5. Uganda & (D) & 1.895 & 1.933 & 2.930 & 4,8 \\
\hline 6. Indonésia & (D) & 1.600 & 1.650 & 2.080 & 3,4 \\
\hline 7. Guatemala & (B) & 1.300 & 1.500 & 1.700 & 2,8 \\
\hline 8. Salvador & (B) & 1.350 & 1.800 & 1.540 & 2,5 \\
\hline 9. México & (B) & 1.450 & 1.500 & 1.250 & 2,0 \\
\hline 10. Etiópia & (C) & 960 & 1.100 & 1.150 & 1,9 \\
\hline 11. Costa Rica & (B) & 1.050 & 1.025 & 930 & 1,5 \\
\hline \multirow[t]{2}{*}{ 12. Congo (Kinshasa) } & (D) & 850 & 850 & 1.050 & 1,7 \\
\hline & & & & & demais: 11,4 \\
\hline Arábicas & & 48.064 & 57.765 & $46 . S 54$ & 76,2 \\
\hline A suaves columbianos & & 8.030 & 7.695 & 7.570 & 12,3 \\
\hline B outras arábicas suaves & & 8.378 & 9.370 & 9.234 & 15,0 \\
\hline C arábicas não-lavadas & & 31.656 & 40.700 & 30.050 & 48,9 \\
\hline D Robustas & & 12.163 & 10.703 & 14.601 & 23,8 \\
\hline comparar: Paraná (C) & & 14.320 & 17.942 & 18.032 & 29,3 \\
\hline
\end{tabular}

Fonte: IBC, Anuário Estatístico do Café (1968-70); Pan American Coffee Bureau. 


\section{MEDIDAS ECONÔMICO-POLÍTICAS DE RESTRIÇÃO NO CULTIVO DO CAFÉ E MUDANÇAS ESTRUTURAIS DA GEOGRAFIA AGRÁRIA NO NORTE DO PARANÁ251}

\section{PROGRAMA DE REDUÇÃO DA QUANTIDADE DE CAFEEIROS (1962-1967)}

Diante da capacidade anual de produção de aprox. 36 milhões de sacas de café (com exportação anual de 18 milhões de sacas e consumo próprio anual de aprox. 6 milhões de sacas), alcançada depois da tendência de desenvolvimento do cultivo de café no Brasil ocorrida no início da década de 1960, o crescimento anual dos estoques de café atingiu a média de 12 milhões de sacas! (v. sobre isso a Figura 6)

Embora em 1961 tenham sido erradicados 7 milhões de sacas, o Instituto Brasileiro do Café (IBC) não se decidiu, no âmbito das medidas de restrição da produção do café, por uma erradicação do produto final, como fora corriqueiro sobretudo nos anos 30, mas sim pela restrição da quantidade de cafeeiros através de desenraizamento de pés menos produtivos (erradicação) ${ }^{252}$. Elaborou-se um programa de racionalização do cultivo de café, e o 'Grupo Executivo de Racionalização da Cafeicultura' (Gerca), fundado em outubro de 1961, foi encarregado do planejamento e da execução do programa de equiparação da produção brasileira de café com a demanda nacional e internacional.

A quantidade de cafeeiros no Brasil atingiu um recorde de 4,3 bilhões em 1960 e 1961, dos quais 36\% se encontravam em São Paulo, 28\% no Paraná, 19\% em Minas Gerais e 9\% no Espírito Santo. Sobretudo as plantações de café com um rendimento em média de até 6 sacas de café descascado por 1000 pés deveriam ser afetadas pela erradicação, isto é, a parcela antiga e inviável economicamente. Para reduzir a capacidade de produção em um terço, isto é, 12 milhões de sacas de café, foi necessário eliminar aproximadamente 2 bilhões de cafeeiros, levando em conta o valor limite de produção de 6 sacas por 1.000 pés!

Além da redução da produção de café, do rejuvenescimento médio dos cafezais e da melhora da qualidade, o cultivo da terra livre onde antes havia café com plantações de outros tipos significa, ao mesmo tempo, um passo importante da monocultura para a policultura e para a pecuária, e com isso também para uma menor dependência econômica em relação a uma cultura permanente dominante.

A 'erradicação' foi realizada em duas etapas, em cujo transcurso ocorreram modificações na execução por causa de mudanças da situação geral e de algumas premissas.

O primeiro programa, realizado entre junho de 1962 e julho de 1966, tinha como objetivo a destruição de 2 bilhões de cafeeiros. Novos plantios de café só podiam ser feitos na base de 1:4; a área anteriormente coberta com cafeeiros deveria ser usada para o plantio de diferentes alimentos básicos. Na execução do programa, os seguintes critérios foram estabelecidos (GERCA, Relatório, 1967, p. 2ss.):

1 Assinatura voluntária de contrato entre os plantadores de café e o Gerca.

2 Pagamento de uma indenização de NCr\$ 15,00 quando se arrancasse um cafeeiro. ${ }^{253}$

3 Livre escolha do modo de uso da terra livre por parte do plantador após a erradicação dos cafeeiros, inclusive em relação aos métodos de empreendimento aplicados. Uma autorização era necessária somente se fossem plantadas novas culturas permanentes.

4 A execução do programa foi confiada ao Banco do Brasil, em cujas filiais os requerimentos tinham de ser apresentados e que efetuava o controle e o financiamento das fases do contrato.

251 Tradução de Dionei Mathias e Natasha Pereira da Silva.

252 Adotaremos a partir daqui a denominação erradicação para o desenraizamento de pés de café.

253 Essa soma correspondia na época do planejamento (junho de 1961) a cerca de $80 \%$ do valor de produção por cafeeiro, num rendimento médio de 6 sacas/mil árvores. 
5 O plantio de culturas sucedâneas foi financiado em geral pelo Banco do Brasil e, mais raramente, pelo Gerca. Nisso o uso de sementes selecionadas resultou num aumento de $10 \%$ na soma de indenização, a aplicação de medidas antierosivas de $20 \%$ e o uso de adubos e inseticidas também de $20 \%$. Assim o valor do financiamento podia ser aumentado em $50 \%$, o que representou um impulso significativo para a agricultura, especialmente porque a quitação tinha ficado mais fácil em decorrência da inflação.

Depois que a progressiva desvalorização monetária fez com que o valor de indenização por cafeeiro erradicado caísse de $80 \%$ (1961) para 8\% do valor de rendimento por árvore (LAZZARINI, 1967, p. 3) até 1965 e, além disso, depois de os grandes prejuízos decorrentes de geada no ano de 1963 terem provocado um elevação brusca de preços do café, a erradicação acabou se estagnando ainda antes do término do período programado. Dos dois bilhões de cafeeiros previstos no programa, somente 36\% foram arrancados até 1965/66 (KOHLHEPP, 1974, p. 432ss.).

Apesar da erradicação de mais de 720 milhões de cafeeiros (Tabela 26), o Brasil testemunhou, em 1965/66, a segunda maior colheita de sua história. Somente o Paraná contribuiu com uma nova colheita recorde - mais de $55 \%$ da safra brasileira total - , já que os cafezais plantados durante fase de expansão na segunda metade dos anos 1950 no Norte Novíssimo estavam alcançando somente agora sua produtividade máxima (Figura 2).

Tabela 25: Pagamentos pela erradicação de cafeeiros no Brasil.

Agosto de 1966 - Abril de 1967

\begin{tabular}{c|c|c|c|}
$\begin{array}{c}\text { Porcentagem de cafeeiros } \\
\text { erradicados no total por em- } \\
\text { preendimento (\%) }\end{array}$ & Zona A & $\begin{array}{c}\text { NCr\$ por árvore } \\
\text { Zona B }\end{array}$ & Zona C \\
\hline $15-24,9$ & 0,30 & 0,28 & 0,26 \\
\hline $25-39,9$ & 0,38 & 0,35 & 0,32 \\
\hline 40 & 0,50 & 0,45 & 0,40
\end{tabular}

Zona A: Norte Novíssimo Paraná (noroeste do Paraná)

Zona B: o resto do Paraná, São Paulo e sudeste de Minas Gerais

Zona C: regiões cafeeiras restantes

Fonte: Gerca Relatório (1967, p. 4).

Uma resolução do Conselho Monetário Nacional decidiu pôr em prática com efeito imediato um segundo programa de 'erradicação' para dar mais um impulso à transição para a policultura.

Esse segundo programa, que teve início em agosto de 1966, diferenciava-se do precedente em pontos essenciais quanto à sua concepção:

1) A indenização por cada cafeeiro erradicado era concedida de acordo com um esquema regional e gradualmente diferenciado (Tabela 25).

Isso significava que o pagamento começava somente a partir de uma redução de $15 \%$ do número total de cafeeiros por fazenda, aumentando à medida que a porcentagem aumentava. No entanto, a indenização foi fixada num máximo de 750 árvores/ha. A soma média da indenização era de NCr\$ 0,45, ou seja, em questões de valores, em média, cerca de 4 vezes mais alto que no primeiro programa!

O objetivo de aumentar a cota de erradicação local - através de pagamentos mais altos nas regiões com um pico momentâneo de produção mas também na área ameaçada pela geada ou nos terrenos arenosos - acabou sendo um fracasso, já que a destruição mais extensa em 1966/67 acontecia no Espírito Santo. Nessa região, pertencente à zona C, mais de 235 milhões de árvores foram erradicadas (Tabela 26), ou seja, $44 \%$ da quantidade total do estado em 1960. Por outro lado, no Paraná e em São Paulo foram somente 12 ou $5 \%$.

2) Novas plantações de café estavam proibidas. 
3) Em consequência dos problemas sociais que surgiam de maneira cada vez mais intensa por causa do crescente desemprego (ver Cap. VI, 4), a transição da antiga área cafeeira disponível depois da erradicação para uma pecuária de trabalho extensivo estava proibida.

4) A seleção de culturas sucedâneas foi definida por agrônomos do IBC.

5) Os cafeeiros tinham de ser arrancados com suas raízes, além disso, a terra tinha de ser arada e cultivada por dois anos. O pagamento foi efetuado somente após um ano.

No total, no decorrer dos dois programas do IBC entre 1962 e 1967 com contratos subvencionados oficialmente, aproximadamente 1,4 bilhões de cafeeiros foram arrancados, ou seja, a meta do plano foi atingida em $70 \%$, sem levar em consideração, no entanto, o pequeno número de novas plantações nesse período (Tabela 26).

Apesar da grande diferença de prazo dos dois programas, aproximadamente $90 \%$ da soma do primeiro programa quadrienal foram alcançados no prazo de 9 meses devido ao impulso maior em consequência da alta cota de indenização em 1966/1967. Enquanto entre 1962 e 1966 a maior quantidade de cafeeiros foi erradicada em São Paulo e em Minas Gerais, sobretudo São Paulo recuou significantemente na segunda etapa. Por outro lado, o estado do Espírito Santo, com seus cafezais caracterizados por cifras baixas de rendimento, executou o plano com grande intensidade. Apesar de o pagamento de indenizações no Espírito Santo se movimentar no grupo mais baixo (o grupo C, Tabela 25), os pagamentos bem maiores durante o segundo programa fizeram com que o custo total da erradicação lá fosse o mais alto. Com relação à quantidade total destruída, esse estado, no entanto, ocupou somente o segundo lugar e, com relação à área liberada durante os dois programas, até mesmo o quarto lugar no Brasil. Os custos totais dos programas de erradicação chegaram a NCr\$ 250 milhões, ou aproximadamente US\$ 78 milhões. A soma investida na erradicação em 1966/67 corresponde aos custos para a construção de cerca de 1.000 km de estradas asfaltadas (LAZZARINI, 1967, p. 8).

A destruição oficial de cafeeiros reduziu a área de plantação de café no Brasil em cerca de 15.000 km² distribuídos em partes aproximadamente iguais nos quatros estados líderes na produção de café. 


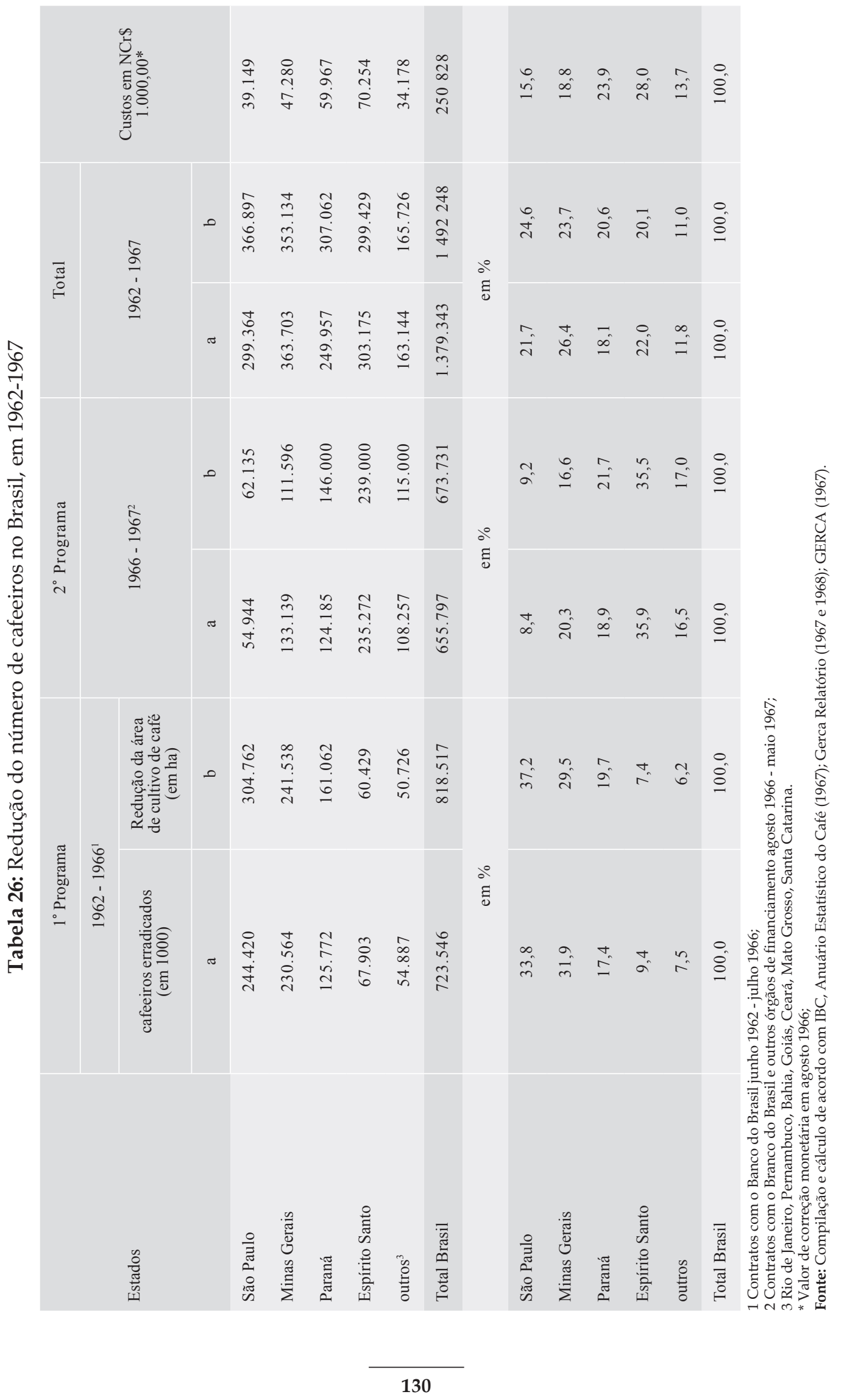


V I. M E D I D A S E C O N Ô M I C O-P O L Í T I C A S D E R E S T R I Ç Ã O...

\section{O DESENVOLVIMENTO DA ERRADICAÇÃO NO NORTE DO PARANÁ. AVALIAÇÃO DA IMPORTÂNCIA E DAS CONSEQUÊNCIAS}

A seguir, apesar da dificuldade no levantamento de dados estatísticos, tentaremos dar uma impressão quantitativa da erradicação no Norte do Paraná numa diferenciação regional.

\section{a) Antes do início dos programas oficiais}

Segundo uma avaliação da pesquisa realizada pelo Instituto Brasileiro do Café no Norte do Paraná em 1960/61, com apoio da Organização de Estados Americanos (IBC-OEA, 1964, p. 132-33), a extensão da erradicação em 1960 e 1961 no Paraná chegou a 47,6 milhões de cafeeiros. Desses, 47\% estavam no Norte Novíssimo, $37 \%$ no Norte Novo e $16 \%$ na região de colonização mais antiga do Norte do Paraná. A porcentagem dos cafeeiros erradicados com relação à quantidade total ficou, em todas as regiões, somente entre 3 e $4 \%$.

Levando em consideração a pouca idade dos cafezais nas zonas pioneiras desenvolvidas havia pouco tempo no Norte do Paraná (cafeeiros com mais de 15 anos: Norte Novíssimo 0,5\%; Norte Novo 15,4\%; em comparação, Norte Velho: 39,6\%), fica claro que 85\% das árvores erradicadas em 1960/61 ainda não tinham 20 anos.

O fato de que, durante a erradicação dos anos de 1960/61, se tratava de uma destruição não subvencionada das reservas de cafeeiros - ou seja, o oportunismo especulativo orientado puramente por fatores financeiros perdeu o seu momento - conduz às seguintes causas da erradicação nessa fase:

1) Preços baixos para o produtor devido à superprodução brasileira e sobretudo paranaense.

2) Queda rápida de rendimento em consequência da falta de qualquer tipo de adubação.

3) Expansão descontrolada das plantações de café durante o período do boom dos anos 50 em áreas ecologicamente inapropriadas do Norte do Paraná, sobretudo na zona periférica meridional com risco de geada, bem como na região dos solos arenosos rapidamente esgotados e com poucos nutrientes do Noroeste (Norte Novíssimo).

A pouca idade dos cafeeiros destruídos na área estudada dá uma ideia da rápida sequência das fases do desenvolvimento da paisagem agrária no Norte do Paraná, que se seguiram umas às outras em breves espaços de tempo.

Especulação e espírito pioneiro, ciclos de rentabilidade em virtude de oscilações de preço dependentes do mercado mundial e a influência dos fatores naturais contribuíram decisivamente para o estabelecimento das novas regiões de colonização no Norte Novo e Novíssimo. Esses fatores constituíam tanto os critérios da intensidade da exploração econômica quanto também os critérios delimitadores para a localização de um produto de exportação expansivo.

A seguinte tabela dá uma ideia do grau de intensidade de erradicação correspondente às ordens de grandeza dos empreendimentos e uma correlação entre proporção de rendimento, extensão da erradicação e o tamanho da plantação de café para o ano de 1962:254

254 Os dados sobre a quantidade de cafeeiros destruídos em 1962, no Paraná, são bastante diversos: De acordo com o IBC-OEA (1964, p. 133), 61,3 milhões de árvores foram arrancados. No contexto da ação Gerca, na segunda metade no ano de 1962, somente 14 milhões (GERCA, 1967, p. 29). Isso significaria que a partir de julho as atividades diminuíram, num momento em que a erradicação subvencionada começava. Isso contrasta com as situações reais. 
Tabela 27: Extensão da erradicação no Norte do Paraná de acordo com o tamanho das plantações de café

\begin{tabular}{|c|c|c|c|}
\hline $\begin{array}{l}\text { Tamanho das } \\
\text { plantações de café } \\
\text { (em } 1000 \text { árvores) }\end{array}$ & $\begin{array}{c}\text { Participação de cada grupo } \\
\text { na erradicação total } \\
\text { em } 1962 \\
(\%)\end{array}$ & $\begin{array}{l}\text { Participação da erradicação } \\
\text { no número de cafeeiros } \\
\text { em cada grupo, } \\
\text { em } 1961(\%)\end{array}$ & $\begin{array}{l}\text { Rendimento médio } \\
\text { por grupo em sacas em cada } \\
1000 \text { árvores }\end{array}$ \\
\hline$<1$ & 2 & 50 & 10 \\
\hline $1-2$ & - & - & $56^{*}$ \\
\hline $2-4$ & 1 & 4 & 14 \\
\hline $4-8$ & 8 & 4 & 19 \\
\hline $8-16$ & 6 & 2 & 20 \\
\hline $16-32$ & 4 & 1 & 16 \\
\hline $32-64$ & 25 & 6 & 18 \\
\hline $64-128$ & 17 & 6 & 19 \\
\hline $128-256$ & 33 & 15 & 12 \\
\hline $256-512$ & 2 & 1 & 22,5 \\
\hline $512-1024$ & 2 & 5 & 25 \\
\hline$>1024$ & - & - & 23 \\
\hline Total & 100 & 5 & 18 \\
\hline
\end{tabular}

* A certeza do dado é questionável Fonte: IBC-OEA (1964, p. 122 e 134).

Tabela 28: Erradicação no Paraná no contexto do programa Gerca (junho 1962 - final de 1965)

(Número de cafeeiros erradicados em 1000)

\begin{tabular}{|c|c|c|c|c|c|c|c|}
\hline Regiões & $\begin{array}{c}1962 \\
\text { segundo } \\
\text { semestre }\end{array}$ & 1963 & 1964 & 1965 & $\begin{array}{c}1962-65 \\
\text { Total }\end{array}$ & $\begin{array}{c}\text { Participação } \\
\text { das regiões } \\
(\text { em \%) }\end{array}$ & $\begin{array}{l}\text { Participação da } \\
\text { erradicação } \\
1962 \text { - } 65 \text { no } \\
\text { número de cafe- } \\
\text { eiros em } 1961\end{array}$ \\
\hline Norte Novo & 5.590 & 26.564 & 15.217 & 3.082 & 50.453 & 39 & 10,7 \\
\hline Norte Novíssimo & 4.415 & 35.382 & 16.802 & 6.208 & 62.807 & 47 & 11,1 \\
\hline Total da área estudada & 10.005 & 61.946 & 32.019 & 9.290 & 113.260 & 86 & 10,9 \\
\hline Norte Velho & 4.043 & 10.449 & 3.334 & 1.257 & 19.083 & 14 & 7,8 \\
\hline Paraná Total & 14.048 & 72.395 & 35.353 & 10.547 & 132.343 & 100 & 10,3 \\
\hline Participação em \% & 8,8 & 54,7 & 28,3 & 8,2 & 100,0 & & \\
\hline
\end{tabular}

Fonte: Gerca, Relatório (1967); Gerca (1967, p. 29); IBC-OEA (1964, p. 42).

Fica evidente que a porcentagem da erradicação dentro de cada classe de grandeza dos cafezais depende do respectivo rendimento. Isso fica especialmente claro no caso das menores propriedades com menos de 1.000 cafeeiros e das grandes propriedades com um número de cafeeiros entre 128 e 256 mil, que apresentam a maior porcentagem de erradicação com o menor índice de rendimento (Tabela 27).

\section{b) Erradicação subvencionada no âmbito do programa do Gerca}

No Norte do Paraná, as duas partes do programa alcançaram, em questão de números, os mesmos volumes, com uma eliminação oficial de aproximadamente 125 milhões de cafeeiros respectivamente (Tabela 27). 
A evolução do programa - de junho de 1962 até o final de 1965, apresentada na Tabela 28 - mostra o grande impulso que a geada de agosto de 1963 deu, num primeiro momento, à erradicação através do extermínio de cafeeiros congelados ou atingidos pela geada.

A partir de 1964, o número de cafeeiros erradicados diminuiu, porque - como já mencionado - a desvalorização monetária da indenização compensava somente menos de 1/10 do valor de rendimento de um cafeeiro, em decorrência da evolução inflacionária. Além disso, os cafeeiros com os menores índices de rendimento já haviam sido arrancados, e os preços do café subiram abruptamente no decorrer do primeiro semestre de 1964, após a baixa da colheita em decorrência dos danos causados pela geada em 1963 - surgindo assim um novo estímulo para o replantio. A erradicação no ano de 1965 foi insignificante e estagnou completamente no final do ano (Tabela 28).

A erradicação alcançou sua maior extensão no Norte Novíssimo e no Norte Novo do Paraná, pelos motivos já mencionados: exaustão rápida da fertilidade do solo do arenito Caiuá, perigo de geada etc. A redução do número de cafeeiros entre 1962 e 1965, no entanto, era de somente $10-11 \%$ - o que era muito pouco diante da alta produtividade da jovem região de cultivo de café do Norte do Paraná. Isso se mostrou, após a regeneração dos cafeeiros danificados pela geada, em uma nova colheita recorde (Figura 2).

A segunda parte do programa, iniciada em agosto de 1966, com sua já mencionada diferenciação dos pagamentos de indenização regional e intensiva, despertou grande interesse entre os cafeicultores. $\mathrm{O}$ desenvolvimento do Noroeste do estado com plantações de café que se degeneravam rapidamente pelos fortes prejuízos causados pela erosão justificou a porcentagem mais alta de erradicação de cafeeiros nessa área (NCr\$ 0,50 no caso de extermínio de mais de 40\%, Tabela 25).

Dos cafeeiros erradicados ao longo de 9 meses no Paraná, $44 \%$ se encontravam no Norte Novíssimo e 28\%, no Norte Novo. Na região ao norte do Ivaí (região de Paranavaí), 20\% dos cafeeiros foram eliminados, $30 \%$ das fazendas cultivadoras de café fecharam contratos para erradicação, nos quais quase 40.000 ha de terra de café ficaram livres nessa região. Na região central de plantio de café do Norte Novo com suas condições naturais favoráveis, a porcentagem de erradicação foi consideravelmente menor, inclusive mais baixa que entre 1962 e 1965. A diferenciação regional é visível na Tabela 29.

Tabela 29: Erradicação no Norte Novo e Novíssimo do Paraná em 1966 e 1967

\begin{tabular}{|l|c|c|c|c|c|}
\hline & $\begin{array}{c}\text { Erradicação } \\
\text { (em 1000 } \\
\text { árvores) }\end{array}$ & $\begin{array}{c}\text { Porcentagem de } \\
\text { erradicação por } \\
\text { número de } \\
\text { cafeeiros 1966 } \\
\text { (em \%) }\end{array}$ & $\begin{array}{c}\text { Porcentagem de fazendas } \\
\text { com erradicação pelo } \\
\text { número total das } \\
\text { fazendas com plantio de } \\
\text { café (em \%) }\end{array}$ & $\begin{array}{c}\text { Área que } \\
\text { ficou livre } \\
\text { (em ha) }\end{array}$ & $\begin{array}{c}\text { Porcentagem da } \\
\text { área de plantio } \\
\text { de café 1966 } \\
\text { (em \%) }\end{array}$ \\
\hline Região de Londrina & 16.823 & 7,7 & 10,3 & 21.686 & 8,9 \\
\hline Região de Maringá & 9.353 & 9,4 & 15,5 & 13.571 & 10,7 \\
\hline Região de Apucarana & 8.238 & 9,8 & 12,9 & 11.928 & 13,5 \\
\hline Norte Novo & 34.414 & 8,5 & 12,5 & 47.185 & 10,3 \\
\hline Região de Paranavaí & 30.348 & 20,0 & 30,1 & 39.432 & 20,0 \\
\hline Região de Umuarama & 15.397 & 8,9 & 11,1 & 19.628 & 11,3 \\
\hline Região de Campo Mourão & 8.584 & 15,7 & 21,3 & 12.368 & 10,3 \\
\hline Norte Novíssimo & 54.329 & 14,3 & 17,7 & 71.428 & 14,5 \\
\hline Total da área analisada & 88.743 & 11,3 & 15,1 & 118.613 & 12,5 \\
\hline
\end{tabular}

Fonte: Cálculos de acordo com levantamentos do Autor realizados nas agências regionais do IBC em Londrina e Maringá, com base em 9153 contratos individuais).

A baixa porcentagem de extermínio do número de cafeeiros na região de Umuarama indica que o plantio de café nessa área começara havia somente uma década e que grande parte das árvores se encontrava em alta produtividade. A discrepância entre a respectiva porcentagem de erradicação pelo número de cafeeiros e pelas áreas de plantio de café resulta das diferentes densidades de plantio. 
A segunda parte do programa foi caracterizada por uma desorganização singular. Em decorrência do preparo insuficiente por parte dos órgãos executores subordinados e do alto pagamento por cafeeiro erradicado, houve logo acusações sobre os (quase inevitáveis) contratos falsificados e a organização defeituosa. Em dezembro de 1966, o diretório do IBC decidiu realizar algumas mudanças ${ }^{255}$.

Assim, foi anulada a obrigação de arar a terra que ficou livre se o terreno tivesse uma inclinação de mais de $20 \%$ e se o solo fosse demasiadamente pedregoso. Além disso, autorizou-se a instalação de pastagens e a criação de gado leiteiro.

Mais tarde também foi possível trabalhar com pastagens para novilhos e com criação de gado de corte na antiga terra do café. Além disso, uma parte do reembolso financeiro pôde ser usado para investimentos em projetos da indústria de processamento de produtos agrícolas, sobretudo na extração de óleo vegetal, e em estabelecimentos industriais autorizados pelo IBC.

Durante uma discussão geral sobre outro aumento de indenização pela erradicação, a geada de junho de 1967 pôs fim ao segundo programa de erradicação, com prejuízos regionais diversos sobretudo no Norte do Paraná, já castigado em 1963 e 1966.

Por causa do acúmulo de geadas nos últimos anos, tinha de se contar com uma restrição natural das colheitas de café. Além disso, já era previsível que as áreas potenciais de novas terras a serem consideradas para o plantio de café estariam esgotadas com a colonização do Norte do Paraná e que a expansão do café já teria alcançado as máximas possibilidades de expansão naturais e políticas na fronteira com o Paraguai. No mais, não se podia mais contar com uma regeneração das plantações na região do Caiuá.

\section{c) Balanço}

É extremamente difícil acompanhar o balanço anual do número de cafeeiros, já que também ocorria, além do extermínio subvencionado, uma erradicação contratualmente não fixada e sem apoio financeiro. Esse foi o caso especialmente durante os anos de 1966 e 1967, quando muitos proprietários de fazendas reduziram seu número de cafeeiros para estender suas áreas de pastagens, o que então não era permitido no programa oficial do Gerca por causa das temidas consequências do desemprego rural.

Tabela 30: Quantidade de cafeeiros no Norte do Paraná entre 1961 e 1963, estimativa (em 1000)

\begin{tabular}{|l|c|c|c|}
\hline & 1961 & 1963 & $\begin{array}{c}\text { Aumento ou redução } \\
\text { em \% }\end{array}$ \\
\hline Norte Novo & 470261 & 493261 & $+4,9$ \\
\hline Norte Novíssimo & 564806 & 594127 & $+5,2$ \\
Norte Velho & 245941 & 229030 & $-6,9$ \\
\hline & 1281008 & 1316418 & $+2,8$ \\
\hline
\end{tabular}

Fonte: IBC-OEA (1964, p. 135).

Dados sobre erradicação particular na região analisada existem somente para os anos de 1962-63: ela chegou a 27,6 milhões de cafeeiros (IBC-OEA, 1964, p. 135).

Por outro lado, houve outras plantações novas até 1963 que foram iniciadas no contexto da última fase do avanço do frontier do café na região do Piquiri.

Isso levou, apesar da mencionada erradicação realizada nesse período, a mais um aumento de 2,8 \% do número de cafeeiros no Norte do Paraná (Figura 2).

Depois que os preços do café voltaram a subir em 1964, aumentou o estímulo para novas plantações. Em 1964, o financiamento chegou a NCr\$ 0,40 por árvore, ou seja, mais que $60 \%$ dos gastos de capital necessários. O empréstimo tinha de ser quitado dentro de 6 anos com juros de

255 Informações na central do Instituto Brasileiro do Café no Rio de Janeiro, bem como nas agências regionais do Norte do Paraná em 1970. 
$7 \% .{ }^{256}$ Em decorrência dos efeitos inflacionários, essas eram condições extremamente favoráveis para os plantadores.

No entanto, o Gerca exigia que a proporção entre erradicação e plantio novo fosse de 4 por 1 . Numa época em que o preço do café aumentava, o extermínio de 4 cafeeiros, com a finalidade de obter o financiamento para o novo plantio de um cafeeiro que começaria a produzir somente em 4 anos, significava, para a maioria dos plantadores, um risco econômico demasiadamente alto. Assim, prevaleceu a plantação nova de cafezais privada e não subvencionada.

O forte retrocesso da quantidade de cafeeiros por volta de 36\% (de 1.316 milhões em 1963 para 846 milhões em 1967257), mostra que no Paraná foi erradicada, além dos 250 milhões de cafeeiros oficialmente destinados à erradicação por contrato (respeitando-se os plantios novos exigidos), uma quantidade pelo menos igualmente grande de cafeeiros sem o aproveitamento das somas de indenização vinculadas às condições mencionadas.

Para o Paraná, a redução da capacidade de produção por meio dos dois programas do Gerca se avalia em aproximadamente 3,4 milhões de sacas, ou seja, cerca de $35 \%$ da soma de 9,8 milhões estimada para o Brasil (GERCA, Relatório, 1967, p. 10-12).

No final dessa fase de desenvolvimento, o IBC era da opinião de que, por meio de suas medidas, produção e demanda estavam em equilíbrio. No entanto, é necessário enfatizar que, tanto em decorrência das geadas de 1963 e 1966 como também do grande prejuízo na colheita por causa da broca-do-café (Stephanoderes hampei Ferr.), o verdadeiro efeito da erradicação e, em decorrência disso, a capacidade de produção de café efetiva dos cafezais não podem ser avaliados com exatidão. Segundo Frederick (1970, p. 263ss., 269), em 1967, a produção potencial de café foi subestimada por órgãos oficiais em, pelo menos, $10 \%$.

Levando-se em consideração também que até a segunda metade dos anos 1960 as plantações de café raramente eram adubadas, assim fica evidente que os esforços do Gerca para erradicar a metade do total de cafeeiros e substituí-los por plantações novas numa proporção de 4 para 1 - executadas de acordo com critérios científicos (rendimento chegando até o óctuplo das árvores erradicadas) traziam consigo novamente o perigo de superprodução (FREDERICK, 1970, p. 266; GERCA, 1967, p. 27).

Nos anos de 1961/62 até 1967/68, no entanto, a produção brasileira de café diminuiu em $30 \%$, e as medidas de erradicação foram acentuadas ainda mais devido aos prejuízos causados pela geada. Além do Brasil, somente o México e a Costa do Marfim cumpriram as obrigações internacionais de restrição da produção. O aumento da produção mundial de café no período mencionado foi de $9 \%$.

Esse desenvolvimento da situação do mercado mundial, unilateral para o Brasil, e o perigo permanente de outras perdas graves na colheita em decorrência de prejuízos causados por geadas nas áreas de plantio de café no Paraná (ao mesmo tempo em que havia um déficit de produção no Brasil desde 1966 - Figura $6^{258}$ ), fez com que, ao final dos anos 60, novas plantações de café parecessem ser novamente o melhor investimento agrícola!

No entanto, no que diz respeito a essas plantações novas, não se trata do aumento da área de plantio, mas geralmente de plantações que foram estruturadas, após o extermínio de cafezais antigos economicamente pouco viáveis, de acordo com diretrizes agronômicas modernas (plantio paralelo à inclinação, sementes selecionadas, seleção de espécies, adubação) e que também apresentam uma capacidade de concorrência, seguindo critérios internacionais.

A forte redução da área de plantio de café do Brasil e, nesse contexto, sobretudo do Paraná em 1961 ou entre 1963 e 1967, foi o resultado da erradicação dirigida e espontânea como consequência da superprodução (Figura 6).

A seguir deve-se analisar quais tendências predominavam no aproveitamento de terra das áreas de plantio de café que ficaram livres, e qual foi o efeito regional da diversificação agrícola.

256 Dos quais 20\% no quarto ano, 30\% no quinto ano e 50\% no sexto ano (FREDERICK, 1970, p. 260).

257 Dados numéricos totais segundo IBC, Anuário (1968-70, p.15); ver também Figura 2.

258 Em 1963 e 1964 já havia no Brasil um leve déficit na produção de café necessária. 


\section{APROVEITAMENTO DA TERRA DAS ANTIGAS ÁREAS DE PLANTIO DE CAFÉ E PROBLEMAS DA DIVERSIFICAÇÃO DOS PRODUTOS A SEREM PLANTADOS}

Dos quase 1,5 milhões de hectares de terra de café que ficaram livres no movimento de erradicação subvencionada entre 1962 e 1967, 307.000 ha (20,6\%) se encontravam no Paraná (Tabela 26). Entre 1963 e 1967, a área de plantio de café nessa região foi reduzida em 36\%.

A transição à policultura, controlada pelo Estado com a ajuda do Instituto Brasileiro do Café, deparou-se com dificuldades especiais numa área que até então tinha vivido quase exclusivamente do boom do café e na qual a mentalidade extrativista pioneira se concentrava especialmente no plantio de café em solos férteis ainda não utilizados.

De acordo com as condições contratuais, durante o primeiro programa do Gerca (1962-66) deixava-se a critério dos plantadores, segundo as condições ecológicas e a situação econômica, a maneira segundo a qual desejariam aproveitar a antiga terra de café que ficou livre.

Com base numa recomendação de caráter geral dada pelo IBC, contava-se com a seguinte diversificação: $29 \%$ da área para produtos de alimentação básica, 25\% para pastagens, $18 \%$ para o plantio de plantas oleaginosas ${ }^{259}, 13 \%$ para o reflorestamento, $7 \%$ para o plantio de árvores frutíferas, o resto para as demais culturas e para a plantação de café a ser executada de acordo com critérios científicos modernos (KRUG; POERCK, 1968, p. 300).

Nesse programa planejado de desenvolvimento, no entanto, o espírito especulativo da população de uma zona pioneira dinâmica foi avaliado como muito baixo, ou nem mesmo chegou a ser levado em consideração.

Correspondendo às condições de preços que dominavam no momento, a terra do café foi cultivada a curto prazo com culturas temporárias ou transformada espontaneamente em pastagens. Com relação aos produtos de alimentação básica, foi registrada uma queda de preço ameaçadora para os produtores, em decorrência do excesso de produção. Assim os preços ao produtor caíram entre 1962 e 1965, tendo como base um índice de 100 em 1962: milho, 71; arroz, 41; feijão, até mesmo a 31. O algodão, por outro lado, aumentou levemente nesse período para 105, e o amendoim para $128 .{ }^{260}$

Com relação ao plano do Instituto Brasileiro de Açúcar e Álcool, no contexto da diversificação para aumentar significativamente a produção de açúcar, uma pequena estimulação de preço foi suficiente para causar uma superprodução que, em decorrência das dificuldades de venda, abalou intensamente a indústria açucareira (LAZZARINI, 1967, p. 3).

A falta de qualquer plano de plantio na fase inicial teve como consequência o fato de que, em vista do desenvolvimento descrito, os órgãos oficiais se abstiveram nos anos seguintes de emitir uma recomendação sobre algum produto para plantio.

Assim, as reais proporções na diversificação de culturas - nos mais de 160.000 ha de antigas áreas de cafezais - se diferenciavam substancialmente da recomendação já mencionada (Tabela 31).

A maior parte da antiga terra de café foi transformada em pastagens para engorda de gado de corte por conta da situação favorável do preço da carne bovina. Com isso, sobretudo a região Noroeste do Paraná, caracterizada por seu solo arenoso, se projetou com $72 \%$. Até mesmo todo o Norte Novíssimo perfazia $45 \%$ sobre o valor médio de todo o Norte do Paraná $(40,4 \%)$. Comparado a isso, foram criadas em São Paulo áreas de pastagem em pouco mais de $1 / 4$ da área, pois as regiões de plantação de café de lá já tinham passado, num ciclo de desenvolvimento anterior, pela tendência à monoestrutura da criação de gado até chegarem a um extremo. No estado do Espírito Santo, ao contrário, foram utilizados mais de $70 \%$ da área para pastagens.

259 Essa parte da recomendação tem de ser vista no contexto do esforço de construir uma indústria nacional de óleo e gordura vegetais que foi fomentada especialmente no Paraná através de investimentos por parte do banco estatal de desenvolvimento, Codepar.

260 Dados da Divisão de Economia Rural da Secretaria da Agricultura do Estado de São Paulo, com base no valor real ajustado dos produtos agrícolas (Fundação Getúlio Vargas apud GERCA, Relatório 1968, p. 32). 
Tabela 31: Utilização da terra da antiga área de cultivo de café no Paraná que se tornou livre por meio da erradicação de 1962 a 1966, em comparação com todo o Brasil

\begin{tabular}{|c|c|c|c|c|c|c|c|c|}
\hline \multirow[b]{3}{*}{ Pastagem } & \multicolumn{2}{|c|}{ Norte do Paraná } & \multicolumn{2}{|c|}{ Brasil } & \multicolumn{4}{|c|}{$\begin{array}{l}\text { Máximo em cada estado } \\
\text { Cota em } \%>\end{array}$} \\
\hline & \multirow{2}{*}{$\begin{array}{c}\text { ha } \\
65.069\end{array}$} & \multirow{2}{*}{$\begin{array}{c}\% \\
40,4\end{array}$} & \multirow{2}{*}{$\begin{array}{c}\text { ha } \\
366.824\end{array}$} & \multirow{2}{*}{$\begin{array}{c}\% \\
44,8\end{array}$} & \multicolumn{2}{|c|}{ Max. } & \multicolumn{2}{|c|}{ Mín. } \\
\hline & & & & & ES & 70,1 & $\mathrm{SP}$ & 26,8 \\
\hline Algodão & 25.770 & 16,0 & 48.412 & 5,9 & PR & 16,0 & MG & - \\
\hline Milho & 17.878 & 11,1 & 151.093 & 18,5 & $\mathrm{SP}$ & 25,6 & ES & 9,4 \\
\hline Feijão & 7.731 & 4,8 & 36.834 & 4,5 & MG & 7,5 & ES & 1,8 \\
\hline Rícino & 4.671 & 2,9 & 10.062 & 1,2 & PR & 2,9 & MG & - \\
\hline Mandioca & 3.382 & 2,1 & 19.682 & 2,4 & ES & 10,6 & $\mathrm{SP}$ & 1,4 \\
\hline $\begin{array}{l}\text { Arroz } \\
\text { (Arroz seco) }\end{array}$ & 2.738 & 1,7 & 64.559 & 7,9 & $\mathrm{SP}$ & 17,0 & E.S. & 0,1 \\
\hline Cana-de-açúcar & 2.255 & 1,4 & 28.824 & 3,5 & $\mathrm{SP}$ & 6,4 & PR & 1,4 \\
\hline Amendoim & 1.772 & 1,1 & 18.585 & 2,3 & $\mathrm{SP}$ & 5,5 & ES/MG & - \\
\hline Reflorestamento & 805 & 0,5 & 4.201 & 0,5 & MG & 0,7 & ES & 0,3 \\
\hline Café & 483 & 0,3 & 4.718 & 0,6 & $\mathrm{SP}$ & 1,0 & ES & 0,2 \\
\hline Outros & 28.508 & 17,7 & 64.723 & 7,9 & & & & \\
\hline Total & 161.062 & 100,0 & 818.517 & 100,0 & & & & \\
\hline
\end{tabular}

ES - Espírito Santo PR - Paraná

SP - São Paulo MG - Minas Gerais

Fonte: Compilação segundo Gerca, Relatório de 1968.

O cultivo de algodão ocupou uma posição essencial no Paraná durante essa fase. O cultivo de milho e, sobretudo, de arroz - com 11,1\% e 1,7\%, respectivamente - recuaram fortemente diante do produzido na região central do Brasil e dos valores elevados de São Paulo, pois essas culturas nas regiões de cultivo recente já tinham uma grande importância como plantio intercalado entre as fileiras de cafeeiros.

O reflorestamento no Norte do Paraná - bem como nas regiões restantes de cultivo de café do Brasil que foram deixadas abertas - foi completamente negligenciado, muito embora os danos causados pela erosão tivessem tornado isso urgentemente indispensável em algumas regiões do Norte Novíssimo. No entanto, essa reação da população pioneira logo depois do fim da primeira grande fase de desmatamento para exploração da terra é condicionada por fatores psicológicos.

Na segunda fase, a partir de 1966, tentou-se conseguir o incentivo reivindicado na Resolução do Conselho Monetário Nacional para a produção dos bens complementares agrários mediante um plano prévio de utilização da terra.

Como os países produtores de café excluíam a possibilidade de encontrar uma cultura economicamente vantajosa que substituísse o café, o Brasil apresentou o seu programa à Organização Internacional do Café, que também não soube apresentar nenhuma sugestão satisfatória do ponto de vista econômico. Arroz, milho e soja foram comercializados aos EUA, em parte a preços correspondentes ao mesmo preço de custo no Paraná. ${ }^{261}$

Assim, em 1966 e 1967, tornou-se perceptível no Brasil uma forte oposição à proibição de instalação de pastagem nas áreas de café não lucrativas. A exigência - feita na celebração de um contrato com a Gerca no programa de 1966/67 - de se cultivar por dois anos consecutivos a terra obtida por meio da erradicação, foi um pouco flexibilizada perto do fim deste prazo, sobretudo em áreas com solos de má qualidade.

261 Entre 3 e 5 dólares a saca de $60 \mathrm{~kg}$. A infraestrutura, o grau de mecanização e a organização do trabalho na área agrária nos EUA permitiram o comércio de produtos a esses preços, apesar do custo cerca de 15 vezes mais elevado pela mão de obra (LAZZARINI 1967, p. 3-4). 
A análise detalhada de 9.158 dos contratos de financiamento ${ }^{262}$ firmados entre os produtores de café e a Gerca e através do Banco do Brasil, Banestado e bancos privados, em 1966 e 1967, e a representação cartográfica no âmbito municipal oferecem uma ideia da diferenciação regional da utilização da terra. A comparação entre 1966/67 (Mapa 30) e 1967/ 68 (Mapa 31) mostra as tendências de desenvolvimento esboçadas.

A Tabela 32 (p. 306, Anexo) oferece uma comparação quantitativa das proporçãos de cultivo nas áreas de erradicação nas seis regiões do Norte Novo e Norte Novíssimo.

Em 1966 e 1967, predominava claramente nas áreas que se tornaram disponíveis o cultivo de milho, que ocupava, na região de Londrina, mais da metade da área total, e era dominante no Norte Novíssimo com $48 \%$ do total. No Norte Novíssimo, a posição do cultivo de milho é um pouco menos acentuada somente na região de Campo Mourão, em benefício da soja.

Enquanto no nordeste da região pesquisada (região de Londrina) arroz, feijão, soja e amendoim (depois do milho) ocupam quase a mesma parte da terra anteriormente destinada ao café, na região nas proximidades de Maringá tem especial importância o cultivo de soja e arroz, e na região sudeste (Apucarana), o cultivo de feijão e arroz (ao lado do milho). O ranking 2-4 dos cultivos alternativos do Norte Novíssimo empregam soja, amendoins e algodão no Noroeste (Paranavaí); na região de Campo Mourão, soja, arroz e feijão; e no Norte Novíssimo recentemente estabelecido, soja, feijão, algodão e amendoim, quase que na mesma proporção (Tabela 32, p. 306, Anexo e Mapa 30).

As fortes oscilações no cultivo de culturas alternativas ficaram evidentes em comparação com dois anos consecutivos de cultivo. $\mathrm{O}$ aumento do preço do algodão colocou em ascensão a proporção das plantas têxteis no Norte Novo - com exceção da região de Apucarana, que tem alto nível de precipitação - , e especialmente em todas as partes da região do Norte Novíssimo ela saltou abruptamente. Enquanto no Norte Novo a área de cultivo do algodão aumentou em quatro vezes e meia e ocupou o segundo lugar atrás do cultivo de milho, que indicava um leve recuo, registrou-se no Norte Novíssimo em 1967/68 ${ }^{263}$ uma forte supremacia do cultivo de algodão $(40,1 \%)$.

A decrescente importância do cultivo de milho no Norte Novo favoreceu um aumento na produção de algodão, especialmente na área dos solos arenosos isolados dos municípios Centenário do Sul, Cafeara, Lupionópolis, Santa Fé, Santa Inês, Colorado, bem como em Porecatu, Primeiro de Maio, Sertanópolis e Ibiporã (ver Mapa 31 com folha de rosto).

No total, a proporção de produção de arroz permaneceu quase a mesma na comparação entre 19661967 e 1967-1968, enquanto a produção de feijão e de soja sofreram pesadas perdas devido ao preço. Ao lado do considerável declínio da produção de milho acima mencionado e da produção de algodão manejada em 1967/ 68 em toda a área do Norte Novo e Norte Novíssimo, a produção de rícino, que teve sua área de produção quase seis vezes maior, mostra uma forte mudança devido à demanda da indústria regional de óleo vegetal (Tabela 32, p. 306, Anexo e Mapa 31).

O Mapa 31, relativo aos anos de 1967 e 1968 - embora faltem dados para o Norte Novíssimo ao sul do rio Ivaí - , mostra uma diferenciação regional clara da especialidade de cultivo de milho e arroz, bem como de algodão. O cultivo de algodão no Oeste e Noroeste, bem como em algumas regiões ao norte do Norte Novo, reflete as proporções de solos, que nessas regiões são arenosos e relativamente apropriados para o cultivo de algodão.

No Noroeste do Paraná, também foram eliminadas as áreas de cultivo de café com ao todo cerca de um terço da área total, sobretudo nos municípios de Paranavaí, Paranacity, Santa Izabel do Ivaí e São João do Caiuá, cada um com cerca 3.000 e 3.800 ha $^{264}$.

262 As bases de dados foram elaboradas e reconhecidas pelas agências regionais do Instituto Brasileiro do Café em Londrina e Maringá. Em Londrina, o autor encontrou resistência a um certo aproveitamento que, em determinadas circunstâncias, era atribuído a uma certa incerteza dos órgãos exportadores devido à acusação pública no sentido de irregularidade na diversificação do programa. - O autor agradece ao Sr. Eng. Agr. G. NEVES CALEFFI (DAC/Gerca) por seu simpático apoio em Maringá.

263 Infelizmente a Agência Regional do IBC em Cianorte foi fechada em 1968, e os dados detalhados de 1967 e 1968 - com exceção do cultivo de algodão - referentes às regiões de Umuarama e Campo Mourão do Norte Novíssimo não foram encontrados. Por causa de algumas amostras aleatórias nesses lugares, das indicações para a região de Paranavaí e das indicações de tendências da Agência em Maringá, o autor teve que estimar o total para o Norte Novíssimo em 1967 e 1968.

264 Do mesmo modo no sul do Norte Novíssimo em Umuarama (3780 ha) e Goioerê (3620 ha), bem como ao norte no Norte Novo de Londrina: Centenário do Sul (2540 ha). 
A maior parte da área do cultivo de café alcançou a erradicação na região de produção mais ao sul, com o perigo anual de geada (Campo Mourão, Boa Esperança, Janiópolis e, sobretudo, Marilândia, com $66 \%$ ), no vale do Ivaí (Doutor Camargo, 67\%, Ivatuba 58\%) e nas partes baixas do mais extremo Noroeste (Querência do Norte 56\%) (Mapa 30). Por outro lado, o Município de Rolândia - que apresentava uma altitude ideal e melhores proporções de solos -, Arapongas, Apucarana e Astorga indicavam apenas uma redução mínima de suas áreas de produção de café (Mapa 31).

O cultivo de algodão na segunda parte do programa de cultivo do Gerca é um indicador claro da fase de transição já instaurada na adaptação às prescrições de cultivo de uma grande parte dos produtores para a instalação de extensas regiões de pasto, que poderiam se tornar apropriadas por meio do cultivo de algodão. Após a acordo das obrigações contratuais, a transição para a pastagem atingiu uma grande extensão e foi intensificada mais ainda pela geada de 1969 (ver Cap. VII).

A instabilidade das relações de preços dos produtos alimentícios básicos e os riscos do cultivo de outras culturas sem a experiência agrícola adequada, mas também sem o conhecimento da situação mercadológica, conduziram inevitavelmente, nos casos das grandes propriedades, especialmente nos solos arenosos, à expansão da criação de gado, que não exige tanto trabalho e é mais favorável economicamente.

\section{PROBLEMAS SOCIAIS E CONSEQUÊNCIAS DA ERRADICAÇÃO}

A expansão do cultivo de café no Norte do Paraná na direção oeste e sudoeste funcionou, durante quase duas décadas, como principal válvula de escape da pressão popular, que se acentuava cada vez mais no Sudeste do país, em São Paulo, em consequência da emigração de inúmeros trabalhadores rurais e desempregados vindos da região Nordeste do Brasil. As secas catastróficas não periódicas do Sertão do Nordeste deram os impulsos para o ritmo migratório para o Sul.

Até o início da década de 1960, a extensão das plantações de café, no Norte Novíssimo do Paraná, pôde receber grande parte dessa população, seja como trabalhadores agrícolas empregados contratualmente, seja como trabalhadores migrantes com possibilidade de ocupações sazonais, seja ainda como arrendatários. Isso poderia ter resolvido a falta permanente de mão de obra na frente pioneira avançada. Mesmo os trabalhadores migrantes poderiam conseguir sua subsistência ao menos acima de um mínimo para sobreviverem, através da migração pendular entre as colheitas de algodão no estado de São Paulo e a safra de café no Norte do Paraná.

A esgotada capacidade de acomodação dos centros de aglomeração que ficam nas grandes cidades ao longo do caminho migratório com destino ao sul - como as cidades litorâneas do Nordeste, Recife e Salvador - , e a falta de possibilidades de trabalho nas metrópoles industriais fartas de mão de obra pouco letrada - Rio de Janeiro e São Paulo - fizeram com que, em face de um concomitante arrefecimento da conjuntura, as correntes de migração interna procurassem tanto mais o interior do estado de São Paulo e do Norte do Paraná.

Os efeitos das alterações na estrutura agrícola em São Paulo com a conversão de vastas áreas do Noroeste e Oeste em pastagem de gado conduziu a migração diretamente ao Norte do Paraná, onde o trabalho intensivo com o cultivo do café oferecia possibilidades de emprego, e, com isso, de subsistência mínima.

A campanha de redução dos cafeeiros, economicamente necessária, acarretou também problemas sociais por lá, devido à conversão desordenada de uma grande parte da terra antigamente destinada ao café para pastagens. Uma parte dos trabalhadores rurais até então em atividade nas plantações de café ficaram desempregados.

Em 1961 havia em todo o Norte do Paraná cerca de 284.000 famílias, o que perfaz ao total 1,45 milhões de pessoas, isto é, quase um terço da população do estado trabalhando no cultivo de café. Dos 576.000 trabalhadores ativos na economia do café, $30 \%$ estavam em atividade no Norte Novo e $38 \%$ no Norte Novíssimo (IBC-OEA, 1964, p. 69). 
A destruição de 113 milhões de cafeeiros no Norte Novo e Novíssimo entre 1962 e 1966 trouxe, para cerca de 49.000 trabalhadores, a perda de seus empregos nas plantações de café, em que foram atingidas cerca de 23.000 famílias com pouco mais de 120.000 pessoas. ${ }^{265}$.

O programa de diversificação agrícola planejado originalmente previa a ocupação da população, que antes trabalhava no cultivo do café e que agora estava desempregada, no cultivo de culturas substitutas, sobretudo de alimentos básicos, em geral nas mesmas propriedades. Devido à pouca mecanização, para esses cultivos também é necessária uma grande quantidade de trabalhadores, calculada na proporção de 1 família/4,8 ha. Nessa proporção, uma família é suficiente para cuidar de 145 ha de terra de pastagens (CODEPAR, 1966).

Ao fim e ao cabo, a taxa de transferência para a pecuária com pouca demanda de mão de obra - surpreendentemente alta para as instituições oficiais, mas previsível devido à tendência geral da agricultura - significou, após os trabalhos de conversão (construção de cercas, semeação do pasto etc.), o desemprego para cerca de 5.400 famílias, algo como 29.000 pessoas.

A proibição da instalação de pastos na segunda fase oficial de transferência, derivada dessa situação, fez com que a taxa de desemprego previsível pelos contratos oficiais aumentasse somente um pouco, mesmo com o intenso retrocesso das áreas de cultivo de café.

Por outro lado, a erradicação privada dos cafeeiros, realizada sem indenização financeira e quase duas vezes maior nesta fase, tinha como objetivo quase exclusivo a instalação de pastagens.

As estimativas e cálculos aproximados sobre o total de pessoas desempregadas devido à erradicação e às suas consequências indicavam mais de 16.000 famílias, com cerca de 82.000 pessoas (GERCA, 1967, p. 34; GERCA, Relatórios, 1965, 1966, 1967); porém, devido aos acontecimentos incontroláveis no nordeste do estado, esses valores podem ser muito mais elevados.

Consequências disso foram um aumento da mobilidade da população rural e uma intensa migração para as cidades do Norte do Paraná. Isso ocasionou, com a baixa vinculação de trabalhadores nos setores secundário e terciário das cidades pequenas e médias, bem como devido à esgotada capacidade de absorção de cidades maiores como Londrina e Maringá, uma aglomeração na periferia das cidades, e a incipiente concentração de moradias do tipo favela (Foto 12).

O repentino excesso de trabalhadores rurais em uma região que, menos de uma década antes, tinha apresentado uma capacidade de absorção aparentemente ilimitada da migração interna brasileira, forçou o governo e o IBC a não reduzir mais as áreas de cultivo de café no Norte do Paraná. O afluxo de 'caboclos' vindos de Minas Gerais e dos estados do Nordeste à procura de trabalho se dirigiu, antes que começasse a exploração controlada da região amazônica, mais ainda para o Norte do Paraná, que então de modo injusto - mantinha sua reputação de 'Eldorado dos solos férteis com a possibilidade de aquisição de terra própria'.

Nessa situação instável, uma nova ocorrência de geada poderia causar um agravamento das relações econômicas e sociogeográficas críticas no Norte do Paraná. Esse temor surgiu já em 1969, quando as plantações de café do Norte do Paraná sofreram graves danos causados por geadas, cuja importância para a economia cafeeira e suas consequências agrário-sociais serão examinadas a seguir.

265 Esses valores numéricos calculam-se com base nos seguintes valores de relação estatísticos: 1 trabalhador cuida no Norte Novo, em média, de 1026 cafeeiros, e no Norte Novíssimo, de 2600. Cada família trabalhadora rural possui no centro do Norte Novo 2,13 trabalhadores e o total de 5,35 pessoas; no Norte Novíssimo, 2,17 trabalhadores e o total de 5,17 pessoas (segundo o IBC-OEA, 1964, p. 70). 


\section{AS CONSEQUÊNCIAS ECONÔMICAS E SOCIOGEOGRÁFICAS DOS DANOS CAUSADOS PELA GEADA NA ECONOMIA CAFEEIRA DO NORTE DO PARANÁ ${ }^{266}$}

\section{OCORRÊNCIAS DE GEADAS E SUA EXPANSÃO ESPACIAL}

Um dos problemas mais graves da economia do café no Paraná é o fato de que a migração do cultivo do café para o sudoeste e para o sul conduziu a um avanço para a área do limite climático do café, isto é, em regiões ameaçadas pela geada. As plantações de café se estendem para além do trópico, até a latitude de $24^{\circ} 30^{\prime}$ S. O Norte do Paraná é com isso a região cafeeira significativa mais meridional do planeta ${ }^{267}$. As áreas de rendimentos mais altos apresentam, contudo, devido aos danos causados pela geada, oscilações de produção fora do comum, cujos efeitos provocavam uma forte instabilidade da oferta, e com isso do preço do café, não só nacionalmente como também no mercado cafeeiro internacional.

Geadas noturnas podem se manifestar na região de cultivo de café no Norte do Paraná entre o começo de junho e o começo de setembro. Excetuando-se as raras geadas no Norte do Paraná causadas por fortes radiações noturnas, são temidas especialmente as ondas de frio provenientes do sul, pois podem provocar danos graves nas plantações sensíveis à geada (como os Northers na América do Norte e América Central). De maio a setembro, as frentes frias de massas polares do Atlântico advindas do sul e do sudoeste alcançam sua maior intensidade e avançam para as planícies baixas da bacia do ParanáParaguai e na região costeira mais ao norte, onde suas consequências devido à forte diminuição de temperaturas são sentidas como 'friagens' até o Mato Grosso e o Acre (até $8^{\circ}$ de latitude sul!), bem como na região costeira da Bahia e inclusive até o Recife.

A aproximação de uma frente fria é anunciada por ventos predominantes do norte e noroeste e por um aquecimento abrupto causado por uma troca rápida da direção do vento. O 'Pampero' gelado e seco e sua continuação no Brasil, o 'Minuano', trazem consigo uma frente fria do sudoeste, que se afasta sob as correntes de ar tropicais quentes e úmidas, e, devido à convecção, trazem consigo pancadas de chuvas torrenciais antes da frente, que muitas vezes estão ligadas a tempestades.

Depois da instabilidade temporária das condições meteorológicas, que está relacionada com o avanço da frente fria, a frente fria entra com o desanuviamento e causa frequentemente uma queda de temperatura de mais de $20^{\circ} \mathrm{C}$; com isso, é comum ocorrer geadas (IBG, 1968, T. 1, p. 133ss.). Por causa da influência das correntes de ar tropicais do Atlântico, a frente fria se desloca geralmente na direção ONO-ESE.

A duração total das intrusões de ar frio depende da intensidade da acumulação de correntes de ar polares na Patagônia e da intensidade do avanço de anticiclones. Em geral, o processo completo dura cerca de uma semana, até a mínima diária voltar a se estabilizar em valores médios. Geadas ocorrem, todavia, geralmente em apenas um ou raramente em dois desses dias (igura 7A).

Com isso, a temperatura cai rapidamente depois do desanuviamento no final da tarde ou no início da noite e alcança, por volta das 6 horas, pouco antes do nascer do sol, o seu mínimo absoluto, para subir de novo abruptamente. Com isso, a geada com frequência dura apenas poucas horas (Figura 7B), que são suficientes para causar prejuízos às plantações de culturas sensíveis a ela. Se até as $22 \mathrm{~h}$ a temperatura cair para menos de $10^{\circ} \mathrm{C}$, então os danos causados pela geada nas plantações de café são esperados, em geral, nas primeiras horas da manhã do dia seguinte.

266 Tradução de Dionei Mathias e Natasha Pereira da Silva.

267 Algumas plantações de café em regiões altas favoráveis (580-600 m) e regiões de declive ao norte chegavam, ao sudoeste de Cascavel (Céu Azul), até mais de $25^{\circ} \mathrm{S}$; contudo, elas produziam apenas produtos pouco significativos e eram, em parte, abandonadas. - Nas terras baixas costeiras livres de geada em Santa Catarina, cultivava-se café nos quintais de casa sob árvores de sombra em forma de sebe para o abastecimento próprio, inclusive até $27^{\circ} \mathrm{S}$. 
Figura 7: Relações de temperatura com a entrada da frente fria no Norte do Paraná

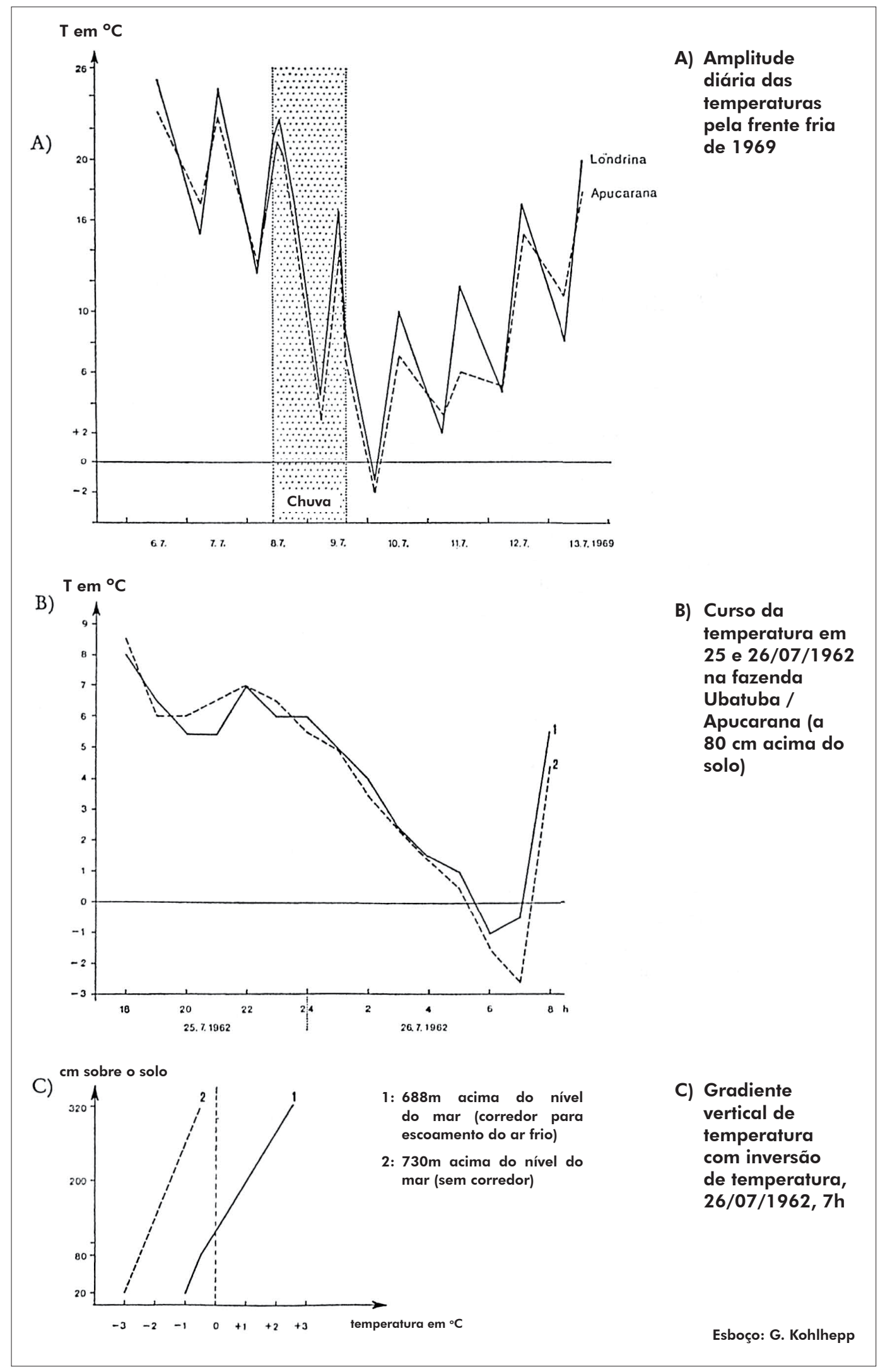

Fontes: A) Anderson, Clayton Co.; B) e C) Ortolani et al., 1963. 
Devido à distribuição irregular das estações de observação meteorológica à falta de dados das áreas pioneiras do Oeste, a frequência das geadas pode ser constatada cartograficamente apenas de maneira parcial. O Mapa 5 mostra a quantidade média anual de dias com geada, onde naturalmente é constatada - com exceção das regiões isoladas de elevada altitude no Planalto Meridional, com geadas anuais e uma grande frequência de geadas - uma contínua diminuição do número de dias de geada por ano em direção norte. A região do cultivo de café no Norte do Paraná vivencia em média de 2 a 4 geadas a cada dez anos (MAACK, 1968, p. 102). Nesse contexto, deve-se salientar que a ocorrência de geadas no Norte do Paraná aumentou muito na última década. Isso deve ser atribuído ao livre avanço dos ventos frios do sul devido à devastação excessiva das florestas subtropicais do Paraná (MAACK, 1956 e 1960b).

Até então, nas regiões cafeeiras no Norte do Paraná haviam sido registradas ${ }^{268}$ as fortes geadas a seguir, como a forte geada de 1918, que provocou enormes danos sobretudo nas plantações de café em São Paulo - já que a colonização no Paraná a oeste do Rio Tibagi ainda não havia começado:

Tabela 33: Prejuízos da geada no cultivo de café

\begin{tabular}{|l|l|l|}
\hline 1918 & 25 de junho & São Paulo \\
\hline 1942 & Final de junho, 7 de julho, 14 de julho & Paraná/São Paulo \\
\hline 1953 & 4 de julho & Paraná \\
\hline 1955 & 31 de julho & Paraná/São Paulo (Região de Marília) \\
\hline 1962 & Início de junho & Paraná \\
\hline 1963 & 6 de julho & Paraná \\
\hline 1966 & 5 de agosto & Paraná \\
\hline 1967 & início de agosto & Paraná \\
\hline 1969 & 9 de julho & Paraná/São Paulo (Marília) \\
\hline
\end{tabular}

Fonte: ver nota 3.

A distribuição temporal das geadas mostra que o período crítico tem a duração de cerca de 8 semanas do início de junho ao início de agosto. O mês de julho apresenta a maioria das geadas e também as temperaturas absolutas mais baixas. No Norte do Paraná, segundo Maack (1968, p. 100-101), ocorrem regularmente geadas acima de $800 \mathrm{~m}$ acima do nível do mar; no entanto, o limite inferior absoluto da ocorrência das geadas fica entre 350 e $450 \mathrm{~m}$. Abaixo dessa altitude, porém, apenas pequenas áreas são apropriadas para o cultivo do café, devido ao tipo de solo e ao perigo de inundação na região de influência dos grandes rios.

Enquanto as geadas de radiação tinham consequências apenas regionais e locais, as ondas fortes de frio manifestavam-se em todo Norte do Paraná e também em parte de São Paulo. A chegada da geada durante a madrugada de 30 a 31 de julho de 1955 representou, na região entre Apucarana e Maringá, temperaturas extremamente baixas, entre $-5^{\circ} \mathrm{C}$ e $-9^{\circ} \mathrm{C}$, principalmente nos vales. Em Apucarana $(870 \mathrm{~m})$, a temperatura caiu para $-2,5^{\circ} \mathrm{C}$, enquanto que nos vales caiu até $-8,5^{\circ} \mathrm{C}$ (MAACK, 1968, p. 104).

A paisagem agrária foi decididamente marcada pelo fato de o ar frio descer para os vales e com isso causar inversões de temperatura. As plantações de café se expandem pelas encostas elevadas dos espigões e ocupam somente as partes superiores das encostas dos vales. O escoamento do ar frio mantém livres de geadas as partes localizadas mais alto, enquanto na área de encosta ocorrem graves danos, ainda mais porque os pequenos cursos d'água, devido à baixa condensação, não conseguem manter os fundos de vale livres de geada por meio da formação de nevoeiros (Fotos 5 e 9).

Medições em Rolândia mostraram que a diferença de temperatura no ponto mais baixo de uma plantação de café ficava de $3^{\circ} \mathrm{C}$ a $4^{\circ} \mathrm{C}$ abaixo da temperatura mínima do ponto mais alto (espigão), com somente $160 \mathrm{~m}$ de diferença de altitude ${ }^{269}$. Isso é confirmado por medições de temperatura nas cidades

268 Compilação segundo informações do Instituto Brasileiro do Café e da empresa Anderson, Clayton \& Co., S/A, bem como reportagens e documentação particular.

269 Informações gentilmente cedidas pelo Sr. Rosenthal da fazenda Nova Breesen, Rolândia. Medições na altitude de $550 \mathrm{~m}-710 \mathrm{~m}$ a $50 \mathrm{~cm}$ do chão. 
localizadas nos espigões, nas quais, entre 1966 e 1970, as temperaturas só muito raramente chegaram a menos de $+5^{\circ} \mathrm{C}$ e só excepcionalmente ocorreram geadas (Tabela 34).

Em 9/10 de julho de 1969 foram registradas geadas em quase todo o norte do Paraná, com intensidades muito variadas regionalmente. Os dados de temperatura variavam, dependendo da altitude, da exposição da encosta e da localização das estações, entre $\pm 0^{\circ} \mathrm{C}$ e $-4^{\circ} \mathrm{C}^{270}$.

As consequências dos danos foram intensificadas em 1969 devido aos gelados ventos do sul. Os municípios mais afetados foram os localizados no sudeste da região estudada, sobretudo Faxinal, Califórnia, Grandes Rios, Bom Sucesso e Marilândia do Sul. As encostas sul ficaram especialmente expostas a esses ventos, de modo que se registrou ali uma perda total das plantações de café devido à geada.

No ano de 1969, a combinação de geada de vento e geada de radiação não ocorreu somente na periferia sul da região de cultivo de café, mas também na fronteira entre Paraná e São Paulo, como por exemplo no município de Porecatu. Uma pesquisa com os membros da cooperativa local mostrou que as plantações de café expostas mais elevadas apresentavam, pela ação do vento, danos devidos à geada já a partir do final da tarde do dia 9/7/1969, enquanto que, em 10 de julho cedo pela manhã, a geada de radiação e o acúmulo do ar frio correspondente eliminaram as plantações nas encostas mais baixas. ${ }^{271 .}$

Tabela 34: Quantidade de dias com temperatura mínima abaixo de $5^{\circ} \mathrm{C}$ por ano (Ø 1966-1970)

\begin{tabular}{|c|c|c|c|c|c|c|c|}
\hline Estação & $\begin{array}{l}\text { m acima do } \\
\text { nível do mar }\end{array}$ & Maio & Junho & Julho & Agosto & \multicolumn{2}{|c|}{ Total } \\
\hline \multirow[b]{2}{*}{ Londrina } & \multirow[b]{2}{*}{ (610) } & \multirow[b]{2}{*}{0,4} & \multirow[b]{2}{*}{0,4} & \multirow[b]{2}{*}{0,8} & \multirow[b]{2}{*}{0,2} & \multicolumn{2}{|c|}{1,8 dias } \\
\hline & & & & & & Mín $-1^{\circ} \mathrm{C}$ & Geadas: 1 dia \\
\hline \multirow[b]{2}{*}{ Apucarana } & \multirow[b]{2}{*}{ (870) } & \multirow[b]{2}{*}{0,6} & \multirow[b]{2}{*}{0,4} & \multirow[b]{2}{*}{0,6} & \multirow[b]{2}{*}{0,4} & \multicolumn{2}{|c|}{2,0 dias } \\
\hline & & & & & & Mín $-2^{\circ} \mathrm{C}$ & Geadas: 1 dia \\
\hline \multirow[b]{2}{*}{ Maringá } & \multirow[b]{2}{*}{ (556) } & \multirow[b]{2}{*}{0,2} & \multirow[b]{2}{*}{0,8} & \multirow[b]{2}{*}{0,8} & \multirow[b]{2}{*}{0,2} & \multicolumn{2}{|c|}{2,0 dias } \\
\hline & & & & & & Mín $0^{\circ} \mathrm{C}$ & Geadas: - \\
\hline \multirow[b]{2}{*}{ Paranavaí } & \multirow[b]{2}{*}{ (508) } & \multirow[b]{2}{*}{-} & \multirow[b]{2}{*}{0,2} & \multirow[b]{2}{*}{0,6} & \multirow[b]{2}{*}{0,6} & \multicolumn{2}{|c|}{1,4 dias } \\
\hline & & & & & & Mín $0^{\circ} \mathrm{C}$ & Geadas: - \\
\hline \multirow[b]{2}{*}{ Cruzeiro do Oeste } & \multirow[b]{2}{*}{$(580)$} & \multirow[b]{2}{*}{0,2} & \multirow[b]{2}{*}{0,2} & \multirow[b]{2}{*}{0,8} & \multirow[b]{2}{*}{0,4} & \multicolumn{2}{|c|}{1,6 dias } \\
\hline & & & & & & Mín $0^{\circ} \mathrm{C}$ & Geadas: - \\
\hline$\varnothing$ (média) & & 0,3 & 0,4 & 0,7 & 0,4 & \multicolumn{2}{|c|}{1,8 dias } \\
\hline
\end{tabular}

Fonte: Análise, pelo Autor, das observações climáticas das filiais da empresa Anderson, Clayton \& Co., S./A., 1966 a setembro de 1970.

Em áreas com maiores diferenças de relevo, pode-se reconhecer as linhas de drenagem do ar frio descendente na composição da vegetação. A palmeira icara (Euterpe edulis), sensível à geada e encontrada largamente nas florestas tropicais até o subtrópico, é cada vez menos frequente nos vales. No seu lugar aparece a palmeira jerivá (Arecastrum romanzoffianum), que desaparece somente com mais de 15 dias de geada ao ano (MAACK, 1948, p. 127). Nas encostas sul e nos vales profundamente encravados, surgem também na floresta exemplares da Araucaria angustifolia, que é resistente a geadas e permanece, nos canais de escoamento, abaixo do seu limite inferior de propagação, em geral estabelecido em cerca de 500m acima do nível do mar. Um exemplo semelhante oferece o Rio Cambé, ao sul do espigão entre Arapongas e Londrina. Depois de a geada causar danos, já em 1933,

270 Dados da companhia aérea Varig, da empresa Anderson, Clayton \& Co., S./A., bem como as medições privadas foram utilizados para a comparação.

271 Fotografias particulares dos cafezais do Sítio Santo Antonio do Sr. E. Frassato já mostravam, em 9/7/1969 às 16 horas, a coloração escura da folhagem dos cafeeiros. Popularmente fala-se em geada de vento, por isso fala-se em geada preta, ao contrário da geada branca, com geada de radiação com formação de gelo sobre as plantas (cf. Cap. II, 2). No último caso aparecem os grandes prejuízos somente com menos de $-2^{\circ} \mathrm{C}$. (CAMARGO 1960; 1966, bem como informações fornecidas oralmente por agrônomos do IBC). 
às plantações de café feitas em 1932 - danos esses que se repetiram de maneira catastrófica em 1942 e 1948 - , as plantações de café localizadas na região do vale foram abandonadas. Por outro lado, os cafeeiros situados no cume não registraram danos causados pela geada por um período de 15 a 18 anos (MAACK, 1968, p. 99-100).

$\mathrm{Na}$ exploração das regiões de florestas tropicais foi especialmente registrado, pelos agrimensores e compradores de terras - ao lado de indicadores de bons solos -, a existência de Euterpe edulis como sinal de ausência de geada; depois, foi feita a escolha da terra prevista para plantações de café. Até a papaya selvagem (Jaracatia dodecaphylla), extremamente sensível à geada, servia de planta dominante na vegetação natural, já que as perturbações de crescimento dessas plantas provocadas pela geada ficam visíveis por muito tempo (SCHRÖDER, 1956, p. 132).

Os desmatamentos extensivos provocaram, contudo, grandes distúrbios no equilíbrio natural do calor e da umidade naturalmente válidos para a floresta tropical. Em especial, ocorriam cada vez com mais frequência maiores amplitudes diárias e temperaturas extremas.

Na região cafeeira do Norte do Paraná há sempre muita tensão na população durante a estação do ano no qual há o risco de geada. Os fortes danos frequentemente ameaçam a existência de pequenos e médios proprietários. Para as grandes fazendas, eles significam perdas de lucro enormes ${ }^{272}$ ou necessitam de grandes investimentos para o novo plantio etc. Além dos proprietários de terras, arrendatários, administradores envolvidos proporcionalmente na colheita, trabalhadores rurais e trabalhadores migratórios, os 'maquinistas' - que executam o preparo do café -, organizações de comercialização, filiais das empresas exportadoras de café, empresas de transporte, atacado e varejo, indústrias produtoras de adubos e também os bancos temem os efeitos sobres seus lucros. Depois de fortes geadas, os investimentos em todos os setores caem bastante, e até a próxima floração predomina uma incerteza - que em geral paralisa qualquer atividade econômica normal - sobre a extensão dos danos causados pela geada.

Reportagens de jornal sobre relatos de geadas oriundas do Uruguai e do Rio Grande do Sul, bem como do Planalto Meridional, e consequentemente sobre a aproximação de frentes frias são acompanhadas com preocupação. Embora ainda não exista, neste início dos anos 1970, um serviço organizado de alerta contra geadas, as filiais das empresas exportadoras de café, os escritórios locais de empresas aéreas e as poucas estações de observação meteorológicas oficiais do Ministério da Agricultura repassam alertas contra perigos de geada por meio das estações de rádio locais que alcançam a uma parte dos plantadores de café.

\section{MÉTODOS PARA IMPEDIR DANOS CAUSADOS PELA GEADA NO PLANTIO DE CAFÉ}

Em face da extensão dos danos, foram feitas tentativas, há muito tempo, por parte do setor privado - e também do setor público através do IBC e do Instituto Agronômico em Campinas-SP - de desenvolver métodos para impedir os danos causados pelas geadas. ${ }^{273}$ Recorreu-se a experiências norteamericanas com plantações cítricas ameaçadas por geadas na Califórnia e na Flórida, bem como também a experimentos aplicados nas regiões vinícolas alemãs.

\section{a) Medidas preventivas}

Com base na experiência anterior com danos causados por geada, foram executadas medidas preventivas referentes à posição e exposição de inclinação das plantações de café. Por conseguinte, os cafeeiros situados numa área com maior acúmulo de ar frio foram arrancados, por exemplo, em depressões e no terço inferior da encosta, como também nos canais de escoamento de ar frio emanante da região da fonte de pequenos córregos até a base do vale.

272 Assim, as perdas totais de uma fazenda perto de Apucarana com aproximadamente 450.000 cafeeiros em decorrência da geada em 1969 foram calculadas em um valor superior a 1 milhão de dólares (de acordo com informações gentilmente cedidas pela Fazenda Ubatuba, em 25 de setembro de 1970).

273 No Paraná, a Secretaria de Agricultura do estado fundou um "Serviço de estudos para a defesa contra a geada". 
Devido ao perigo de inversões térmicas no inverno, as plantações de café se estendem ao longo de espigões, frequentemente com restos de mata na área inferior da encosta, sobretudo em plantações maiores. O acúmulo de ar frio no limite superior da mata causou, em parte, prejuízos significantes, de maneira que foram abertos aceiros na mata, em pequenos vales íngremes para o escoamento do ar frio.

O Mapa 32 mostra uma comparação dos danos causados pela geada de 1955 e 1962 numa parte de uma fazenda de café perto de Apucarana. Lá fica especialmente clara a importância dos 100 - $150 \mathrm{~m}$ de largura para o escoamento de ar frio e, consequentemente, para a prevenção de danos de geada $(1962,1)$, enquanto os danos causados por geada em 2 ficaram constantes.

O efeito do corredor estabelecido pode ser comprovado também por meio de uma medição comparativa de temperatura (Mapa 32 e Figura 7B, C). O ar frio que escoa rapidamente deixa a temperatura no ponto mais baixo 1 cair quase $2^{\circ} \mathrm{C}$ apesar da inversão térmica. ${ }^{274} \mathrm{O}$ ponto 2 , por outro lado, continua indicando um acúmulo de ar frio. Essa diferença aparece também nos dois pontos, ao observar-se os gradientes de temperatura verticais (Figura 7C). A $20 \mathrm{~cm}$ acima do solo, a diferença é de $2^{\circ} \mathrm{C}$ (no ponto $1:-1^{\circ} \mathrm{C}$; no ponto $2:-3^{\circ} \mathrm{C}$ ), a uma altura de $3,20 \mathrm{~m}$ até mesmo $3^{\circ} \mathrm{C}\left(1:+2,5^{\circ} \mathrm{C} ; 2:-0,5^{\circ} \mathrm{C}\right.$ ). O escoamento rápido de ar frio, em ponto 1 , faz com que numa altura de pouco mais de $1 \mathrm{~m}$ já não haja mais geada.

Por razões climáticas, plantios de café em encostas com uma inclinação superior a 10\% são especialmente favorecidos, já que aqui o ar frio escoa mais rapidamente. Por outro lado, plantações situadas em depressões localizadas em planaltos são mais intensamente ameaçadas por geadas.

Entre as medidas preventivas microclimaticamente importantes está o capinar entre as fileiras de cafeeiros para um melhor arejamento das plantações. Em noites de geada, os cafeeiros tenros têm de ser cobertos com palha, no buraco de plantio.

\section{b) Combate direto à geada}

Para o combate direto à geada na noite, foram empregados até aquele momento o aquecimento do ar por meio de disposição de fornos a óleo, de circulação de ar através de grandes ventiladores, do borrifamento (chuvisco artificial) e da nebulização.

Em face da grande extensão das plantações de café, seja na forma de latifúndios isolados ou de muitas fazendas de pequeno e médio porte, e por causa dos investimentos excepcionalmente altos necessários para a instalação das respectivas aparelhagens e sua manutenção, as medidas de combate direto à geada só foram executados esporadicamente. Nisso a nebulização se afirmou, por causa dos baixos custos ${ }^{275}$ e das condições de relevo, como a única solução recomendável para o Norte do Paraná, por motivos práticos e econômicos. ${ }^{276}$ Especialmente importantes, no entanto, são o modo de nebulização (combustão de cápsulas de fumaça ou pulverização), a técnica correta da aplicação e momento adequado da execução. A nebulização tem de ser iniciada quando é alcançada uma temperatura de $+2^{\circ} \mathrm{C}$ a $50 \mathrm{~cm}$ acima do solo, antes das 4 da madrugada, pois então deve-se temer uma queda para $-2^{\circ} \mathrm{C}$ até o nascer do sol, a temperatura-limite para a aparição de prejuízos maiores nas plantações de café. Preparativos planejados são necessários para a execução da nebulização em noites de geada por empregados capacitados.

A nebulização, que tem a função de impedir o acúmulo de ar frio sobre o solo, é melhor executada em diferentes pontos na parte superior da encosta. O método é especialmente apropriado para depressões e pequenas bacias de vales cuja área não ultrapasse 250 ha (CAMARGO, 1960, p. 18ss.).

274 Cf. sobre isso uma reportagem de Camargo (1959) sobre tentativas práticas de combate à geada, na Fazenda Stinnes em Ubatuba, perto de Apucarana, como também Ortolani, Camargo e Salati 1963. - A mudança das condições de temperatura na Figura 7B, em 25 de julho de 1962, antes das 24h, tem de ser atribuída à ação do vento, que somente diminuiu na madrugada.

275 Tentativas realizadas pelo Instituto Agronômico em Campinas-SP e no Paraná mostraram que os custos do aquecimento do ar com aparelhagens de combustão de óleo chegavam a 50 vezes o valor da nebulização (CAMARGO 1960, p. 11/12; 1966, p. 17ss.).

276 Aparelhagens para borrifamento de chuvisco artificial sobre plantas e, com isso, para formação artificial de escarcha como medida de proteção contra geadas de irradiação rigorosas foram instaladas a título de experiência em algumas plantações, mas, pelo autor, só puderam ser observadas em funcionamento em 1970 no Planalto de Amambay no leste do Paraguai, ao sul de Pedro Juan Caballero. 
Êxito, no entanto, só pode ser alcançado quando se trata de geadas de irradiação, pois a nebulização localizada somente é possível com calmaria completa.

Enquanto até agora somente fazendas de médio e grande porte levantaram o capital para um combate ativo à geada, há planos para realizar um combate direto à geada no setor de pequenas propriedades, em partes relativamente estreitas, numa base cooperativa.

O acúmulo de geadas com consequências econômicas graves na década de 1960 aumentou a disposição geral dos plantadores para experimentos com o propósito de combater a geada. As dúvidas sobre a eficácia das medidas em áreas grandes, no entanto, permaneceram, especialmente quando a névoa artificial é movida para baixo pela ação do vento, em direção ao vale.

O fato empírico de que com cafeeiros bem adubados e saudáveis se registrava, em geral, relativamente pouca perda de colheita devido a danos causados pela geada garantiu à indústria de fertilizantes um forte aumento de vendas nos 4 anos anteriores à conclusão desta pesquisa.

\section{ANÁLISE QUANTITATIVA DOS DANOS CAUSADOS PELA GEADA EM 1969}

Se algumas das ocorrências mais fracas de geada no passado, durante o boom do plantio de café no Norte do Paraná, tiveram um efeito que freou o aumento excessivo de produção - consequentemente, um efeito positivo - , a última geada de 1969 atingiu a economia cafeeira do Paraná numa fase de consolidação, após a finalização das diferentes medidas de restrição ao plantio. Os danos causados pela geada de 10 de julho de 1969 foram os mais amplos registrados até agora em sua extensão, incluindo todo o Norte do Paraná (Foto 15).

A dimensão das geadas e, com isso, as perdas de colheita são classificadas pelo Instituto Brasileiro do Café em três níveis de intensidade, de acordo com o seguinte esquema:

a) O congelamento das folhas e dos ramos medianos do cafeeiro até um terço do comprimento do ramo. Isso significa, em geral, a perda de uma colheita, ou seja, da colheita do ano seguinte.

b) Morte das folhas e dos ramos (até dois terços): Perda da colheita dos dois anos seguintes.

c) Morte das folhas, dos ramos e do tronco: Perda de 3 colheitas ou, em caso de morte completa, perda total. Isto torna necessário erradicar o cafeeiro ou podá-lo até cerca de $30-40 \mathrm{~cm}$ acima do solo.

A Tabela 35 dá uma ideia da intensidade e da extensão dos danos causados pela geada nos últimos 10 anos no Paraná.

Enquanto em 1962 somente um terço e, em 1963, dois terços dos cafeeiros sofreram danos causados pela geada, em 1969 quase todos os cafeeiros do Norte do Paraná (97\%) foram atingidos. 42\% revelaram danos leves causados pela geada, 33\% medianos e 22\% fortes. Uma comparação da distribuição de frequência da intensidade da geada mostra que, no ano da geada de 1963, houve a maior concentração de danos graves, com $38 \%$, enquanto, em 1969, puderam ser registrados danos fracos com maior frequência $(42 \%) .^{277}$

A diferenciação regional da intensidade dos danos causados pela geada ${ }^{278}$ na região de plantio de café do Norte do Paraná é mostrada no Mapa 33. Houve fortes danos causados pela geada na região do médio Ivaí e do Rio Pirapó, onde foram registrados danos graves nas plantações de café localizadas no declive inferior da encosta e nos vales fluviais, em decorrência de inversões de temperatura e acúmulo de ar frio. Nos municípios de Flórida, Lobato, Paiçandu, Floresta, Doutor Camargo e Ivatabu, mais de $75 \%$ dos cafeeiros apresentam fortes danos causados pela geada e, com isso, provavelmente uma perda de colheita de três anos. Também as partes mais baixas dos

277 Para comparação: em 1953 houve danos causados pela geada em 72\% dos cafeeiros (37\% danos fortes, 35\% fracos); em 1955, houve danos causados pela geada em 36\% (MAACK, 1968, p. 132).

278 Avaliação, pelo Autor, da análise aleatória por parte dos agrônomos do IBC/Gerca, usando o método Tschuproff-Neyman, e dos relatórios para as áreas SAG individuais (área de trabalho de um agrônomo), por município. Coleta de material nas agências regionais do IBC em Londrina e Maringá, bem como no Departamento Estadual do Café, Escola de Agronomia (Projeto Cerena) e Faep em Curitiba. 
municípios de Terra Boa até Rondon, localizados ao sul do Ivaí, foram gravemente atingidas, e até mesmo as plantações situadas na região dos espigões entre o Ivaí e o Pirapó numa altitude de aproximadamente $500 \mathrm{~m}$ sofreram perdas significativas por conta dos gelados ventos meridionais. Sobretudo houve somente danos fracos a medianos ou medianos nas regiões elevadas de plantio em volta de Apucarana e na cumeada até Londrina, ou seja, na área dos divisores de água Pirapó/ Bandeirantes e Ivaí/Tibagi.

Tabela 35: Intensidade e extensão de danos causados pela geada em plantações de café no Norte do Paraná

\begin{tabular}{|c|c|c|c|c|c|}
\hline \multirow{3}{*}{ Intensidade da geada } & \multirow{3}{*}{ Perda de colheita em anos } & \multicolumn{4}{|c|}{ Danos causados pela geada } \\
\hline & & 1962 & 1963 & 1966 & 1969 \\
\hline & & \multicolumn{4}{|c|}{ em \% do número total } \\
\hline Nível a (fraco) & 1 & 12 & 13 & 22 & 42 \\
\hline Nível b (mediano) & 2 & 10 & 15 & 20 & 33 \\
\hline Nível c (forte) & 3 & 11 & 38 & 15 & 22 \\
\hline \multicolumn{2}{|c|}{ Total de cafeeiros com danos causados pela geada } & 33 & 66 & 57 & 97 \\
\hline
\end{tabular}

Fonte: Dados fornecidos pelo IBC e Gerca (1969).

As plantações de café pouco extensas, situadas na Serra do Cantu, a sudoeste da região de análise, entre Mamborê e Goio-Erê, sofreram relativamente poucos danos por causa da inversão de temperatura de julho de 1969.

Do Mapa 33 pode-se inferir que a influência da geada diminui em direção ao Nordeste. Na região em volta de Cambé e Sertanópolis, em parte 20-30\% dos cafeeiros não apresentam danos significativos causados pela geada. Isso é confirmado no Norte Velho, no Nordeste do Paraná - localizado fora da região estudada - , onde, em contraste evidente com o restante do Norte do Paraná, $14 \%$ dos cafeeiros não foram atingidos pela geada e somente $9 \%$ foram danificados gravemente.

No panorama regional, resultaram os seguintes danos causados pela geada em 1969, no plantio de café paranaense ${ }^{279}$ (ver Tabela 36).

Enquanto os efeitos negativos da geada (cerca de 10\%) foram pequenos sobre a colheita de café em julho de 1969, - cerca de 9\% dos frutos já estavam maduros de acordo com IBC ${ }^{280}$ —, os danos na colheita do ano de 1970 são estimadas em $81 \%$.

As plantações de café de um a 2 anos foram, em parte, mais fortemente danificadas do que é mostrado na Tabela 37 no grupo de até 4 anos.

279 Empregada para fins de comparação, a avaliação de um levantamento da representação regional da firma norte-americana Anderson Clayton \& Co, em Londrina e Maringá, mostrou cotas percentuais similares de danos causados pela geada, para o ano de 1969, usando também uma diferenciação de intensidade tripartida, em nível municipal.

Nisso, somente o Norte Novíssimo II representa uma exceção, ou seja, as regiões ao sul do Ivaí, onde foram constatados danos fortes em $26 \%$ dos cafeeiros, em contraste com os dados do IBC (18\%). Agradeço aqui pela autorização para a verificação dos levantamentos de uso interno da empresa.

280 Somente os grãos de café verdes e não maduros ressecam em consequência da geada, ficando pretos. Por esse motivo, chamam-se de queimados os cafeeiros que sofreram danos causados pela geada. Os grãos pretos da colheita têm um efeito negativo na qualidade do sabor. 
Tabela 36: Danos causados pela geada no plantio de café no Paraná em 10 de julho de 1969 (em 1000 cafeeiros)

\begin{tabular}{|c|c|c|c|c|c|c|c|c|c|c|c|c|}
\hline \multirow{3}{*}{ Região } & \multicolumn{8}{|c|}{ Danos causados pela geada em cafeeiros } & \multirow{2}{*}{\multicolumn{2}{|c|}{$\begin{array}{l}\text { Sem danos } \\
\text { causados por } \\
\text { geada }\end{array}$}} & \multirow{2}{*}{\multicolumn{2}{|c|}{$\begin{array}{l}\text { Qtd. total } \\
\text { cafeeiros }\end{array}$}} \\
\hline & \multicolumn{2}{|c|}{ fraco } & \multicolumn{2}{|c|}{ mediano } & \multicolumn{2}{|c|}{ forte } & \multicolumn{2}{|c|}{ total } & & & & \\
\hline & Qtd. & $\%$ & Qtd. & $\%$ & Qtd. & $\%$ & Qtd. & $\%$ & Qtd. & $\%$ & Qtd. & $\%$ \\
\hline Norte Novo & 129212 & 41 & 91032 & 29 & 83255 & 26 & 303499 & 96 & 10511 & 4 & 314010 & 37 \\
\hline \multicolumn{13}{|l|}{ Norte Novíssimo I } \\
\hline (Região Paranavaí) & 91131 & 41 & 73717 & 33 & 54673 & 25 & 219521 & 99 & 1935 & 1 & 221456 & 26 \\
\hline $\begin{array}{l}\text { Norte Novíssimo II } \\
\text { (Reg. Umuarama e } \\
\text { Campo Mourão) }\end{array}$ & 93869 & 44 & 77760 & 37 & 38814 & 18 & 210443 & 99 & 1013 & 1 & 211456 & 25 \\
\hline Norte Velho & 43165 & 43 & 34730 & 34 & 9355 & 9 & 87250 & 86 & 13494 & 14 & 100744 & 12 \\
\hline Paraná total & 357375 & 42 & 277239 & 33 & 186097 & 22 & 820713 & 97 & 26953 & 3 & 847666 & 100 \\
\hline
\end{tabular}

Fonte: Gerca, 1969.

Tabela 37: Danos causados pela geada em 1969 nas plantações de café, no Norte do Paraná, de acordo com a idade e a situação de produção dos cafeeiros

\begin{tabular}{|l|c|c|c|c|c|c|}
\hline & \multicolumn{3}{|c|}{$\begin{array}{c}\text { Danos causados pela geada } \\
\text { Intensidade da geada }\end{array}$} & \multicolumn{3}{c}{ Total de cafeeiros } \\
\hline $\begin{array}{l}\text { Cafeeiros } \\
\text { Idade e estágio de produtividade }\end{array}$ & $\begin{array}{c}\text { leve } \\
\%\end{array}$ & $\begin{array}{c}\text { médio } \\
\%\end{array}$ & $\begin{array}{c}\text { forte } \\
\%\end{array}$ & $\begin{array}{c}\text { Total } \\
\%\end{array}$ & Quant. & $\%$ do total do Paraná \\
\hline Até 4 anos (ainda não produzindo) & 28 & 36 & 28 & 92 & 49.199 & 5,8 \\
\hline Mais de 4 anos (produzindo) & 44 & 32 & 21 & 97 & 775.730 & 91,5 \\
\hline Mais de 4 anos (não produzindo) & 26 & 21 & 53 & 100 & 22.737 & 2,7 \\
\hline Paraná & 42 & 33 & 22 & 97 & 847.666 & 100,0 \\
\hline
\end{tabular}

Fonte: Gerca, 1969b.

Tabela 38: Retrocesso de produção no plantio de café no Paraná, após a ocorrência de geadas

\begin{tabular}{|c|c|c|c|}
\hline \multirow{2}{*}{ Ano da geada } & \multicolumn{2}{|c|}{$\begin{array}{c}\text { Produção de café } \\
\text { (em } 1000 \text { sacas } 60 \text { kg) }\end{array}$} & \multirow{2}{*}{ Retrocesso de produção em \% } \\
\hline & no ano da geada & no ano seguinte & \\
\hline 1953 & 3.198 & 1.337 & 58 \\
\hline 1955 & 6.306 & 2.178 & 65 \\
\hline 1962 & 18.032 & 9.157 & 49 \\
\hline 1963 & 9.157 & 7.146 & 22 \\
\hline 1969 & $8.500^{*}$ & $1.600^{*}$ & 81 \\
\hline
\end{tabular}

* Última estimativa de colheita do IBC (de acordo com: Anuário Estatístico do Café 1972)

Fonte: 1953-1963: IBC-Divisão de Estatística, informações pessoais.

No entanto, a influência das novas plantações atingidas sobre a tendência de desenvolvimento da produção de café nos próximos anos é relativamente baixa, já que sua porcentagem no total de cafeeiros é menor que $6 \%$ e, com isso, uma perda total também não será de importância decisiva. Com a morte completa das plantas jovens mais vulneráveis à geada por terem menor proteção pelas folhas, contudo, investimentos maiores se fazem necessários para plantios novos, estendendo o período não-produtivo até mais de quatro anos, até o alcance da idade produtiva das árvores. 
As perdas de produção no ano de colheita após os danos causados pela geada alcançaram, antes do ano de 1969, o seu máximo com 65\%, levando em consideração a geada forte de 1955 (Tabela 38). Sobre a geada extremamente forte de 1942 não há dados relativos à provável perda de produção. No Paraná, o plantio de café, no entanto, encontrava-se nessa época somente em fase inicial, de maneira que pelo menos as perdas absolutas foram baixas.

No entanto, é necessário relativizar os dados do IBC e rever sua expressividade e suas consequências efetivas. Para a perda da colheita é decisivo se a geada cai num período 'alto' ou 'baixo', durante o ritmo produtivo bianual de colheitas boas e ruins (Figuras 2 e 14).

No primeiro caso, teria de ser esperar de qualquer modo uma colheita mais fraca no ano seguinte, de maneira que o retrocesso de produção, aumentado pelos danos causados pela geada, é de fato muito alto, mas a perda propriamente dita pode ser muito mais baixa (por exemplo em 1955/56).

Se, contudo, a geada surge num ano com uma colheita pequena, ou seja, numa fase de regeneração dos cafeeiros, então a perda da colheita do ano seguinte, no qual era de se esperar uma colheita boa, é relativamente maior, embora a produção absoluta comparada com o ano de geada pode aumentar levemente (Figuras 2 e 14).

Na redução de produção, a geada de 1969 excedeu mais ainda o retrocesso de 1955 para 1956, em relação à colheita seguinte, do ano de 1970. Via de regra, a colheita do ano de 1970 teria caído, de qualquer modo, no período baixo de produção, de maneira que a perda de colheita 'real' foi amenizada.

Uma estimativa de colheita da firma Anderson, Clayton \& Co., S.A. indica somente uma produção de 1,16 milhões de sacas, no estado do Paraná, em $1970 .{ }^{281}$ De acordo com observações próprias, o Norte Novo e o Norte Novíssimo foram atingidos em 1970 por uma ausência total de colheita de café, de maneira que o último dado provavelmente corresponde mais à realidade do que a estimativa oficial do IBC de 1,6 milhões de sacas.

A avaliação dos dados sobre colheitas de café de acordo com os anos de geada é especialmente difícil, porque as primeiras estimativas de perda foram determinadas com índices altos por motivos táticos, na esperança de eventualmente receber uma ajuda imediata por parte do governo. Por outro lado, as estatísticas do registro de café282 do IBC incluem igualmente café que, no primeiro momento, se retém dos plantadores após a geada, por especulação de preços e que então, no ano seguinte com a oferta sendo pequena, pode ser posto à venda como nova safra a um preço mais favorável.

\section{CONSEQUÊNCIAS SOCIOGEOGRÁFICAS DIRETAS E INDIRETAS DA GEADA DE 1969}

\section{a) Tendências de desenvolvimento agrário-sociais}

A geada de 10 de julho de 1969 causou um choque nos plantadores de café do Norte do Paraná, especialmente porque, depois de uma primeira avaliação provisória dos danos causados pela geada, já se contava com uma produção nula da colheita em 1970.

Uma grande parte dos plantadores parou todos os investimentos nas plantações de café arruinadas, e a colheita que se acabara de fazer foi retida na esperança de um forte aumento de preços. Muitas vezes, as plantações de café foram abandonadas, sobretudo, nas áreas periféricas meridionais e em áreas localizadas em encostas sul ou bacias (Foto 15).

A imagem da lavoura mostra claramente que os galhos congelados e secos foram retirados somente parcialmente e que árvores completamente mortas não foram erradicadas num primeiro momento. Somente uma parte dos cafeeiros congelados foram cortados a 30-50 $\mathrm{cm}$ acima do solo, para possibilitar que plantas voltassem a brotar e a crescer.

281 "Crop production estimate" de acordo com o Coffee Statistics da firma Anderson, Clayton \& Co, S.A. de 15 de julho de 1970, em Santos, como também informações pessoais do Senhor Fenner, Santos, de 23 de julho de 1970. 1969: 11,14 milhões de sacas; 1970: 1,16 milhões de sacas = perda de produção de $90 \%$.

282 Para 1970: 3,918 milhões de sacas (IBC, Anuário Estatístico do Café, 1972, p. 22). 
O comportamento por parte dos plantadores de café, primeiramente de expectativa, arraigada na esperança por uma ajuda financeira do governo para plantios novos ou para a adaptação a outras culturas, logo se alterou. Um grande número de trabalhadores rurais aos quais se havia cofiado até agora o cuidado dos cafeeiros e que tinham suas residências fixas nas casas de trabalhadores das fazendas e dos sítios foi demitido. Além disso, já era possível antever que as grandes massas de trabalhadores migrantes ficariam desempregadas no ano seguinte, em decorrência da colheita nula.

O número de 10 a 12 mil trabalhadores do Norte Novo e Norte Novíssimo do Paraná que ficou desempregado em decorrência da erradicação de 28 milhões de cafeeiros (GERCA, 1969b, p. 6) após a geada, em 1969, aumentou ainda mais em consequência do abandono de plantações maiores no Noroeste do estado.

O afluxo da população rural, repentinamente desempregada, às cidades de pequeno e médio porte no Norte do Paraná piorou significativamente a situação social que estava tensa naquela região, em decorrência da execução dos programas de erradicação.

Após a recuperação relativamente rápida das plantações de café danificadas pela geada e sobretudo após a florescência intensiva de 1970 - que, depois da colheita quase completamente nula desse ano, foi um indicador de uma boa colheita para $1971^{283}$ — , cada vez mais se fez necessária mão de obra para a limpeza das plantações de café, para o corte dos brotos secos, para capinar etc. As casas desocupadas de trabalhadores das fazendas só paulatinamente foram atribuídas às famílias.

Essa evolução confirma de modo claro, uma tendência que já pôde ser observada a partir da reformulação das leis de direitos sociais rurais: $\mathrm{O}$ abandono de famílias trabalhadoras com base em contratos de trabalhos por tempo indeterminado e assentadas nas terras da fazenda. Danos causados pela geada e o abandono simulado de plantações de café frequentemente serviam apenas de subterfúgio. Para evitar as requisições da legislação agrário-social, muitos trabalhadores rurais foram demitidos de seus contratos fixos nessa ocasião. A readmissão dos trabalhadores rurais demitidos como boias-frias sem contrato estava vinculada a custos baixos e sem qualquer risco para os proprietários de terras. A migração diária das periferias às fazendas da região fez surgir uma relação de emprego totalmente nova e uma situação de ilegalidade trabalhista.

A seguir, analisaremos as bases da legislação social rural e o novo sistema de emprego dos trabalhadores rurais conhecido como 'boias-frias' ${ }^{284}$.

\section{b) Legislação dos trabalhadores rurais e seus efeitos}

Em 1963, durante do governo do presidente Goulart, com o Estatuto do Trabalhador Rural ${ }^{285}$ foi votada uma nova legislação do trabalhador rural que regulava, pela primeira vez de maneira exata, a relação de trabalho e o relacionamento entre empregador e empregado na área rural. Os aspectos mais importantes dessa lei são:

1) Torna-se obrigatória a carteira profissional para todos trabalhadores rurais, que contém, além de dados pessoais, também detalhes sobre o tipo e a duração do contrato de trabalho em cada local de trabalho, e tem a finalidade de ser utilizada em conflitos diante da Justiça do Trabalho e do Seguro Social.

2) Todo empregado na economia rural acima de 16 anos $^{286}$ tem de receber, pelo menos, o salário mínimo previsto pela lei estipulado regionalmente.

Desse salário mínimo, o patrão pode descontar $20 \%$ para o aluguel de uma casa sobre suas terras como também os custos para alimentos postos à disposição. Os preços dos mantimentos, no entanto ao contrário do praticado por muitos proprietários de plantações até agora - não podem estar acima no nível de preço regional comum. Além disso, não se pode descontar mais de $25 \%$ do salário mínimo para mantimentos. As colheitas das plantações intermediárias dos trabalhadores rurais não podem mais ser descontadas do salário por parte do proprietário das terras.

283 De acordo com os mais novos dados do IBC, a colheita de 1971 já voltou a alcançar 12,8 milhões de sacas de café (IBC, Anuário Estatístico do Café, 1972, p. 27-28).

284 Cf. sobre isso a seção (c) adiante.

285 Lei n. 4.214 de 2 de março de 1963; veja também Feteap, 1967: Manual de legislação rural; e Contag: Estatuto do trabalhador rural.

286 Trabalhadores com menos de 16 anos recebem meio salário-mínimo. 
3. A jornada diária é de 8 horas, com uma pausa no meio para alimentação. Horas extras e trabalho noturno são remunerados com um aumento de $25 \%$ sobre salário normal.

4. Além de um dia de repouso remunerado por semana, todo trabalhador tem direito, após 12 meses de trabalho e com não mais que 6 dias de faltas nesse período, a 20 dias de férias remuneradas.

5. No caso de rescisão de um contrato de trabalho assinado com base em prazo indeterminado por parte do empregador, este tem de pagar ao trabalhador rural um salário mensal por cada ano de trabalho - com exceção do período probatório de um ano - como indenização.

6. Depois de 10 anos de serviço, o trabalhador rural alcança a estabilidade e não pode ser demitido, a não ser que tenha cometido erros graves.

7. Para o seguro social ${ }^{287}$ dos trabalhadores rurais e seus familiares dependentes, o empregador tem de pagar o equivalente a $1 \%$ do valor dos produtos agrícolas produzidos por ele. $\mathrm{O}$ assegurado 288 paga uma contribuição anual que corresponde a $8 \%$ do triplo ao quíntuplo do salário mínimo.

Depois da legislação do trabalhador rural ser controlada de maneira extremamente superficial após entrar em vigor, tanto pelo governo esquerdista de Goulart como também, depois do golpe em abril de 1964, pelo governo militar, a situação dos trabalhadores rurais no Brasil quase não mudou até 1967. As determinações legais foram interpretadas de tal maneira que - quando não eludidas - geravam uma desvantagem para o trabalhador rural.

A intensificação dos controles de contratos trabalhistas por meio de órgãos do governo militar desde 1967, o novo texto dos regulamentos legais no contexto do seguro social ${ }^{289}$ como também a organização e o melhoramento da funcionalidade dos sindicatos de trabalhadores rurais ${ }^{290}$ provocaram, como reação por parte dos proprietários de terras, inúmeras demissões de trabalhadores rurais. A geada e as restrições das plantações de café frequentemente proporcionavam somente o motivo aparente para a dissolução aparentemente justificada dos contratos de trabalho. Muitas fazendas de médio e grande porte se esquivaram desse modo da responsabilidade pela segurança social de seus empregados!

Os trabalhadores rurais desempregados e suas famílias se dirigiram aos grandes centros urbanos regionais, diretamente ou após uma procura de trabalho fracassada na zona rural. Logo uma parte desses trabalhadores foi recontratada para o cuidado das plantações de café que estavam se regenerando, para a transição das fazendas para outros produtos de cultivo, ou para a organização de pastagens e a construção de cercas de arame etc.

\section{c) A problemática social do sistema de 'boia-fria' e a mobilidade espacial forçada dos trabalhadores rurais}

Esse novo sistema de contratação baseado no assim chamado sistema de 'boia-fria'291 se diferencia, contudo, de maneira fundamental da antiga situação de emprego dos trabalhadores rurais assegurada, ao menos temporariamente, por um contrato de trabalho. Esses trabalhadores agora vivem nas favelas, que crescem rapidamente e medram nas periferias (Foto 12), e não mais nas casas de trabalhadores dos sítios e fazendas. Eles se transformaram, em grande parte contra sua vontade, em 'jornaleiros' que vão e voltam diariamente; eles não são mais dependentes do proprietário de terra, mas sim do assim chamado 'gato', geralmente o proprietário de um ou mais caminhões.

Esse 'gato' intervém como mediador de trabalho e age como 'corretor de mão de obra'. Ele não dá qualquer tipo de seguro social.

O recrutamento da mão de obra de boias-frias acontece diariamente, de madrugada, entre 4 h30 e 6h, em locais de encontro na periferia (em Londrina, por exemplo, na favela de Shangri-lá), nos quais

287 Funrural: Fundo de Assistência e Previdência do Trabalhador Rural. O seguro abarca vantagens como assistência médica, apoio quando de nascimentos e mortes, como também pensão por invalidez e para família do falecido.

288 Obrigatoriamente assegurados são trabalhadores rurais, arrendatários, empreiteiros e proprietários de pequenas propriedades. Desde o começo de 1970, existe um seguro público de acidentes para trabalhadores rurais registrados.

289 Cf. sobre isso Contag: Fundo Rural (de acordo com o Decreto Lei n. 276, 28.2.1967).

290 Sobre as tarefas dos 110 sindicatos rurais no Paraná, veja Fetaep (1967, p. 3ss.), bem como também informações orais fornecidas pelo Senhor J. Lazaro Dumont, presidente da Federação dos Trabalhadores na Agricultura do Estado do Paraná, no dia 11 de agosto de 1970, em Londrina.

291 O termo coloquial 'boia-fria' é derivado da comida levada numa panela (arroz, feijão, farinha de mandioca) e esquentada na hora do almoço pelos trabalhadores rurais. 
os caminhões levam respectivamente 50-70 trabalhadores, conduzindo-os a uma determinada fazenda (Foto 11), frequentemente a uma distância de $30 \mathrm{~km}$ ou mais. Em certos dias, aparecem mais de 50 caminhões $^{292}$. O número de pessoas que procura emprego nesse sistema de bóia-fria alcançou em 1970 picos diários de até 3000 pessoas na cidade de Londrina, cuja idade oscilava entre 13 e 55 anos.

Como o 'gato' frequentemente é contratado na função de empreiteiro para trabalhos de empreitada em propriedades maiores, ele está interessado em homens jovens e fortes sob seu comando para realizar esse trabalho, escolhidos por ele nos pontos de encontros entre aqueles que estão esperando. O proprietário de terra somente negocia com o 'gato' e paga a este, em geral, diariamente a quantia estipulada. O gato desconta do ganho diário dos trabalhadores rurais - que recebem cerca de NCr\$ 4,50 a 5,50 (junho de 1970: 1 NCr\$= 0,85 DM) - de NCr\$ 1,00 a NCr\$2,50 pelos custos de transporte de e para o local de trabalho! O valor dos custos de transporte é determinado ${ }^{293}$ pelo 'gato', frequentemente de acordo com a idade ou a capacidade de trabalho, significando, além disso, um ganho considerável.

O salário de empreitada para os diferentes trabalhos foi pago, em junho de 1970, em média com as seguintes quantias por pessoa:

Colheita de milho
Colheita de café (Norte Velho)
Colheita de cana-de-açúcar
Colheita de algodão
Colheita de feijão

Os salários de empreitada são escalonados de maneira que o trabalhador poderia alcançar o salário mínimo com 30 dias de trabalho, porém nos finais de semana não há trabalho, e os altos custos de transporte reduzem o ganho do trabalhador em 20 a 40\%. Além disso, os trabalhos tomados por base a serem realizados geralmente são bastante pesados e só podem ser feitos por trabalhadores jovens.

A migração diária de ida e volta dos boias-frias - das áreas residenciais, na periferia urbana, às fazendas rurais de médio e grande porte na região - foi analisada mais detalhadamente pelo exemplo de Londrina ${ }^{294}$. No Norte Novo do Paraná, sobretudo na área de colonização da Cia. Terras Norte do Paraná (já denominada Cia. Melhoramentos Norte do Paraná/CMNP, à época da pesquisa), a alta porcentagem de propriedades de pequeno e médio porte atenuou a problemática e as consequências do sistema de 'boia-fria'.

Como a antiga área da CMNP tem seu extremo sudeste perto de Londrina; o limite com as grandes fazendas mais afastadas transcorre no norte a somente cerca de $18 \mathrm{~km}$, e no sul a $15 \mathrm{~km}$ de Londrina; e como muitos trabalhadores rurais que anteriormente tinham um contrato fixo se assentaram na periferia da cidade grande após serem demitidos, pode-se observar especialmente bem nessa área o fenômeno de mobilidade de boias-frias.

A Figura 8 mostra a distribuição percentual dos lugares de trabalho de boias-frias, a partir da respectiva distância das fazendas da cidade de Londrina e sua localização.

292 Em primeiro de junho de 1970, o primeiro dia da entrevista realizada pelo autor em Londrina, somente 5\% dos caminhões para o transporte dos boias-frias foram providenciados pelos proprietários de terra.

293 Esses dados e as exposições seguintes são o resultado de entrevistas realizadas pelo Autor com boias-frias, num local de encontro em Londrina e em fazendas nos municípios de Rolândia e Londrina. Para a avaliação da situação geral, recorreu-se também a relatórios de filiais dos Sindicatos dos Trabalhadores Rurais, às quais foi possível ter acesso na Fetaep, em Londrina. O Autor agradece aqui também ao Senhor J. L. Dumont pelas inúmeras informações e pelo apoio na aquisição de documentos.

294 Entrevistas realizadas pelo Autor com 237 pessoas em diferentes lugares de encontro de boias-frias, em $1^{\circ}$ de junho e 2 de junho de 1970, como também no Sindicato dos Trabalhadores Rurais em Londrina em 11 de agosto de 1970. 
Figura 8: Regiões alvo dos trabalhadores pendulantes boias-frias vindos de Londrina, segundo a distância e a distribuição quantitativa

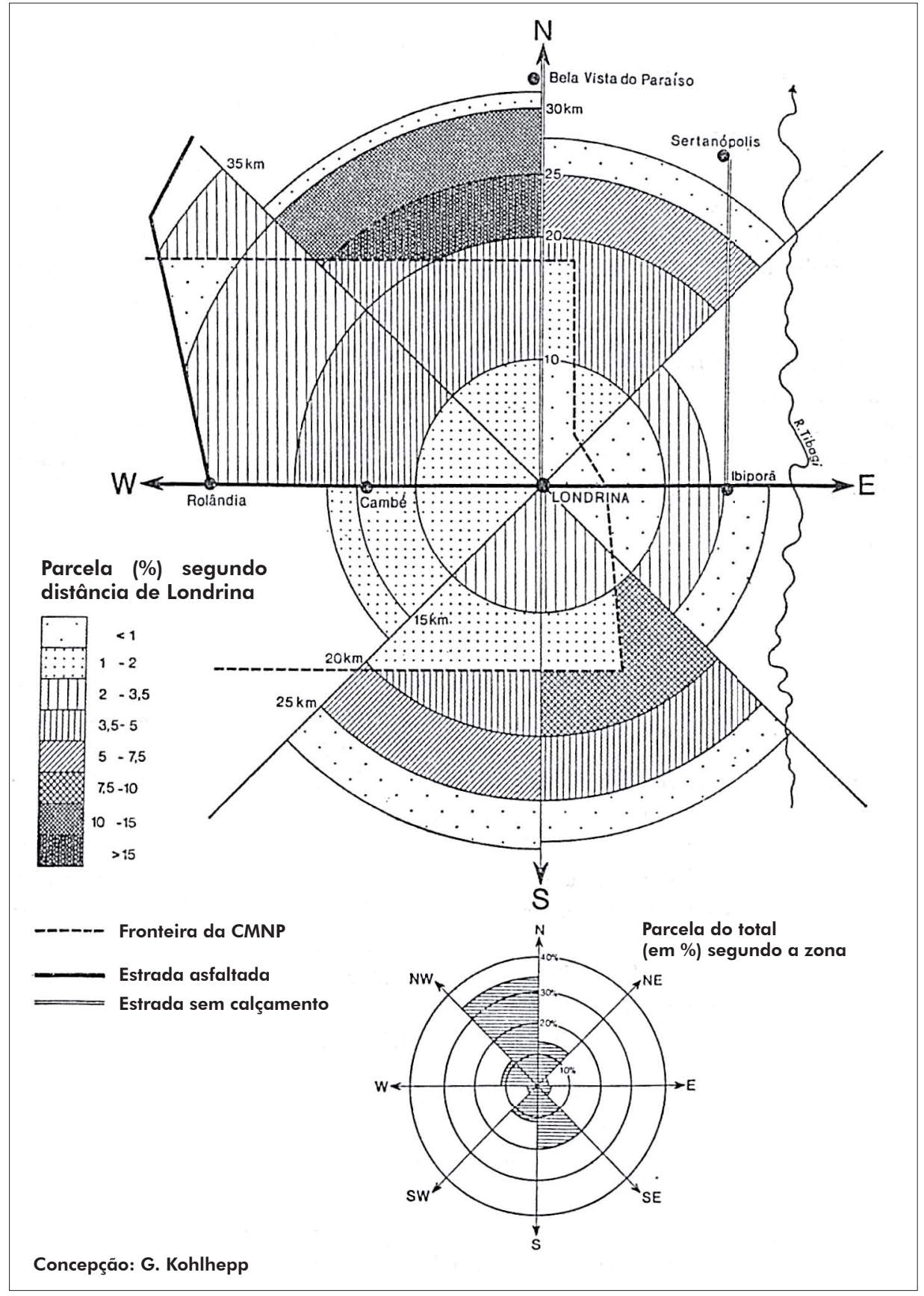

Fonte: Entrevistas do Autor em $1^{\circ}$ e 2 de junho de 1970.

O ponto de concentração de emprego claramente fica fora dos limites da CMNP, sobretudo no Noroeste, onde um número de grandes fazendas faz limite diretamente com as terras da antiga companhia de colonização. $16 \%$ dos boias-frias que fazem viagens de ida e volta ao trabalho a partir de Londrina estão empregados nessa região entre $20-25 \mathrm{~km}$, e $12 \%$ entre 25 e $30 \mathrm{~km}$ de distância da cidade. No total, $33 \%$ do total de trabalhadores pendulares de Londrina estava empregada na região entre o noroeste e o norte, e a maior distância entre a moradia e o local de trabalho dos entrevistados chegava aqui a $32 \mathrm{~km}$ em linha reta (cerca de $46 \mathrm{~km}$ de viagem). 
No oeste e especialmente no sudoeste, somente uma pequena quantidade de trabalhadores boiasfrias estão empregados, pois nessa região predominam as pequenas propriedades. A quantidade de trabalhadores boias-frias ocupados é, na região imediatamente ao sul de Londrina, um pouco maior do que nas regiões próximas equidistantes da cidade, devido às muitas propriedades adjacentes. Seguese uma zona intermediária relativamente estreita com pequenas propriedades e pouca demanda por trabalhadores, próximo da fronteira sul da CMNP. A isso segue-se, sobretudo no sudeste, uma região com grande quantidade de jornaleiros pendulares a uma distância entre 10 e 15-20 km da cidade (cerca de $9 \%$ da quantidade total dos trabalhadores boias-frias entrevistados e que moravam em Londrina).

Mais para o sul, a influência da migração pendular de Londrina diminui muito rapidamente, uma vez que a quantidade de propriedades agrícolas dependentes de trabalhadores boias-frias é muito menor, devido à fronteira climática para o cultivo do café, que passa a cerca de 40-50 km ao sul de Londrina.

A região a leste de Londrina, de Ibiporã a Sertanópolis, foi agrimensada em pequenas propriedades no início da colonização a oeste do rio Tibagi por companhias privadas - da mesma forma que a região da CMNP - , necessitando portanto de pouca mão de obra adicional e tendo um papel relativamente reduzido para os trabalhadores pendulares (Figura 8).

Ao se analisar a expansão e a amplitude espacial do movimento pendular cidade-campo com ponto de partida em Londrina, deve-se levar em conta que, ao longo dos eixos rodoviário e ferroviário para o leste e sobretudo para o oeste, os movimentos pendulares próprios de Ibiporã, Cambé, Rolândia etc. se sobrepõem aos movimentos pendulares de Londrina, e colocam limites à influência de longa distância deles.

O problema dos boias-frias no Norte do Paraná levou a grande agitação, instatisfação geral e a confrontos públicos ${ }^{295}$. Muitos fazendeiros afirmam não estar mais em condições de empregar uma grande quantidade de trabalhadores fixos com famílias numerosas, devido às obrigações determinadas pela legislação dos trabalhadores agrícolas e, além disso, devido aos danos causados pela geada ${ }^{296}$.

Por outro lado, inúmeros trabalhadores rurais pensam haver sido demitidos injustamente às custas da sua seguridade social e sem acerto de contas. As queixas dos trabalhadores sobre o não cumprimento das obrigações legais por parte dos proprietários de terras se empilham nos escritórios dos sindicatos locais. Só em Londrina, no primeiro semestre de 1970 entravam diariamente de 30 a 40 trabalhadores rurais com queixas contra seus antigos empregadores. Nas disputas trabalhistas até o momento da pesquisa haviam se decidido vários casos litigiosos em favor dos reclamantes, e paralelamente houve também uma grande quantidade de acordos. Em junho de 1970, a quantidade de trabalhadores rurais que recebiam o salário mínimo determinado por lei $^{297}$ no Norte do Paraná era estimada em pouco mais de $5 \%{ }^{298}$.

Em proveito dessa situação, surgiu um tipo de assistência jurídica ambulante, conduzida por advogados experientes na área agrícola e que não raro convenciam os trabalhadores a entrar com processos, nos quais, em caso de decisão favorável ao colono, frequentemente uma grande parte da indenização acabava ficando em mãos do advogado. Por outro lado, comprovaram casos - a quantidade de números não oficiais é, contudo, extraordinariamente alta - nos quais os advogados se uniam com os proprietários de terras, de modo que cada ganho de causa implicasse o pagamento ou de um honorário mais elevado ou de uma indenização menor, em desvantagem para o trabalhador dentro da lei. Essa forma de ajuda jurídica foi recusada também pelos sindicatos de trabalhadores rurais, que preferiam centralizar o cuidado dos casos.

No total, deve-se contar com uma grande quantidade de casos nos quais os colonos aceitam condições extremamente ruins por medo de serem demitidos, de modo a garantir um mínimo de subsistência para suas famílias.

Os proprietários das terras não colocam a culpa por todo o problema somente nos danos da geada de 1969, mas também no governo, já que a alta taxação pelo 'confisco cambial' na exportação reduziu a receita das colheitas de café em cerca de $50 \%$. De fato, o governo brasileiro falhou ao não criar novas

295 Em maio e junho de 1970, foi publicada no jornal londrinense Folha de Londrina uma grande quantidade de reportagens, denúncias e defesas, bem como inúmeras cartas e opiniões sobre o problema dos trabalhadores boias-frias.

296 Na discussão pública, os familiares menores de idade dos 'colonos' eram chamados da parte de alguns fazendeiros de 'almas mortas' ou 'boca fria', descrevendo a pouca 'utilidade' deles como mão de obra!

297 Cr\$170,00/mês = 140 DM segundo a cotação de junho de 1970.

298 Informações cedidas pelo Sr. J. L. Dumont, Londrina, presidente da Fetaep. 
iniciativas, elevando o preço ao produtor após os péssimos resultados das colheitas de café daqueles últimos anos. A lavoura de café, que oferece como único cultivo a possibilidade de trabalho permanente a uma parcela relativamente grande da mão de obra, sofria naquele momento, pela maior necessidade de adubação, com os altos preços dos adubos, pesticidas etc. produzidos no Brasil, os quais, devido à taxação adicional, em parte tinham preço mais alto do que o de produtos estrangeiros. Esse é o caso, por exemplo, de fertilizantes nitrogenados, extremamente necessários para a agricultura.

Por outro lado, a política de diminuição dos preços ao produtor está direcionada a produtos agrícolas - exceto o cafée 299 - e à fixação dos preços mínimos segundo padrões internacionais que, contudo, conhecem um alto grau de todo tipo de mecanização, adubação, subvenções e consultoria.

Até agora não se conseguiu quebrar o círculo vicioso. Os baixos preços ao produtor trazem pouca ou nenhuma vantagem ao consumidor, devido à disseminação e diversificação dos atravessadores. A tentativa dos produtores de aumentar as receitas sobretudo com as lavouras de milho, arroz, feijão, soja e trigo com a melhoria dos métodos agrícolas - como medidas antierosão, mecanização, adubação e medidas fitossanitárias - e, com isso, de equiparar os baixos preços ao produtor, frequentemente falha devido aos custos elevados. $\mathrm{O}$ apoio garantido pelo governo para a indústria brasileira em rápido desenvolvimento - frequentemente subsidiárias de grandes conglomerados estrangeiros - se dá portanto largamente às custas das camadas mais pobres da população.

Uma vez que a agricultura demanda muita mão de obra devido à baixa mecanização, a reorganização da legislação trabalhista agrícola e as obrigações sociais correspondentes levaram, nas propriedades maiores, a uma forte tendência da pecuária extensiva, que consegue se manter a longo prazo com pouco investimentos e com uma quantidade de trabalhadores muito menor. A proporção de reserva de mão de obra entre uma propriedade dedicada à pecuária extensiva e uma fazenda de café do mesmo tamanho é de cerca de 1:30.

A determinação de se proibir a dedução das receitas de entressafra do salário dos trabalhadores rurais, ancorada na legislação social agrária, foi preparada pelos legisladores certamente com as melhores intenções de evitar uma discriminação dos colonos. Contudo, é justamente na lavoura de café do Paraná que essa passagem do texto não se mostra necessariamente favorável aos colonos. No antigo sistema de colonato, além de um valor fixo por quantidade de cafeeiros trabalhados, havia também uma grande parte dos lucros das plantações intermediárias, que eram feitas em acordo com o patrão quanto à época do plantio, ao tipo da cultura e também à quantidade de fileiras intermediárias de milho, arroz e feijão.

Para muitos colonos, a venda dos produtos de cultivo intermediário com frequência era uma preparação para atingir a independência econômica. Os férteis solos de terra roxa davam grandes colheitas, com cujos lucros se adquiria terra barata na frente pioneira e com isso se lançava a pedra fundamental de uma economia independente.

Atualmente o proprietário de terras deve pagar aos trabalhadores rurais o salário mínimo estabelecido por lei. Ao lado disso, ele não tem em geral mais nenhum interesse em repassar as lavouras intermediárias para os colonos, comercializando-as ele mesmo. No interesse de um cuidado diligente das plantações de café, alguns proprietários de terra ainda dão mesmo hoje em dia uma pequena parte dos lucros das colheitas intermediárias.

De maneira geral, contudo, a regulamentação legal organizada das relações de trabalho e a fixação de salários mínimos baixos demais dificultaram a iniciativa própria e a mobilidade social dos colonos, já reduzidas nas zonas pioneiras. De fato, o salário mínimo garante em geral a subsistência, contudo a eliminação dos cultivos intermediários da área de influência econômica dos colonos tornou impossíveis, naquele momento, as chances de ascensão deles por meio do próprio trabalho.

Em face disso deve-se levar em conta, contudo, que com o assentamento de populações do Norte do Paraná no contexto da expansão cafeeira as novas áreas de terra nas regiões Sul e Sudeste brasileiras estão esgotadas. Atualmente, a compra de terras no Norte Novo e no Norte Novíssimo são praticamente impraticáveis para os colonos, devido aos altos preços das terras.

Levantamentos estatísticos realizados no Norte do Paraná entre maio e outubro de 1970 mostram que, em média, somente de 15 a 30\% dos colonos necessários nas plantações de café e antigamente com

299 Segundo dados de plantadores de algodão, em 1970 o preço da arroba do algodão de NCr\$ 8,70 não chegava para cobrir os custos. O mercado brasileiro do algodão é fortemente influenciado - e, em parte, manipulado - por grandes grupos estrangeiros. De 1968 a 1969, a área de cultivo do algodão no Paraná foi ampliada em 75\%; a colheita, contudo, foi a pior dos últimos 30 anos, em parte devido à falha de orientações e consultoria técnicas para os plantadores, inexperientes com o cultivo do algodão. 
emprego fixo ainda têm suas residências nas plantações e fazendas. Os restantes foram dispensados ou migraram - em quantidade muito menor - em pequenos grupos para as cidades médias e pequenas, e foram substituídos por jornaleiros. Assim, muitas casas de trabalhadores das plantações de café estão vazias.

Da mesma maneira que essas moradias são casas de madeira muito simples e pequenas demais para as grandes famílias, cobertas de telhas e sem qualquer conforto, encontram-se nas proximidades das casas instalações sanitárias em geral muito primitivas. Poços localizados a uma distância segura das fossas garantem um fornecimento de água perfeito. O controle do serviço de proteção contra a malária e as inspeções para prevenção de outras doenças infecciosas são realizadas frequentemente nas casas dos trabalhadores.

Os trabalhadores empregados no sistema de boias-frias informaram que o motivo para uma emigração espontânea ${ }^{300}$ para as periferias das cidades foi a possibilidade adicional de uma ocupação assalariada das esposas e das filhas mais velhas em casas na cidade ou prestando outros serviços simples. Ao lado disso, foram mencionados também o alugel alto demais das casas de trabalhadores na fazenda, péssimo tratamento e insatisfação com o trabalho e com a vida no campo, melhores condições de educação na cidade para as crianças, possibilidades de ganho adicional como lavador de carros, ajudante, mensageiro, engraxate etc., bem como o atrativo de passatempos 'urbanos' como cinema, futebol ou de maneira geral o 'ambiente'.

Nessa situação faltam às famílias, alojadas nos bairros rapidamente crescentes das favelas, tanto alimentos básicos quanto as instalações higiênicas mais básicas. Frequentemente também não há fornecimento limpo de água potável. Os barracos feitos de restos de madeira, papelão, chapas de metal e galões de plástico (Foto 12) oferecem condições sanitárias piores dos que as oferecidas nas casas de trabalhadores no campo; por outro lado, aqui pelo menos não há custos com aluguel. Por outro lado, crescem muito a delinquência e a prostituição, especialmente porque as favelas das cidades do Norte do Paraná já estão superlotadas devido à migração interna para o estado e por ser difícil para os agricultores não escolarizados arranjar oportunidades de emprego fixo nas cidades. $\mathrm{O}$ desenvolvimento industrial do Norte do Paraná avançou, até o momento, com relativa lentidão e oferece poucos postos de trabalho.

A migração pendular para as propriedades agrícolas maiores no contexto do recrutamento de boiasfrias (Foto 11) é vital para a maior parte dos migrantes, mesmo com a pior exploração por parte do 'gato'.

As condições de moradia e de salário dos moradores das favelas ficam evidentes com base em uma pequisa feita em Londrina ${ }^{301}$ : em 1970 viviam 981 pessoas nas 181 moradias da Favela da Caixa Econômica, das quais 50,2\% tinham menos de 14 anos de idade. $38 \%$ dos barracos possuíam somente um cômodo, 71 \% com chão de terra batida. As condições sanitárias e higiênicas são extremamente precárias.

De 470 pessoas em idade ativa entre 14 e 60 anos de idade $(=47,9 \%), 271$ informaram ter uma ocupação ou emprego (57,7\%), e cerca de $30 \%$ já tinham se sujeitado a trabalhar como jornaleiros boiasfrias. $41 \%$ das pessoas acima dos 7 anos de idade são analfabetas, $59 \%$ são supostamente alfabetizados, isto é, uma grande parte sabe somente escrever o próprio nome (condição básica para o direito ao voto) e ler com dificuldades. Somente $6 \%$ tinham terminado o ensino primário.

Das 271 pessoas com alguma ocupação:

65\% recebiam menos que o salário mínimo legal por mês ${ }^{302}$

16\% recebiam aproximadamente o salário mínimo

10\% recebiam mais do que o salário mínimo (em parte devido a mais de um trabalho)

9\% $\quad$ sem dados

300 9\% dos entrevistados informaram ter abandonado espontaneamente as plantações de café. Uma parte desses migrantes certamente só estava se antecipando à demissão vindoura.

301 Resultados de uma entrevista realizada em junho de 1970 na Favela da Caixa Econômica em Londrina, ao norte da BR 369 sentido Cambé, km 01, com complementações de investigações do Ministério da Saúde, Departamento Nacional de Endemias Rurais, Posto de Esquistossomose de Londrina.

302 O salário mínimo mensal para um adulto por 30 dias de trabalho ou 240 horas de trabalho mensais correspondia, em $1^{\circ}$ de maio de 1970, na $1^{\circ}$ microrregião do Paraná - isto é, nos municípios economicamente significativos - a NCr\$170,40 (para se ter um valor de comparação, um almoço muito simples na região agrícola do Norte do Paraná custava, à mesma época, de $\mathrm{NCr} \$ 5,00$ a NCr\$ 6,00, isto é, o ganho de um dia de trabalho). 
Para o morador da favela, o trabalho como jornaleiro nas fazendas da região não era de maneira nenhuma uma ocupação adicional, mas sim a fonte principal de renda.

O problema dos boias-frias não surgiu somente nas cidades maiores do Norte do Paraná Londrina e Maringá -, mas também apareceu em Cambé, Bela Vista do Paraíso, Ibiporã, Nova Esperança, Paranavaí, Marialva e Itambé, e também no Norte Velho (sobretudo Jacarezinho e Cornélio Procópio).

O afastamento do sistema de colonato das tradicionais lavouras de café paulistanas já tinha começado anteriormente nas lavouras de algodão e de cana-de-açúcar do estado de São Paulo e no Norte Velho do Paraná.

A questão sobre o sistema de boias-frias, marcado por uma alta mobilidade espacial, ser uma ocorrência passageira na lavoura de café como consequência de grandes perdas na colheita causadas pela geada, ou uma ocorrência duradoura, tendo-se em vista as disposições de legislação social para os trabalhadores rurais, não é passível de ser respondida definitivamente no momento em que se escreve este livro.

Ao governo restam certas medidas para controlar as relações trabalhistas agrárias por meio da elevação dos preços do café para o produtor. Mesmo várias grandes propriedades preferem ter força de trabalho confiável e fixa à flutuação diária dos inexperientes trabalhadores boias-frias.

Depois de terminada a fase pioneira, a agricultura do Norte do Paraná apresenta, por um lado, diversos problemas naturais: erosão do solo, grande diminuição da fertilidade do solo, instabilidade das condições de precipitação, danos causados por geadas e ataques de pestes.

Por outro lado, essa crítica situação de transição é reforçada por absentismo, relações de arrendamento de curto prazo, pouca experiência agrícola para além da lavoura de café, problemas da segunda cultura depois do café, mobilidade espacial dos trabalhadores rurais, venda de terras e especulação.

A geada de 1969 produziu tanto consequências 'diretas' (queda na colheita, abandono de plantações de café, mudanças na estrutura de uso da terra) dos quais decorreu a perda do emprego para inúmeros trabalhadores rurais, quanto também consequências negativas 'indiretas', em especial a tentativa motivada pelos danos das geadas de se contornar as leis sociais na região agrária, pela rescisão de contratos de trabalho.

O maior perigo para as relações sociais agrárias advém, contudo, da tendência de muitos proprietários de terra de procurarem uma "solução" dos problemas pendentes e uma maneira de evitar maiores contribuições previdenciárias pela transferência para a pecuária extensiva com muito pouca demanda de mão de obra.

Em regiões com condições ecológicas desfavoráveis e perigo permanente de geadas devido à localização, essa transferência é necessária; em todas as outras áreas ela é principalmente um desenvolvimento da especulação condicionada pela conjuntura, com sérias consequências sociais. 


\section{A SITUAÇÃO AGRÁRIA DO NORTE NOVO E NORTE NOVÍSSIMO DO PARANÁ NO INÍCIO DOS ANOS $1970^{303}$}

\section{DIFERENCIAÇÃO ESPACIAL DAS MUDANÇAS NA ESTRUTURA AGRÁRIA}

Desde o auge do cultivo do café no Norte do Paraná por volta de 1960, que se documentou como uma preponderância absoluta da área das plantações de café na utilização do solo (Mapa 27), ocorreram essenciais mudanças estruturais no âmbito agroeconômico. Primeiramente, a ampliação da área cultivada para regiões não propícias ao cultivo do café trouxe um relativo retrocesso da fração de área das plantações de café em relação à área cultivada. O risco de produção excessiva levou, alem disso, a uma absoluta redução direcionada das áreas de cultivo de café (ver Cap. VI). Essa tendência foi acentuada por diversos e fortes danos causados por geada, bem como pela erradicação espontânea conjuntural.

Em face do risco econômico de uma concentração unilateral sobre a plantação de café comprometida pela geada, o cultivo de produtos agrícolas anuais foi ampliado e - em caso de empreendimentos maiores - realizou-se a plantação em grande escala de pastagens artificiais para criação de gado (Fotos 8,14 e 16).

A estrutura do uso do solo nos anos de 1969/70 mostra essas mudanças em nível municipal (vide Mapa 34) ${ }^{304}$. Enquanto na região central e sul do Norte Novo, sobretudo os alimentos básicos passaram a ocupar - com algumas exceções - a maior parte área cultivada, e no norte dessa região as pastagens assumem essa posição. Somente nas regiões com condições de solo favoráveis e altitudes propícias, especialmente no âmbito das divisoras de águas principais, o cultivo do café nada perdeu da sua preponderância territorial.

Quase todo o noroeste e o oeste (Norte Novíssimo nas regiões de Paranavaí e Umuarama) tiveram uma rápida expansão das pastagens, que coincidiu, já em meados e ao fim dos anos 1960, com um forte decréscimo de rendimento no cultivo do café nos solos arenosos do Caiuá (Mapa 34).

A diferenciação espacial das tendências do desenvolvimento das mudanças estruturais na utilização do solo na área investigada entre 1960 e 1970 deve ser esclarecida com base em diagramas triangulares (Figuras 9, 10,11), que apresentam o desenvolvimento discrepante dentro das diversas regiões em valor mediano, bem como na concentração e dispersão dos valores (dentro das linhas pretas de demarcação nas Figuras 9-11, ver Mapa 35). Nisso as frações percentuais de culturas permanentes, de produtos agrícolas anuais e de pastagem serão observadas comparativamente na utilização do solo.

Na região de Londrina no Norte Novo podem ser constatadas, desde 1960, duas tendências de desenvolvimento claramente diferentes entre si (Figura 9). Mesmo que, no valor mediano, a fração da área de cultivo de café tenha diminuído pela metade, na região principal de cultivo de café (nas Figuras 9-11 e Mapa 35 indicados com I) foi fortemente ampliada a área ocupada por produtos de cultivo anual, enquanto se percebe, em parte, uma clara tendência de ampliação das pastagens no noroeste dessa região (II), dominado por terrenos arenosos. As cifras são apresentadas resumidamente na Tabela 39 (p. 308, Anexo) ${ }^{305}$.

303 Tradução de Caio Heleno da Costa Pereira e Elisete Antoniuk.

304 Os dados estatísticos do Mapa 34, em razão da falta de estatísticas oficiais até aquele momento, resultam de levantamentos próprios isolados feitos em 1970 em diversos municípios, bem como de levantamentos da fábrica de insumos Ultrafertil (filial de Londrina). Agradece-se aqui à firma pela possibilidade de avaliação desses dados internos da empresa. As estatísticas do Departamento Estadual de Estatística em Curitiba infelizmente não fornecem dados sobre as áreas de pastagem. O Ministério da Agricultura no Rio de Janeiro forneceu, para 1968, dados sobre as áreas de cultivo de culturas anuais em nível municipal. Para os municípios deixados em aberto no Mapa 34 não foram obtidos dados confiáveis. 
Figura 9: Mudanças na estrutura de uso do solo entre 1960 e 1970 (parcela da área cultivada):

Norte Novo de Londrina e Maringá.

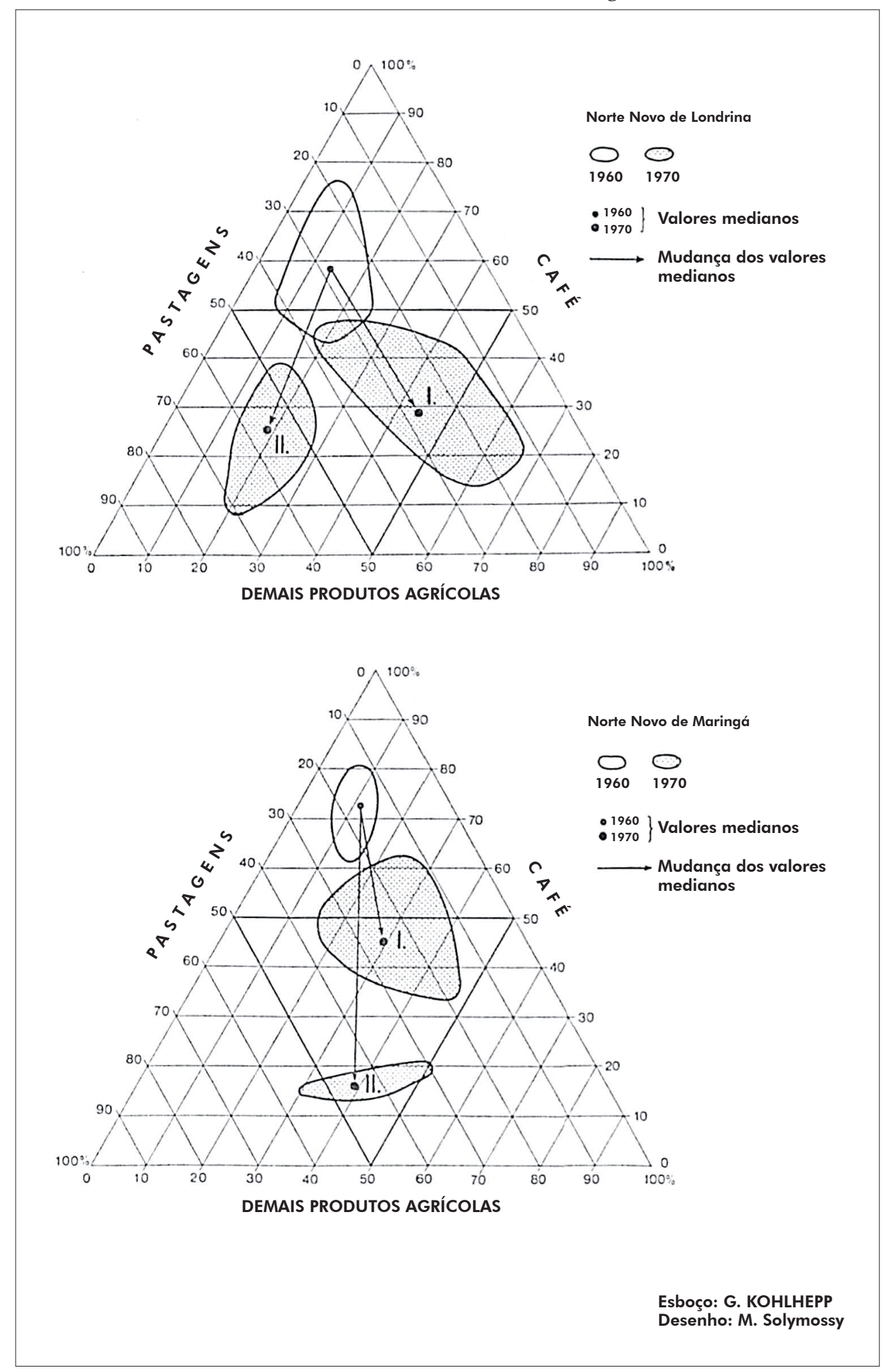

Fontes: Fig. 9-11: cf. Lista de Mapas, Mapa 34. 
Figura 10: Mudanças na estrutura de uso do solo entre 1960 e 1970 (parcela da área cultivada):

Norte Novíssimo.

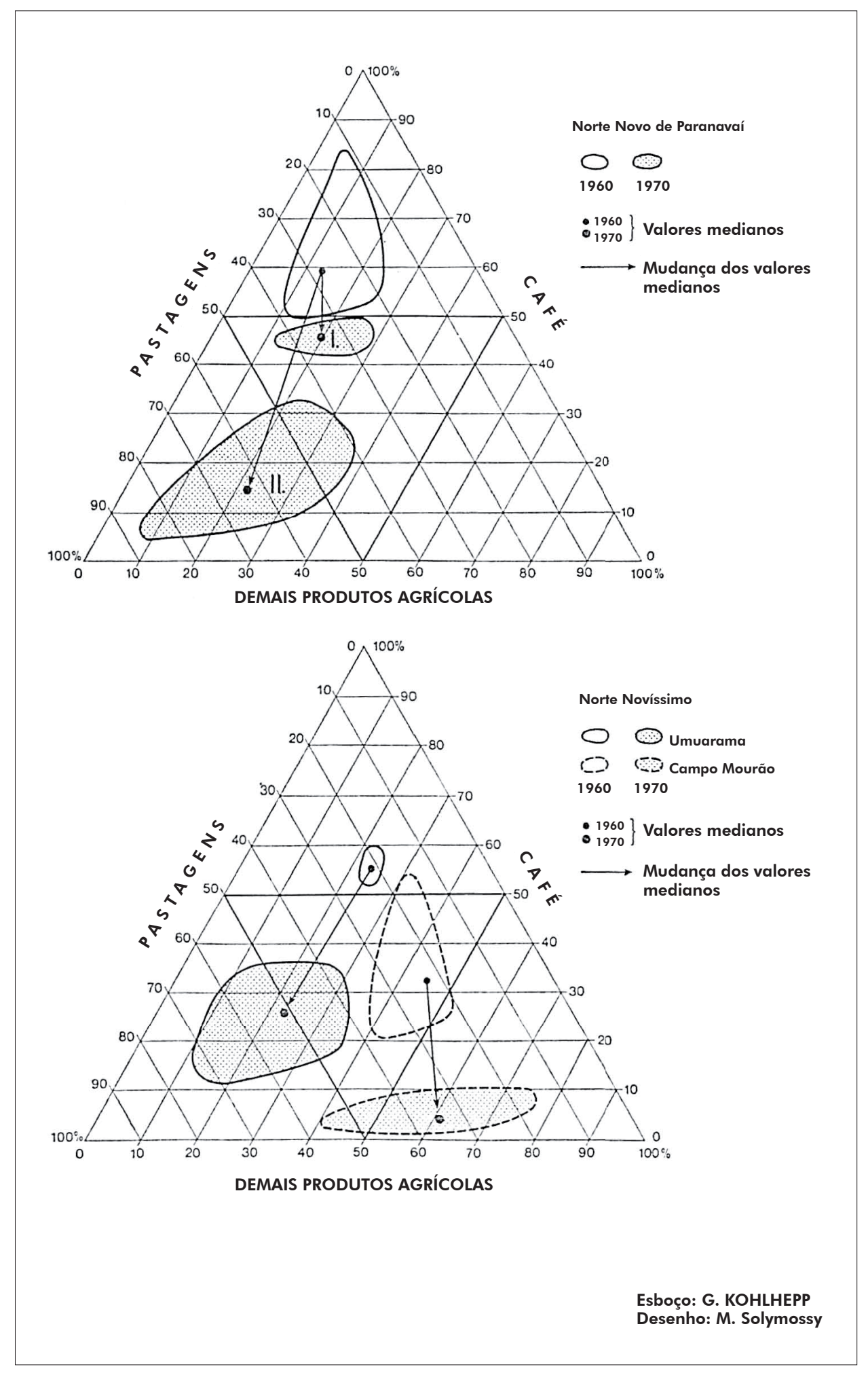


Figura 11: Mudanças na estrutura de uso do solo entre 1960 e 1970 (parcela da área cultivada):

Norte do Paraná e Norte Novo de Apucarana.

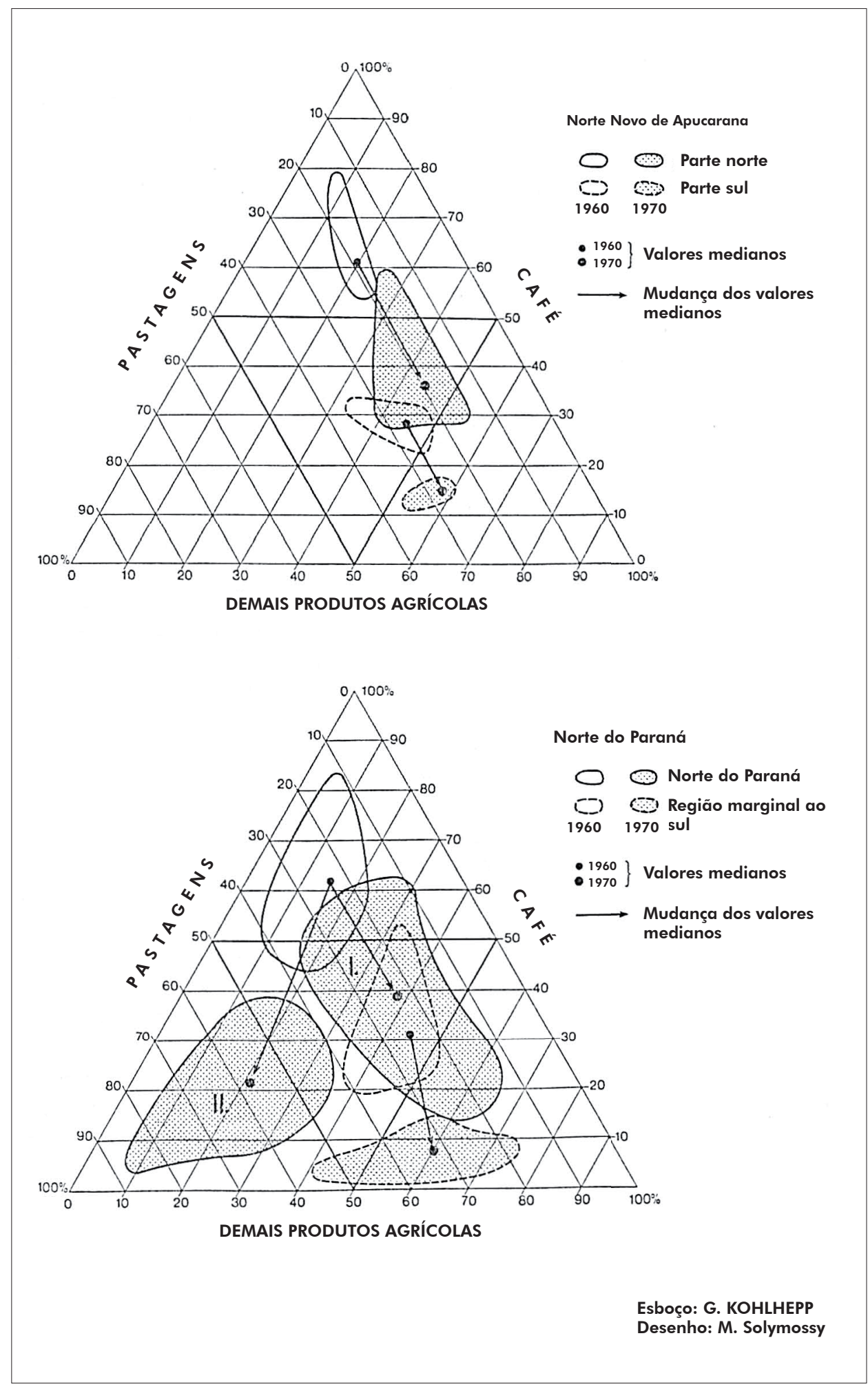


Em torno de Maringá, numa parcela da região central de cultivo do café, apesar de um evidente retrocesso, as plantações de café ainda ocupam quase a metade da área cultivada. O cultivo do café só foi fortemente reduzido nas áreas mais profundas, no vale do Ivaí e do Pirapó, em razão do risco de geada (Foto 9 e Mapa 35: II). O cultivo de alimentos básicos (milho, feijão, arroz, soja etc.) e a ampliação de pastos artificiais se deram aproximadamente na mesma medida.

O desenvolvimento da utilização do solo no Norte Novo de Apucarana é caracterizado por uma evidente diferença regional na importância do cultivo de café. No norte $(\mathrm{N})$, ainda hoje líder na área de cultivo, o plantio de café nas regiões marginais do sul (S) - com exceção de uma incidência em torno de Ivaiporã e Jardim Alegre - tem apenas uma importância reduzida, sobretudo por motivos climáticos. A redução da fração de área de cultivo de café na área cultivada ocorreu, tanto na região norte quanto na região sul, exclusivamente a favor da ampliação do plantio de milho, arroz e feijão ${ }^{306}$.

No Norte Novíssimo ao norte do rio Ivaí (região de Paranavaí, Figura 10, Mapa 35), o aumento da área cultivada ocorreu, desde 1960, com exceção da parte sudeste (I), na forma de implementação de pastagens de arroteamento, cuja área mais do que duplicou até 1970. A disseminação dos valores na região parcial II indica, na sua orientação geral, um forte direcionamento para a economia de pastagens. Através da erradicação direcionada, bem como, em grande medida, espontânea, foram utilizadas grandes áreas das antigas terras do café para o plantio de algodão, que ocupa hoje, em alguns municípios, mais do que $50 \%$ da área cultivada provida de produtos agrícolas anuais (Mapa 35). Na região parcial I do Norte Novissímo de Paranavaí, o plantio de café manteve sua posição predominante, pois na zona de transição de terra roxa e solos arenosos do Caiuá, a chamada terra roxa misturada possui uma maior fertilidade do que os solos arenosos puros do Noroeste. Além disso, o decurso da divisora de águas principal, com a possibilidade do plantio de café no cume dos morros, favorece esse desenvolvimento.

Ao sul do Ivaí, na região de Umuarama, observa-se uma evidente tendência para a economia de pastagens (Figura 10) que, em dez anos (1960-70), se fez notar em um aumento da fração de área na área cultivada de 21 para 51\%. A concentração dos valores isolados em 1960, que acentua a uniformidade da utilização do solo da época, cedeu, entretanto, no âmbito do desenvolvimento geral, a uma forte dispersão.

Na região de Campo Mourão, também na parte norte, as frações da área do plantio de café, ainda altas em 1960, diminuíram a valores entre 1 e 10\%, em razão do risco de geada. Enquanto as pastagens predominam somente em uma parte do noroeste dessa região, o plantio de milho, seguido pelo de arroz, feijão, soja e algodão, ocupa uma posição predominante (Figura 10 e Mapa 35).

A análise sintética (Figura 11) das mudanças estruturais do uso da terra no Norte Novo e Norte Novíssimo permite, porém, perceber um retrocesso das áreas de cultivo de café em todas as regiões, mas sua extensão varia fortemente conforme a região. Partindo-se dos valores médios, a tendência nas regiões parciais identificadas com 'I' (regiões principais de cultivo de café) (Mapa 35 e Tabela 39, p. 308, Anexo) indica claramente uma crescente importância da policultura, do plantio de alimentos básicos, de oleaginosas e de plantas têxteis, o que, entretanto, não prejudica o papel economicamente dominante do café. A fração de pastagens permaneceu inalterada (Figura 11: Norte do Paraná).

A discrepância do desenvolvimento na região II ocorre, principalmente, devido às diversas condições de solo da maior parte do Norte Novíssimo, onde preponderam os solos arenosos. A uma reduzida tendência à policultura (parcela do grupo dos produtos agrícolas anuais = demais produtos agrícolas em 1960: 15\%; em 1970: 21\%) contrapõe-se a expansão excepcionalmente forte das áreas de pastagem, que hoje ocupam, nessa região, quase $60 \%$ da utilização do solo. A orientação geral da dispersão dos dados isolados é claramente oposta em I e II.

\section{a) Tendências à policultura}

Para o desenvolvimento econômico do Norte do Paraná foi de grande importância, desde fins dos anos 50, a distribuição do risco na agricultura através do fomento de um cultivo variado. Nisso os alimentos básicos, característicos no Norte do Paraná em grande parte como plantações intermediárias no cultivo de café, ocuparam, a princípio, uma posição decisiva (Foto 6). Isso vale, sobretudo, para milho, arroz e feijão, que perfazem ao todo $90 \%$ de todas as culturas intermediárias.

306 Figura 11, Mapa 35 (N-S) bem como Mapas 27 e 34 (dados individuais por município). 
Tabela 40: Cultivos paralelos nos cafezais do Norte do Paraná em 1970 (parcela dos cultivos paralelos em relação à área total, em \%)

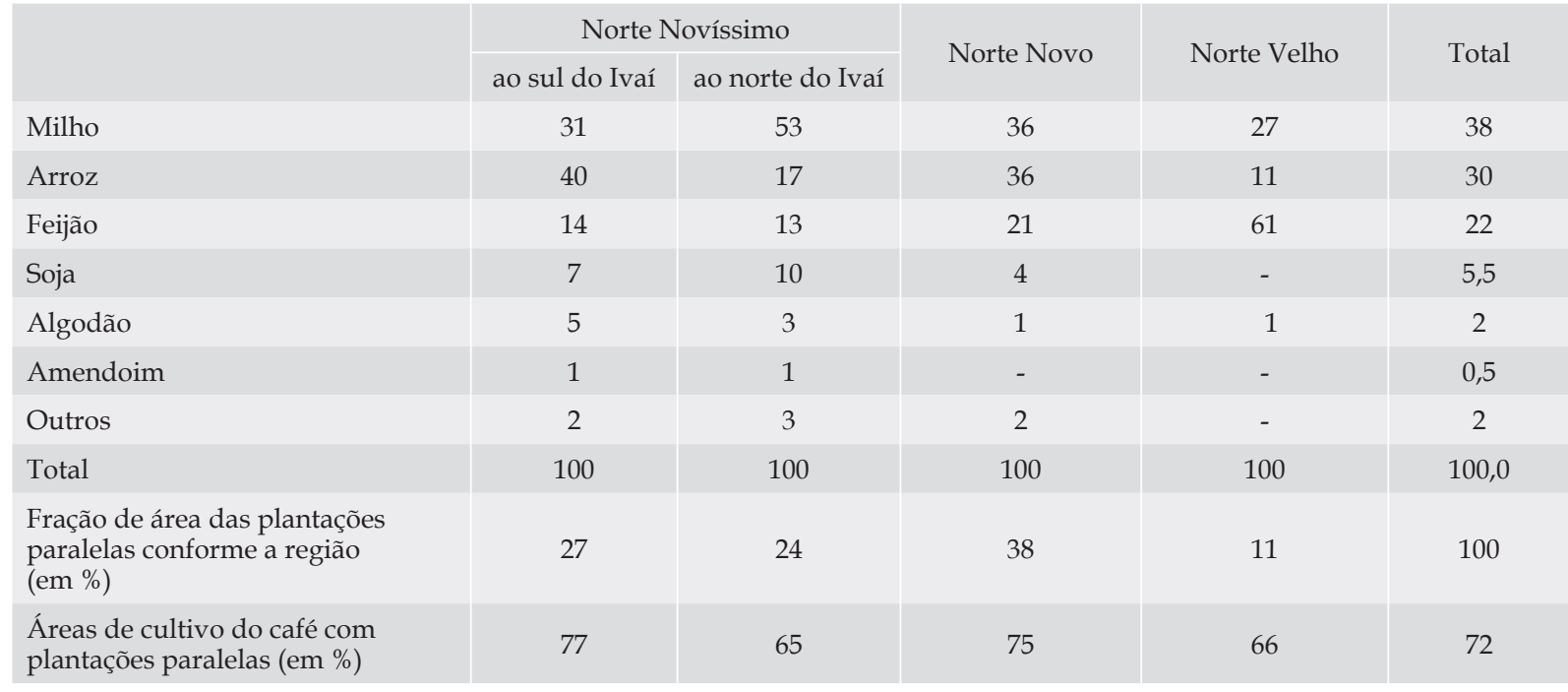

Fonte: Cálculos segundo documentos do Instituto Brasileiro do Café de 1970.

\section{Plantações paralelas}

No Norte Novo do Paraná, 75\% das áreas de cultivo do café possuem plantações paralelas, no Norte Novíssimo a porcentagem oscila entre 65 e $77 \%$.

$\mathrm{Na}$ área em estudo, privilegia-se especialmente milho e arroz, como plantações paralelas na lavoura de café. Ao contrário do Norte Velho, o plantio de feijão se coloca somente em terceiro lugar. O plantio de milho entre fileiras de cafeeiros predomina no Norte Novíssimo de Paranavaí, enquanto que ao sul do Ivaí prevalece o arroz. No Norte Novo a fração desses dois produtos agrícolas se iguala.

Especialmente disseminadas são as plantações paralelas no Norte Novo, onde milho, feijão e, sobretudo, arroz aparecem em grande escala como cultivo paralelo ao café. As respectivas áreas de cultivo desses produtos agrícolas e a forma do plantio como plantação paralela, plantação mista ou cultivo principal são apresentadas com base em valores municipais nos Mapas 36 a $38^{307}$. Em complementação a isso, a Tabela 41 (p. 310, Anexo) mostra as porcentagens de formas de cultivo de milho, arroz, feijão, soja e algodão em diferenciação regional. Dependendo da respectiva importância do plantio de café, diversos produtos agrícolas são cultivados quase que exclusivamente como plantação paralela (por exemplo, feijão na região de Maringá a 76\%). De toda a área de arroz no Norte Novo, $58 \%$ são plantações paralelas ao café. Na região de Umuarama são cultivados feijões somente em $4 \%$ da área de plantio como cultivo principal (região de Paranavaí: 31\%), porém 43\% como plantação paralela e $53 \%$ como plantação mista com outros produtos agrícolas. A porcentagem das plantações paralelas em toda a área de cultivo dos produtos agrícolas anuais corresponde, na área em estudo, para arroz a $40 \%$, feijão $32 \%$, milho $19 \%$, soja $13 \%$ e algodão $4 \%$ (Tabela 41 , p. 310, Anexo).

O plantio de culturas paralelas tem um fundamento tanto econômico como também ecológico. No novo plantio de café, o cultivo de alimentos básicos serve como uso principal da terra até a maturidade do cultivo permanente e, com isso, serve tanto para cobrir os meios de subsistência utilizados no empreendimento, como também - antes de a nova legislação dos agricultores entrar em vigor - como pagamento da força de trabalho em 'produtos naturais'. Porém, o uso suplementar da terra através de plantações paralelas somente pode ocorrer se não houver risco de prejuízos do cultivo principal com a subtração de nutrientes e água das plantações paralelas concorrentes. Com relação ao abastecimento

307 Os valores representados no Mapa 38 se referem ao feijão ('das águas'), plantado de agosto a outubro, que compõe 73\% das áreas de plantio de feijão. 
de água, o clima úmido do Norte do Paraná oferece evidentes vantagens em comparação com o clima alternadamente úmido de São Paulo central, com seus 3 a 4 meses áridos. No Norte Novo, a alta fertilidade do solo da 'terra roxa' garante um abastecimento suficiente de nutrientes para o cultivo principal e paralelo.

Os cultivos paralelos adquirem grande importância como proteção do solo contra excessiva insolação e influências da erosão do solo. Somente em casos raros a colheita da plantação paralela é sucedida pelo cultivo de leguminosas, tão importante para a adubação verde, sendo que estas não representam concorrência à plantação de café em relação à absorção de nitrogênio. Os cultivos paralelos abastecem o solo com importantes substâncias orgânicas e também contribuem para o melhoramento de suas qualidades físicas (SCHMIDT; MARCUS, 1943, p. 200-201). Na região dos terrenos arenosos do Noroeste, o cultivo das plantações paralelas é de extrema importância para evitar a lavagem entre as fileiras das árvores de café.

Enquanto o milho, o feijão e o arroz foram plantados tradicionalmente como culturas paralelas, sobretudo o plantio de soja aumentou nos últimos anos no Norte do Paraná, até a realização do presente estudo. Em razão da conjuntura favorável para plantas oleaginosas através da iniciativa do Banco Paranaense de Desenvolvimento com a implantação de uma indústria de óleo vegetal no início dos anos 1960, também foi recomendado pelo IBC o plantio de girassol como plantação paralela, mas isso pouco se consolidou. Por outro lado, na concessão de crédito pelo Banco do Brasil não são aceitas plantações de algodão e rícino entre as fileiras de árvore de café. Desde meados dos anos 1960 também não se pode mais plantar arroz nas recentes plantações de café financiadas pelo banco estatal. Essa medida tem motivos político-econômicos, pois há o risco de uma produção excessiva e não se apresentam possibilidades de exportação.

Tendo em vista que as plantações de café sensíveis à geada sofrem fortes oscilações de rendimento, o cultivo de produtos agrícolas anuais no Norte do Paraná tem a intenção de encontrar um segundo produto de cultivo economicamente favorável. Isso também explica a instabilidade das áreas de cultivo dos produtos agrícolas, cuja extensão depende da situação de preço correspondente. Como já acentuado na análise do uso da terra de antigas áreas de cultivo do café (ver Cap. VI, 3), as recomendações de cultivo de organizações estatais e privadas levaram a enormes oscilações, que na sequência se caracterizaram por produção excessiva e consequente queda de preço.

A situação apresentada no Mapa 35 para os anos de 1969/70 permite reconhecer uma evidente diferenciação espacial na plantação de produtos agrícolas anuais e combinações de produtos agrícolas ${ }^{308}$. No Norte Novo e no sul do Norte Novíssimo predomina o plantio de milho, que em uma série de municípios ocupa mais do que $50 \%$ ou mais do que um terço da área de cultivo das plantas anuais cultivadas. A comparação das áreas de cultivo no Mapa 36 confirma essa imagem, assim como a distribuição espacial da produção (Mapa 39). No sul do Norte Novo de Londrina, a plantação de arroz também assume maior importância.

Em toda a área dos terrenos arenosos, tanto no noroeste do Norte Novo como também em todo o Norte Novíssimo (especialmente ao norte de Ivaí), o cultivo de algodão tem posição predominante entre os produtos agrícolas anuais. O Mapa 35 mostra, de acordo com a quantidade de produtos agrícolas que ocupam acima de 5\% da área de cultivo, a concentração regional de algodão e milho. Mas ao mesmo tempo ele oferece uma impressão do avanço da diversificação dos produtos cultivados em proporção equilibrada das áreas dos produtos agrícolas e suas combinações standard (milho feijão - arroz; algodão - milho - feijão; algodão - milho - amendoim; arroz - feijão - soja) em grande número de municípios nos quais nenhum dos produtos anuais cultivados alcança um terço das áreas de cultivo.

Nas áreas pioneiras do Oeste e do Noroeste, o milho, o feijão, o algodão, o arroz e a soja frequentemente ocupam uma posição predominante ao fazer uso por alguns anos da fertilidade das áreas de floresta após o arroteamento. Isso ocorre tanto como plantação paralela no cultivo de café quanto como transição para a pecuária, em parte imediatamente após um curto intervalo do cultivo de algodão.

308 Cf. sobre isso os trabalhos metódicos para classificação estatística de crop combination regions e suas modificações em Weaver (1954a e b); Weaver (1956); Weaver, Hoag e Fenton (1956), bem como Scott (1957); Coppock (1964), que também considera as combinações de pecuária; Bhatia (1965), que investiga a crop concentration and diversification e nesse fundamento Mesquita e Silva (1970). 


\section{Algodão}

O fortalecido cultivo de algodão, que desde início dos anos 1930 vivenciou um boom a princípio em São Paulo como consequência da crise do café ${ }^{309}$ e trouxe para o Brasil uma diferenciação na estrutura de uso da terra (mas também na de exportação) ${ }^{310}$, pela primeira vez se distanciou da concentração da exportação de produtos agrícolas estimulantes (café, cacau, açúcar, banana) ${ }^{311}$.

O cultivo de algodão vivenciou um aumento significativo no Norte do Paraná na década de 1960 em função do risco de geada nas plantações de café, da procura por um produto agrícola economicamente favorável ao lado do café (ou até mesmo em substituição a este), e da fase de transição de amplas áreas do Noroeste para a economia de pastagens. De 1963 ate 1969, as áreas de cultivo do algodão aumentaram de 246.000 ha para 593.000 ha no Norte do Paraná, e a produção no mesmo período de 270.000 para $567.000 \mathrm{t}^{312}$. O Paraná teve participação de $25 \%$ na produção global do Brasil. Com isso, quase alcançou São Paulo como produtor de algodão em 1969, e assumiu o segundo lugar no Brasil.

No Norte do Paraná, o algodão alcançou, assim como o café, o limite meridional de cultivo no Brasil. O algodão, nas suas exigências climáticas, depende mais da temperatura do que da precipitação. Entretanto, o excesso de precipitação provoca grandes perdas na época da colheita, fator que enseja problemas especiais no Norte do Paraná. A planta exige bastante calor e possui um período de vegetação de seis meses, que deve ser livre de geada. Nisso a temperatura média do segundo ao quinto mês não deve ser inferior a $20^{\circ} \mathrm{C}^{313}$. No Norte do Paraná planta-se Gossypium hirsutum (algodão de terras altas/upland) com um comprimento de fibra de 30 a $32 \mathrm{~mm}$. Os arbustos, ao contrário dos cultivos plurianuais de g. barbadense (Sea-Island) no Nordeste do Brasil, são aproveitados somente durante um ano. A plantação ocorre de setembro a novembro, ou seja, após as últimas geadas, a colheita é realizada de março a abril/maio. O algodão prefere, sobretudo, solos arenosos argilosos profundos e solos argilosos arenosos, assim como terra roxa. Solos virgens especialmente ricos em nitrogênio (entre outros elementos) provocam um crescimento opulento de plantas, isso à custa da maturação das cápsulas. Por esse motivo, em recentes arroteamentos deveriam ser plantados, a princípio por um a três anos, milho, arroz e feijão, antes de se iniciar o cultivo de algodão (MORGENROTH, 1942a, p. 24-25). Contudo, isso raramente é feito no Norte Novíssimo. O cultivo ocorre geralmente como cultura principal, somente em pouca medida como plantação paralela ou cultura mista (vide Tabela 41 no anexo). Ainda é raro o cultivo de algodão em rotação regular de culturas. Em razão da fertilidade natural do solo planta-se algodão no mesmo campo inicialmente em anos seguidos. Mas isso logo leva a uma diminuição dos nutrientes do solo e a acentuada incidência de parasitas.

Os conhecimentos técnicos do cultivo de algodão no Norte do Paraná melhoraram um pouco após um começo evidentemente rudimentar no início dos anos 50. A colônia japonesa Assaí a leste do Rio Tibagi despontou como centro de inovação, para assumir a liderança, quantitativa e qualitativa, no cultivo de algodão do Paraná (Mapa 39, concentração a leste da região em estudo). A distribuição de sementes apropriadas por uma organização estatal afirmou-se de modo excelente.

Um forte incentivo à produção de algodão foram os baixos preços mínimos legalmente fixados para milho e amendoim, bem como a iniciativa estatal para o fomento da indústria de óleo vegetal ${ }^{314}$. A

309 A produção de algodão em São Paulo aumentou de 1930 até 1944 de 13.114 t para mais de 460.000 t (MATOS, 1954, p. 277, imagem IX).

310 No ano de 1969, a exportação de algodão representou 8,8\% do valor total de exportações do Brasil (IBGE, Anuário Estatístico do Brasil, 1970).

311 Matos (1954, p. 254) denominou a antiga agroeconomia orientada para a exportação como "agricultura de sobremesa".

312 A primeira estimativa de colheita para 1969 totalizou 687.000 t de algodão não descaroçado (segundo Rev. Paran. de Desenvolvimento n. 17, 1970, p. 29). Dados acima segundo: O Dirigente Rural. Anuário Rural (1970, p. 21).

313 No primeiro e no sexto meses a temperatura deve variar entre 15 e $18^{\circ} \mathrm{C}$, a temperatura mais baixa de germinação é entre 15 e $16^{\circ} \mathrm{C}$.

314 O conteúdo de óleo dos grãos de algodão varia de 12 a $21 \%$ e até $80 \%$ podem ser utilizados, enquanto o restante do óleo nos resíduos de prensa fica retido e pode ser utilizado como adubo e ração de gado. 
comercialização de algodão é bem organizada e se encontra em grande parte nas mãos de multinacionais e suas filiais ${ }^{315}$.

A importância do cultivo de algodão para o Norte do Paraná repousa na intensidade de trabalho da colheita e, com isso, na vinculação das forças de trabalho, que, nos anos com grandes danos no cultivo de café devido à geada, tem grande influência sobre a situação social geral.

Enquanto as operações no Norte Novo já estão em parte mecanizadas, nas áreas pioneiras do Norte Novíssimo - ou seja, em algo mais do que $50 \%$ de toda a área de cultivo de algodão do Paraná - falta quase que totalmente a mecanização. Nos recentes arroteamentos o algodão é plantado entre os tocos remanescentes e os troncos não removidos, e manejado com enxada. A colheita, que se estende por mais de 70 dias, é realizada em dois terços por trabalhadores itinerantes, cuja quantidade na colheita de algodão na região investigada deve corresponder a cerca de 70.000 pessoas (PEREIRA, 1968, p. 8-9). Os problemas da obtenção da força de trabalho na região de fronteira reduziram-se devido à quebra da safra do café, e hoje, no cultivo de algodão em geral predomina um excesso na oferta de força de trabalho.

No Norte do Norte Novo (região em torno de Colorado) e no Norte Novíssimo dominam maiores empreendimentos no cultivo de algodão. Diferentemente dos plantadores proprietários japoneses em torno de Assaí, o algodão é plantado no Noroeste do Paraná quase que exclusivamente por arrendatários e subarrendatários, cujas possibilidades econômicas são mínimas e que dependem do crédito que lhes é concedido pelos donos das terras junto ao Banco do Brasil. Muitas vezes atravessadores se imiscuem nisso, concedendo eles mesmos crédito aos arrendatários em condições bastante desfavoráveis. Assim, geralmente os meios financeiros para aumentar a produtividade através de adubo artificial e pesticida se apresentam somente em pequena monta. Plantações mistas de algodão com milho, feijão, rícino, amendoim etc. ou mais raramente como cultura paralela ao café, diminuem a produção em razão da concorrente subtração de nutrientes, especialmente nos solos arenosos do Norte Novíssimo, que rapidamente se esgotam.

Após excelentes resultados da colheita em 1968, a área de cultivo de algodão aumentou em 79\% em 1969, contudo a produção reduziu em torno de $38 \%{ }^{316}$. Em uma área de cultivo só pouco reduzida, a colheita de 1969/70 trouxe outra diminuição de produção de 1.121 kg/ha (1968/69) para 911 kg/ ha, depois de a produção média ainda ter sido de $1.649 \mathrm{~kg} / \mathrm{ha}^{317}$. Os motivos para essa extrema queda das colheitas são, sobretudo, as más condições climáticas (seca persistente, que adia a germinação das plantas; fortes precipitações em época de colheita) bem como a incidência extremamente forte de parasitas e a ocorrência de doenças nas plantas ${ }^{318}$.

Áreas de cultivo demasiadamente extensas dos arrendatários, poucos conhecimentos agronômicos, investimentos mínimos para a melhoria do solo e para a proteção das plantas e a discrepância na evolução dos preços de sementes, pulverização e trabalhos de colheita (1968-1969: + 30 até 50 \%) e preço de compra do produto final (1968-1969: + 8 \%) levaram a uma insegurança generalizada nos plantadores de algodão. A disseminação cada vez mais forte de parasitas de cápsula e de folha, paralelamente à alta excessiva dos preços de pulverização (que além disso geralmente se mostrou ineficiente), levou o Presidente da Associação dos Plantadores de Algodão a advertir publicamente sobre a continuação do cultivo ${ }^{319}$. Isso produziu um abandono do cultivo de algodão, expresso na transição para a criação extensiva de gado em empreendimentos maiores, e na adoção de plantação de soja e de grãos em pequenos e médios empreendimentos.

Em oposição ao algodão que avança de São Paulo para o sul, a disseminação de soja e trigo se relaciona com a migração interna de colonos gaúchos para o Norte do Paraná.

315 Sanbra; Anderson, Clayton \& Co., S.A.; Mc Fadden; Woolley-Dixon etc. Segundo dados da Indusfibra (Londrina) existiam, em 1970 no Norte Novo e Norte Novíssimo, 67 usinas de beneficiamento, instalações de desencaroçamento de algodão, limpeza, classificação etc., das quais 14 somente em Maringá e 10 em Umuarama.

316 Dados da Indusfibra, 1969, Relatório da Safra 1968/69.

317 Dados segundo a Folha de Londrina, suplemento técnico-agronômico ano 1, n. 9, 13/06/1970 e Indusfibra, 1969, Relatório da Safra 68/69.

318 Parasitas animais: Larva vermelha de cápsula (Parasitas de cápsula, folha e de rebento) (Platyedra gossypiella), Bemisia tabaci. Doenças de plantas: Spodoptera latisfascia; Agromyza sp. e capnodium sp. (segundo dados do agrônomo H. L. Pereira, Londrina).

319 Folha de Londrina, 30/06/70: Cultivar algodão é jogar dinheiro fora. 
Soja

O cultivo de soja se iniciou no Norte do Paraná desde os danos causados no cultivo de café pela geada de 1963. Em virtude da terra liberada quando foram arrancadas as árvores de café, o Instituto Brasileiro do Café colocou em circulação 10.000 t de sementes. Ate 1970 foram ampliadas as áreas de cultivo para 298.000 ha, e a produção aumentou para 279.000 t. Dessas, 45\% recaem sobre o Norte do Paraná (Mapa 40). A evolução favorável de preços, boas possibilidades de venda para o beneficiamento industrial (óleo vegetal, margarina, fabricação de sabão etc.), como produtos alimentícios para o mercado nacional bem como para a exportação e a possibilidade da mecanização dos processos de trabalho (por exemplo, colheita com ceifeira-debulhadora, também utilizada para a colheita de trigo) ofereceram pontos de partida para uma rápida expansão dessa cultura, que no afolhamento é cultivada com trigo. ${ }^{320}$

Tabela 42: Cultivo de trigo no Norte Novo e Norte Novíssimo do Paraná

\begin{tabular}{|c|c|c|}
\hline & $1966 / 67$ & $1969 / 70$ \\
\hline Qtd. de áreas de cultivo de trigo & 29 & 3.674 \\
\hline Área de cultivo em ha & 580 & 46.350 \\
\hline Produção em $t$ & 374 & 26.266 \\
\hline Produção kg/ha & 645 & 566 \\
\hline \multicolumn{3}{|l|}{ Parcela no Paraná (em \%): } \\
\hline Empreendimentos & 1,8 & 26 \\
\hline Área de cultivo & 3,6 & 24 \\
\hline Produção & 2,2 & 16 \\
\hline
\end{tabular}

Fonte: Quadro sinóptico segundo Ministério da Agricultura (CCLEF): Anuário Estatístico do Trigo. Safra 1966/67 e 1969/70.

\section{Trigo}

O plantio de trigo teve um extraordinário desenvolvimento desde o auge da segunda fase da redução da área de plantio de café em 1966/67, atingindo a $22^{\circ}$ de latitude sul seu limite de cultivo setentrional no Brasil. A favorável evolução de preços e um fomento estatal reforçado do cultivo ${ }^{321}$ contribuíram decisivamente para a expansão das áreas de cultivo (Tabela 42). Ao contrário do algodão, o trigo não é cultivado nos solos arenosos do Noroeste. Um forte avanço do cultivo de trigo do Rio Grande do Sul chega até a fronteira sudoeste da região em estudo junto ao Rio Piquiri, onde termina a migração interna da população teuto e ítalo-brasileira (Toledo, General Rondon) na fronteira do cultivo de café. As áreas centrais de cultivo de trigo no Norte do Paraná se localizam na região de terra roxa, sobretudo nas áreas marginais no sul do Norte Novo de Apucarana e na região de Campo Mourão, onde o vale do Ivaí se destaca (Mapa 41). Como o cultivo de café ocupa as regiões altas entre 400 e $800 \mathrm{~m}$, as plantações de trigo se encontram nas regiões altas e na exposição sul da encosta, com acentuado risco de geada como, por exemplo, nas regiões marginais do cultivo de café, ou na região de vale com inversão de temperatura no declive médio e inferior abaixo das plantações de café que se estendem nas encostas superiores. Isso traz consigo grandes problemas de erosão do solo que só foram solucionados por poucas empresas através da instalação de diques paralelos ao declive (Mapa 54, Fotos 9 e 14).

320 O Brasil vivenciou nestes últimos anos, até a realização desta pesquisa, um extraordinário boom no cultivo da soja e ocupa a terceira posição na produção mundial de soja. A produção brasileira de soja aumentou seis vezes de 1968 até 1973 , a exportação de soja e produtos de soja ficou em segundo lugar em 1973 no Brasil com US\$ 916,8 milhões, depois do café (US\$ $1.244,3$ milhões).

321 A importação de trigo representa no Brasil 11\% de todo o valor de importação. Esses gastos devem ser diminuídos através da ampliação do cultivo próprio. 
O crescimento da produção de trigo se deve exclusivamente ao aumento da área de cultivo. A produção média em 1969/70 foi menor em comparação a 1966/67, e com 566 kg/ha também se encontra substancialmente abaixo do valor médio para o Paraná. Por um lado, deve-se buscar o motivo para essas baixas produções na falta de experiência dos plantadores, para os quais o cultivo de trigo ainda se encontra em estágio experimental; por outro lado, a aplicação de adubo é pouco disseminada e a escolha da área não é adequada às condições climáticas. ${ }^{322}$

Uma análise do cultivo de trigo em cinco municípios selecionados segundo características regionais (Astorga, Marialva, Jardim Alegre, Campo Mourão e Cianorte) ${ }^{323}$ permite inferir que, somente no município de Campo Mourão, em 17\% dos empreendimentos com lavoura de trigo, $32 \%$ da área de cultivo foram adubados. A quantidade de adubo por hectare correspondeu somente quase à metade $(74 \mathrm{~kg} / \mathrm{ha})$ do valor médio, de toda forma reduzido, do Paraná. Em todos os outros municípios - com exceção de um empreendimento extensivo em Marialva - o trigo não foi adubado. Nisso, $93 \%$ da área de cultivo são trabalhados pelo proprietário e somente $7 \%$ são terras arrendadas. $14 \%$ dos empreendimentos tem uma área de cultivo de trigo de até dois hectares (fração de área 1,5\%), 38\% entre dois e cinco hectares (11\%), 22\% entre cinco e 10 hectares (15\%), e $15 \%$ se situavam entre 10 e 20 hectares em uma parcela de $18 \%$ de toda a área de cultivo de trigo. Somente $7 \%$ dos empreendimentos plantam trigo em mais de 20 hectares, a fração de área desses empreendimentos perfaz, porém, $54,5 \%$.

A parcela das plantações realizadas com créditos do Banco do Brasil oscilou entre zero (Cianorte) e 68\% (Campo Mourão) da área de cultivo de trigo por município. A maioria dos empreendimentos prefere por conta própria o cultivo primitivo sem rotação regular de culturas, em vez dos contratos oficiais, que têm uma série de exigências (adubação, mecanização, medidas protetivas contra erosão do solo etc.). Nos municípios citados a colheita de trigo é feita em $81 \%$ dos empreendimentos de forma manual. Somente $10 \%$ têm uma ceifeira-debulhadora à disposição, que pertence a grandes latifundiários e é emprestada.

Para o desenvolvimento futuro do cultivo de trigo no Norte do Paraná (que teve, desde 1970, outra forte expansão, ainda não registrada estatisticamente enquanto se escreve este livro) é de importância decisiva o cultivo de tipos de trigo resistentes à ferrugem. Até o momento seguem ocorrendo danos à colheita em razão do ataque da ferrugem. A irregularidade das precipitações levou frequentemente, nos últimos anos, à semeadura tardia (em geral, de abril a meados de junho), de forma que a colheita (de setembro a novembro) se estendeu até o fim do ano e o trigo sofreu com as altas precipitações e umidade do ar. O cultivo de trigo ainda tem cunho especulativo. Elevada aplicação de adubos artificiais, a ampliação da assistência agroeconômica tanto por organizações estatais (Acarpa) quanto por firmas privadas (indústria de adubo e de máquinas agrícolas) e a introdução de tipos de trigo mexicanos podem se tornar pontos de partida de uma crescente estabilização do cultivo de trigo, visto que a disponibilização de créditos e a garantia de preços mínimos pelo governo, que controla todo o comércio, oferecem aos plantadores boas possibilidades iniciais.

\section{Rami}

Na busca por uma complementação econômica para as plantações de café no caso de danos causados por geada, foi introduzida no Norte Novo a rami perene (Boehmeria nivea), principalmente por colonos japoneses. A rami foi introduzida em 1934 em São Paulo, proveniente do Japão. No Paraná, o centro de inovação dessa cultura era a colônia japonesa de Uraí, no Norte Velho. A rami, uma fibra vegetal em forma de arbusto, pertencente à família Urticaceae e com origem no leste asiático, destaca-se pela alta produtividade em um solo de húmus profundo, levemente ácido e rico em nutrientes. A fibra mede até $60 \mathrm{~cm}$ de comprimento e é extremamente resistente, possuindo uma superfície lisa, resistente à umidade e ao apodrecimento, podendo ser utilizada

322 'Frontana' e 'IAS-20 iassul' são as variedades de trigo mais disseminadas. Mas a primeira vem sendo cada vez mais substituída por IAS-20, que deve apontar um aumento de $70 \%$ no rendimento (Coopercotia, Dez. 1967, p. 23). Um grupo de especialistas alemães está realizando, enquanto este livro é escrito, tentativas de cultivo de novas variedades de trigo no Segundo Planalto em Ponta Grossa no Paraná, no âmbito de um projeto de desenvolvimento.

323 Segundo CCLEF, Anuário de Estatístico do Trigo: Safra 1969/70 e Dados da Acarpa, Curitiba. 
de diversas maneiras. ${ }^{324}$ Com três cortes úteis por ano ${ }^{325}$, o cultivo de rami oferece, por mais de 10 anos, 5 a 10 vezes mais quantidade de fibra por área, em comparação com o algodão. Embora a rami seja sensível à geada, as geadas noturnas não danificam as suas raízes, de modo que a planta pode continuar a brotar. Uma vez que nenhum corte útil ocorre no inverno, a rami, que de abril a novembro não requer nenhum procedimento de trabalho, adequa-se bem à organização do trabalho em plantações de café, onde ocorre neste período a intensa e laboriosa colheita do café.

As fortes geadas de 1953 e 1955 forçaram a diversificação dos produtos agrícolas e levaram à expansão do cultivo de rami no Norte Novo do Paraná. Depois da geada de 1955, os trabalhos só puderam ser continuados em muitas plantações extensas de café devido aos rendimentos das plantações de rami. ${ }^{326}$ Uma vez que as geadas não impedem o crescimento de rami, a área das plantações fica, em geral, no caso de relevo levemente ondulado, no terço inferior da encosta (Mapa 54), ou seja, na região em que se evitam as plantações de café devido a possíveis danos causados por geadas.

O problema enfrentado pela adicional expansão do cultivo de rami, que compreende atualmente a cerca de 8.500 hectares no Norte Novo e Novíssimo, é a carência de capital para a aquisição de pequenas máquinas móveis para o desfibramento, bem como a mão de obra com o processo de desfibramento e com o subsequente processo de degomagem. A construção de uma indústria de processamento também traz dificuldades, uma vez que, devido ao seu comprimento, as fibras não podem ser processadas em fiações de algodão. As fiações e as tecelagens de rami localizamse no Estado de São Paulo, sendo a comercialização das fibras secas em grande parte assumida pela Cooperativa Agrícola de Cotia. Os plantadores têm contratos fixos, obtendo bons preços a uma demanda sempre crescente - apesar da concorrência de fibras sintéticas e de algodão. Se o processo de desfibramento puder ser melhorado por meio de máquinas agrícolas maiores e com um desempenho diário mais alto, então pode haver uma chance de exportação para a cultura de rami (WILHELMS, 1963, p. 64-73).

\section{A importância da 'Cotia' para o desenvolvimento da policultura}

A Cooperativa Agrícola de Cotia (CAC ou Cotia), que foi fundada em 1927 por colonos japoneses em Cotia (a $30 \mathrm{~km}$ de São Paulo) ${ }^{327}$ e que tem sua sede principal em São Paulo, oferece uma importante contribuição para a expansão da policultura e para ampliação da oferta de produtos agrícolas. No fim da década de 1930, a cooperativa estendeu seu empreendimento a todo o Estado de São Paulo. Hoje, a 'Cotia' é a maior cooperativa agrícola da América Latina. A sua área de influência é dividida em 8 zonas, ${ }^{328}$ nas quais as cooperativas regionais têm sede, e onde existem mais de 80 depósitos, entre os quais 19 estão no Norte do Paraná. Entre os 11.500 membros da cooperativa, 3.300 vivem no Norte do Paraná (maior cooperativa regional), entre os quais 1.660 no Norte Novo e Novíssimo. 52\% dos membros são de nacionalidade japonesa (imigrantes), 44\% são brasileiros; a maioria, no entanto, é de ascendência japonesa (geração dos filhos), e os demais estão distribuídos entre imigrantes de 45 nacionalidades. ${ }^{329}$

Os produtos agrícolas dos membros são entregues nos depósitos regionais e, de acordo com as diretrizes das centrais, são entregues ao mercado a bons preços, com uma organização exemplar, que compreende até o transporte. Além disso, a cooperativa possui uma organização exportadora própria.

A CAC realiza consultoria agrícola junto a seus membros, organiza a venda mais barata de fertilizantes e possui numerosas instalações industriais (abatedouros, fábricas de conservas, produção

324 Utensílios domésticos (roupa de cama e de mesa, cobertas), vestimentas (na II Guerra Mundial, os uniformes de luta do exército japonês eram feitos de rami por sua resistência e secagem rápida) e utilização técnica (tubos, tecidos, planos, redes, cintos, faixas etc.) (WILHELMS, 1963, p. 7ss.)

325 Cerca de 70 dias depois do começo de novembro até meados de março. Em Rolândia: colheitas de 1.200 a 2.000 kg de fibra seca por hectare (dados gentilmente cedidos pelo sr. Bresslau, de Rolândia)

326 Cf. artigo Desenvolve-se a produção de rami na região norte do Paraná. Indústria Têxtil, dez. de 1957, p. 20 (Rio de Janeiro)

327 A CAC foi fundada por 82 plantadores de batatas, com a ajuda de um empréstimo do governo japonês. Na década de 1930, determinou-se que a venda de legumes e de tomates seria o ponto central da CAC, e a partir de 1935 organizou-se também a venda de ovos (cf. sobre isso ANDO, 1961)

328 'Cinturão verde' de São Paulo, Rio de Janeiro, norte, oeste e sudoeste de São Paulo, norte e sul do Paraná e sul do Mato Grosso.

329 Relatório dos Serviços Sociais, 1969 e informações gentilmente fornecidas pela direção da CAC, São Paulo - quantidade de membros correspondente ao início de 1970. 
de óleo vegetal, fabricação de chá, unidades de processamento e classificação para diversos produtos agrícolas, entre outros também para o café). Além disso, é ligada a ela uma cooperativa de crédito agrícola própria, bem como instalações sociais e culturais.

Os membros da CAC possuem, em grande parte, empreendimentos agrícolas pequenos e médios (Foto 8), mas também grandes empreendimentos de fazendeiros não japoneses estimam a efetividade da organização. A parcela anteriormente alta de arrendatários japoneses entre os membros diminuiu, uma vez que a maior parte deste grupo adquiriu propriedades. A direção sólida dos negócios da CAC também é responsável por esse desenvolvimento, protegendo seus membros da exploração dos atravessadores, através de garantias de preço e pré-financiamento para condições mais vantajosas e possibilitando uma venda dos produtos agrícolas com preços favoráveis também para os empreendimentos situados em locais mais afastados.

Tabela 43: Comercialização de produtos agrícolas dos membros da Cotia em 1969 (em \% do valor total)

\begin{tabular}{|c|c|c|c|}
\hline & Área total de captação & & Norte Novo e Novíssimo do Paraná \\
\hline Batatas & 18 & & - \\
\hline Ovos & 17 & & 24 \\
\hline Aves & 10 & & 3 \\
\hline Algodão & 8 & & 16 \\
\hline Café & 7 & & 28 \\
\hline Tomates & 6 & & 0,6 \\
\hline Óleo de amendoim & 5 & Soja & 14 \\
\hline Bananas & 2 & Uvas & 3 \\
\hline Chá & 1,5 & Milho & 2,5 \\
\hline Rami & 1,2 & & 6 \\
\hline \multirow[t]{2}{*}{ Demais produtos (95) } & 24,3 & & 2,9 \\
\hline & 100,0 & & 100,0 \\
\hline Volume em milhões de Cruzeiros & 263,4 & & 28,3 \\
\hline
\end{tabular}

Fonte: Dados gerais da CAC, São Paulo; para a região de estudo no Paraná, entrevistas próprias feitas pelo Autor nos depósitos.

A CAC possui depósitos no Norte Novo em Londrina, Rolândia, Arapongas, Apucarana, Maringá e Mauá, no Norte Novíssimo em Nova Esperança, Diamante do Norte e em Cruzeiro do Oeste. A entrada de produção mais representativa é apresentada por Maringá (soja 36\%, algodão 27\%, café $17 \%$ ), Londrina (café 35\%, ovos 25\%, rami 17\%), Nova Esperança (ovos 56\%, café $28 \%$ ) e Cruzeiro do Oeste (algodão $60 \%$, café $21 \%$, soja $13 \%$ ). ${ }^{330}$ Os focos do empreendimento da CAC são as áreas com uma forte concentração de cultivadores com ascendência japonesa. Por parte dos produtores lusobrasileiros ocorre com frequência uma postura de distanciamento em relação à CAC, que é chamada de 'japonesa', sobretudo em círculos nacionalistas. O verdadeiro motivo, contudo, é a rejeição da influência da cooperativa sobre a direção do empreendimento e a seleção dos produtos do cultivo, que em geral desconsidera o elemento especulativo.

Enquanto a estrutura dos produtos agrícolas negociados na área total de alcance da cooperativa apresenta participações individuais relativamente equilibradas, com uma forte diversificação - em que apenas a batata e o ovo aparecem com mais força - , no Norte do Paraná a oeste do Tibagi pode ser apontada uma concentração mais forte em alguns produtos principais. Isso mostra que uma policultura agrícola preparada para o mercado ainda é pouco difundida. Apesar do surgimento de cooperativas de produção de café especializadas na parte norte do Paraná, o café ocupa, com $28 \%$ de participação nos rendimentos, o máximo entre os produtos comercializados pelos membros da CAC. A produção

330 Segundo alguns levantamentos do Autor feitos em 1970 nos depósitos, dados sobre 1969. 
de ovos teve um crescimento especial, que claramente supera, com $24 \%$, a participação média no total $(17 \%)$. Algodão (16\%) e soja (14\%), bem como rami (6\%), ocupam os próximos lugares segundo sua importância no Norte do Paraná, enquanto a batata e o tomate não têm importância alguma (Tabela 43).

Devido à grande distância em relação ao centro comercial de São Paulo, frutas e legumes têm apenas uma reduzida importância regional. A grande produção de ovos, por outro lado, deve ser considerada em relação com a utilização do esterco de galinha na fertilização das plantações de café. Neste caso especial, rompe-se a organização espacial do cultivo dos membros da cooperativa, que é direcionada diretamente para a Metrópole de São Paulo no esquema dos anéis de Thünen, de acordo com a perecibilidade dos produtos.

Ao todo, a participação do Norte Novo e do Norte Novíssimo do Paraná no total das receitas da 'Cotia' é de aproximadamente $11 \%$ e ainda é capaz de crescer significativamente.

Contrapõe-se, contudo, à expansão da diversificação agrícola e a uma intensificação do cultivo de produtos agrícolas anuais a tendência para a criação de gado, que se manifesta na mudança estrutural dos grandes empreendimentos, na ampliação das áreas de empreendimentos médios maiores através da aquisição propriedades menores e na expansão das áreas de pastagem através da instalação de pastagens de arroteamento nas florestas remanescentes às margens do Paranapanema e do Paraná.

\section{b) Desenvolvimento da pecuária}

A diminuição das áreas de cultivo de café em vales ameaçados por geada, os problemas no cultivo de produtos agrícolas anuais de trabalho intensivo, as condições da nova legislação social da terra, a queda da produtividade natural no cultivo desprovido de fertilizantes em solos desgastados e a conjuntura favorável do mercado de carnes fizeram que a criação de gado se desenvolvesse extraordinariamente no Norte do Paraná na última década.

Além das mudanças internas aos empreendimentos, como a ampliação das áreas de pastagens para a criação de gado leiteiro no caso de propriedades cafeeiras de tamanho pequeno e médio localizadas próximas a cidades, os empreendimentos médios maiores e os empreendimentos grandes transferiram o foco econômico para a criação de gado ou mudaram de fazenda de tipo misto exclusivamente para a criação ou para a engorda de gado.

A forte tendência iniciada no começo dos anos 1960 para o estabelecimento de pastagens artificiais fez que as reservas de florestas úmidas tropicais, que então ainda eram significativas no Norte Novíssimo, se transformassem em pastagens de arroteamento (Foto 16). Esse processo foi raramente realizado de maneira direta, mas - como mencionado - passava principalmente por um estágio intermediário de cultivo plurianual de grãos e leguminosas, plantas oleaginosas e fibrosas.

Enquanto a quantidade de cabeças de gado se multiplicou quase quatro vezes de 1950 a 1960, passando de 177.000 para 673.000 cabeças, de 1960 a 1967 ocorreu um acréscimo de 158\%, ultrapassandos-se, com isso, a cifra de 1 milhão. Infelizmente não estão disponíveis dados estatísticos mais atuais, no momento de conclusão desta pesquisa. ${ }^{331}$ No entanto, pode-se concluir, a partir de comunicados da Secretaria de Agricultura do Paraná, da Acarpa e de informações sobre as tendências de municípios particulares, que a quantidade de cabeças de gado da região pesquisada chega neste momento a cerca de 2,5 milhões.

O maior crescimento na criação de gado ocorreu devido às crises no cultivo de café e em consequência dos solos arenosos pouco apropriados para a agricultura no Norte Novíssimo, principalmente ao norte do Ivaí, no extremo noroeste do Paraná (Mapa 42). Nos anos 1950, paulistas da região de Alta Sorocabana se estabeleceram lá com a intenção de realizar criação extensiva de gado. Depois de aproximadamente uma década eles atingiram sua meta econômica. Poucos ainda residem na região, principalmente em Loanda, o centro dos mercados agropecuários e das exposições. A maioria vive em Maringá ou Londrina ou retornou para o estado de São Paulo (entre outras cidades, para Presidente Prudente) e confiaram os empreendimentos a administradores.

331 Segundo o Censo Agrícola 1960 do Estado do Paraná (Sinopse preliminar), a parcela dos empreendimentos dedicados à pecuária, com relação ao total dos empreendimentos agrícolas na região em estudo, compreendia $40 \%$, e a quantidade média de cabeças de gado por empreendimento era de 16 . Apenas 2,3\% dos empreendimentos com pecuária possuíam mais de 100 cabeças de gado (parcela de $44 \%$ da quantidade total de cabeças!) A capacidade de suporte média anual girava em torno de 1,2 cabeças por hectare. 
Tabela 44: Desenvolvimento da pecuária no Norte Novo e Norte Novíssimo do Paraná entre 1960 e 1967

\begin{tabular}{|l|c|c|c|}
\hline Região & 1960 & 1967 & Aumento entre 1960 e 1967 (em \%) \\
\hline Londrina & 258.000 & 395.000 & 53 \\
\hline Maringá & 65.000 & 168.000 & 158 \\
\hline Apucarana & 77.000 & 148.000 & 92 \\
\hline Norte Novo & 400.000 & 711.000 & 345 \\
\hline Paranavaí & 133.000 & 592.000 & 322 \\
\hline Umuarama & 71.000 & 300.000 & 91 \\
\hline Campo Mourão & 69.000 & 132.000 & 275 \\
\hline Norte Novíssimo & 273.000 & 1.024 .000 & 158 \\
\hline Total & 673.000 & 1.735 .000 & 345 \\
\hline
\end{tabular}

Fonte: IBGE, Sinopse preliminar do Censo Agrícola de 1960, Estado do Paraná, e DEE Paraná, Animais existentes no Estado em 1967.

Em oposição às áreas de criação de gado do Paraná central e a leste, as pastagens do Norte do Paraná não são pastagens naturais dos 'Campos limpos', mas quase exclusivamente pastagens artificiais cujas áreas foram fortemente ampliadas na última década (Figuras 9-11). Tanto as raças bovinas quanto as pastagens do norte tropical do Paraná são diferentes das outras regiões do Estado, um sinal da clara mudança climática nos planaltos ao sul da região em estudo.

Enquanto nos 'Campos' e nas pastagens plantadas recentemente com pasto jesuíta (Paspalum platycaulon), que é resistente ao frio, em Guarapuava no Paraná central, pastam principalmente as raças bovinas europeias (Charolês, Hereford, Holstein, Friesen) e gado mestiço, no norte dominam raças de Zebu e pastagens tropicais de origem africana ricas em nutrientes, principalmente o pasto de guiné (Panicum maximum), chamado no Brasil de capim colonial. ${ }^{332}$ Além disso, também é crescentemente plantado capim de pangola (Digitaria decumbens) ${ }^{333}$, que se recupera mais rapidamente das geadas. Mas também cresce a importância do capim kikuyu (Pennisetum clandestinum) e capim-elefante e napier (Pennisetum purpureum), ambos naturais da zona de tierra fria na África Oriental e conhecidos há cerca de 50 anos no Brasil devido a sua baixa sensibilidade à geada, nas regiões do Norte do Paraná que recentemente foram diversas vezes atingidas por geadas.

A criação de gado leiteiro é limitada às terras em torno de cidades maiores como Londrina, Apucarana, Maringá e Paranavaí, onde alguns empreendimentos medianos se especializaram com sucesso na reprodução de linhagens leiteiras das variedades de Zebu Guzerat e Gir. ${ }^{334}$

O foco da pecuária no Norte do Paraná está na criação de gado de corte. Aqui domina o gado Zebu, que foi trazido da Índia para o Brasil no começo do século XX, até que a peste bovina causou a proibição total de importação, a qual só foi parcialmente suspensa depois do estabelecimento de uma estação de quarentena na Ilha de Fernando de Noronha, sob rígido controle governamental.

A criação paranaense de Zebu obteve impulsos extraordinários através de iniciativas de alguns criadores. Assim, criadores residentes em Londrina estabeleceram contato direto com um conhecido criador indiano de Zebu e importaram em 1959 mais de 100 animais de reprodução para o Paraná, burlando a proibição de importação através da Guiana Francesa. Em um acordo com o secretário de agricultura paranaense e posterior governador Pimentel, os animais importados da Índia serviram

332 Sobre a questão da introdução de variedades africanas de capim na América do Sul, cf. Parsons (1970). Assim, p. ex. o capimgordura (Melinis minutiflora) e o pasto jaraguá (Hyparrhenia rufa), que Schmidt e Marcus (1943) ainda consideravam nativas do Brasil, chegaram ao Brasil vindos de Angola provavelmente já no séc. XVIII em navios-negreiros como palha dos dormitórios.

333 Capim pangola e kikuyu se espalham exclusivamente por ramificações ou por mudas, uma vez que não produzem sementes, enquanto o capim da guiné é espalhado por semeadura ou por mudas (PARSONS, 1970, p. 145 e 151).

334 Cruzamentos entre Holsteins puros e Zebu-Girs puros foram uma fase transitória para a pecuária leiteira de Girs, que, contudo, atualmente ainda se encontra num estágio inicial (NIXDORF, 1967, p. 59/69). 
como base para a criação de Zebu de raça pura no Paraná e substituíram os animais de reprodução qualitativamente piores de até então, um experimento que foi citado pela FAO como modelo para projetos semelhantes na América Latina. ${ }^{335}$

As variedades de Zebu Gir, Guzerat e Nelore (na Índia: Ongole) são extremamente apropriadas para o clima das margens tropicais do Norte do Paraná, são especialmente resistentes a doenças e suportam a piora das pastagens no inverno melhor do que o gado brasileiro mestiço (CODEPAR, 1964a, I, p. 59ss.). Além da criação de gado das variantes zebu, também foi realizado um cruzamento de Gir com Guzerat, que foi chamado de Indubrasil, tendo atualmente, após um sucesso inicial, uma importância reduzida entre os criadores. ${ }^{336}$

Na pecuária extensiva do Norte do Paraná, impôs-se o Nelore, que é mais frugal do que o Gir e, ao contrário deste, vai à procura de pasto também em caso de pastagens de arroteamento cobertas desuniformemente com capim (Fotos 15 e 16); por outro lado, os bezerros jovens de Nelore são mais independentes no recebimento de alimentação e mais resistentes. Em contrapartida, de acordo com a experiência dos criadores, o gado Nelore não é tão manso quanto o Gir.

O gado Santa Gertrudis, um produto de criação de raça de corte do famoso King Ranch, no Texas ${ }^{337}$, foi trazido dos EUA no final dos anos 1950. Ele matura cedo e combina a alta produtividade de raças europeias com a resistência no caso de más condições de pastagem. Os resultados da criação na região de Alta Sorocabana foram bons. De lá também foi vendido o Santa Gertrudis para o Norte do Paraná, onde ele se adequa principalmente para empreendimentos explorados de maneira intensiva, os quais, aliás, são representados apenas em pequena medida (entre outros, em Rolândia).

Pode-se distinguir três fases de desenvolvimento da pecuária no Norte do Paraná:

1. O ponto de partida foi uma pecuária reduzida no fundo do vale dos sítios de cultivo de café e fazendas, para o abastecimento próprio dos empreendimentos com leite e carne. Quando a capacidade de suporte atingia dois bois por hectare, os animais mais velhos eram vendidos para evitar que se excedesse essa capacidade.

2. A segunda fase desenvolveu-se na região em estudo principalmente desde o início dos anos 1960 com o tipo de empreendimento café-gado já conhecido em São Paulo em grandes propriedades (geralmente acima de 250 hectares). Essas fazendas mistas localizam-se tanto no Norte Novo quanto no Norte Novíssimo. Além da plantação de café, que em geral constitui o foco econômico, é realizada a engorda de gado. Em anos com queda das colheitas de café devido a geadas, a venda dos bois prontos para o abate para abatedouros regionais ou localizados em São Paulo garantem financeiramente o empreendimento.

3. Se a segunda fase já revela transições graduais para a pecuária como foco principal, a terceira fase é determinada pela especialização em criação ou engorda de gado. Participam deste desenvolvimento tanto empreendimentos grandes quanto médios.

Além da sequência temporal destas três fases de desenvolvimento dentro das regiões, essas fases também ocorrem paralelamente no espaço. Enquanto os empreendimentos café-gado se mantêm principalmente no Norte Novo e na região de transição para os solos arenosos do Norte Novíssimo, os empreendimentos exclusivos de pecuária se concentram na parte norte do Norte Novíssimo, principalmente ao norte do Ivaí e no vale do Paranapanema. Este desenvolvimento é condicionado pelo esgotamento da produtividade do solo, destruição dos cafezais pelas geadas e pela crescente erosão do solo na região do arenito Caiuá. A transição da plantação de café para a pastagem ocorre em empreendimentos pequenos e médios, especialmente através da fase intermediária de cultivo de algodão ou milho, ou arroz, dependendo da situação dos preços. Em seguida é semeado o capim entre os pés de café (maio). Em agosto, o capim e os cafeeiros são queimados superficialmente. Se os cafeeiros secos e danificados pela geada não tiveram queimado completamente, eles são cortados em parte dos empreendimentos para evitar que o gado se machuque. No caso dos grandes empreendimentos, os

335 Cf. Realidade (São Paulo), 5, 52, julho de 1970, p. 66.

336 De acordo com a opinião de Nixdorf (1967, p. 62), a Indubrasil ainda não tinha se fixado suficientemente como nova raça, e logo houve segregações em larga escala.

337 Cruzamento de shorthorn (5/8) e brahman (3/8), um zebu brastante próspero há décadas nos estados do sul dos EUA. Faz mais de 50 anos que o gado Santa Gertrudis tem muito sucesso nos EUA e atualmente está difundido em 30 estados dos EUA, bem como em 33 outros países (WEBSTER e WILSON, 1969, p. 442). 
cafeeiros danificados pela geada ou com baixa produtividade são arrancados com o trator, a terra é arada e em seguida ocorre a semeadura com capins de pastagem.

Figura 12: Rotação das pastagens na Fazenda Paranapanema (município de Inajá)

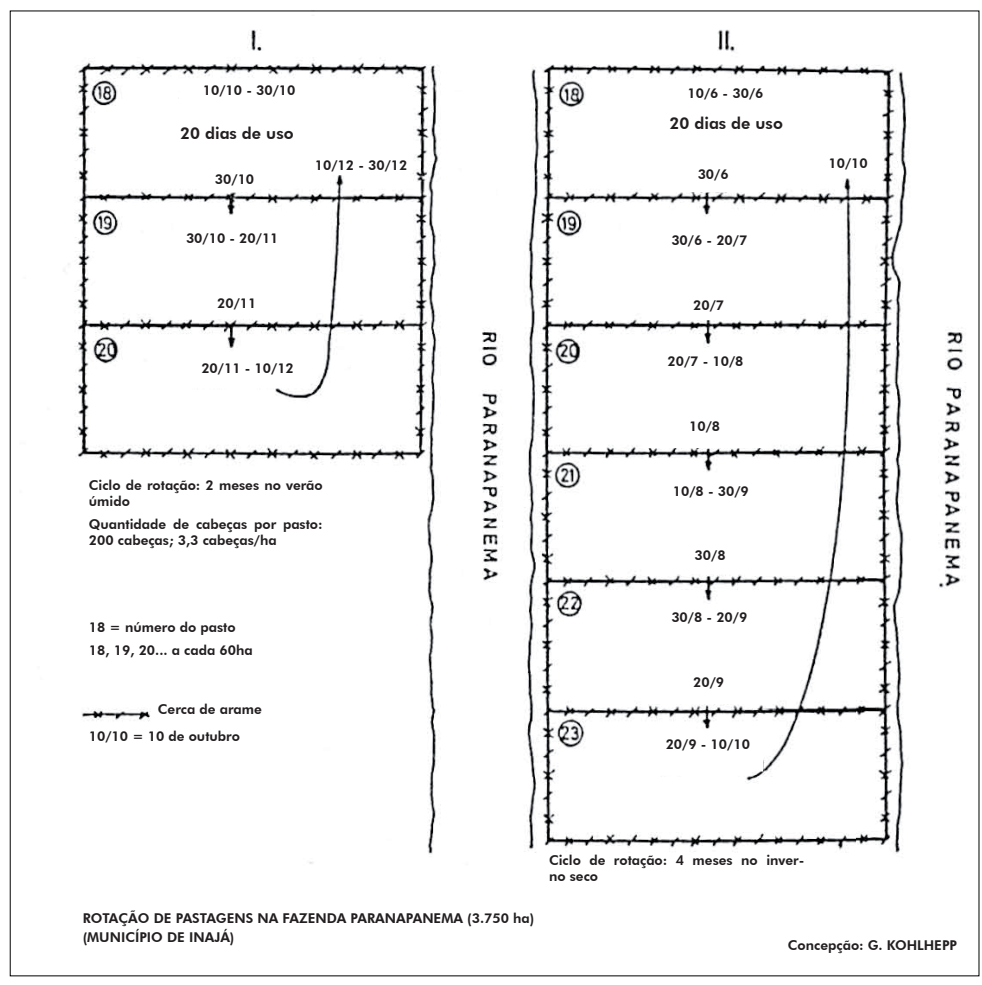

Com exceção de um número relativamente reduzido de fazendas-modelo de grandes empresas e de criadores apaixonados de grande capital, a pecuária de gado de corte encontra-se ainda em um estágio bastante primitivo. Em vários empreendimentos as pastagens não são subdivididas - em geral por causa dos custos com arame, postes e mão de obra -, de maneira que o gado sofre grandes perdas de peso devido a longos percursos e torna-se impossível sua seleção por grupos de idade e diversas categorias. No caso de encostas apenas levemente descendentes dos amplos espigões da região a oeste do Paranavaí, os animais precisam percorrer longas distâncias até o curso de água. No caso de subdivisão da pastagem, faz-se necessária a instalação de poços com profundidade média de $50 \mathrm{~m}$ à meia altura, para assegurar o abastecimento de água para o gado.

Ainda é rara a rotação de pastagens com frequência regulada de manejo e povoamento temporário de partes individuais de pastagens para a regeneração do capim. Assim, por exemplo, na Fazenda Paranapanema, no município de Inajá (Figura 12) é realizado no verão úmido um ciclo rotacional de dois meses com três partes de pastagem de 60 hectares respectivamente. Cerca de 200 cabeças de gado pastam por 20 dias nas pastagens cobertas com Panicum maximum e passam então para o próximo pasto. No inverno seco, a rotação é estendida para seis partes de pastagem para a regeneração das pastagens e é, com isso, elevada para quatro meses. No caso de vacas e bezerros, a mudança é feita já após 14 dias devido ao rápido esgotamento do capim.

Ainda não se estabeleceu no Norte Novo e Norte Novíssimo uma clara organização espacial nas formas de empreendimento de criação de gado. Há empreendimentos com criação própria, aquisição e engorda de touros e bezerros, bem como empreendimentos puros de engorda de gado já amadurecido, com um grau de especialização mais ou menos alto. Ao lado desses, há também os empreendimentos que operam no esquema tradicional e criam os próprios animais até a idade de abate. 
Observando-se a distribuição espacial das formas de empreendimento de criação de gado, pode-se estabelecer um primeiro critério da organização espacial no caso dos empreendimentos de engorda. Estes começam a se concentrar ao longo do Rio Paranapanema e Paraná, no norte e no oeste da região em estudo. Os motivos disso são a alta produtividade das pastagens de engorda ('invernadas'), por conta dos poucos danos causados pelo frio no inverno, bem como a localização desta zona, na região de influência direta dos grandes abatedouros do oeste de São Paulo.

A Cia. Melhoramentos Norte do Paraná quer estabelecer todos os seus empreendimentos de criação ao sul do Ivaí, entre outras cidades, em Cianorte (Fazenda Lagoa e Água do Indío, entre outras). Os touros jovens serão então engordados em fazendas próprias próximas ao Paranapanema. No entanto, a divisão interna do empreendimento ainda não foi completamente realizada. Em 1961, o efetivo de cabeças de gado da sociedade estava em 2.500, em 1965 em cerca de 11.000, ao final de 1970 em cerca de 26.500, devendo ser sistematicamente ampliado até 50.000.

30 a 50\% dos bois magros localizados nas pastagens de engorda no Norte do Paraná vêm das regiões de criação do centro e do oeste do Mato Grosso do Sul (entre outros, do Pantanal). Eles têm entre $21 / 2$ e 3 anos de idade e, após a condução durante semanas, são engordados durante 8 a 12 meses, ganhando então de 60 a $90 \mathrm{~kg}$ de peso. O gado Nelore se destaca pelo ganho mais acelerado de peso em relação ao Gir (CODEPAR, 1964, I, p. 83). Pesando entre 250 e 300 kg, os bois são então vendidos para grandes abatedouros regionais (Paranavaí, Maringá, Londrina) ou para São Paulo. O transporte a partir das invernações próximas ao Rio Paraná até São Paulo é feito com embarcações de transporte de gado (com capacidade para até 400 animais), partindo dos pequenos portos de embarque em Porto Camargo, Querência, Brasílio, Porto Rico ou São José até o grande porto fluvial paulista em Presidente Epitácio, no Rio Paraná, o ponto final da Ferrovia Sorocabana, de onde a distribuição para os abatedouros ocorre por trem ou caminhão.

Alguns dos empreendimentos paranaenses de engorda estabeleceram novas pastagens de arroteamento no sul do Mato Grosso, aumentando com isso as suas áreas de operação. Criadores de gado do Paraná também possuem fazendas de criação no Mato Grosso do Sul.

Os estabelecimentos de criação intermediária compram bezerros com idade entre 1 e 11/2 ano de criadores com menos capital, criam-nos até cerca de 14 a 18 meses de idade e então vendem os bois para os empreendimentos de engorda (NIXDORF, 1967, p. 61).

Estão entre os maiores empreendimentos com engorda de gado no Norte do Paraná as Fazendas Paranapanema (3.750 ha) e Guanabara (6900 ha), ambas localizadas à margem do Rio Paranapanema. A primeira é um puro empreendimento de engorda, sendo $67 \%$ da área do empreendimento pastagens de colonião e $27 \%$ de floresta, que atualmente está sendo derrubada. A fazenda Guanabara foi adquirida somente mais tarde por diversos proprietários e unificada com uma parte de terra devoluta da companhia de colonização (Mapa 43). Embora mais de 75\% da área do empreendimento seja coberta por pastagens artificiais, o empreendimento também possui em suas localizações mais elevadas uma plantação de café recente ${ }^{338}$, cultivada de acordo com as perspectivas mais modernas, com 106.000 cafeeiros (1970), que devem ser ampliados até 500.000. As florestas tropicais úmidas à margem do Rio Paranapanema foram quase totalmente destruídas pelas queimadas. As pastagens de colonião foram implementadas na ghost-forest, que, com suas ruínas de árvores carbonizadas, compreende amplas partes da fazenda. O estabelecimento das pastagens de rotação ainda está em curso. Em parte, as cercas não são mais providas de arame farpado, mas de arame de aço liso (ao todo $235 \mathrm{~km}$ ), para evitar o risco de ferimento e infecção do gado. A área dos pastos individuais varia entre 31 e 163 hectares, e é em média de 95 hectares. O tempo de manejo transcorre de acordo com a Figura 12, com uma capacidade de suporte de 3 animais por hectare. Para cada 400 cabeças de gado é necessário apenas um trabalhador. Para o abastecimento ininterrupto de água foram construídas barragens e bebedouros para o gado, assim como dois poços, a partir dos quais parte respectivamente uma tubulação de água com diversos quilômetros de extensão. $\mathrm{O}$ gado é vacinado contra brucelose, febre aftosa e esplenite. Em 1970, a idade média dos animais vendidos aos abatedouros era de 3 anos e 4 meses, o peso de $260 \mathrm{~kg}$.

É especialmente importante na engorda de gado que as pastagens não sejam superpovoadas (Fazenda Guanabara e Paranapanema $\varnothing 1,9 /$ ha/ano) e que o gado tenha sal à disposição. Muito raramente o gado recebe nos meses de inverno, de junho a agosto, cana de açúcar picada e milho triturado como alimentação.

338 A plantação de café dos proprietários anteriores caiu vítima da 'erradicação'. 
A fábrica de açúcar em Porecatu montou um celeiro com cana de açúcar desfibrada (15 kg/ animal/dia), bolo de algodão, melaço, milho moído e sal mineral (4 kg/dia), que proporciona que, dentro de alguns meses, os bois de $2 \frac{1}{2}$ anos comprados atinjam um ganho de peso de 100-140 $\mathrm{kg}$ ! A meta do projeto é a engorda de 30.000 bois/ano! Essa iniciativa pioneira dá perspectivas totalmente novas à engorda de gado, pois com ela alcança-se pela primeira vez uma idade de abate e peso ideais.

Oferecem-se no Norte do Paraná boas possibilidades de desenvolvimento à criação e à engorda de gado: o satisfatório estado de saúde do gado; a capacidade de suporte relativamente alta das pastagens (que não se degradam, como em São Paulo, quando há uma seca prolongada); e, com a crescente demanda por carne, a ampliação de mercados locais e regionais, bem como o estabelecimento de uma rede de abatedouros.

Mas ainda prepondera entre muitos criadores de gado a mentalidade puramente extrativa, à maneira dos pioneiros. Rotação de pastagens, ração ou mesmo ensilagem, bem como instalações para o controle do gado, são amplamente desconhecidos. Poucos criadores de gado possuem os necessários conhecimentos fundamentais. Muitos dos empreendimentos médios precisam vender os bezerros crescidos a criadores intermediários por falta de pastagem. Os empreendimentos extensivos de engorda trabalham com um volume de trabalho muito pequeno e um risco muito baixo, com ganhos elevados. Atualmente, a engorda de gado é objeto da especulação dos grandes proprietários, que pretendem ampliar suas áreas de pastagem por meio de novas compras ${ }^{339}$. Ao invés de utilizar o crédito dos bancos paranaenses e do Banco do Brasil para a melhoria dos rebanhos através de seleção, para o cercamento das pastagens, para construir barragens e poços ou para a alimentação no inverno, uma grande parte do crédito é usada apenas para a aquisição de bois magros, ou seja, para a ampliação dos rebanhos.

As transformações estruturais na geografia agrária e a forte concentração com variação regional sobre a criação de gado de trabalho extensivo causaram na década passada consideráveis transformações geográficas e migrações populacionais no Norte Novo e Norte Novíssimo.

\section{ORGANIZAÇÃO ESPACIAL DAS TRANSFORMAÇÕES POPULACIONAIS}

O forte aumento populacional, que foi característico do Norte do Paraná até 1960 e que resultou de uma migração interna, ligada ao boom do cultivo de café, com origem no interior de São Paulo, prosseguiu entre 1960 e 1970 apenas nas partes do oeste e do sul da região pesquisada, sobretudo ao sul do Ivaí, com a colonização dos remanescentes de floresta.

Contrapõe-se ao alto crescimento da população urbana ${ }^{340}$ em todas as partes do Norte Novo e Norte Novíssimo (valores regionais entre 84 e 438\%, Tabela 12 , p. 305, Anexo) um aumento muito pequeno da população rural no Norte Novo $(7 \%$ ), assim como um aumento maior no Norte Novíssimo $(74 \%)$. Observando-se as regiões individuais, constata-se entre 1960 e 1970 um retrocesso de 16, 15 e 4\% na população rural na região de Paranavaí, Londrina e Maringá. Trata-se aqui parcialmente de êxodo rural e migração para a cidade grande mais próxima ou para a sede do município, mas também parcialmente de uma migração para as regiões de colonização mais recentes nos arredores de Umuarama.

O Mapa 44 oferece uma diferenciação da transformação absoluta e relativa da população urbana, da população rural e da população total em base municipal. Mostra-se com isso uma clara organização espacial das transformações populacionais. A diminuição da população rural, que, no geral, também está ligada à diminuição da população total do município, ocorreu de 1960 a 1970 quase que exclusivamente ao norte do Ivaí. Atingiram-se perdas populacionais superiores a 60\% em Nova Aliança do Ivaí (74\%),

339 Os preços médios de terra por alqueire paulista (2,42 ha), em agosto de 1970 na região do arenito Caiuá, compreendiam Cr $\$ 1.500,00-2.000,00$ para floresta, Cr $\$ 2.000,00$ para pastagem e Cr\$2.500,00 para área de lavoura (algodão). Sobre 'terra roxa', a terra utilizada para produtos agrícolas de um ano, $\mathrm{Cr} \$ 3.000,00-4.000,00$, e a terra para pastagem $\mathrm{Cr} \$ 3.000,00$ (dados de diferentes agrônomos da Acarpa).

340 Compreende-se 'população urbana', segundo a estatística populacional brasileira, como os habitantes das cidades principais dos municípios e das sedes distritais. 
Mirador, Presidente Castelo Branco e Inajá. As pequenas localidades municipais insignificantes ao norte do Norte Novo de Londrina (Guaraci, Miraselva, Iguaraçú, Itaguajé, Centenário do Sul etc.) também sofreram perdas populacionais nesse período.

As taxas de crescimento mais significativas ocorrem entre o Ivaí e o Piquiri, bem como ao sul do Piquiri, na região do extremo avanço populacional riograndense, com valores de $100 \%$ e, em parte, acima de $300 \%$. Em contraste com a discrepância do desenvolvimento da população urbana e rural no Norte Novo e na região de Paranavaí, nas regiões pioneiras em torno de Umuarama, Goio-Erê, Xambrê, Iporã etc., as taxas de crescimento da população rural e das localidades municipais em estágio pioneiro são igualmente altas.

Ao se interpretar o aumento populacional no Noroeste (Diamante do Norte, Marilena, Porto Rico, Santa Izabel do Ivaí etc., Mapa 44), deve-se mencionar que este ocorreu sobretudo até 1965/1966, sofrendo então uma leve perda populacional. O turno de 10 anos do censo populacional entre 1960 e 1970 só pode apreender o valor médio para essa década, mas não a oscilação durante esse período. Isso significa que, em parte, a tendência de despovoamento também já se estabeleceu nas regiões que, no centro, apresentam ainda um pequeno aumento populacional entre 1960/1970.

A representação da transformação da população rural em relação ao crescimento natural torna mais clara a tendência evolutiva geral (Mapa 45) ${ }^{341}$. A mais forte evasão da população rural pode ser constatada no norte central da região pesquisada, onde a economia de pastagem sobre solo arenoso se desenvolveu como fator econômico dominante e numerosos trabalhadores rurais perderam o trabalho. As localidades municipais possuem - se é que possuem - apenas uma pequena capacidade de recepção; em geral, no entanto, elas também apresentam evasão.

Ao redor dessa região com migração iniciada já no começo dos anos 60 fecha-se, em forma de semicírculo, uma estreita zona de transição com perda populacional relativa, ou seja, com fraca evasão. Esta compreende, no Norte Novo, municípios em que a área de cultivo de café foi diminuída no âmbito dos programas de erradicação e em que as cidades grandes absorveram muitos dos colonos despedidos. Estão entre elas regiões no Norte Novíssimo em que as áreas de pastagem foram ampliadas depois da última geada, iniciando-se só então a migração dos trabalhadores rurais. Por outro lado, em torno de Loanda a parcela das áreas de pastagem já era significativa em 1960, de modo que até 1970 apenas pôde ocorrer uma perda populacional relativamente pequena.

À zona de transição segue-se um anel externo com uma imigração forte ou muito forte, que inclui no oeste as zonas pioneiras e no sul a zona da margem tropical. Enquanto essa imigração entre o Ivaí e o Piquiri ainda está ligada ao avanço extremo do sudoeste da fase final da colonização do café, as florestas úmidas subtropicais e florestas de araucárias remanescentes na fronteira sul ameaçada por geada da região em estudo foram utilizadas na forma da primitiva rotação da terra, isoladas do boom do café. Apenas na região de Jardim Alegre e Ivaiporã o cultivo de café foi responsável por uma imigração mais forte (Mapas 44 e 45).

As direções de migração regionais principais da população rural ocorrem do nordeste para o sudoeste. A migração suprarregional direcionada a regiões rurais da área pesquisada ocorre para o noroeste na direção do sul do Mato Grosso (Dourados), bem como, em casos isolados, em ocupações de fazendeiros paranaenses no norte de Mato Grosso.

Os projetos de exploração na Amazônia, com sua grande ressonância em todas as partes do Brasil, levou, já no início dos anos 1970, alguns grupos de trabalhadores rurais desempregados e meeiros a se assentarem em Altamira no Estado do Pará. Em julho de 1970, um grupo de 226 pessoas (38 famílias) abandonou o município de Tapira (Norte Novíssimo, ao sul do Ivaí), para se assentar em terra própria na região de colonização do Incra (Instituto Nacional de Colonização e Reforma Agrária), em Altamira,

341 No Mapa 45, o crescimento natural (1960-1970: 29,7\%, ou seja, uma taxa de crescimento de algo mais de 26 para cada 1.000 habitantes por ano) é marcado com o valor-índice ' 1 '. Se o crescimento absoluto da população está acima desse valor, então ocorre uma migração $(>1)$. No caso de um crescimento menor que o crescimento natural $(<1)$, ocorreu uma perda relativa de população, ou seja, iniciou-se uma evasão perceptível. Valores negativos no Mapa 45 indicam que a evasão supera o crescimento populacional natural. 
à margem da estrada transamazônica, que estava em construção. ${ }^{342}$ No entanto, já foi iniciada nesse ínterim uma migração de retorno de colonos insatisfeitos. ${ }^{343}$

O êxodo da população rural, que até hoje aumentou ainda mais, foi causado pela mudança em grandes áreas para a criação extensiva de gado. As causas foram os fortes danos por erosão nas plantações de café da região de arenito, o fim do boom do café, assim como os danos causados pela geada.

O ditado brasileiro 'onde entra casco de boi, sai pé do homem' é certeiro em relação às consequências da ampliação das pastagens. Com o retrocesso da economia do café também cessou o desenvolvimento dinâmico dos pequenos subcentros regionais. Isso deve ser mostrado através do exemplo da sede do município de Inajá, a nordeste de Paranavaí (Mapa 46): a colonização conduzida por particulares começou no auge do cultivo de café em 1954/1955. O patrimônio de 69 hectares estabelecido pela companhia de colonização foi elevado em 1960 à sede de município. Na segunda metade dos anos 1950, foi vendida uma primeira grande parte dos 750 terrenos no local, surgindo um dos típicos locais pioneiros do frontier cafeeiro, com uma vida comercial ativa e certa medida de espírito especulativo.

Contudo, mal os cafeeiros haviam atingido a idade ideal de produção, a superprodução brasileira tornou necessária a redução dos cafezais. Além disso, surgiram em Irajá fortes danos causados nas plantações pela voçoroca (gully erosion). Em 1966/1967 - apesar da pouca idade - ,43\% do efetivo de pés de café do município de Inajá foram arrancados. À fase de transição para milho e algodão seguiu-se a mudança para as pastagens. Depois da geada de 1969, a área de cultivo de café continuou a diminuir em favor da área de pastagem. Atualmente, $82 \%$ da área do município é ocupada com pastagem, $8 \%$ com café, $5 \%$ com floresta, $4 \%$ com produtos agrícolas anuais, sendo o $1 \%$ restante ocupado com ruas, caminhos, área local etc.

A população rural do município retrocedeu de 1960 a 1970 em $63 \%$, a população total em $45 \%$. O desenvolvimento da localidade de Inajá, que no início dos anos 1960 vivenciou ainda uma forte imigração, estagnou. Em 1970, dos terrenos medidos no local, 62\% foram vendidos, e das datas vendidas, apenas $40 \%$ foram construídas. No momento do mapeamento (outubro de 1970) nenhum terreno fora vendido em 10 meses. $15 \%$ das moradias do local foram abandonadas, assim como quatro comércios, dois bares, um posto de gasolina e dois galpões (Mapa 46). Inajá conta ainda com cerca de 1.500 habitantes.

Enquanto a escola construída pela sociedade de colonização e um pequeno hospital ainda funcionam, o local não possui mais nenhuma filial de banco e só tem uma escassa pensão. As ordens iniciais de construir casas de alvenaria ao longo da rua principal foram canceladas. Muitos dos pequenos negócios estão próximos da ruína. Nenhuma rua é pavimentada, partes da planta da cidade estão abandonadass e lá pastam porcos e cavalos. Algumas quadras marginais foram aradas e serão utilizadas para a agricultura.

O destino do êxodo dos habitantes de Inajá é geralmente Paranavaí, o centro regional mais próximo. $70 \%$ da população rural que emigrou do município mudou-se para a região recém explorada de Goio-Erê (30\%), Umuarama, Xambrê, Pérola, Alto Piquiri, Iporã, assim como alguns se mudaram para a margem sul do Rio Piquiri (Formosa d'Oeste, Assis Chateaubriand etc.). Por outro lado, 20\% se assentaram como colonizadores da floresta nos municípios de Ivinheíma e Naviraí no sul do Mato Grosso. ${ }^{345} \mathrm{Na}$ zona rural de Inajá havia, em outubro de 1970, 330 casas desabitadas. Fenômenos semelhantes podem ser observados em muitas localidades municipais da região do arenito Caiuá.

A análise do balanço total das transformações populacionais entre 1960 e 1970 (Tabela 12, p. 305, Anexo) mostra entre o Rio Tibagi e o Rio Pirapó (Norte Novo de Londrina) apenas um aumento de 15\%, na região de Paranavaí até mesmo de apenas $8 \%$. Esses números baixos, que estão muito abaixo da taxa

342 A viagem se deu de ônibus até Belém, de lá pelo rio de barco ou por barcos da marinha até Altamira, às margens do Xingu. Os colonos recebiam 100ha de terra por família, casas de madeira e 6 meses de apoio financeiro, bem como sementes e algumas ferramentas. O acompanhamento médico devia ser garantido pelo Incra (Folha de Londrina, 23/07/1970).

343 Segundo questionários do Autor em julho/agosto de 1973 aplicadas na Transamazônica, no âmbito de investigações para o planejamento do desenvolvimento da Amazônia.

344 Uma grande fazenda (2.420 ha) na fronteira com o município Paranacity, que ocupava, até 1966, 350 famílias de agricultores com 1,1 milhões de cafeeiros, necessita de somente 3 famílias, depois da mudança total para a pecuária de engorda (com um total de 4 trabalhadores!)

345 Dados da prefeitura de Inajá. 
de crescimento natural, resultam - apesar do forte crescimento populacional das cidades - do elevado êxodo rural. No Norte Novo, o aumento populacional entre 1960 e 1970 estava no total em 33\% (1950/60: 132\%), no Norte Novíssimo em 96\% (1950/60: 963\%!) e desacelerou-se correspondentemente ao curso do desenvolvimento da colonização agrária com o avanço do frontier ao Rio Paraná. ${ }^{346}$

A densidade populacional média é no Norte Novo de 70 hab./ $\mathrm{km}^{2}$. A densidade populacional rural dessa região aumentou de 1960 até 1970 apenas de 39 para 41 (Tabela 7, p. 304, Anexo). No Norte Novíssimo, a densidade populacional total duplicou até 43 desde 1960; fora das cidades no centro, aumentou de 19 para 32; ao norte do Ivaí, no entanto, diminuiu de 26 para 22!

A densidade populacional rural ${ }^{347}$ revela na faixa da pequena e média propriedade no cultivo de café na terra roxa na região de colonização do CMNP e de algumas pequenas companhias privadas (Ivaiporã, Jardim Alegre, entre outros) valores elevados, acima de 50 hab./ $\mathrm{km}^{2}$ (vide Mapa 47). Ao sul da fronteira do arenito Caiuá na região do Piquiri, esses valores de densidade são atingidos em uma ramificação do cultivo de café próximo a Goio-Erê, mas também fora da região de café em solos férteis de argila vermelha na região agrária dos colonisadores riograndenses (ao sul do Piquiri). Em 1970, as regiões arenosas do Norte Novíssimo apresentaram, sobretudo entre o Ivaí e o Paranapanema (onde ocorreu a expansão principal da economia de pastagem), densidades populacionais rurais mais reduzidas do que a média paranaense $\left(23 \mathrm{hab} . / \mathrm{km}^{2}\right)$. Destaca-se claramente no nordeste a zona de plantação de açúcar e café utilizada de maneira extremamente intensiva nas propriedades de Lunardelli, em torno de Porecatu à margem do Paranapanema.

Ao sul de Campo Mourão, a densidade populacional rural é pequena na altitude, nas florestas de araucárias arroteadas e, em parte, também destruídas pelos incêndios florestais de 1963. Isso vale também para a área do perímetro de Faxinal, Marilândia e a parte sul do município de Londrina.

A comparação da densidade populacional em 1960 (Mapa 25) e 1970 (Mapa 48) mostra no Norte do Paraná o avanço da zona de adensamento $\left(>50 / \mathrm{km}^{2}\right.$ para oeste/sudoeste). Na primeira metade dos anos 1960, esse desenvolvimento entre Ivaí e Piquiri ainda era marcado pela expansão do café. Os maiores valores de densidade acima de $100 / \mathrm{km}^{2}$ são atingidos entre Londrina, Apucarana e Maringá sobre o espigão, o centro dos maiores assentamentos urbanos.

O norte peritropical do Paraná, em que somente na parte oeste do Tibagi vivem $43 \%$ (3 milhões) dos cerca de sete milhões de habitantes do estado em 1970, destaca-se nitidamente quanto à densidade populacional das zonas restantes (Mapa 48). O que permaneceu foi a abrupta transição N-S para o Paraná central e oriental com suas florestas de araucária arrasadas por posseiros, indústria e comércio de madeira, bem como regiões de pastagens naturais dos 'campos limpos'.

Isoladamente aparecem as concentrações populacionais de Curitiba e Ponta Grossa. Por outro lado, a densidade populacional no Sudoeste aumentou evidentemente e quase atinge, nos arredores de Toledo e Assis Chateaubriand, ao sul do Piquiri, os valores da região de cultivo de café.

Nas partes do Noroeste utilizadas há mais tempo, os solos arenosos esgotados devido às transformações estruturais agrárias descritas levaram ao esvaziamento das zonas rurais.

\section{IMPORTÂNCIA DO PLANTIO DE CAFÉ NO NORTE DO PARANÁ AO CONCLUIR-SE A PESQUISA}

\section{a) Posição econômica e produtividade}

Uma ideia da importância do plantio de café após o final dos programas oficiais de erradicação, porém antes da ocorrência de geada em 1969, se apresenta no Mapa 49 pela porcentagem dos

346 A mudança absoluta da população alcançou, tanto entre 1950 e 1960 quanto entre 1960 e 1970 no Norte Novíssimo, com 705.000 e 750.000, quase o mesmo valor (Tabela 12, p. 305, Anexo).

347 Critérios de delimitação no Mapa 47: densidade populacional média do Brasil: 11 hab/ km²; densidade populacional rural média: Paraná fora da região estudada, 17; Paraná total, 23; área estudada, 36 (ou seja, mais do que o dobro do restante do Paraná). 
empreendimentos com plantio de café em relação ao número total dos empreendimentos agrícolas, bem como pela porcentagem das áreas de cultivo de café na área municipal ${ }^{348}$.

A posição econômica predominante é ocupada pelo plantio de café no Norte Novo, onde este perfaz em média mais de dois terços, e em alguns municípios acima de $90 \%$ de todos os rendimentos agroeconômicos. Na região de terra roxa em Londrina e Maringá entre Pirapó e Tibagi, entre 40 e 89\% (Rolândia) dos empreendimentos agrários possuem plantações de café. Mas também na região de Cianorte ao sul do Ivaí atinge-se em parte mais de 70\%.

$\mathrm{Na}$ fração de área do plantio de café na área municipal, especialmente os valores acima de $25 \%$ refletem espaços naturais adequados em razão da qualidade do solo e da altitude; nas áreas principais de produção, a fração se encontra em torno de 37 e $50 \%$. Em alguns municípios menores, mais da metade da área total subsiste de plantações de café (no máximo: Presidente Castelo Branco, 71\%). Com o crescente risco de geada, reduz-se a importância do plantio de café tanto no número de empreendimentos como também na fração de área em direção sul.

Em 1968, a área em estudo possuía mais de 60.500 empreendimentos agrícolas com plantio de café, que com 975.000 ha atingiam uma fração de 35\% de toda a área brasileira de plantação de café $^{349}$. Por volta de dois quintos de todos os empreendimentos tinham plantação de café, na parte norte até mesmo mais da metade. Após a geada de 1969, reduziu-se em torno de $4 \%$ o número de empreendimentos de plantação de café no Paraná até 1970, segundo primeiras estimativas do IBC, ou seja, por volta de 2.400 empreendimentos abandonaram totalmente o plantio de café. A diminuição da área de cultivo de 1969 a 1970 perfaz, entretanto, quase $10 \%{ }^{350}$, de forma que na área em estudo ainda existem por volta de 880.000 ha com café. Essas recentes modificações - como já citado - ocorrem, sobretudo, no Norte Novíssimo de Paranavaí bem como nas áreas marginais meridionais do Norte do Paraná (Figuras 9 a 11).

Tabela 45: Quantidade de empreendimentos com plantações de café e área de cultivo de café no Norte Novo e Novíssimo do Paraná em 1968

\begin{tabular}{|l|c|c|c|c|c|}
\hline & $\begin{array}{c}\text { Empreendimentos } \\
\text { com plantação de } \\
\text { café }\end{array}$ & $\begin{array}{c}\text { Fração no número } \\
\text { total dos empreen- } \\
\text { dimentos agrários } \\
\text { (em \%) }\end{array}$ & $\begin{array}{c}\text { Cafeeiros } \\
\text { (em milhões) }\end{array}$ & $\begin{array}{c}\text { Área de plantio } \\
\text { de café } \\
\text { (em 1.000 ha) }\end{array}$ & $\begin{array}{c}\text { Fração de área de } \\
\text { plantio de café na } \\
\text { área municipal } \\
\text { (em \%) }\end{array}$ \\
\hline $\begin{array}{l}\text { Londrina } \\
\text { Maringá }\end{array}$ & 12.161 & 53 & 202,8 & 282,6 & 28 \\
Apucarana & 7.915 & 52 & 90,3 & 126,0 & 34 \\
\hline Norte Novo & 9.439 & 36 & 76,1 & 108,4 & 15 \\
\hline Paranavaí & 29.515 & 46 & 369,2 & 517,0 & 25 \\
\hline Umuarama & 8.455 & 46 & 121,8 & 170,0 & 17 \\
Campo Mourão & 4.450 & 20 & 157,2 & 219,9 & 16 \\
\hline Norte Novíssimo & 31.029 & 35 & 46,4 & 68,3 & 5,5 \\
\hline Total & 60.544 & 39 & 325,4 & 458,2 & 12,5 \\
\hline
\end{tabular}

Fonte: Resumo próprio segundo dados do IBC, Agência Curitiba; cálculo da área de cultivo segundo valor médio de 720 cafeeiros/ha.

348 Os mais recentes dados sobre a quantidade dos empreendimentos plantadores de café bem como sobre a quantidade de árvores de café existem para os anos de 1967/68. O cálculo sobre a área de plantio de café correspondente foi feito com base no valor médio de 720 cafeeiros/ha. Em razão da falta de dados estatísticos sobre o uso da terra ou a área de atividade, a relação foi tirada da área de plantio de café pela área do município (Mapa 49). Dados: Agências do IBC em Curitiba, Londrina e Maringá.

349 83\% da área de plantação de café do Paraná se localiza no Norte Novo e Norte Novíssimo.

350 IBC, Anuário Estatístico do Café, 1968/70. 
Contudo, no ano de 1972, a fração do norte do Paraná a oeste do rio Tibagi em relação ao efetivo de pés de café do Brasil ainda estava em 35\% (= 850 milhões de cafeeiros). A porcentagem paranaense da produção assumiu novamente no ano de 1971, após a baixa de 1970, a posição dominante na produção brasileira de café (Figura 2) ${ }^{351}$.

Os rendimentos médios das plantações de café repousam no Paraná em 34\% dos cafeeiros abaixo de 10 sacas de $60 \mathrm{~kg}$ de café cru descascado por 1000 árvores; em 35\% entre 10 e 16 sacas, e em 31\% acima de 16 sacas $^{352}$. Com isso, o Paraná, com somente $17 \%$ dos pés de café, se encontra bem acima da média brasileira no grupo de produtividade acima de 16 sacas (> $960 \mathrm{~kg} / 1.000$ pés). Isso não é consequência de uma ampla adubação disseminada, mas sim da alta fertilidade natural da terra roxa do Norte Novo.

Figura 13: Rendimentos das plantações de café G. Schlieper/Rolândia

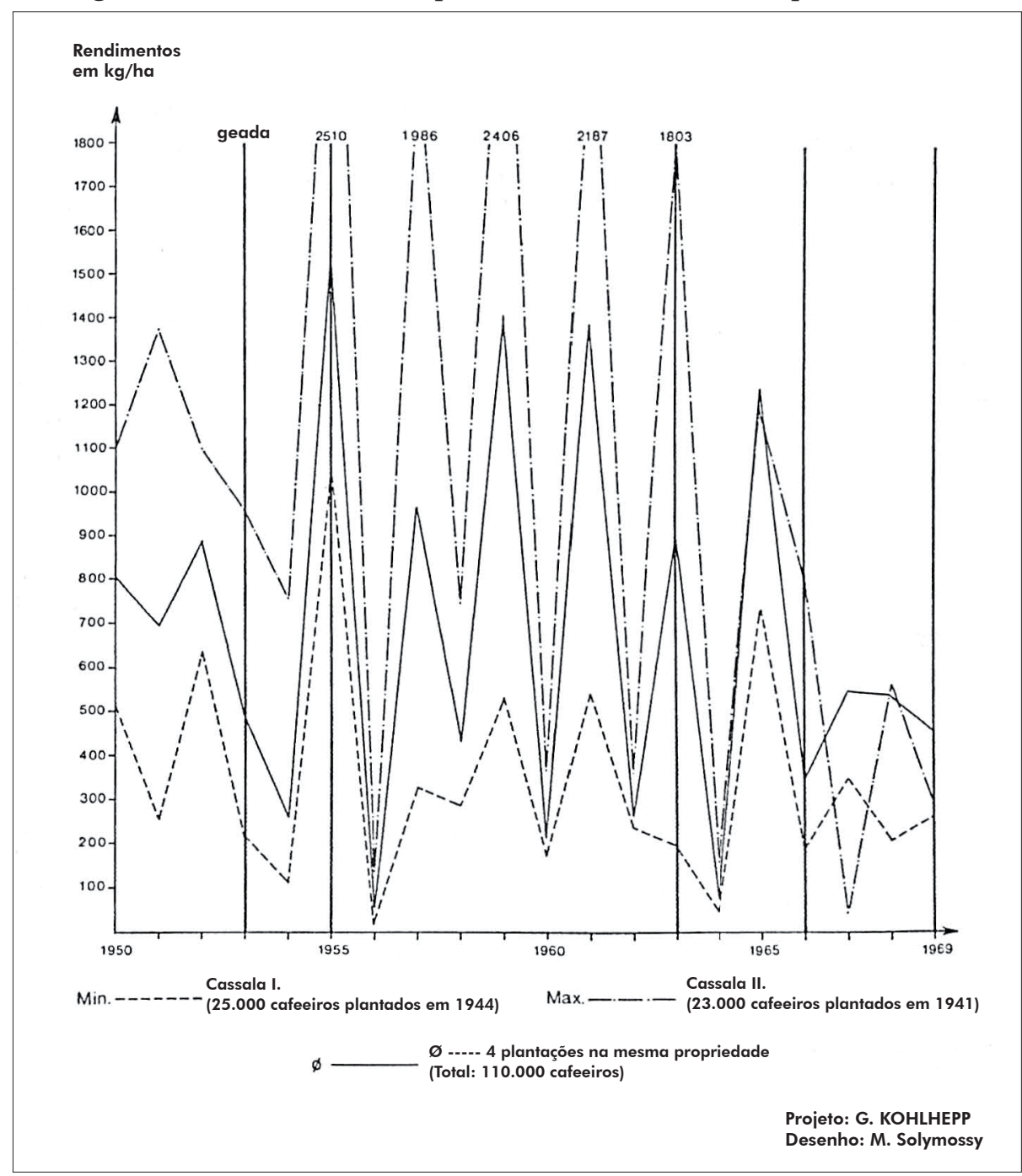

Fonte: Informações pessoais do proprietário.

351 IBC, Anuário Estatístico do Café, 1972.

352 Em São Paulo: 64\% até 10; 25\% entre 10 e 16; e 11\% acima de 16 sacas de 60 kg/1.000 pés de café (IBC/Gerca, Plano de Renovação e revigoramento de cafezais, [s. d.], p. 27). - O rendimento médio correspondeu em 1957 a 390 kg/1.000 pés. 
Os rendimentos máximos das fazendas e dos sítios intensivamente cultivados estão muito acima dos valores citados. A Fazenda Ubatuba no município de Apucarana, uma das maiores plantações do Norte Novo, com uma plantação de café de 453.000 cafeeiros (1970), aponta em um período de 22 anos, incluindo a queda total de produção da colheita de 1956 após a forte geada de 1955, um rendimento de $1960 \mathrm{~kg} / 1.000$ pés em maturidade produtiva. A colheita máxima foi atingida em 1967/68 com $3.780 \mathrm{~kg} / 1.000$ pés, o que, no estoque da época de quase 500.000, resultou numa colheita de 94.400 sacas de $60 \mathrm{~kg}$ de café cru! ${ }^{353}$

No ritmo de produção, segue-se a uma boa colheita um ano com rendimentos mais fracos. Isso fica claro na Figura 13, na qual são analisados, no decorrer de 20 anos, os rendimentos de quatro plantações de café médias em posse do mesmo produtor. ${ }^{354}$ Os empreendimentos diretamente vizinhos entre si no município de Rolândia receberam o mesmo cuidado e adubação. Apesar disso, a diferença entre o empreendimento com os rendimentos mais altos (Cassala II) e com os mais baixos (Cassala I) é extremamente grande (média/1.000 pés: $1.765 \mathrm{~kg}$ e $844 \mathrm{~kg}$ ). ${ }^{355} \mathrm{O}$ motivo dessa diferença de rentabilidade se deve tanto à diferente exposição das plantações, das quais as mais fracas em rendimentos ficam para o sul, bem como também à altitude por volta de $80 \mathrm{~m}$ mais baixa de Cassala $\mathrm{I}$, em parte em um recorte de vale. Geadas de vento e de radiação, bem como correntes de ar frio, geralmente pouco perceptíveis nas áreas protegidas e mais altas, fazem que os rendimentos em Cassala I se reduzam a pouco mais do que a metade, na média de muitos anos.

O mesmo fenômeno pode ser observado em duas plantações localizadas em lados diferentes de um espigão (Mapa 54), que são de mesma propriedade e administração e exploradas de forma semelhante. A Fazenda Balu é exposta para sudoeste, a plantação do Sítio Pindorama para leste/nordeste. Nos ventos gelados incidentes do sul e do sudoeste, os danos devidos à geada em Balu são mais significativos, de forma que o rendimento médio fica somente em $1.260 \mathrm{~kg} / 1.000$ pés, enquanto que em Pindorama fica em $1.638 \mathrm{~kg}^{356}$. Nisso as diferenças ocorrem menos após fortes geadas de radiação (em 1956 e 1970 a produção caiu totalmente em ambas as plantações), mas sim mais após fracas geadas de vento, que têm consequências menores em Pindorama, localizada na posição leste. Na encosta voltada a oeste/sudoeste do sítio deixou-se a vegetação nativa original.

Grandes problemas são causados pela erosão do solo nos pequenos empreendimentos, cuja linha de propriedade vai do espigão ao vale. A plantação de café foi realizada verticalmente em relação ao declive, e em razão da largura comum de somente 150-250 m a construção de diques é pouco eficaz. Isso atinge, sobretudo, as regiões da CMNP, nas quais a pequena distribuição agrária espacial aponta o modelo de distribuição característico para o Norte Novo em torno de Londrina e Maringá, mas também no Norte Novíssimo a leste de Cianorte (Mapas 52 e 53).

As encostas são compostas em até um terço por plantações de café. Nas áreas mais altas sobre as divisoras de águas ('espigões'), os cafeeiros das melhores áreas foram em parte substituídos por novas variedades (Mundo Novo). Em grande parte as culturas paralelas são realizadas em meio às plantações de café. No limite inferior do cultivo de café fica a residência do proprietário, seu pomar, chiqueiro, bem como algumas plantações para subsistência. O solo de vale, fortemente ameaçado por ar frio descendente, é ocupado por pastagens artificiais. O sítio no Mapa 53 obtém $90 \%$ de seus rendimentos a partir do cultivo de café (14.000 cafeeiros, $72 \%$ da área de empreendimento), e o restante, da venda de produtos de culturas paralelas (arroz, milho), bem como de suínos de engorda. A plantação de café alcança o fundo da encosta e sofre prejuízos nas suas partes mais baixas quando há inversão de temperatura, como no ano de 1963.

\section{b) Localização e ordem espacial do cultivo de café no Norte Novo e Norte Novíssimo}

A concentração das localizações do cultivo de café na região com as condições naturais mais favoráveis ocorreu nas novas plantações já no início dos anos 1960 e ainda foi relativamente acentuada durante a fase de erradicação através da redução das reservas em áreas inadequadas.

353 A idade dos cafeeiros correspondia a 5-26 anos, em média por volta de 18 anos (informação pessoal na Fazenda Ubatuba).

354 Aqui se agradece ao Sr. G. Schlieper (Rolândia) por seu cordial apoio na compilação de dados sobre a produtividade das plantações de café.

$355 \mathrm{Na}$ densidade de plantio existente, esses valores correspondem a 1.034 ou $447 \mathrm{~kg} / \mathrm{ha}$. O valor máximo de 2.510/ha no ano de 1955 corresponde a um resultado Recorde de $4.249 \mathrm{~kg} / 1.000$ pés de café.

356 Informações gentilmente cedidas pelo Sr. H. M. Bresslau, Rolândia. 
A distribuição espacial dos pés de café (vide Mapa 50 ${ }^{357}$ mostra que as plantações se estendem principalmente sobre as encostas mais altas e evitam as baixadas em razão do risco de geada em caso de inversão de temperatura (Mapa 52). O adensamento das reservas ocorre entre Mandaguari e Nova Esperança, enquanto que o restante do Norte Novo mostra um modelo de distribuição relativamente equilibrado nas áreas altas apropriadas. Ao sul do Ivaí ainda há plantações extensivas de café nos municípios de Terra Boa, Jussara, São Tomé e Japurá, localizados na região de 'terra roxa', assim como no esporão de São João do Ivai - Jardim Alegre - Ivaiporã, na maior região meridional de cultivo. A oeste se destaca claramente das regiões vizinhas a atual área pioneira de Umuarama - Xambré Pérola.

A produção de café, a exemplo do ano do café de 1968/69 (safra 1968, ano normal), mostra um forte sobrepeso do Norte Novo (região de Londrina e Maringá). No ápice se encontram os municípios de Maringá, Rolândia e Londrina com mais de 600.000 sacas de café cru (de $60 \mathrm{~kg}$ ), seguidos por uma série de municípios vizinhos na área do espigão entre Ivaí e Pirapó, bem como Paranapanema e Ivaí (Mapa 50). Na interpretação das cifras de produção deve-se, entretanto, considerar que se tratam de valores do registro de colheita das agências $I B C$, ou seja, de uma colheita registrada em um município, que também pode se referir a municípios vizinhos.

O fato de 39\% dos pés de café do Norte do Paraná se localizarem em terrenos arenosos pouco férteis explica a pequena produção do Norte Novíssimo, que se aproxima muito pouco do volume das plantações de café do Norte Novo (Tabela 45). Após 12-15 anos de uso, os rendimentos já retrocederam fortemente nas regiões pioneiras do Noroeste e Oeste, apesar de os pés de café estarem na sua melhor fase de produção nessa idade.

Após a geada de 1969, iniciou-se um programa de renovação sucessiva das plantações de café do Brasil, que depois da ocorrência do fungo da ferrugem (Hemileia vastatrix) se concentra nas regiões de cultivo ao norte (ver Cap. VIII, 5), sobretudo nos estados de São Paulo e Paraná, bem como no sul de Minas Gerais.

Apesar de na área observada somente $11 \%$ do efetivo de pés de café serem mais velhos do que 20 $\operatorname{anos}^{358}$ (entre 4 e 20 anos: $84 \%$; ate 5 anos: 5\%), esses exemplares vêm sendo cada vez mais substituídos por novas plantações. Nos primeiros 7 meses do ano de 1970 foram plantados por volta de 4 milhões de pés de café (vide Mapa 51), um número muito aquém dos planos do IBC, mas que se justifica tendo em conta a postura hesitante dos plantadores de café após o choque da já prevista queda quase total da safra em 1970. 62\% das plantações novas foram realizadas por contratos com o IBC, que asseguram um financiamento dos trabalhos de cultivo através do Banco do Brasil.

O motivo das novas plantações dentro das regiões individuais é claramente diversificado ${ }^{359}$ (em \%):

Expectativa de alta rentabilidade

Norte Novo

Norte Novíssimo ao norte do Ivaí

Norte Novíssimo ao sul do Ivaí

\section{7}

29

46
Venda garantida

11

41

29 melhor
possibilidade

52

1

13
Tradição dos

plantadores de café

20

29

12

Nas zonas pioneiras do Norte Novíssimo, sobretudo ao sul do Ivaí, o espírito especulativo ocupa ainda um amplo espaço. A venda garantida da produção foi decisiva ao norte do Ivaí, enquanto que no Norte Novo $52 \%$ dos plantadores entendem a nova plantação de café como melhor possibilidade de uso da terra (sobretudo nos pequenos e médios empreendimentos).

357 Sobre as fontes da apresentação, vide índice de mapas, Mapa 50.

358 Em São Paulo, 31\% dos cafeeiros têm mais de 20 anos. (Dados do IBC e da GERCA).

359 Avaliação de pesquisas de opinião do IBC em 175 celebrações de contrato em 1970. 
O pressuposto para a celebração dos contratos de financiamento é a inspeção do terreno previsto para a plantação pelos agrônomos do IBC. Nisso são considerados como critérios a qualidade do solo, altitude, condição da terra (danos devido à erosão) e a exposição da encosta. O plantador é obrigado a utilizar sementes testadas, a plantar o café em curvas de nível, a tomar medidas preventivas contra a erosão do solo e realizar a adubação. Para incentivar a intensificação do trabalho, são autorizados primeiramente até 20.000 cafeeiros para as plantações. Esse limite foi aumentado para 40.000 a partir de setembro de 1970.

A avaliação dos contratos de plantação celebrados de janeiro até julho de 1970 com o IBC (Figura 14) mostra uma dispersão das altitudes de 400 a $890 \mathrm{~m}$. As ordens de grandeza oscilam entre 2.000 e 20.000 pés, com uma concentração no limite superior. De acordo com as condições de altitude, as novas plantações se localizam acima de 650 m exclusivamente nas regiões de Londrina (parte central), Maringá, bem como em menor monta em Campo Mourão (posição do espigão). As plantações autorizadas nas altitudes abaixo de $500 \mathrm{~m}$ estão localizadas nas partes mais ao norte do Estado, menos atingidas pela geada, na região de Paranavaí e no norte da região de Londrina.

Figura 14: Altitude e extensão das novas plantações de café de janeiro a junho de 1970

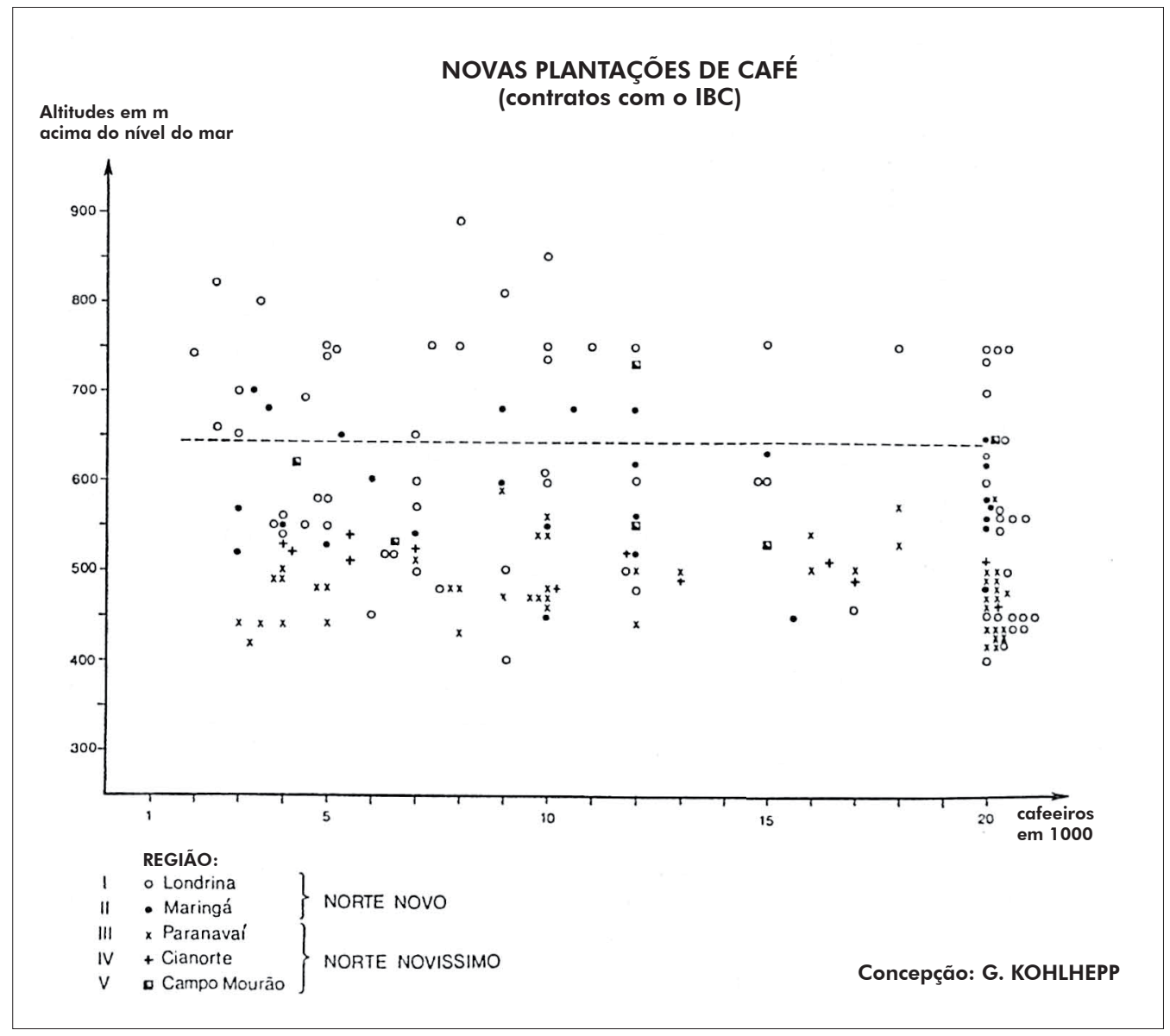

Fonte: Mapa 51.

\section{c) Inovações}

Faz parte das inovações mais significativas no âmbito da economia do café no Norte do Paraná a colocação de canteiros, nos quais se faz uso de sementes selecionadas de café em pequenos recipientes cilíndricos de plástico preenchidos com terra de húmus. Os canteiros são protegidos contra geada de 
vento e radiação solar direta através de uma cobertura colocada por volta de $2 \mathrm{~m}$ acima do solo, através da qual se pode dosar a insolação conforme as plantas vão crescendo. Após 7 meses as plantas são mudadas, entre outubro e junho, para a terra preparada na medida de duas para cada grupo de plantas (Foto 13).

Ao contrário do sistema antigo, em que se colocavam 4-6 sementes (frequentemente até mais) diretamente nas covas de $20-30 \mathrm{~cm}$ de profundidade e se as cobriam com varas de madeira durante 12 a 18 meses, no novo sistema os pés de café jovens começam a produzir cerca de um ano antes. Esse método foi disseminado mais fortemente apenas em São Paulo, mas vinha sendo propagado pelo IBC à época da realização deste estudo e utilizado de forma crescente no Paraná, sobretudo no Norte Novo central, tanto pelas cooperativas de plantadores de café como, também, pelos plantadores individuais ${ }^{360}$.

A escolha de sementes de qualidade e o cuidado intensivo no primeiro estágio de crescimento têm valor especial. Além disso, há a densidade de plantação (até 3,5 × 2,3 m, em parte), que vem diminuindo em relação ao período anterior $(3,8 \times 3,8 \mathrm{~m})$, vide Foto 6 .

Também houve inovações significativas entre as variedades de arábica plantadas. Até meados dos anos 1950, Bourbon predominava nas plantações de café paranaenses a oeste do rio Tibagi. A antiga variedade brasileira Typica (também conhecida como 'Comum' e 'Nacional') foi substituída por Bourbon, que apontou maiores rendimentos. Na primeira metade dos anos 50 surgiu a variedade 'Sumatra', mas cuja importância até hoje retrocede, assim como a da Caturra. Com a última variedade, uma mutação anã de Bourbon, acreditou-se ter encontrado um tipo resistente à geada (autoproteção) em razão do entroncamento do pé e de seus galhos estreitamente dispostos, que facilitavam sobremaneira a colheita. A geada de 1955 mostrou, porém, que 'Caturra' sofrera extremamente com os danos da geada.

Desde essa época apareceu 'Mundo Novo', uma variedade criada pelo Instituto Agronômico de Campinas, um tipo melhorado de 'Sumatra', mais produtivo e resistente à geada do que seu antecessor. Já em 1960, 45\% do novo café plantado era 'Mundo Novo'. Atualmente, 90\% dos plantadores compram essa semente, de forma que com as novas plantações 'Mundo Novo' a fração de Bourbon continua a decrescer ${ }^{361}$.

Assim, acabou o ciclo das transposições do local de cultivo do café em razão da existência de solos florestais mais férteis. Com a fase de consolidação do plantio de café impõe-se então a adubação cada vez mais forte nas principais regiões de produção.

No Norte Novo fixaram-se ao longo do eixo principal de Londrina a Maringá dez firmas de adubos com filiais, mas que realizam nesse âmbito somente a mistura de tipos e não a produção propriamente. Os anos decisivos do desenvolvimento foram 1967/68. Dentro de um ano cresceu a área adubada de cultivo de café no Norte do Paraná em torno de 45\% (GERCA, 1970c, p. 28). A iniciativa das firmas era a princípio voltada aos plantadores de café. Quando, após o bom início, estagnou o interesse após a geada de 1969, ocorreu uma forte inclinação para os demais produtos agrícolas.

Contudo, atualmente o interesse principal se volta novamente para o café. Para a regeneração dos pés e para proteção contra doenças de plantas começou-se com adubação regular. Na região em torno de Londrina-Rolândia, por volta de $70 \%$ dos plantadores de café adubam, porém no máximo $20 \%$ o fazem corretamente $^{362}$. Segundo dados do IBC, em maio de 1970 foi realizada adubagem artificial em $35 \%$ dos cafezais no Norte Novo; no Norte Novíssimo - apesar da baixa produtividade dos solos arenosos - , somente por $10 \%$ dos plantadores.

Os empreendimentos mistos de café e gado não podem utilizar o esterco gerado devido à falta de instalação de estrebaria para o gado. Por outro lado, alguns empreendimentos com criação significativa de aves (para produção de ovos) têm uma base de adubo orgânico extremamente boa. Assim a Fazenda Balu em Rolândia (Mapa 54) possui, além de uma plantação de 152.000 cafeeiros, uma granja com 30.000 aves. As 300 t geradas de esterco aviário/ano resultam em $2 \mathrm{~kg} / \mathrm{cafeeiro/}$ ano.

360 Em 1970, no Norte Novo somente 24\% possuíam canteiros de café, no Norte Novíssimo 15\%.

361 Cf. sobre isso IBC-OEA (1964, p. 59) e Krug e Poerck (1968, p. 286-87), dados do Instituto Brasileiro do Café, Agência Curitiba, e informações gentilmente cedidas pelo Sr. Bresslau, Rolândia.

362 Segundo dados da Cia. Ultrafertil, Londrina, a relação N-P-K deve corresponder, no $1^{\circ}$ ao $4^{\circ}$ ano do plantio de café, a 10 : $9: 10$; a partir do $5^{\circ}$ ano, $7: 2: 9$, a quantidade de adubo de $600 \mathrm{~g}$ por cova é adicionada em 4 partes iguais em setembro, novembro, janeiro e março. As questões de qualidade do solo e adubação correspondente estão sendo atualmente pesquisadas em um projeto da Comissão de Estudo dos Recursos Naturais Renováveis do Paraná (Cerena). 
Empreendimentos grandes e médios bem conduzidos iniciam com uma reorganização sistemática de suas plantações de café. Assim, por exemplo, a Fazenda Balu de 480 ha (Rolândia), hoje com um total de 152.000 cafeeiros (Mapa 54) arrancou, desde 1963, 34.000 cafeeiros com pouco rendimento ou danificados pela geada. Como a plantação de café se estendeu, no início da colonização, de seu limite atual no terço inferior da encosta em direção ao espigão, a erradicação se iniciou com as reservas mais antigas e mais atingidas pela geada na corrente de ar frio, em razão da altitude. O cultivo de trigo paralelo à encosta (em rotação de cultura com a soja) com arrimos contra a lavagem do solo substituiu nesse âmbito o café.

A mais recente erradicação foi, porém, realizada nas encostas mais altas e as plantas Bourbon foram substituídas por 'Mundo Novo'. Segundo pontos de vista mais modernos, a nova plantação é colocada em curvas de nível ( Fotos 6 e 10). As valas para os novos pés de café, transplantados a partir da produção própria de sementes da fazenda, foram feitas mecanicamente com uma escavadeira ${ }^{363}$ (Foto 13). A Fazenda Balu faz parte dos poucos empreendimentos que deixaram reservas florestais suficientes e que com $25 \%$ da área empreendida (café: $41 \%$ ) se situa muito além da média de 6,5\% (1968) indicada pelo IBC para o Norte Novo ${ }^{364}$.

O empreendimento que arrecada anualmente em média por volta de $70 \%$ de seus rendimentos com o cultivo de café pode apoiar-se, em caso de quebra da safra por danos de geada (por exemplo, em 1970), na venda de rami bem como na produção de ovos, mantendo por volta de 30.000 aves $^{365}$.

No total, a área central de cultivo de café do Norte Novo do Paraná (Mapa 35) mostra uma diversificação essencial do uso da terra em comparação com a monocultura na época do boom do café em meados dos anos 1950. Apesar disso, o cultivo de café continua a manter a hegemonia nessa região.

Tendo como exemplo o mapeamento do uso da terra no município de Marialva (Mapa 55) a leste de Maringá, torna-se evidente a clara tendência de concentração das plantações de café nos locais favoráveis em razão das condições naturais. Ao sul do espigão principal onde se localiza Marialva $(640 \mathrm{~m})$ junto à rodovia asfaltada e da estrada de ferro, estendem-se as extensas encostas em forma de platô entre os pequenos rios ${ }^{366}$ profundamente encravados no vale e que correm para o Ivaí, nas quais predomina o cultivo do café. Grande parte das antigas reservas mostra indícios de degradação por influências dos ventos frios do Sul. Os pequenos vales e, sobretudo, as áreas mais profundas no sul mediano do município são tomados por pastagens e produtos agrícolas anuais bem como por pequenas reservas de mata remanescente. Foi realizada erradicação exclusivamente ao sul do espigão, enquanto que para o norte, na posição de sotavento, as recentes plantações de café extensas ocupam o amplo espigão - que suavemente se inclina para o Rio Pirapó (Mapa 55).

77\% dos 2595 empreendimentos agrícolas (Ø 15,1 ha) do município de Marialva realizam cultivo de café (10,5 milhões de pés), o que corresponde a $72 \%$ dos lucros.

As plantações de café na melhor idade produtiva ocupam $26 \%$ da área do município, as mais antigas e menos produtivas, $18 \%{ }^{367}$ Os pequenos empreendimentos, fracos em capital, em parte ainda fragmentados por divisão real (área média dos empreendimentos com cultivo de café: 8,2 ha!) evidenciam a problemática desse tamanho de empreendimento: somente $2 \%$ dos empreendimentos, apesar de declives em parte acentuados, implantaram arrimos contra a lavagem do solo. Somente $3 \%$ aplicam adubo artificial, e 5\% aplicam adubo orgânico ${ }^{368}$.

No comércio do café fica evidente a dependência que os pequenos empreendimentos têm dos maquinistas locais e regionais (24 no município), que assumem uma posição de comerciante intermediário/atravessador. Estes realizam o beneficiamento dos grãos de café, secos nos locais de secagem (terreiros) dos empreendimentos, até chegar ao produto final, o café cru (limpeza,

363 Os trabalhos ainda estavam sendo realizados durante o mapeamento do Autor, em meados de setembro de 1970.

364 Uso da terra dos empreendimentos com cultivo de café no Paraná: café, 40,4\%; 'outros produtos', 14,9\%; pastos, 30,1\%; floresta, 8,1\%; capoeira (floresta secundária), 1,3\%; outro uso, 5,2\% (segundo dados do IBC para 1968).

365 Informações pessoais da Fazenda Balu. Agradecimentos especiais do autor ao Sr. H.M. Bresslau por seu apoio na aquisição do material e disposição para numerosas discussões.

366 O ponto mais baixo do município de Marialva fica no Ribeirão Marialva, cerca de $290 \mathrm{~m}$ acima do nível do mar.

367 Demais usos da terra (em \% da área do município): 1\% plantação nova de café, 2\% erradicação, 23\% pastagens, 22\% produtos agrícolas anuais, 7\% mata, 1\% outros (áreas construídas, estradas etc.) (cálculo de área segundo GERCA, 1969a.).

368 Dados da Acarpa para 1968. 
descasque, seleção, classificação etc. ${ }^{369}$. Apesar de haver Cooperativas do Café nos municípios vizinhos Maringá e Mandaguari, somente 0,7\% da colheita de Marialva é comercializada através de cooperativas.

\section{d) Cooperativismo e comercialização}

Ao contrário de São Paulo e Minas Gerais, onde todas as grandes plantações de café possuem instalações próprias de beneficiamento e o pequeno empreendimento também tem uma possibilidade de se servir das máquinas descascadoras de café do vizinho, no Paraná essas instalações de beneficiamento estão em posse dos maquinistas, sediados na sede do município e nos postos distritais.

Das 617 instalações de beneficiamento da região investigada, $69 \%$ se situam no Norte Novo, sobretudo na região de Londrina. Desses empreendimentos, $79 \%$ têm sua sede nos municípios, $9 \%$ nos postos distritais e 12\% nas fazendas. Instalações próprias existem, sobretudo, nos municípios de Florestópolis, Bela Vista do Paraíso, Astorga, Alvorada do Sul e Rolândia. Das 194 instalações de beneficiamento do Norte Novíssimo (concentração: região de Paranavaí), 91\% se localizam na sede do município, 6\% nos distritos e somente $3 \%$ nas fazendas ${ }^{370}$.

Em geral, o cooperativismo se desenvolveu de forma muito hesitante no cultivo de café. Os motivos se devem, sobretudo, à postura especulativa dos plantadores no frontier, que não aceitam qualquer 'estreitamento' através de estatutos cooperativistas. Em vez disso, o plantador de café vende sua safra de café de forma tradicional ao maquinista, que paga a colheita ao produtor através de créditos aos bancos locais ${ }^{371}$ e muitas vezes age até mesmo sem capital próprio. O café cru é vendido pelos maquinistas a grandes empresas exportadoras brasileiras e internacionais ou ao IBC.

Essa forma de comercialização mantém-se tradicional no Paraná, apesar de parecer que a grande estrutura das plantações de café tende a uma união cooperativista dos pequenos cafeicultores.

Dos empreendimentos, tem-se a seguinte porcentagem ${ }^{372}$ :

$\begin{array}{lrll}39 \% \text { menos que } & 5 & \text { mil pés de café } & =8 \% \text { da reserva de pés de café } \\ 29 \% \text { entre } & 5-10 & \text { mil pés de café } & =15 \% \text { da reserva de pés de café } \\ 18 \% \text { entre } & 10-20 & \text { mil pés de café } & =19 \% \text { da reserva de pés de café } \\ 10 \% \text { entre } & 20-50 & \text { mil pés de café } & =21 \% \text { da reserva de pés de café } \\ 4 \% \text { mais que } & 50 & \text { mil pés de café } & =37 \% \text { da reserva de pés de café }\end{array}$

A mentalidade de frontier dos cafeicultores pode ser percebida até hoje pela divisão espacial das sedes das cooperativas (Mapa 56). Das 17 cooperativas existentes em 1970 na região de estudo, 12 têm sua sede no Norte Novo, quatro no Norte Novíssimo de Paranavaí, e somente uma ao sul do Ivaí (Cidade Gaúcha). A organização da 'Cotia' tem diversas filiais paralelamente no Norte do Paraná, que comercializam café, entre outros produtos. Com exceção da "Cotia" e três cooperativas de cafeicultores (Ibiporã em 1947, Londrina em 1956, Apucarana em 1959), todas as outras cooperativas foram fundadas nos anos de 1961 a 1964, em sua maioria em 1962/63. As cooperativas em Iguaraçu e São João do Caiuá encerraram suas atividades.

369 V. p. 88.

370 Avaliação própria dos dados sobre beneficiamento do café cf. IBGE, Cadastro Industrial 1965, v. 8, Estado do Paraná.

371 Aqui se testa, com base em um modelo, a renda do café em casca; em geral, três sacas de $40 \mathrm{~kg}$ de café com casca resultam em uma saca com $60 \mathrm{~kg}$ de café cru descascado pronto para o comércio. Além disso, é avaliada a qualidade. O preço de compra é composto por ambos.

372 Segundo uma análise de amostra do IBC para 1968 (IBC, 1970a, p. 5). 
O total de 4.437 membros (somente 7,5\% de todos os empreendimentos de café) das cooperativas têm 68,5 milhões de pés de café, ou seja, quase 10\% de todas as reservas. Os proprietários de tamanhos diferentes de empreendimentos estão representados de forma relativamente equilibrada entre os membros. Segundo avaliação dos dados de 920 membros de cooperativas, ${ }^{373} 35 \%$ dos pequenos empreendedores possuem menos de 15 mil pés de café, 42\% de empreendimentos médios detém 15-50 mil, e $23 \%$ mais de 50 mil pés de café.

As áreas de inserção das cooperativas (vide Mapa 56) são bem diversificadas. Mandaguari e Maringá têm um caráter suprarregional. Também Paranavaí e Nova Londrina, tem uma área de inserção maior, com membros no município de Naviraí (Mato Grosso do Sul), mas que não produzem café.

As cooperativas oferecem a seus membros uma série de vantagens significativas: melhores possibilidades de preparação do café com modernas máquinas descascadeiras e selecionadoras com grande rendimento diário em alta qualidade do produto final; ${ }^{374}$ a possibilidade de controlar a venda, desviando-se dos maquinistas, conforme as realidades do mercado; uma grande participação na margem de lucro para os produtores; e melhores possibilidades de armazenamento. ${ }^{375}$ Elas realizam a consultoria agroeconômica para os membros, e em geral possuem boas vinculações bancárias para aquisição de crédito. Como a cooperativa vende o café cru de seus membros um a um, segundo classes de qualidade, não se impede a própria iniciativa dos plantadores para a produção de qualidade. A comercialização cooperativista impede sobretudo os lucros especulativos dos comerciantes. No âmbito das mudanças estruturais agrárias, as cooperativas, ao lado de sua especialização no café, também se voltaram, em parte, à preparação e comercialização de algodão, arroz e milho.

Às cooperativas se conferiu uma função importante nos trabalhos preparatórios do IBC para fixação do cinturão do café e eventual determinação de cotas de produção.

Apesar de todos os aspectos positivos das cooperativas dos cafeicultores, somente $2,5 \%$ da colheita de 1968/69 foram comercializados através das cooperativas, 68,3\% porém através dos maquinistas. ${ }^{376}$ Disso, dois terços foram através de maquinistas regionais independentes e um sexto através de firmas estrangeiras, cujas filiais atuam como compradores de café na região de produção. Somente $4 \%$ da colheita foram beneficiados por pequenos maquinistas, e por volta de $5 \%$, diretamente nas fazendas. $\mathrm{Na}$ exportação, a proporção entre firmas regionais e estrangeiras é 60:40.

Para apoiar o preço do café, o Instituto Brasileiro do Café compra grandes quantidades de café dos maquinistas, conforme a situação do mercado. Para evitar a longa estocagem nas cidades portuárias quentes e úmidas, o IBC instalou uma rede de depósitos na região de cultivo. As sedes se localizam - com poucas exceções - bem junto às estradas principais e à linha férrea (Figura 15). A capacidade total dos 41 depósitos, dos quais 25 se localizam no Norte Novo, é de 31 milhões de sacas no Norte do Paraná. Ao final de 1969, os depósitos estavam completos com 15,2 milhões de sacas num total de $57 \% .377$ Os maiores depósitos do IBC possuem uma capacidade de estoque de mais de 1 milhão de sacas (Londrina, Rolândia, Arapongas, Apucarana, Maringá, Paissandu) ${ }^{378}$

373 Entrevistas detalhadas foram realizadas pelo autor em Londrina, Mandaguari, Maringá, Paranavaí e Porecatu. Dados complementares sobre as demais cooperativas provém de documentos do IBC em Maringá.

374 A capacidade/dia fica entre 600 e 2.000 sacas.

375 No total para 1,7 milhões de sacas a $60 \mathrm{~kg}$.

376 Dados de Gerca/IBC através de gentil intermediação do Sr. Dr. Meirelles, Curitiba.

377 Folha de Londrina, 11/12/1969. - Em razão da pouca safra brasileira de 1970 (quase perda total da safra no Paraná), o IBC cobriu as obrigações de exportação de café do Brasil a partir desses estoques.

378 Além do IBC, cooperativas e maquinistas, também a linha férrea possui uma rede própria de 34 depósitos, entretanto com menor capacidade de estocagem: 0,6 milhões de sacas. 


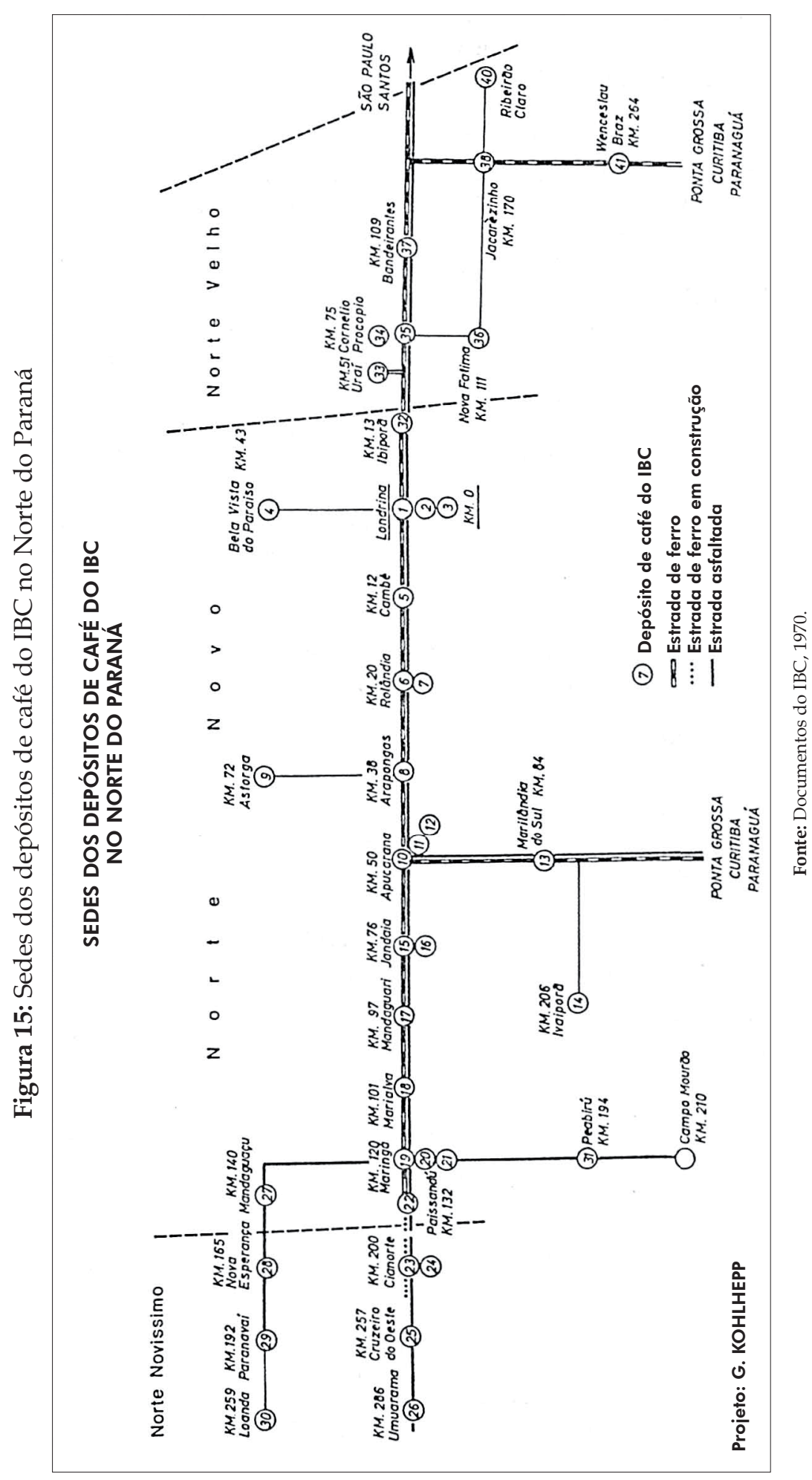




\section{e) Estrutura de transportes da região cafeicultora}

A urbanização do Norte do Paraná provinda de São Paulo fez que a região cafeicultora do Paraná se tornasse um 'guindaste' das zonas pioneiras paulistanas, em razão das conexões viárias e da origem populacional, em direta dependência econômica de São Paulo. Uma conexão por rodovia asfaltada de Londrina a São Paulo-Santos existia muito antes de haver uma estrada transitável o ano todo entre o Norte e o Sul do Paraná. A linha férrea da antiga estação final de Maringá à capital Curitiba e ao porto de Paranaguá leva a leste até a divisa estatal com São Paulo através de Ourinhos - o ponto de conexão ao trecho da Sorocabana -, e somente dali para o sul em direção a Ponta Grossa - Curitiba. Assim, ocorreu que a conexão férrea ao porto paulistano de Santos não era muito mais longa que a conexão até Paranaguá (Mapa 58).

Depois que a Rodovia do Café - uma rodovia asfaltada de Apucarana até Ponta Grossa e Curitiba - possibilitou, desde 1965, o transporte de café diretamente a Paranaguá, foi recentemente terminada a construção da central da linha férrea Central do Paraná, que reduz o trecho Apucarana-Ponta Grossa para $330 \mathrm{~km}$ em conexão direta. Antes eram $624 \mathrm{~km}$, através de Ourinhos. Além de significativo ganho de tempo, isso também diminui os custos de transporte ${ }^{379}$.

A situação dos transportes do Norte do Paraná modificou-se essencialmente nos últimos anos. ${ }^{380}$ Mas isso vale quase que exclusivamente para a construção de estradas, pois a linha férrea para o Oeste foi continuada somente de forma muito hesitante e, após a conclusão da ponte sobre o Ivaí, chegou primeiro a Cianorte, sem ter sido conectada ao trânsito de carreira, até a conclusão do presente estudo. Por outro lado, a malha viária asfaltada foi ampliada (Mapa 57) e Maringá se tornou o ponto de entroncamento dos trechos a Paranavaí, Campo Mourão e da rodovia principal a Umuarama, terminada em 1971. Em Rolândia bifurca a planejada conexão asfaltada com São Paulo, mas que termina em Porecatu. A rodovia principal de Londrina a Maringá é fortemente utilizada, e em 1969 acusou nos trechos entre Londrina e Cambé um fluxo diário de 7.270 veículos, e de Maringá em direção a Marialva até mesmo 8.475 veículos por dia. ${ }^{381}$

Para o sul continua a existir somente uma via transversal asfaltada (Apucarana-Ponta Grossa) entre os eixos principais leste-oeste São Paulo - Londrina - Umuarama e Paranaguá - Curitiba - Guarapuava Foz do Iguaçu, que assinalam o processo de urbanização no Norte ou no Sul. ${ }^{382}$ Fora das vias asfaltadas existem, nas estradas naturais do Norte do Paraná, condições viárias muito precárias em caso de chuva. Na região arenosa do Noroeste, as estradas principais sem macadame de Paranavaí a Nova Londrina e Loanda estão frequentemente intransitáveis por conta da voçoroca. Mas também na região de terra roxa, após fortes precipitações, as estradas vicinais não são transitáveis devido ao risco de deslizamento.

Os pontos finais das estradas asfaltadas são os locais de confluência para a continuação do transporte de produtos agrícolas. Durante grandes colheitas de café todos os veículos disponíveis são utilizados para o transporte, seja para os maquinistas, para os depósitos do IBC ou diretamente para os portos de exportação.

No transporte ferroviário, Maringá, como ponto final efetivo do trecho principal, continua a ser o local mais importante de coleta e transbordo. Segundo o valor das mercadorias expedidas, Maringá ocupa o primeiro lugar em todo Paraná, antes mesmo de Paranaguá383.

\section{f) Exportação de café e diferenciação de qualidade}

Até meados dos anos 1920, as colheitas de café do Norte Velho tinham sido transportadas exclusivamente através de Santos. Desde 1924, pequenas quantias também foram transportadas a partir do Norte Velho em Paranaguá. A ascensão de Paranaguá ocorreu paralelamente ao desenvolvimento do cultivo de café no Norte Novo e Norte Novíssimo. Ainda no início dos anos 1950 existia, porém, um transporte oculto do café paranaense por estrada até as estações da via férrea Sorocabana, para de lá ser

379 Para o desenvolvimento da condição de transporte, v. Brum (1964) e Revista de Desenvolvimento n. 3, 1967, p. 13ss. (Central do Paraná) = Fayet, 1967.

380 Mapa 17 (situação dos pioneiros em 1948) e Mapa 57 (desenvolvimento da malha viária em 1971).

381 Informação do Departamento de Estradas e Rodagem (DER) em Curitiba, para 1969.

382 No Mapa 57 é visível a rodovia de longa distância Paranaguá-Assunção/Paraguai passando por Cascavel no sul.

383 Segundo informação da Rede de Viação Paraná - Santa Catarina (RVPSC - Setor de Estatística) em Curitiba, para o ano de 1969. 
enviado para Santos ou Rio como café paulista, que alcançava um preço melhor. Sobretudo em Santos as transações eram mais fáceis em razão da tradição do café desse porto e das instalações de carregamento substancialmente melhores (GUIMARÃES, 1953, p. 57).

A ampliação do Porto de Paranaguá e as conexões de transporte com as regiões de produção de café do estado acarretaram na integração do Norte com o sistema de transporte paranaense. Com isso, em grande parte, a exportação de café saiu do âmbito de influência paulistana (Mapa 58).

A exportação de café do Norte do Paraná se deu, em 1969, 87\% por Paranaguá. O transporte ao porto foi feito em $79 \%$ por caminhão e somente $21 \%$ por trem. O café paranaense exportado por Santos (aproximadamente um milhão de sacas) foi transportado na mesma proporção por estrada e por via férrea. ${ }^{384}$

Desde o surgimento da conexão por estrada asfaltada da região de cultivo ao porto de exportação (1965), diminuiu a parcela do transporte mal organizado e demorado por ferrovia. A nova via férrea que cruza o Paraná Central irá assumir a parte do carregamento da via férrea do antigo trecho no leste do estado que, com isso, irá perder totalmente sua importância. Face aos problemas gerais de transporte das ferrovias brasileiras não se pode esperar que, na exportação de café, o transporte por ferrovia possa superar o fornecimento direto por caminhão. Em 1969, Paranaguá tinha quase superado Santos, que até então era o porto mais importante de exportação de café do planeta. Entrementes Paranaguá foi novamente remetido ao segundo lugar por Santos. ${ }^{385} \mathrm{O}$ porto paranaense não é especializado somente em exportação de café, mas possui também significativa exportação de milho, que na quantidade supera o café. Entretanto, no valor de transbordo o café está muito além na liderança, com $83 \%$, antes do milho $(8 \%)$ e madeira $(6 \%)$.

Na diferenciação entre tipos e sabor do café exportado através de Santos e Paranaguá e no destino de exportação refletem-se as diferenças de qualidade do café produzido nas diversas regiões brasileiras de cultivo, bem como dos costumes internacionais de consumo (vide Mapa 58). O café é classificado em razão do número de 'defeitos' ${ }^{386}$ por $300 \mathrm{~g}$ de modelo cru em 8 tipos, segundo uma graduação de qualidade 1-8 (com valores intermediários). Tipo 1 corresponde à pureza excelente do produto. Enquanto em Santos os tipos 2, 2/3, bem como 3 e $3 / 4$ predominam, em Paranaguá prevalece o tipo 6 (53\%). O motivo dessa diferença na pureza do café cru repousa, por um lado, na pior preparação feita no Paraná; por outro, os diversos processos de trabalho no Paraná são realizados forçosamente de maneira superficial, pois a colheita se inicia somente em junho (um mês mais tarde do que São Paulo) e até as chuvas de setembro todo o processo deve estar concluído, inclusive secagem e preparação. Isso se expressa na diminuição da qualidade de tipos. Só muito lentamente os cafeicultores estão se adaptando da fase pioneira da produção em quantidade (que São Paulo já superou) para a produção com qualidade. A ampliação do setor cooperativo e a consultoria por agrônomos do IBC poderiam oferecer ajuda essencial nesse sentido.

Além do tamanho dos grãos, da aparência (cor e condição superficial) e do grau de pureza (tipo), tem importância especial o sabor (qualidade de xícara; 'bebida'). Ao contrário dos milds, ou seja, todos os arabicas não brasileiros, as espécies de café do Brasil pertencem ao sabor 'forte'. Nisso tem papel decisivo a técnica da colheita, que no Brasil é realizada em grande parte através da derriçagem dos grãos de café sobre o solo, bem como a preparação. No Brasil aplica-se o processo 'seco' em razão das enormes quantidades de colheita. Como grupos principais se distinguem 'mole', 'duro', 'riada' e 'rio'387, em que os dois últimos possuem um sabor mais forte. Enquanto em Santos 31\% do café exportado tinham um sabor 'suave' (procedência de regiões de cultivo mais secas: Mogiana, Ribeirão Preto, Franca), em Paranaguá $93 \%$ pertencem ao grupo riada.

Esse sabor, por motivos de preço, é utilizado, sobretudo, na fabricação do café solúvel nos Estados Unidos, de forma que quase um terço do café paranaense é exportado aos Estados Unidos por Paranaguá. A República Federal da Alemanha importa somente 1,4\% do café riada. De Santos partem 35\% das

384 Segundo dados de RVPSC, DER e das administrações portuárias em Paranaguá e Santos (em parte, estimativas).

385 Exportação de café em 1972: Santos: 9,055 milhões de sacas de 60 kg; Paranaguá: 7,071 milhões de sacas de 60 kg (IBC, Anuário Estatístico do Café 1972).

386 Grãos pretos, partidos, ocos ou verdes, casca com calosidade, lascas de madeira ou pequenas pedras etc. Esses defeitos e impurezas são calculados em um complexo sistema sobre 'defeitos básicos' de um 'grão de café', que corresponde, por exemplo, a 3 cascas com calosidade ou 5 grãos verdes ou partidos. Tipo $1=0$ defeito; tipo 8 até 360 defeitos.

387 Esse sabor vem, sobretudo, das regiões de cultivo muito úmidas e de locais mais baixos nos estados do Rio de Janeiro e Espírito Santo. 
exportações qualitativamente melhores para os países da CEE (Comunidade Econômica Europeia) 388 (entre esses $9 \%$ à RFA) e somente $16 \%$ aos Estados Unidos.

\section{g) Panorama geral}

Devido à intenção do Brasil de aumentar a própria produção de café solúvel, desenvolveu-se uma acirrada controvérsia com os Estados Unidos, que tentam manter o barato produto brasileiro longe de seu mercado. Sob a pressão americana, o Brasil impôs um imposto de 13\% sobre exportações de café solúvel, que à indústria americana parece muito baixo. Como o Brasil é fortemente dependente dos Estados Unidos como grande importador de café cru, a indústria brasileira de café em pó não pode trabalhar com total eficiência. A importância que esse ramo industrial poderia assumir é revelada pela Cia. Cacique em Londrina, que em 1970, com uma produção diária de 30t de café solúvel, forneceu sozinha quase $1 \%$ do valor brasileiro global de exportação. ${ }^{389}$

A regulamentação da prorrogação do acordo internacional sobre o café depende da questão do café solúvel. A isso se agregam discrepâncias sobre o valor das cotas de exportação, bem como sobre ajustes especiais que a CEE quer garantir às ex-colônias francesas da África ${ }^{390}$.

Também após o fim do boom do cultivo de café nas novas regiões, a situação do cultivo brasileiro de café, com fortes oscilações de produção dos últimos anos devido a geadas no Paraná e à seca em São Paulo, prejudicou fortemente e perturbou o mercado internacional de café. A grande dificuldade de se fazer uma previsão sobre as futuras colheitas brasileiras (ROURKE, 1970) ainda aumenta com a surpresa da ocorrência do fungo da ferrugem no café. As reservas brasileiras de café reduziram fortemente nos últimos cinco anos em razão da diminuição da produção para cumprir as obrigações do ICA, bem como devido a más colheitas. Desde 1966, a produção de café do Brasil indica um déficit anual que pôde ser coberto por meio das reservas estocadas (vide Figura 6). Outra geada no Paraná nos anos seguintes iria consumir o capital de café do Brasil e, com isso, levar a desenvolvimentos internacionais descontrolados do mercado (ROURK, 1971, p. 4ss.).

O desenvolvimento da economia cafeeira no Paraná irá depender de a parcela do mercado no Brasil, ou seja, as 'arábicas' não lavadas, manter os 37,5\% na exportação total do café mundial, como o ICA previu. Outro fator é se as 'robustas', como espécies baratas, podem continuar elevando sua fração de mercado, sobretudo em vista da expansão do mercado para café solúvel.

\section{CONSEQUÊNCIAS DO DESMATAMENTO EXCESSIVO NO CURSO DA COLONIZAÇÃO CAFEICULTORA PARANAENSE}

No curso da colonização agrária, a vegetação florestal tropical do Norte do Paraná, bem como as florestas úmidas subtropicais e as florestas de Araucária da região marginal do sul foram, em grande parte, destruídas. Responsáveis por esse desenvolvimento foram a instalação de cultivos permanentes até o início dos anos 1960 e a partir deste momento em crescente medida a constituição de pastagens de arroteamento. A instituição de grandes reservas florestais governamentais sob o interventor Manuel Ribas sofreu retrocesso através de seus sucessores, de maneira que hoje apenas restos muito reduzidos de floresta estão ainda presentes.

Pressupondo um ritmo de desmatamento constante desde os cálculos de Maack para meados dos anos 1960 (MAACK, 1963, p. 25ss.; MAACK, 1968, p. 196-200), restam hoje apenas 12 a 13\% de floresta na área em estudo, ou seja, desde o início da colonização, há pouco mais de 40 anos, quase $50.000 \mathrm{~km}^{2}$ de floresta foram destruídos, em geral através de queimadas.

A tentativa de mapear os remanescentes de floresta ainda disponíveis (Mapa 59) ${ }^{391}$ mostra que a vegetação florestal originária no Norte Novo desapareceu quase por completo. Apenas na região

388 Designação para o estágio anterior da União Europeia (N. E.).

389 Dados segundo a empresa correspondente em Londrina.

390 Ver sobre isso Frederick (1970, p. 256ss.) e The Standard Bank Review (Londres), 1970, p. 2-9.

391 Fontes: vd. índice de mapas, bem como fotos aéreas mais recentes e dados da Escola Florestal em Curitiba. 
de afluência do Ivaí (Norte Novíssimo) ainda restam áreas contínuas de floresta úmida, em que foi surpreendentemente descoberta, ainda nos anos 1950, uma pequena tribo de índios Xetá (MAACK, 1962). Notícias recentes afirmam que a destruição desses remanescentes de floresta avançou fortemente nos dois últimos anos.

O desflorestamento radical no Norte do Paraná teve como consequência uma crescente instabilidade de fatores climáticos, bem como erosões extremamente fortes, cujas consequências são imprevisíveis.

A acentuada fronteira climática entre o clima de savana de inverno seco a oeste de São Paulo e o clima sempre úmido da região de floresta tropical ao norte do Paraná (que antigamente coincidia com o vale do Paranapanema) já não pode mais ser claramente reconhecida. Revezam-se no Norte do Paraná tempos secos acentuados no inverno, que podem se estender, em parte, de maio até setembro, com fortes chuvas de inverno, que senão só são conhecidas nas regiões mais ao sul do Brasil.

Não apenas a distribuição sazonal de precipitação, mas também os volumes anuais de precipitação apresentam uma instabilidade significativa. Tempo de plantio e processos de amadurecimento do plantio de diversas culturas atrasam-se por meio disso e causam grandes perdas nas culturas, provocando crescente insegurança entre os plantadores. As oscilações nos rendimentos das colheitas no cultivo de produtos agrícolas anuais e o problema de se encontrar um segundo produto economicamente favorável além do café também devem ser levados em conta neste contexto.

O coeficiente de variação na precipitação, que ficava entre 1,4 e 1,6 na paisagem natural da região tropical do Norte do Paraná, duplicou em poucas décadas. Valores extremados aparecem cada vez com mais frequência (MAACK, 1960, p. 3.).

A quantidade de infiltrações de ar frio aumentou. De 1962 a 1969 ocorreram quatro geadas. Um avanço dessa concentração de danos causados por geada, que até 1974 felizmente ainda não ocorreu, traria problemas existenciais à economia cafeeira do Paraná. A destruição florestal causou relevantes distúrbios sobre os recursos hídricos. As precipitações correm rapidamentee carregam do solo importantes nutrientes minerais. Depois de uma elevação inicial do fluxo das nascentes, a baixa contínua do nível do lençol freático leva ao esgotamento do horizonte mais alto da nascemte. Os problemas de abastecimento de água que estão surgindo precisaram ser resolvidos por inúmeras perfurações profundas, como, por exemplo, em Londrina e Maringá. ${ }^{392} \mathrm{O}$ fluxo irregular de água dos rios repentinamente ocasiona enchentes graves.

A destruição da cobertura vegetal originária levou, por meio de intensiva insolação e forte perda de umidade, ao encrostamento superficial do solo através de óxidos de ferro. A destruição das bactérias do solo teve por consequência uma perda significativa de fertilidade do solo.

A permanente erosão do solo fortalece o retrocesso de rentabilidade que ocorre com o esgotamento natural devido ao cultivo permanente sem fertilizantes. ${ }^{393}$ Medições do Instituto Agronômico de Campinas indicam a perda de solo de $750-1875 \mathrm{~m}^{3}$ por alqueire $(=2,42 \mathrm{ha}$ ) e ano (SOUZA, 1965, p. 90 ss.). A forte permeabilidade dos solos arenosos de Caiuá, roubados de sua cobertura vegetal, levou parcialmente a erosões catastróficas. No Norte Novíssimo formaram-se na região em torno de Paranavaí, Nova Esperança, São João do Caiuá, Loanda etc. valas em parte com profundidades de mais de 20 m (MAACK, 1956; KUROWSKI, 1962; KAVALADRIDZE, 1963 e 1966). ${ }^{394}$

No cultivo de café, que se estende, sobretudo, na parte superior dos declives nas encostas, a falta de medidas de proteção do solo e a técnica incorreta de cultivo favoreceram a erosão do solo. A limpeza do terreno ou a aragem entre as fileiras de cafeeiros para o cultivo de culturas intermediárias foram frequentemente realizadas de maneira perpendicular ao declive - assim como a instalação de plantações de café. A falta de sulcos e de terraplanagem para a proteção contra a lavagem do solo tiveram consequências negativas. Apenas recentemente se firmaram o arado de contorno, as drenagens, a instalação de contenções para voçorocas etc. A estrumação, ou seja, a cobertura do solo com material orgânico como proteção contra a erosão, só é feita às vezes no Paraná, apesar da adição ligada a ela de substâncias húmicas, devido à possível disseminação de pragas e por causa da técnica de colheita de derriçagem dos grãos de café sobre o solo.

392 Em Londrina, o fluxo das nascentes diminuiu para um sexto. Cf. sobre isso Maack (1968, p. 241-242) e Idem (1970).

393 Mesmo na 'terra roxa' ocorreram as seguintes perdas de minerais depois de 22 anos de cultivos: 37\% do fósforo, 39\% do molibdênio, $50 \%$ do nitrogênio, $80 \%$ do cálcio, $85 \%$ do magnésio e $93 \%$ do potássio (BARROS, 1956, p. 255 apud Vageler).

394 Em um período de três meses, a erosão levou consigo cerca de 200.000 m³ de areia (MAACK, 1968, p. 244-5). 
Para amplas partes da região arenosa no Noroeste, a única solução econômica para empreendimentos com tamanho pelo menos médio é a transferência para a economia de pecuária. Simultaneamente, as espécies africanas de capim, parcialmente densas e de raízes profundas, oferecem a melhor proteção contra erosão. Na região do arenito Caiuá, a formação de dunas com ventanias de areia e de marcas onduladas levou em alguns casos ao total abandono do cultivo. Essas regiões estão irrevogavelmente perdidas para o uso agrário.

A falta de experiência e a busca especulativa por lucro de proprietários rurais e posseiros e uma reação muito lenta das agências governamentais paranaenses não permitiram, que surgisse até o momento de conclusão desta pesquisa um programa integrado para o combate da erosão. A lei aprovada em 1966 para o impedimento do corte descontrolado e da destruição de florestas chegou com uma década de atraso.

O reflorestamento estabeleceu-se de maneira apenas pontual em áreas pequenas no Norte Novo. Uma vez que os locais mais favoráveis ao reflorestamento são cumeadas, que ao mesmo tempo formam os locais ideais para o cultivo de café, devido ao solo e a particularidades climáticas, não se deve contar com o sucesso do programa governamental nesta região de solos altamente valiosos. A destruição de grandes áreas de floresta dentro de um período de poucas décadas causou rigorosos danos ao ecossistema do Norte do Paraná. O combate às consequências adversas é um problema existencial para o desenvolvimento agrícola futuro.

\section{A AMEAÇA DO CULTIVO DE CAFÉ PELO SURGIMENTO DA HEMILEIA VASTATRIX}

Os problemas da economia cafeeira brasileira - como superprodução com consequente queda de preço, redução de rendimento devido a solos lixiviados pelo cultivo em maior parte desprovido de fertilizantes, erosão do solo e fortes danos causados por geada - foram ampliados em janeiro de 1970 nas principais regiões de cultivo do Paraná e São Paulo pelo surgimento, na Bahia, do fungo da ferrugem do café (Hemileia vastatrix).

A primeira verificação dessa doença fúngica na América do Sul significa uma séria ameaça para o cultivo de café no Brasil, principalmente para as regiões fortemente dependentes do cultivo de café no Norte Novo e partes do Norte Novíssimo do Paraná. As manchas amareladas nas folhas, nas quais se formam esporos de cor alaranjada, surgem a princípio no lado inferior das folhas, onde a infestação da doença se torna visível geralmente em torno do fim da época de chuvas (COOLHAAS; DE FLUITER; KOENIG, 1960, p. 118ss.). As folhas infectadas caem, assim como os galhos fortemente afetados, reduzindo-se assim a produção a um mínimo. Segundo a experiência até o momento, o coffea arabica é especialmente suscetível à Hemileia vastatrix, sobretudo no caso de plantas menos bem tratadas e de menor porte.

O curso da proliferação do fungo da ferrugem do café depois de sua descoberta no Lago Vitória na África Oriental em 1861, passando pelo Ceilão, pelo Sul da Índia em 1869 e Java em 1879, causou pesadas crises econômicas e transformações estruturais da agricultura desses países. No Ceilão, a cafeicultura teve de ser abandonada em favor do cultivo de chá, em Java ocorreu uma transição para a resistente coffea robusta. A produção de café reduziu-se lá, dentro de 30 anos, a 11\% do valor médio anterior à infestação por ferrugem (GERCA, 1970a, p. 6).

Até 1970, a Hemileia vastatrix havia surgido em 33 países produtores de café da África, Ásia e Indonésia; na África ainda no ano de 1952 em Fernando Pó, e em 1966 em Angola. Por outro lado, as Américas Central e do Sul estavam livres do fungo da ferrugem. No caso de um breve caso em Porto Rico, em 1903, o foco da infecção pôde ser destruído.

Em janeiro de 1970, a Hemileia vastatrix foi observada no município de Aurelino Leal no sudeste da Bahia. Após uma confirmação oficial da infestação com base em exames em um instituto especializado em Portugal ${ }^{395}$ foram empreendidas medidas imediatas para a proteção das plantações de café, as quais

395 Desde 1955 existe em Oeiras, Portugal, um ‘Centro de Investigações das Ferrugens do Cafeeiro’. 
previam a erradicação e a destruição dos efetivos de pés de café afetados, bem como a proibição do transporte de café e de sementes de café da região do bloqueio.

Uma pesquisa por amostragem realizada imediatamente nas regiões de cultivo de café dos estados da Bahia, Espírito Santo e Minas Gerais revelou a aparição da Hemileia vastatrix em 107 municípios da Bahia e em 39 municípios de Minas Gerais. ${ }^{396}$ A comprovação do fungo da ferrugem em Caratinga e Simonésia no sul de Minas Gerais alarmou o Instituto Brasileiro do Café, uma vez que essas regiões localizam-se espacialmente isoladas da região originária da proliferação. Ao mesmo tempo, tornou-se evidente a rápida migração da doença das folhas para o sul. No Espírito Santo foram atingidas plantações de café isoladas em 33 municípios, entre eles também no extremo sul do Estado. A proliferação do fungo da ferrugem ocorre por meio da transmissão de esporos no ar com chuva e através das pessoas, em suas roupas, carros, equipamentos etc.

Como principal medida de proteção para os pontos centrais do cultivo de café no sudoeste de Minas, principalmente, porém, em São Paulo e no Paraná, decidiu-se pela instauração de um 'corredor livre de café', estendendo-se por $44^{\circ}$ de longitude ocidental, com uma largura de 35 a $50 \mathrm{~km}$ na região a norte de Belo Horizonte em Minas Gerais em direção ao sul, até o oeste do Rio de Janeiro, estendendo-se por $380 \mathrm{~km} .{ }^{397}$ Nesta faixa de segurança, na qual o cultivo de café possui uma importância muito reduzida, os pés de café disponíveis deveriam ser arrancados para evitar que o fungo da ferrugem continuasse a se proliferar para o oeste e para o sul (DIAS, 1970, p. 39). ${ }^{398}$ Da mesma maneira, pés de café infectados ao longo de estradas de longa distância no sudeste foram arrancados, uma vez que, por conta dos fluxos de trânsito principal em direção ao sul e da migração interna, esporos da Hemileia vastatrix poderiam ser introduzidos nas plantações de São Paulo e do Paraná.

Ao leste do corredor não foram mais realizadas plantações de café subsidiadas, os focos da ferrugem do café deveriam ser totalmente eliminados e a colheita de café dessa região só pôde ser exportada através dos portos regionais. Houve uma uma campanha geral de esclarecimento dos plantadores de café sobre a possibilidade do reconhecimento precoce da infestação da ferrugem, sobre medidas preventivas, como o combate com substâncias protetoras das plantas e um melhor tratamento, principalmente sobre a boa fertilização dos pés de café. Seguiu-se a ela a implementação de um sistema de monitoramento do Instituto Brasileiro do Café.

Além disso, foram realizadas no Instituto Agronômico de Campinas outras tentativas de cultura para obter com a coffea arabica variedades resistentes à ferrugem que já foram cultivadas na Tanzânia, no Quênia e na Etiópia. Pode ser necessária até uma década para que variedades correspondentes sejam testadas e possam ser recomendadas para um cultivo rentável no Brasil. Após uma fase adicional de adiamento, os primeiros resultados se revelam com o alcance da produtividade ideal dos pés de café. Já em abril de 1970, pouco mais de três meses após o descobrimento da Hemileia vastatrix no Brasil, foram disponibilizados 40 milhões de cruzeiros ao IBC para a realização das medidas.

As pesquisas realizadas pelo IBC em maio/junho de 1970 em 2.440 plantações do Norte Velho, Novo e Novíssimo do Paraná com efetivos de pés de café infectados com a ferrugem, revelaram um diagnóstico negativo, assim como em São Paulo e no estado do Rio de Janeiro, embora a última região tenha sido fortemente afetada devido à sua localização. Focos de infecção foram descobertos já em 1970 nos municípios fronteiriços ao corredor. Relatos sobre um surgimento de Hemileia vastatrix no sul de Minas Gerais (DIAS, 1970, p. 36), ${ }^{399}$ imediatamente próximo à fronteira com o estado de São Paulo, o que teria significado uma transposição da faixa de segurança e, portanto uma ameaça direta aos pontos centrais da produção brasileira, a princípio não foram confirmados pelo IBC.

Contudo, em outubro de 1971 o fungo da ferrugem do café, apesar do corredor de bloqueio, após uma proliferação incomumente rápida em direção ao sul, atingiu as regiões de cultivo mais ao sul no Paraná! (WALLER, 1972, p. 403; ROURK, 1972, p. 6). Nesse ínterim tornou-se claro que a ferrugem não pode mais ser eliminada no Brasil. Ao invés disso, deve-se muito mais tentar reorganizar o cultivo de

396 Nas áreas do médio Jequitinhonha, Mucuri, Rio Doce e na Zona da Mata.

397 Revela-se um fator favorável o fato de 58 municípios da região desse corredor possuirem somente cerca de 0,5 milhões de cafeeiros, espalhados em mais de 1.250 empreendimentos.

398 Indica que, até o início de julho de 1970, infelizmente ainda não haviam sido tomadas medidas coordenadas para a implantação desse corredor. De todo modo, já tinha sido preparada uma fórmula de distribuição para as indenizações e concessões de créditos em conjunto com o Banco do Brasil (GERCA, 1970d).

399 Relatório publicado em 04/07/1970: Novo foco de infecção no município de Soledade no sul de Minas, a oeste do corredor! 
café no país e considerar, quando da escolha do local das plantações, outros aspectos ecológicos para a determinação dos espaços naturalmente adequados.

A intensidade da infestação do fungo da ferrugem depende da temperatura, dos volumes de precipitação e distribuição sazonal, incidência de luz e espessura das folhas. Uma vez que a formação dos esporos exige temperaturas médias relativamente elevadas, espera-se estar, no frio inverno do Paraná, a princípio protegido da Hemileia vastatrix. ${ }^{400}$ No entanto, uma vez que as temperaturas mais elevadas coincidem lá com a época de maior precipitação, entre outubro e março, e o Paraná é caracterizado por umidade ao longo do ano todo (Figura 1), o fungo da ferrugem pode se desenvolver bem. Além disso, o sistema brasileiro tradicional de plantação de café (quatro plantas ou mais por buraco) favorece, devido à espessa folhagem dos pés de café que crescem rapidamente sobre os frutíferos solos de terra roxa, a formação de um micro-clima quente e úmido e, com isso, a prosperidade da Hemileia vastatrix. Pés de café situados muito próximos uns aos outros e diversas plantas por buraco revelaram-se desvantajosos - o que no Paraná foi considerado favorável por muito tempo devido às melhores chances de sobrevivência das plantas de café e também da proteção contra a geada e das sombras. Felizmente, o café é plantado no Brasil sem árvores umbrosas, que em geral também favorecem doenças nas plantas.

De acordo com as mais recentes pesquisas do Instituto Agronômico de Campinas, as altitudes abaixo de $700 \mathrm{~m}$ podem ser favoráveis, por motivos de temperatura, à formação de esporos do fungo da ferrugem e inapropriadas, portanto, para o cultivo de café. Em altitudes acima de $900 \mathrm{~m}$ a Hemileia vastatrix não pode mais vingar no Paraná, mas a essas altitudes o risco de geada também aumenta fortemente, de modo que o cultivo de café nesta localização longitudinal no Trópico de Capricórnio atinge seu limite de altitude de 950 a $1.000 \mathrm{~m}$ acima do nível do mar.

Os efeitos da infestação da ferrugem sobre a economia cafeeira brasileira não podem, neste momento de conclusão da pesquisa, ser analisados como um todo. O surgimento da ferrugem significa um perigo sério para as regiões de cultivo intensivo do Paraná, as quais já têm grandes problemas a resolver devido à geada de 1969. Extremamente graves não são apenas as consequências econômicas para o Brasil como um todo, mas também as consequências sociais de uma infestação do fungo da ferrugem em grandes áreas.

No entanto, apesar de todos os aspectos negativos, o IBC vê a possibilidade, com a aplicação dos correspondentes recursos técnicos, sobretudo o emprego de pesticidas, de reduzir o percentual da infestação por ferrugem, de maneira tal que um cultivo rentável de café possa ser mantido (GERCA, 1972, 1970a, 1970b). Considera-se, contudo, que por meio disso seja possível um aumento de 20-30\% dos custos de produção. Os gastos com substâncias para a proteção de plantas por hectare correspondem aproximadamente ao valor de três sacas de $60 \mathrm{~kg}$ de café descascado. Isso significa custos acima de $80 \%$ dos valores médios de rendimento do café por hectare no Brasil (ROURK, 1972, p. 8), o que sugere a concentração do combate químico à Hemileia vastatrix em regiões de rendimento intensivo.

Em regiões em que as condições de temperatura e precipitação favorecem fortemente o desenvolvimento do fungo da ferrugem do café, os pesticidas precisariam ser aplicados com tanta frequência que o cultivo de café se revelaria economicamente inviável.

No Paraná, o desenvolvimento da infestação por fungo da ferrugem levou muitos plantadores que ainda estavam indecisos após a forte geada de 1969, sobretudo na região baixa dos solos arenosos do Norte Novíssimo, ao norte do Rio Ivaí, a uma redução adicional das áreas de cultivo de café, em parte até mesmo a abandonar plantações de café fortemente dependentes de cuidados. A queda de rentabilidade ocorrida nas últimas décadas e os altos investimentos de capital necessários para o combate da Hemileia vastatrix com pesticidas, fertilizantes etc. favoreceram essa tendência de desenvolvimento, especialmente no caso de pequenos empreendimentos.

No Norte Novo, por outro lado, os métodos de cultivo e, sobretudo, o cuidado e o controle das plantações de café foram muito intensificados. Em 1970/1971 as cifras das vendas das empresas de fertilizantes ${ }^{401}$ puderam ser mais do que duplicadas no curso de um ano e continuam a subir, o que não tem como causa última a intenção de cultivar pés de café possivelmente mais fortes que possam resistir melhor ao fungo da ferrugem. A urgente aplicação necessária de pesticidas para o combate à doença nas plantas exige meios financeiros adicionais.

400 Uma temperatura média de pouco mais de $21^{\circ} \mathrm{C}$ parece ser ideal para o desenvolvimento do fungo da ferrugem, com limiares inferior e superior em $15^{\circ} \mathrm{C}$ e $28^{\circ} \mathrm{C}$, respectivamente (informações gentilmente fornecidas pelo IBC, bem como em ROURK, 1972, p. 7).

401 Informações das firmas Ultrafertil (Londrina), Ricasolo (Rolância) e Nortox (Apucarana). 
O impulso que a ameaçadora Hemileia vastatrix causou no Norte Novo do Paraná com a cultura de variedades de 'arábica' resistentes à ferrugem, bem como uma intensificação dos métodos de processamento e plantação no cultivo de café, tem um significado positivo no âmbito da consolidação da economia cafeeira paranaense nos espaços naturais adequados. O destino do cultivo de café paranaense e, com isso, do desenvolvimento do Norte do Paraná depende, contudo, da efetividade das medidas do Instituto do Café para a redução dos danos e perdas nas colheitas causados pela doença do fungo da ferrugem. 


\section{CONSIDERAÇÕES FINAIS ${ }^{402}$}

Dentro de 40 anos realizou-se no Norte do Paraná a oeste do rio Tibagi, em diversas fases e níveis de intensidade, o processo de desenvolvimento de uma zona pioneira temperada para uma paisagem fortemente diferenciada em termos regionais, marcada pela mobilidade espacial e social de diversas camadas sociais e grupos populacionais de origem diversa e com variados objetivos econômicos.

O curso da colonização agrária no Norte do Paraná é caracterizado por três fases principais:

1. A fase pioneira de 1930 até o fim dos anos 1940.

O início da exploração esteve na sombra da grande crise cafeeira do Brasil, que impediu a especulação fundiária da tradicional classe dos proprietários de plantações de café paulistas no Norte Novo do Paraná. Com isso surgiu a possibilidade de uma ocupação dirigida e de uma colonização com grupos heterogêneos de colonos de diversas nacionalidades com base na pequena e média propriedade e com o direcionamento econômico para a policultura, tendo o café a princípio apenas um papel reduzido.

A região explorada no Norte Novo por uma companhia privada de colonização, a Cia. Terras Norte do Paraná, é exemplar como modelo de planejamento de desenvolvimento regional de uma zona de frontier para a América Latina.

Por outro lado, a colonização estatal iniciada em 1939, sobretudo com colonos brasileiros de todas as partes do país, não conseguiu, por conta de conflitos de interesse político, garantir sem impedimentos a segurança do título de propriedade das porções de terra dividas em todas as ordens de tamanho.

2. Avanço do frontier e fase de expansão do cultivo do café do fim dos anos 1940 até início dos anos 1960.

O início desta segunda fase de desenvolvimento foi determinado pela recuperação do mercado internacional de café após a Segunda Guerra Mundial. Fortes impulsos conjunturais, com efeito direto sobre a apropriação da terra e a colonização, provocaram no Norte do Paraná um boom do cultivo de café que ainda não era conhecido mesmo no Brasil, o qual atingiu seu ápice por volta do fim dos anos 1950 com o esgotamento da alta fertilidade dos solos paranaenses de 'terra roxa'. O avanço rápido da frente do café teve como consequência uma forte migração interna de São Paulo, Minas Gerais e dos estados do Nordeste para o Norte Novo do Paraná e para as zonas pioneiras do Norte Novíssimo. É característica da dinâmica das regiões jovens de colonização sob a influência do cultivo de café uma mobilidade social incomum no Brasil. Sobretudo os descendentes de empregados italianos de latifúndios paulistas ascenderam da classe social dos trabalhadores rurais, passando por meeiros e empreiteiros para se tornarem proprietários de terras autônomos, assim como colonos japoneses apoiados por organizações de imigrantes próprias e sociedades de colonização. Por outro lado, apenas uma pequena parte dos trabalhadores rurais oriundos da região Nordeste conseguiram essa ascensão, da qual os trabalhadores itinerantes não obtiveram parcela alguma.

Com a chegada ao vale do rio Paraná e com a chegada à fronteira climática de cultivo em consequência da ocorrência das geadas anuais, a transferência permanente do local de cultivo de café no Brasil - que já durava dois séculos, iniciado no Pará, no Norte do Brasil, passando pelo litoral até o Rio de Janeiro, entrando no sul de Minas Gerais e passando pelo Vale do Paraíba até São Paulo -, encontrou seu fim na zona de transição tropical do Norte do Paraná para a região subtropical do centro do Paraná.

Fenômenos de concentração da monocultura do café nos pontos mais importantes de cultivo do Norte do Paraná, por um lado, bem como - apesar dos danos causados por geada e das perdas de colheita a eles ligadas - a ameaça renovada de superprodução de café com suas consequências mundiais, por outro, caracterizam a fase final da expansão do cultivo de café, determinada pelo espírito especulativo dos plantadores de café a explorar sua posição de domínio de mercado.

3. A fase dirigista no cultivo de café a partir de 1962/1963

Essa fase é determinada pelo emprego de medidas estatais de direcionamento, vinculadas a obrigações contratuais no âmbito do Acordo Internacional do Café, que tiveram como objetivo a redução 
das áreas de cultivo de café e se distinguiram com isso da valorização do café praticada em São Paulo nos anos 1920 e 1930 através da destruição das colheitas.

Como principal processo de desenvolvimento espacial, iniciou-se uma intensa seleção de áreas de cultivo de café ecologicamente apropriadas com rejuvenescimento simultâneo das plantações de café. Com isso, iniciou-se uma valorização dos fatores de produção qualitativos em vez do cultivo extensivo, até então direcionado unicamente para resultados quantitativos.

A localização excepcional dos solos de decomposição vulcânica fez que o Norte Novo se tornasse, na região de altitudes entre 450 e 800 m, a área ideal de cultivo de café, enquanto o Norte Novíssimo, em grande parte dominado por solos arenosos, cuja fertilidade é rapidamente exaurida, perdeu rapidamente importância.

A redução das áreas de cultivo de café está ligada à propagação oficial de uma rede poliestrutural de aproveitamento da terra. O desenvolvimento agrário foi determinado fortemente pela busca por um segundo produto de cultivo economicamente rentável ao lado ou depois do café. A experimentação dos plantadores com base nas relações de preço submetidas a oscilações de tempo curto levou a um aumento do cultivo de algodão, bem como, mais tarde, de soja e trigo; ao mesmo tempo, contudo, também através da superprodução temporária, subiu a instabilidade dos preços dos produtores no caso de arroz, milho e feijão, os quais são atualmente apoiados pelo governo através de preços mínimos. A grande insegurança no desenvolvimento dos preços desses produtos, cujos rendimentos estão submetidos a fortes oscilações por causa das condições climáticas desfavoráveis e da aparição de pragas, estimulou em crescente medida a reorientação empresarial para a criação de gado, sobretudo no caso de empreendimentos médios e grandes no Norte Novíssimo - cujas pastagens artificiais foram criadas desde meados dos anos 1960, em parte após uma fase de transição de 2 a 4 anos de cultivo de algodão, em parte diretamente pelo arroteamento das florestas remanescentes.

Formas primitivas de exploração no cultivo do café levaram, nas zonas pioneiras do Noroeste do Paraná, à degradação dos recursos naturais. A queima das florestas úmidas tropicais foi seguida pela erosão do solo, bem como pelo esgotamento da produtividade do solo.

A forte geada de julho de 1969, que causou uma perda quase total da colheita de café de 1970, fortaleceu a discrepância do desenvolvimento econômico agrário do Norte do Paraná e acelerou a migração de partes da população rural para as periferias urbanas ou para a Amazônia. Relações trabalhistas contratuais de colonos assentados no empreendimento foram dissolvidas através de um sistema de jornada remunerada diariamente de trabalhadores não assentados e sem garantias sociais, o qual escapa às tentativas de estabilização socioagrária do governo. Os fluxos desorganizados de trabalhadores migrantes do Nordeste, chegando mesmo após o fim da alta do café, intensificaram as tensões sociais na região.

Passa a haver, portanto, em todo o Noroeste do estado, sobretudo no Norte Novíssimo entre Ivaí e Paranapanema, uma tendência acentuada para o ciclo econômico, conhecido de São Paulo, da economia do café para a economia de pastagens, em que os empreendimentos mistos de café e gado transferem de maneira crescente sua ênfase para a engorda de gado, uma vez que os investimentos de capital necessários nesta região para a regeneração das plantações de café são altos demais. Em partes do Norte Novíssimo surgiu um hollow frontier [frontier oco] com todas as suas formas típicas de manifestação.

O fim das possibilidades de expansão do cultivo de café no Norte do Paraná levou a uma reconcentração nas regiões da terra roxa e a uma intensificação do cultivo nessas regiões. As tentativas de consolidação da economia do café, que também podem ser observadas na valorização das regiões tradicionais de cultivo nos espaços naturalmente apropriados ao cultivo de café em São Paulo, são realizadas em parte dos empreendimentos do Norte Novo do Paraná por meio da utilização de numerosas inovações, entre elas o cultivo de sementes, cultivo paralelo ao declive, adubagem e tratamento contra pragas, bem como a seleção de plantações intermediárias adequadas. Na falta de capital dos empreendimentos pequenos e médios (que são ali preponderantes), deve ser feita futuramente uma distribuição mais generosa de créditos para poder continuar se elevando o padrão geral do cultivo de café.

Ampliar a assistência ao agricultor, evitar os atravessadores na comercialização e aumentar a qualidade do produto final através de melhores instalações de preparação são as propostas mais importantes do sistema de cooperativas, que, no entanto, só se desenvolve lentamente, no mesmo ritmo do recuo da mentalidade especulativa pioneira dos plantadores de café. 
O cultivo de café assume ainda no Norte Novo uma posição dominante na vida econômica, mas é ao mesmo tempo integrado a um sistema de policultura da propriedade pequena e média baseado na fertilidade naturalmente alta do solo. Por conta da base socioeconômica estável e - ao contrário do que se dá nas regiões de colonização estatal - por conta da infraestrutura bem instalada desde o início da colonização e do recente desenvolvimento dos centros urbanos regionais e de uma espessa rede de cidades pequenas, o Norte Novo central entre Londrina, Apucarana e Maringá, que já deixou para trás de si a fase do solid frontier [frontier sólido] (TAYLOR, 1972), tem perspectivas favoráveis de desenvolvimento.

Em consequência do intenso fluxo de capitais para São Paulo e do fornecimento de energia que só agora está sendo implementado, a indústria de transformação, com exceção do processamento de produtos agrícolas, está apenas no início.

Restrições ao cultivo de café e a erradicação de plantações de rendimento baixo foram no início dos anos 1960 os meios escolhidos para evitar a superprodução de café e ocasionaram uma forte redução das áreas de cultivo. As consequências dessas medidas - em grande parte dirigidas pelo Estado, mas também em parte tomadas espontaneamente - foram, contudo, intensificadas em razão dos fortes danos causados pela geada no cultivo de café no Paraná. Assim o Brasil se encontrou repentinamente diante do problema de uma produção de café pequena demais, de maneira que as quotas de exportação puderam ser realizadas apenas com ajuda de reservas armazenadas, que já tinham diminuído significativamente. A rápida regeneração das plantações danificadas por geadas relaxou um pouco a situação econômica na primeira metade dos anos 1970.

No curso dos processos socioeconômicos e sociogeográficos, partes do Norte Novo do Paraná se cristalizaram como locais favoráveis ao cultivo de café por motivos ecológicos e socioeconômicos. Para o desenvolvimento da estabilidade social e econômica do Norte do Paraná, mas também para a garantia das exportações brasileiras, o sucesso das melhorias estruturais do Paraná no cultivo de café tornou-se na época uma questão de importância decisiva.

Os esforços para a consolidação da economia do café sob a utilização de métodos modernos de exploração anunciaram então uma nova fase de desenvolvimento agrícola, que no momento da conclusão deste trabalho ainda se encontra, contudo, em estágio de transição.

O risco de geada e a ameaça por meio do fungo da ferrugem, que aparece no Paraná desde 1971, aceleraram, por meio de medidas político-econômicas, as tendências de diversificação no uso da terra, que devem levar a uma redução das oscilações dependentes da monocultura e do mercado mundial na área socioeconômica, e a superar o elemento especulativo na economia agrícola, em proveito de um planejamento de cultivo coordenado. 


\title{
X. REFERÊNCIAS
}

\author{
ABREVIATURAS \\ AAAG $=$ Annals of the Association of American Geographers (Lawrence/Kansas) \\ $\mathrm{ABT}=$ Arquivos de Biologia e Tecnologia (Curitiba) \\ Bol. Geogr. = Boletim Geográfico (Rio de Janeiro) \\ Bol. Paul. Geogr. = Boletim Paulista de Geografia (São Paulo) \\ Econ. Geogr. = Economic Geography (Worcester/Mass.) \\ Geogr. Rev. $=$ Geographical Review (Nova Iorque) \\ GR = Geographische Rundschau (Braunschweig) \\ GZ $=$ Geographische Zeitschrift (Wiesbaden) \\ HGA = Heidelberger Geographische Arbeiten (Heidelberg) \\ Rev. Bras. Geogr. = Revista Brasileira de Geografia (Rio de Janeiro) \\ Rev. Paran. Desenv. = Revista Paranaense de Desenvolvimento (Curitiba) \\ Z. Ges. Erdk. = Zeitschrift der Gesellschaft für Erdkunde zu Berlin (Berlim)
}

ACARPA. Contribuição ao diagnóstico da agropecuária Paranaense. Curitiba, 1969a.

ACARPA. Plano Diretor da Acarpa 1969-72. Curitiba, 1969 b.

AIGNER, G. Der Jesuitenstaat in Paraguay und seine Wirtschaft. Dissertação (Mestrado), Viena, 1959.

ALBRECHT, G. Soziologie der geographischen Mobilität. Stuttgart: F. Enke, 1972.

ALMEIDA, F. MARQUES DE. Relevo de "cuestas" na bacia sedimentar do Rio Paraná. Bol. Paul. Geogr., 3, p. 43$50,1949$.

ALSBERG, C. L. The food supply in the migration process. In: Limits of land settlement. A preliminary report on present-day possibilities. Baltimore: Council of Foreign Relations, p. 25-56, 1937.

AMARAL, A. Zingra do; CHIARINI, J. V. Distribuição e características da cultura cafeeira no Estado de São Paulo, levantadas através de fotografias aéreas. Bragantia, Campinas, v. 27, n. 2, p. 267-277, 1968.

CONGRESSO NACIONAL DE CONSERVAÇÃO DO SOLO, 1, São Paulo, Anais..., 1960

ANDO, Z. Pioneirismo e cooperativismo. História da Cooperativa Agrícola de Cotia. São Paulo: Editora "Sociologia e Política", Fundação Escola de Sociologia e Política de São Paulo, 1961.

ANDREAE, B. Betriebsformen in der Landwirtschaft. Stuttgart: Ulmer, 1964.

ANDREAE, B. Die Bodenfruchtbarkeit in den Tropen. Hamburgo e Berlim: Parey, 1965.

ANDRIGUETTO, J. M. Possibilidade do aproveitamento econômico do resíduo de rami no Paraná. ABT, n. 12, p. 81-113, 1966.

ARAÚJO FILHO, J. R. de. O café, riqueza paulista. Bol. Paul. Geogr., n. 23, p. 78-135, 1956.

ASPLAN. Londrina - Plano Diretor de desenvolvimento urbano. São Paulo, 1968.

AUGELLI, J. P. Cultural and economic changes of Bastos, a Japanese colony on Brazil's Paulista frontier. AAAG, v. 48, n; 1, p. 3-19, 1958a.

AUGELLI, J. P. The Latvians of Varpa: A foreign colony on the Brazilian pioneer fringe. Geogr. Rev., v. 48, n. 3, p. 365-387, 1958b.

AULICH, W. Parana und die Deutschen. Versuch einer charakterologischen Geschichtsschreibung. Curitiba: Grupo Étnico Germânico do Paraná, 1953. 
AULICH, W. Wandlungen in Brasilien. Charakterologische und soziologische Perspektiven zur Geschichte der deutschen Einwanderung in Paraná. (manuscrito), [s.d.].

AZEVEDO, A. de et al. Brasil. A terra e o homem. Vol. 1, as bases físicas. São Paulo: Companhia Editora Nacional, 1964.

BADEP O café e a industrialização do Paraná: Histórico e problemas. Curitiba, 1969.

BAKER, CH. L. The lavafield of the Paraná Basin. The Journal of Geology, Chicago, v. 31, n. 1, p. 66-79, 1923.

BAKLANOFF, E. N. (org.) New perspectives of Brazil. Nashville: Vanderbilt University Press, 1966.

BALDI, P. E. La colonizzazione agricola del Brazile, e l'opera delia Compagnia de Terras Norte do Paraná. Rivista de Agricoltura Subtropicale, Roma, v. 42, n. 4-6, p. 109-116, 1948.

BALHANA, A. P. Aspectos da geografia humana do Paraná. Instituto de Biologia e Pesquisas Tecnológicas, boletim 35, Curitiba, 1955.

BALHANA, A. P. Immigración italiana en Paraná. Estudios Americanos, Sevilla, v. 12, n. 63, p. 475-482, 1956.

BALHANA, A. P. Política imigratória do Paraná. Rev. Paran. Desenv., n. 12, p. 1-16, 1969.

BALHANA, A. P.; MACHADO, B. Pinheiro et al. Campos Gerais. Estruturas agrárias. Curitiba: Faculdade de Filosofia, 1968.

BARROS, E. H. Lins de. Recursos florestais da Bacia Paraná-Uruguai. São Paulo, 1956.

BARROS, H. Moraes. Dados históricos compreendendo o período de fevereiro de 1944 a outubro de 1953. In: Cia. Melhoramentos Norte do Paraná. A maior empresa colonizadora da América do Sul, São Paulo, p. 7-18, 1953.

BARROS, M. de Souza. Café chega ao ponto crítico. Coopercotia, São Paulo, setembro, p. 15-20, 1968.

BARROS, W. Duarte de. A erosão no Brasil. Rio de Janeiro: Ministério da Viação e Obras Públicas, Serviço de Documentação, 1956.

BARTHELMESS, H. Ante-projeto de divisão regional do Estado do Paraná. DGTC, Boletim da Divisão de Geografia, 1, Curitiba, 1964.

BARTHELMESS, H. Methodologische Überlegungen zu einer dynamischen Agrargeographie am Beispiel Paranás. GZ, v. 55, n. 3, p. 207-224, 1967.

BECK, R. H. Die Frontiertheorie von F. J. Turner. Zürcher Studien zur allgemeinen Geschichte, n. 13, p. 59-63, 1955.

BERNARDES, N. Expansão do povoamento do Estado do Paraná. Rev. Bras. Geogr., v. 14, n. 4, p. 427-456, 1952.

BERNARDES, L. M. Cavalcanti. Excursão ao Paraná e Santa Catarina: Londrina e a zona pioneira do Norte do Paraná. Bol. Geogr., v. 3, n. 28, p. 603-608, 1945.

BERNARDES, L. M. Cavalcanti. Distribuição da população no Estado do Paraná em 1940. Rev. Bras. Geogr., v. 12, n. 4, p. 565-586, 1950.

BERNARDES, L. M. Cavalcanti. Crescimento da população do Estado do Paraná. Rev. Bras. Geogr., v. 13, n. 2, p. 265-274, 1951.

BERNARDES, L. M. Cavalcanti. O problema das "frentes pioneiras" no Estado do Paraná. Rev. Bras. Geogr., v. 18, n. 3, p. 335-384, 1953.

BEURLEN, K. Geologie von Brasilien. Beiträge zur regionalen Geologie der Erde, Stuttgart, n. 9., 1970.

BHATIA, S. Patterns of crop concentration and diversification in India. Economic Geography, v. 41, n. 1, p. 39-56, 1965.

BIGG-WITHER, T. P. Pioneering in South Brazil. Three years of forest and prairie life in the province of Paraná. 2 vol., Londres, 1878.

BLANCKENUURG, P. v. e CREMER, H. D. (orgs.) Handbuch der Landwirtschaft und Ernährung in den Entwicklungsländern. Vol. 1 (1967) Die Landwirtschaft in der wirtschaftlichen Entwicklung. Ernährungsverhältnisse. Vol. 2 (1971) Pflanzliche und tierische Produktion in den Tropen und Subtropen.

Stuttgart: E. Ulmer, 1967-1971. 
BLAUT, J. M. The ecology of tropical farming systems. In: Plantation systems of the New World. Washington, Ed. Pan American Union, p. 83-97, 1959.

BOUEK, H. Stellung u. Bedeutung der Sozialgeographie. Erdkunde, n. 2, p. 118-125, 1948.

BOUEK, H. Aufriß einer vergleichenden Sozialgeographie. Mitt. Geogr. Ges. Wien, Viena, n. 92, p. 34-45, 1950.

BOUEK, H. Über den Einbau der sozialgeographischen Betraditungsweise in die Kulturgcographic. Tag. ber. u. wiss. Abh. Dt. Geogr. Tag Köln 1961, Wiesbaden, p. 148-165, 1962.

BOLTE, K. M. Vertikale Mobilität. In: KÖNIG, R.(org.): Handbuch der empirischen Sozialforschung. Stuttgart: Enke, vol. 2, p. 1-42, 1969.

BOLTON, H. E. The Mission as a frontier institution in the Spanish-American colonies. American Historical Review, Nova Iorque, n. 23, p. 42-61, 1917.

BONASEWICZ, A. Population pressure in the State of São Paulo, Brazil. In: ZELINSKY, W.; KOSINSKI, L. A.; PROTHERO, R. M. (eds.) Geography and a crowding world. Nova Iorque: Oxford University Press, p. 556-573, 1970.

BORCHERDT, C. Die Innovation als agrargeographische Regelerscheinung. Arb. Geogr. Inst. d. Univ. d. Saarlandes, Saarbrücken, n. 6, p. 13-50, 1961.

BORIO, L. Lopes. Exposição sobre política cafeeira. Rio de Janeiro: Instituto Brasileiro do Café, Departamento de Relações Públicas, Div. Divulgação, Seção de Publicações, 1966.

BOWMANN, I. (ed.) The pioneer fringe. American Geograph. Society. Nova Iorque, n. especial 13, 1931.

BOWMANN, I. Planning in pioneer settlement. Annals of the Association of American Geographers, Cambridge/Mass., v. 22, n. 2, p. 93-107, 1932.

BOWMANN, I. Possibilities of settlement in South America. In: Limits of land settlement, Baltimore, p. 293-337, 1937.

BRAGA, R. Contribuição ao estudo fitogeográfico do Estado do Paraná: Serra dos Dourados. Bol. Paranaense de Geografia, Curitiba, n. 6 e 7, p. 29-41, 1962.

BRÜCHER, W. Die Erschließung des tropischen Regenwaldes am Ostrand der Kolumbianischen Anden. Tübinger Geogr. Stud. n. 28, 1968.

BRUM, H. ALMEIDA de. Escoamento da safra do Paraná. Desenvolvimento e Conjuntura, Rio de Janeiro, v. 8, n. 5, p. 63-74, 1964.

BUTLAND, G. J. Frontiers of settlement in South America. Revista Geográfica, Rio de Janeiro, n. 65, p. 93-108, 1966.

CAC. Relatório da Diretoria. Ano Social. São Paulo, 1969.

CAC. Relatório dos serviços sociais do ano de 1969. São Paulo, 1970.

CALDEIRA, C. Mutirão. Formas de ajuda mútua no meio rural. Bibl. Pedagógica Brasileira, série. 5, vol. 289. São Paulo: Brasiliana, 1956.

CÂMARA, A. Lima e NEIVA, A. Hehl. Colonizações nipônica e germânica no sul do Brasil. Revista de Imigração e Colonização, Rio de Janeiro, v. 2, n. 1, p. 39-122, 1941.

CAMARGO, A. Paes de. Pesquisas sôbre o combate à geada. Relatório dos trabalhos realizados em Apucarana, Paraná. Campinas, 1959.

CAMARGO, A. Paes de. Instruções para o combate à geada em cafezais. Curitiba, São Paulo: IAC, 1963.

CAMARGO, A. Paes de. O clima do Estado de São Paulo e a cafeicultura. In: Boletim 163, Campinas, publ. 2712, Inst. Agronom. Campinas, 1966.

CAMARGO, J. de. Êxodo rural no Brasil. Ensaio sobre suas formas, causas e consequências econômicas principais. São Paulo: Ofic. de artes graf. Bisordi, 1957.

CAMARGO, R. Paes e.TELLES JR., A. de Queiroz. O café no Brasil. Sua aclimação e industrialização. Série Estudos Brasileiros, Rio de Janeiro, n. 4, 2 vol., 1953. 
CAMBIAGHI, S. M. O povoamento do Norte do Paraná. Anais da Associação dos Geógrafos Brasileiros, São Paulo, v. 6, parte 1, 1951-52, p. 81-90, 1954.

CAVIEDES L., C. La moderna colonizzazione nell'Amcrica del Sud tropicale e subtropicale: l'esempio di Misiones. Rivista Geografica Italiana, Florença, v. 78, n. 2, p. 129-141, 1971.

CEPRES. Levantamento da produção agrícola do Estado do Paraná. Safra 1967/68 (s. 1.), 1969.

CERON, A. O. e DINIZ, J. A. Felizola. Tipologia da agricultura. Questões metodológicas e problemas de aplicação no Estado de São Paulo. Rev. Bras. Geogr., v. 32, n. 3, p. 41-71, 1971.

CHMYZ, J. Contribuição arqueológica e histórica ao estudo da comunidade espanhola de Ciudad Real do Guairá. Rev. de História, Curitiba, n. 2, 1963.

CIBPU. Condições geográficas e aspectos geoeconômicos da Bacia Paraná-Uruguai. 2 vol. (vol. 2: Atlas), São Paulo, 1955.

CIBPU. Problemas de desenvolvimento. Necessidades e possibilidades dos Estados do Rio Grande do Sul, Santa Catarina e Paraná. 3 vol. (vol. 3: Atlas), São Paulo, 1958.

CIBPU. Solos da Bacia Paraná-Uruguai. São Paulo, 1961.

CLARKE, J. I. Population Geography. Londres: Pergamon Press, 1968.

CODEM. Londrina - Situação 1966. Curitiba, 1966.

CODEM. Plano diretor de desenvolvimento de Maringá. 2 vol., Curitiba, 1968.

CODEM. Plano diretor de desenvolvimento de Apucarana. [s. 1.]: [s. a.]

CODEPAR. O Paraná e a economia cafeeira. Curitiba, 1963.

CODEPAR.O Paraná e a economia madeireira. Curitiba, 1964a.

CODEPAR. Estudo econômico das fibras têxteis no Paraná. Vol. 1 Algodão. São Paulo, 1964b.

CODEPAR. O Paraná e a economia pecuária. 3 vols., Curitiba, 1964c.

CODEPAR. Plano preliminar de diversificação da produção na região cafeeira. Programa de investimentos 19661971. Curitiba, 1966.

COMNINOS, C. Alguns aspectos populacionais do Paraná. Rev. Paran. Desenv., n. 3, p. 47-57, 1967.

CONTAG. Fundo Rural. Questões Agrárias. DOE. n. 6, Rio de Janeiro, [s. a.].

CONTAG. Estatuto do trabalhador rural. Questões Agrárias. DOE. n. 7, Rio de Janeiro, [s. a.].

CONTAG. Estatuto da terra. Questões Agrárias. Doe. n. 8, Rio de Janeiro, [s. a.].

COOLHAAS, C.; FLUITER, H. J. de; KOENIG, H. P. Tropische und subtropische Weltwirtschaftspflanzen. Ihre Geschichte, Kultur und volkswirtschaftliche Bedeutung. Parte III: Genußpflanzen, v. 2: Kaffee. 2. neue bearb. Aufl. Stuttgart: Enke, 1960.

COPPOCK, J. T. Crop, livestock and enterprise combinations in England and Wales. Economic Geography, v. 40, n. 1, p. 65-81, 1964.

CORTESÃO, J. Jesuítas e Bandeirantes no Guairá. Biblioteca Nacional, v. 1. Rio de Janeiro, 1951.

COSTE, R. Les caféiers et les cafés dans le monde. Parte. 1: Les caféiers (1955); Parte 2: Les cafés (1961). Paris: Larose, 1955/1961.

COURTENAY, P. P. Plantation agriculture. Londres: Bell\&Hyman, 1969.

CZAJKA, W. Lebensformen und Pionierarbeit an der Siedlungsgrenze. Hannover: H. Schroedel, 1953.

DAMBAUGH, L. N. The coffee frontier in Brazil. Latin American Monographs 7. Gainesville: University of Florida Press, 1959.

DEAN, W. The planter as entrepreneur: The case of São Paulo. The Hispanic American Historical Review, Durham/N. C., v. 46, n. 2, p. 138-152, 1966.

DEFIONTAINES, P. The origin and growth of the Brazilian network of towns. Geogr. Rev., n. 28, p. 379-399, 1938. 
DELFIM NETTO, A. O problema do café no Brasil. São Paulo: FGV, Instituto de Documentação: Ministério da Agricultura/SUPLAN, 1959

DELFIM NETTO, A.; PINTO, C. A. de Andrade. O café do Brasil. Estudos ANPES, São Paulo, n. 3. 1967.

DIAS, R. ARAÚJO. Problemas atuais da economia cafeeira. Agricultura em São Paulo, São Paulo, v. 16, n. 1 e 2, p. 31-48, 1969.

DIAS, R. ARAÚJO. Café enfrenta outra grande crise. Visão, São Paulo, 4/7/1970, p. 36-39.

DIÉGUES JR., M. População c propriedade da terra no Brasil. Washington: União Pan-Americana, 1959.

DORFMUND, L. Pereira. Geografia e história do Paraná. Coleção Didática do Brasil, Série Paraná, vol. 1, 4. ed. São Paulo: Editora do Brasil, 1963.

DORNEICH, K. C. Einwanderung in Brasilien unter bes. Berücksichtigung ihrer Bedeutung für die Landwirtschaft zwischen 1930 und 1960. Tese (Doutorado). Freiburg i. Brsg., 1960.

DOZIER, C. L. Northern Paraná, Brazil: An example of organized regional development. Geogr. Rev., 46, p. 318333, 1956.

DOZIER, C. L.Land development and colonization in Latin America. Case studies of Peru, Bolivia and Mexico. Nova Iorque: Praeger, 1969.

EIDT, R. C. Die staatliche und private Besiedlung von Misiones (Argentinien). GR, v. 17, n. 11, p. 464-470, 1965.

EIDT, R. C. Pioneer settlement in Northeast Argentina. Madison/Wisc.: University of Winsconsin Press, 1971.

ELFES, A. Estudos: Agro-econômico e social. Guaira, Toledo etc. Curitiba: Instituto Nacional do Desenvolvimento Agrário, Delegacia Regional do Paraná, 1970

EL-KHATIB, F. (org.) História do Paraná. 4 vol., 2. ed. Curitiba: Grafipar, 1969.

ERIKSEN, W. Kolonisation und Tourismus in Ostpatagonien. Ein Beitrag zum Problem kulturgeographischer Entwicklungsprozesse am Rande der Ökumene. Bonner Geogr. Abh., Bonn, n. 43, 1970.

ESDORN, I. Die Nutzpflanzen der Tropen und Subtropen der Weltwirtschaft. Stuttgart: G. Fischer, 1961

ETEPLAN. Porque o Instituto Agronômico em Maringá. Maringá, 1970.

FARACO, D. Agostinho; BORIO, L. Lopes. Café: uma política. Rio de Janeiro: Departamento de Relações Públicas, IBC, 1964.

FASSBINDER, M. Der Jesuitenstaat in Paraguay. Halle a. d. Saale: M. Niemeyer, 1926.

FAYET, L. A. Central do Paraná. Racionalização do sistema de circulação do Estado. Rev. Paran. Desenv., n. 3, p. 13-35, 1967.

FAYET, L. A. Café solúvel. Curitiba, 1963.

FETAEP. Manual de legislação rural. Diário Oficial, 10/9/63, Londrina, 1967

FIGUEIREDO, J. de Lima. Oeste paranaense. Bibl. Ped. Bras. Série 5a, vol. 97. São Paulo: Brasiliana, 1937.

FINCK, A. Tropische Böden. Einführung in die bodenkundlichen Grundlagen tropischer und subtropischer Landwirtschaft. Hamburgo e Berlim: P. Parey, 1963.

FITTKAU, E. J.; ILLIES, J.; KLINGE, H.; SCHWABE, G. H.; SIOLI, H. (eds.) Biogeography and Ecology of South America. In: Monographiae Biologicae, vol. 18. e 19, Haia, 1968.

FRANÇA, A. The coffee trail and pioneer fringes. Guide of excursion 3. $18^{\text {th }}$ International Geography Congress, Rio de Janeiro, Proceedings..., 1956.

FRANCO, F. de A. Carvalho. Bandeiras e bandeirantes de São Paulo. Bibl. Ped. Bras. Série 5a, vol. 181. São Paulo: Brasiliana, 1940.

FREDERICK, K. D. Production controls under the international coffee agreements: an evaluation of Brazil's programs. Journal of Inter-American Studies and World Affairs, Gainesville/Fla., v. 12, n. 2, p. 255-270, 1970.

FREEDEN, H. V. Tatú kolonisiert in Südamerika. Berlim: W. Moller, 1936.

FRICKE, W. Die Rinderhaltung in Nordnigeria und ihre natur-und sozialräumlichen Grundlagen. Frankfurter Geogr. Hefte, n. 46, 1969. 
FUGMANN, W. Die Deutschen in Paraná. Das deutsche Jahrhundertbuch. Curitiba: Empreza Editora Olivero, 1929.

FURTADO, C. The economic growth of Brazil. A survey from colonial to modern times. 3. ed., Berkeley, Los Angeles: Universityu of California Press, 1968.

GARCIA, F. Braun. Levantamento industrial de Maringá. [s. 1.], 1967a.

GARCIA, F. Braun. Levantamento industrial de Londrina. [s. 1.], $1967 \mathrm{~b}$.

GARSCH, B. Der Einfluß der Jesuiten-Missionen auf den Wandel der Naturlandschaft zur Kulturlandschaft im Stromgebiet des Paraguay-Paraná während des 17. und 18. Jhdts. Breslau: Frankes Verlag und Druckerei, O. Borgmeyer, 1934.

GATES, P. W. Frontier estate builders and farm laborers. In: WYMAN, W. D.; KROEBER, C. B. (orgs.) The frontier in perspective, Madison/Wisc: University of Wisconsin Press, p. 143-163, 1957.

GEER, Th. An oligopoly. The world coffee economy and stabilization schemes. Nova Iorque: Dunellen, 1971.

GERCA. Programa de diversificação econômica da região cafeeira do Estado do Paraná. Rio de Janeiro, 1967.

GERCA. Relatório 1965, 1966, 1967, 1968, 1969. Rio de Janeiro.

GERCA. Levantamento do município de Marialva através de fotografias aéreas. Maringá (cópia), 1969 a.

GERCA. Levantamento dos danos causados pela geada de 10 de julho de 1969 no Estado do Paraná. Rio de Janeiro (cópia do relatório), 1969 b.

GERCA. Ferrugem do cafeeiro. Rio de Janeiro, 1970 a.

GERCA. Programa de racionalização da cafeicultura. Rio de Janeiro, 1970 b.

GERCA. Plano de renovação e revigoramento de cafezais. Rio de Janeiro, 1970 c.

GERCA. Controle da ferrugem. Rio de Janeiro, $1970 \mathrm{~d}$.

GERCA. Situação da cafeicultura em 1965. Estado do Paraná. Rio de Janeiro, 1971.

GERCA. Novos resultados de controle químico da ferrugem do cafeeiro no Brasil. Rio de Janeiro, 1972.

GERLING, W. Die Plantage. Fragen ihrer Entstehung, Auswertung und wirtschaftlichen Eigenart. Würzburg: Stahel, 1954.

GESELLSCHAFT FÜR SIEDLUNG IM AUSLANDE.Die Siedlung Roland und Terra Nova im brasilianischen Staate Paraná. Berlim: Gesellschaft für Siedlung im Auslande, 1937.

GLASER, G. Neue Aspekte der Rinderweidewirtschaft in Zcntralbrasilien. In: Beiträge zur Geographie Brasiliens (Edição comemorativa para G. Pfeifer), Heidelberg, HGA n. 34, p.19-38, 1971.

GÖLTE, W. Das südchilenische Seengebiet. Besiedlung und wirtschaftliche Erschließung seit dem 18. Jh. Bonner Geograph. Abh., caderno 47. Bonn: Dümmler in Komission, 1973.

GUIMARÃES, M. Mazzei. O café, marco de uma nova era no Paraná. Boletim da Superintendência dos serviços do café, São Paulo, v. 28, n. 311, p. 42-68; n. 313, p. 71-90, 1953.

GULLEY, J. L. M. The Turnerian frontier. A study in the migration of ideas. Tijdschrift voor Economische en Sociale Geografie, Roterdã, v. 50, n. 1, p. 65-72 e p. 81-91, 1959.

GUTERSOHN, H. São Paulo, Natur und Wirtschaft. Vierteljahresschrift d. Naturforsch. Ges. in Zürich, n. 85, p. 149-255, 1940.

HAARER, A. E. Modern coffee production. Londres: Leonard Hill, 1962.

HÄGERSTRAND, T. Innovation diffusion as a spatial process. Chicago: University of Chicago Press, 1967.

HAHN, H. Sozialgruppen als Forschungsgegenstand der Geographie. Gedanken zur Systematik der Anthropogeographie. Erdkunde, n. 11, p. 35-41, 1957

HANSEL, J. M. Os sete povos das missões sob o regime jesuítico. Santo Ângelo: Missões, 1958.

HARMS-BALTZER, K. Die japanische Einwanderung und Niederlassung in Brasilien. Jahrbuch für Geschichte von Staat, Wirtschaft u. Gesellschaft Lateinamerikas, Colônia/Graz, n. 5, p. 347-365, 1968 a. 
HARMS-BALTZER, K. Forschungen zum Kulturwandel bei den Japanern und ihren Nachikommen in Brasilien. Jahrbuch für Geschichte von Staat, Wirtschaft u. Gesellschaft Lateinamerikas, Colônia/Graz, n. 5, p. 422-431, $1968 \mathrm{~b}$.

HARTKF, W. Gedanken über die Bestimmung von Räumen gleichen sozialgeographischen Verhaltens. Erdkunde, n. 13, p. 426-436, 1959.

HERNÁNDEZ, P.Misiones del Paraguay: Organización social de las doctrinas guaranies de la Compania de Jesus. 2 vol., Barcelona: G. Gill, 1913.

HETTNER, A.; SCHMITTHENNER, H.; PLEWE, E. (orgs.). Allgemeine Geographie des Menschen. Vol. 2: Wirtschaftsgeographie. Stuttgart: W. Kohlhammer, 1957.

HOFSTADTER, R.; LIPSET, S. M. (orgs.) Turner and the sociology of the frontier. Série The sociology of American History, v. 2. Nova Iorque: Basic Books, 1968.

HOLLANDA, S. Buarque de. Índios e mamelucos na expansão paulista. Anais do Museu Paulista, São Paulo, n. 13,1949 .

HOLZMANN, M. Contribuição ao estudo do clima do Paraná. Curitiba, 1967.

HORSTMANN, K. Horizontale Mobilität. In: KÖNIG, R. (org.) Handbuch der empirischen Sozialforschung. Vol. 2, p. 43-64, Stuttgart: Enke, 1969.

HUECK, K. Die Wälder Südamerikas. Ökologie, Zusammensetzung und wirtschaftliche Bedeutung. Stuttgart: G. Fischer, 1966.

IBC. I Congresso Mundial do Cafe. Rio de Janeiro, 1954.

IBC. Curso de Economia Cafeeira. 2 vols. Rio de Janeiro, 1962.

IBC. Expansão do cooperativismo na cafeicultura. 2. ed. Rio de Janeiro, 1964.

IBC. A contribuição das cooperativas de cafeicultores na melhoria do tipo do café. Rio de Janeiro, 1966.

IBC. Resultados da 2. previsão da safra 1970/71. Rio de Janeiro (cópia), 1970 a.

IBC. Parâmetros climáticos e a cafeicultura. [s. 1.], 1970 b.

IBC. (org.) Essays on coffee and economic development. Rio de Janeiro: FGV, 1973.

IBC-OEA. Cafeicultura no Paraná. Rio de Janeiro, 1964.

IBGE. Geografia do Brasil. Grande Região Sul. Vol. IV, Parte 1 (2. ed.), parte 2, Rio de Janeiro, 1968.

IBGE. Enciclopédia dos Municípios Brasileiros. Vol. 31 Paraná. Rio de Janeiro, 1959.

IBGE. Atlas Nacional do Brasil. Rio de Janeiro: IBGE, Conselho Nacional de Geografia, 1966.

ILO. The landless farmer in Latin America. ILO Studies and Reports, Nova Série n. 47. Genebra, 1957.

INDA. Delegacia Regional do Paraná. Relatório 1969. Curitiba, 1969.

ISAY, R. Aus meinem Leben. Weinheim, 1960.

JÄTZOLD, R. Ein Beitrag zur Klassifikation des Agrarklimas der Tropen. (Mit Beispielen aus Ostafrika). In:

Beiträge zur Geographie der Tropen und Subtropen (Edição comemorativa para H. Wilhelmy), Tübinger Geogr. Stud., n. 34 (Número especial 3), p. 57-69, 1970.

JAMES, P. E. The coffee lands of Southeastern Brazil. Geogr. Rev., n. 22, p. 225-244, 1932.

JAMES, P. E. The surface configuration of Southeastern Brazil. AAAG, n. 23, p. 165-193, 1933.

JAMES, P. E. The changing patterns of population in São Paulo State, Brazil. Geogr. Rev., n. 28, p. 353-362, 1938.

JAMES, P. E. Expanding settlements of Southern Brazil. Geogr. Rev., n. 30, p. 601-626, 1940.

JAMES, P. E. Expanding frontiers of settlement in Latin America. The Hispanic American Historical Rev. Durham/N. C., v. 21, n. 2, p. 183-195, 1941.

JAMES, P. E. Trends in Brazilian agricultural development. Geogr. Rev., n. 43, p. 301-328, 1953.

JAMES, P. E. Latin America. 4. ed. Nova Iorque: Odyssey Press, 1969. 
JOERG, J. L. G. (org.) Pioneer settlement. Amer. Geogr. Soc., Special Publ. n. 14. Nova Iorque, 1932.

JONASSON, O. The potential areas of coffee-growing and their relation to the settlement of the white man. Geografiska Annaler, Estocolmo, n. 40, p. 89-100, 1958.

KALCKMANN, R. E. et al. Regiões de trigo no Brasil. Rio de Janeiro: Edições SIA, 1965.

KAVALARIDZE, W. C. Erosão na região noroeste do Estado do Paraná e projeto para sua eliminação. $2^{\circ}$ Congr. Nac. de Conservação do Solo. Anais..., Belo Horizonte, 1963.

KAVALARIDZE, W. C. Os solos do Estado do Paraná. Algumas idéias para um projeto dc combate à erosão. Congr. Pan Americano de Conservação do Solo, Anais..., São Paulo, p. 309-319, 1966.

KELLER, E. Coelho de Sousa. Notas sôbre a evolução da população do Estado de São Paulo de 1920 a 1950. Aspectos Geográficos da Terra Bandeirante, Rio de Janeiro, p. 209-236, 1954.

KING, W. C. Brazil's coffee industry. Washington: Foreign Agricultural Service, U.S. Dept. of Agriculture, 1962. KOCH-WESER, G. Roland, Kaffee und Kolonisation. In: SCHAUFF, J. (org.) 25 Jahre Rolândia, Berlim, Bonn: Landschriften, p. 56-68, 1957.

KÖNIG, R. (Org.) Handbuch der empirischen Sozialforschung. 2 vols. Stuttgart: Enke, 1969a.

KÖNIG, R. Soziale Gruppen. GR., n. 1, p. 2-10, 1969 b.

KOHLHEPP, G. Die deutschstämmigen Siedlungsgebiete im südbrasilianischen Staate Santa Catarina. In:

Heidelberger Studien z. Kulturgeogr. (Edição comemorativa para G. Pfeifer), HGA, Wiesbaden, n. 15, p. 219-244, 1966a.

KOHLHEPP, G. Types of agricultural colonization on subtropical Brazilian Campos limpos. Revista Geográfica, Rio de Janeiro, n. 70, p. 131-155, 1969.

KOHLHEPP, G. Grundzüge der Bevölkerungs- und Wirtschaftsstruktur Brasiliens. Geographisches Taschenbuch 1970/72, Wiesbaden, p. 233-256, 1972.

KOHLHEPP, G. Staatliche Produktionssteuerung und gelenkte Diversifizierung der Landnutzung im Bereich tropischer Monokulturen. Am Beispiel des Kaffeeanbaus in Brasilien. In: HGA, n. 40 (Edição comemorativa para H. Graul), p. 429-442, 1974.

KOHLHEPP, G. Gelenkte Agrarkolonisation im Rahmen der Expansion des Kaffeeanbaus im Norden Paranás (Brasilien). In: Göttinger Geogr. Abh. 66, 1975.

KOSTROWICKI, J.; TYSZKIEWICZ, W. (orgs.) Essays on agricultural typology and land utilization. Geographia Polonica, n. 19, Varsóvia, 1970.

KRAUS, T. Räumliche Ordnung als Ergebnis geistiger Kräfte. Ein Beitrag zu den Grundfragen der Wirtschaftsgeographie. Erdkunde, n. 2, p. 151-155, 1948.

KRAUS, T. Häufung und Streuung als raumordnende Prinzipien. In: Individuelle Länderkunde u. räumliche Ordnung. Erdkundl. Wissen, n. 7, Wiesbaden, p. 94-107, 1959.

KRETZEN, J. As grandes potências econômicas no Estado do Paraná em 1949. Compêndio informativo. São Paulo/Curitiba, 1949.

KRETZEN, J. As grandes potências econômicas no Estado do Paraná. 2. ed. Curitiba: Escritório Sul-Brasil Econômico, 1951.

KRUG, C. A.; POERCK, R. A. de. World coffee survey. Roma: FAO, 1968.

KUROWSKI, G. Aspectos gerais da erosão no Norte do Paraná. Boletim Paranaense de Geografia, Curitiba, n. 6 e 7, p. 3-16, 1962.

LAMBERT, J. Amérique Latine, structures sociales et institutions politiques. Paris: Presses universitaires de France, 1963.

LASSERRE, G.; SANTOS, M. Les plantations tropicales et la régionalisation de l'espace au Brésil. In: La Régionalisation de l'Espace au Brésil, Paris, p. 57-72, 1971.

LAUER, W. Humide und aride Jahreszeiten in Afrika und Südamerika und ihre Beziehung zu den Vegetationsgürteln. In: Studien zur Klima- u. Vegetationskunde der Tropen. Bonner Geogr. Abh., Bonn, n. 9, p. 15-98, 1952. 
LAUER, W. Wandlungen im Landschaftsbild des Südchilenischen Seengebietes seit Ende der spanischen Kolonialzeit. In: Beitr. z. Geogr. d. Neuen Welt (Edição comemorativa para O. Schmieder), Schr. d. Geogr. Inst. d. Univ. Kiel, n. 20, p. 227-276, 1961.

LAUER, W. Naturgeschehen und Kulturlandschaft in den Tropen. Beispiel Zentralamerika. In: Beitr. z. Geogr. d. Tropen u. Subtropen (Edição comemorativa para H. Wilhelmy), Tübinger Geogr. Stud. n. 34, p. 83-105, 1970.

LAZZARINI, W. A cafeicultura Brasileira. In: IBC. Curso de economia cafeeira, Rio de Janeiro, vol. 1, p. 169-268, 1962.

LAZZARINI, W. Erradicação de cafeeiros e nôvo programa do GERCA. Boletim Informativo do IBC. Curitiba, 1967.

LEHMANN, E. Historische Züge der Landesentwicklung im südlichen Brasilien. N. F. 15/16, p. 51-93, Leipzig, Wiss. Veröffentl. d. Dt. Inst. f. Länderkunde, 1958.

LINDLEY, F. Lord Lovat, 1871-1933: A biography. Londres: Hutchinson, 1935.

LINHARES, T. Paraná vivo; um retrato sem retoques. Rio de Janeiro: José Olympio, 1953.

LOPES, R. Paula. Land settlement in Brazil. Internat. Labour Rev., n. 33, p. 152-184, 1936.

LOWDEN, M. S. Fire crisis in Brazil. Amer. Forests, n. 71, p. 42-44; 46, 1965.

MAACK, R. Urwald und Savanne im Landschaftsbild des Staates Paraná. Zeitschrift der Gesellschaft für Erdkunde, Berlim, p. 95-116, 1931.

MAACK, R. Deutsche Ivahy-Expedition 1934. Zeitschrift der Gesellschaft für Erdkunde, Berlim, p. 44-46, 1936.

MAACK, R. Die neuerschlossenen Siedlungsgebiete und Siedlungen im Staate Paraná. Ibero-Amerikanisches Archiv, Berlim, v. 11, n. 2, p. 208-242, 1937.

MAACK, R. Sobre a extensão de sedimentos mais recentes na capa das camadas eruptivas básicas no Estado do Paraná. American Scientific Congress, 8, Proceedings..., Washington, v. 4, p. 577-591, 1940.

MAACK, R. Breves notícias sôbre a geologia dos Estados do Paraná e Santa Catarina. ABT, n. 2, p. 62-154, 1947.

MAACK, R. Notas preliminares sôbre clima, solos e vegetação do Estado do Paraná. ABT, n. 3, p. 99-200, 1948.

MAACK, R. Notas complementares à apresentação preliminar do mapa fito-geográfico do Estado do Paraná (Brasil). Arq. Museu Paranaense, Curitiba, n. 7, p. 351-361, 1949.

MAACK, R. O aspecto fitogeográfico atual do Paraná e considerações sôbre o problema do reflorestamento. ABT, n. 8, p. 425-436, 1953a.

MAACK, R. As consequências da devastação das matas no Estado do Paraná. ABT, n. 8, p. 437-457, 1953 b.

MAACK, R. Bericht über die Transportmöglichkeiten wirtschaftlicher Produkte im Gebiet der schiffbar zu machenden Flüsse Paraná, Paranapanema, Tibagi, Ivai, Ivinheima e Brilhante. Curitiba (não publicado), 1955.

MAACK, R. Uber Waldverwüstung und Bodenerosion im Staate Paraná. Erde, n. 87, p. 191-228, 1956.

MAACK, R. Sôbre o itinerário de Ulrich Schmidel através do Sul do Brasil (1552-1553). Publ. do Cons, de Pesquisas da Univ. do Paraná, série II, nº 1, Curitiba (em portguês e alemão), 1959.

MAACK, R. Die Veränderung der Naturlandschaft und ihre Folgen in Nordparaná durch die Besiedlung. Mitt. d. Bundesforschungsanstalt f. Forst- u. Holzwirtschaft, Reinbek b. Hamburgo, n. 45, p. 1-7, 1960.

MAACK, R. Unbekannte Indianer in West-Paraná. Das Drama eines neuentdeckten Indianerstammes in Brasilien. Kosmos, Stuttgart, v. 58, n. 9, p. 385-394, 1962.

MAACK, R. O ritmo da devastação das matas no Estado do Paraná, suas consequências e problemas de reflorestamento. Revista Ciência e Cultura, São Paulo, v. 15, n. 1, p. 25-33, 1963.

MAACK, R. Geografia física do Estado do Paraná. Curitiba: Imprensa da Universidade do Paraná, 1968.

MAACK, R. Notas preliminares sobre as águas do sub-solo da Bacia Paraná-Uruguai. Curitiba: Comissão Internacional da Bacia Paraná-Uruguai, 1970.

MAAS, A. Entwicklungen und Perspektiven der wirtschaftlichen Erschließung des tropischen Waldlandes von Peru, unter bes. Berücksichtigung der verkehrsgeographischen Problematik. Série Tübinger Geogr. Stud. n. 31, 1969. 
MACHADO, B. Pinheiro. Sinopse da história do Paraná. Bol. do Inst. Histórico, Geográfico e Etnográfico, Curitiba, 1952.

MACHADO, B. Pinheiro; BALHANA A. Pilatt. Contribuição ao estudo da história agrária do Paraná. Bol. da Univ. do Paraná, Dep. de História, Curitiba, n. 3, p. 1-52, 1963.

MAIER, M. H. Rolândia, ein Siedlungsbeispiel mit Deutschen. In: SCHAUFF, J. (org.) 25 Jahre Rolândia. Berlim, Bonn: Landschriften, p. 24-30, 1957a.

MAIER, M. H. Den Baumeistern Rolândias zum Gedächtnis. Roland, Rolândia, n. 5, Nov. 1957b.

MANSHARD, W. Einführung in die Agrargeographie der Tropen. Mannheim: Bibliogr. Inst, 1968.

MARGOLIS, M. Ouro Verde: A frontier community in Northern Paraná, Brazil. Dissertação (Mestrado). Columbia University, 1970.

MARGOLIS, M. The coffee cycle on the Paraná frontier. Luso-Brazilian Review, Madison/Wisc., v. 9, n. 1, p. 3-12, 1972.

MARTIN, H. H. Land that smells like money. The Saturday Evening Post, Philadelphia, 22/11/1952.

MARTINS, R. História do Paraná. 2. ed., São Paulo, 1939.

MARTINS, R. Quantos somos e quem somos. Curitiba: Empreza grafica paranaense, 1941.

MARTINS, R. Terra e gente do Paraná. Curitiba: Diretoria Regional de Geografia do Estado do Paraná, 1944.

MARTINS, W. Um Brasil diferente. Ensaio sôbre fenômenos de aculturação no Paraná. São Paulo: T. A. Queiroz, 1955.

MARTINS, A. Feitosa. Mutirão cafeeiro. 2. ed., São Paulo: Brasiliense, 1962.

MATOS, D. L. de. Contribuição ao estudo da geografia do algodão no Estado de São Paulo. In: Aspectos Geográficos da Terra Bandeirante, Rio de Janeiro, p. 253-288, 1954.

MATULEVICIUS, S. Porecatú: Império paranaense do açúcar. Panorama, Revista mensal de cultura geral, Curitiba, v. 12, n. 126, p. 44-49, 1962.

MAULL, O. Die Bestimmung der Tropen am Beispiel Amerikas. Ein Beitrag zur allgemeinen vergleichenden Länderkunde. In: Festschrift zur 100-Jahrfeier d. Ver. f. Geogr. u. Stat. Frankfurt, Frankfurt a.M., p. 339-365, 1936.

MCPHERSON, W. W. (org.) Economic development of tropical agriculture. Theory, policy, strategy and organisation. Gainesville: University of Florida Press, 1968.

MESQUITA, O. Vianna; SILVA, S. Tietzmann. Regiões agrícolas do Estado do Paraná: uma definição estatística. Rev. Bras. Geogr., v. 32, n. 1, p. 3-42, 1970.

MÉTRAUX, A. Jesuit missions in South America. In: Handbook of South American Indians, Washington, v. 5, p. 645-653, 1949.

MILLIET, S. Roteiro do café e outros ensaios. Col. do Dep. de Cultura, São Paulo, v. 25, 3. ed., 1941.

MÖRNER, M. The political and economic activities of the Jesuits in the La Plata region. The Hapsburg Era. Estocolmo: Victor Pettersons Bokindustri Aktiebolag, 1953.

MÖRNER, M. (org.) Race and class in Latin America. Nova Iorque, Londres: Columbia University Press, 1970. MOESCHLIN, F. Groß-Siedlung in Brasilien? Ein Kolonie-Plan Schweiz-Paraná. Horw, Lucerna: MontanaVerlag, 1936.

MONBEIG, P. A zona pioneira do Norte do Paraná. Geografia, São Paulo, v. 1, n. 3, p. 221-236, 1935.

MONBEIG, P. A zona pioneira do Norte do Paraná. Bol. Geogr., v. 3, n. 25, p. 11-17, 1945.

MONBEIG, P. Les zones pionnières de 1'État de São Paulo. Annales d'Histoire Econ. et Sociale, n. 9, p. 343-365, 1937.

MONBEIG, P. Pionniers et planteurs de São Paulo. Paris: Colin, 1952.

MONHEIM, F. Junge Indianerkolonisation in den Tiefländern Ostboliviens. Braunschweig: Westmann, 1965.

MONHEIM, F.; KESSLER, A. Beiträge zur Landeskunde von Peru und Bolivien. Erdkundliches Wissen, n. 20 (todos os cadernos suplementares), Wiesbaden, 1968. 
MOOG, C. Vianna. Bandeirantes and pioneers. Nova Iorque: G. Braziller, 1964.

MORGENROTH, E. Der Baumwollanbau Brasiliens. Deutsche Forscherarbeit in Kolonie u. Ausland, caderno 7, Berlim, 1942a.

MORGENROTH, E. Die Kaffeekultur im Staat São Paulo, Brasilien. Deutsche Forscherarbeit in Kolonie u. Ausland, Berlim, caderno 8, 1942b.

MÜLLER, N. Lecocq. Sítios e sitiantes do Estado de São Paulo. Bol. 132. Geografia, São Paulo, n. 7, Universidade de S. P., 1951.

MÜLLER, N. Lecocq. Contribuição ao estudo do Norte do Paraná. Bol. Paul. Geogr., n. 22, p. 55-97, 1956.

MULLER, K. D. Pioneer settlement in South Brazil: the case of Toledo, Paraná. Série "Publications of the Research Group for European Migration Problems", n. 19. Haia: Nijhoff, 1974.

NAKAMAE, J. Caderno regional do Paraná. Coopercotia, São Paulo, dez. 1967, p. 13-25, 1967.

NEUFELDT, G. Das neu erschlossene Siedlungsgebiet in Nord-Paraná (Brasilien). Erdkunde, n. 5, p. 233-237, 1951.

NICHOLLS, W. H. The agricultural frontier in modern Brazilian history: The State of Paraná 1920-1965. In: Midwest Ass. for Latin American Studies (org.) Cultural change in Brazil. Muncie: Ball State Univ., p. 36-64, 1970.

NICHOLLS, W. H.; PAIVA, R. Miller. Ninety-nine fazendas: The structure and productivity of Brazilian agriculture, 1963. Capítulo 6. The North of Paraná: Maringá. Nashville/Tenn: Graduate Center for Latin American Studies, 1969.

NIENSTEDT, J. Kaffee-Erzeugung und Handel in São Paulo und Paraná. Hamburgo, 1950.

NITZ, H.-J. Die ländlichen Siedlungsformen des Odenwaldes. HGA 7, 1962.

NITZ, H.-J. Agrarlandschaft und Landwirtschaftsformation. In: Moderne Geographie in Forschung und Unterricht. Série B, n. 39/40. Hannover: Schroedel, p. 70-93, 1970.

NITZ, H.-J. Formen der Landwirtschaft und ihre räumliche Ordnung in der oberen Gangesebene. Série HGA, n. 28. Wiesbaden: F. Steiner, 1971a.

NITZ, H.-J. Begriffliche Erfassung kleinräumiger Nutzungseinheiten innerhalb einer Landwirtschaftsformation. In: PFEIFER, G. (org.) Symposium zur Agrargeographie, série HGA, n. 36. Heidelberg: Geographisches Institut, p. $42-46,1971 b$.

NITZ, H.-J. Reihensiedlungen mit Streifeneinödfluren in Waldkolonisationsgebieten der Alten und Neuen Welt. In: MEYNEN, E. (org.). Im Dienste der Geographie und Kartographie. Symp. E. Meynen, série Kölner Geogr. Arb., caderno 30. Colônia: Geographisches Institut der Universitat Köln im Selbstverlag, p. 72-93, 1974.

NIXDORF, O. Zur Rinderzucht und Rinderhaltung in Brasilien. Der Tropenlandwirt, Witzenhausen, n. 68, p. 57$76,1967$.

NIXDORF, O. Eigene Entwicklungshilfe in Nord-Paraná, Brasilien. Südamerika, Buenos Aires, v. 18, n. 4, p. 189$193,1967 / 68$.

OBERG, K.; JABINE, T. Toledo, um município da fronteira oeste do Paraná. Rio de Janeiro: Edições SSR, 1960.

OCHSE, J. J.; SOULE JR., M. J.; DIJKMANN, M. J.; WEHLBURG, C. Tropical and subtropical agriculture. Vol. 2. Nova Iorque: Macmillan, 1961.

ORPLASE. Plano Diretor de desenvolvimento integrado. Rolândia, [s. a.].

ORTOLANI, A. A.; CAMARGO, A. Paes de; SALATI, E. Efeito térmico de escoadouro aberto em mata à jusante de cafezal para a proteção preventiva contra a geada. Curitiba, 1963.

OTREMBA, E. Die landwirtschaftlichen Betriebsformen in Venezuela und das Problem der Agrarkolonisation durch Europäer. Wiss. Veröff. d. Dt. Inst. f. Länderkunde, nova série, n. 15/16, p. 5-50, Leipzig, 1958.

OTREMBA, E. Allgemeine Agrar-und Industriegeographie. In: LÜTGENS, R. Erde und Weltwirtschaft, vol. 3, 2. edição, Stuttgart: Franck, 1960.

OTREMBA, E. Die Gestaltungskraft der Gruppe und der Persönlichkeit in der Kulturlandschaft. Tag. ber. u. wiss. Abh. Dt. Geogr. Tag Köln 1961, Wiesbaden, p. 166-176, 1962.

OTREMBA, E. Soziale Räume. GR, v. 21, n. 1, p. 10-14, 1969. 
OTREMBA, E. Der Wirtschaftsraum - seine geographischen Grundlagen und Probleme. Erde und Weltwirtschaft, v. 1, 2. ed., Stuttgart: Franck, 1970.

OTRUBA, G. Der Jesuitenstaat in Paraguay. Idee und Wirklichkeit. Viena: Bergland, 1962.

PAFFEN, K. H. Caatinga, Campos und Urwald in Ostbrasilien. Ein Beitrag zum Savannenproblem. Tag. ber. u. wiss. Abh. Dt. Geogr. Tag Hamburg 1955, Wiesbaden, p. 214-226, 1957.

PAN AMERICAN COFFEE BUREAU. Annual Coffee Statistics. Washington: Pan American Coffee Bureau, 1959.

PARANÁ. The State of Paraná. An official handbook. São Paulo: British Chamber of Commerce of São Paulo \& Southern Brazil, 1930.

PARSONS, J. J. Antioqueno colonization in Western Colombia. Ed. Revista. Berkeley, Los Angeles: University of California Press, 1968.

PARSONS, J. J. The "Africanization" of the New World tropical grasslands. In: Beiträge zur Geographie der Tropen und Subtropen (Ed. Comemorativa para H. Wilhelmy), Série Tübinger Geogr. Stud. n. 34, p. 141-153, 1970.

PELZER, K. J. Japanese migration and colonization. In: Limits of land settlement, p. 155-194, Baltimore, 1937.

PEREIRA, H. L. Aspectos do algodão no Estado do Paraná. Londrina (cópia mimeografada), 1963.

PEREIRA, H. L. Alguns aspectos da importância econômica e social da cotonicultura no Estado do Paraná. Londrina (exemplar batido à máquina), 1968.

PETRONE, P. O homem Paulista. Bol. Paul. Geogr., n. 23, p. 39-77, 1956.

PETRONE, P. No Rio Paraná, de Pôrto Epitácio a Guaíra. (Relatório de viagem). Bol. Paul. Geogr., n. 27, p. 55-94, 1957.

PFEIFER, G. Die Bedeutung der "Frontier" für die Ausbreitung der Vereinigten Staaten bis zum Mississippi. GZ, n. 41, p. 138-158, 1935.

PFEIFER, G. Die räumliche Gliederung der Landwirtschaft im nördlichen Kalifornien. Série Wiss. Veröff. d. Ges. f. Erdk. zu Leipzig, v. 10. Leipzig: F. Hirt \& Sohn, 1936.

PFEIFER, G. Städtische und ländliche Bevölkerung in Brasilien und die Binnenwanderungsbewegung. Geographisches Taschenbuch, Wiesbaden, p. 392-402, 1956/57.

PFEIFER, G. Zur Funktion des Landschaftsbegriffes in der deutschen Landwirtschaftsgeographie. Studium Generale, n. 11, p. 399-411, 1958.

PFEIFER, G. Observaciones a lo largo de las nuevas fronteras de colonización en Paraná y Mato Grosso. In: UGIConf. Reg. Latinoamericana, parte I, "La Geografia y los problemas de población". México: Sociedad Mexicana de geografia y estadistica, p. 314-328, 1966a.

PFEIFER, G. Atlantische Welt. Probleme der Gestaltung neuweltlicher Kulturlandschaften am Beispiel Brasiliens. Série Würzburger Geogr. Arb., n. 18. Würzburg : Geogr. Inst. der Univ. Würzburg in Verb. mit der Geogr. Ges. Würzburg, 1966b.

PFEIFER, G. Kontraste in Rio Grande do Sul: Campanha und Alto Uruguai. GZ, v. 55, n. 3, p. 163-206, 1967.

PFEIFER, G. Frontera del Norte Kaliforniens, 1800-1846: Russen, Spanier und Angelsachsen. In: Beiträge zur Geographie der Tropen und Subtropen (Edição comemorativa p/ H. Wilhelmy), Série Tübinger Geogr. Stud., $n$. 34, p. 255-278, 1970.

PFEIFER, G. (org.) Symposium zur Agrargeographie. Série HGA, n. 36. Heidelberg: Geographisches Institut, 1972.

PFEIFER, G.; KOHLHEPP, G. Wirtschafts- und sozialgeographische Studien in Südbrasilien. Cópia mimeografada. Relatório de pesquisa, p. 1-66, Heidelberg, 1966c.

PINHO, D. BENEVIDES. O cooperativismo na cafeicultura brasileira. Rio de Janeiro: Inst. Brasileiro do Café, 1965.

PLANO. Plano de desenvolvimento do Paraná. 2 vol., [s. 1.]: [s. a.].

PLATT, R. S. Coffee plantations in Brazil. A comparison of occupance patterns established in frontier areas. Geogr. Rev., n. 25, p. 231-239, 1935. 
PORTO, A. História das Missões orientais do Uruguay. Série Publ. Serv. Patrim. Hist. Art. Nac. 9, vol. 1, Rio de Janeiro, 1943.

PRADO JR., C. História econômica do Brasil. 7. ed., São Paulo: Brasiliense, 1962.

PRANDINI, N. Aspectos da geografia urbana de Londrina. Anais da Ass. dos Geogr. Bras., São Paulo, n. 6, parte 1, 1951/52, p. 61-80, 1954.

PRÜSER, F. Roland und Rolândia. Bremen: R, Bargmann, 1957.

QUELLE, O. Das Problem des Jesuitenstaates Paraguay. Ibero-Amerikanisches Archiv, Berlim/Bonn, n. 8, p. $260-$ $282,1934 / 35$.

RAPOSO, H. Café fino e seu preparo. Rio de Janeiro: Serviço de Informação Agrícola, Ministério da Agricultura, 1959.

RIBAS, R. N. Aspectos dos óleos vegetais comestíveis do Paraná. Curitiba, 1967.

RIBEIRO, E. Branco. Esboço da história do oeste do Paraná. Curitiba: Tip. J. Haupt, 1940.

RIOS, J. A. Conceituação sociológica sôbre trabalhador autônomo. Questões Agrárias, DOE, n. 5, Rio de Janeiro, [s. a.].

ROCCHETTI, G. L'emigrazione agricola italiana in Brasile nell' ultimo decennio. Rivista di Agricoltura Subtropicale e Tropicale, Florença, v. 52, n. 4/6, p. 183-222, 1958.

ROMARIZ, D. de Amarante. Mapa da vegetação original do Estado do Paraná. Rev. Bras. Geogr., v. 15, n. 4, p. 597-609, 1953.

ROTHFOS, B. Kaffee-Handbuch. Hamburgo: De Gruyter, 1960.

ROURK, J. P. World coffee prospects in 1970's: Brazilian production is the key. Foreign Agriculture, Washington/ D.C., v. 9, n. 37, p. 4-6 e 16, 1971.

ROURK, J. P. Coffee rust menaces Brazil's chief export. Foreign Agriculture, Washington/D. C., v. 10, n. 20, p. 6-8, 1972.

ROURKE, B. E. Short-range forecasting of coffee production. Food Research Institute Studies in agricultural economics, trade and development, Stanford/Cal., v. 9, n. 3, p. 197-214, 1970.

ROWE, J. W. F. The world's coffee. Londres: H.M. Stationery Office, 1963.

RÜHI, A. Das Standortproblem in der Landwirtschaftsgeographie. (Das Neuland Ostaustralien). Veröff. d. Inst. f. Meereskde. Nova série, volume "Hist.-Volkswirtschaft", caderno 6, Berlim, 1929.

RUPPERT, K. Die gruppentypische Reaktionsweite. Gedanken zu einer sozialgeographischen Arbeitshypothese. In: Zum Standort der Sozialgeographie (Edição comemorativa Hartke), série Münchner Stud. z. Sozial- u. Wirtschaftsgeogr. n. 4, p. 171-176, Kallmünz, 1968.

RUPPERT, K.; SCHAFFER, F. Zur Konzeption der Sozialgeographie. GR, v. 21, n. 6, p. 205-214, 1969.

SAINT-HILAIRE, A. de. Voyage dans les provinces de Saint-Paul et de Sainte-Cathérine. Paris: Arthus Bertrand, 1851

SAHOTA, G. S. An economic analysis of internal migration in Brazil. The Journal of Political Economy, Chicago, v. 76, n. 2, p. 218-245, 1968.

SAITO, H. O Japonês no Brasil: Estudo de mobilidade e fixação. São Paulo: Editora “Sociologia e Política”, 1961.

SAMHABER, E. Südamerika. Gesicht-Geist-Geschichte. Hamburgo: Goverts, 1939.

SANDNER, G. Agrarkolonisation in Costa Rica. Siedlung, Wirtschaft und Sozialgefüge an der Pioniergrenze. Série Schriften d. Geogr. Inst. d. Univ. Kiel, vol 19, caderno 3, Kiel, 1961.

SANDNER, G. Die Erschließung der karibischen Waldregion im südlichen Zcntralamerika. Erde, v. 95, n. 2, p. 111-131, 1964.

SANDNER, G. Ursachen und Konsequenzen wachsenden Bevölkerungsdruckes im zentralamerikanischen Agrarraum. In: Beiträge zur Geographie der Tropen und Subtropen. (Ed. Comemorativa para H. Wilhelmy), Série Tübinger Geogr. Stud., n. 34, p. 279-292, 1970. 
SANDNER, G. Die Hauptphasen der wirtschaftlichen Entwicklung in Lateinamerika in ihrer Beziehung zur Raumerschließung. In: Wirtschafts- und Kulturräume der außereuropäischen Welt (Ed. comemorativa p/ A. Kolb), Série Hamburger Geogr. Stud., n. 24, p. 311-334, 1971.

SANDNER, G; NUHN, H. Das nördliche Tiefland von Costa Rica. Geographische Regionalanalyse als Grundlage für die Entwicklungsplanung. Série Abh. a. d. Gebiet d. Auslandskunde (Univ. Hamburg), vol. 72. Berlim, Nova Iorque: De Gruyter, 1971.

SANTIAGO, A. Zebu e cruzamentos. Produção de carne E leite nos trópicos. São Paulo: Obelisco, 1965.

SASAKI, J. Japanese emigrants in Brazil. A study of integration of the Japanese people. Rio de Janeiro: National Confederation of the Industry, Departamento Nacional, 1958.

SCHAUFF, J. (org.) 25 Jahre Rolândia. Studien zur Besiedlung des Nordens von Paraná. Berlim, Bonn: Landschriften-Verlag, 1957a.

SCHAUFF, J. Die private Eisenbahn- und Siedlungsgesellschaft. In: SCHAUFF, J. 25 Jahre Rolândia, p. 33-42, 1957b.

SCHAUFF, J. (org.) Landerschließung und Kolonisation in Lateinamerika. Berlim, Bonn: Landschriften-Verlag, 1959.

SCHMIDT, G. A.; MARCUS, A. (orgs.) Handbuch der tropischen und subtropischen Landwirtschaft. 2 vols., Berlim: Mittler, 1943.

SCHMIEDER, O. Die Neue Welt. 1. parte: Mittel- und Südamerika. Heidelberg, Munique, 1962.

SCHÖLLER, P. Leitbegriffe zur Charakterisierung von Sozialräumen. In: Zum Standort der Sozialgeographie (Ed. comemorativa Hartke), Série Münchner Studien z. Soz.- u. Wirtschaftsgeographie, n. 4, p. 177-184. Kallmünz/ Regensburg: Lassleben, 1968.

SCHOOP, W. Vergleichende Untersuchungen zur Agrarkolonisation der Hochlandindianer am Andenabfall und im Tiefland Ostboliviens. Série Aachener Geogr. Schr., caderno. 4. Wiesbaden: Steiner, 1970.

SCHRÖDER, R. Einige tropische Nutzpflanzen Brasiliens in ihrer Abhängigkeit vom Klima. Staden-Jahrbuch, São Paulo, n. 4, p. 19-30, 1956a.

SCHRÖDER, R. Die klimatischen Bedingungen für den Kaffeeanbau auf der Erde, insbes. in Zentral- und Südamerika. Peterm. Geogr. Mitt., n. 100, p. 122-136, 1956b.

SCHRÖDER, R. Die Niederschlagsjahreszeiten Brasiliens. Peterm. Geogr. Mitt., n. 102, p. 264-270, 1958.

SCHRÖDER, R. Climatologia agrícola na região da Bacia Paraná-Uruguai. São Paulo: CIBPU, 1961.

SCHUCH, W. H. Abwanderungsgebiete und Neusicdlungsräume in Brasilien. In: Abh. d. 1. Geogr. Inst, der FU Berlim 13. Aktuelle Probleme Geogr. Forschung (ed. comemorativa de J. H. Schultze), p. 383-409, 1970.

SCHUH, G. E. The agricultural development of Brazil. Nova Iorque: Praeger Publishers, 1970.

SCHULMAN, S. The colono-system in Latin America. Rural Sociology (Madison/Wisc.), n. 20, p. 34-40, 1955.

SCOTT, P. The agricultural regions of Tasmania: a statistical definition. Econ. Geogr., n. 33, p. 109-121, 1957.

SERETE. Estudo econômico das fibras têxteis no Paraná. 4 vols., São Paulo, 1964.

SICK, W.-D. Wirtschaftsgeographie von Ecuador. Série Stuttgarter Geograph. Studien, vol. 73. Stuttgart: Selbstverlag des Geographischen Instituts der T.H. Stuttgart, 1963.

SILVA, J. GOMES da. Reforma agrária. Questões Agrárias, Doc. 3, Rio de Janeiro, 1968.

SILVEIRA, C. Café, um drama na economia nacional. Retratos do Brasil, v. 12, Rio de Janeiro, 1962.

SIMÕES, R. Matos de Almeida. Notas sôbre o clima do Paraná. Rev. Bras. Geogr., n. 16, p. 126-132, 1954.

SIMÕES, R. Matos de Almeida. Notas sôbre o clima do Sul do Brasil. (Paraná, Santa Catarina, Rio Grande do Sul). Bol. Geogr., v. 16, n. 134, p. 459-482, 1956.

SMITH, T. L. Brazil, people and institutions. Ed. revista, Baton Rouge: Louisiana State University Press, 1963.

SOROKIN, P. A. Social mobility. Nova Iorque: Harper, 1927.

SORRE, M. Les migrations des peuples. Essai sur la mobilité géographique. Paris: Flammarion, 1955. 
SOUZA, D. M. de Paula. Contribuição ao reconhecimento dos solos da região cafeeira do Estado do Paraná. UFPR, Curitiba: Cadeira de Solos, Escola de Agronomia e Veterinária, 1965.

STEGER, H.-A. (org.) Sozio-ökonomische Typologie Lateinamerikas. Beiträge zur Soziologie und Sozialkunde Lateinamerikas, COSAL, vol. 3. Bad Homburg, Berlim, Zurique: Wilhelm Fink, 1968.

STELLFELD, C. Fitogeografia geral do Estado do Paraná. Arquivo do Museu Paranaense, Curitiba, n. 7, p. 309350, 1949.

STERNBERG, H. O'Reilly. Agriculture and industry in Brazil. The Geographical Journal, Londres, n. 121, parte 4, p. 488-502, 1955.

STERNBERG, H. O'Reilly. Man and environmental change in South America. In: FITTKAU, E. J. et al. Monographiae Biologicae, vol. 18: Biogeography and ecology of South America, v. 1, p. 413-445. Haia: W. Junk N.V. Publ, 1968.

STERNBERG, H. O'Reilly. A geographer's view of race and class in Latin America. In: MÖRNER, M. (ed.) Race and class in Latin America, p. 279-293. Nova Iorque, Londres: Columbia University Press, 1970.

STÖHR, W.; PEDERSEN, P. Economic integration and spatial development of South America. Ms. Paper SIAP Congress, Lima, Proceedings..., 1968.

STREETEN, P.; ELSON, D. Diversification and development: The case of coffee. Nova Iorque: Praeger, 1971.

TAUNAY, A. de E. Na era das bandeiras. Estudos de história colonial paulista. Rev. do Inst. Hist. e Geogr. Bras., Rio de Janeiro, n. 84, 1919.

TAUNAY, A. de E. História das bandeiras paulistas. São Paulo: Melhoramentos, 1946.

TAUNAY, A. de E. O café e a economia brasileira. Bol. Geogr., v. 19, n. 163, p. 447-459, 1961.

TAYLOR, J. A. New Brazilians set the pace in Paraná. The Geograph. Magazine, v. 44, n. 6, p. 420-423, 1972.

TESSMANN, G. Paraná. Pflanzenformationen, Klima, Wirtschaftsformen. Passat, Hamburgo, n. 2, p. 35-44, 1949.

THOMAS, A. H. Miller. Companhia de Terras Norte do Paraná. In: Cia. Melhoramentos Norte do Paraná, p. 1-6, São Paulo, 1949.

THOMAS, A. H. Miller. Richtlinien für eine rationelle Urwaldkolonisation. In: SCHAUFF, J. (org.) 25 Jahre Rolândia, p. 48-55, 1957.

THORNTHWAITE, C. W.; MATHER, J. R. The water balance. Climatology, Centerton/N. J., v. 8, n. 1, 1955.

TORRES, J. B. de Vasconcelos. Movimentos migratórios das populações rurais brasileiras. Rio de Janeiro, São Paulo: Freitas Bastos, 1957.

TÔRRES, J. C. de Oliveira. Estratificação social no Brasil. Corpo e Alma do Brasil, n. 15, São Paulo, 1965.

TROLL, C. Plural societies of developing countries: aspects of social geography. Int. Geogr. Congr., 20,

Proceedings... p. 9-33, Londres, 1964.

TURNER, F. J. The frontier in American history. Nova Iorque: H. Holt and Co., 1920.

UHLIG, H.; LIENAU, C. (orgs.) Materialien zur Terminologie der Agrarlandschaft. vol. 1: Flur und Flurformen. Gießen: Lenz, 1967.

UNITED NATIONS (ECLA/FAO). Coffee in Latin America. II. Brazil. State of São Paulo. 2 vol., Mexico, 1960.

VAGELER, P. Grundriß der tropischen und subtropischen Bodenkunde. 2. ed., Berlim: Verlagsgesellschaft für Ackerbau, 1939.

VALVERDE, O. The Southern Plateau. Série Int. Geogr. Congr. 18, Excursion Guidebook n. 9. Rio de Janeiro: International Geographic Union, 1956.

VALVERDE, O. Geografia agrária do Brasil. vol. 1, Rio de Janeiro: Centro Brasileiro de Pesquisas Educacionais, Instituto Nacional de Estudos Pedagógicos, Ministério da Educação e Cultura, 1964.

VALVERDE, O. Geografia da pecuária no Brasil. Finisterra, Rev. Portuguesa de Geografia, Lisboa, v. 2, n. 4, p. 244-261, 1967.

VALVERDE, O. Brazil. In: World Atlas of Agriculture, vol. 3. Americas, p. 88-125, Novara: Istituto Geografico de Agostini, 1970. 
VIANNA, H. História do Brasil. 2 vols. São Paulo: Melhoramentos, 1963.

VIANNA, F. J. Oliveira. Populações meridionais do Brasil. Brasiliana, Série 5, v. 8, 4. ed., São Paulo, 1938.

VIDAL DE LA BLACHE, P. Les genres de la vie dans la geographic humaine. Annales de Geographie, Paris, $\mathrm{n}$. 20, p. 193-212 e 289-304, 1911.

VIDIGAL, C. Contribuição para o estudo de uma região do Paraná. Revista do Ateneu Paulista de História (São Paulo), v. 6, n. 6, 1969, p. 60-70; v. 7, n. 7, 1970, p. 115-130, 1969/70.

WAIBEL, L. Probleme der Landwirtschaftsgeographie. Série Wirtschaftsgeograph. Abh. 1. Breslau: F. Hirt, 1933.

WAIBEL, L. Reise in Paraná im Jahre 1948. Diário não publicado, V, p. 470-639, 1948.

WAIBEL, L. Princípios da colonização européia no Sul do Brasil. Rev. Bras. Geogr., v. 11, n. 2, p. 159-222, 1949.

WAIBEL, L. O que aprendi no Brasil. Rev. Bras. Geogr., v. 12, n. 3, p. 419-428, 1950.

WAIBEL, L. Die europäische Kolonisation Südbrasiliens. (Bearb. u. Vorwort G. Pfeifer), Colloquium Geographicum vol. 4. Bonn: F. Dümmler, 1955a.

WAIBEL, L. As zonas pioneiras do Brasil. Rev. Bras. Geogr., v. 17, n. 4, p. 389-422, 1955b.

WALLER, J. M. Coffee rust in Latin America. PANS, v. 18, n. 4, p. 402-408, 1972.

WEAVER, J. C. Crop-combination regions in the Middle West. Geogr. Rev., n. 44, p. 175-200, 1954 a.

WEAVER, J. C. Changing patterns of cropland use in the Middle West. Econ. Geogr., n. 30, p. 1-47, 1954b.

WEAVER, J. C. The county as a spatial average in agricultural geography. Geogr. Review, n. 46, p. 536-565, 1956.

WEAVER, J. C; HOAG, L. P.; FENTOM, B. L. Livestock units and combination regions in the Middle West. Econ. Geogr., n. 32, p. 237-259, 1956.

WEBSTER, C. C.; WILSON, P. N. Agriculture in the Tropics. 3. Ed. Londres: Longman, 1969.

WESTPHALEN, C. M.; MACHADO, B. Pinheiro; BALHANA, A. Pilatti. Nota prévia ao estudo da ocupação da terra no Paraná moderno. Boletim da Univ. Fed. do Paraná. Dept. de História, n. 7, p. 1-52, Curitiba, 1968.

WILHELMS, C. Möglichkeiten für eine Steigerung der brasilianischen Exporte durch

Angebotschversifizierung. Parte 1: Ramie, ein entwicklungsfähiges Ausfuhrprodukt. Hamburgo: Hamburgisches Welt-Wirtschafts-Archiv, Forschungsst. Aussenhandel, 1963.

WILHELMY, H. Probleme der Urwaldkolonisation in Südamerika. Z. Ges. Erdk., p. 303 - 314, 1940.

WILHELMY, H. Die deutschen Siedlungen in Mittelparaguay. Schr. d. Geogr. Inst. d. Univ. Kiel, v. 11, caderno 1, 1941.

WILHELMY, H. Aufbau und Landformen des Alto Paraná-Gebietes. Peterm. Geogr. Mitt., n. 92, p. 32-38, 1948.

WILHELMY, H. Siedlung im südamerikanischen Urwald. Hamburgo: Kröger, 1949a.

WILHELMY, H. Bestandsaufbau und Wirtschaftswert des Urwaldes am Alto Paraná. Z. f. Weltforstwirtschaft, p. 61-67, 1949b.

WILHELMY, H. Zur Klimatologie und Bioklimatologie des Alto-Paraná-Gebietes in Südamerika. Peterm. Geogr. Mitt., n. 94, p. 130-139, 1950.

WILHELMY, H.; ROHMEDER, W. Die La Plata-Länder. Argentinien - Paraguay - Uruguay. Braunschweig: G. Westermann, 1963.

WILLEMS, E. Immigrants and their assimilation in Brazil. In: SMITH, T. L.; MARDIANT, A. (eds.) Brazil. Portrait of Half a Continent. Nova Iorque: Dryden Press, p. 209-225, 1951.

WIRTH, E. Zum Problem der allgemeinen Kulturgeographie. Raummodelle - kulturgeographische Kräftelehre raumrelevante Prozesse - Kategorien. Erde, n. 100, p. 155-193, 1969.

WISSMANN, H. Von. Pflanzenklimatische Grenzen der warmen Tropen. Erdkunde, n. 2, p. 81-92, 1948.

WYMAN, W. D.; KROEBER, C. B. (orgs.) The frontier in perspective. Madison/Wisc: University of Winsconsin Press, 1957. 
ZAVALA, S. The frontiers of Hispanic America. In: WYMAN, W. D.; KROEBER, C. B. (orgs.) The frontier in perspective, p. 35-58, 1957.

ZELINSKY, W.; KOSIŃSKI, L. A.; PROTHERO, R. M. (orgs.) Geography and a crowding world. A Symposium on population pressures upon physical and social resources in the developing lands. Nova Iorque: Oxford University Press, 1970.

\section{ANÔNIMOS, ANUÁRIOS, RELATÓRIOS, REVISTAS, JORNAIS}

Anuário de Maringá (desde 1962). Maringá/Paraná.

Boletim Informativo FETAEP. Curitiba, Londrina 1969/70.

Boletim Informativo do IBC, Agência de Curitiba.

Cafeicultura enfrenta a fase mais difícil de sua história. O Dirigente Rural (São Paulo), v. 10, n. 1, 2, p. 13-18, 1970.

Centenário Paraná (1953). Edição Comemorativa. Curitiba.

Certeza de lucro e garantia do direito de propriedade colonizaram o Norte do Paraná. O Estado de São Paulo, 15/1/1965.

Cia. Cacique de café solúvel 1959-1969.

Companhia de Terras Norte do Paraná. Die große Kolonisationsgesellschaft Südamerikas. São Paulo, 1935.

Coopercotia (mensal), n. 26, 1969; n. 27, 1970, São Paulo.

Departamento de Estradas de Rodagem do Estado do Paraná. Relatório. Exercício de 1968, Curitiba.

Desenvolve-se a produção de rami na região norte do Paraná. Indústria Têxtil (Órgão oficial do Sindicato da Indústria dc Fiação e Tecelagem do Rio de Janeiro), Dez. 1957.

O Dirigente Rural. Anuário Rural, vol. 10, n. 1, 2, São Paulo, 1970.

Immigration and settlement in Brazil, Argentina and Uruguay. International Labour Review, v. 35, n. 1,1937.

Indusfibra (1969). Relatório da safra 1968/69. Londrina.

"Little Londres" in the forest. The story of Londrina, a boom town. Brazil (Nova Iorque), v. 22, n. 11, p. 3-5, 15-17, $19 ; 1948$

Maringá e o planejamento. 1969 [s. 1.]

Mensagens e Relatórios de Presidentes e Governadores do Paraná. Biblioteca Pública do Paraná, Curitiba.

Novo Paraná (Curitiba).

Paraná econômico. Órgão oficial da Federação do Comércio do Paraná, Curitiba.

Paraná em páginas. Curitiba.

Pragas e doênças do cafeeiro no Estado do Paraná. 1965 (s. 1.)

Prefeitura Municipal de Londrina. Levantamento sócio-econômico: Distritos, Povoados, Bairros. 1969/70.

Relatórios do Departamento de Terras e Colonização do Estado do Paraná (não publicados): O. Mäder (1933/34); A. Marques (1935/1936/1937/1947); A. Ribas (1938 a 1944). Curitiba.

Revista Paranaense de Desenvolvimento (Curitiba), n. 1, julho/agôsto 1967 a n. 17, março/abril 1970.

Revista Paranaense dos Municípios (Curitiba).

A Pioneira. Revista bimensal ill. (Londrina), n. 1,1947 a n. 7, 1954.

Roland (Das monatl. Mitteilungsblatt von Pro-Arte-Rolândia), 5/11/1957.

Secretaria da Agricultura do Estado do Paraná. Plano de incentivo à cafeicultura Paranaense. Curitiba, 1969.

The song is ended - but what of the International Coffee Agreement? The Standard Bank Review (Londres), agosto de 1970, p. 2-9.

Usina Central do Paraná S./A. Agricultura, Indústria e Comércio. Porecatu. 


\section{JORNAIS DE CIRCULAÇÃO DIÁRIA}

O Estado do Paraná (Curitiba)

O Estado de São Paulo (São Paulo)

Folha de Londrina (Londrina) com Suplemento técnico-agronômico (semanal)

Folha do Norte do Paraná (Maringá)

Diário do Noroeste (Paranavaí)

A Gazeta de Umuarama (Umuarama)

Jornal de Loanda (Loanda)

ACARPA (Curitiba) "Realidade Rural" dos Municípios

Arapongas, Astorga, Cambé, Cambira, Campo Mourão, Centenário do Sul, Goiorê, Ivaiporã, Jaguapitã, Jandaia do Sul, Mamborê, Mandaguaçu, Mandaguari, Maringá, Nova Esperança, Rolândia, Ubiratã, Sertanópolis.

ACARPA (Curitiba) Realidade Rural da região de Umuarama.

\section{ESTATÍSTICAS}

DEE Paraná (Curitiba):

13 Tábuas itinerárias Paranaenses 1963.

14 Estimativa da produção agrícola 1964-1968.

15 Animais existentes no Estado 1964-1967.

16 Gado abatido no Estado 1966-1967.

17 Produtos de origem animal 1966.

18 Sinópse Estatística do Paraná 1966.

19 Movimento bancário 1968.

20 Comércio Exterior 1968.

21 Comércio Interior - cabotagem 1969.

22 Comércio Interior - vias internas 1968.

23 Finanças públicas 1966.

24 Estimativa da população dos municípios existentes em $1^{\circ}$ de julho de 1967.

IBC (Rio de Janeiro):

k) Anuário Estatístico do Café 1964, 1965, 1966, 1967, 1968/70, 1971, 1972.

1) Movimento da comercialização de café segundo estados, municípios e micro-regiões homogêneas. [s. d.].

m) Produção Brasileira de café segundo as zonas fisiográficas e os municípios, periodo 1963/64 - 1966/67, 1967/68 - 1968/69. Rio de Janeiro 1968/70.

n) Boletim do Departamento Econômico.

IBGE (Rio de Janeiro):

h) Anuário Estatístico do Brasil, 1960 a 1970. - Rio de Janeiro.

i) VI Recenseamento Geral do Brasil, 1950. Estado do Paraná. Seleção dos principais dados. Rio de Janeiro, 1953.

j) VII Recenseamento Geral do Brasil 1960. Sinopse preliminar de Censo Demográfico 1960. Recenseamento Geral do Brasil 1960. Sinopse preliminar de Censo Demográfico 1960. Brasil.

k) VIII Recenseamento Geral 1970. Sinopse preliminar do Censo Demográfico 1970. Paraná.

1) Sinopse preliminar do Censo Demográfico 1970. Brasil.

m) Tabulações avançadas do Censo Demográfico 1970. Resultados preliminares.

n) VII Recenseamento Geral do Brasil 1960. Sinopse preliminar do Censo Agrícola 1960. Estado do Paraná. 
Rio de Janeiro 1963.

o) Censo Agrícola de 1960. Série Regional, vol. II, tomo 12, 1ª parte. Paraná - Santa Catarina. Rio de Janeiro 1967.

p) Registro Industrial 1965. Rio de Janeiro, 1968.

q) Cadastro Industrial 1965. vol. 8. Estado do Paraná. Rio de Janeiro, 1968.

r) Estimativas de população para os municípios brasileiros em $1^{\circ}$ de julho de 1965. Estado do Paraná.

s) Comércio Interestadual. Exportação por vias internas 1968. Paraná. - Rio de Janeiro.

Ministério da Agricultura (CCLEF): Anuário Estatístico do Trigo. Safra 1966/67, 67/68, 69/70 Rio Grande do Sul, Santa Catarina, Paraná. 1968/69 Paraná. Porto Alegre.

Ministério da Agricultura: Dados estatísticos municipais do Paraná 1965. Produção agrícola.

Ministério da Agricultura: Informativo da produção agropecuária nacional. Rio de Janeiro, dezembro de 1968.

Rede Viação Paraná - Santa Catarina. Estatísticas da RVPSC, 1967ss.

Secretaria da Agricultura do Estado do Paraná. Contribuição relativa dos municípios à produção agrícola paranaense, 1968.

\section{MAPAS}

Séries de mapas oficiais:

Dep. de Geografia, Terras e Colonização, Divisão de Geografia. (Curitiba/Paraná) 1963.

1:50.000 SF - 22 - U - II - 1 Maragogipe

- 2 Sertanópolis

-3 Rolândia

-4 Londrina

Conselho Nacional de Geografia (atualmente Instituto Brasileiro de Geografia) Rio de Janeiro.

Carta do Brasil 1:100.000 (1 $1^{\text {a }}$ ed. 1966)

Fôlha SF - 22 - U - IV Apucarana (1966)

SF $-22-\mathrm{V}-$ III Congonhinhas (1967)

SG - 22 - C - II Faxinal (1967)

SF - 22 - U - II Londrina (1965)

Carta do Brasil 1:500.000

Folha SF - 22 Paranapanema SO, SE (1965)

SG - 22 Curitiba NO (1967)

SG - 21 Asunción NE (1964)

Carta do Brasil 1:1.000.000 (2 $2^{\mathrm{a}}$ ed. 1966)

Fôlha SF -21 Rio Apa

SF - 22 Paranapanema

SG - 21 Asunción

SG - 22 Curitiba

\section{MAPAS INDIVIDUAIS}

Mapa do Estado do Paraná (Dep. de Geografia, Terras e Colonização, Curitiba)

1919 1:500.000 1953 1:650.000

$19221: 750.000 \quad 19591: 650.000$

$19381: 750.000 \quad 19651: 650.000$

$19481: 500.000 \quad 19691: 600.000$

Mapa do Paraná. Ilustrado, Londrina, 1967, 1:1.500.000.

USAF Operational Navigation Chart 1:1.000.000 (St. Louis), ONC P-27 Argentina, Bolivia, Brazil, Paraguay.

Operational Navigation Chart 1:1.000.000 (St. Louis) ONC P-27, Argentina, Bolivia, Brazil, Paraguay. 
Mapa Fitogeográfico do Estado do Paraná 1:750.000 (R. Maack, Serviço dc Geologia e Petrografia do IBPT, Curitiba, 1950).

Mapa Geológico do Estado do Paraná 1:750.000 (R. Maack, Serv. de Geologia do IBPT, Curitiba, 1953).

Coffee producing districts in São Paulo, Paraná and South Minas Gerais 1:1.500.000 (Anderson, Clayton Co., 1956). Zonas produtoras de café 1:2.000.000 (Anderson, Clayton Co., 1967).

Mapas do Arquivo de Francisco Beltrão. (Coleção do Dep. de Geografia, Terras e Colonização do Estado do Paraná, Curitiba).

\section{MAPAS E PLANTAS NÃO PUBLICADOS (CÓPIAS)}

Situação dos trabalhos de colonização na região Noroeste do Estado do Paraná em 1947. 1:500.000 (DGTC, Curitiba). Terras devolutas e algumas colônias federais e particulares em 1938. 1:750.000 (DGTC, Curitiba).

Mapa demonstrativo das terras devolutas e particulares existentes no Noroeste do Estado do Paraná em 1939. 1:750.000 (DGTC, Curitiba).

Grilos de terras. 1:750 000 (DGTC, Curitiba).

Companhia Melhoramentos Norte do Paraná:

9. Planta parcial No I. Colonização das glebas dos ribeirões Três Bôcas, Jacutinga e Vermelho. 1:80.000.

10. Planta parcial No II. Colonização das glebas dos ribeirões Bandeirantes do Norte e Pirapó. 1:80.000.

11. Planta parcial N No III Colonização das glebas dos ribeirões Cambará, Cambira, Nova Ucraina e Barra Nova. 1:80.000.

12. Planta parcial No IV. Colonização das glebas dos rios Bom e Pirapó. 1:80.000.

13. Planta parcial $N^{\circ}$ V. 1:80.000

14. $\quad N^{\circ}$ VI. $1: 80.000$

15. $\quad$ No VIII. 1:80.000

16. Colonização do Núcleo Cruzeiro (Glebas $\left.N^{o} 4,6,8,10,12,14\right)$ e do Núcleo Rio d'Areia (Gleba No 3). 1:50.000

17. Planta da gleba do patrimônio Maringá. 1:20.000 (1947)

18. Plantas dos patrimônios (diversos) entre outros, Inajá. 1:2.000

Planta da cidade de Londrina. 1:10.000 (Londrina, 1961).

Município de Porecatu 1:20.000 (Bases topográficas com curvas de nível, 1970).

Diversas plantas municipais (Bases topográficas sem curvas de nível, várias escalas).

Mapas de cidades (planta baixa com layout das ruas, várias escalas): Londrina, Maringá, Cianorte, Paranavaí, Umuarama (cópias).

\section{FOTOGRAFIAS AÉREAS}

Dep. de Geografia, Terras e Colonização do Estado do Paraná, Curitiba.

1953: Q68, 69. 1:100.000

1963/64: F 1 até F 15. 1:100.000, 2698-2703; 2727-2732; 2750-2756; 2769-2775; 2785-2791 (respectivamente $\mathrm{NO}, \mathrm{NE}, \mathrm{SO}, \mathrm{SE})$

Informações das firmas Ultrafertil (Londrina), Ricasolo (Rolândia) e Nortox (Apucarana). 


\section{LEGENDAS DAS FOTOS}

Foto 1. Altônia. Jovem colônia no frontier do Norte Novíssimo do Paraná (12 ago. 1963).

A colônia, distante apenas $25 \mathrm{~km}$ do rio Paraná, foi fundada no extremo sudeste da região cafeeira e na época do registro fotográfico estava a poucos dias de completar dois anos de existência.

Altônia - vê-se na foto sua principal rua comercial, ladeada de casas de madeira cobertas de telhas e com fachadas de alvenaria - experimentou um crescimento rápido em razão da intensa acorrida migratória, principalmente do Nordeste, via São Paulo, e de Minas Gerais, e em casos isolados também dos estados do Sul. Com a diminuição da importância da economia do café desde o final dos anos 1960, seguiram-se a esse crescimento estagnação e perda populacional.

Foto 2. Avanço da frente pioneira próximo a Tapira (Norte Novíssimo de Umuarama) (Foto aérea, 4 maio 1968)

Colonização das áreas residuais da floresta tropical úmida no Vale do Ivaí em pequenas e médias propriedades (corredor em faixas nuas). Passado o boom do café e a fase de redução da área de cultivo de café induzida pelo Estado, evidencia-se aqui a tendência à policultura.

Foto 3. Paisagem de cultivo no final da fase pioneira entre Umuarama e Iporã (5 out. 1970)

O início do desenvolvimento deu-se em 1956, as plantações ao fundo estão em sua melhor idade de produção, os rendimentos, no entanto, já decaem em razão da fertilidade logo exaurida do tereno arenoso no Norte Novíssimo. No meio da foto: Plantação de café jovem em desmatamento recente. A propriedade, entre média e grande, é dirigida por um administrador que emprega arrendatários de parte da propriedade (casa em primeiro plano) e camponeses.

Foto 4. Plantação de café em minifúndio no município de Marialva (Norte Novo de Maringá) (3 maio 1968)

Paisagem de cultivo com 25 anos de idade com sítios explorados economicamente pelo pequeno proprietário e poucas famílias de camponeses em solos férteis de terra-roxa da principal região cafeeira do Paraná. Ao fundo, a colônia Marialva, com características de cidade pequena, situada no divisor de águas. Localização: $660 \mathrm{~m}$ acima do nível do mar.

Foto 5. Plantações de café em pequenas propriedades agrícolas perto de Apucarana (29 maio 1965, foto aérea IBC-GERCA PR-URB-Apa. -04-072; fotografado à altitude de $2024 \mathrm{~m}$ acima do nível do mar; altitude em relação ao solo: aprox. 1050 a 1140 m)

Os sítios (na foto: 7-22 ha) na região da CTNP, medidos a partir de 1938 no sistema de corredor de faixa latitudinal (sobre o planalto: blocos, v. a parte superior esquerda da imagem) revelam uma estrutura agrária em minifúndios característica, morfologicamente condicionada. Do divisor de águas, sobre o qual passa o eixo de transporte (no máximo a $980 \mathrm{~m}$ acima do nível do mar), as plantações de café estendem-se até o terço mais baixo do declive, onde ficam as moradias e galpões de trabalho, com pequenas plantações (próximas às casas) de árvores frutíferas e produtos de subsistência. As regiões baixas são tomadas por campinas em razão do perigo de geada decorrente do acúmulo de ar frio. Na parte inferior da foto é possível verificar danos ocasionados nas plantações de café pela geada e pela erosão. Já se veem algumas plantações novas.

Foto 6. Plantação de café com um ano e culturas nos canteiros intermediários (13 jun. 1970)

Entre as fileiras de pés de café jovens plantadas em paralelo em relação ao declive ( 3 a 4 plantas por pé) são feitas plantações intermediárias de milho (na foto), arroz, feijão, soja e tremoço, até que o café atinja sua maturidade produtiva (no quarto ano).

Foto 7. Terreiro de um sítio no Norte Novo próximo a Apucarana (8 jul. 1965)

O sítio explorado economicamente por um meeiro e sua família só produz café como cash crop. O proprietário vive em Curitiba, capital do estado. As tarefas de peneirar e secar os grãos de café acontecem em um terreiro próprio, sua preparação se dá por meio dos 'maquinistas' do centro urbano mais próximo.

Foto 8. Paisagem agrícola próxima à cidade de Maringá (28 jun. 1970)

Pequena propriedade ( 9 ha) de colonizadores japoneses próxima a Maringá, destinada à policultura. Além da plantação de café também se faz, ainda mais orientado ao mercado, o cultivo de legumes e frutas, bem como a criação de aves.

Foto 9. Empreendimento de café e trigo na região de Campo Mourão (3 jul. 1970) 
A plantação de café de porte médio a grande (com culturas intermediárias) foi feita no esquema tradicional, na vertical em relação ao declive. Em razão do acúmulo de ar frio no vale fluvial (rio Campo Mourão) o terço mais baixo do declive é ocupado com trigo, revela, contudo, fortes danos ocasionados pela erosão, já que no cafezal não há quaisquer barreiras de terra para deter o fluxo das águas.

Foto 10. Fazenda de café próximo a Paiquerê (Norte Novo de Londrina) (foto aérea, 2 maio 1968)

Plantação de café paralela ao declive (altitude: 480-540 m acima do níve do mar) em um grande empreendimento (520 ha), bem organizado e com grande lastro de capital, $15 \mathrm{~km}$ ao sudeste de Londrina. Na área de vale, campinas, terreiro de secagem de café e colônia de camponeses.

Foto 11. Trabalhadores boias-frias (4 ago. 1970)

Em razão de novas leis trabalhistas e dos danos causados pela geada do ano de 1969, camponeses dispensados de seus contratos de trabalho são transportados em um caminhão pertencente ao "gato", o qual se apresenta como mediador de possibilidades de trabalho; para trabalhar por dia, na condição de itinerantes, o veículo os leva de suas atuais áreas de moradia, na periferia da cidade, até os cafezais (Londrina-Cambé).

Foto 12. Favela na periferia urbana de Londrina (5 ago. 1970)

O retrocesso da importância do cultivo de café, com a dispensa de trabalhadores rurais, e a continuidade ainda bastante acentuada da migração suprarregional, sobretudo proveniente do Nordeste, levaram ao surgimento de bairros pobres na periferia dos maiores centros urbanos do Norte Novo, cuja capacidade de gerar novos postos de trabalho já está esgotada.

Foto 13. Plantações de café depois de estragos causados pela geada no município de Rolândia (10 ago. 1970)

No Norte Novo do Paraná, sempre que havia condições de solo e altitude favoráveis, as plantações de café congeladas eram substituídas por novas plantações de variedades mais rentáveis e resistentes à geada ('Mundo Novo'). A erradicação dos velhos pés de café congelados e a realização mecanizada de buracos, paralelos ao declive, para a plantação de pés de café distantes cerca de $4 \mathrm{~m}$ entre si, a partir dos cachos de sementes, exigem investimentos altos, facilitados pela concessão de créditos estatais.

Foto 14. Transição da monocultura do café à policultura no Norte Novo (10 set. 1970)

Em decorrência dos danos causados pela geada na plantação de café, e após a erradicação de uma parte dos pés de café na área fortemente ameaçada por novas geadas, firmou-se sobretudo o cultivo de trigo e teve início, assim, a fase da policultura.

Foto 15. Estragos causados pela geada no cafezal e adaptação à atividade pecuária (18 jun. 1970)

Depois da forte geada de 1969, partes das plantações de café congelaram totalmente e foram abandonadas. Mesmo antes da erradicação dos pés de café, ocorreu a semeadura de gramíneas e a alteração rumo à economia pecuária ('Nelore' e cruzamentos de 'Santa Gertrudis', 'Gir', 'Charolais' etc.)

Foto 16. Pecuária extensiva em campos desmatados no Norte Novíssimo do Paraná (7 out. 1970).

Os restos das florestas úmidas tropicais-subtropicais no valo do Piquiri (30 km a leste de Guaíra) foram desmatadas em meados dos anos 1960 para se tornarem campos de cultivo. Na ghost forest com suas ruínas de árvores carbonizadas foi semeada a gramínea 'Guinea' (Panicum maximum; chamado "colonião" no Brasil) para a criação de gado zebu ('Nelore'). Queimadas extensivas, assim como oa ocupação excessiva das pastagens ocasionaram danos por erosão, sobretudo nos solos arenosos do Noroeste do Paraná.

Todas as fotos - com exceção da n. 5 - foram tiradas pelo Autor. 
FOTOS 


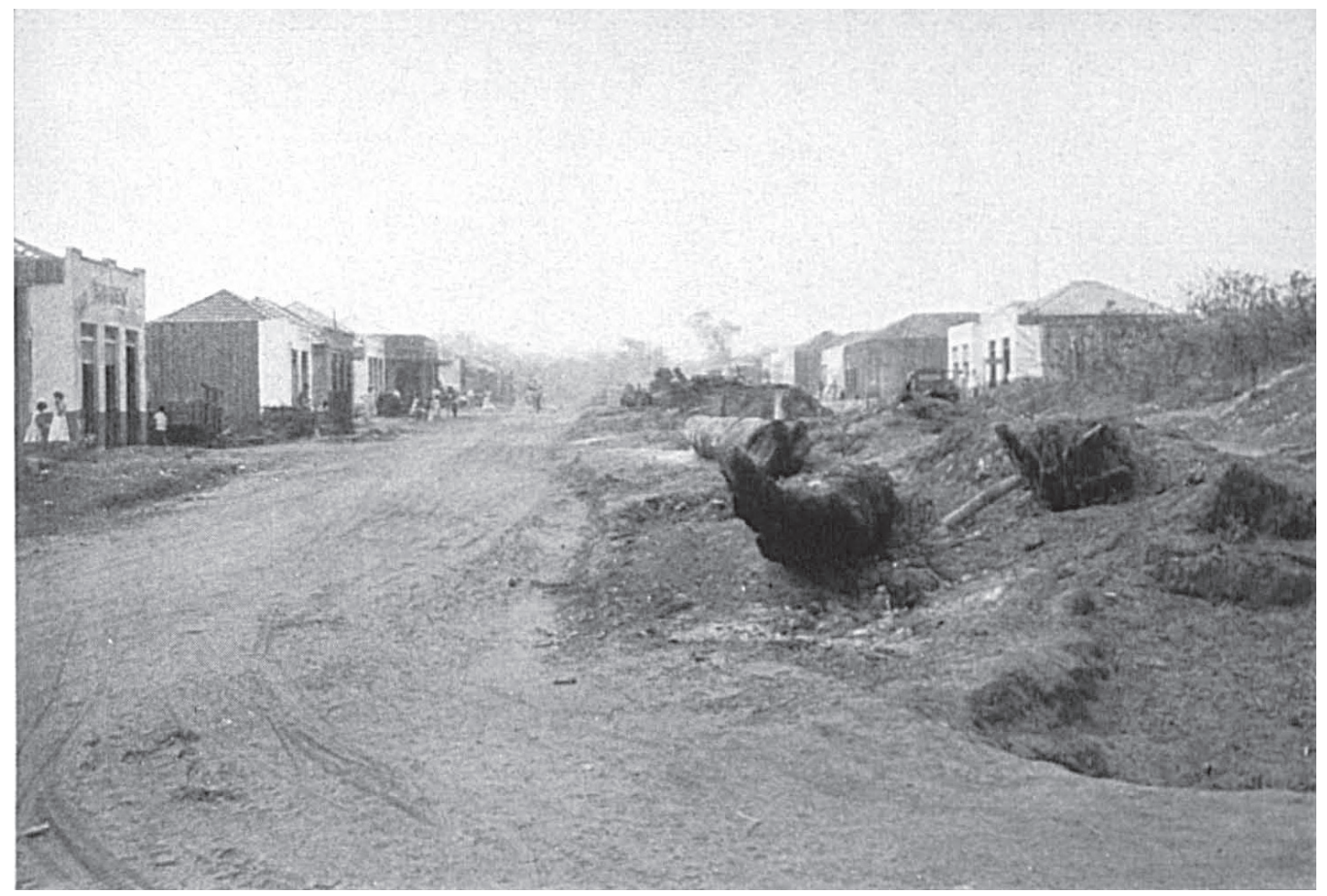

Foto 1: Altônia. Jovem colônia no frontier do Norte Novíssimo do Paraná

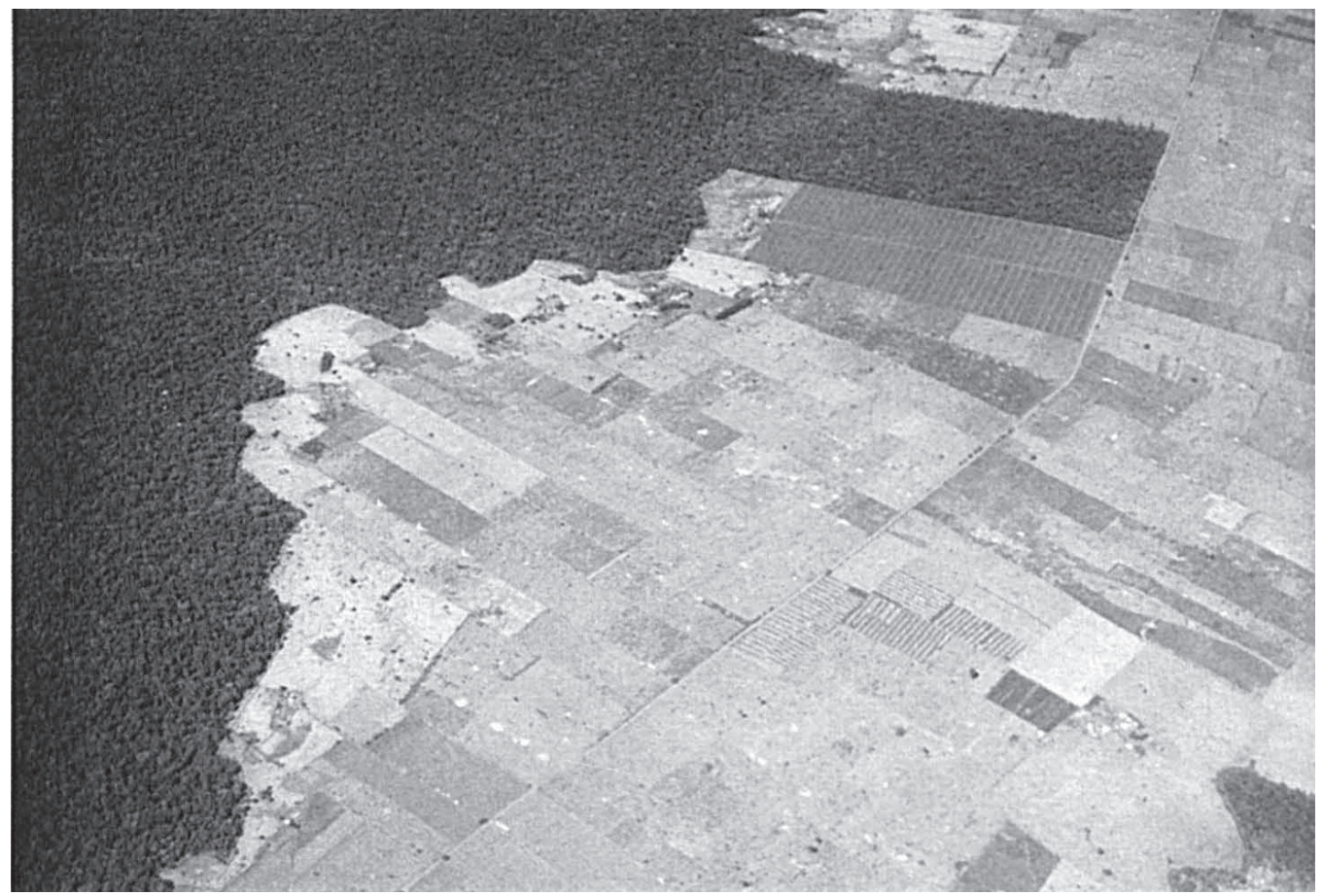

Foto 2: Avanço da frente pioneira próximo a Tapira (Norte Novíssimo de Umuarama) (foto aérea) 


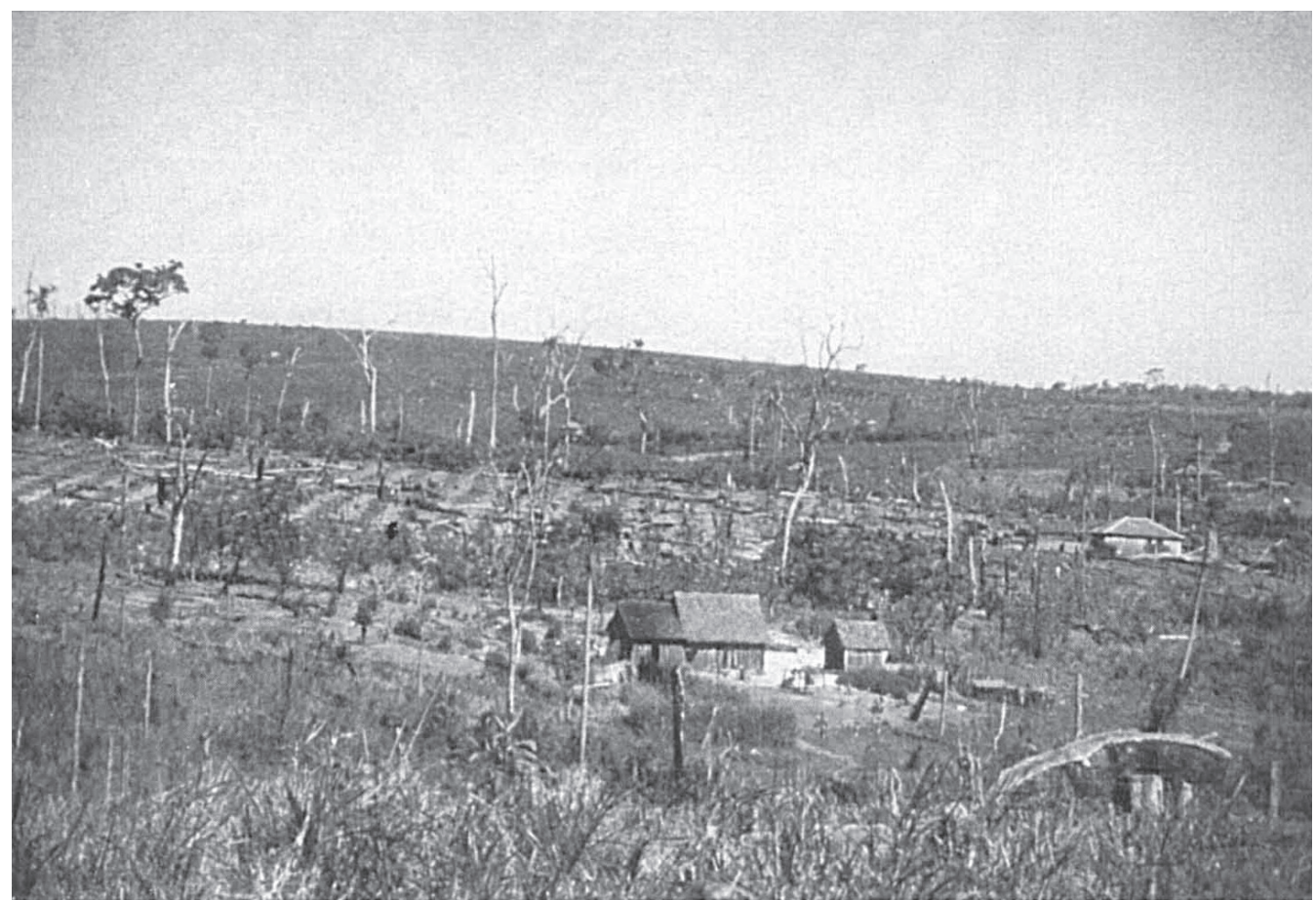

Foto 3: Paisagem de cultivo no final da fase pioneira entre Umuarama e Iporã

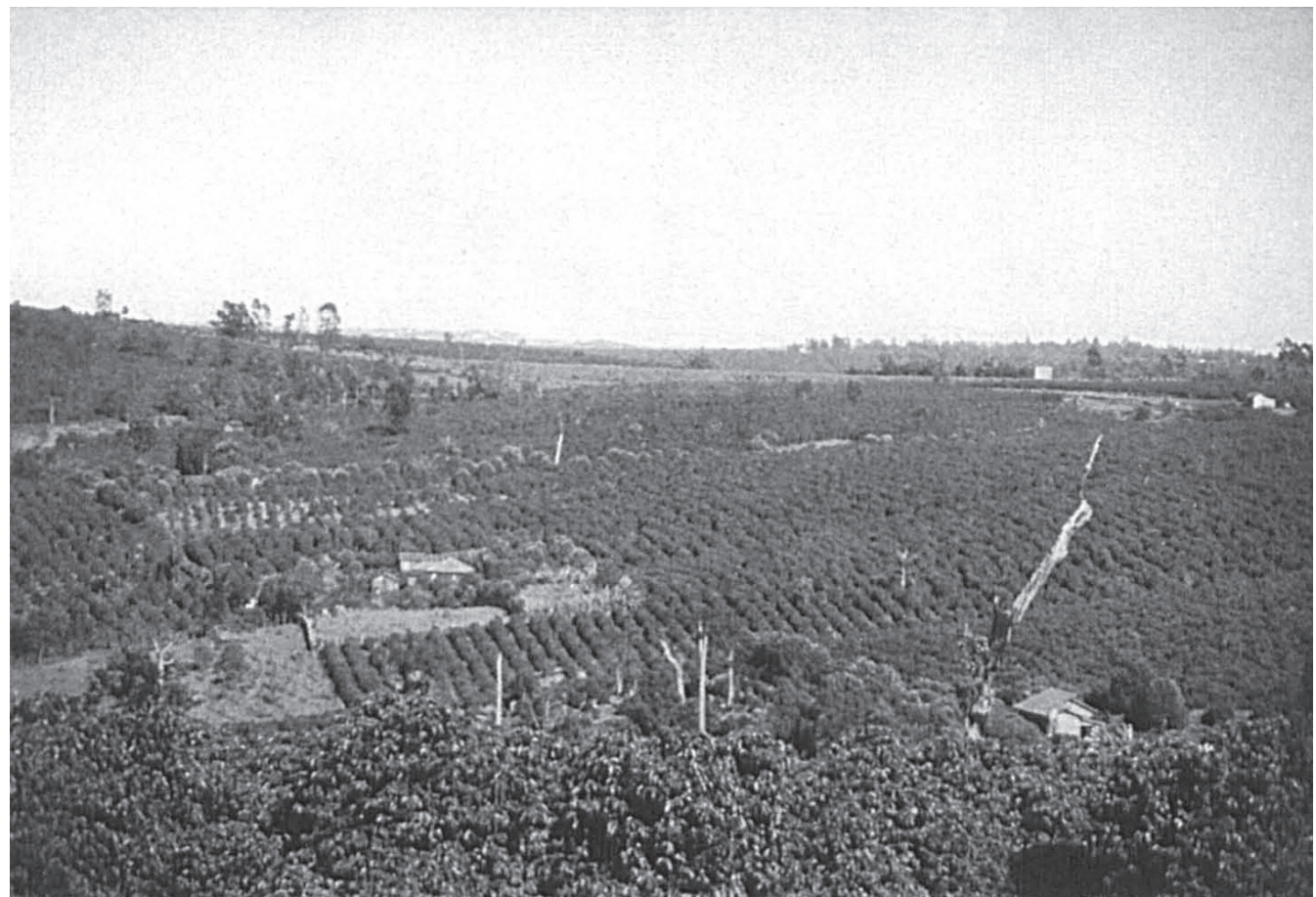

Foto4:PlantaçãodecaféemminifúndionomunicípiodeMarialva(NorteNovodeMaringá) 


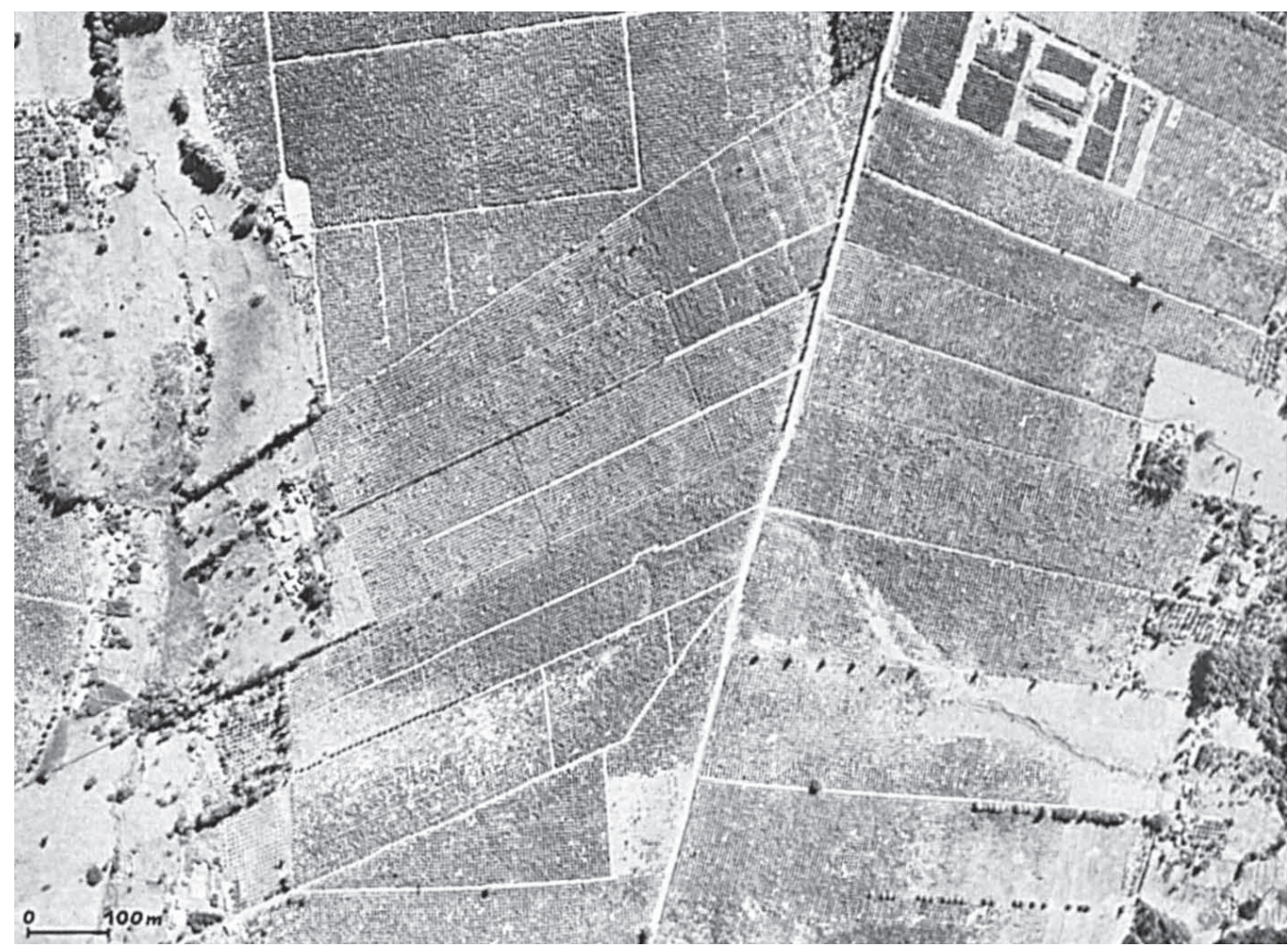

Foto 5: Plantações de café em pequenas propriedades agrícolas perto de Apucarana (foto aérea)

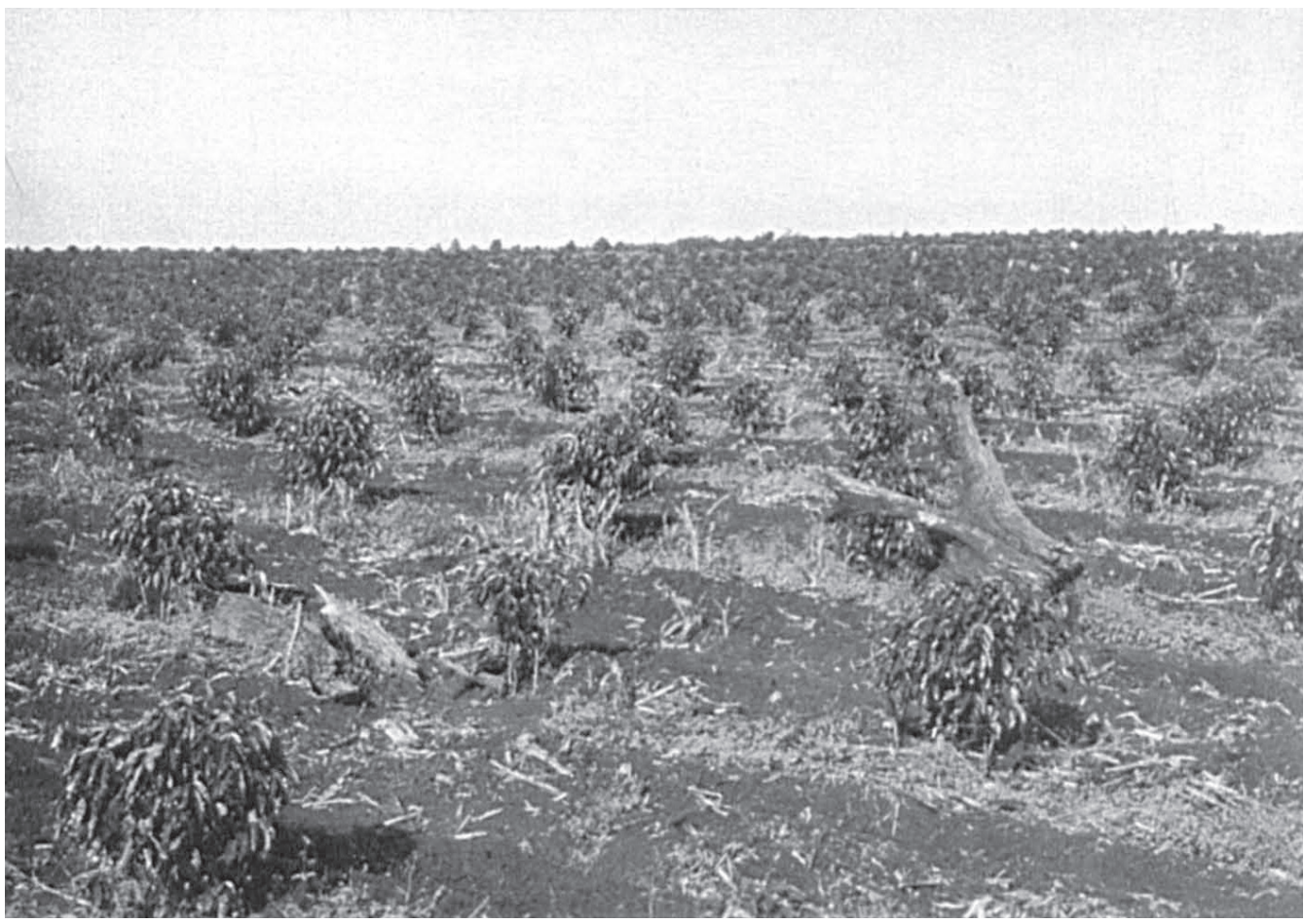

Foto 6: Plantação de café com um ano e culturas nos canteiros intermediários 


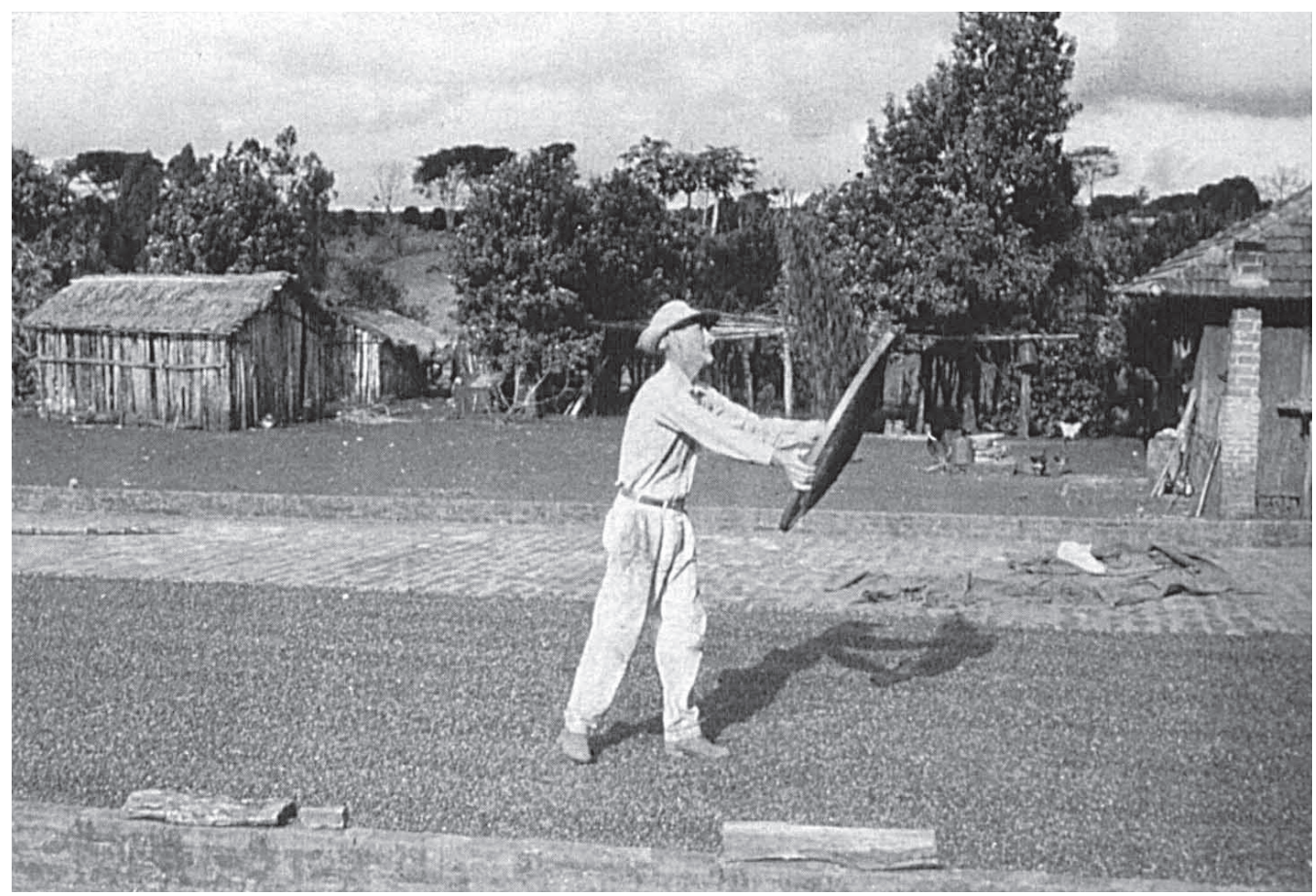

Foto 7: Terreiro de um sítio no Norte Novo próximo a Apucarana

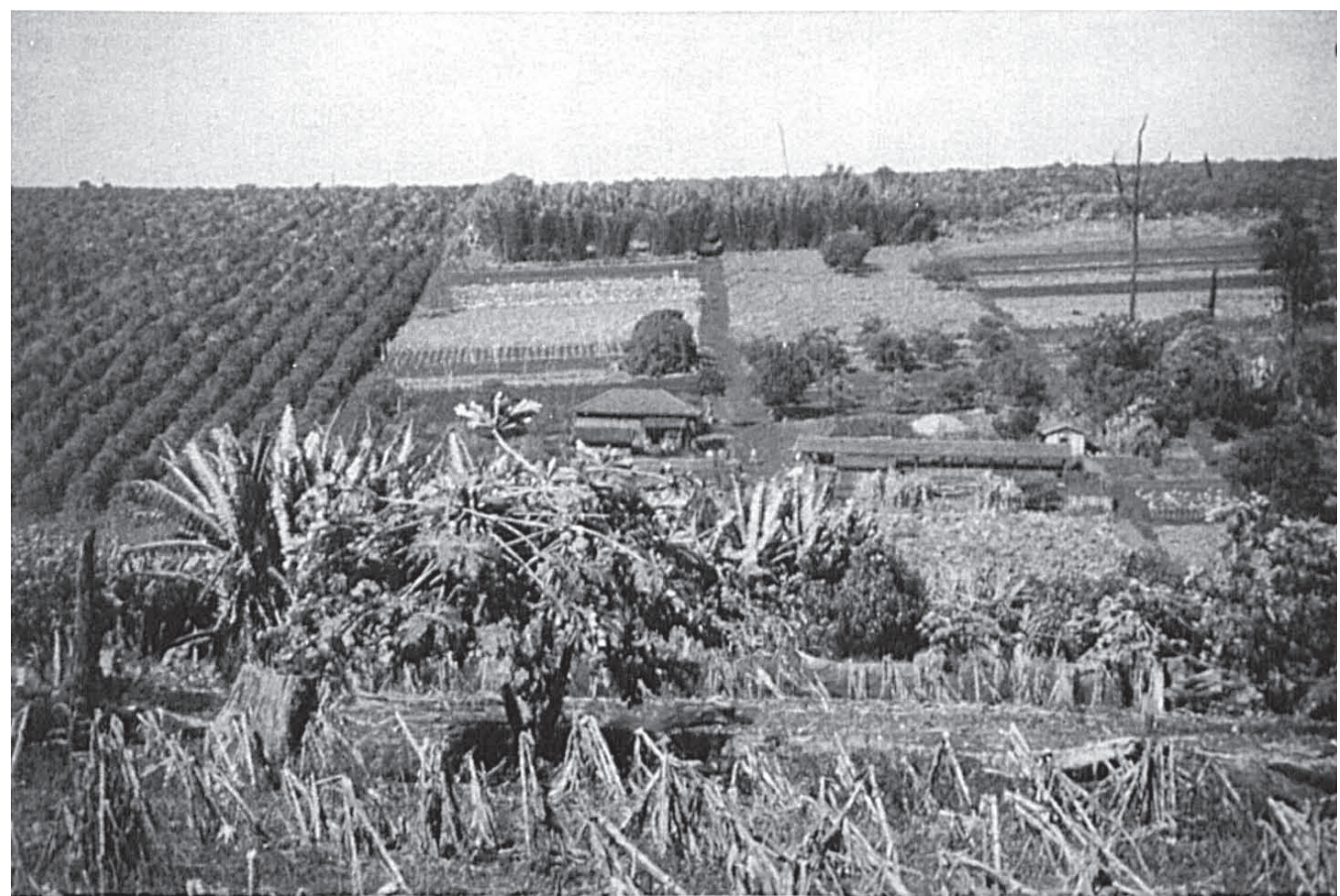

Foto 8: Paisagem agrícola próxima à cidade de Maringá 


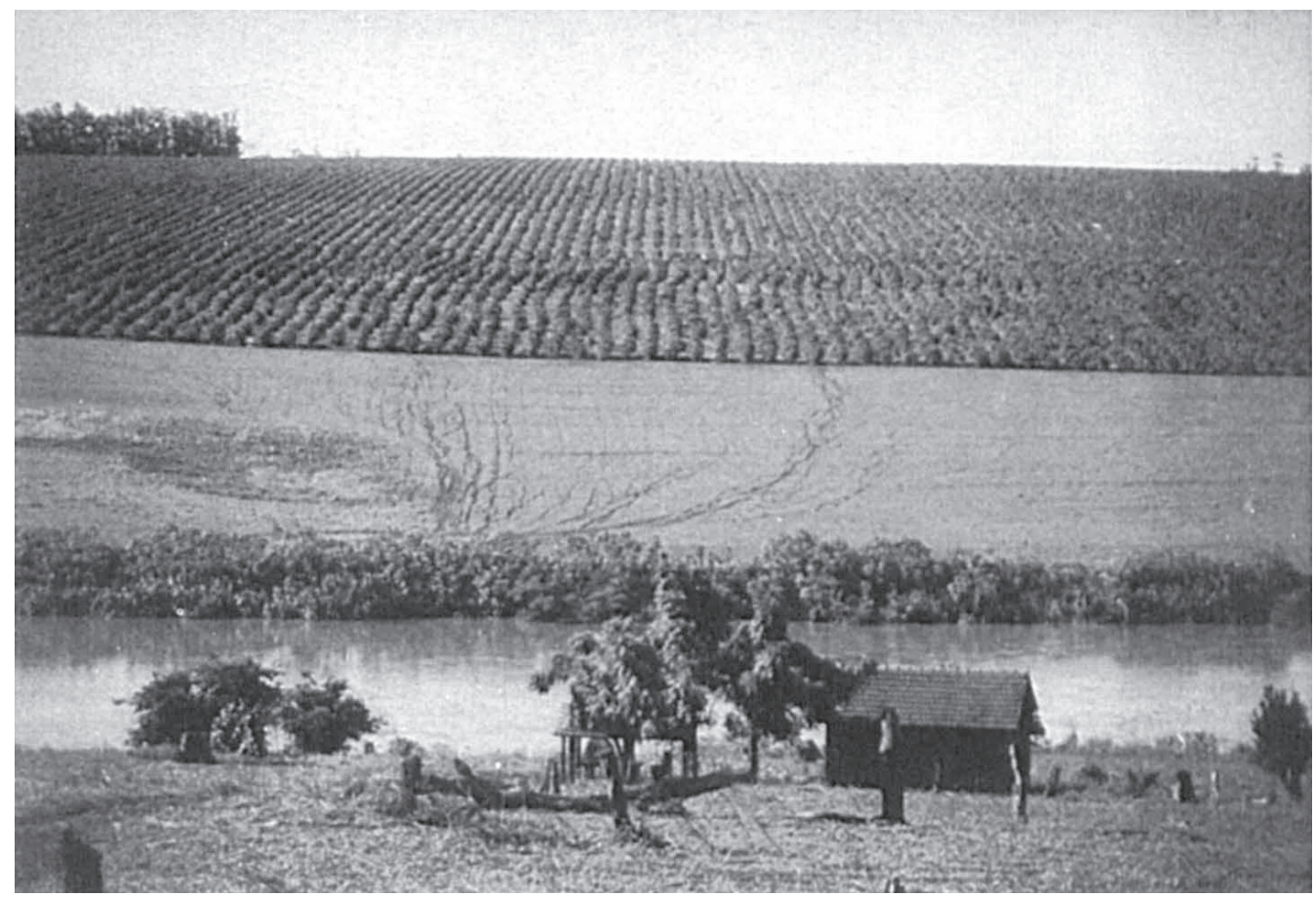

Foto 9: Empreendimento de café e trigo na região de Campo Mourão

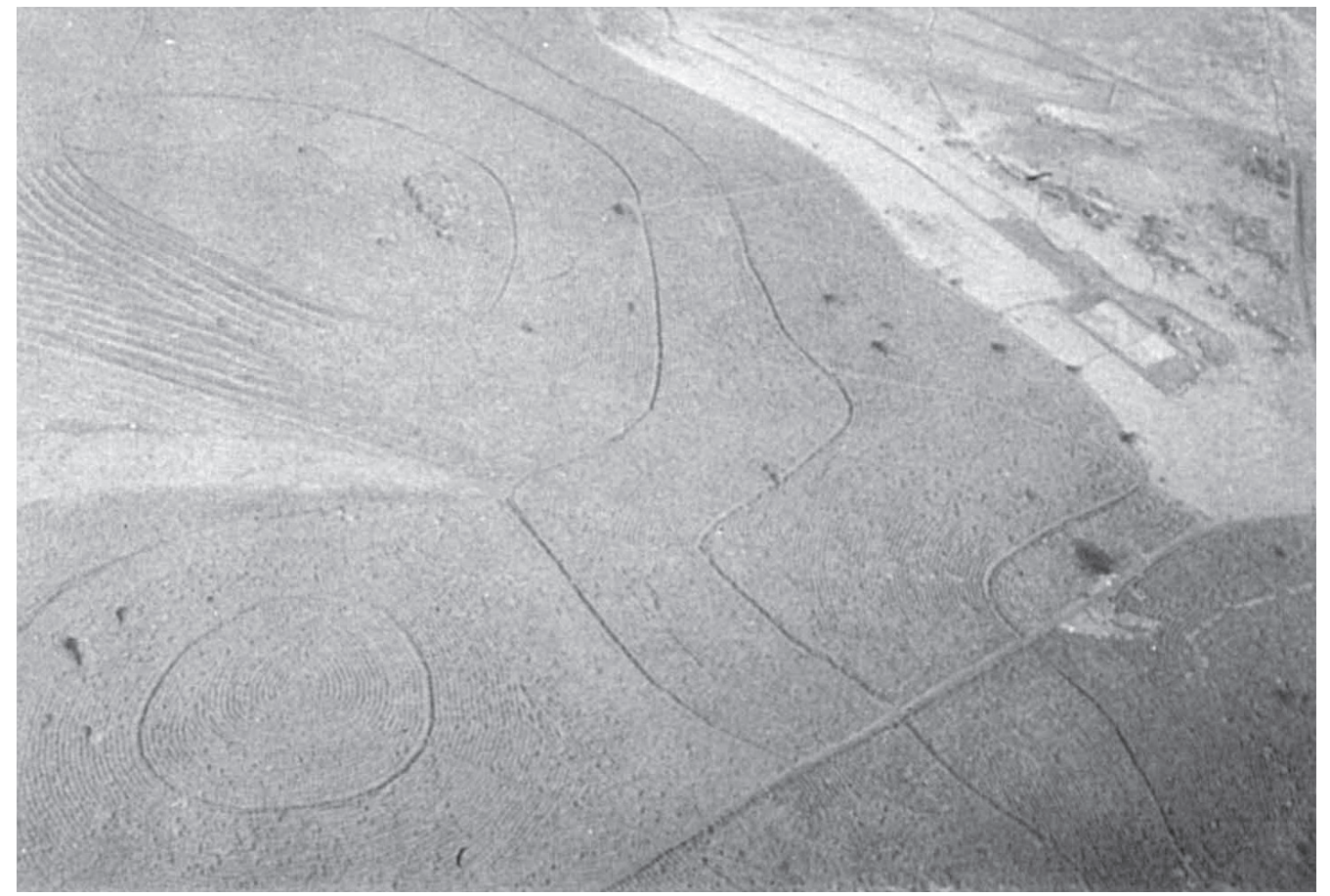

Foto 10: Fazenda de café próximo a Paiquerê (Norte Novo de Londrina) (foto aérea) 


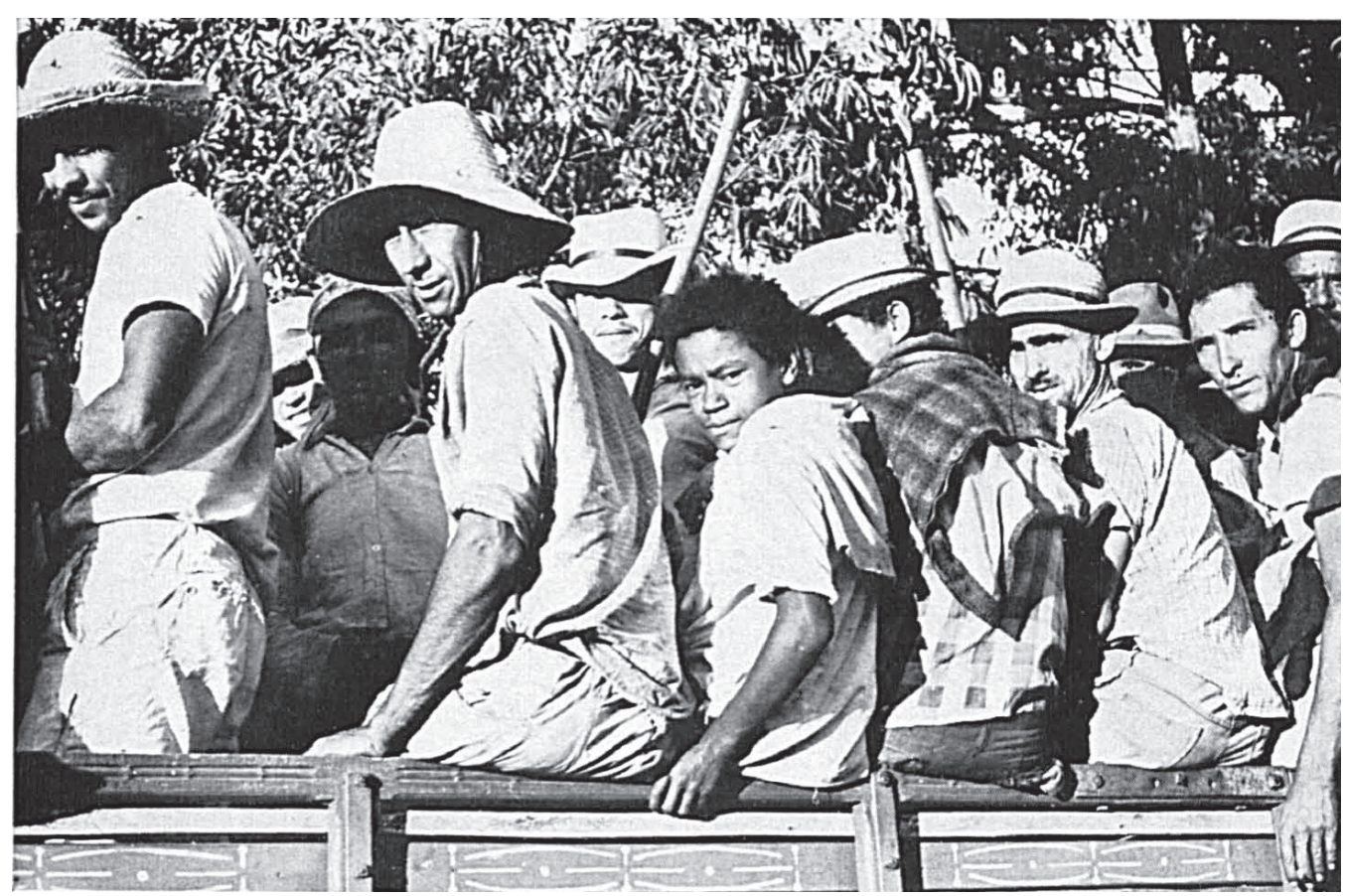

Foto 11: Trabalhadores boias-frias

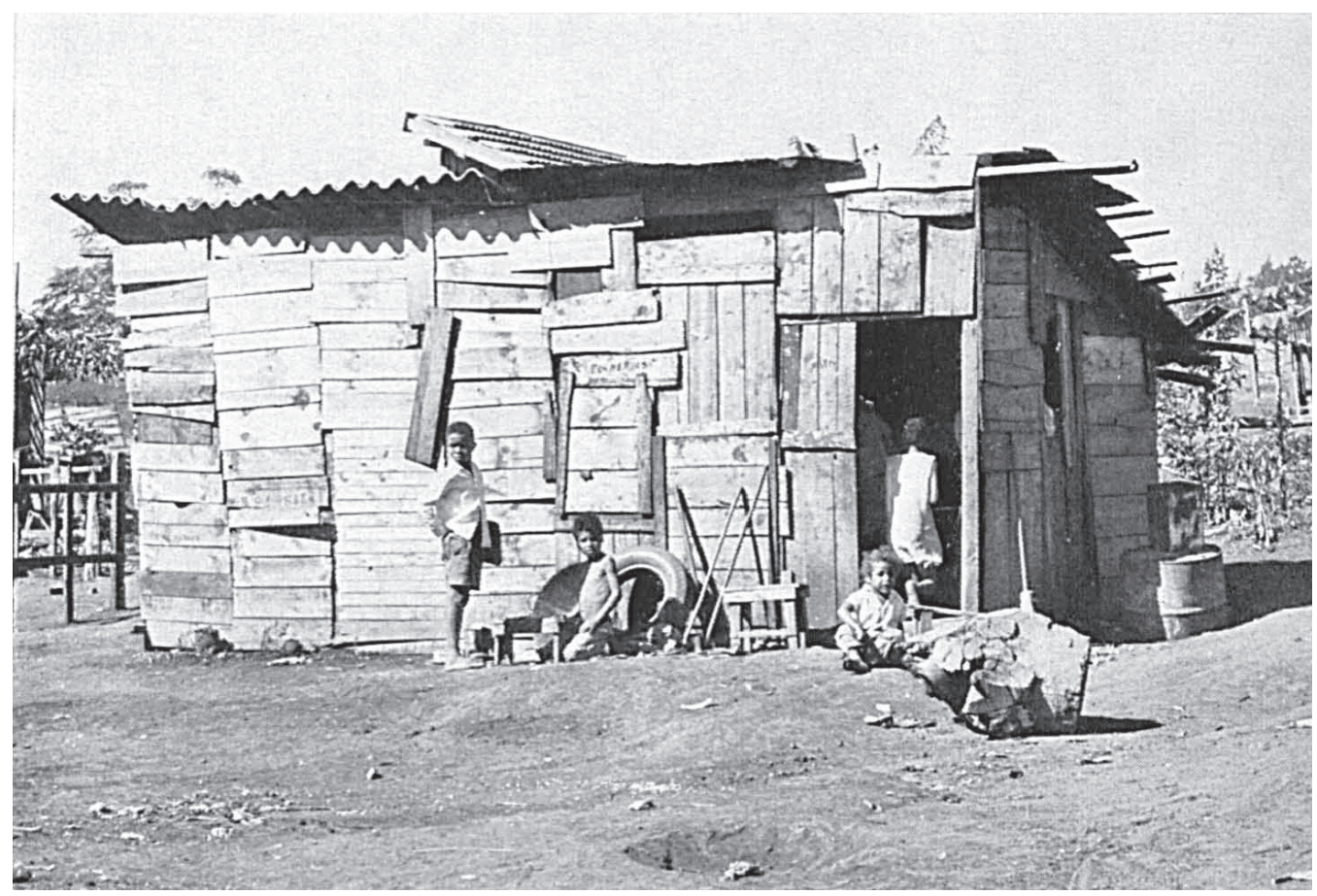

Foto 12: Favela na periferia urbana de Londrina 


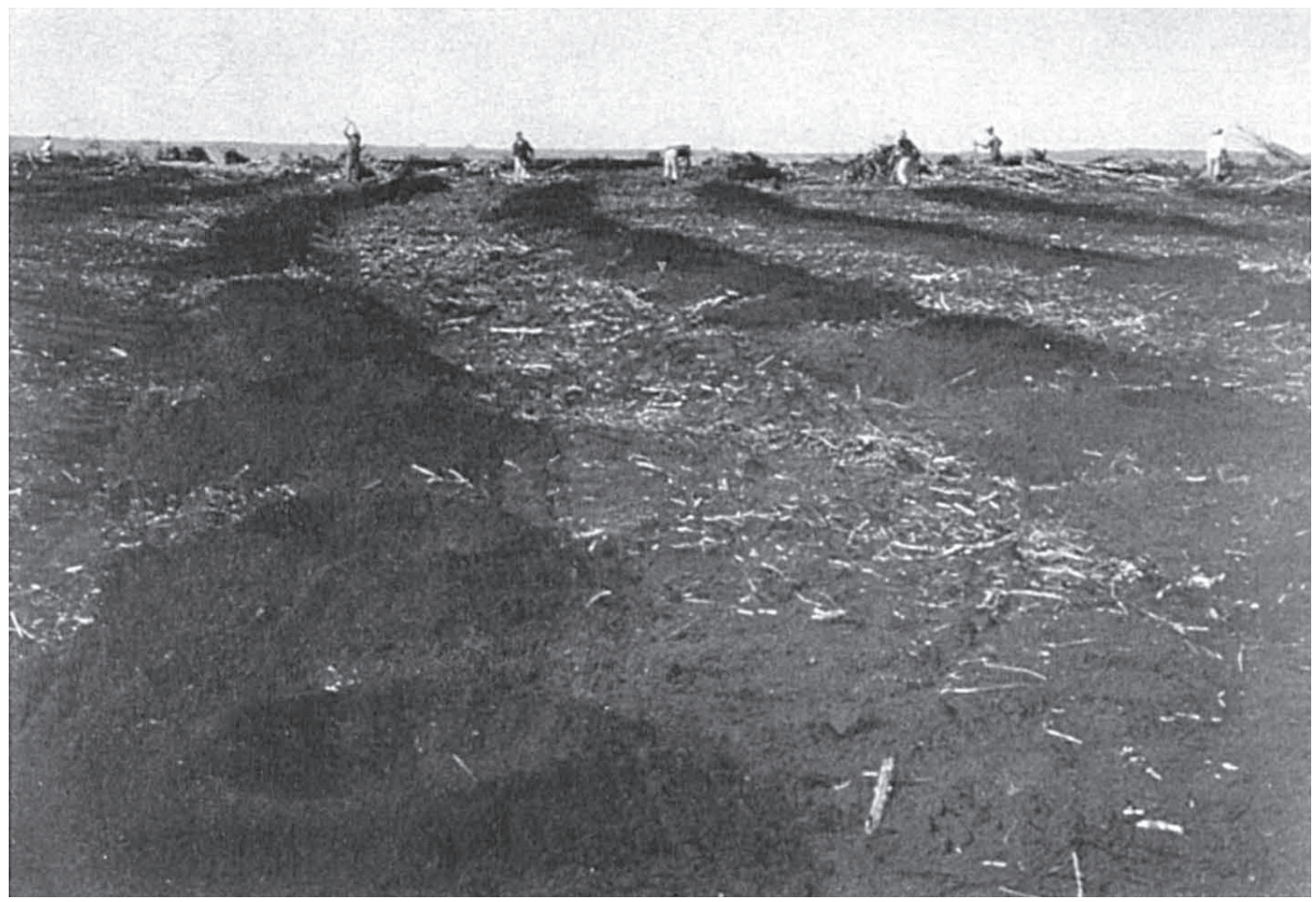

Foto 13: Plantações de café depois de estragos causados pela geada no município de Rolândia

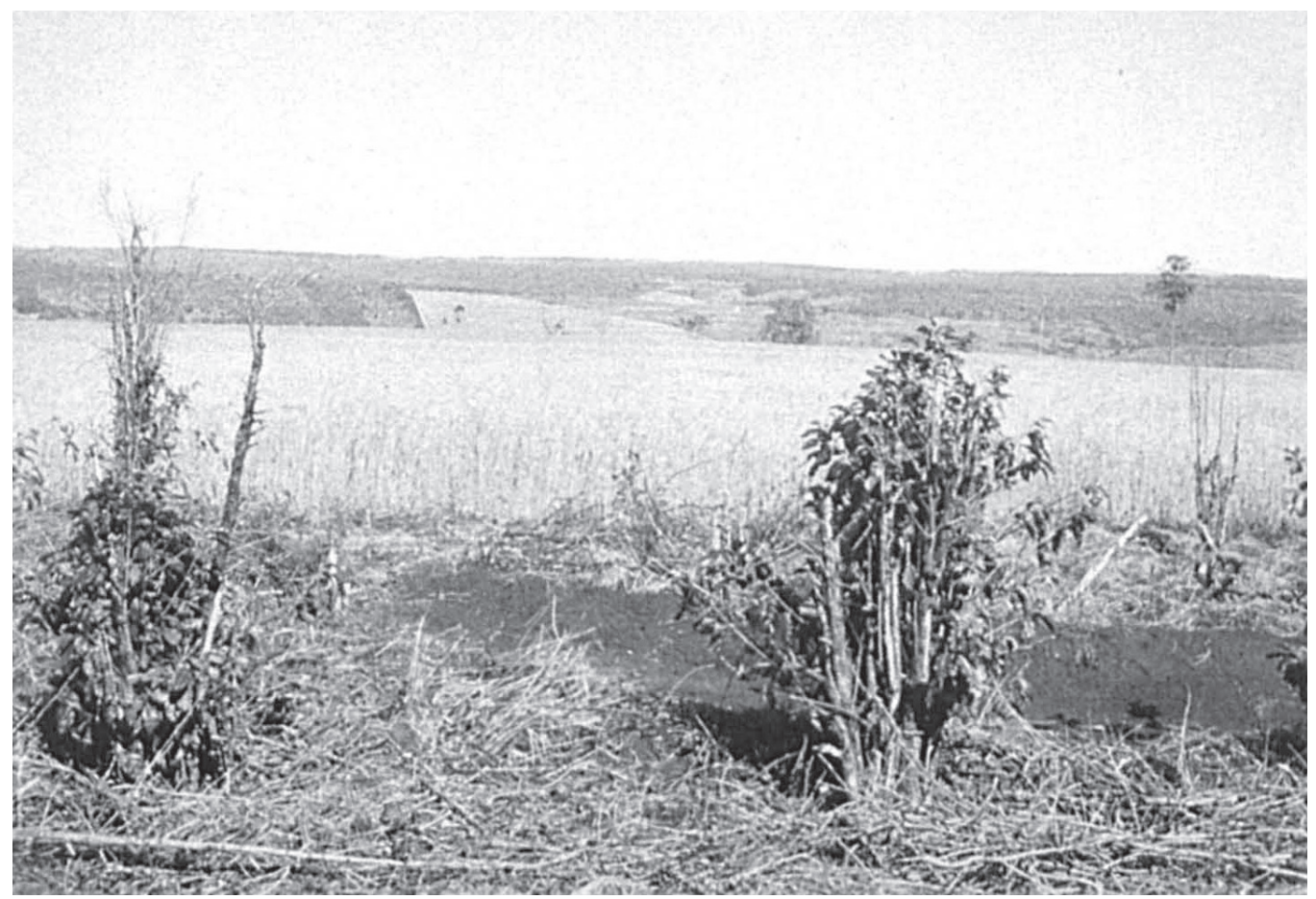

Foto 14: Transição da monocultura do café à policultura no Norte Novo 


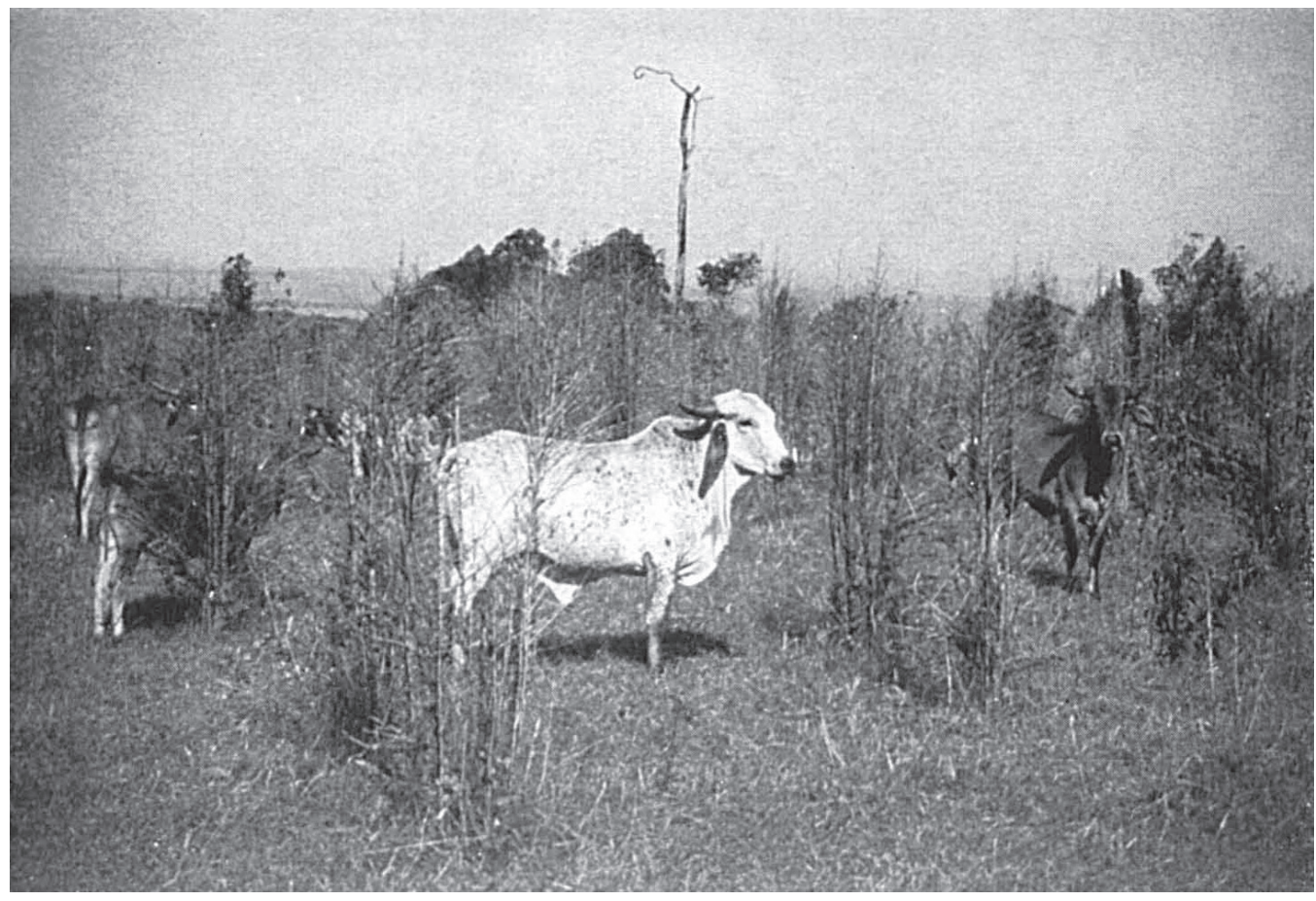

Foto 15: Estragos causados pela geada no cafezal e adaptação à atividade pecuária

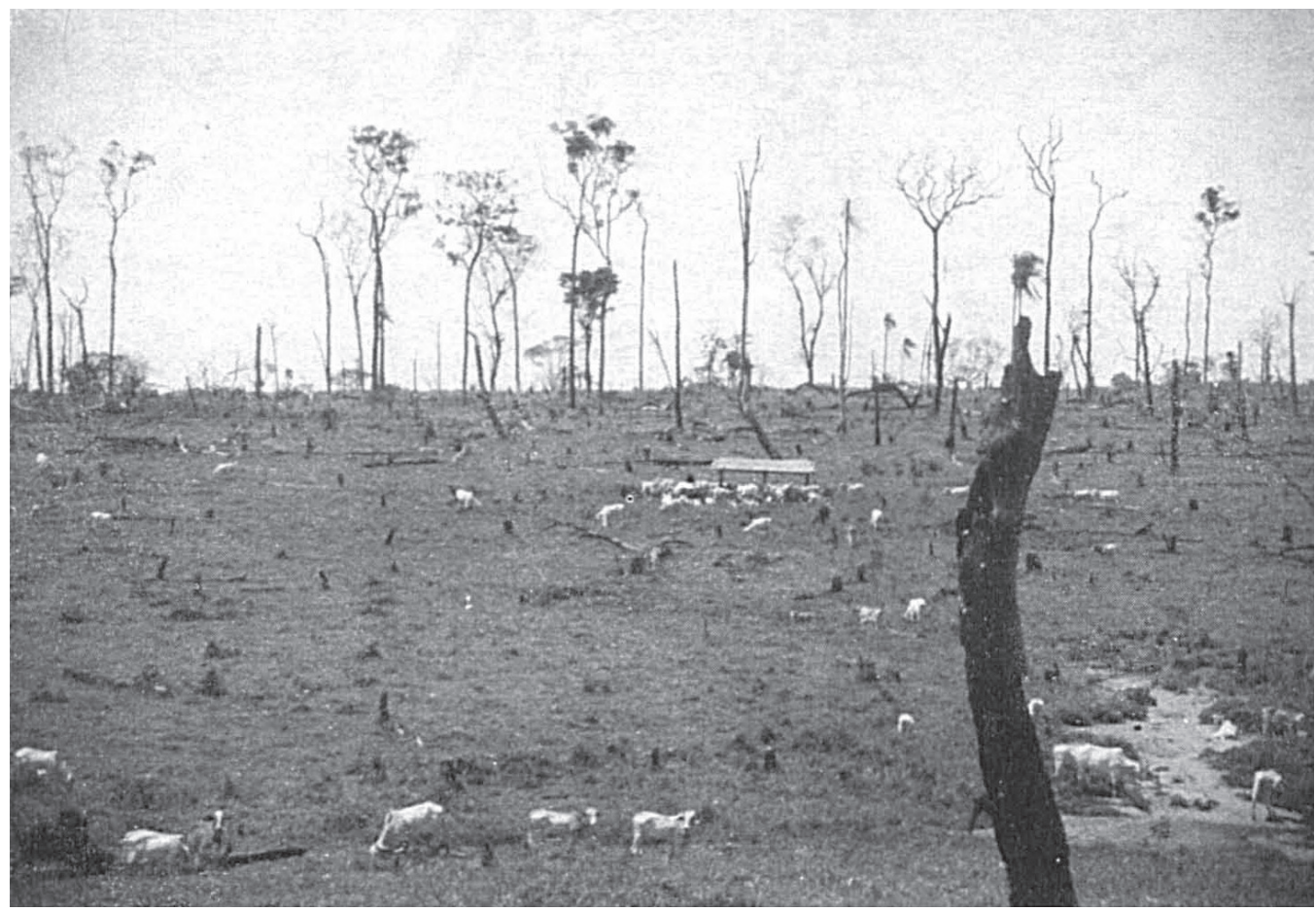

Foto 16: Pecuária extensiva em campos desmatados no Norte Novíssimo do Paraná 


\section{MAPAS}




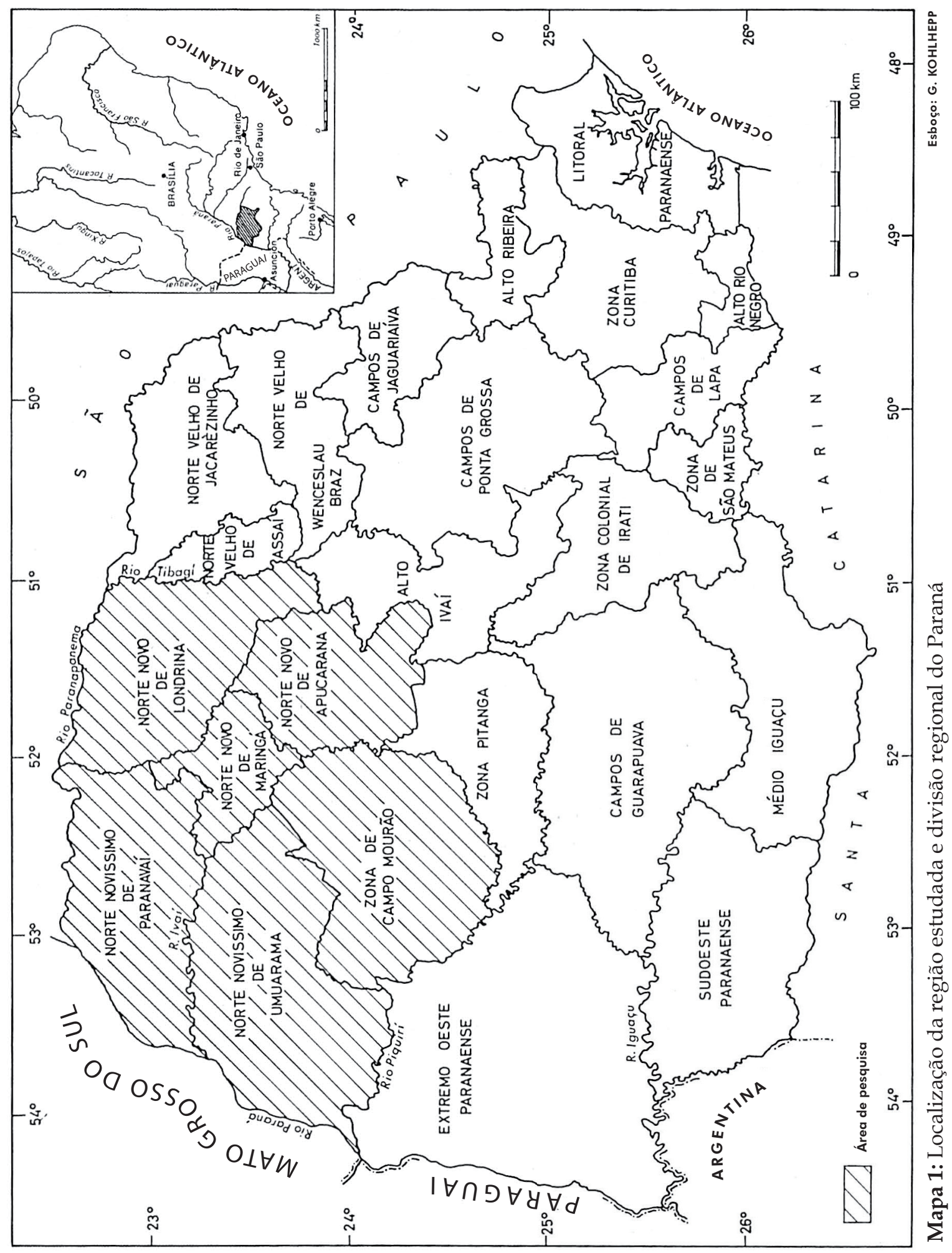




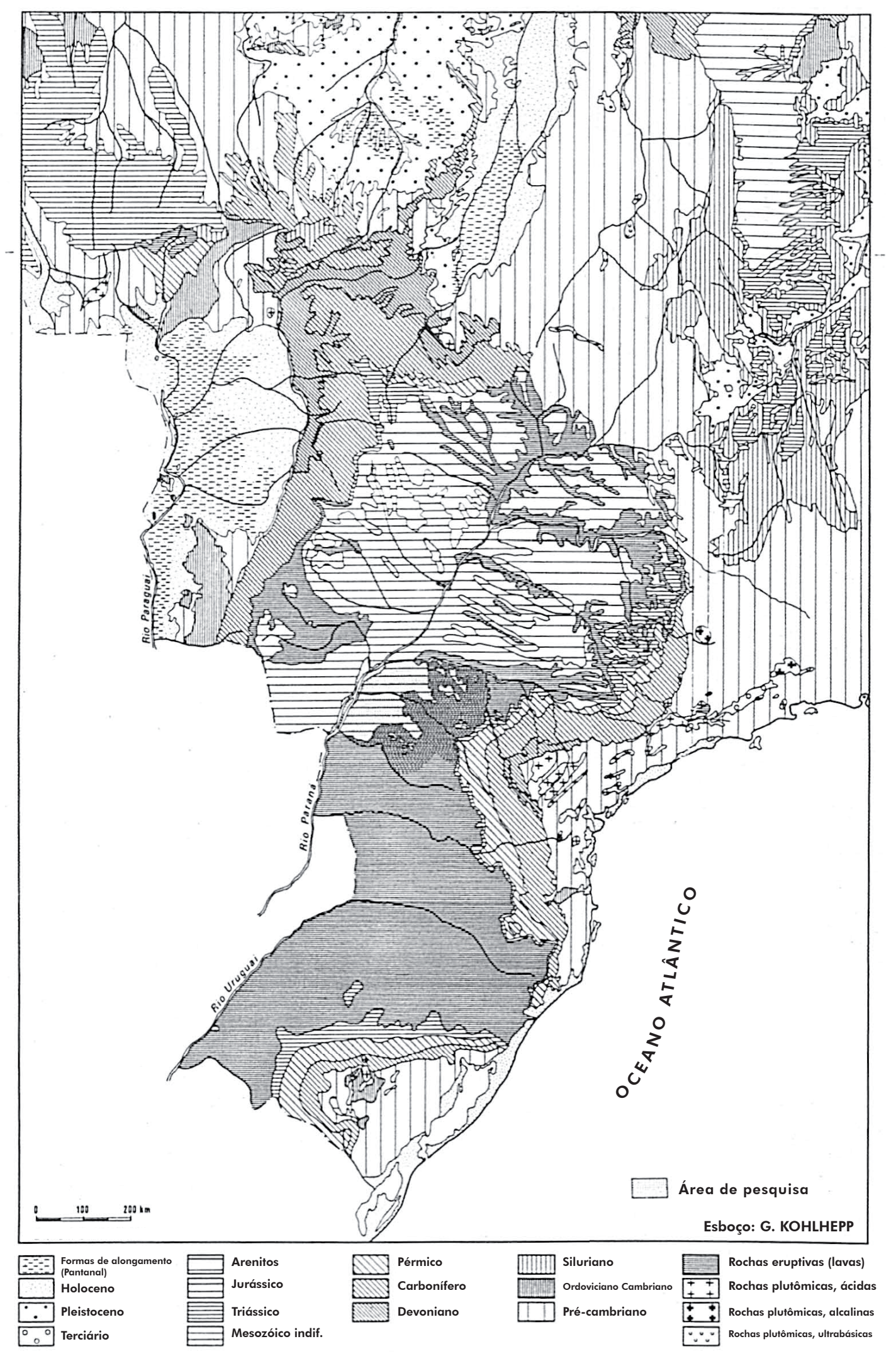

Mapa 2: Panorama geológico 

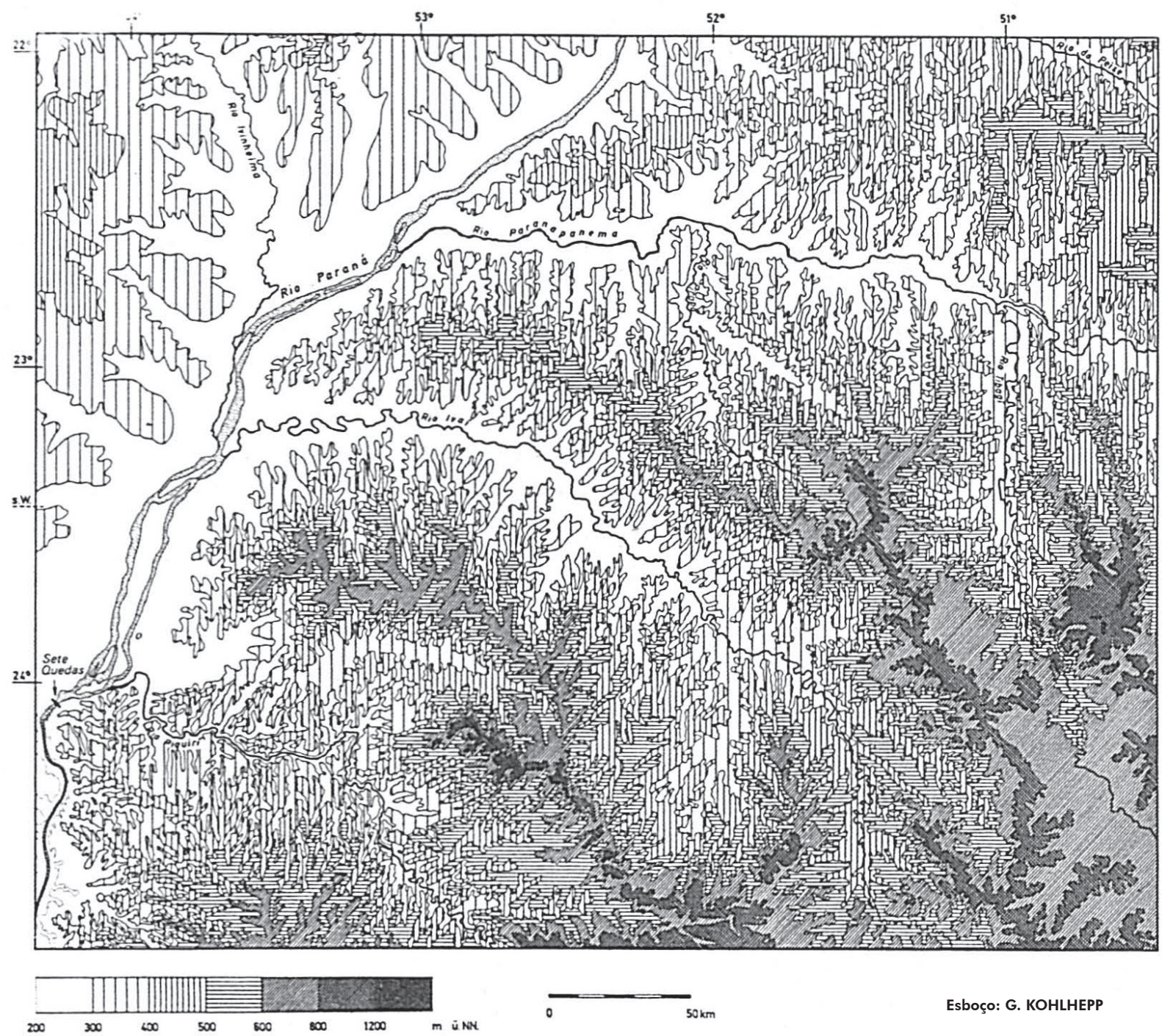

Esboço: G. KOHLHEPP

Mapa 3: Relações de atitude 


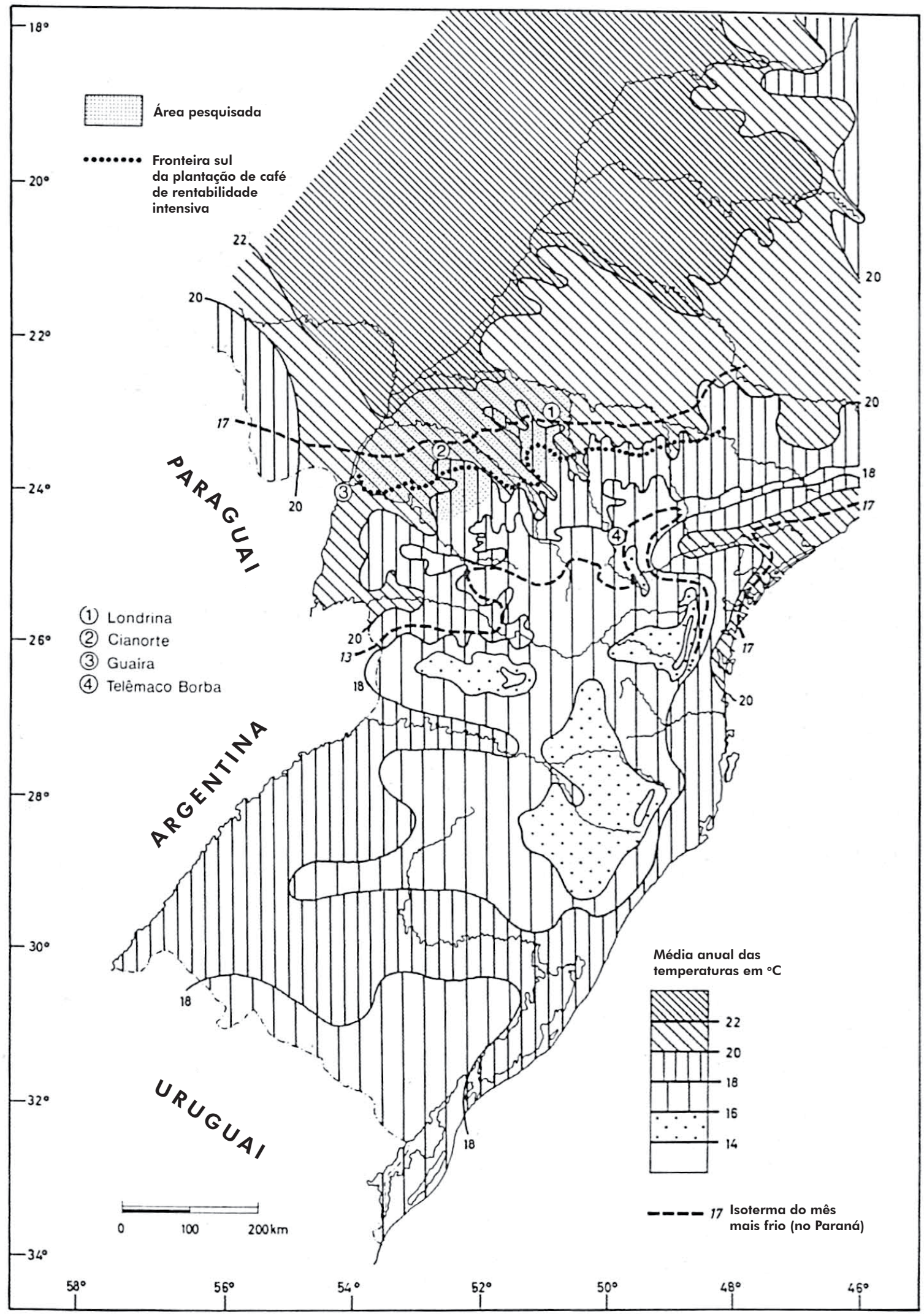

Mapa 4: Temperaturas médias anuais no Sul do Brasil 


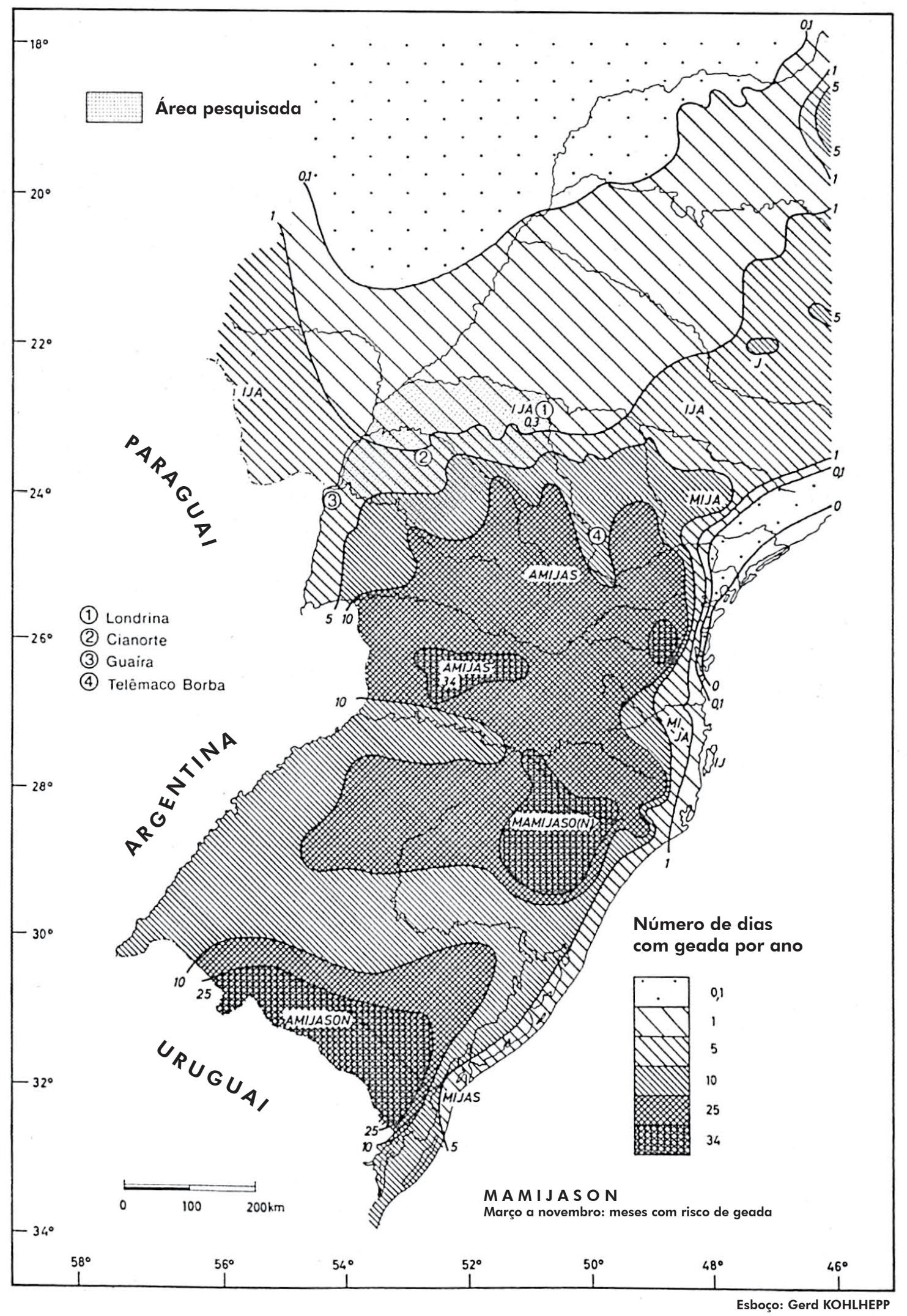

Mapa 5: Número médio de dias de geada por ano no Sul do Brasil 


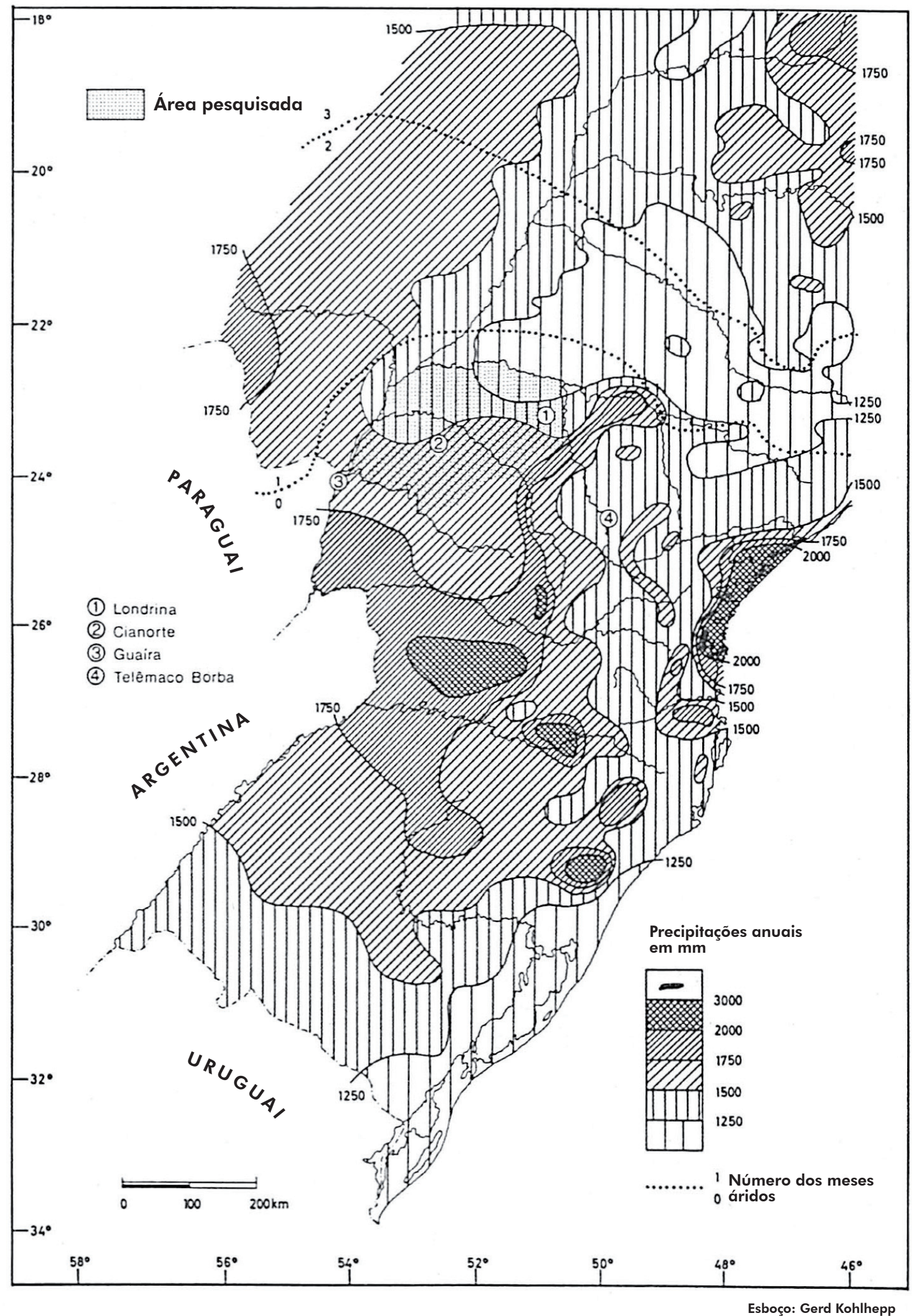

Mapa 6: Precipitações anuais médias e número de meses áridos no Sul do Brasil 


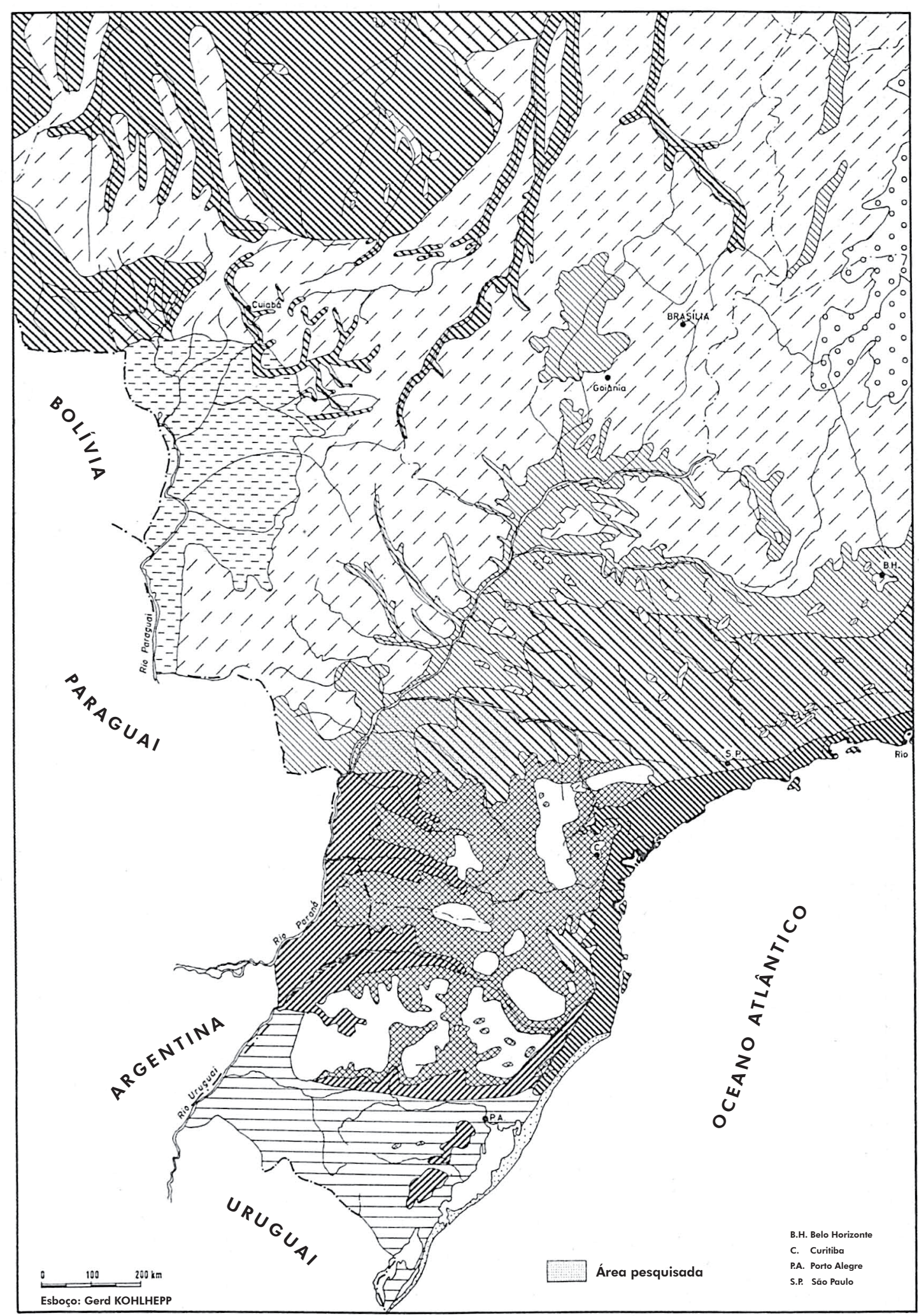

வ

Mapa 7: Vegetação natural. Mapa panorâmico 


\section{Legenda para 0}

\section{Mapa 7}

1. Floresta amazônica úmida persistente (Hileia)

2. Floresta tropical úmida persistente da costa atlântica montanhosa

3. Floresta tropical úmida com elementos deciduais

4. Floresta tropical úmida semi-decidual

5. Floresta subtropical úmida persistente

6. Cerradão: vegetação de transição entre a floresta tropical úmida e os campos cerrados

7. Floresta úmida e verde: seca, espinhosa e suculenta (caatinga)

8. Floresta com araucárias

9. Pantanal

10. Campos cerrados

11. Campos limpos (pradarias subtropicais do altiplano sub-brasileiro)

12. Estepes e pradarias extra-tropicais (campanha)

13. Regiões principais de vegetação praiana pramófila (dunas e restingas)

14. Mangue 


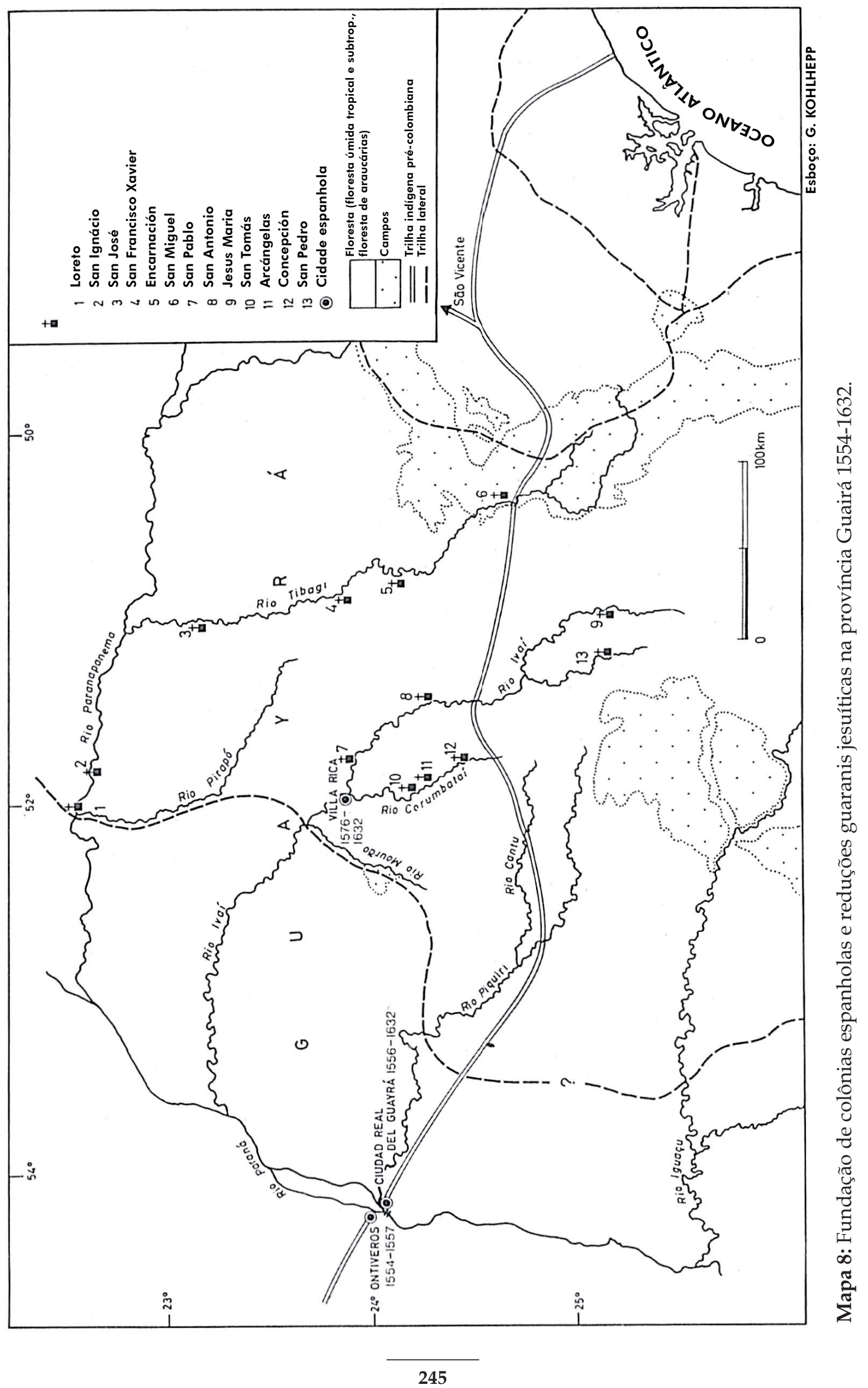




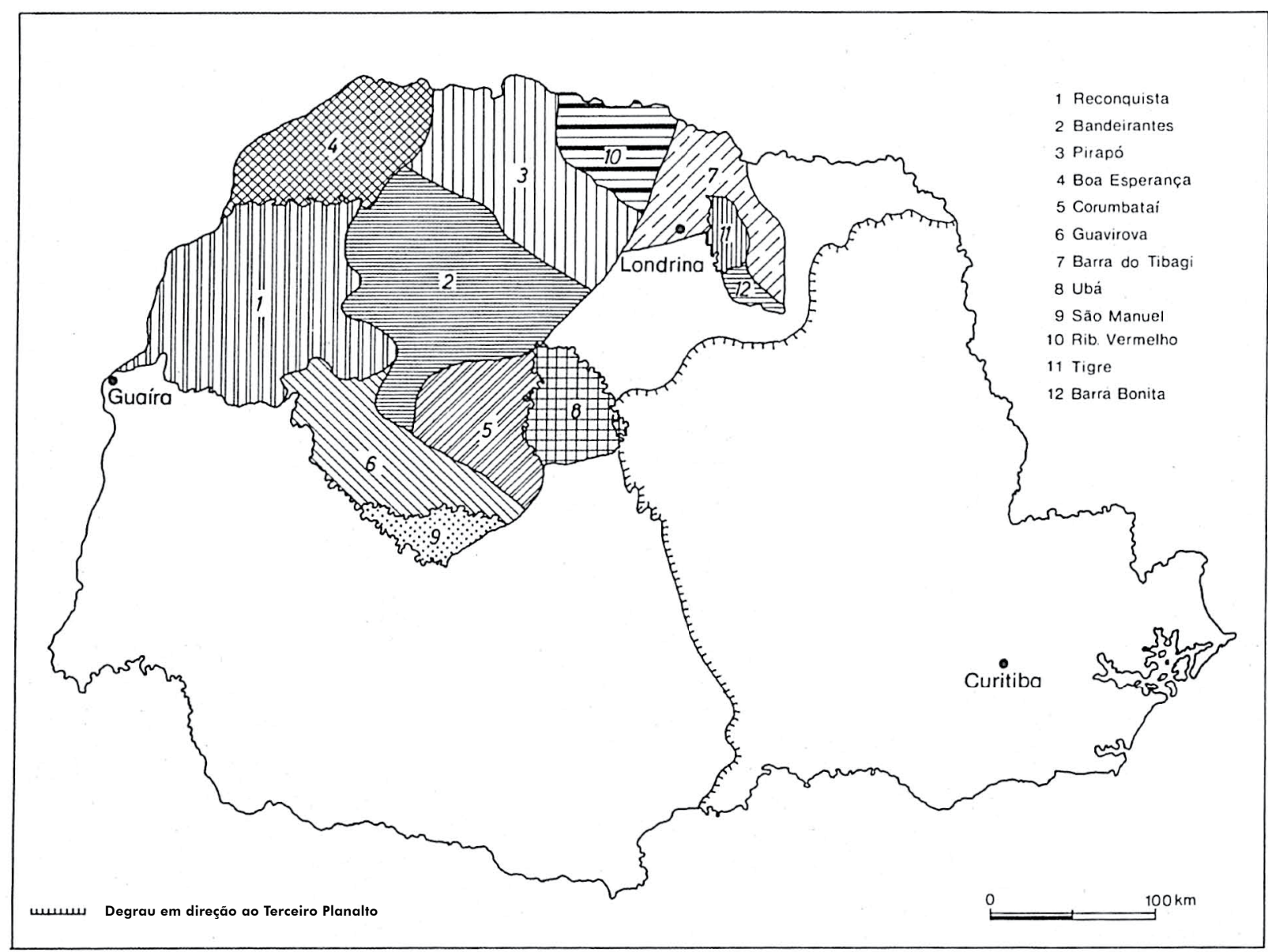

Mapa 9: Grilos no Norte do Paraná 


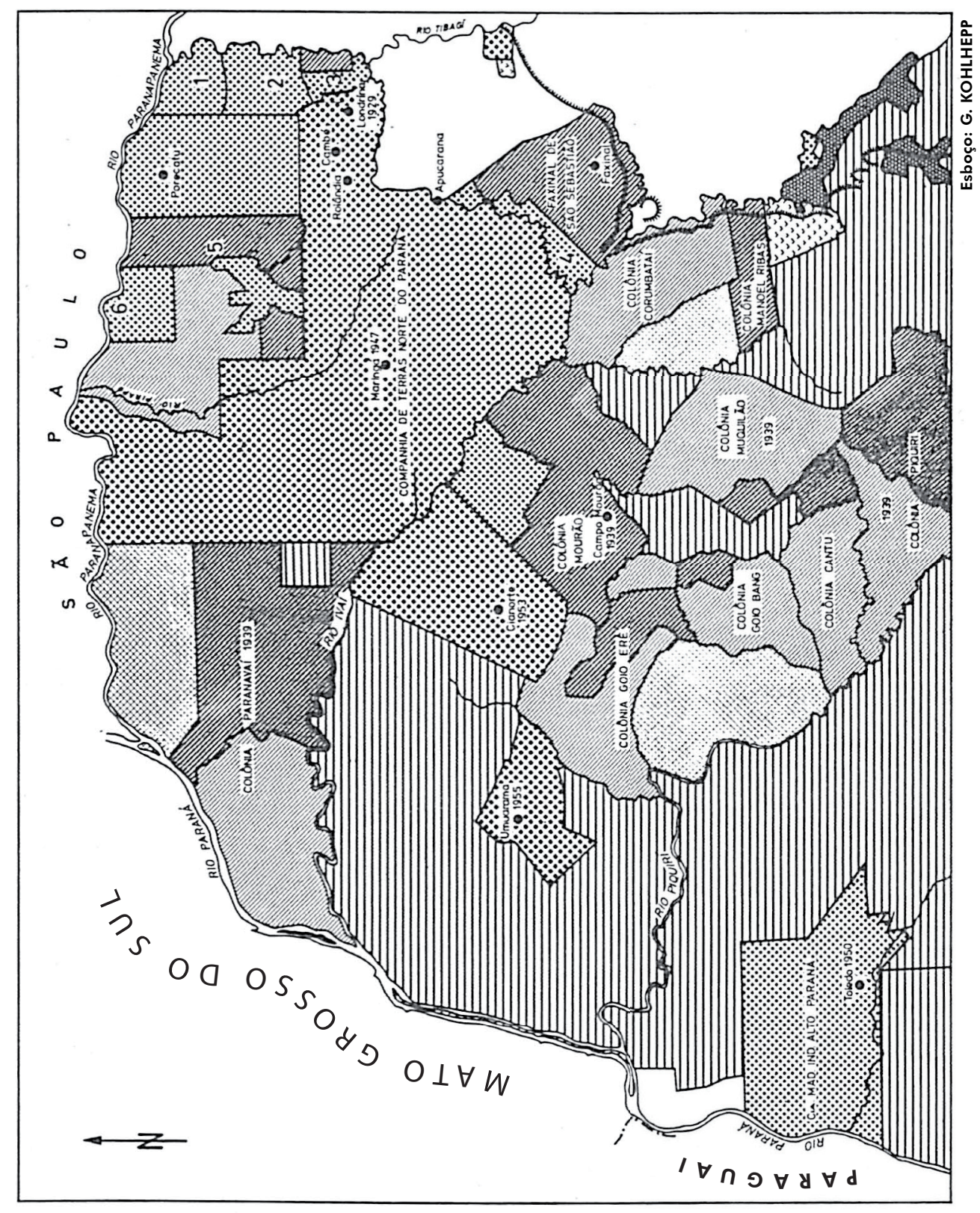

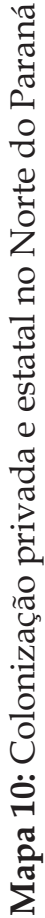




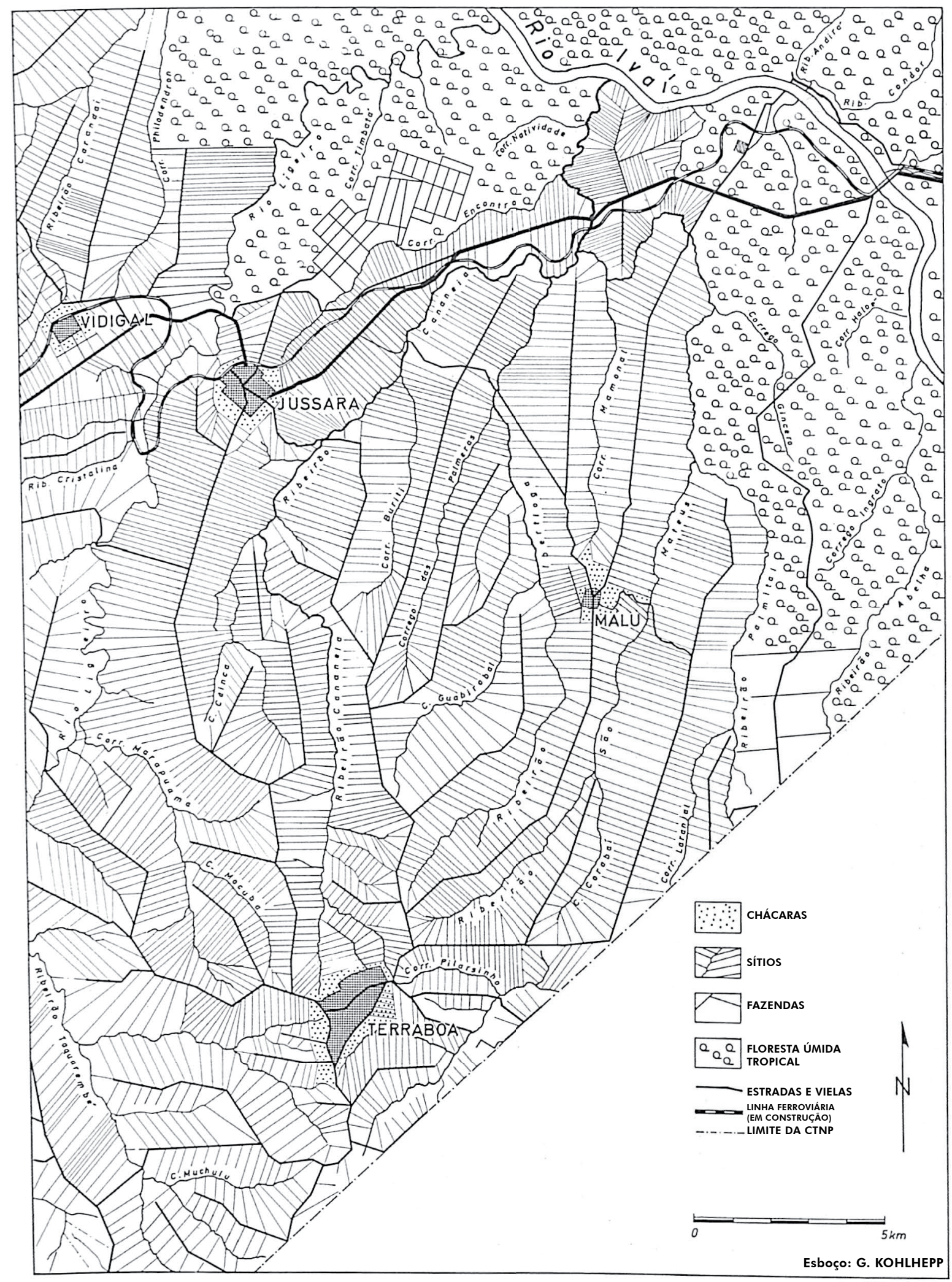

Mapa 10a: Lotes em linhas latitudinais na área de colonização particular controlada da CTNP, Gleba Cianorte 


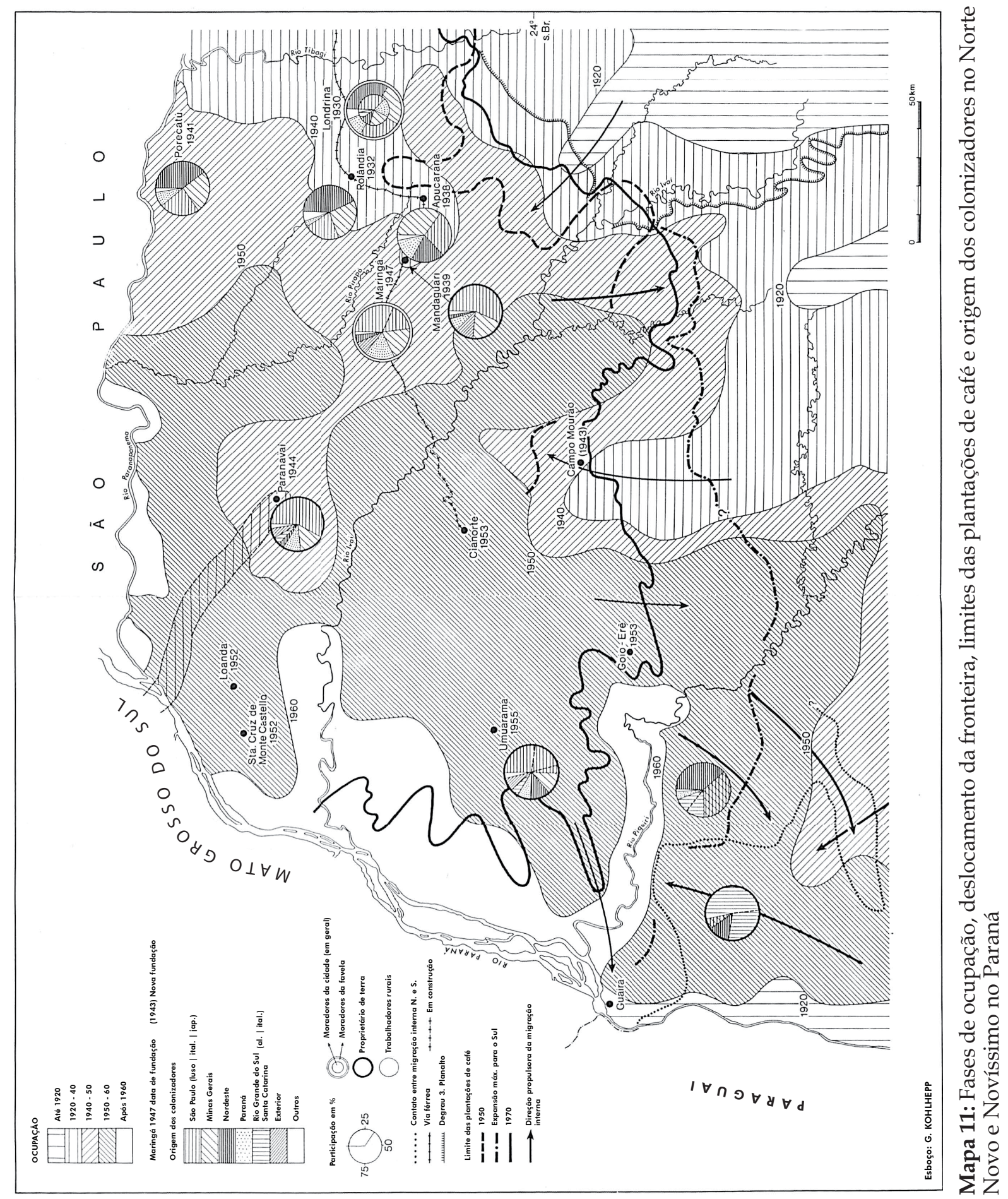




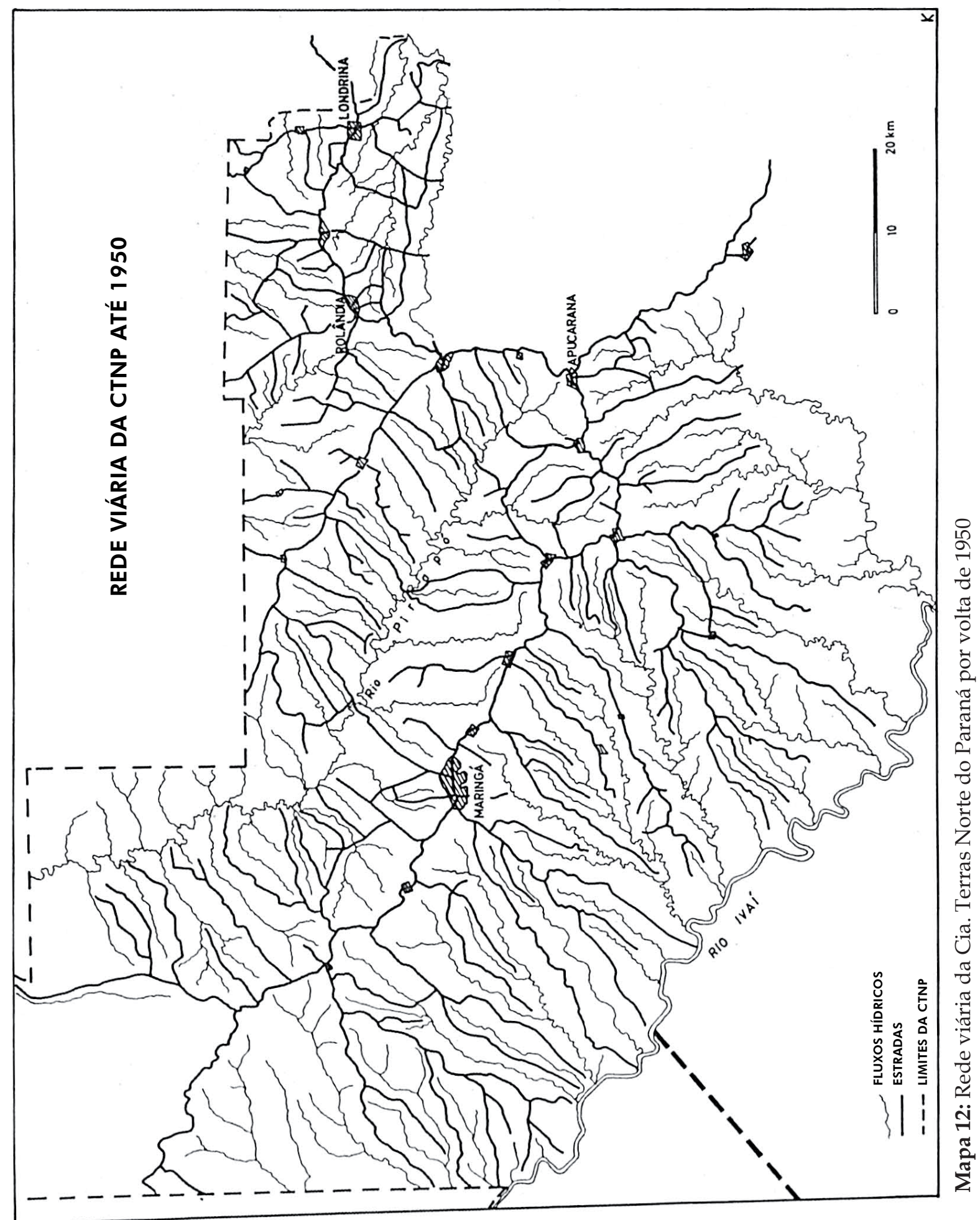




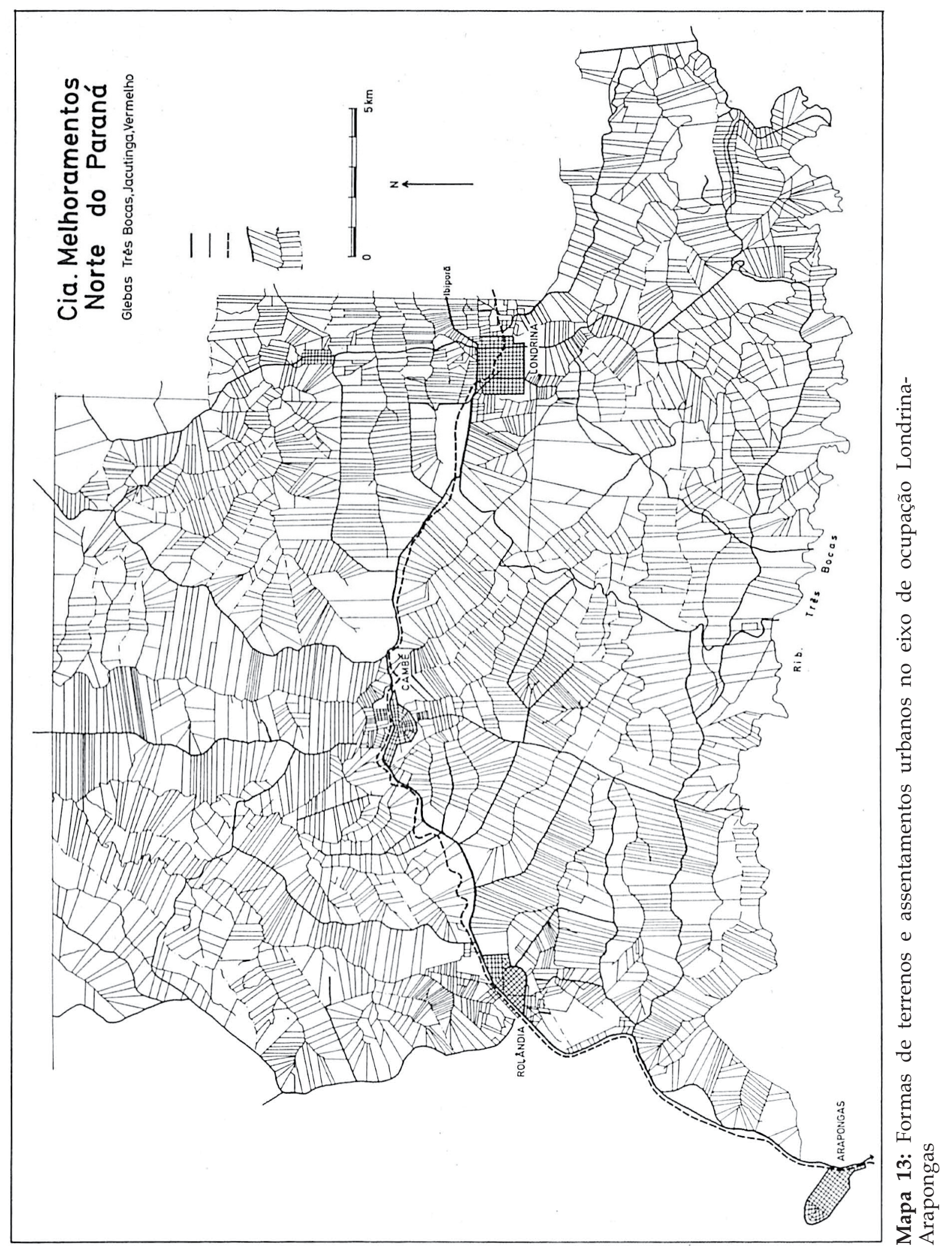




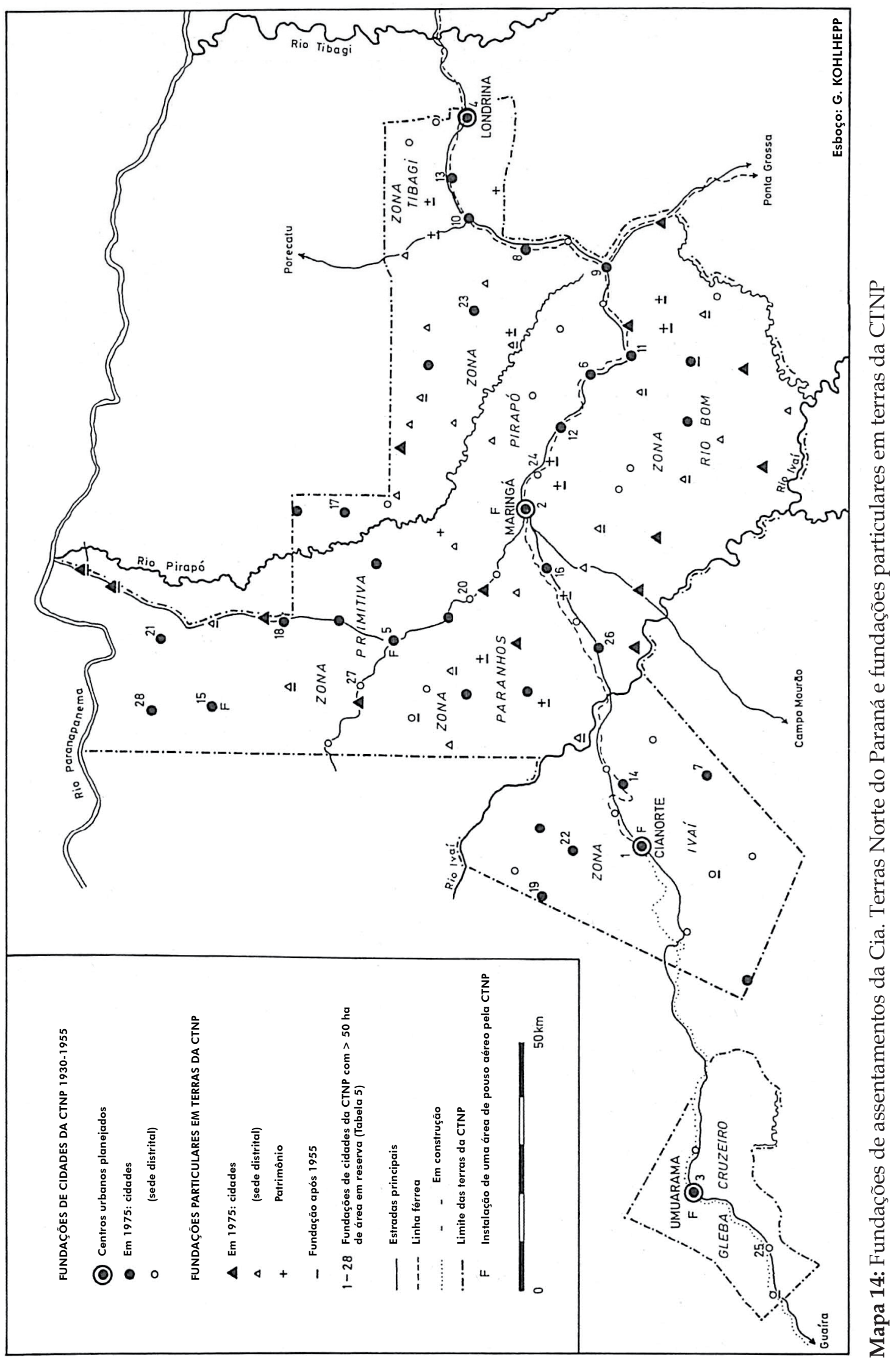



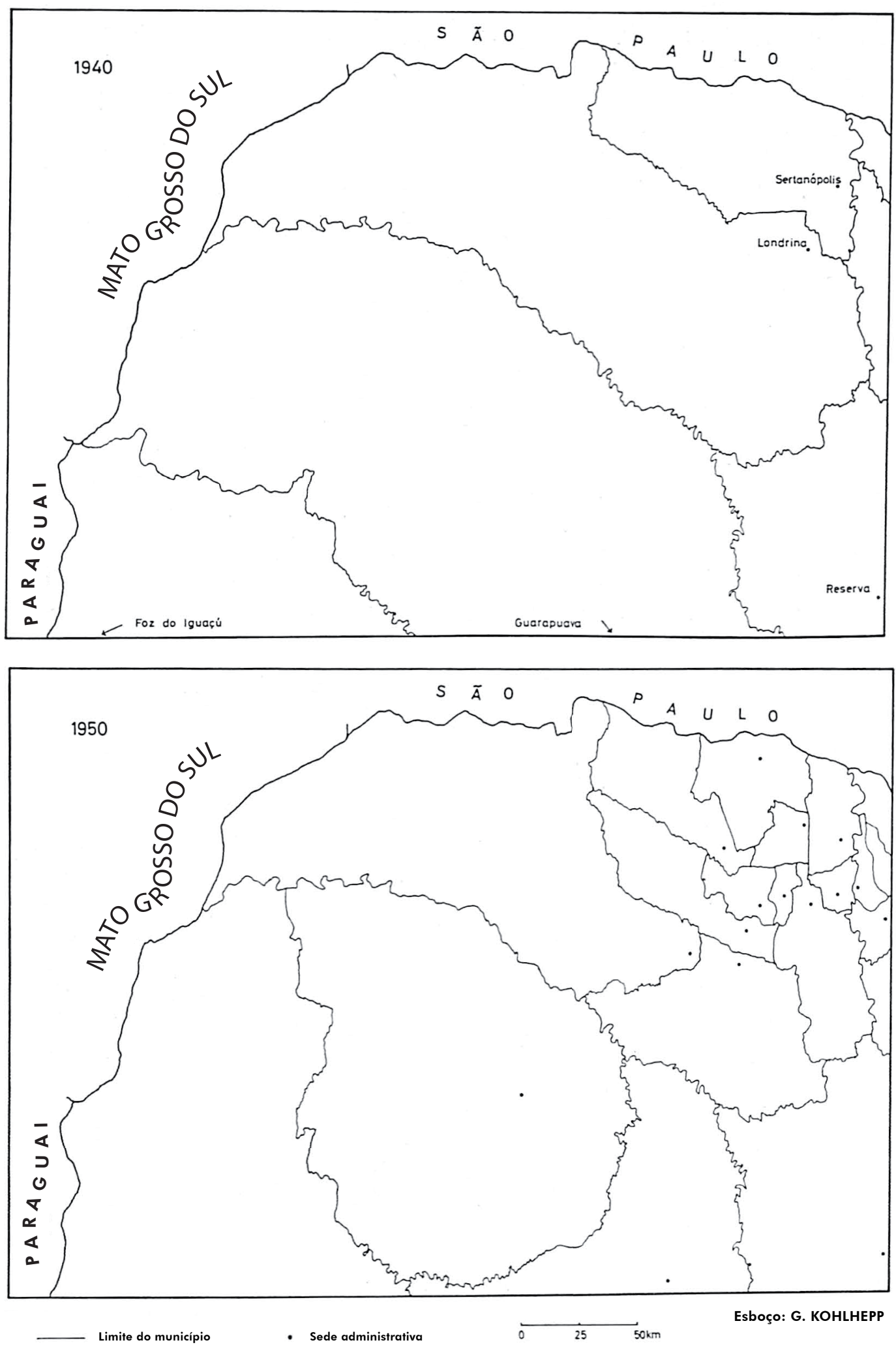

Mapa 15: Desenvolvimento da divisão administrativa do Norte Novo e Novíssimo do Paraná 1940-1950 

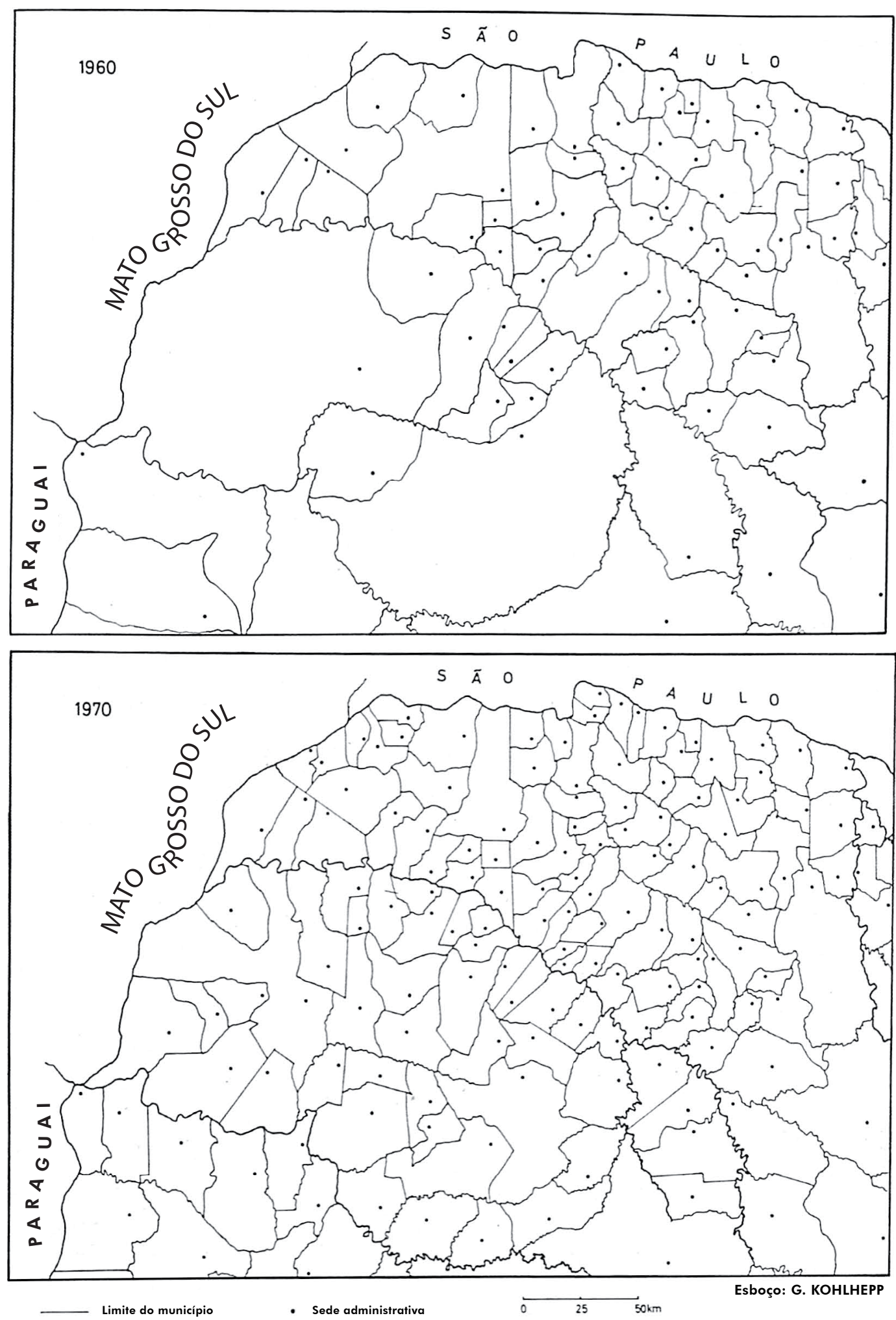

Mapa 15a: Desenvolvimento da divisão administrativa do Norte Novo e Novíssimo do Paraná 1960-1970 


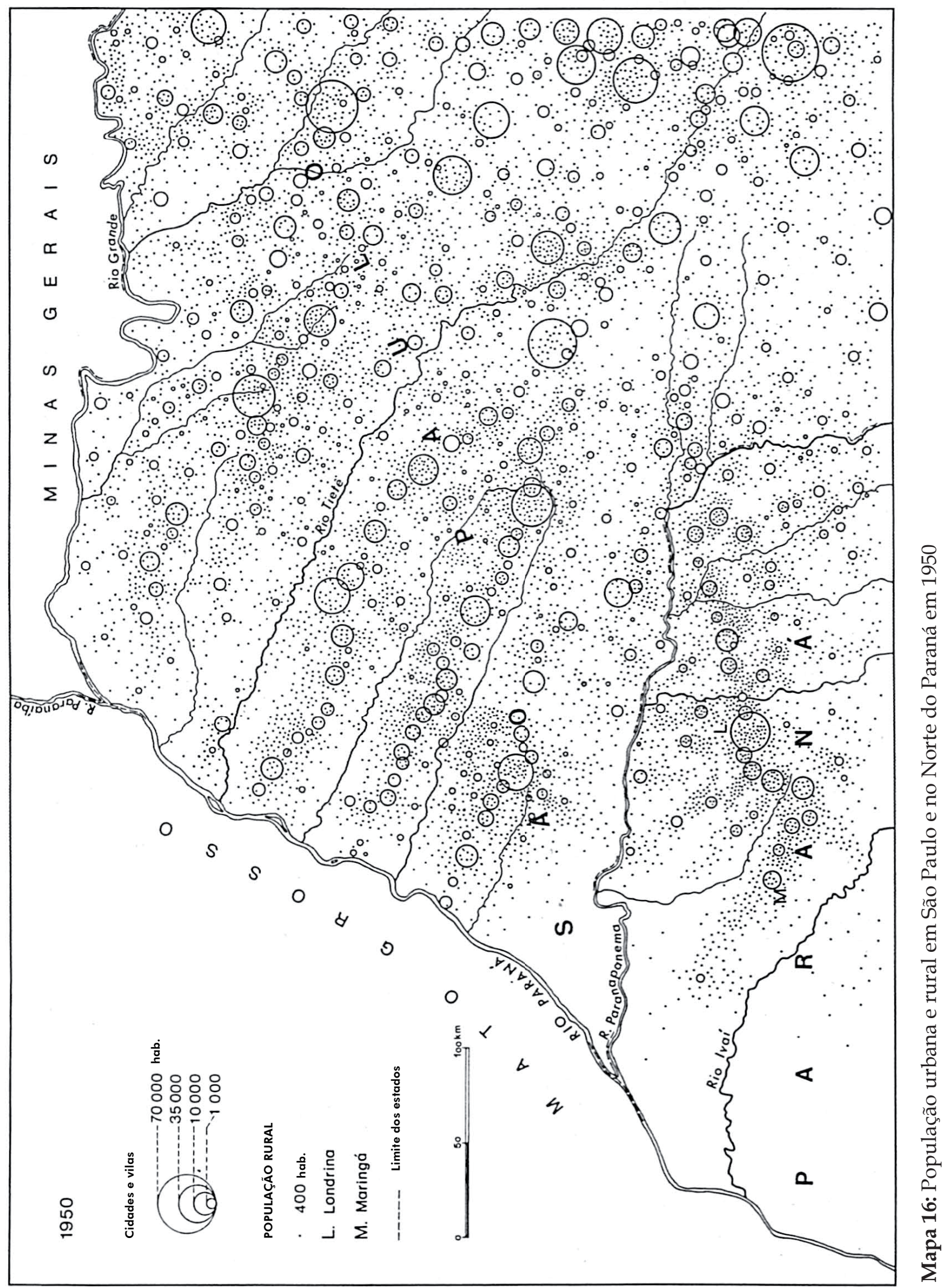




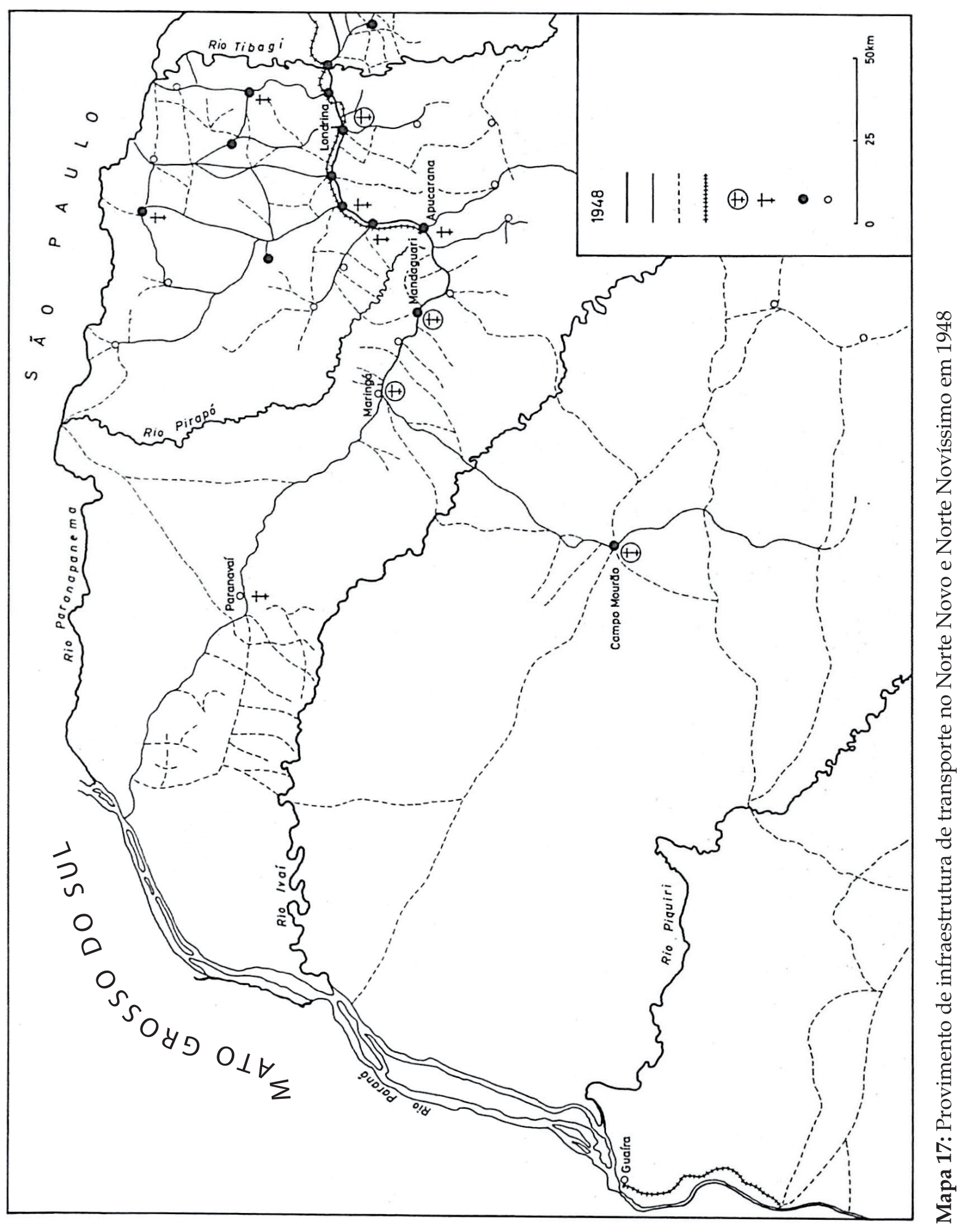



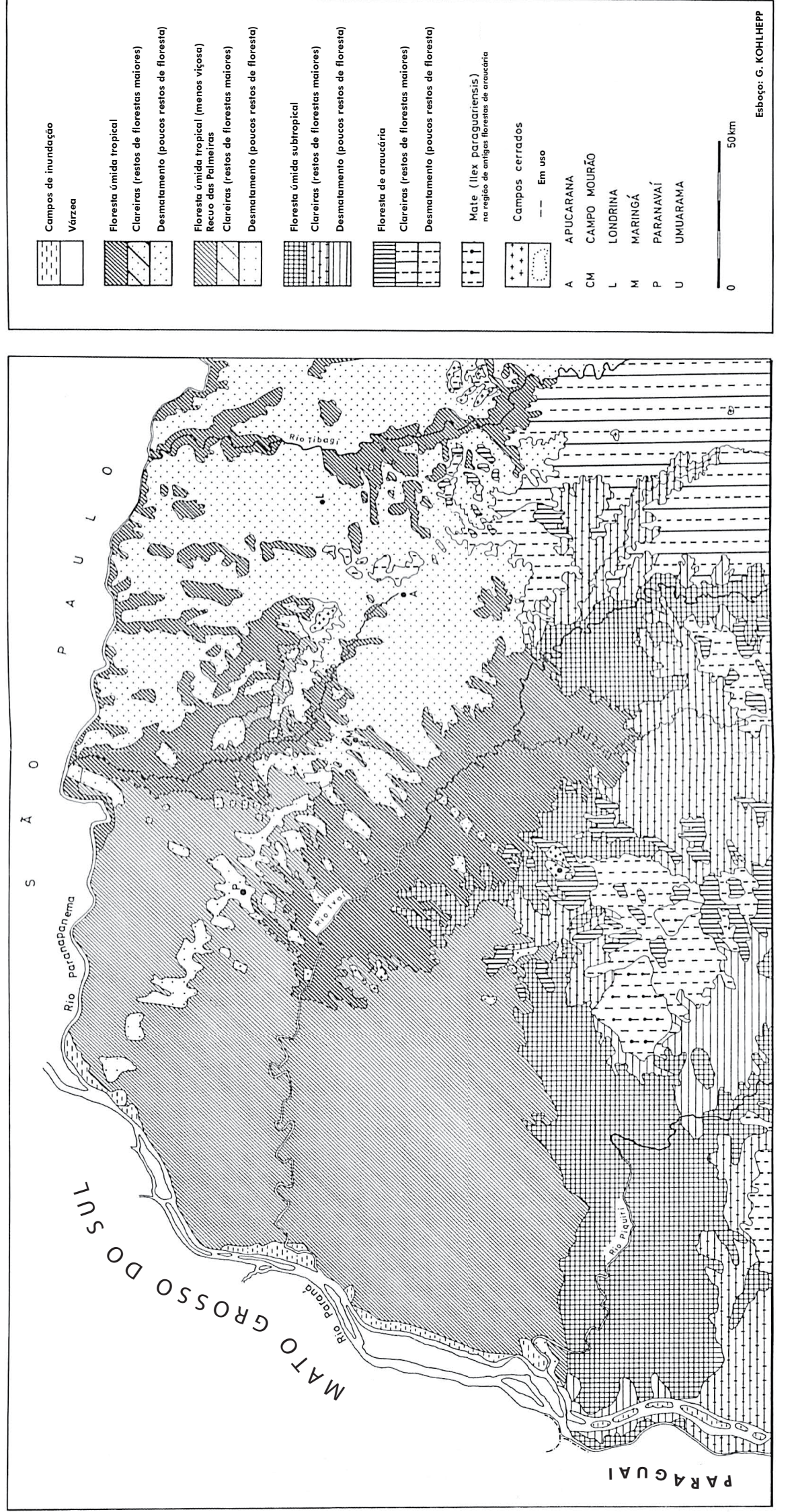

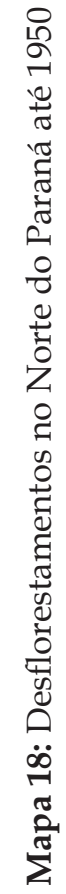



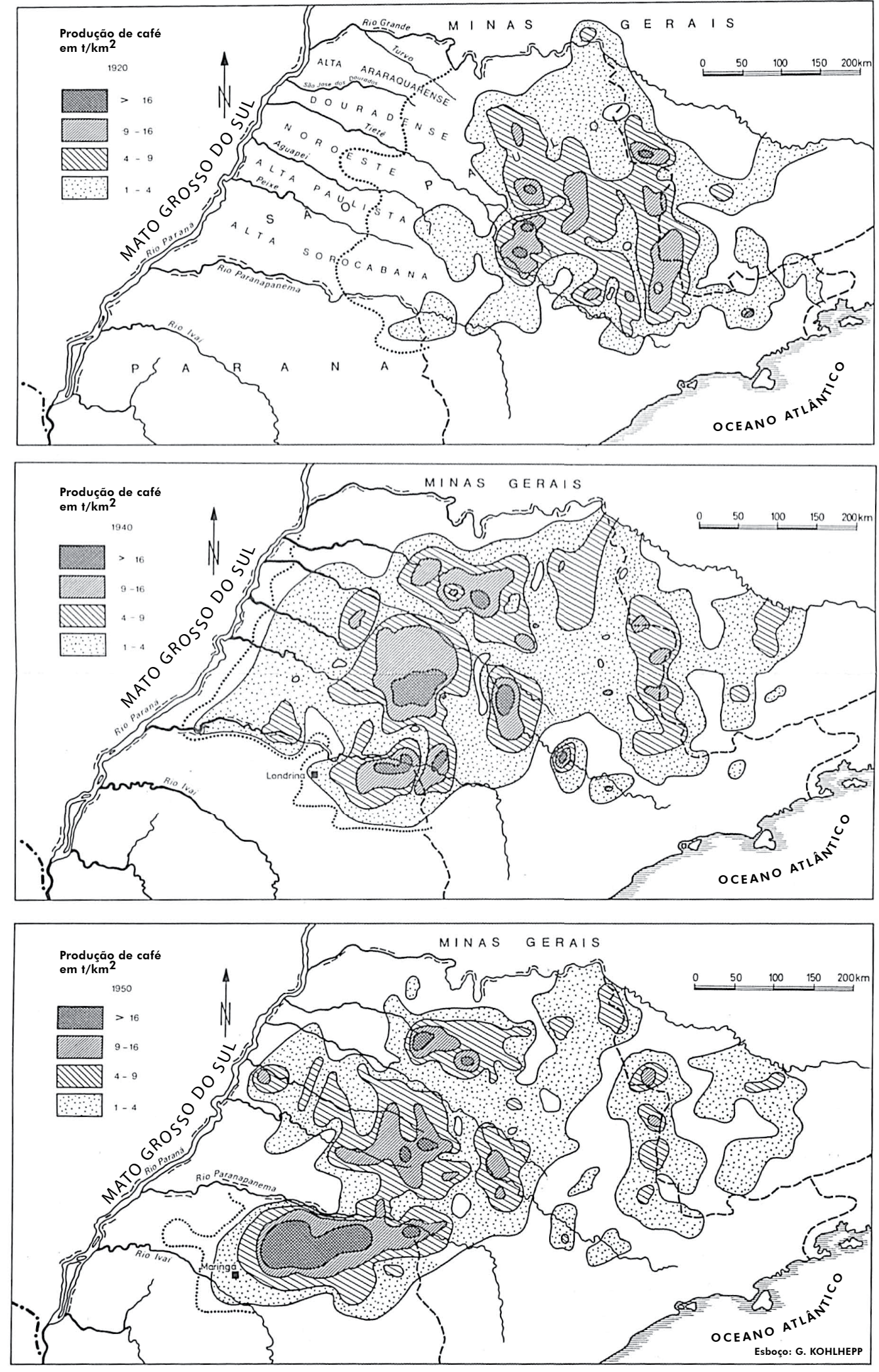

Mapa 19: Deslocamento das áreas de produção do café em São Paulo e no Paraná em 1920, 1940 e 1950 


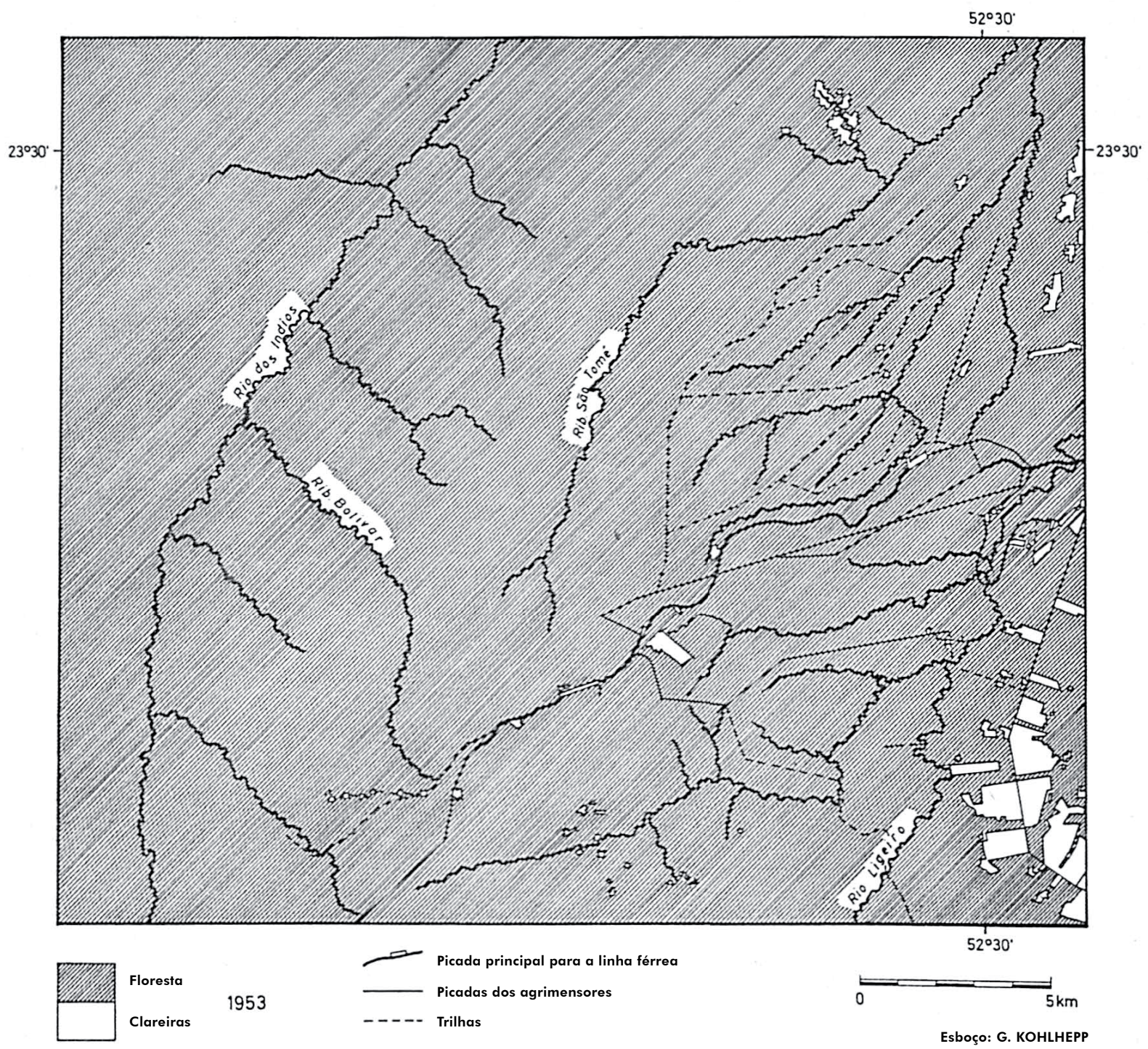

Mapa 20: Situação da ocupação da região em torno de Cianorte, em 1953 


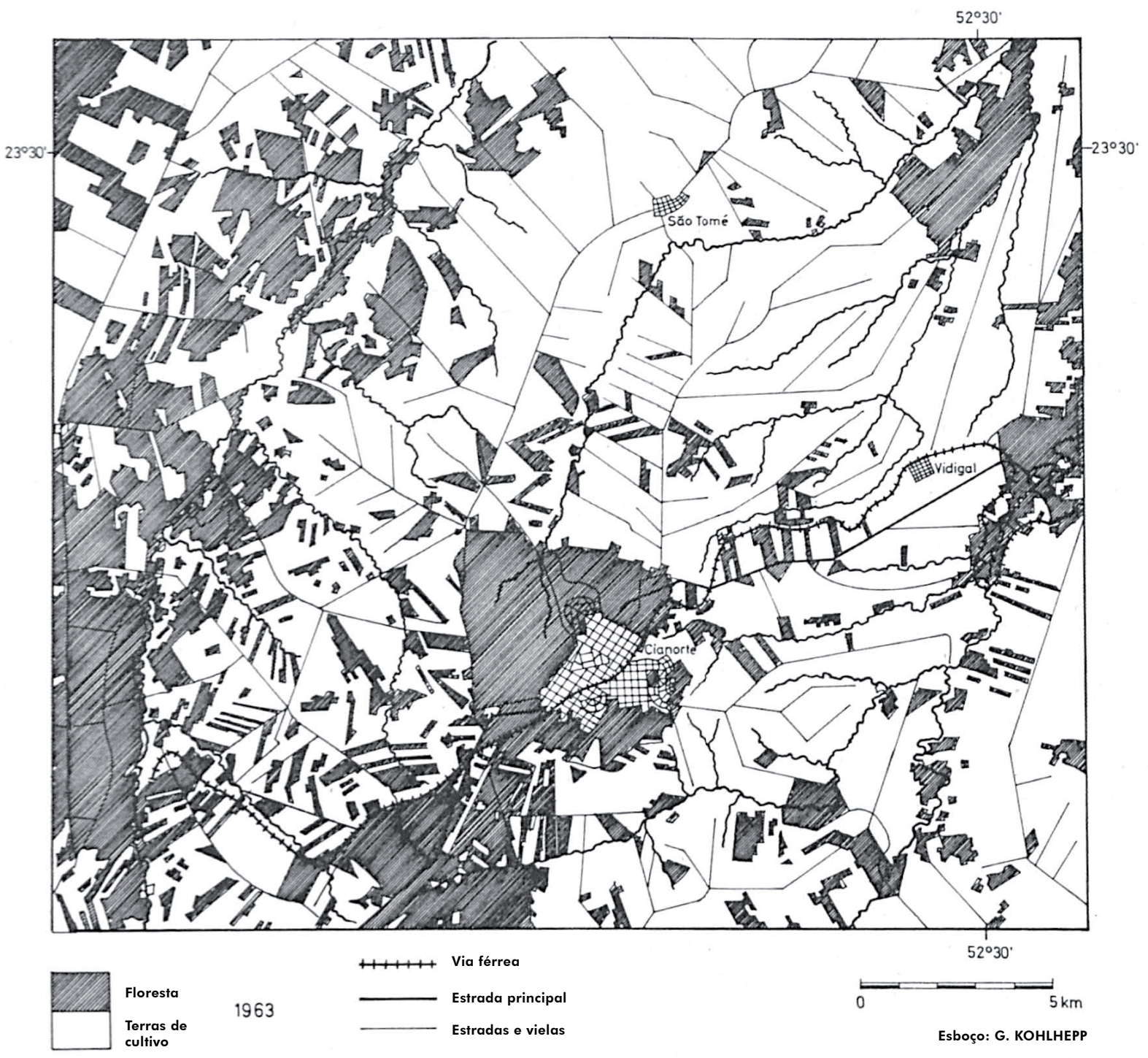

Mapa 21: Situação da ocupação da região em torno de Cianorte, em 1963 


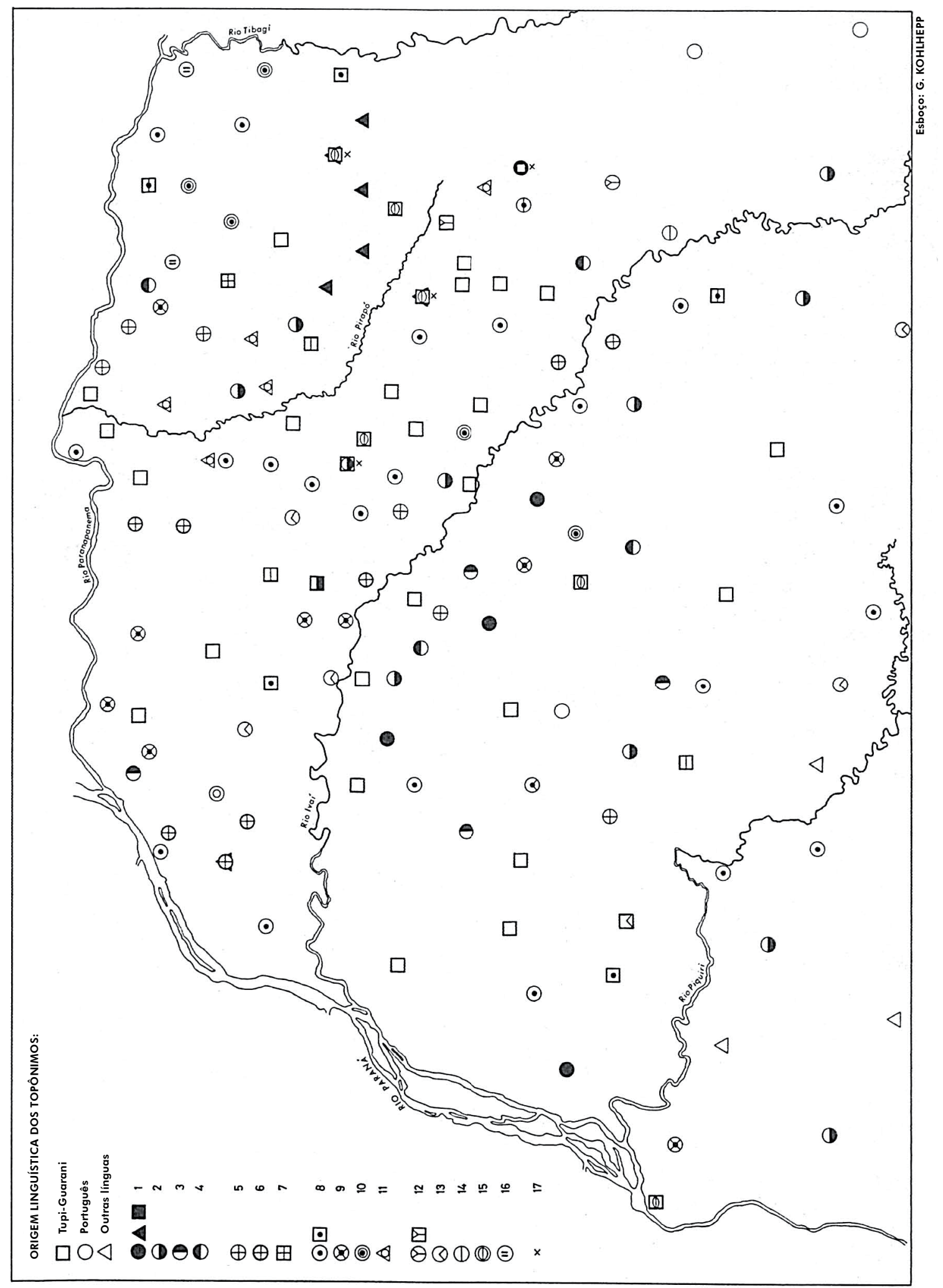

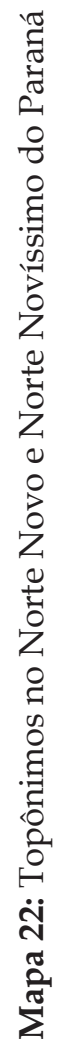


Legenda para

Mapa 22: Topônimos no Norte Novo e Norte Novíssimo do Paraná

\section{Significado dos topônimos}

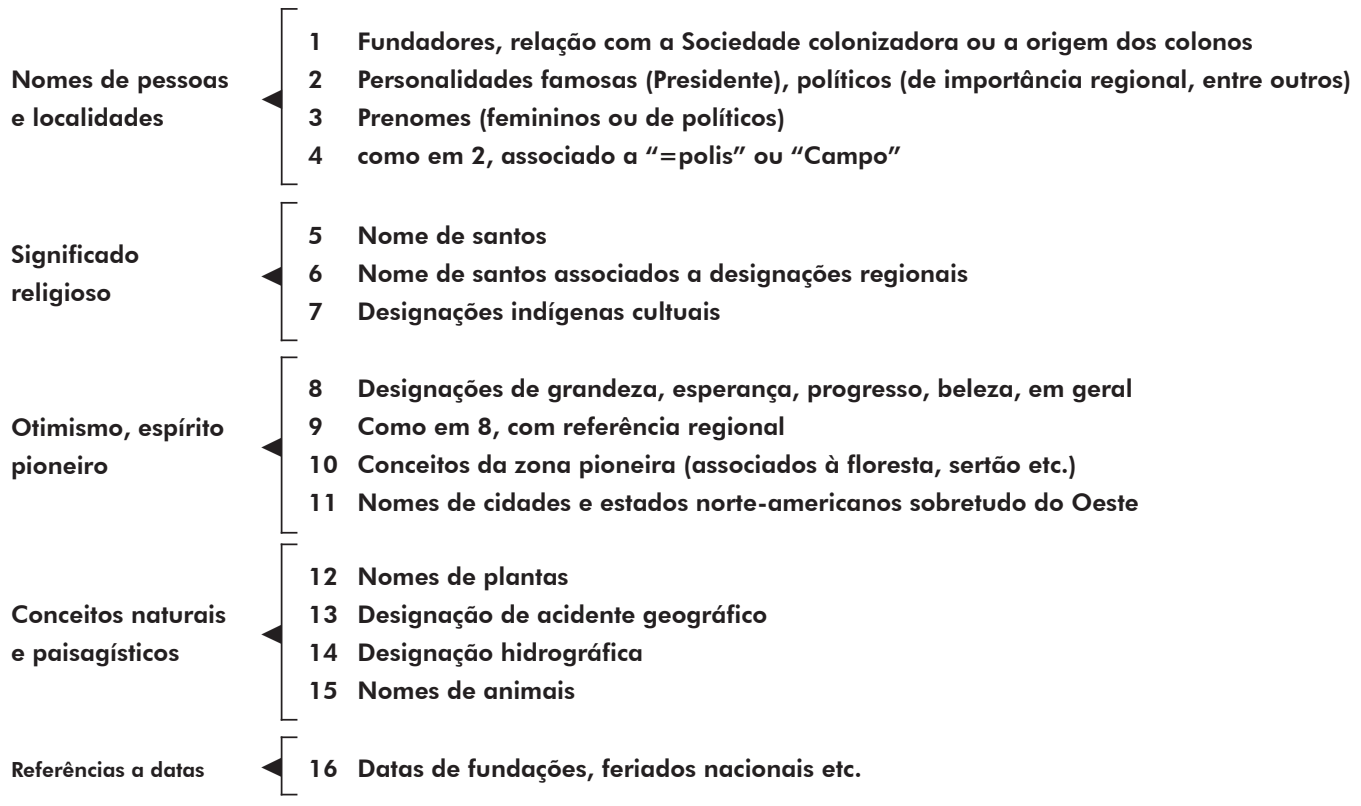

17 Mudanças de nomes 


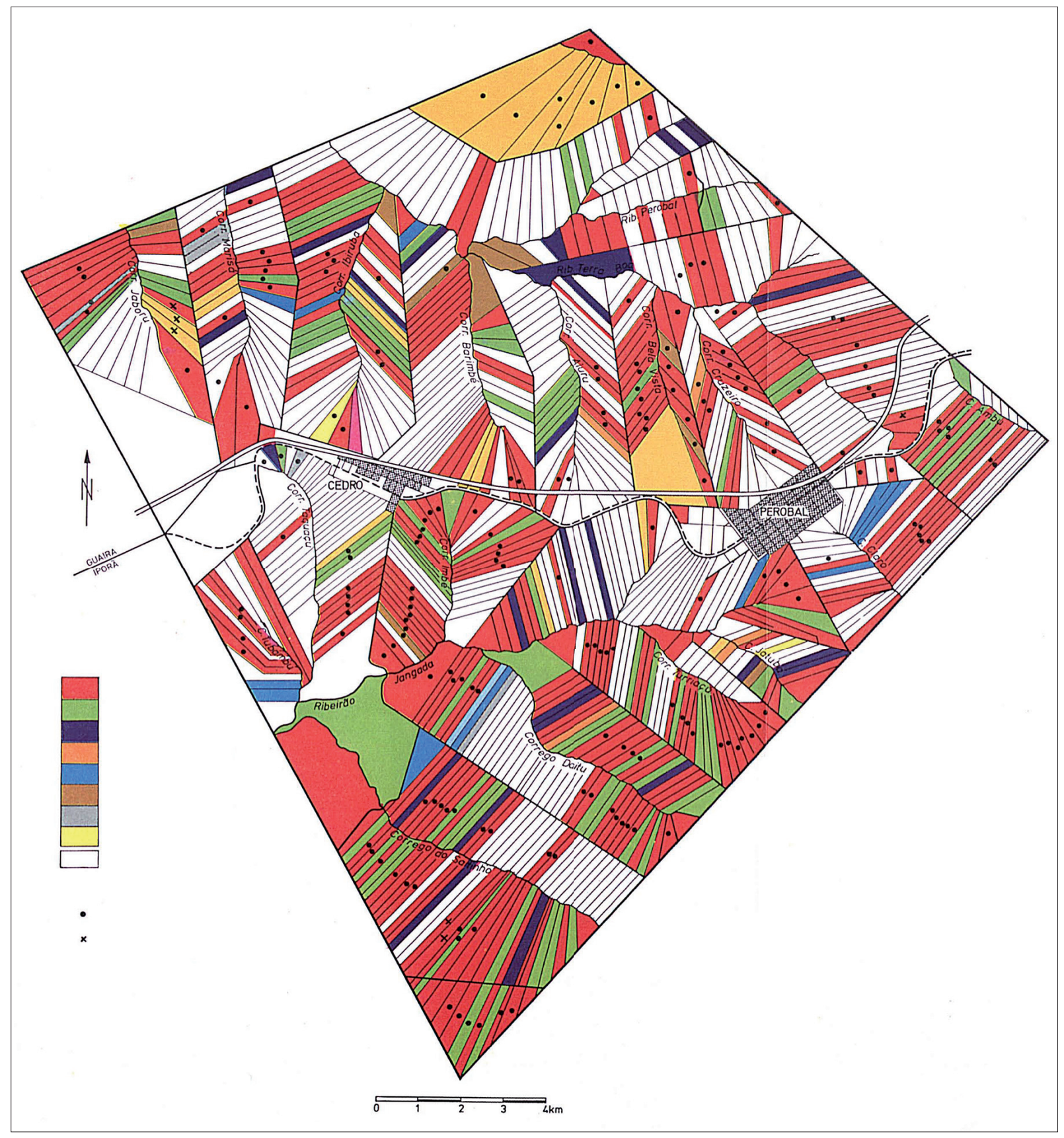

Mapa 23: Origem étnica e regional dos proprietários de terras da gleba Jacaratiá/Município de Umuarama (Norte Novíssimo) 


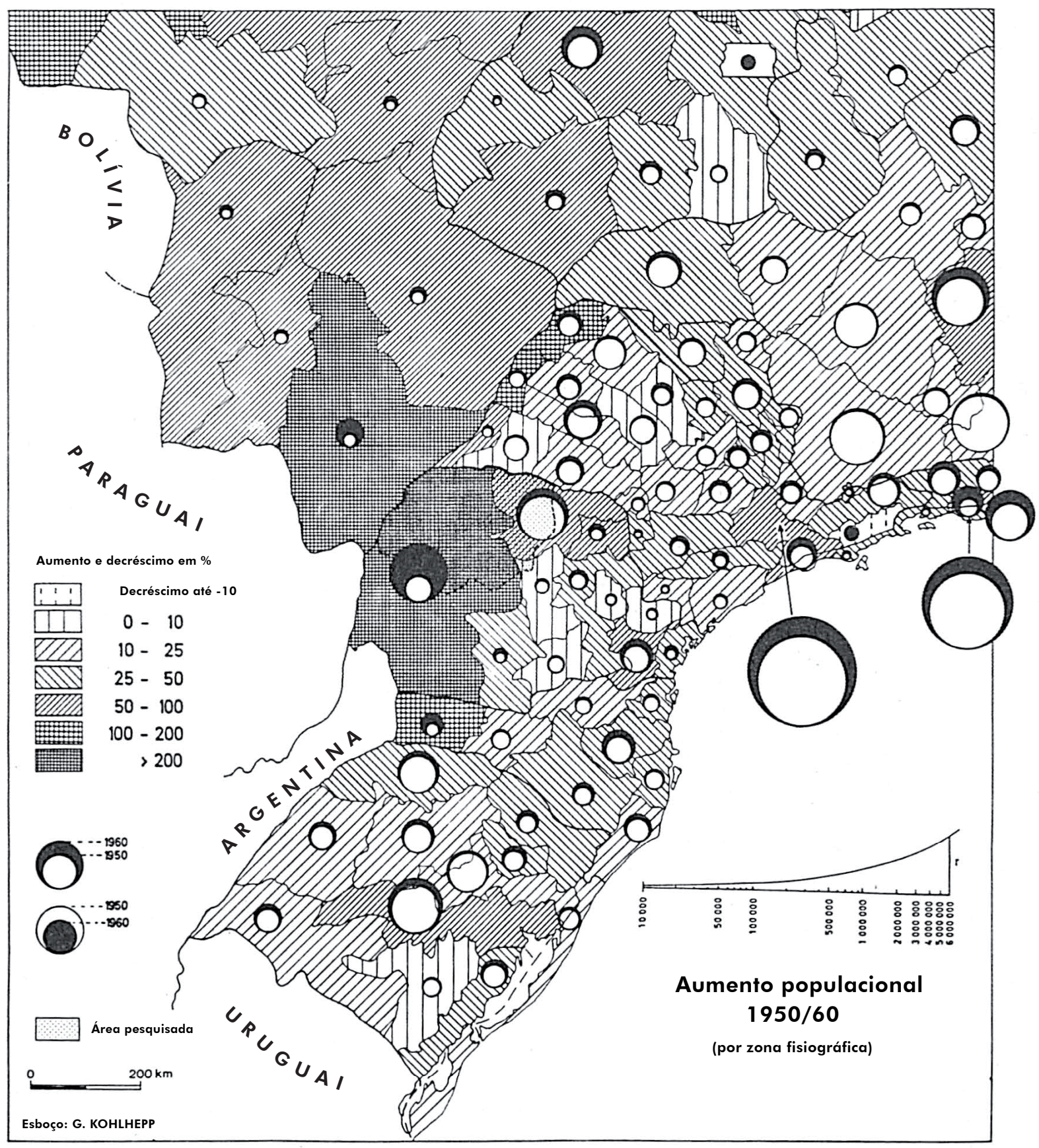

Mapa 24: Aumento populacional absoluto e relativo no Sul, Sudeste e Centro-Oeste do Brasil, 1950/1960 


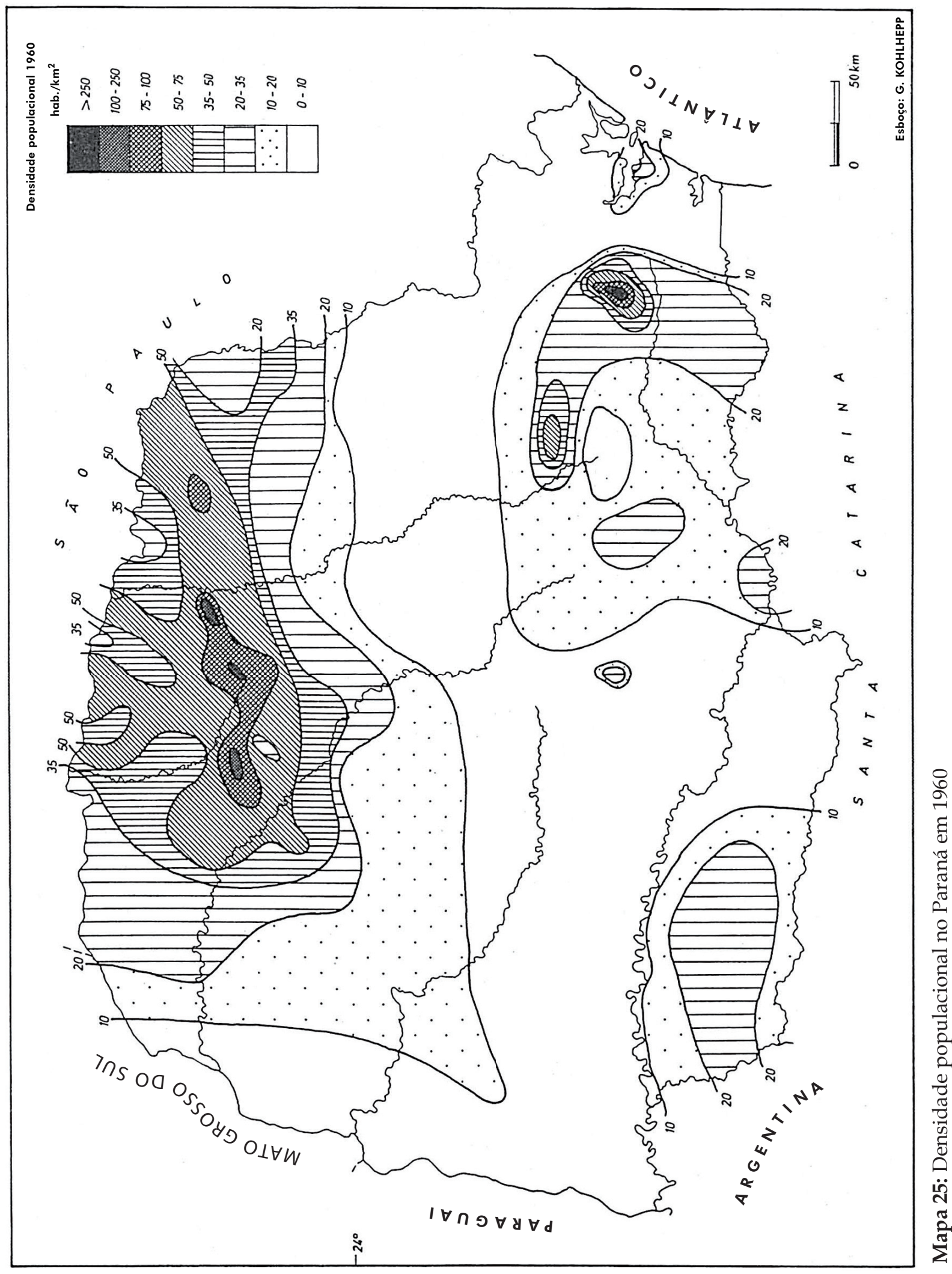




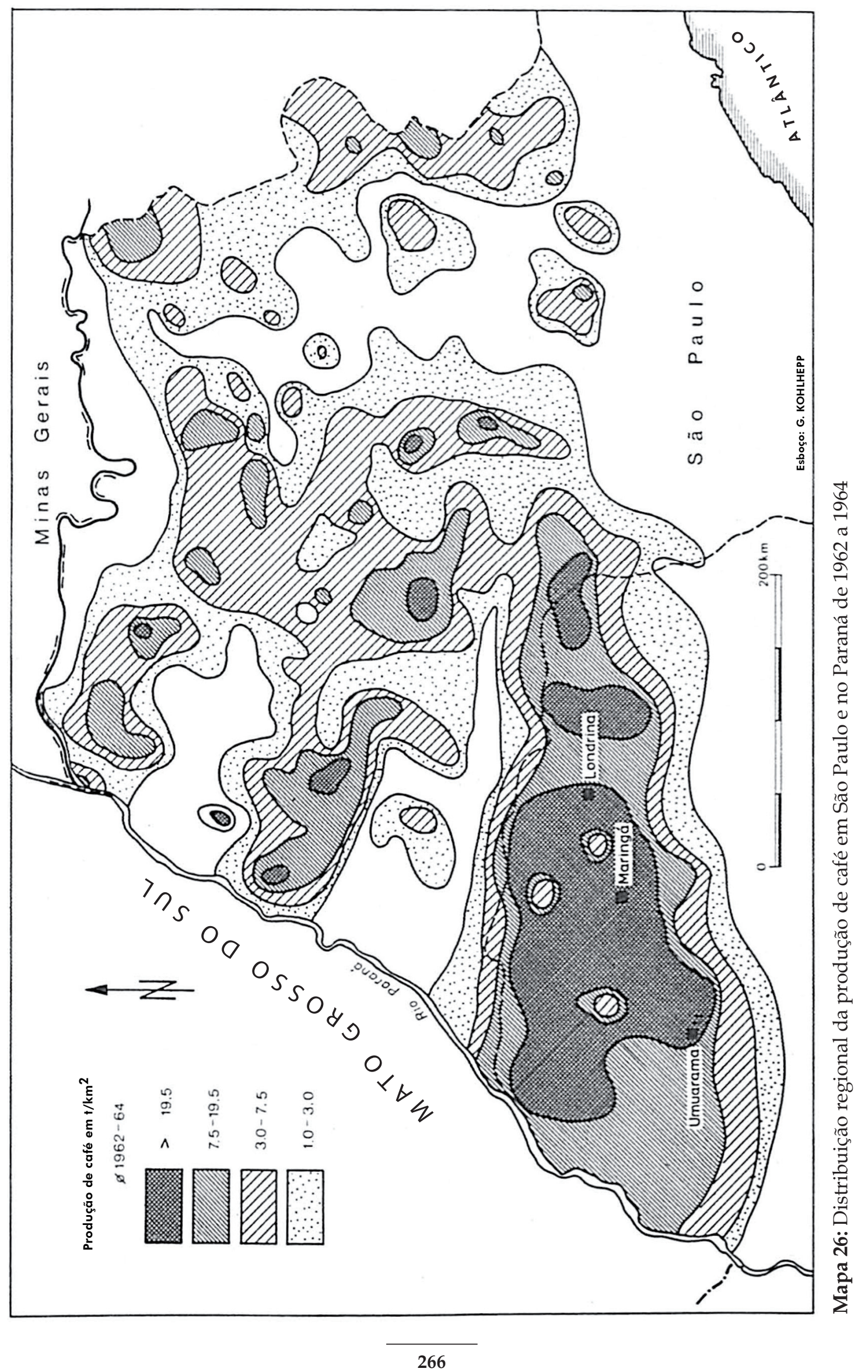




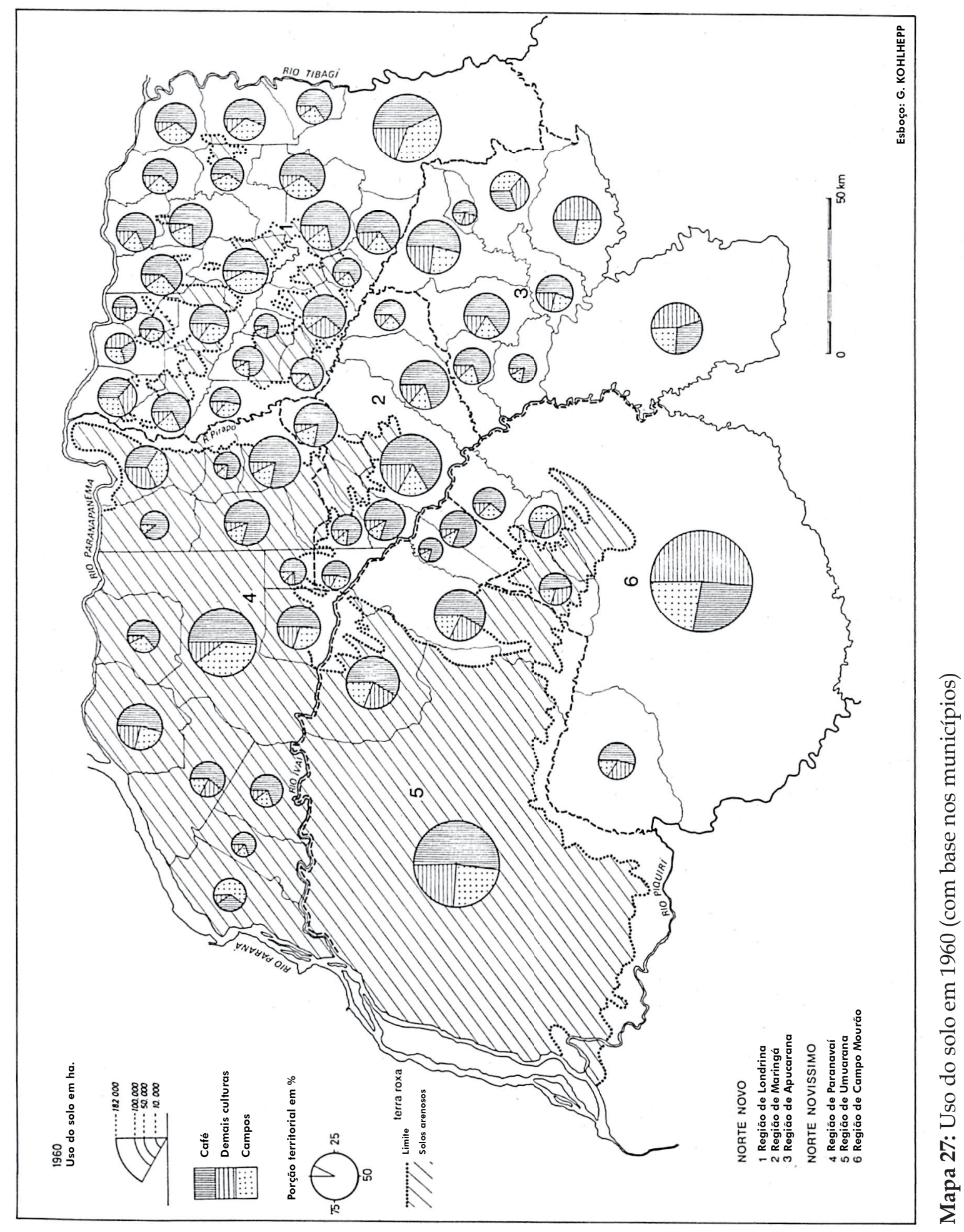




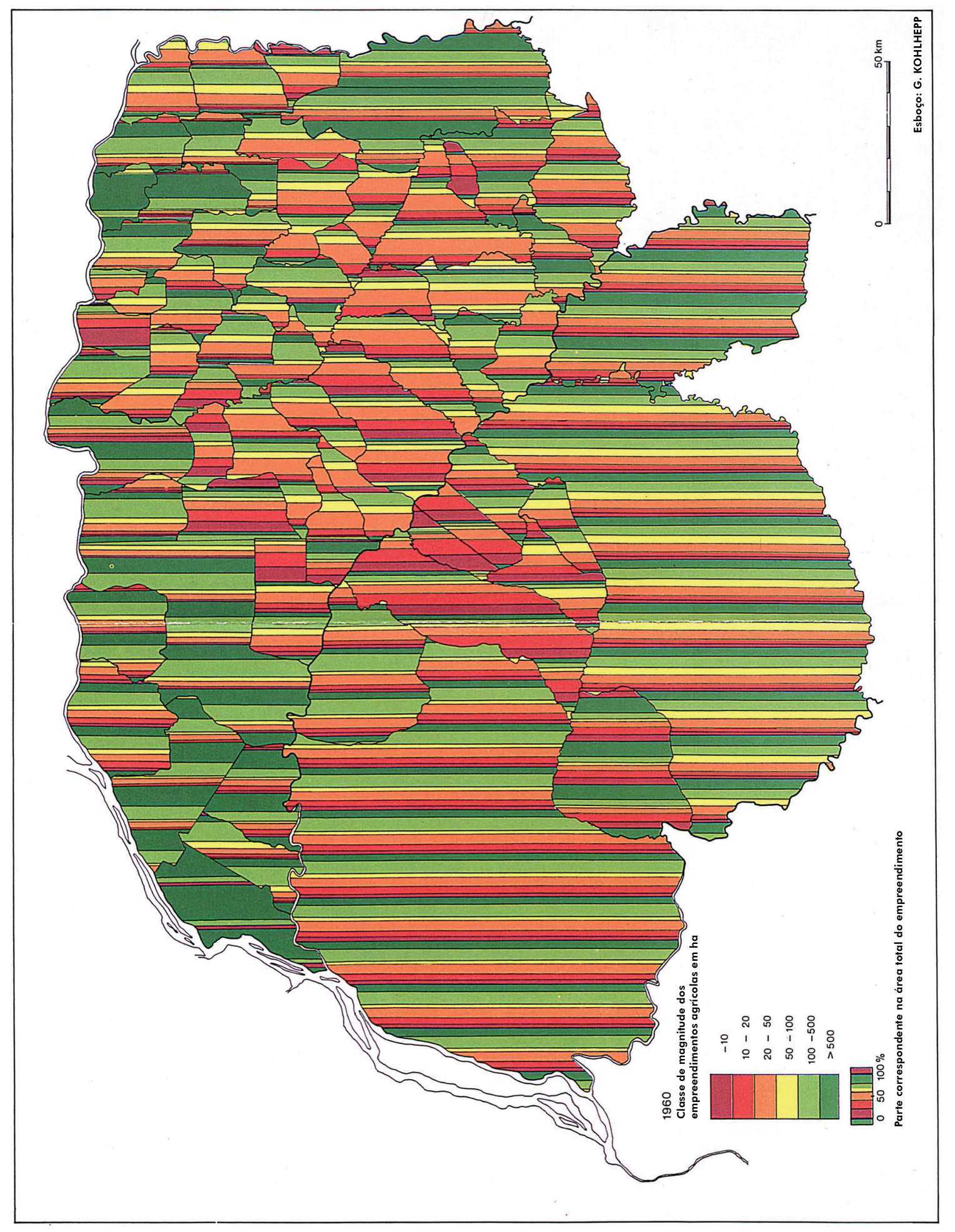

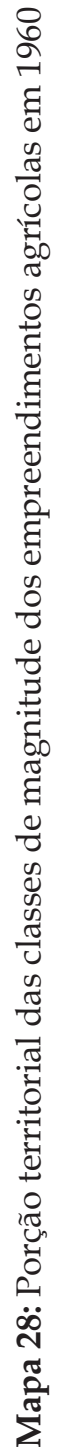




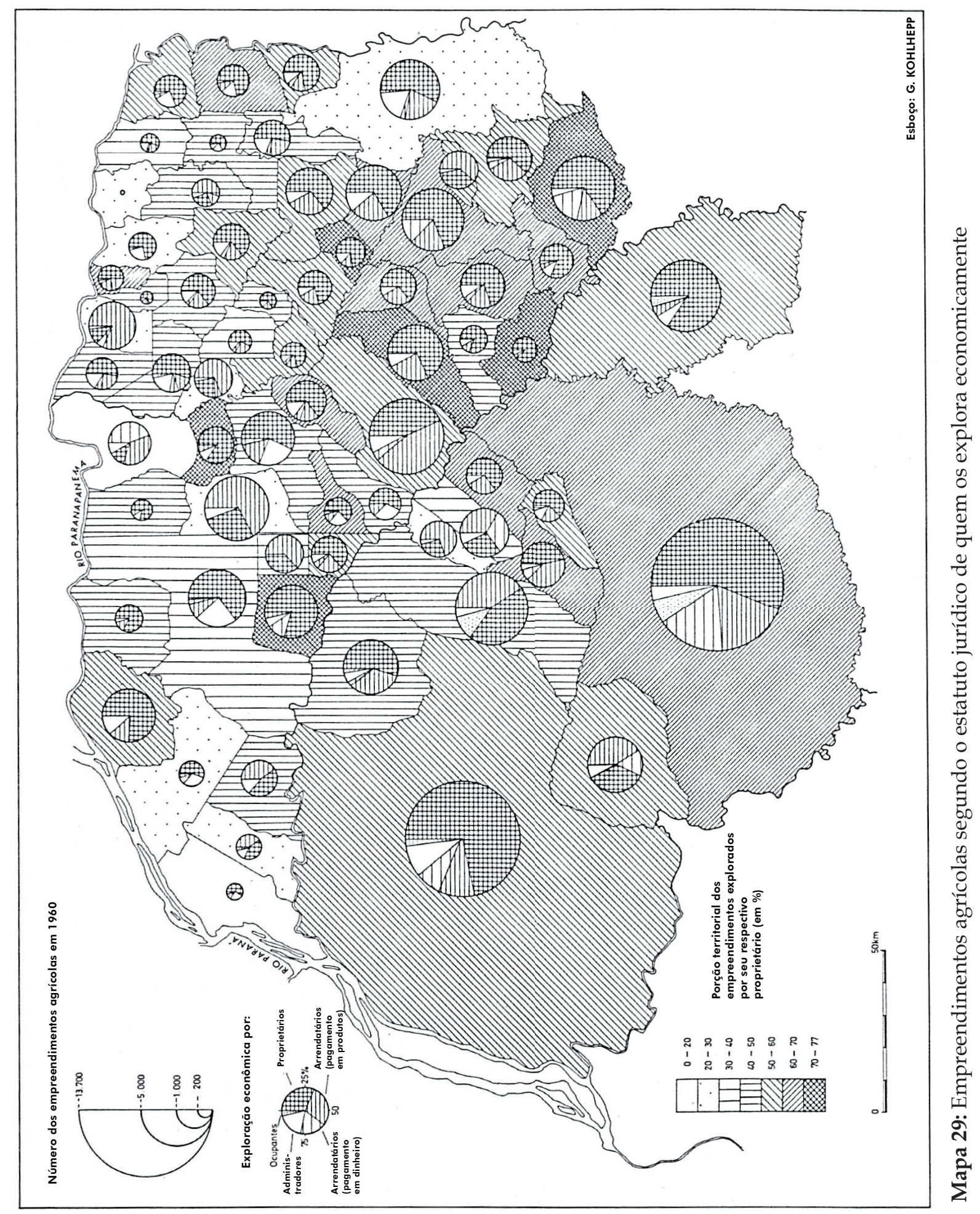



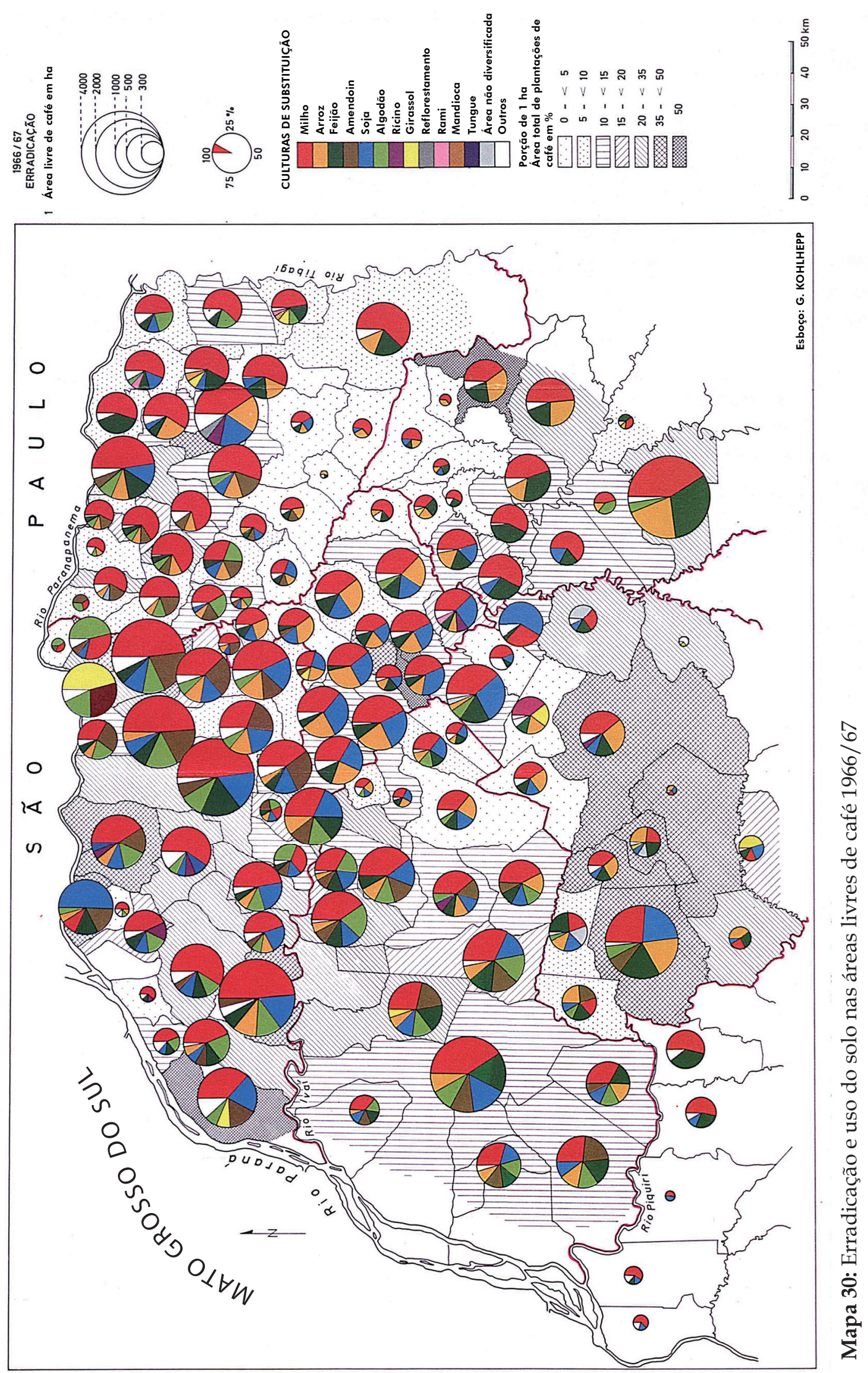

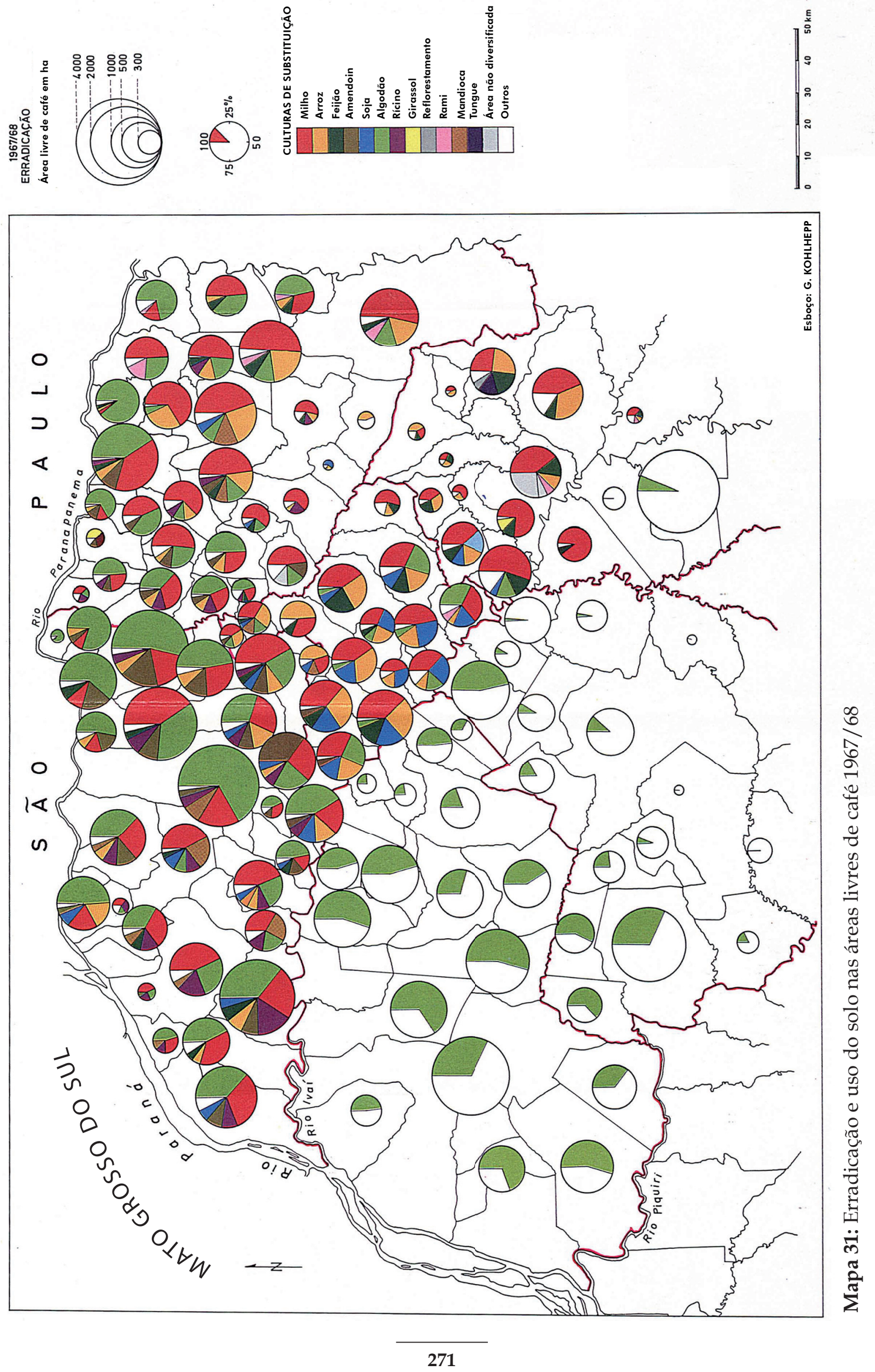


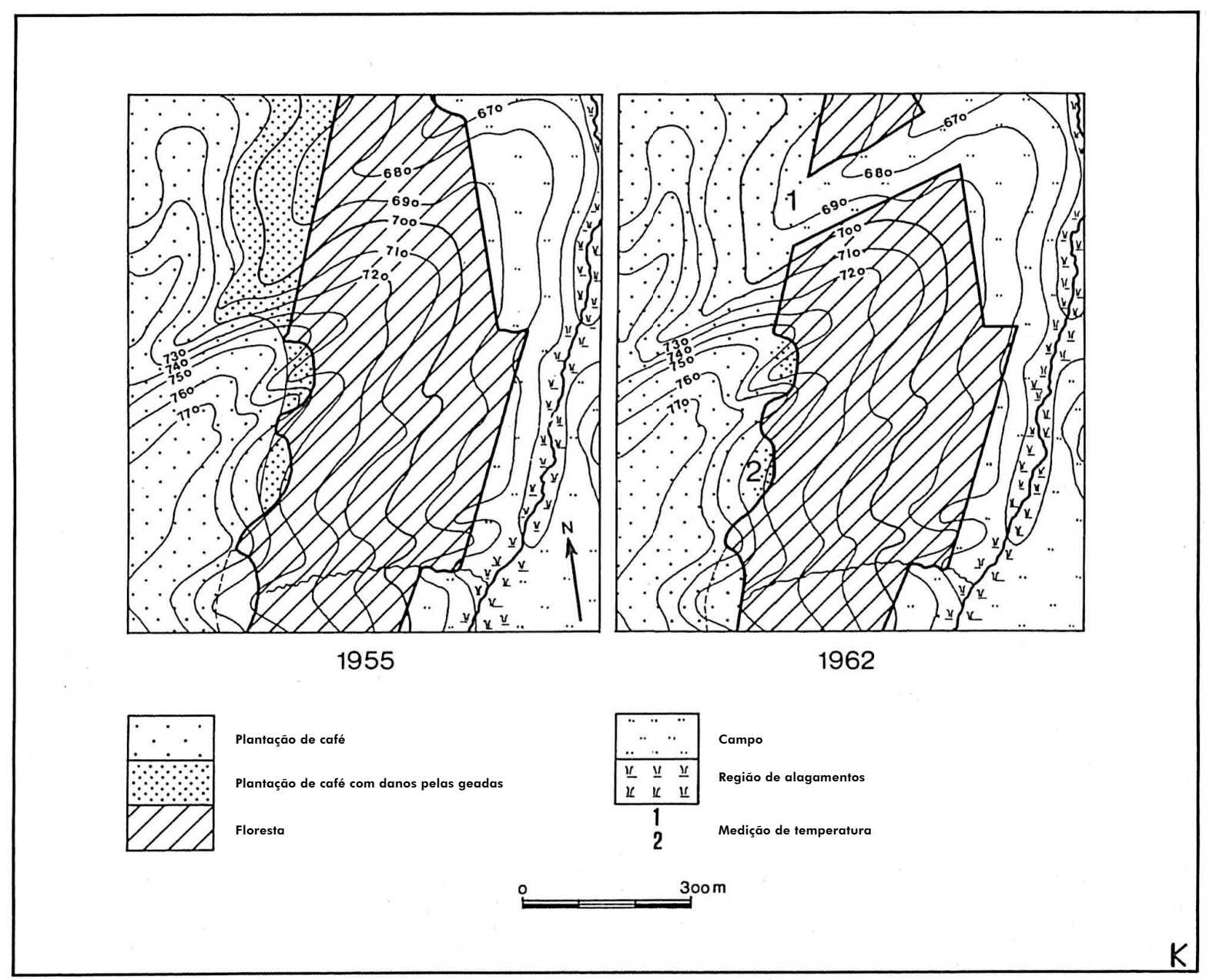

Mapa 32: Danos por geadas em plantações de café da Fazenda Ubatuba/Apucarana em 1955 e 1962 (com e sem corredor para escoamento de ar frio) 


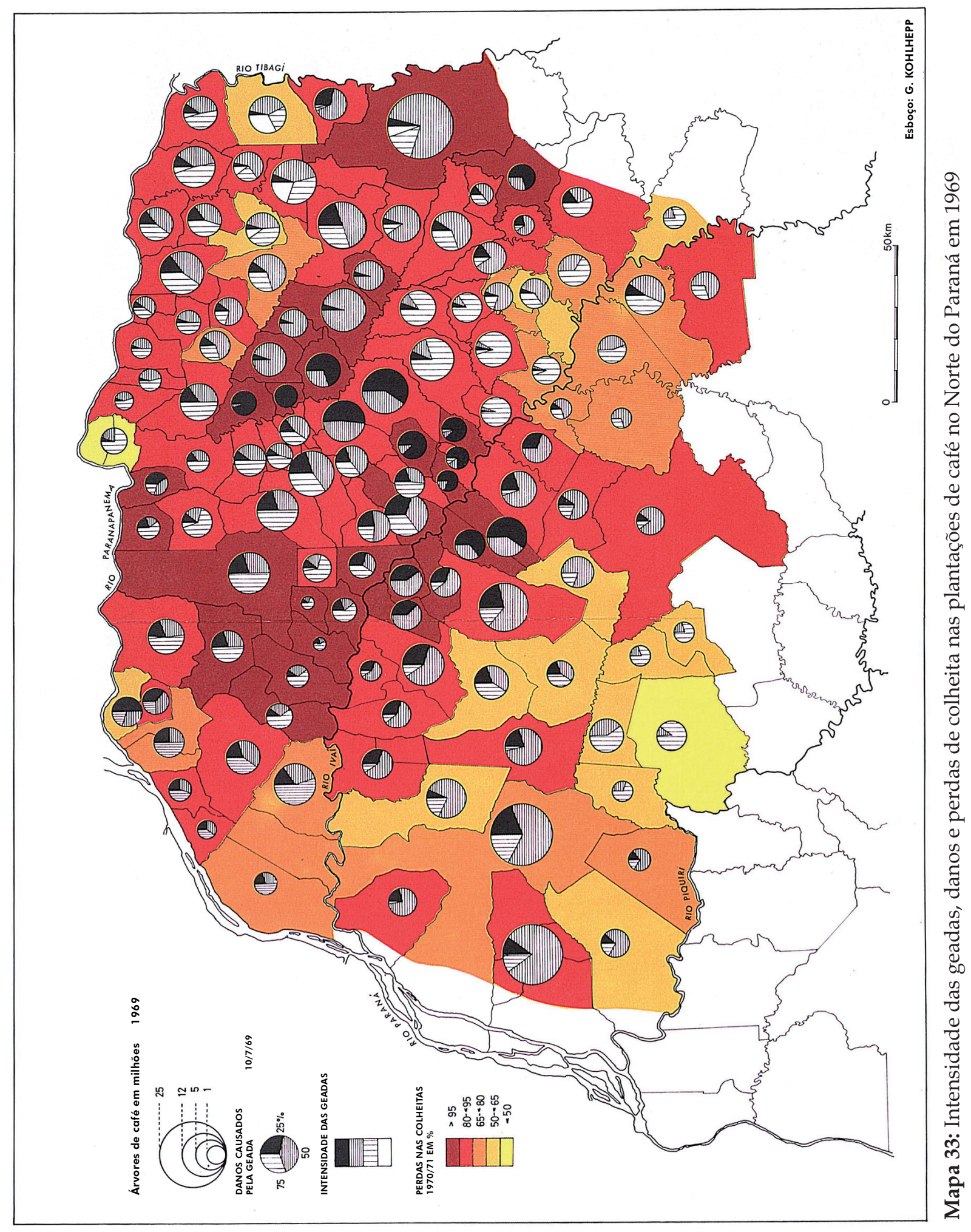




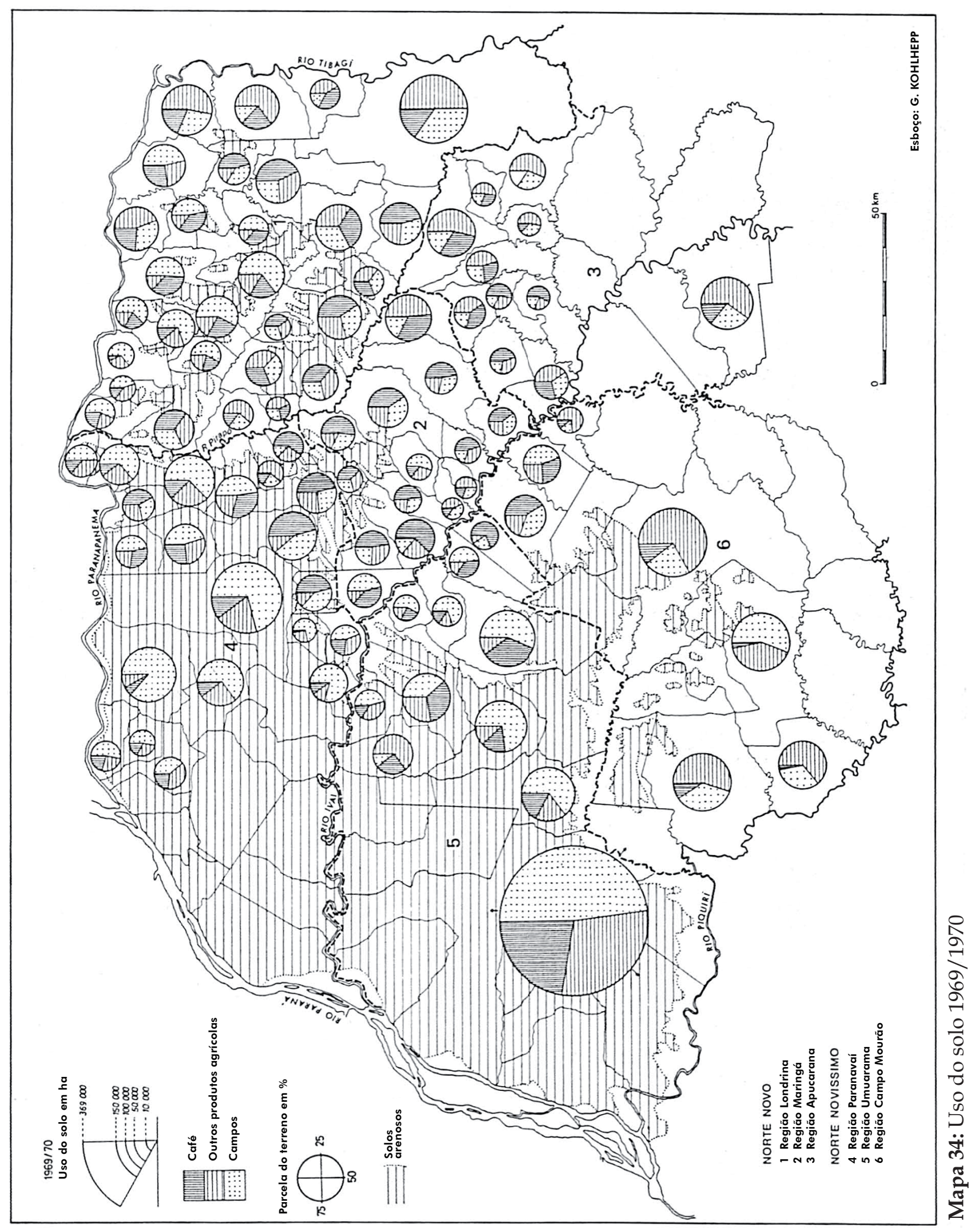




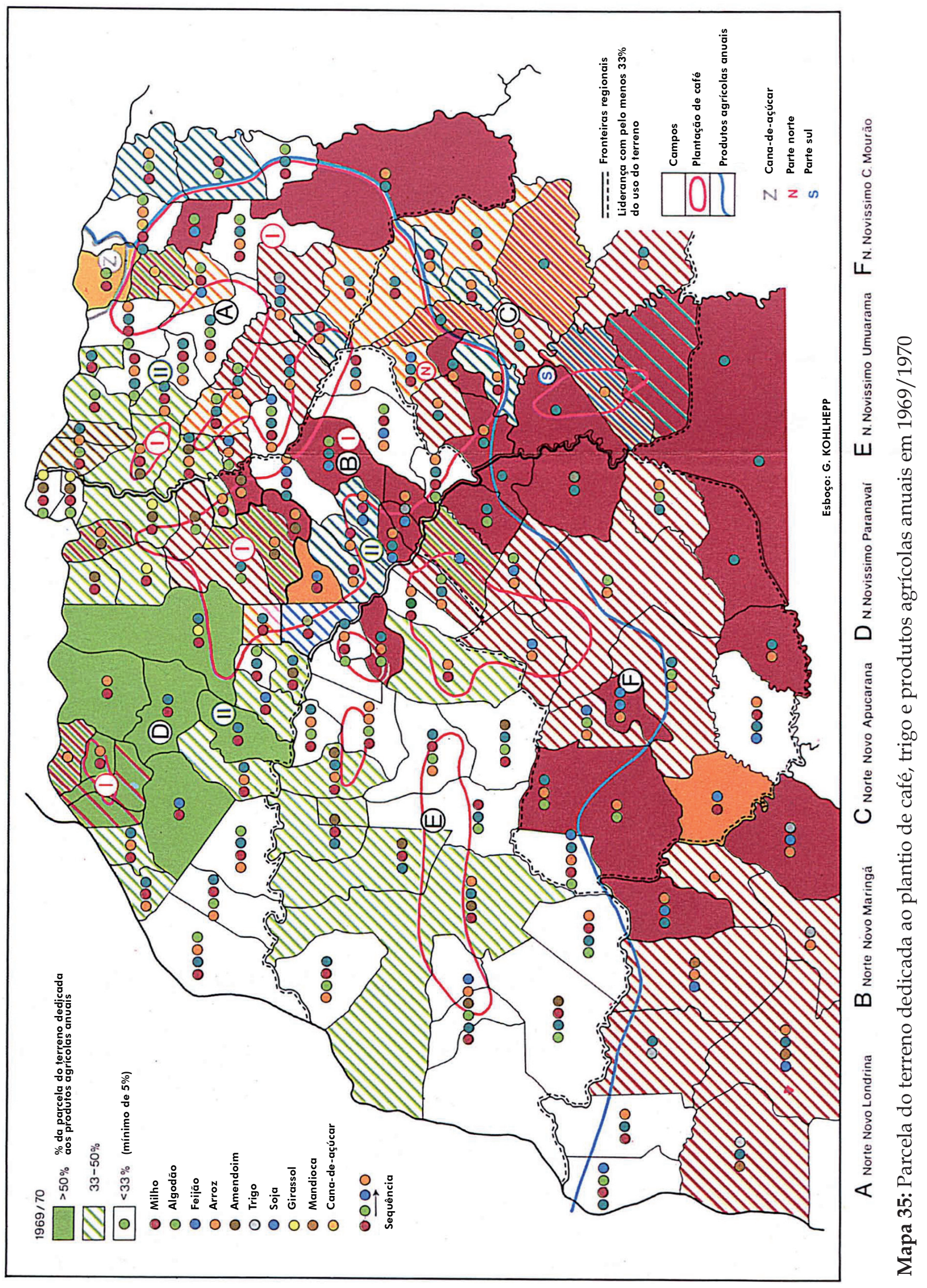




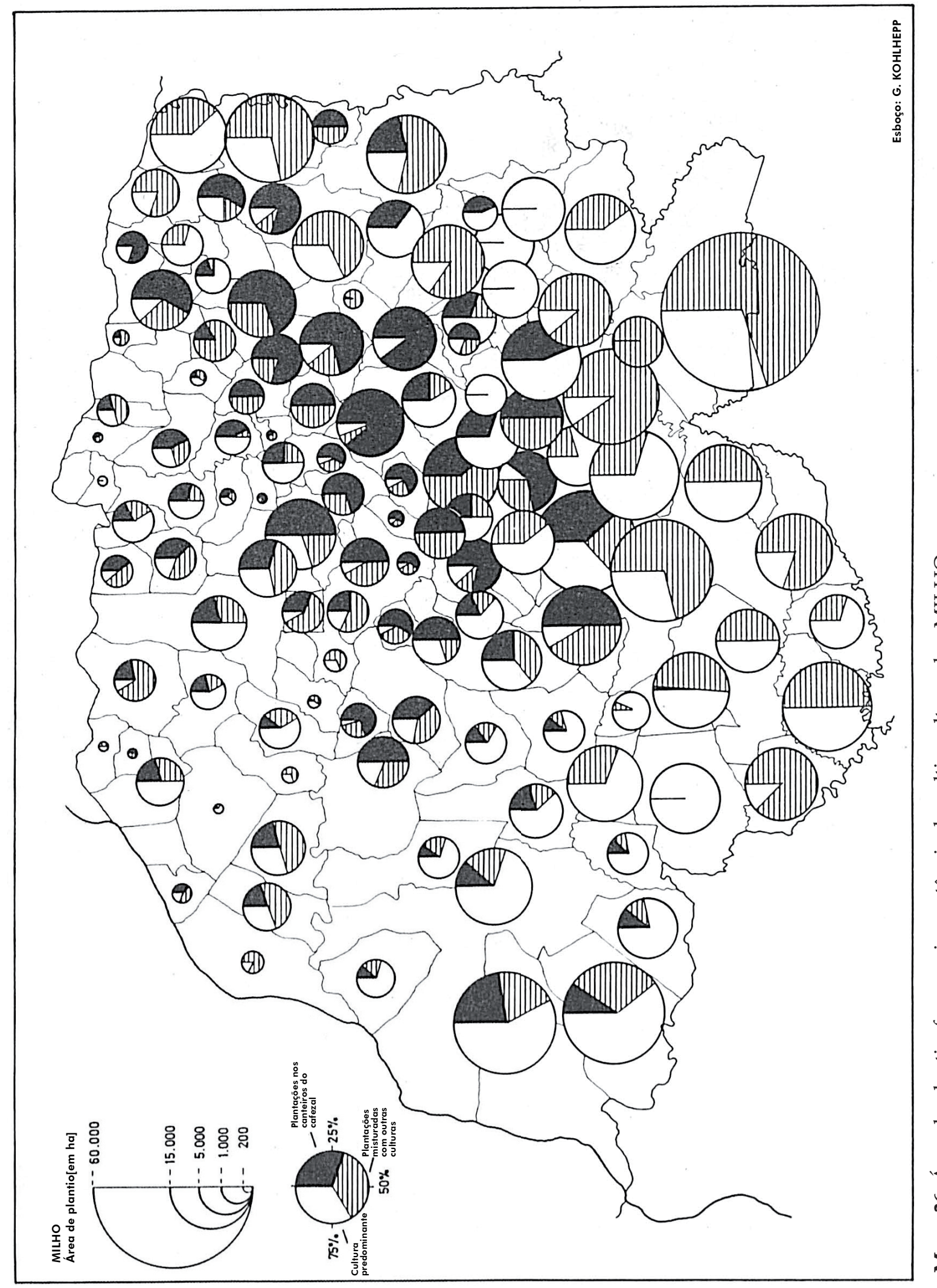

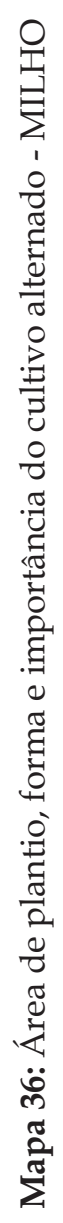




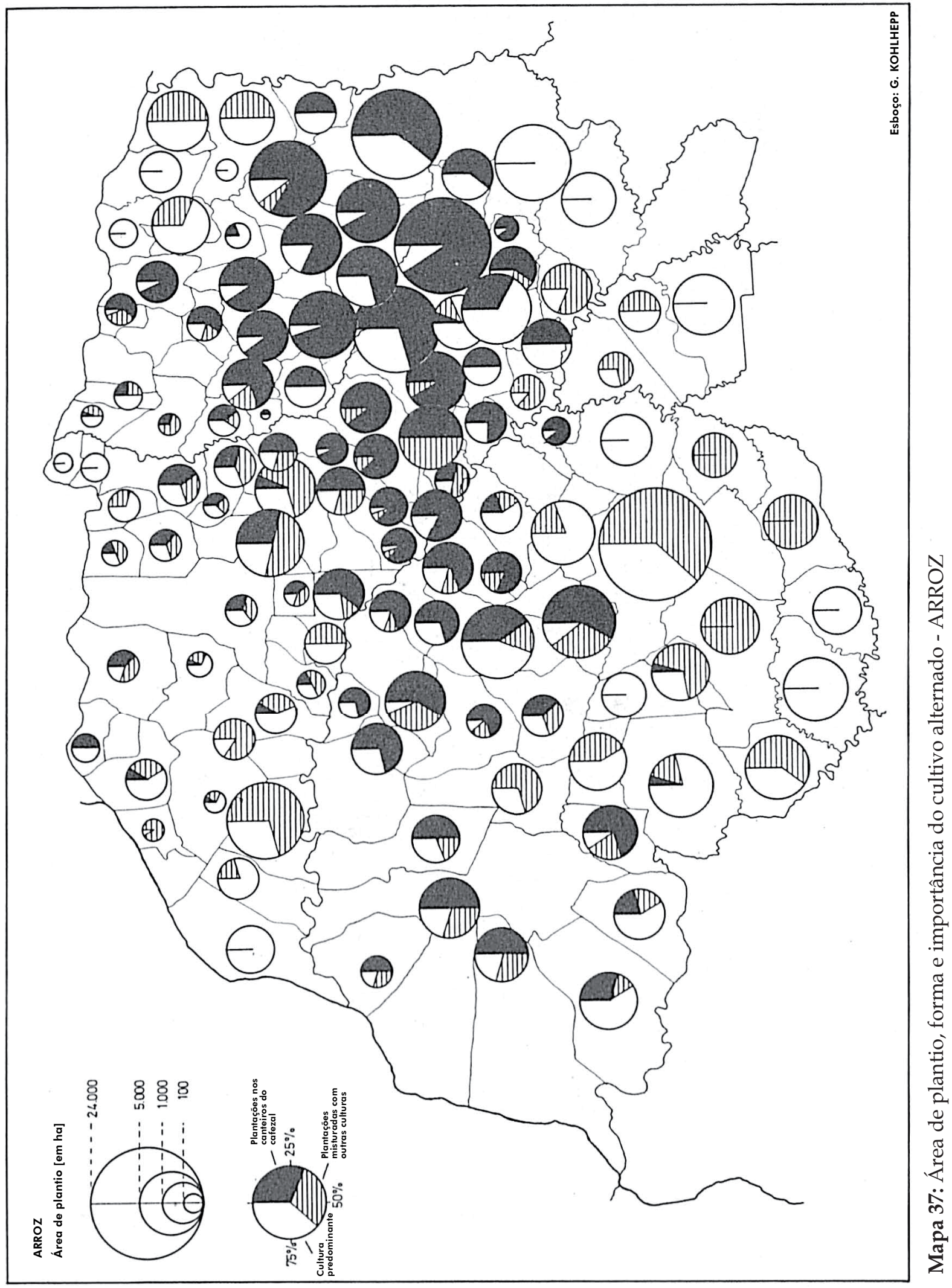




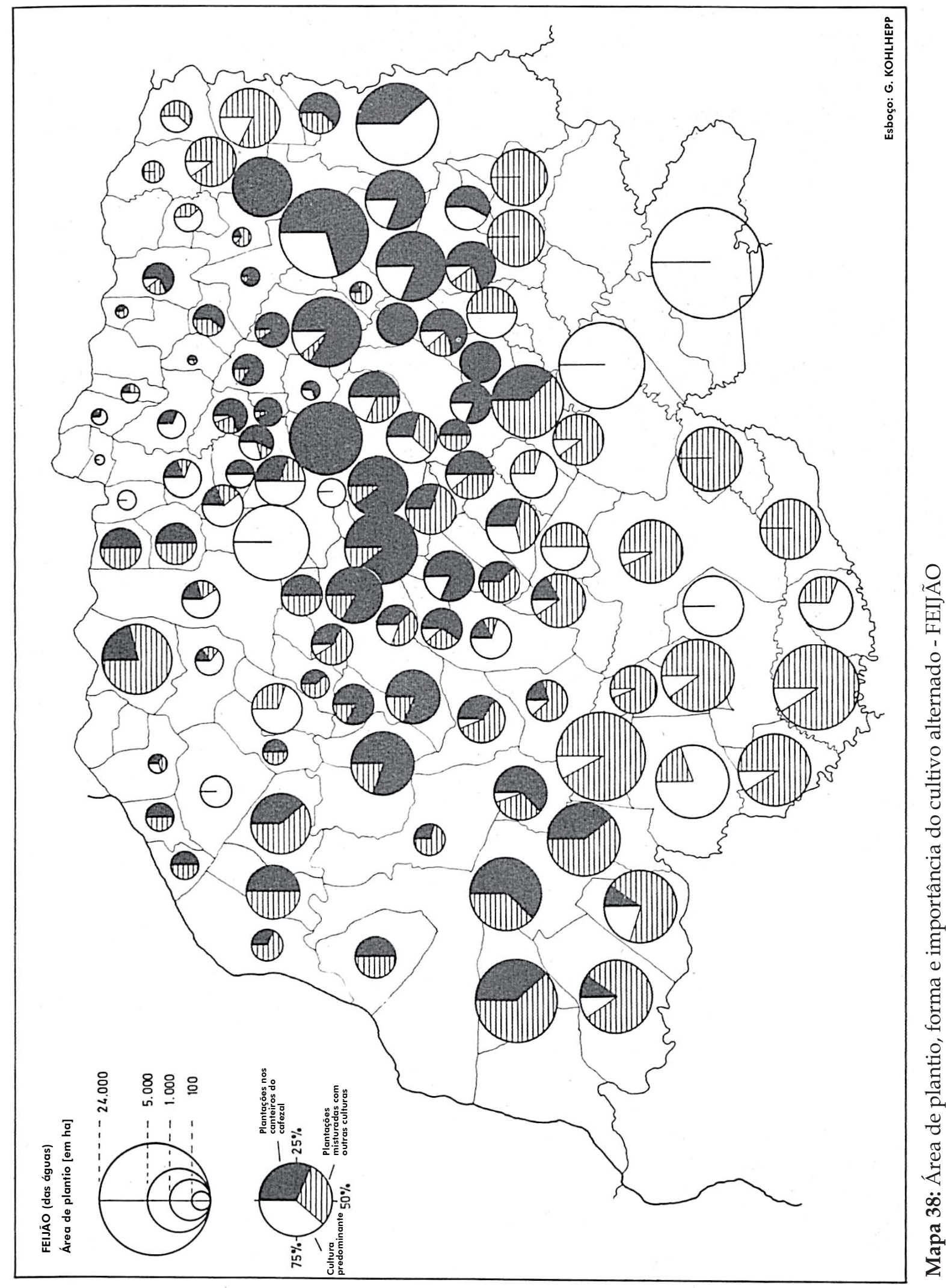




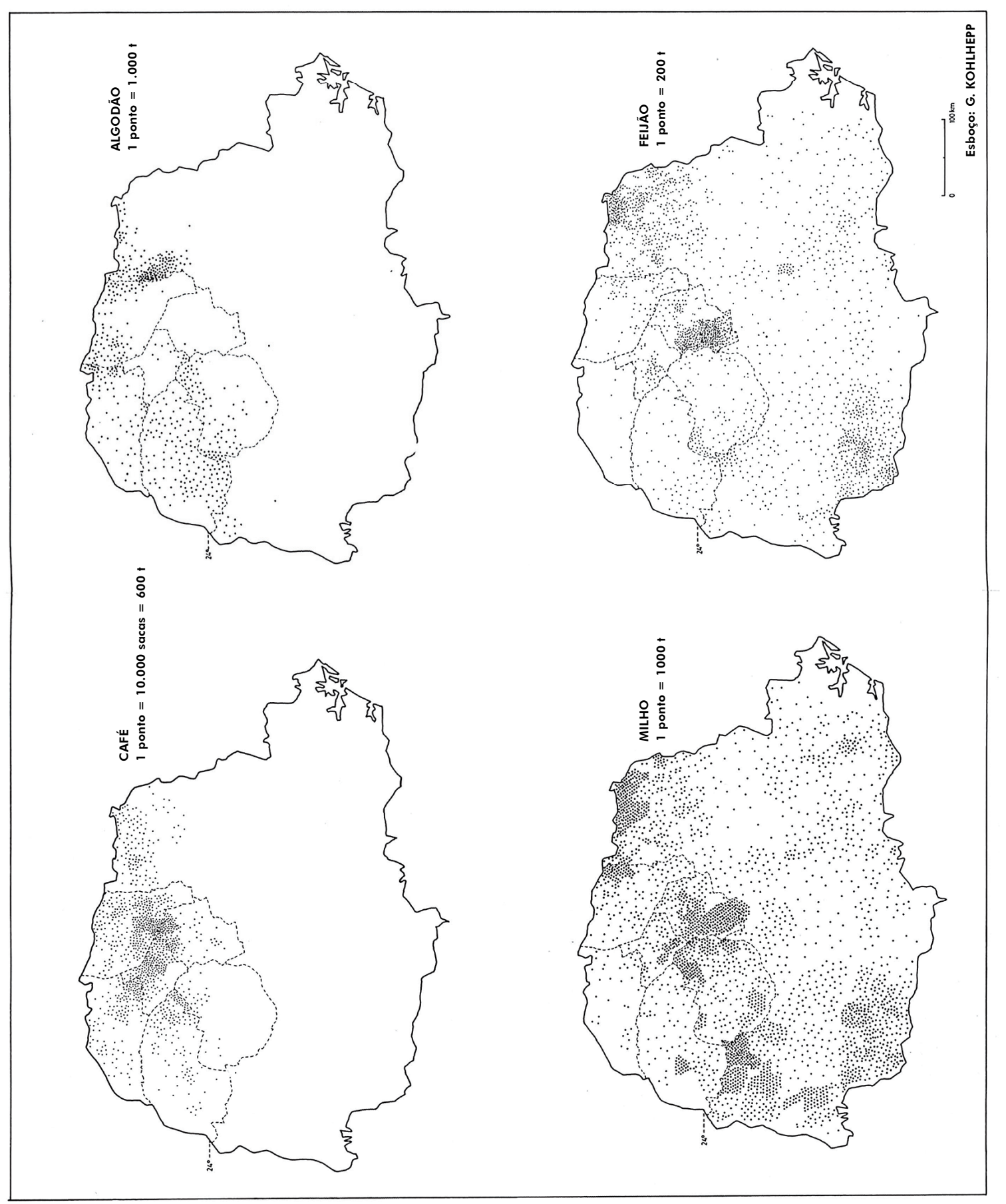

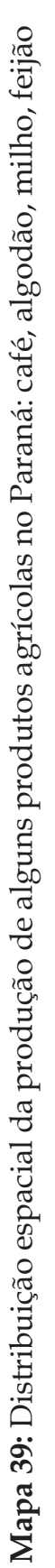




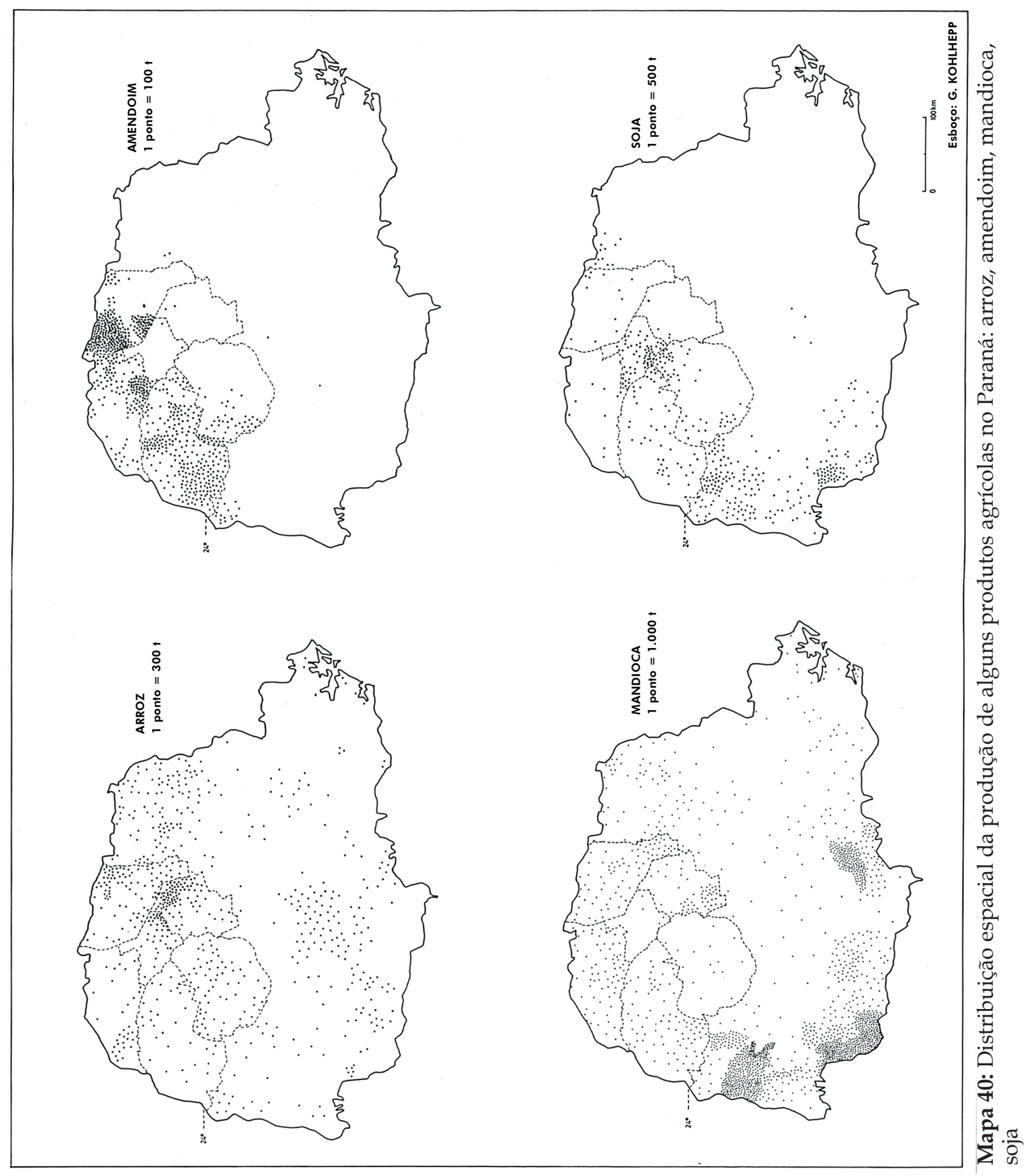




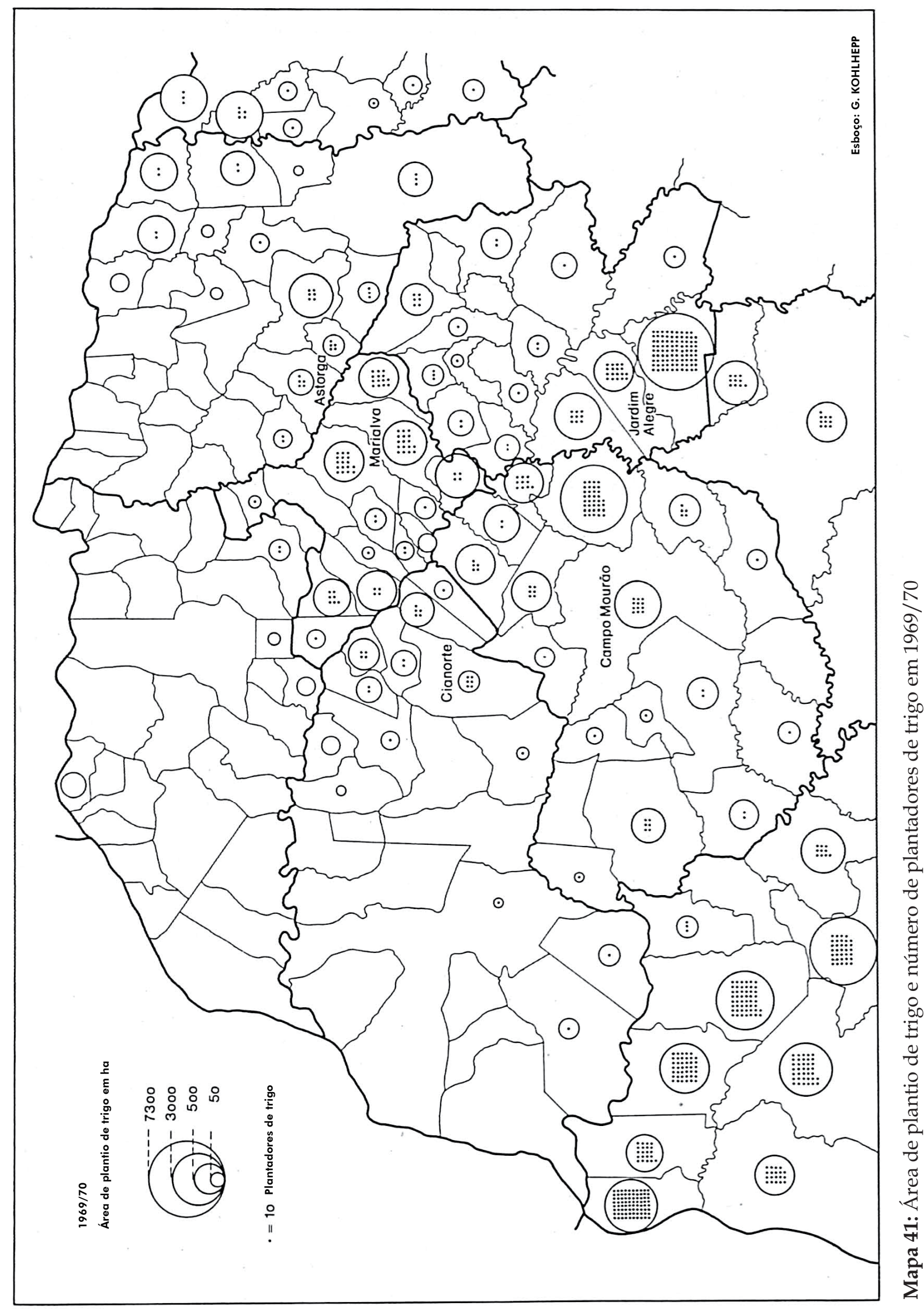




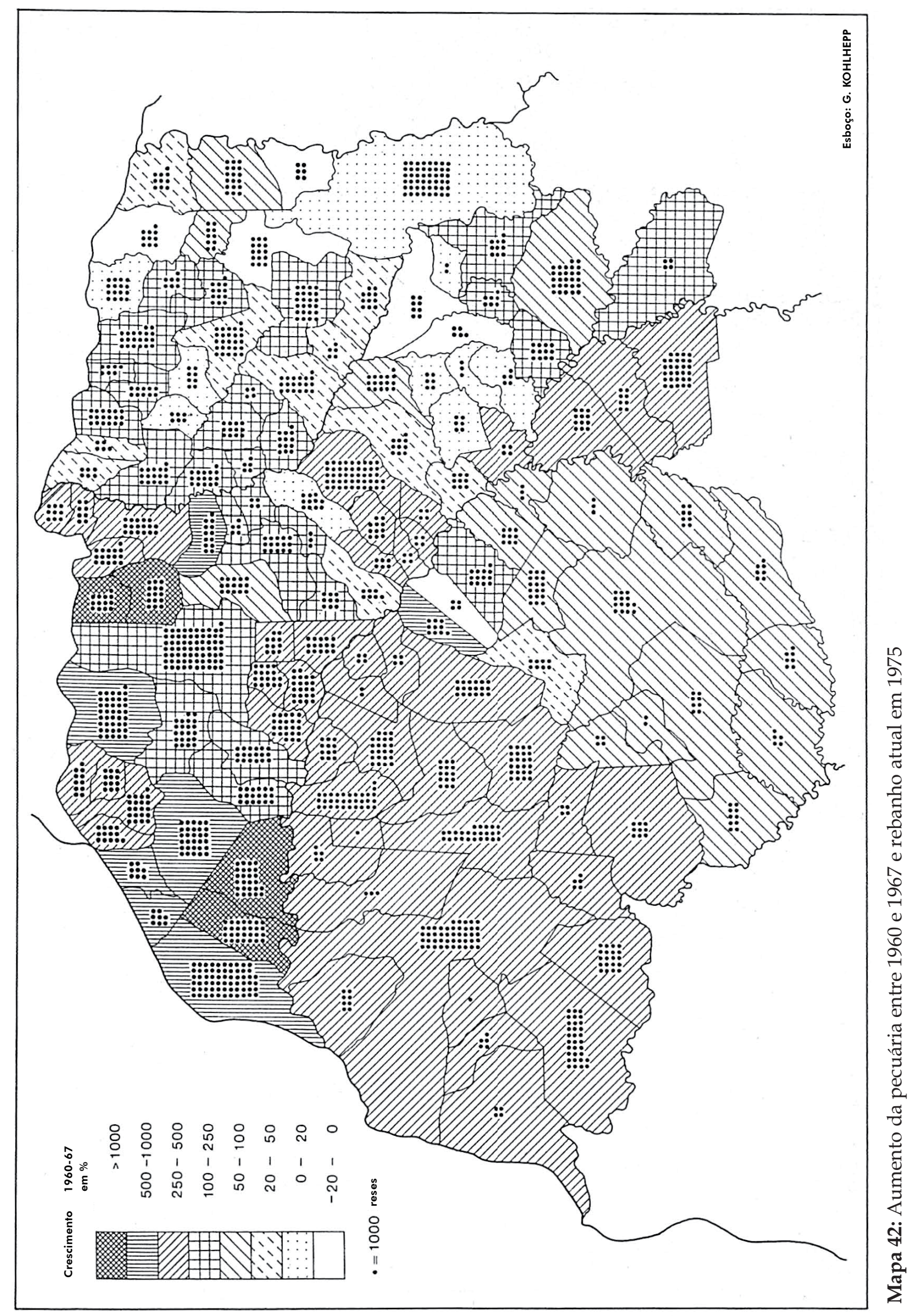




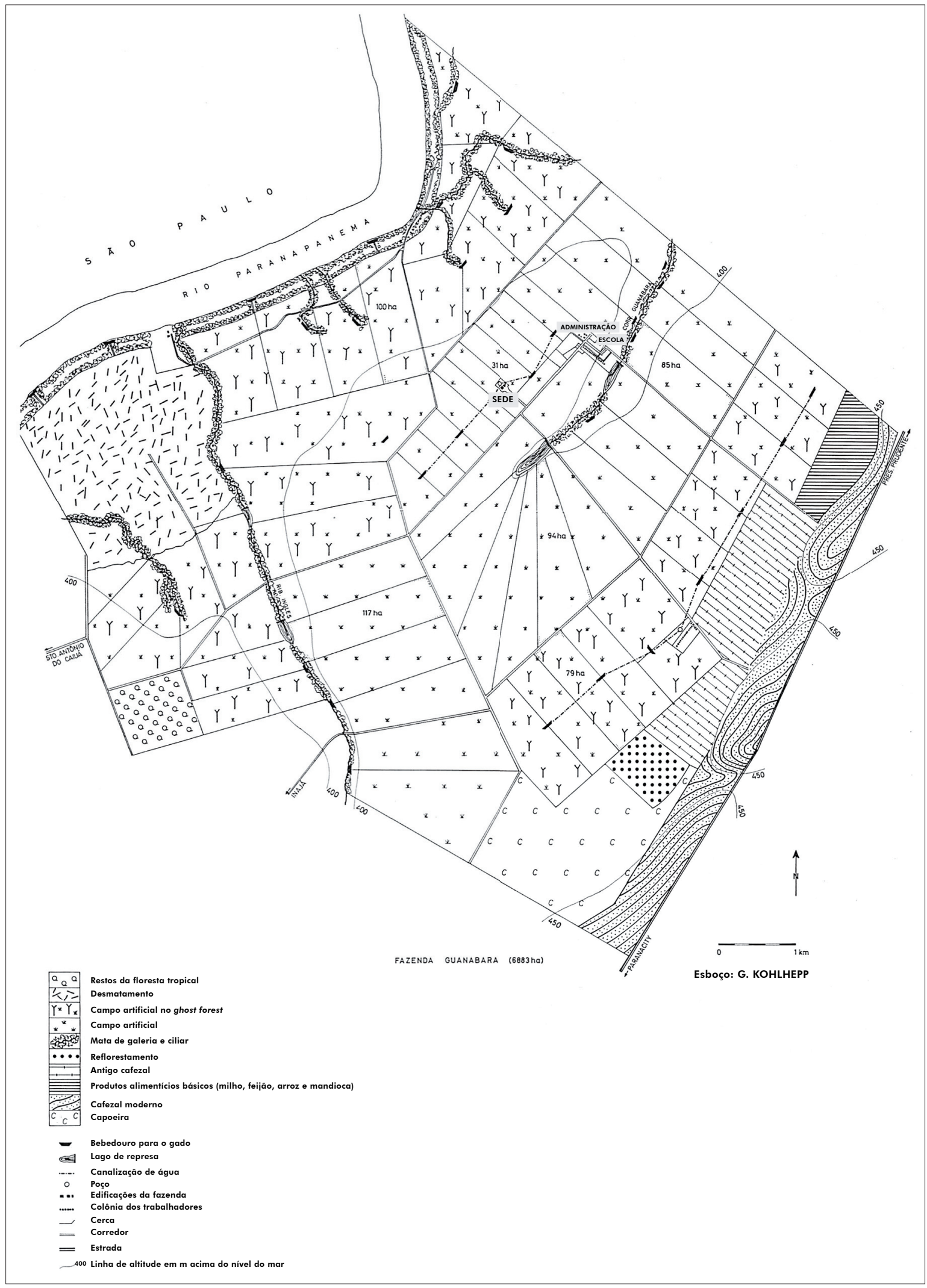

Mapa 43: Fazenda Guanabara. Uso do solo 


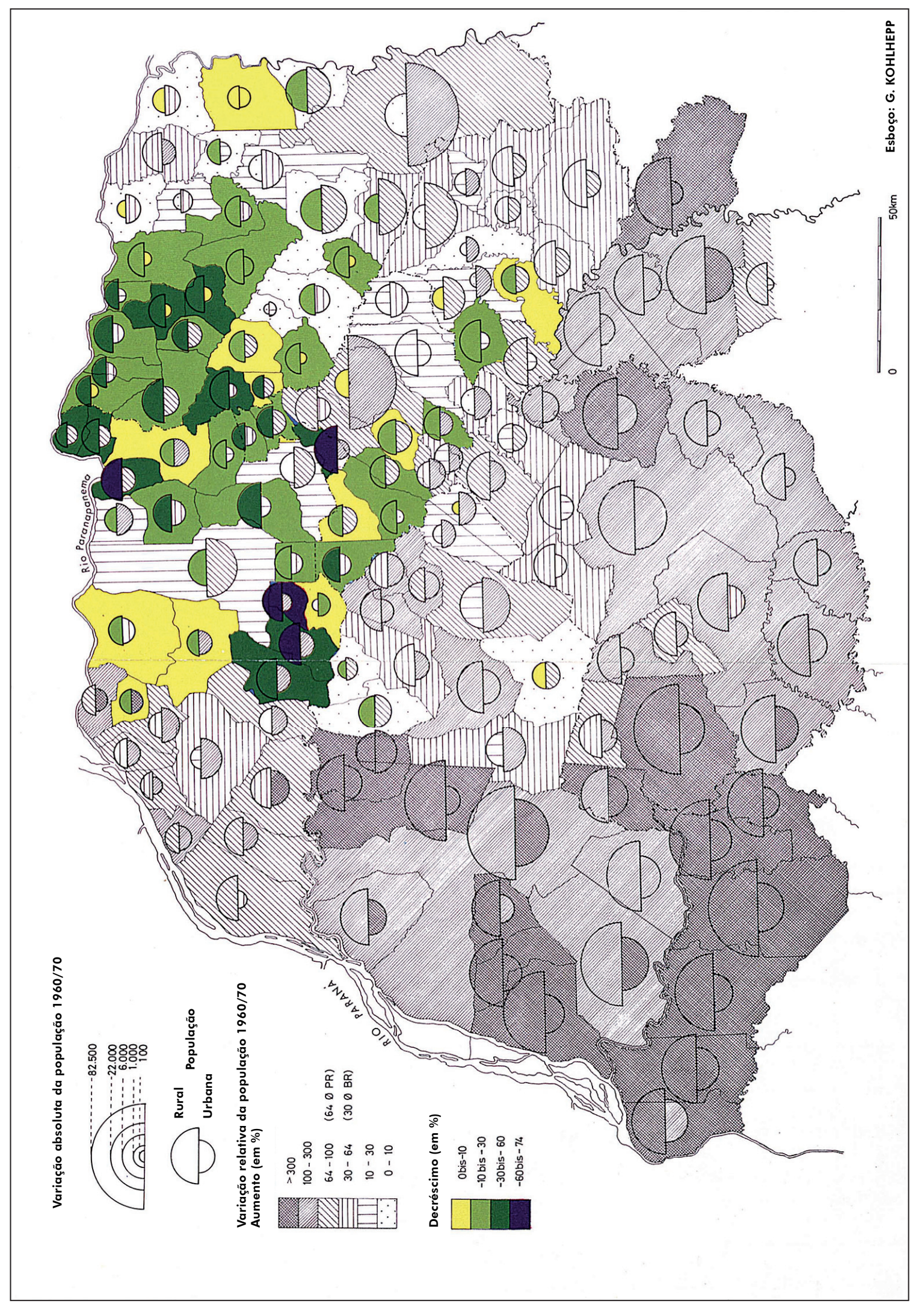

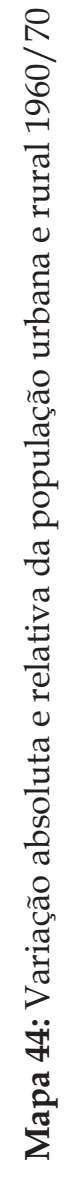




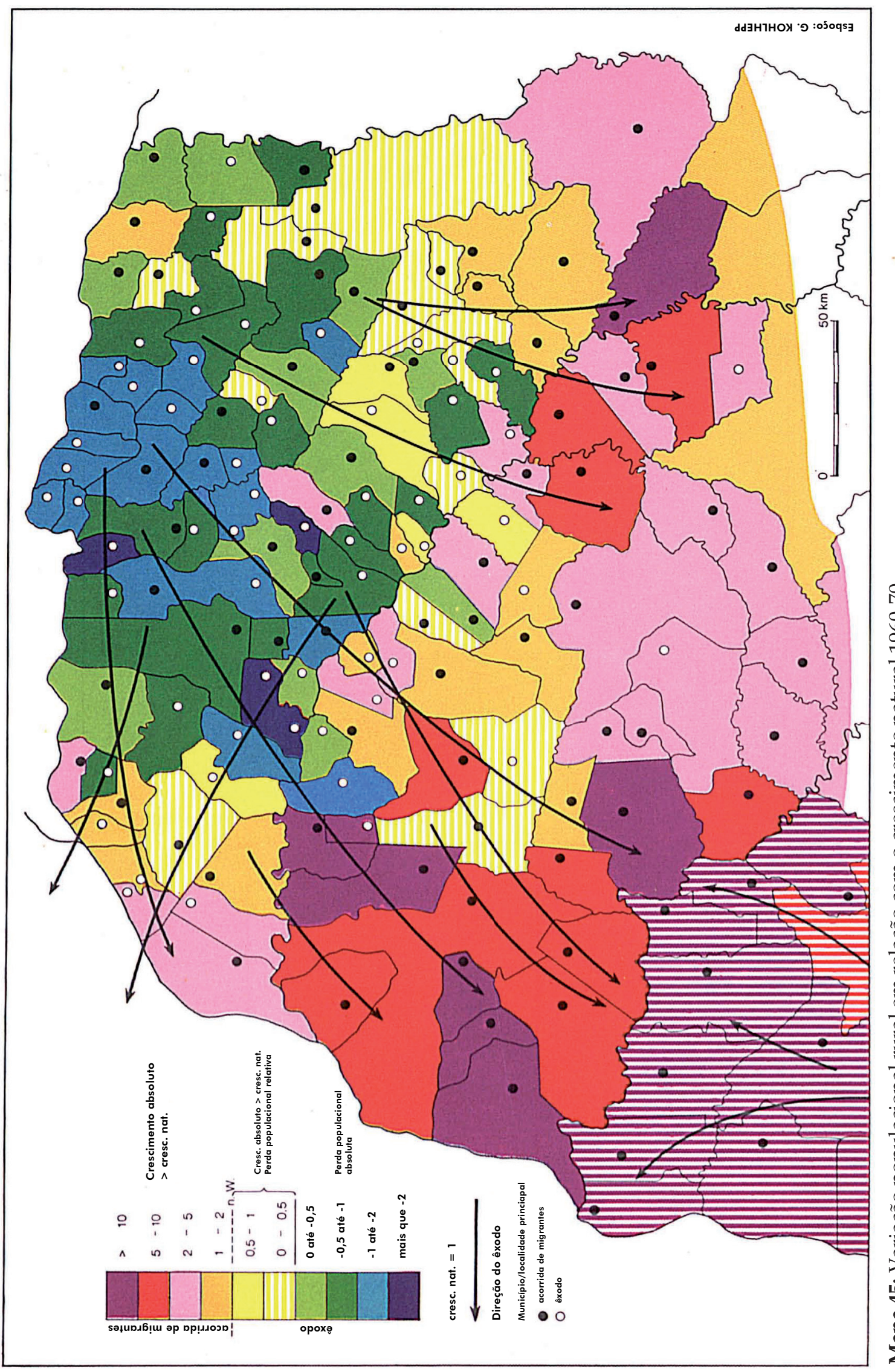

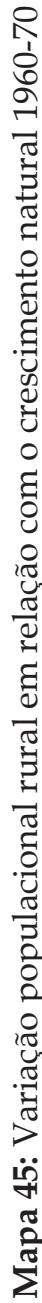




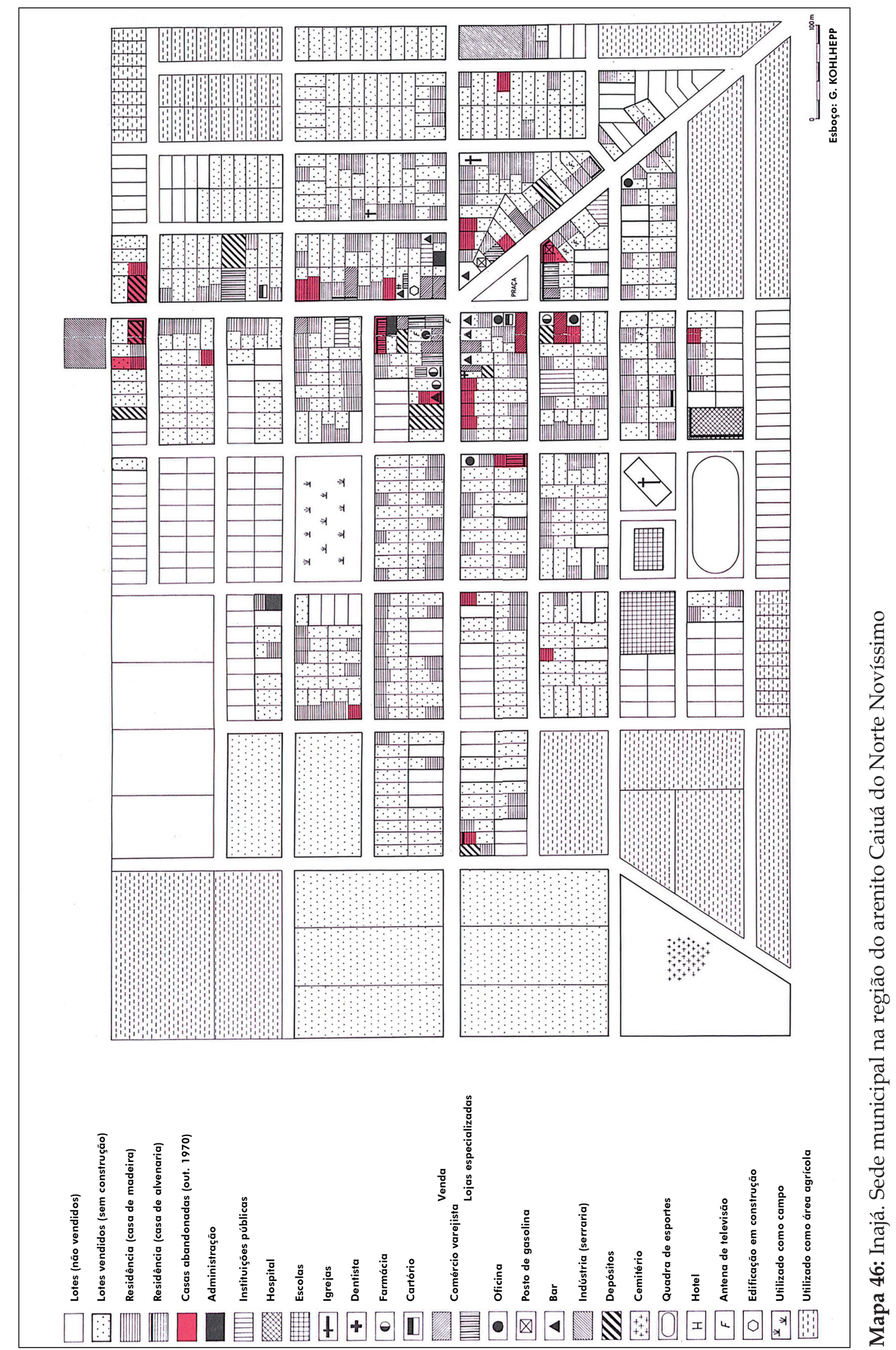




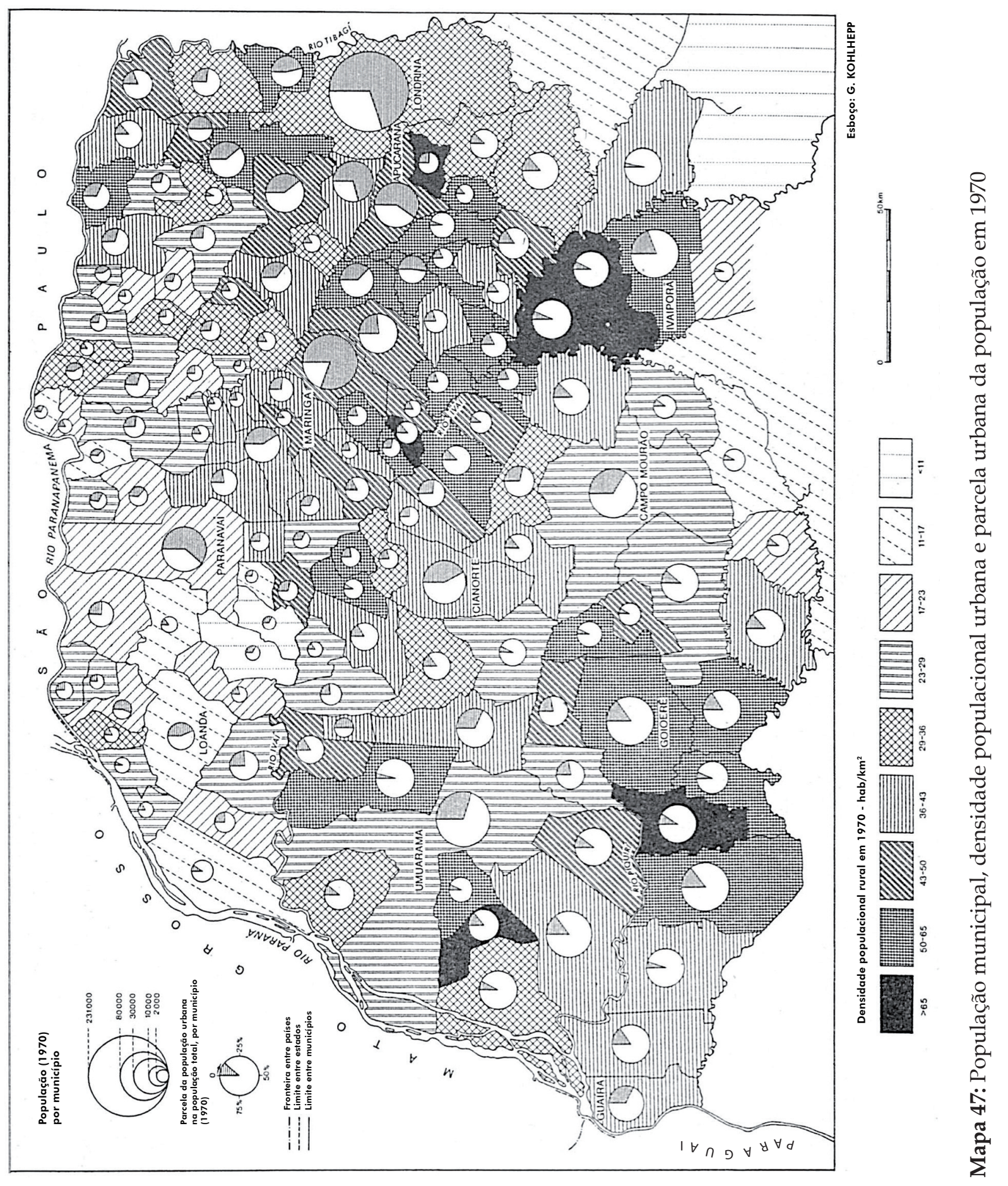




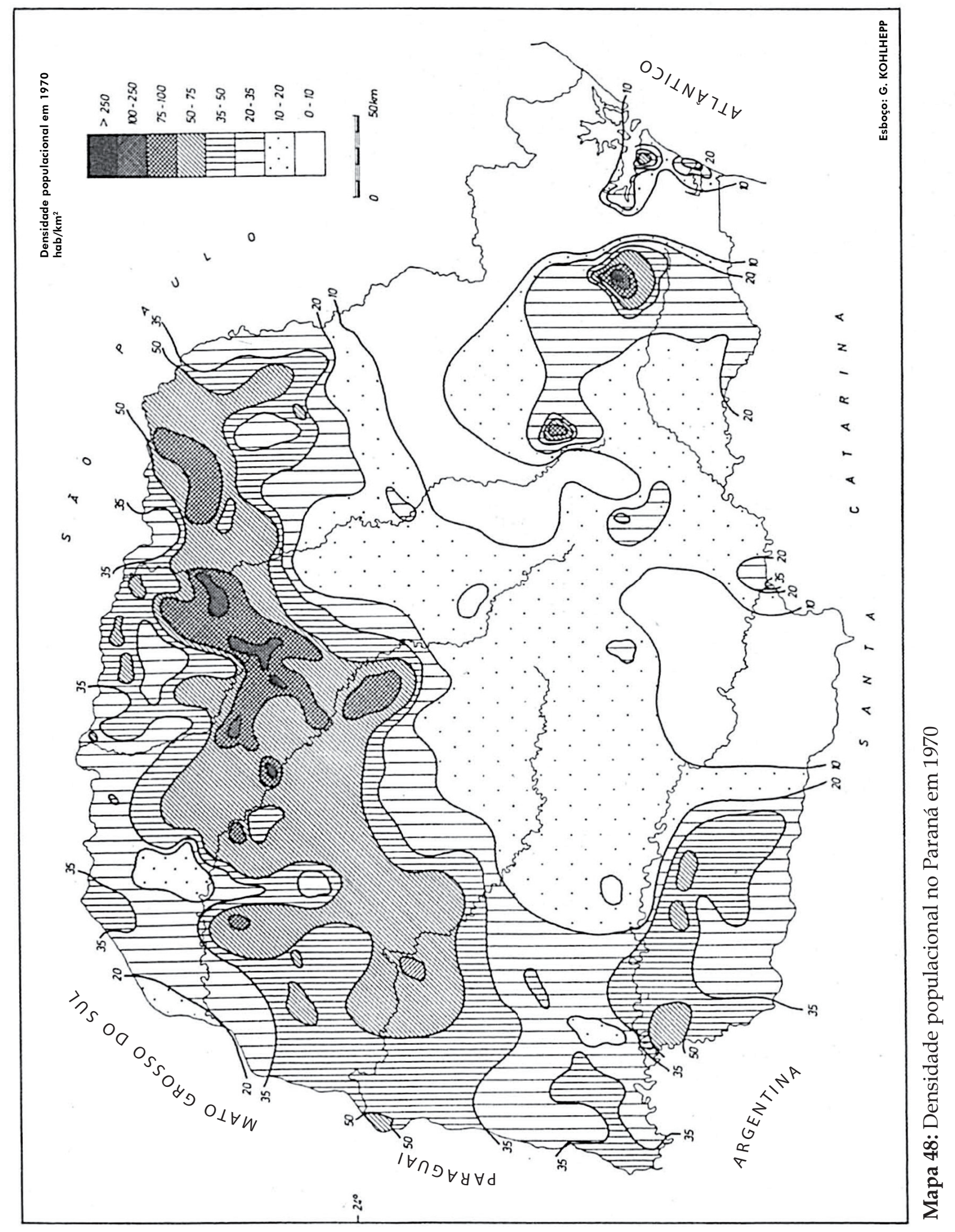




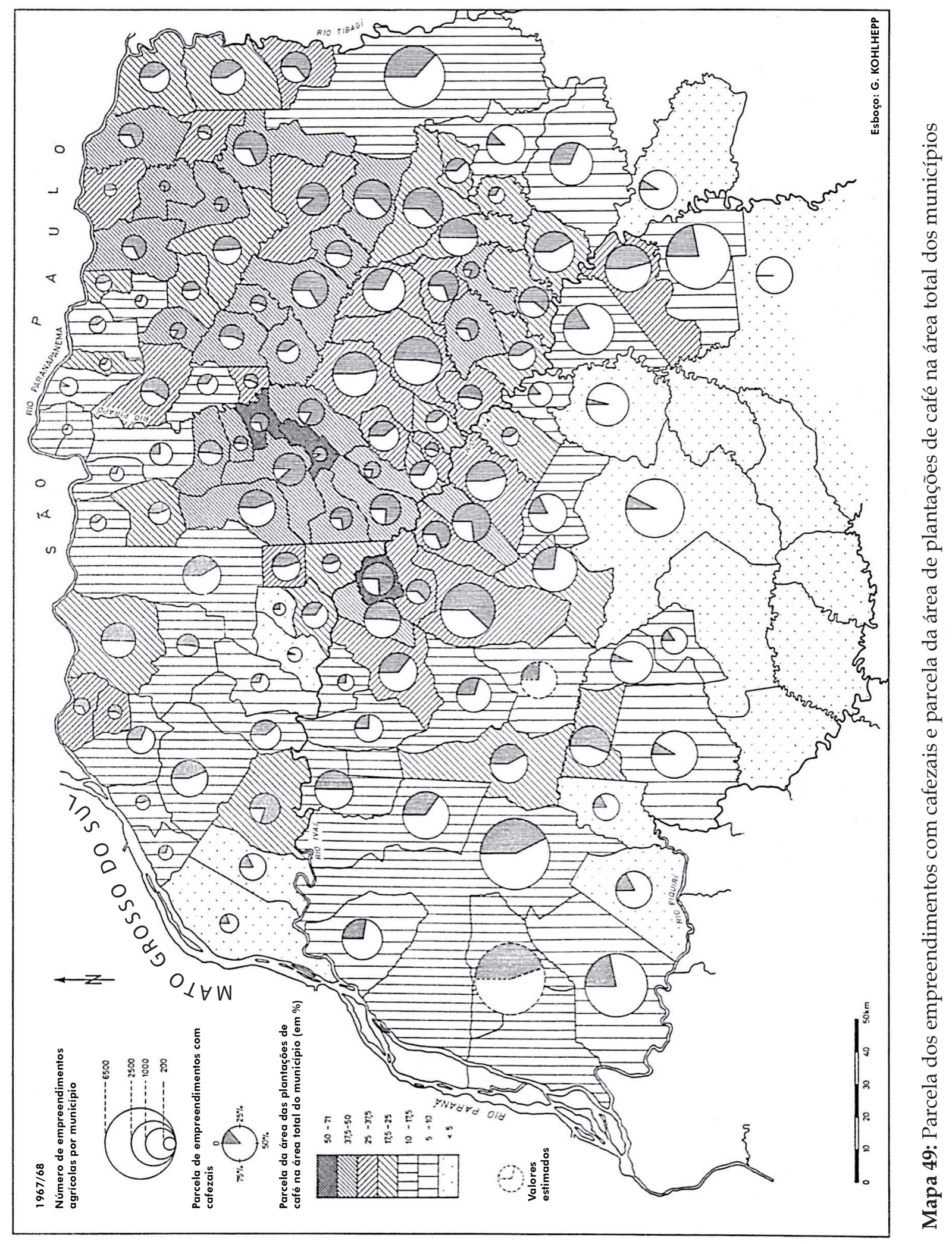




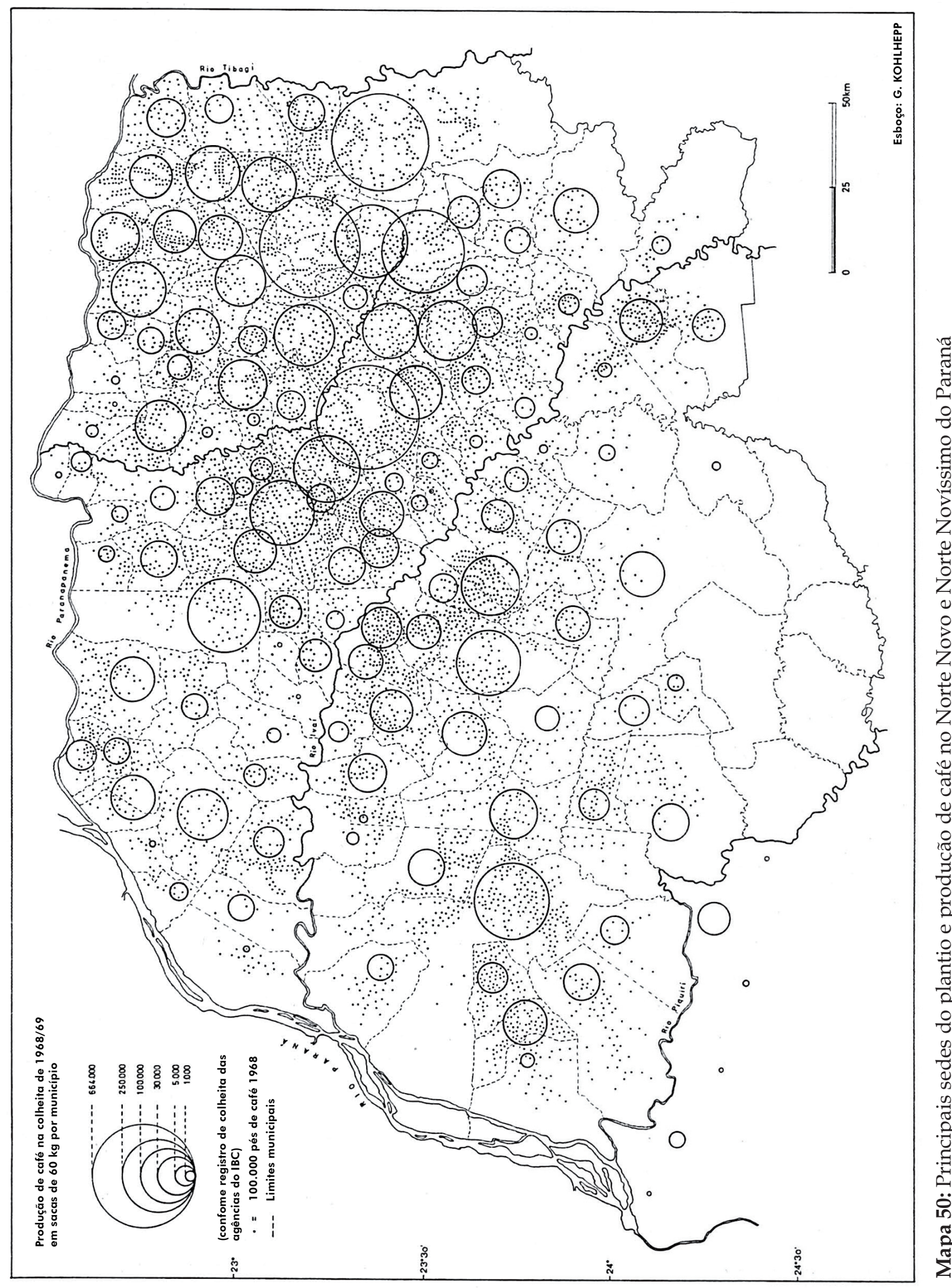




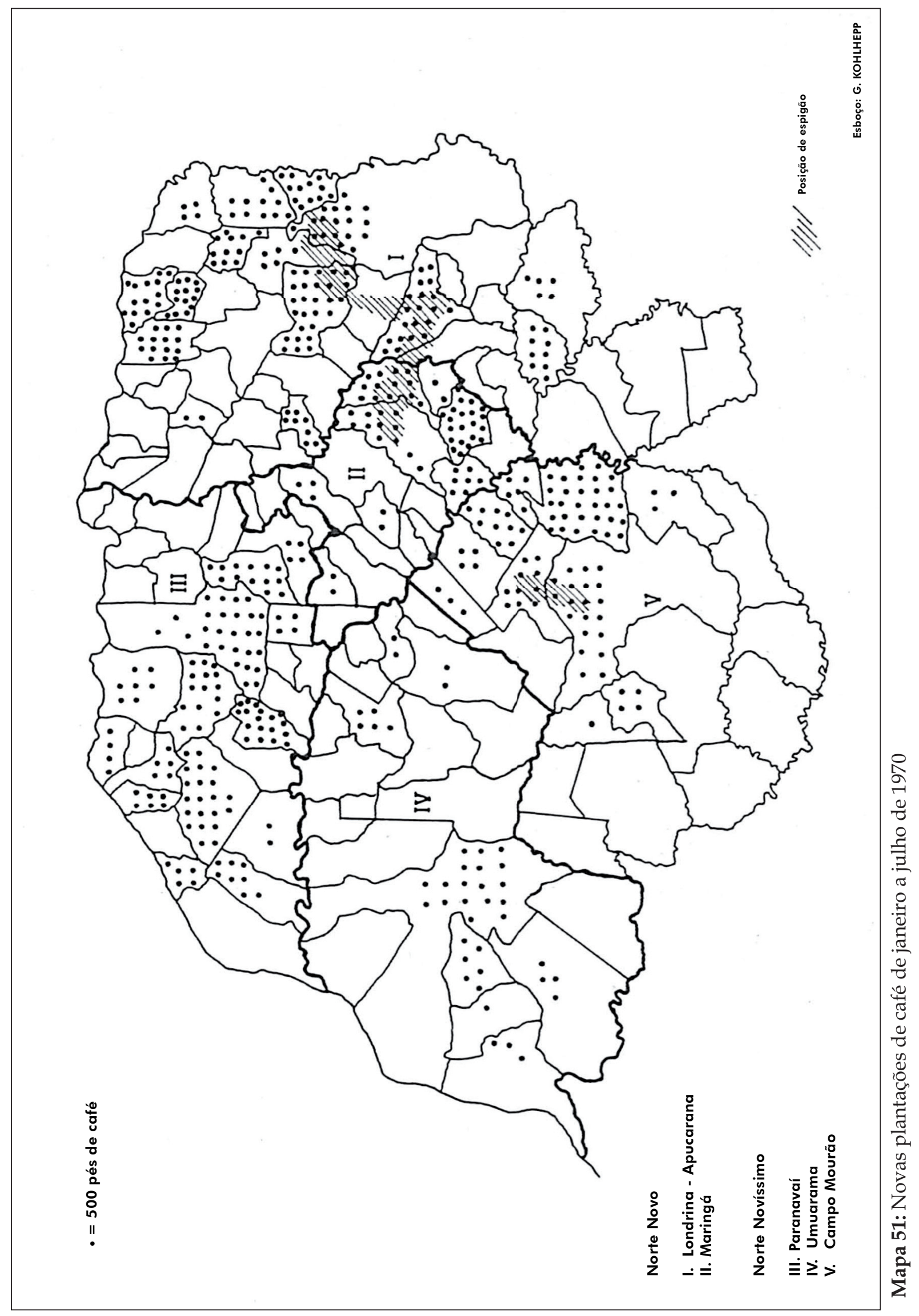




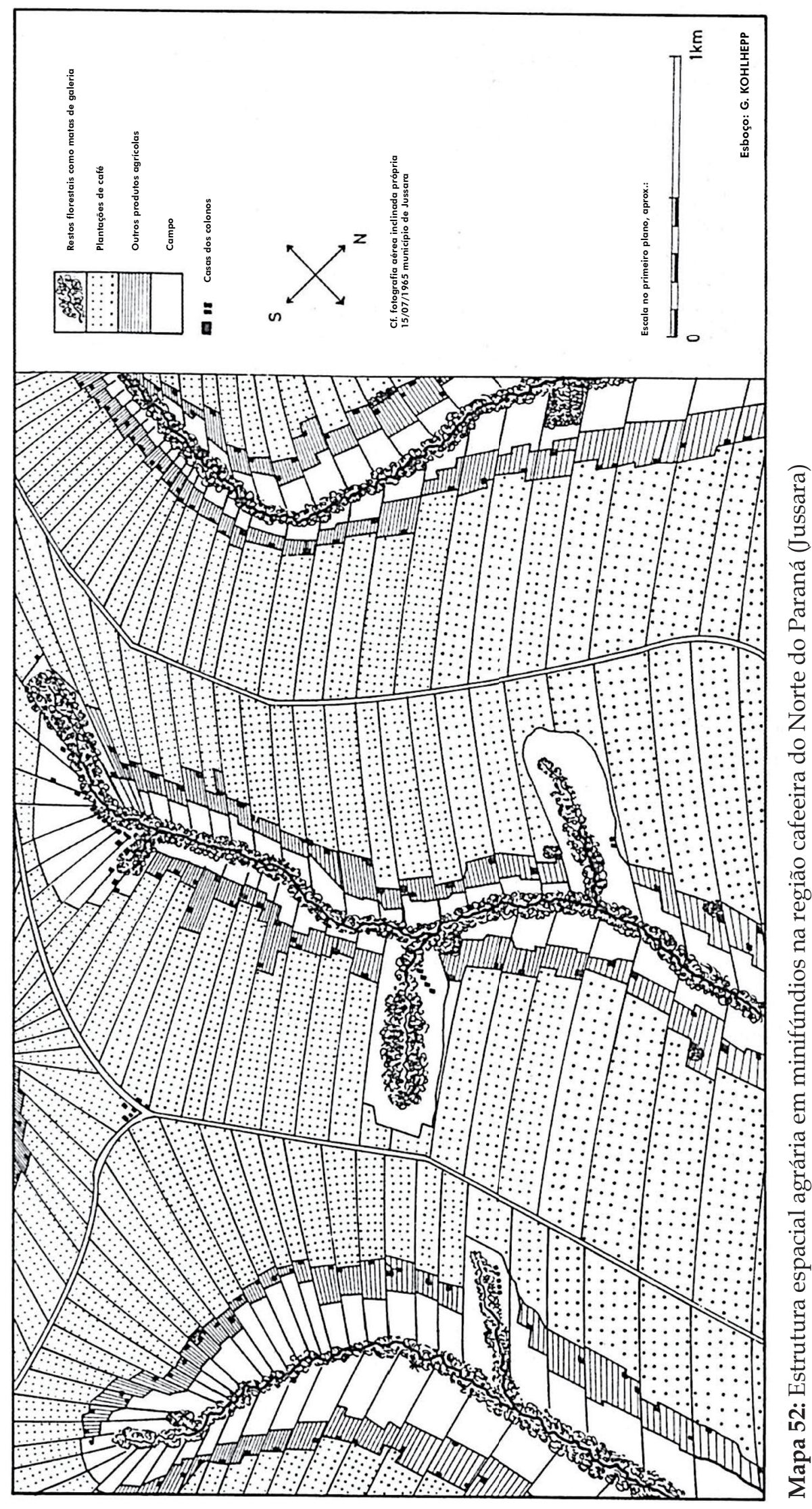




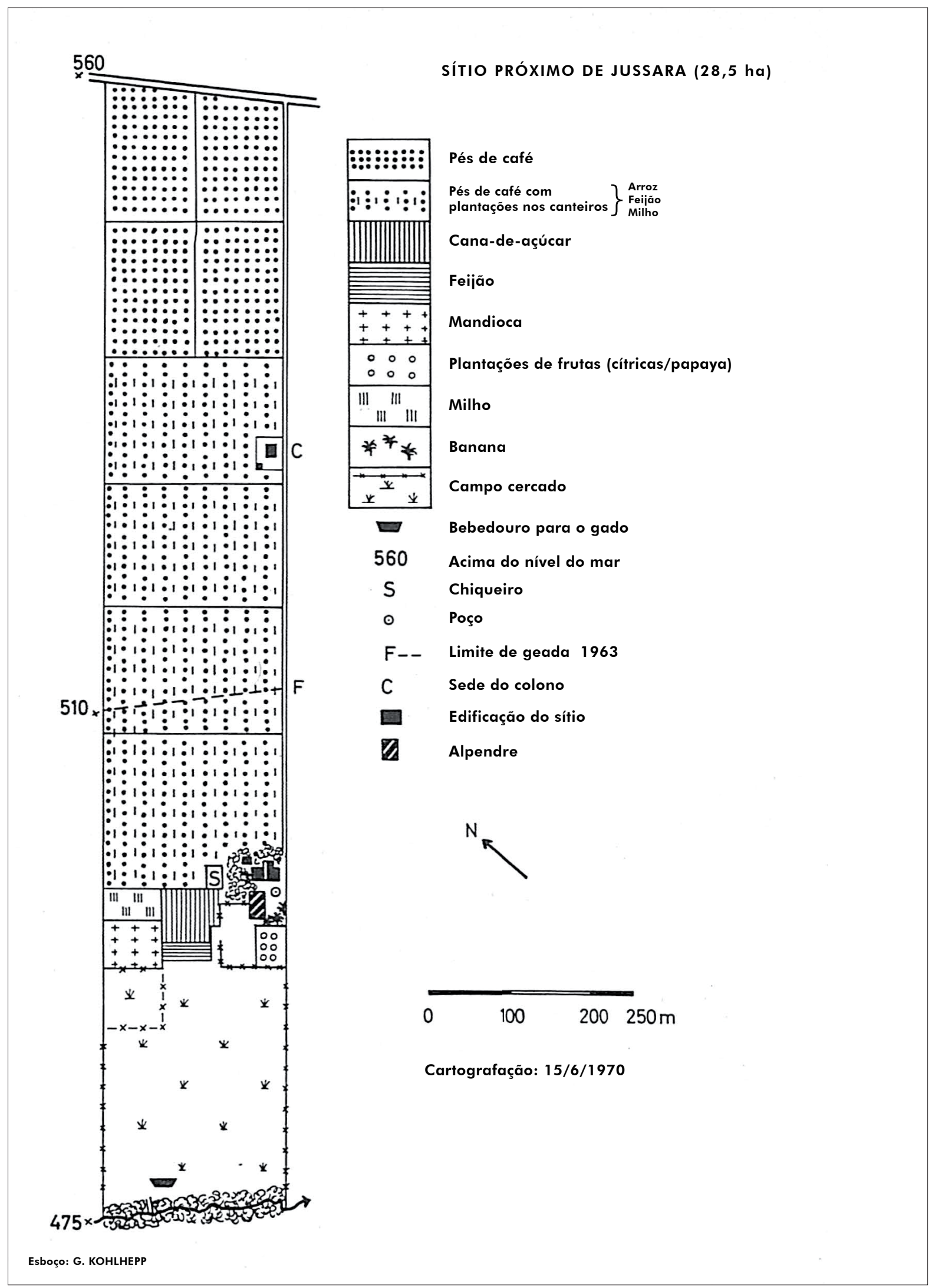

Mapa 53: Uso do solo: próximo a Jussara 


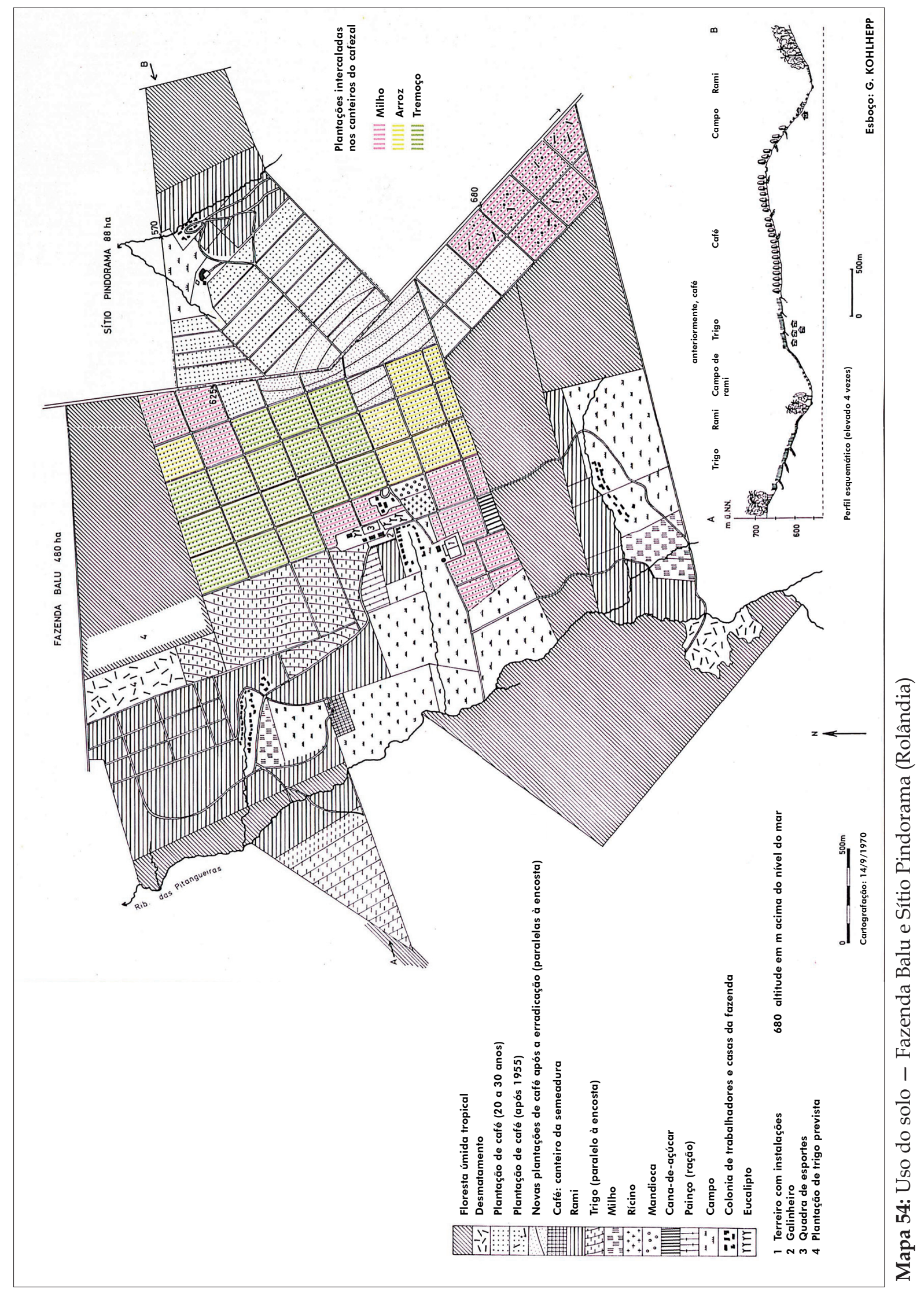




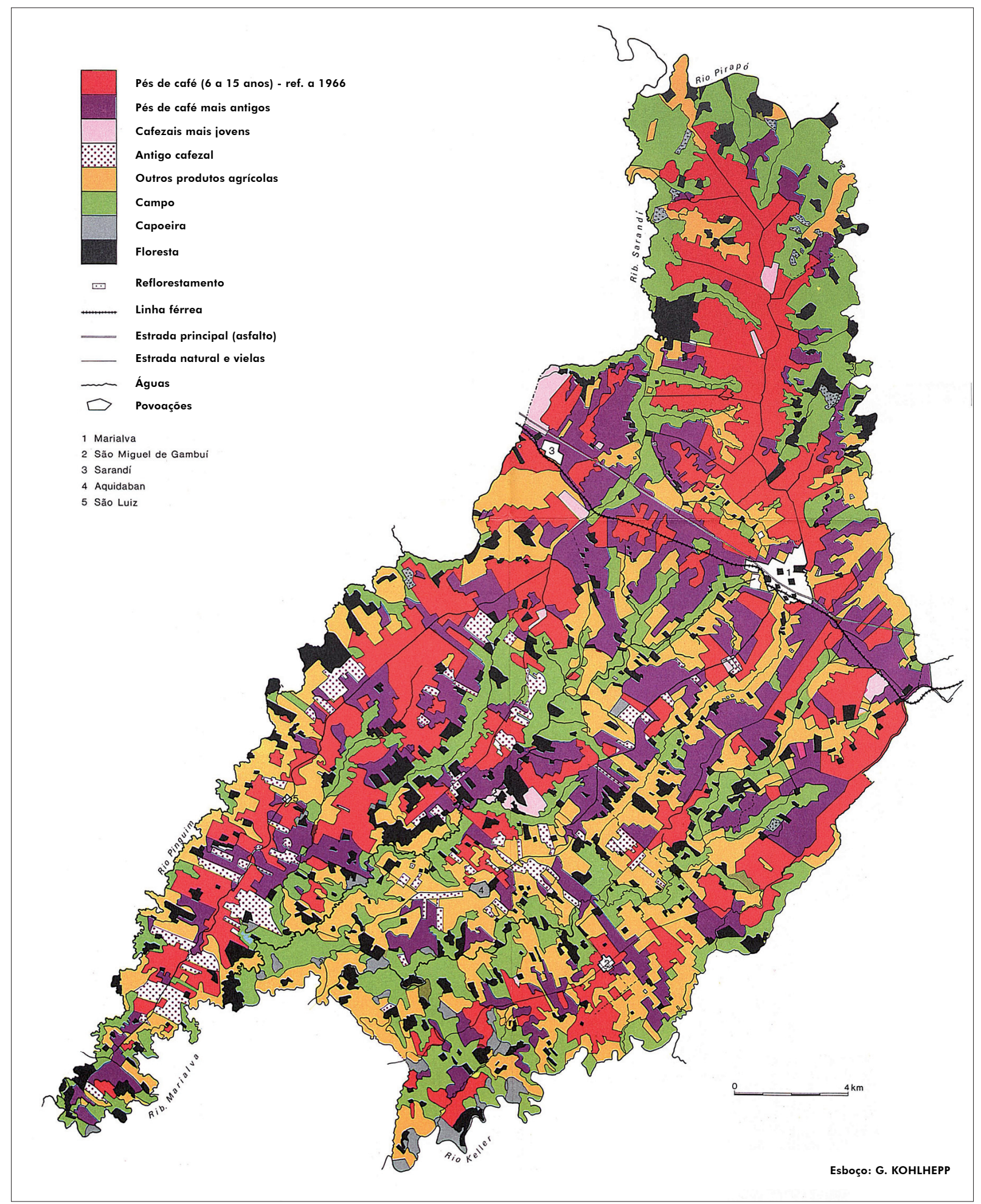

Mapa 55: Mapa de uso do solo. Município de Marialva 


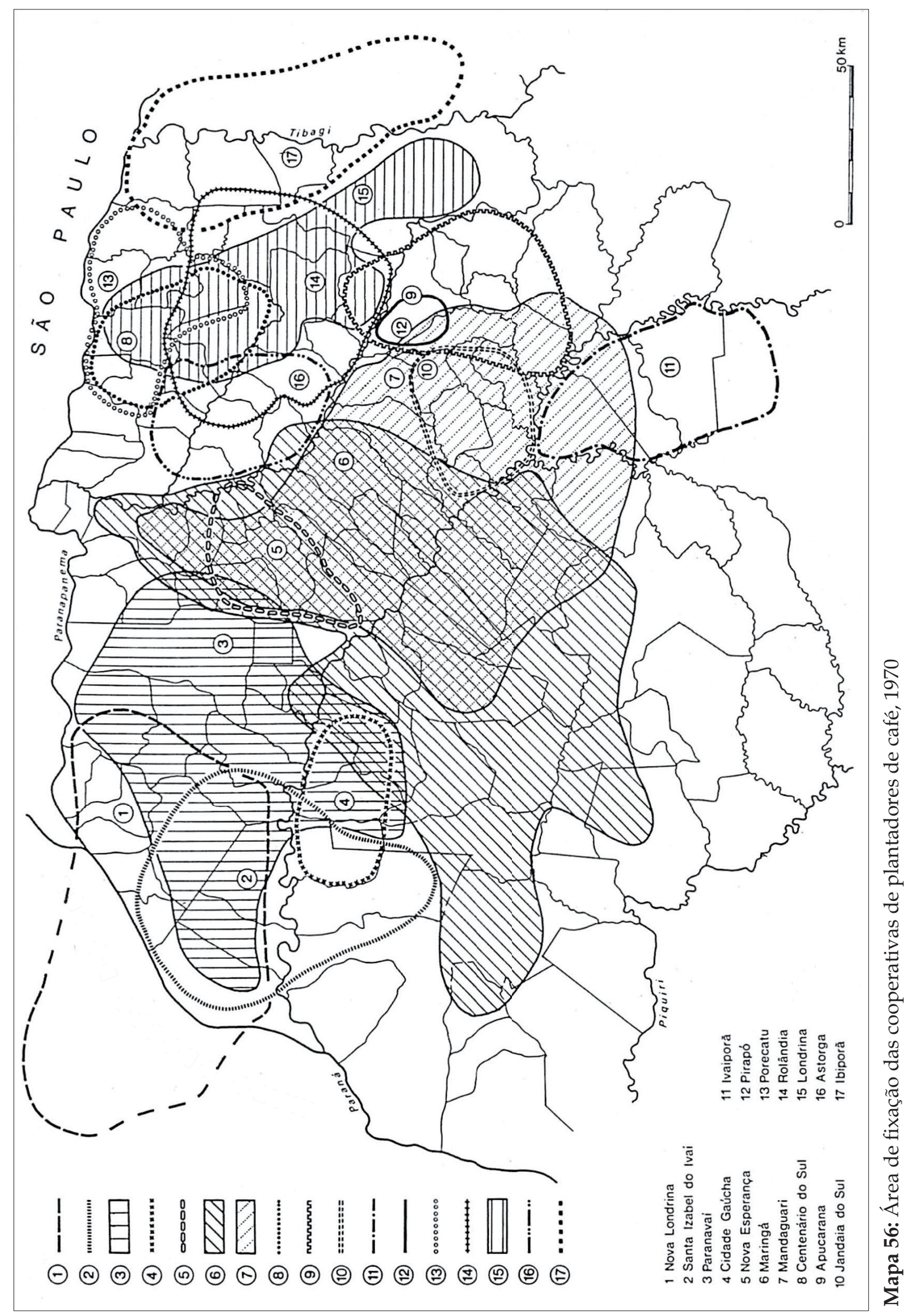




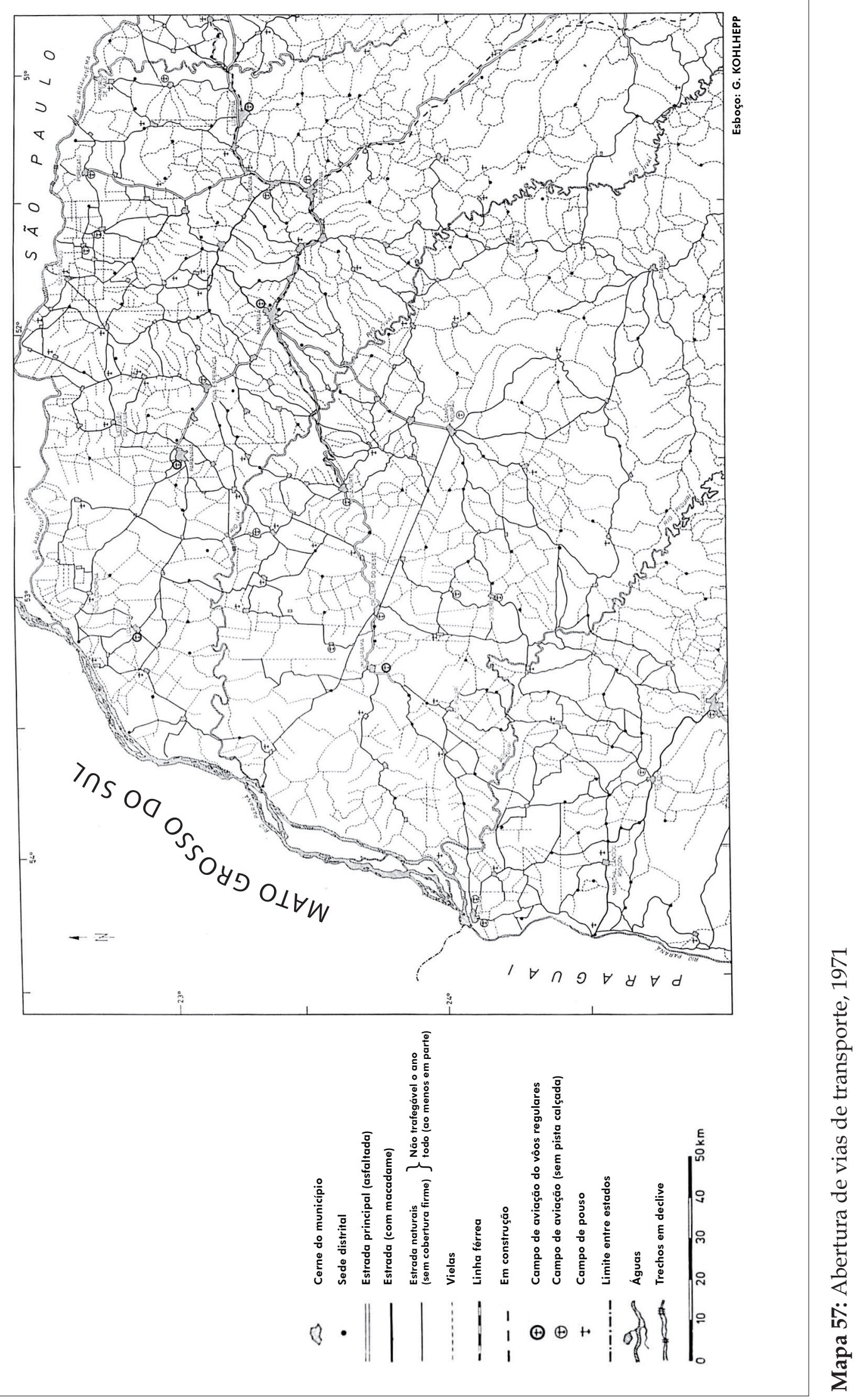



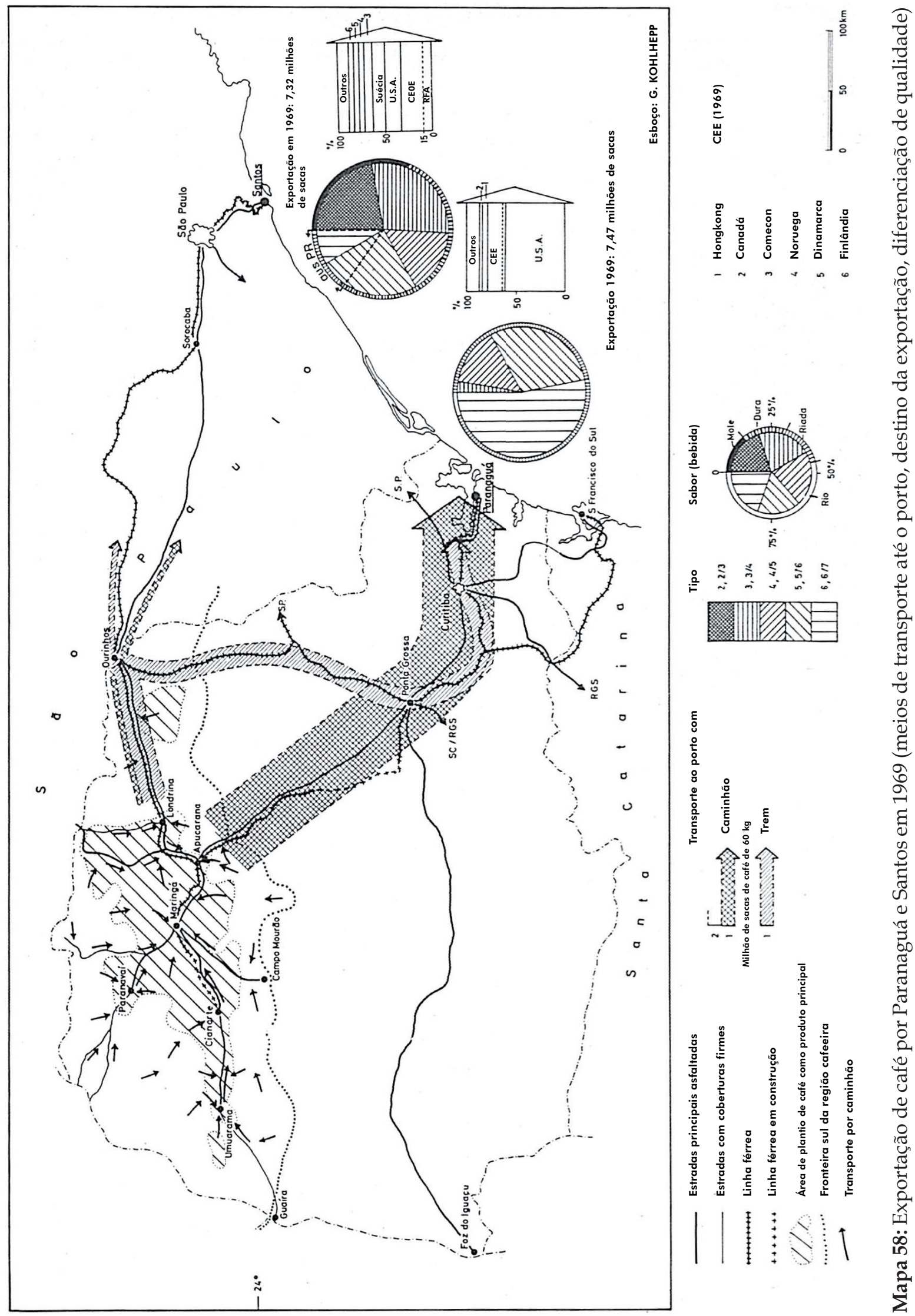

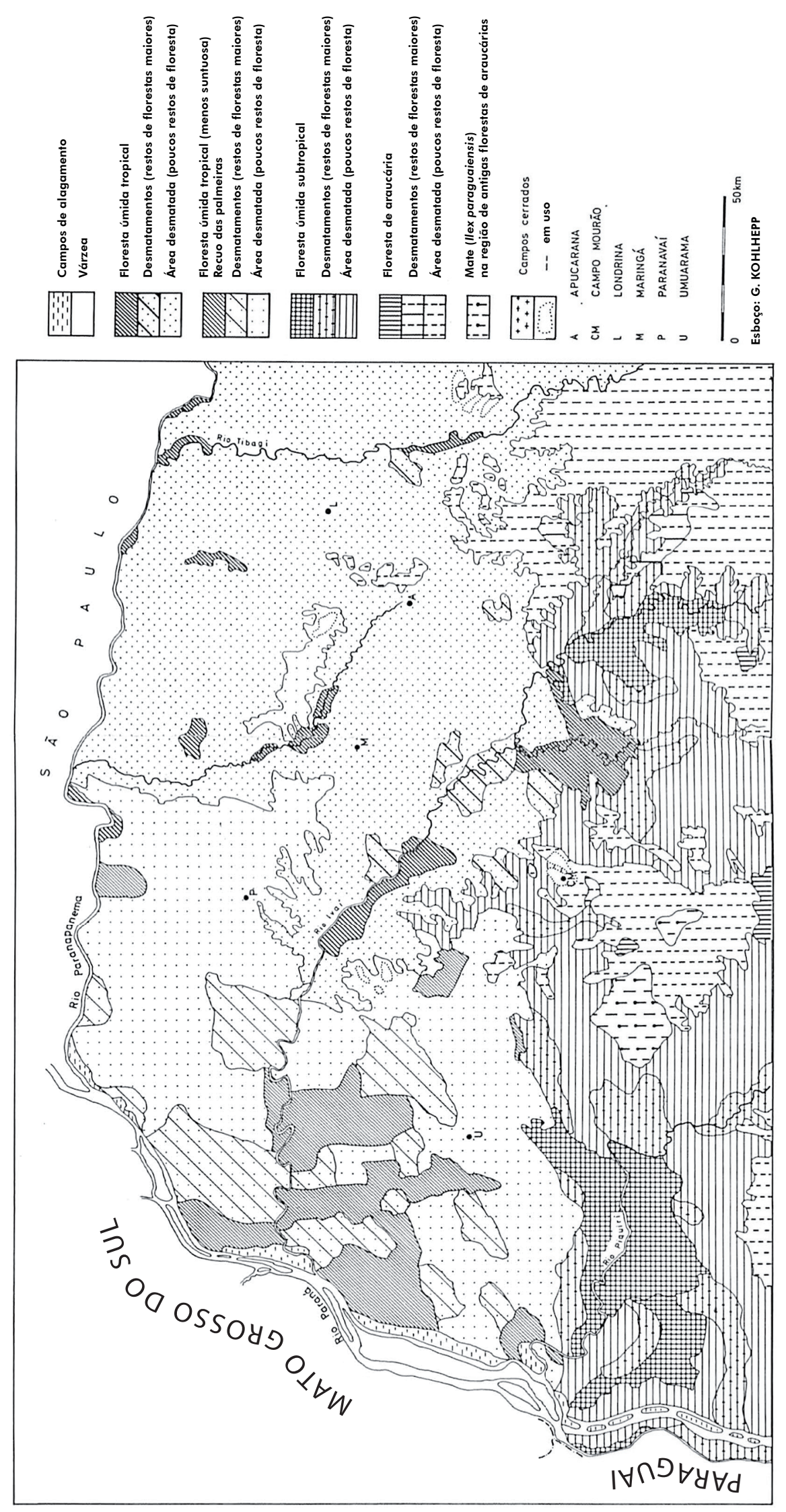

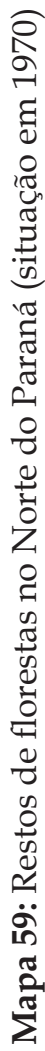


ANEXO 
ఠิ

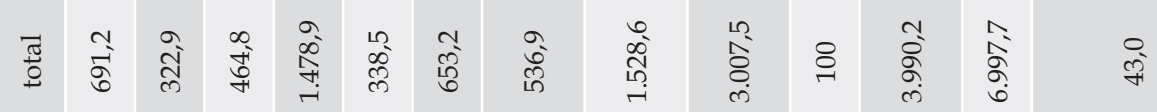

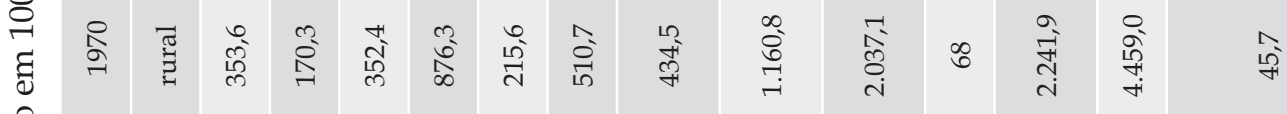

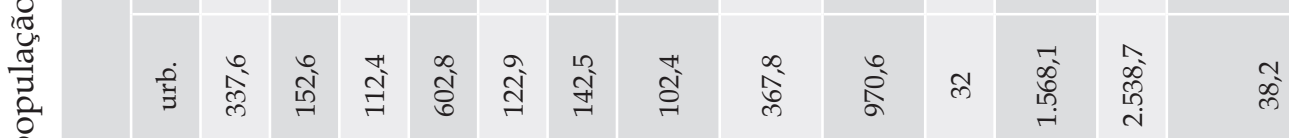

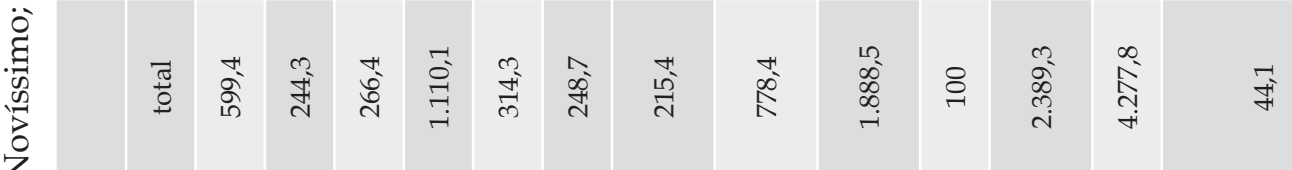

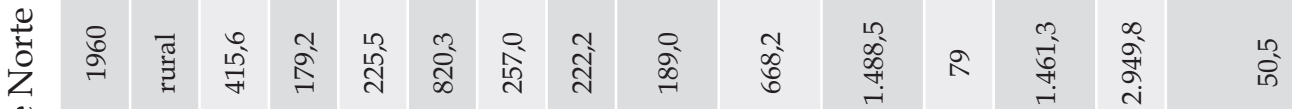

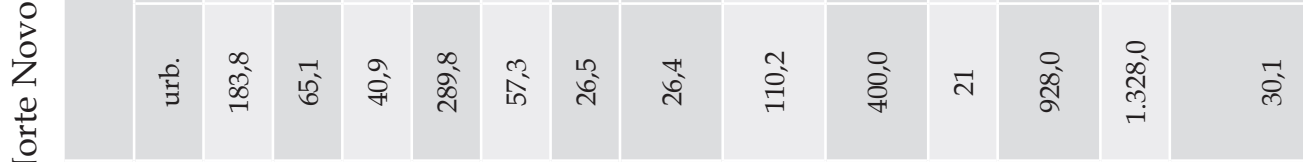

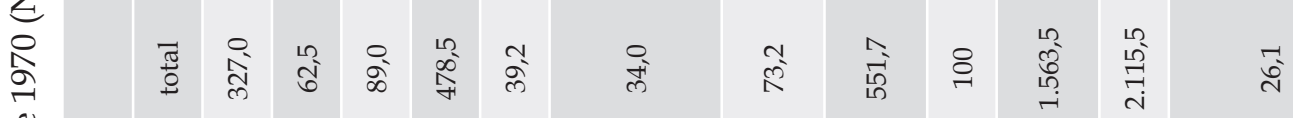

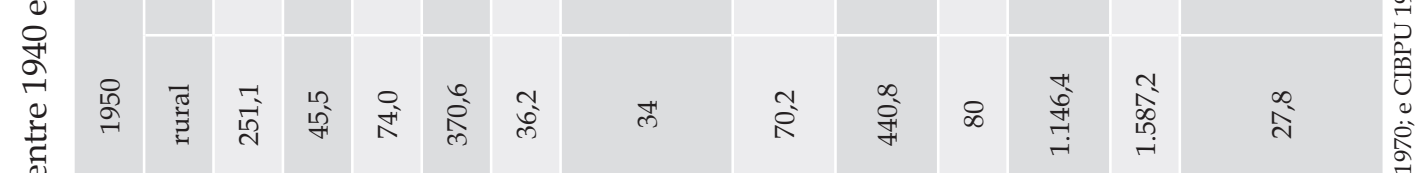

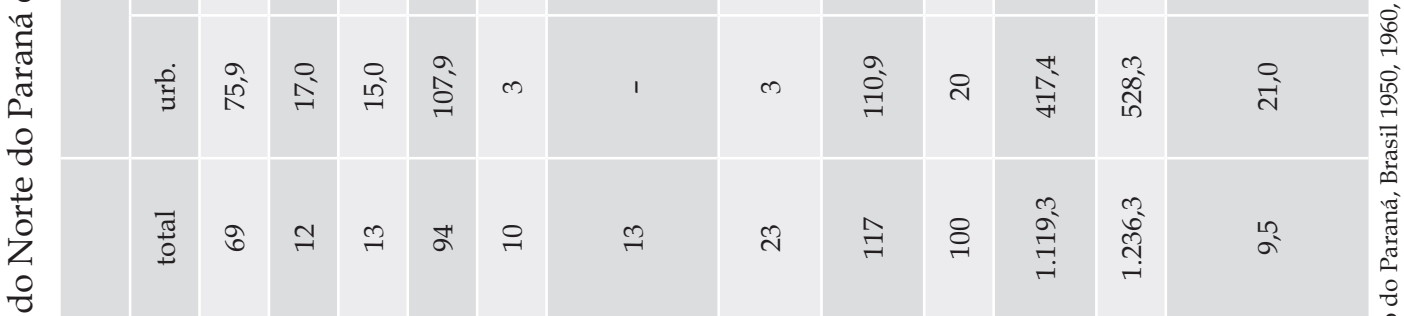

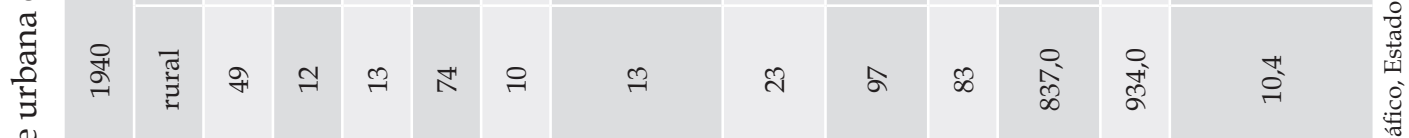

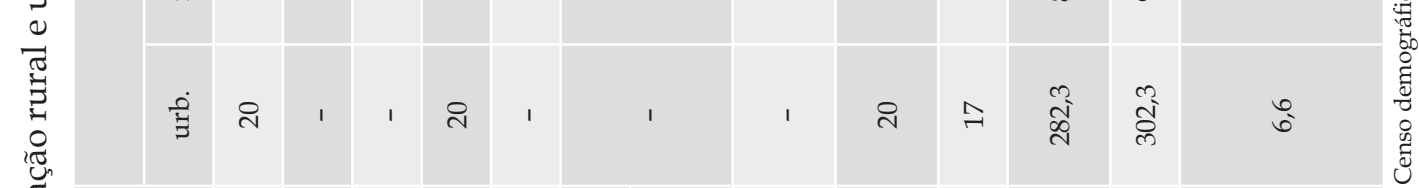

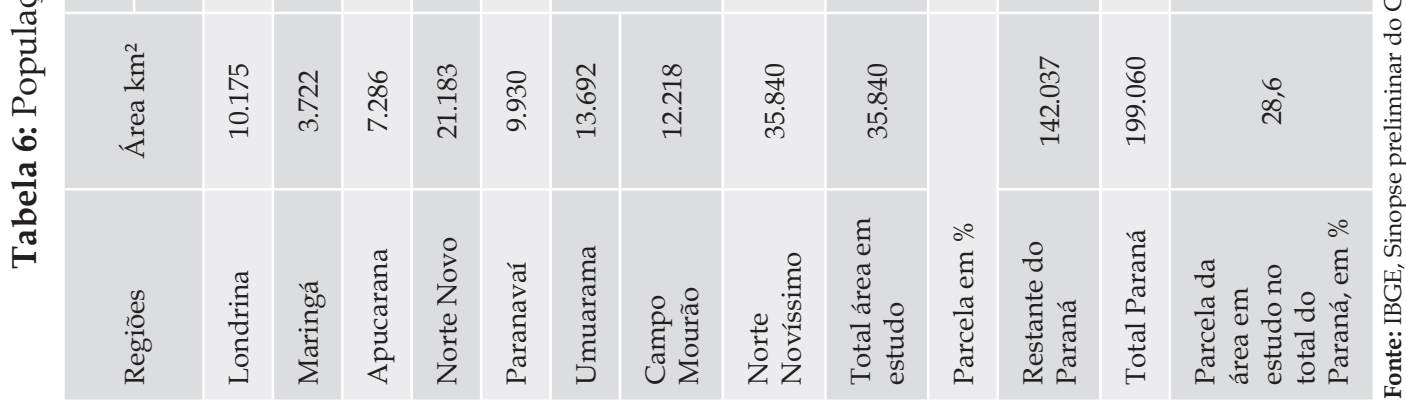




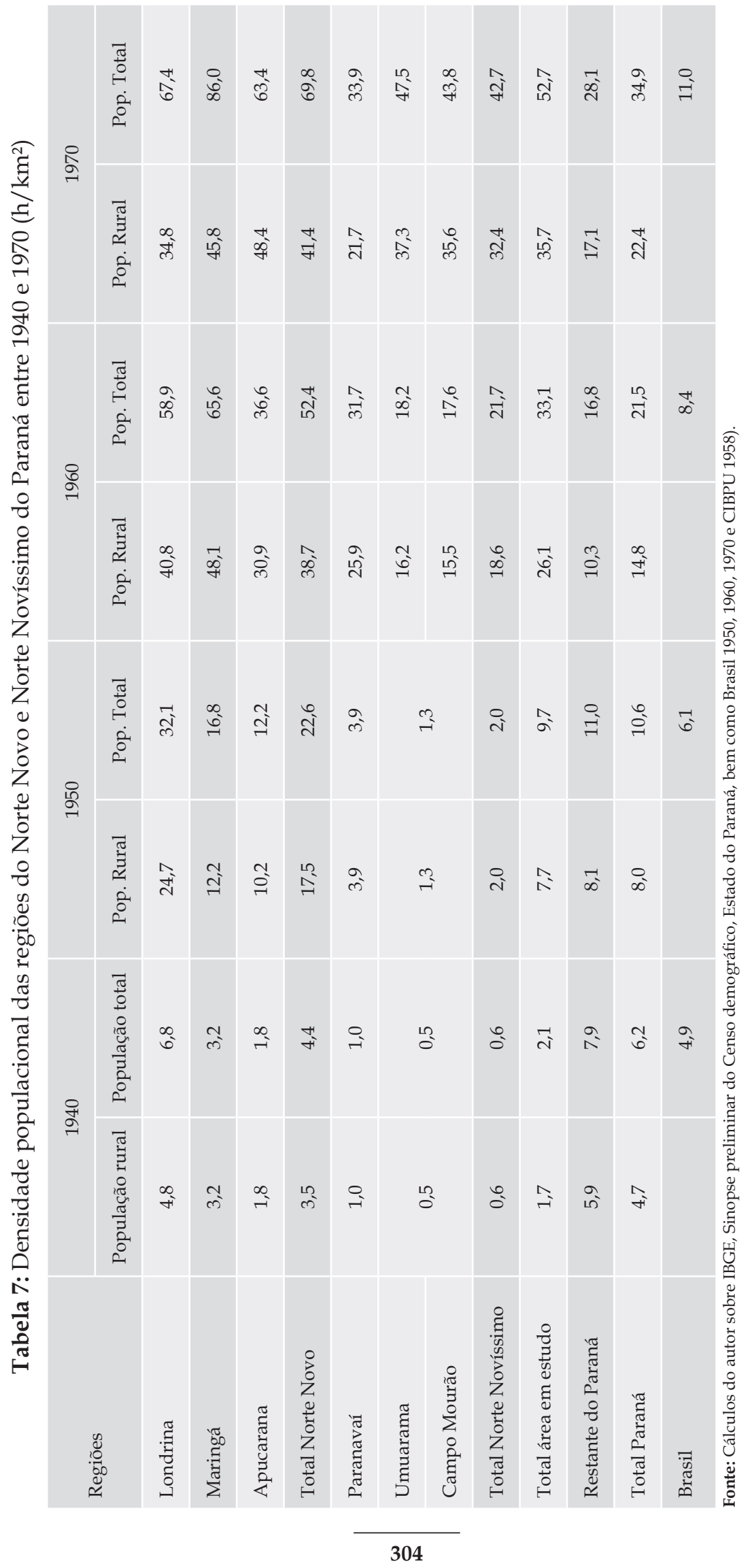




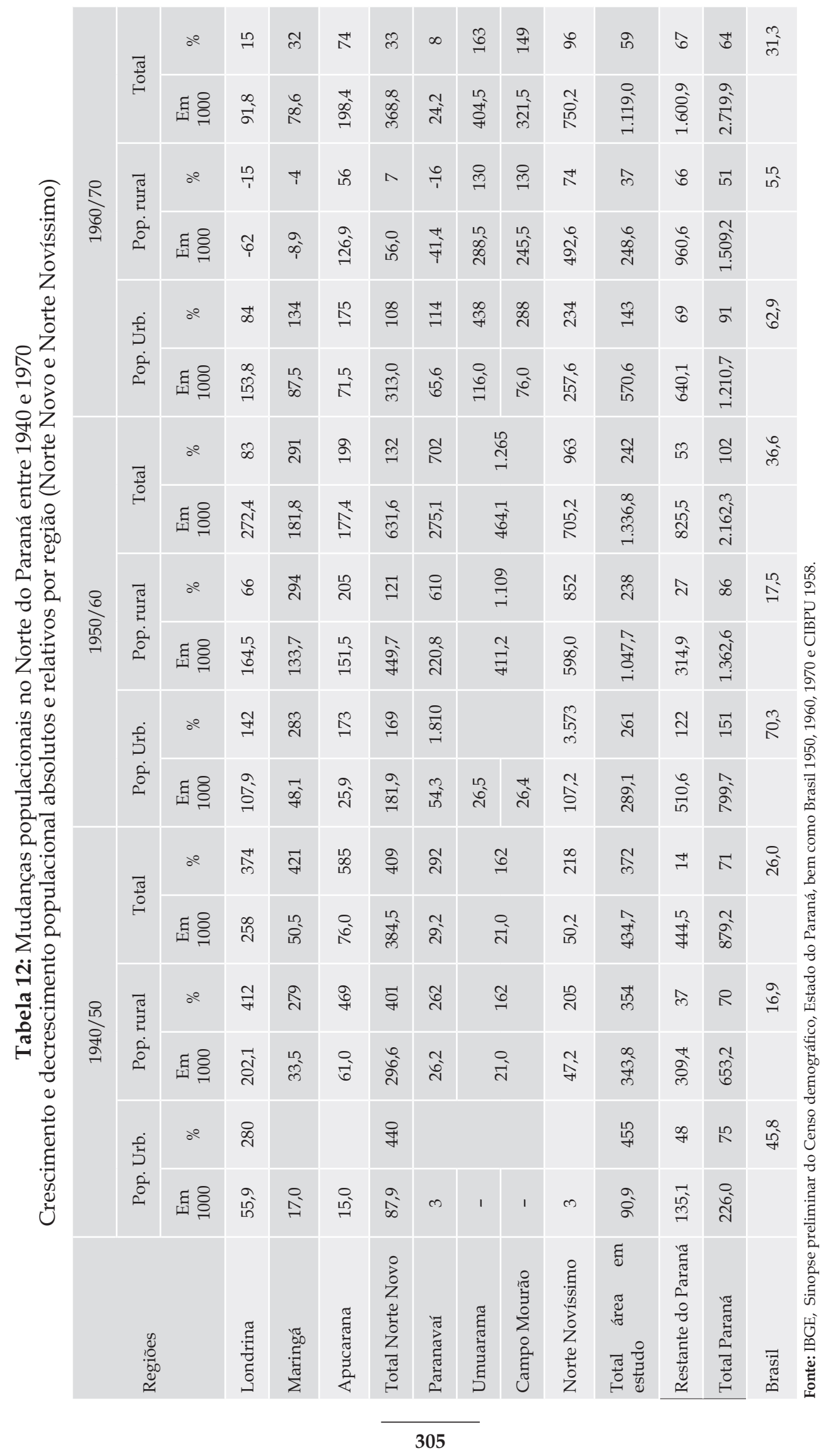




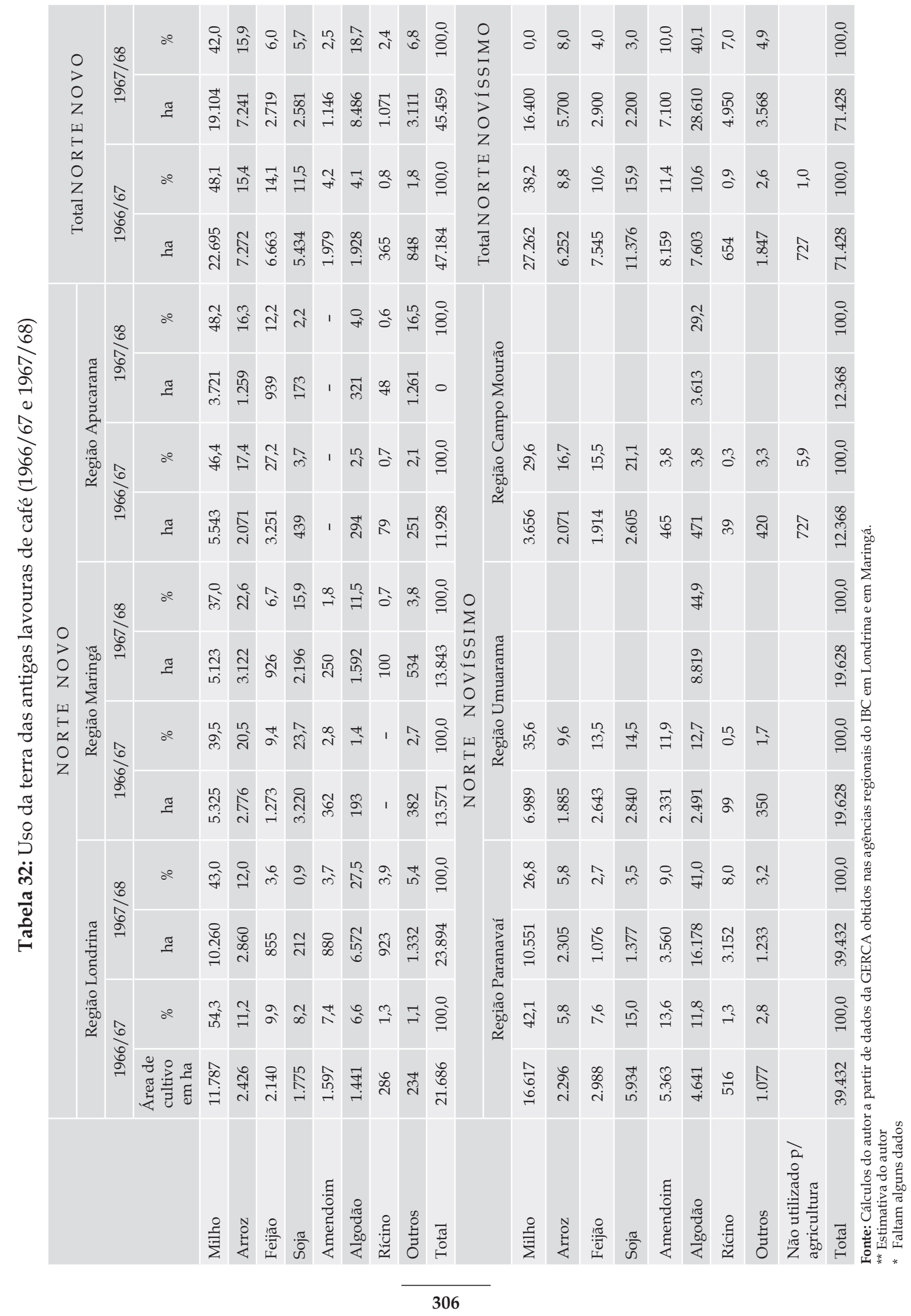




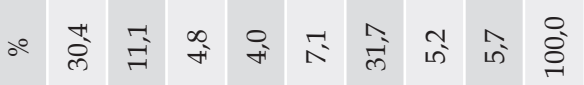

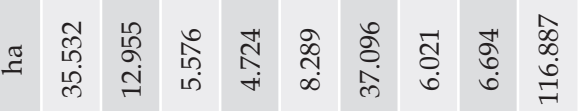

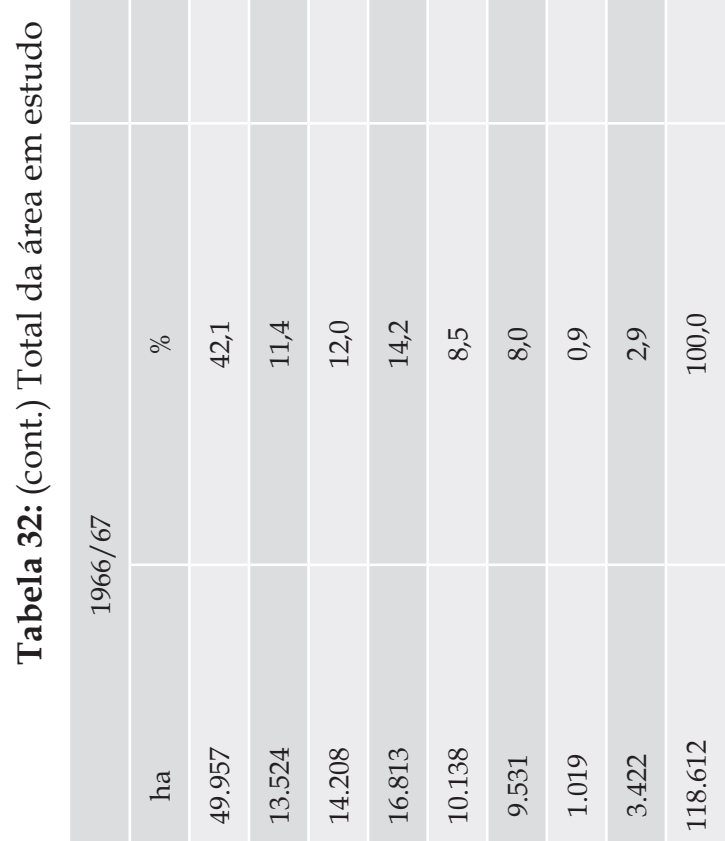

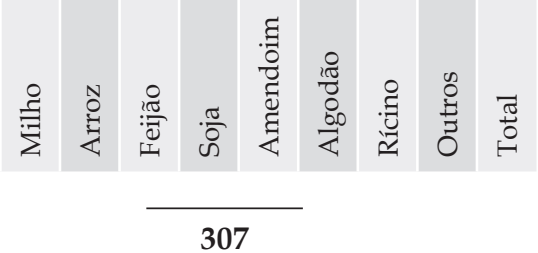




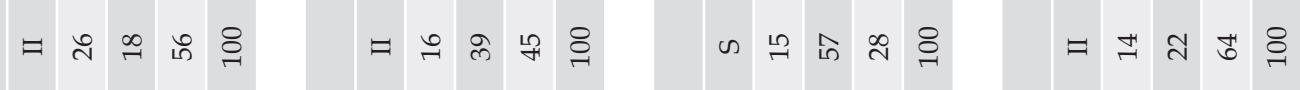
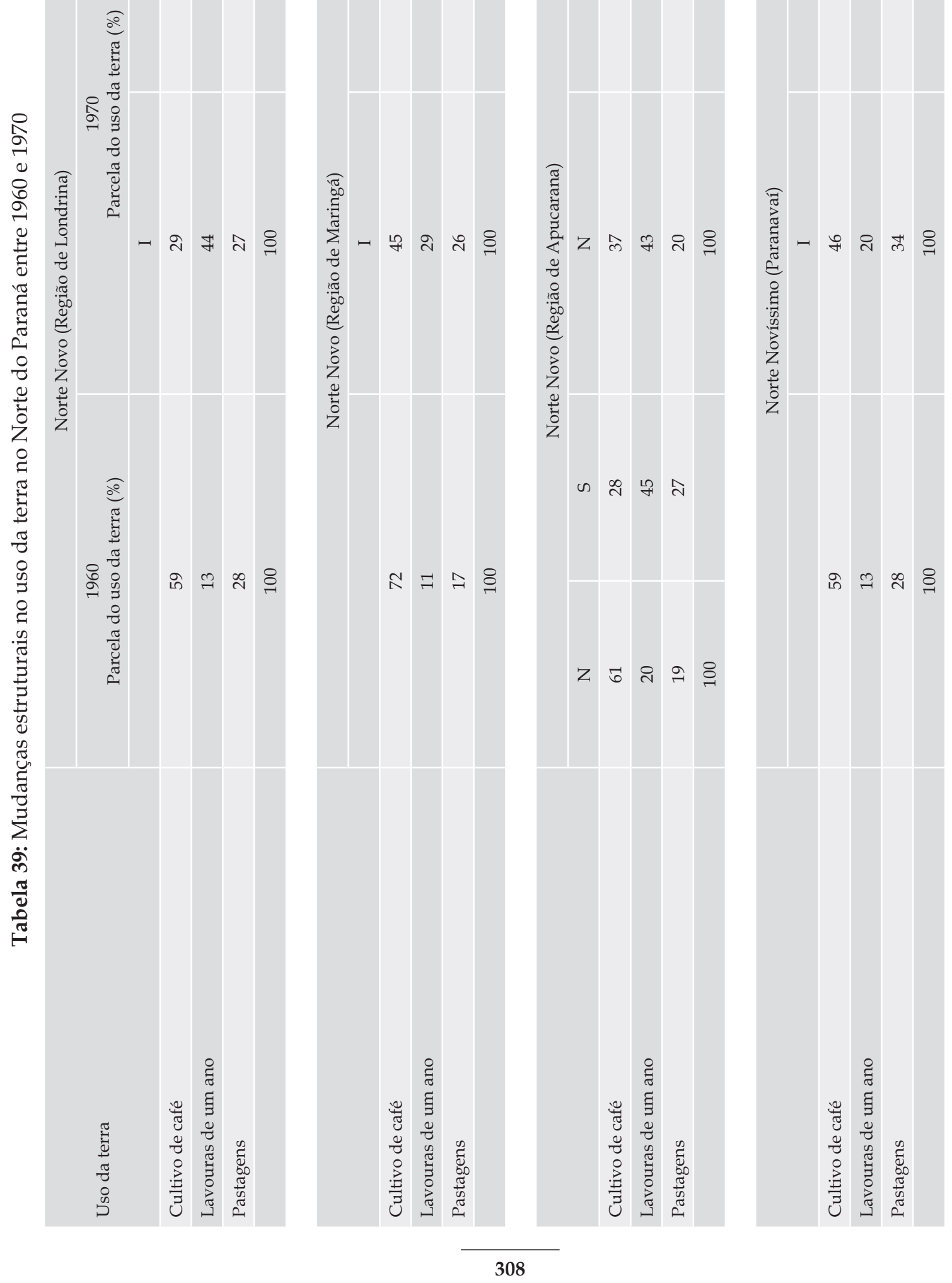


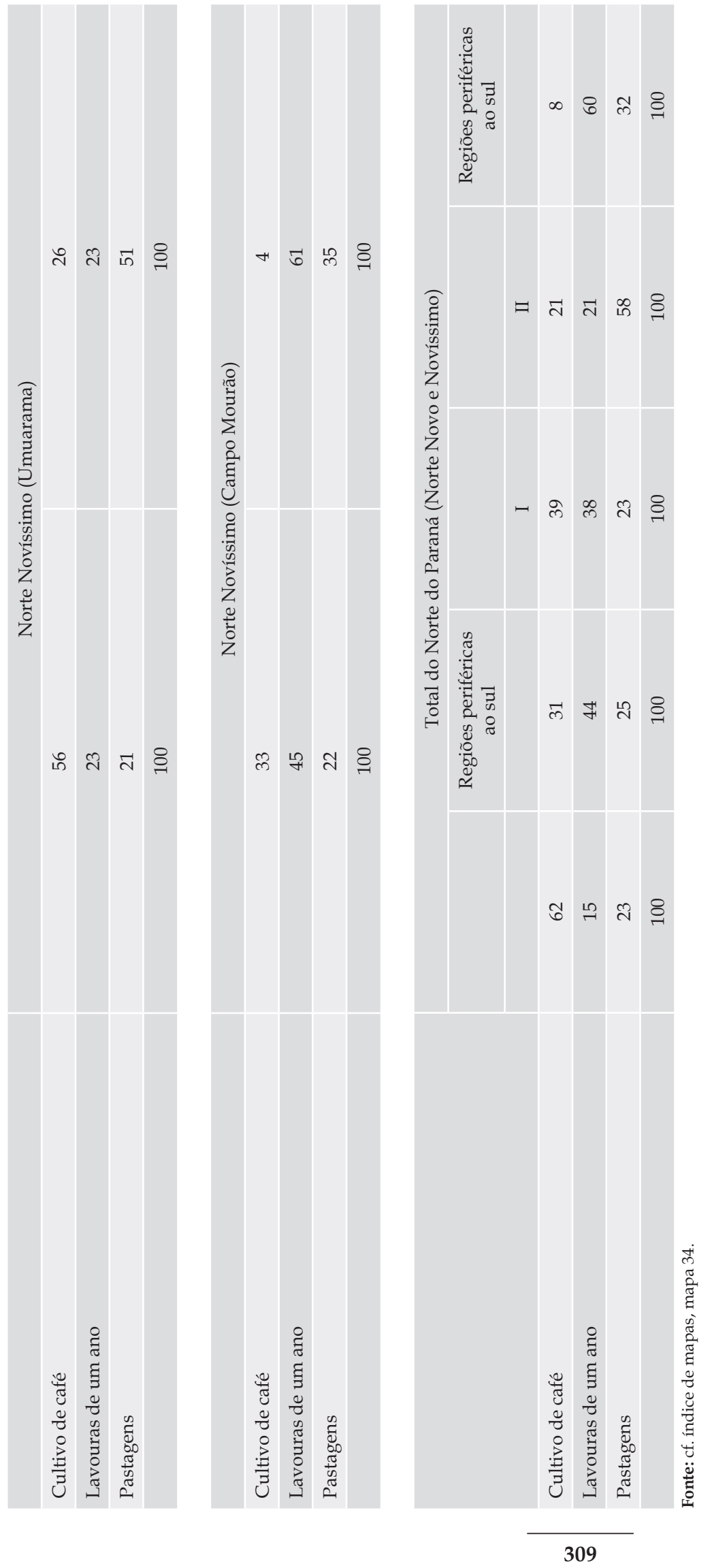




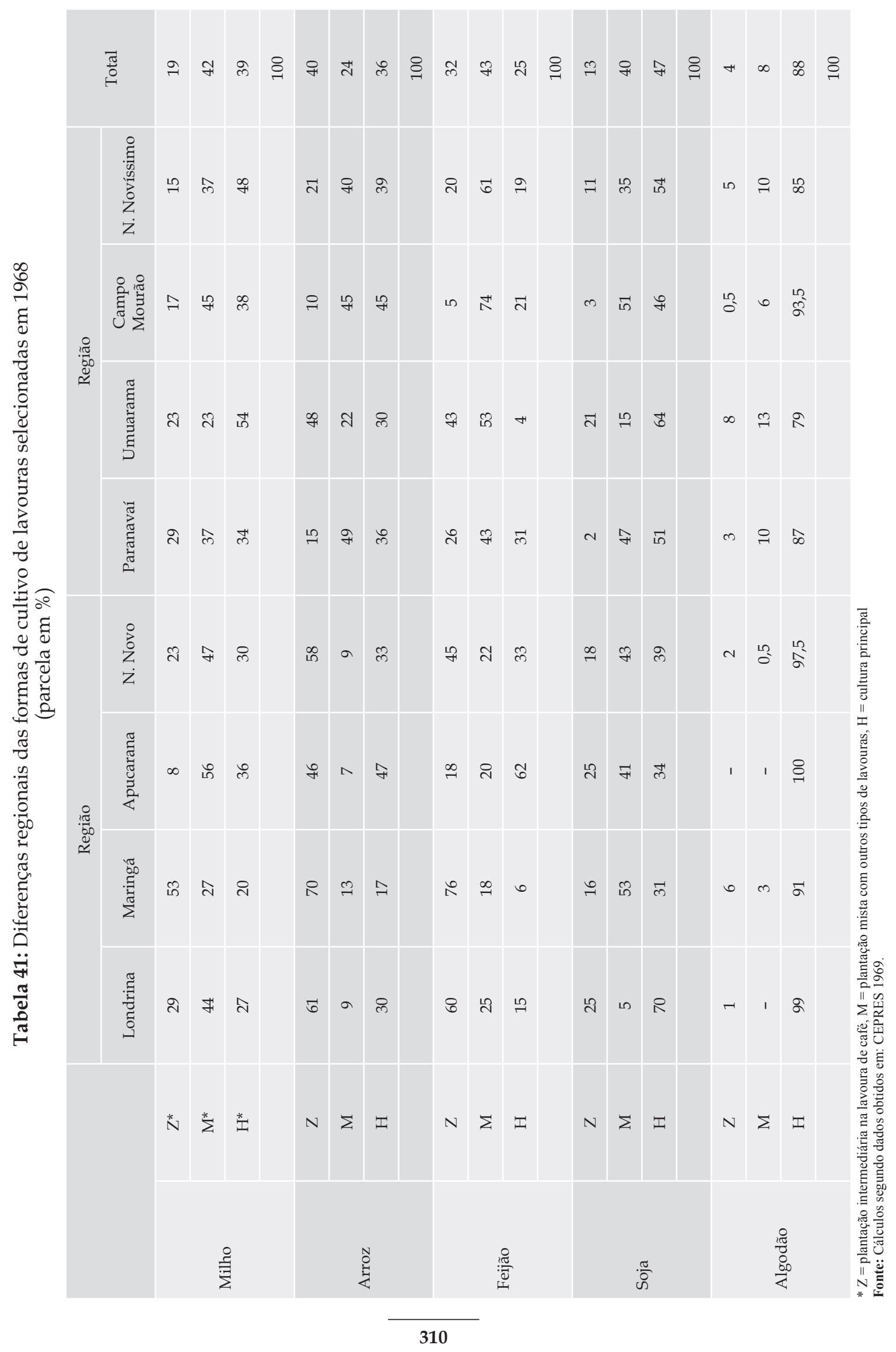

